\title{
Sediment-Hosted Stratabound Copper Deposit Model
}

Chapter M of

Mineral Deposit Models for Resource Assessment
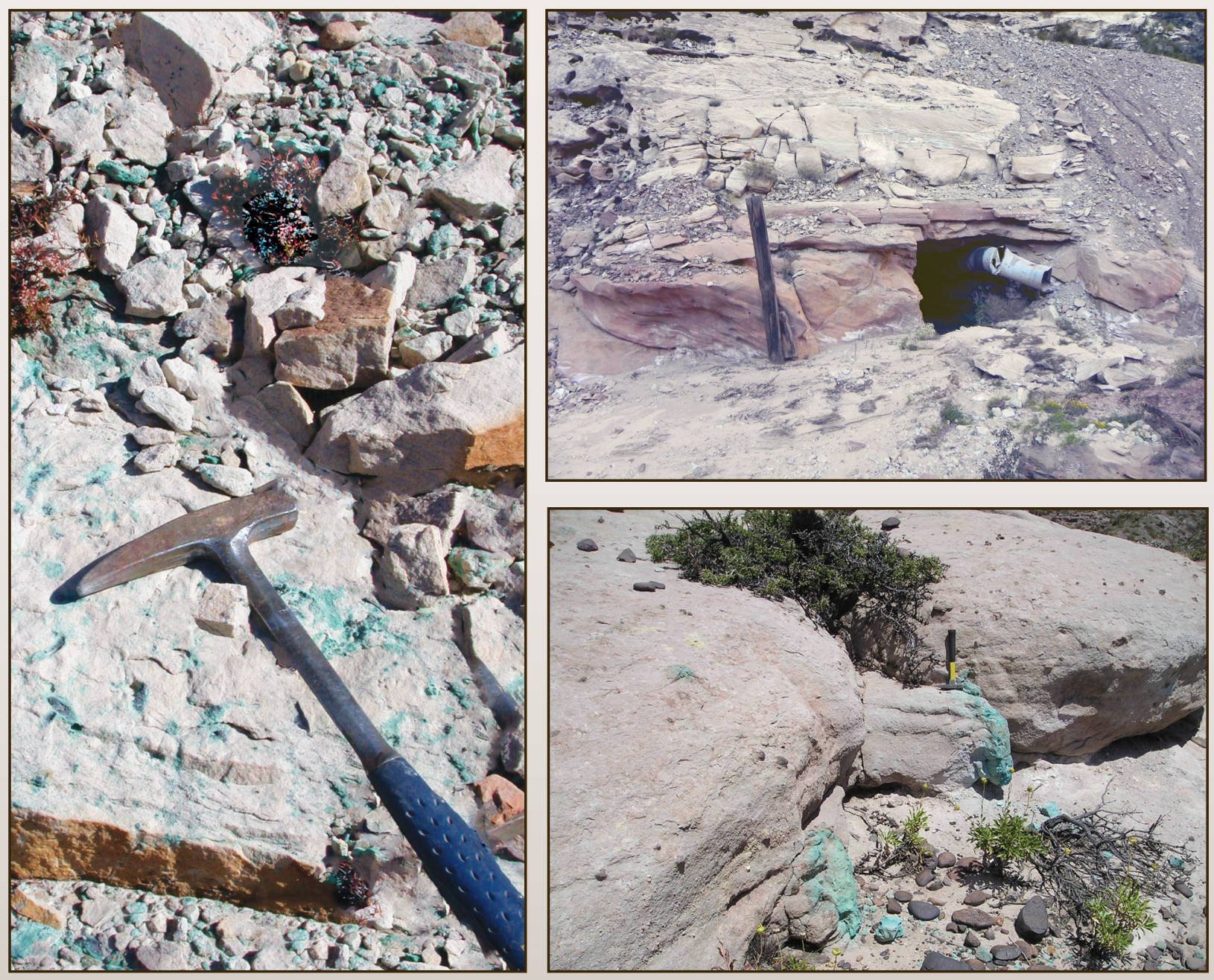

Scientific Investigations Report 2010-5070-M 


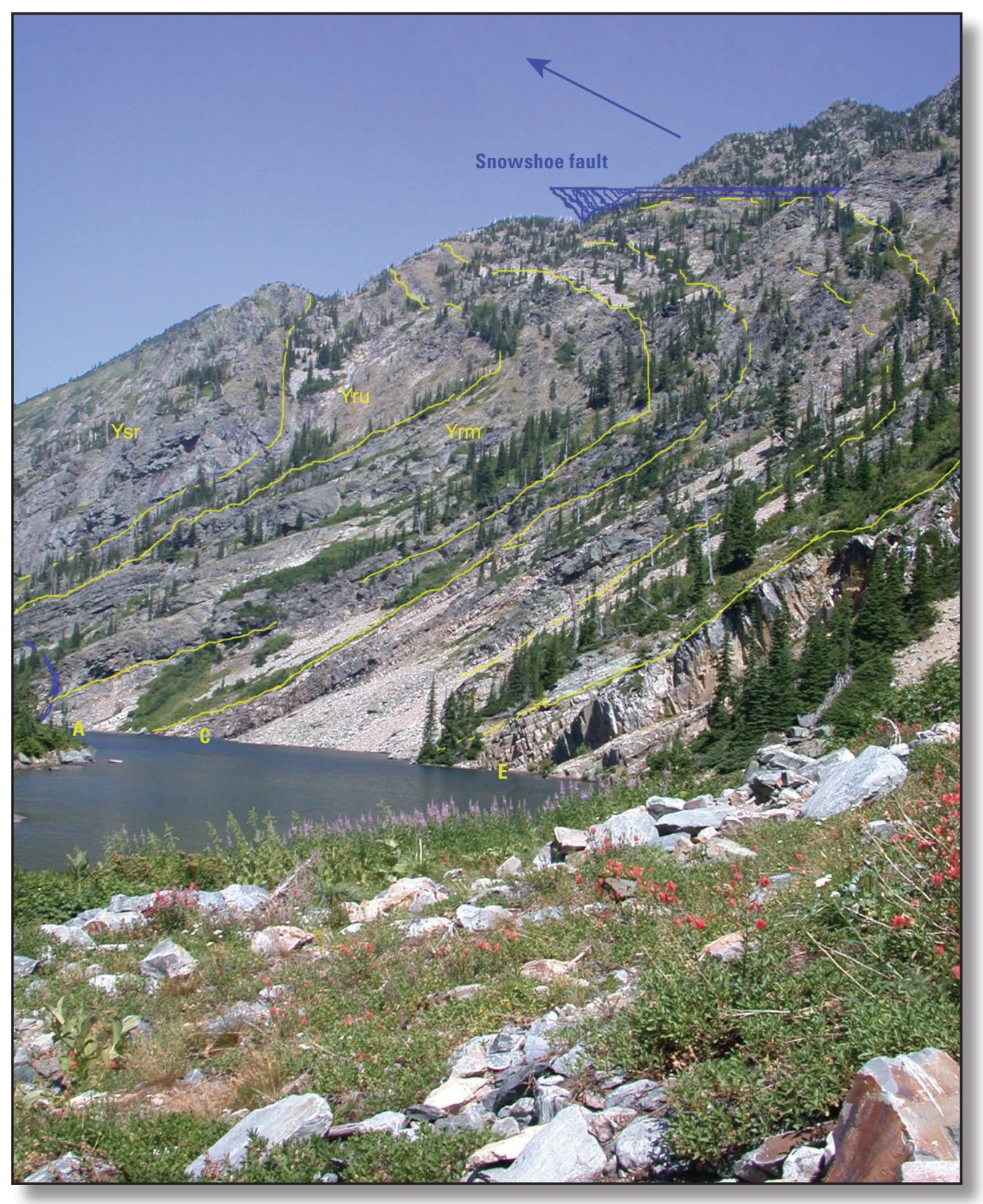

Annotated view of the outcrops and geology along the east side of Rock Lake, Sanders County, Montana, showing the setting of the discovery outcrops of the Montanore sandstone copper deposit. The view looks approximately due north. Stratigraphic unit abbreviations are: Ysr, Mesoproterozoic St. Regis Formation; Yru, Mesoproterozoic Revett Formation, upper member; Yrm, Revett Formation, middle member; A, Revett Formation, lower member, A quartzite beds; C, Revett Formation, lower member, C, quartzite beds; and E, Revett Formation, lower member, E quartzite beds. The $A$ and $C$ beds of the lower member of the Revett are mineralized and dipping west toward the axis, beneath the lake, of a narrow syncline. The syncline formed as a drag fold between the Rock Lake Fault, approximately beneath the photographer, and the Snowshoe Fault, sketched in blue with the relative movement of the eastern (opposite) block shown to illustrate the cause of the fold. (Photograph by Timothy S. Hayes, U.S. Geological Survey).

Cover. Left, Mineralized burrows in Burro Canyon Formation sandstone at the Sentinel copper deposit, Lisbon Valley, Utah. Chalcocite has weathered to bright blue chrysocolla. Rock hammer for scale. (Photograph by Timothy S. Hayes, U.S. Geological Survey). Top right, Bleached and later copper mineralized Wingate Formation sandstones overlie red sandstones at the Cashin sandstone copper deposit, southwestern Colorado. Light blue colors mark chrysocolla and malachite along cross-laminae just above a hammer, for scale, at the point of the arrow. (Photograph by Timothy S. Hayes, U.S. Geological Survey). Bottom right, Chrysocolla-mineralized water escape structures (pillars) cut light red Upper Jurassic Tordillo Formation sandstones, Neuquén Basin, Argentina. Rock hammer for scale. (Photograph by Jon Thorson). 


\section{Sediment-Hosted Stratabound Copper Deposit Model}

By Timothy S. Hayes, Dennis P. Cox, Nadine M. Piatak, and Robert R. Seal, II

Chapter M of

Mineral Deposit Models for Resource Assessment

Scientific Investigations Report 2010-5070-M 


\section{U.S. Department of the Interior SALLY JEWELL, Secretary}

\section{U.S. Geological Survey Suzette M. Kimball, Acting Director}

U.S. Geological Survey, Reston, Virginia: 2015

For more information on the USGS - the Federal source for science about the Earth, its natural and living resources, natural hazards, and the environment-visit http://www.usgs.gov or call 1-888-ASK-USGS.

For an overview of USGS information products, including maps, imagery, and publications, visit http://www.usgs.gov/pubprod/.

Any use of trade, firm, or product names is for descriptive purposes only and does not imply endorsement by the U.S. Government.

Although this information product, for the most part, is in the public domain, it also may contain copyrighted materials as noted in the text. Permission to reproduce copyrighted items must be secured from the copyright owner.

Suggested citation:

Hayes, T.S., Cox, D.P., Piatak, N.M., and Seal, R.R., II, 2015, Sediment-hosted stratabound copper deposit model: U.S. Geological Survey Scientific Investigations Report 2010-5070-M, 147 p., http://dx.doi.org/10.3133/ sir20105070M.

ISSN 2328-0328 (online) 


\section{Contents}

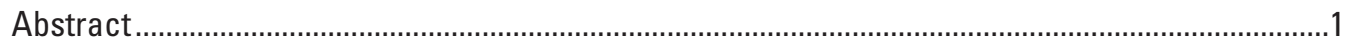

Summary of Sediment-Hosted Stratabound Copper Deposit Model ...................................................1

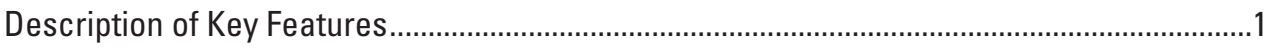

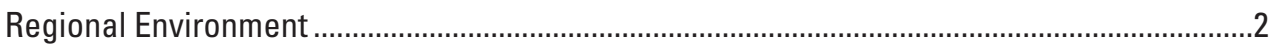

Hypogene Ore and Gangue Characteristics and Alteration .....................................................2

Supergene Ore and Gangue Characteristics .........................................................................2

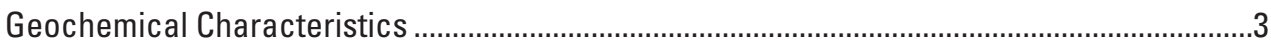

Petrology of Associated Sedimentary Rocks......................................................................

Petrology of Associated Metamorphic Rocks ............................................................................5

Genetic Theory and Mineral Resource Potential Assessment....................................................5

Environmental Geology and Effects of Mining..........................................................................

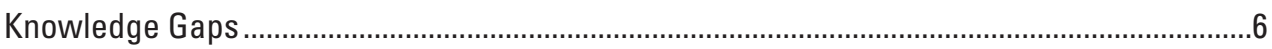

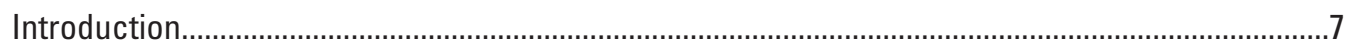

Deposit Type and Associated Commodities ......................................................................................

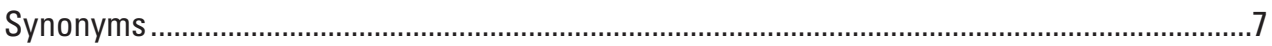

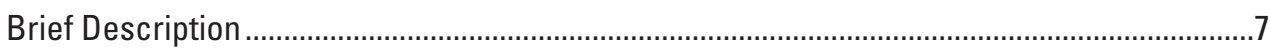

Associated and Transitional Deposit Types ...........................................................................16

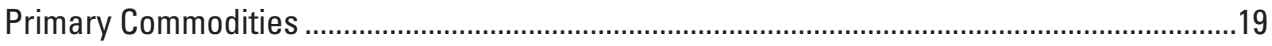

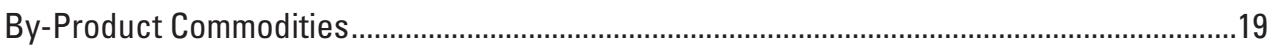

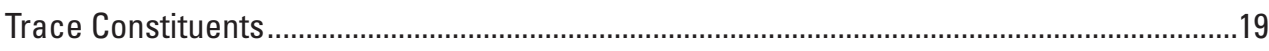

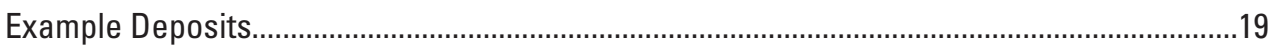

History of Exploitation of Sediment-Hosted Stratabound Copper Deposits and History

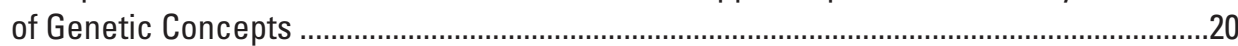

Archeometallurgy of Copper and of Sediment-Hosted Stratabound Copper Deposits ..........20

Evolution of Concepts of SSC Deposit Genesis ........................................................................21

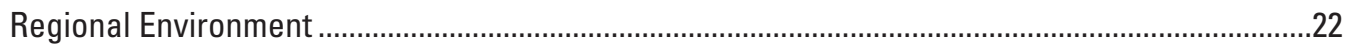

Temporal and Secular Environment..............................................................................................22

Geotectonic Environment and Relations to Sedimentary Rocks ............................................22

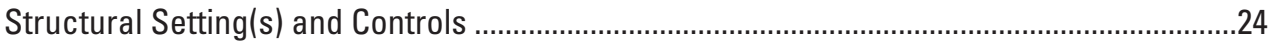

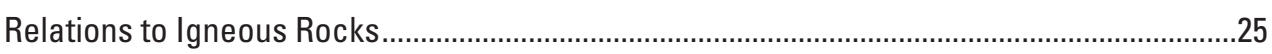

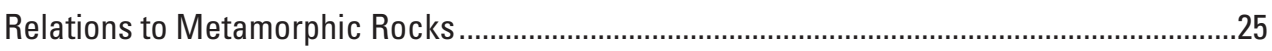

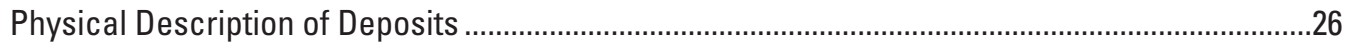

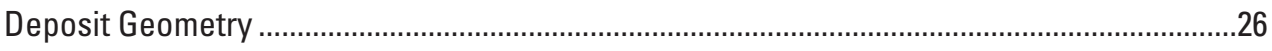

Dimensions and the Size of Hydrothermal Systems Relative to Extent of Economically

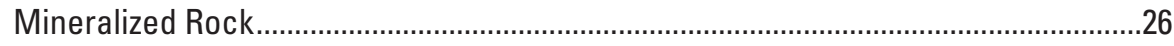

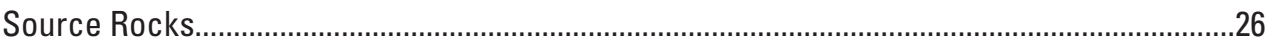

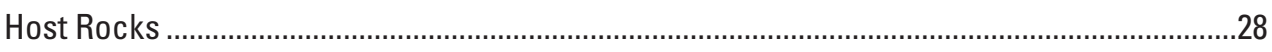

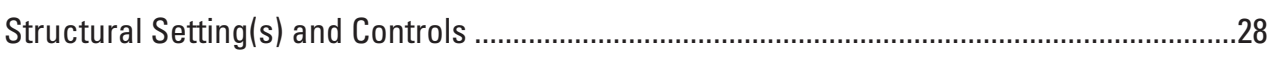

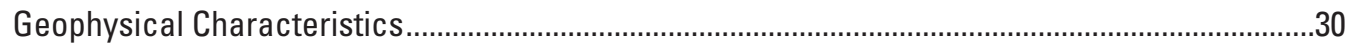

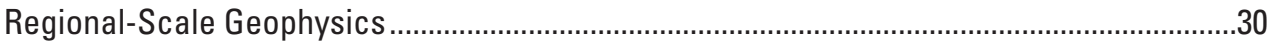

Deposit-Scale Geophysics .......................................................................................................30

Remote Sensing of Sediment-Hosted Stratabound Copper Deposits .....................................32 


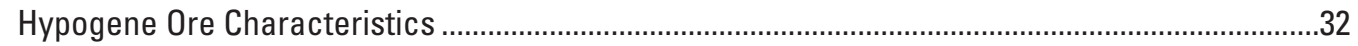

Grade

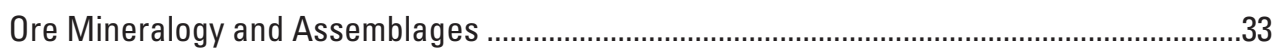

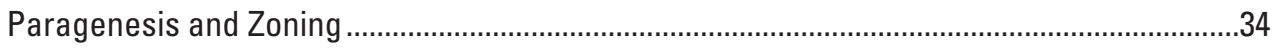

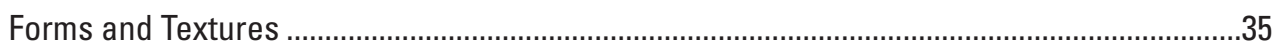

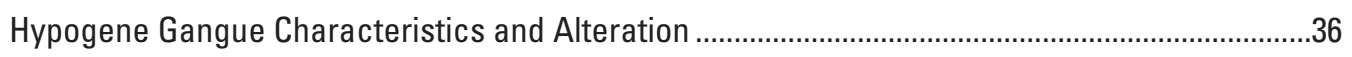

Gangue Mineralogy, Paragenesis, and Zoning.....................................................................

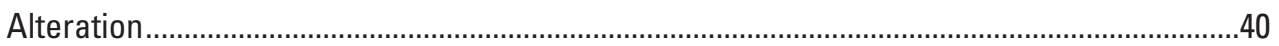

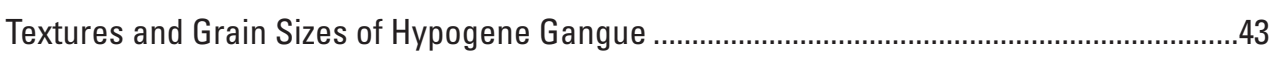

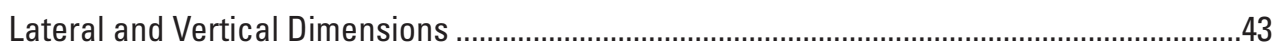

Weathering and Supergene Ore and Gangue Characteristics ....................................................44

Enrichment or the Lack of it in the Central African Copperbelt ............................................45

Mineralogy and Mineral Associations in Weathered and Enriched Zones..............................49

Leached Capping ..................................................................................................... 49

Oxide Copper Zones …….........................................................................................

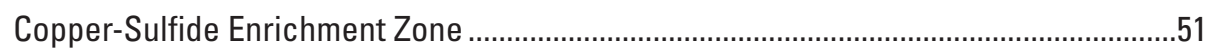

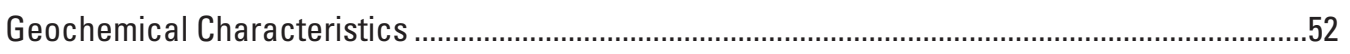

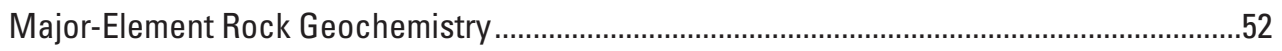

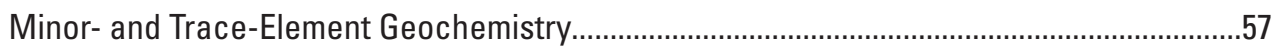

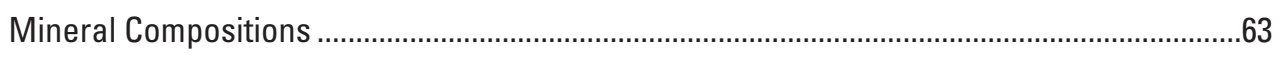

Fluid-Inclusion Geochemistry .....................................................................................

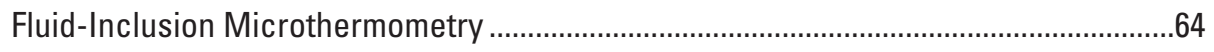

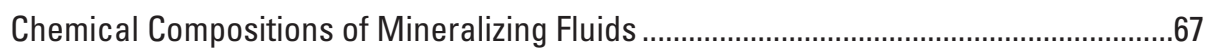

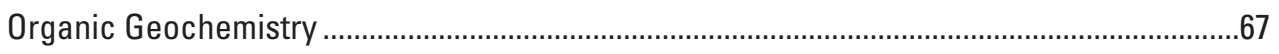

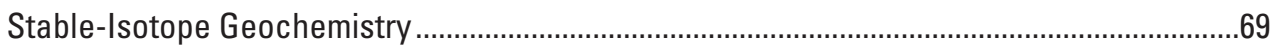

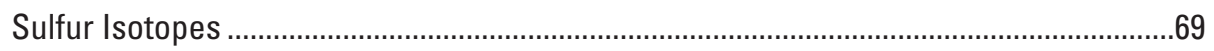

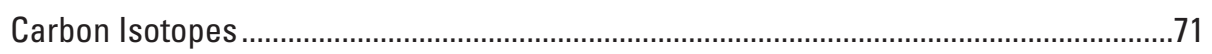

Integrated Isotopic Studies.....................................................................................72

Isotopic Dating and Radiogenic Isotope Geochemistry......................................................74

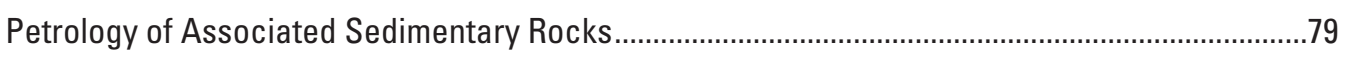

Depositional Environments .........................................................................................

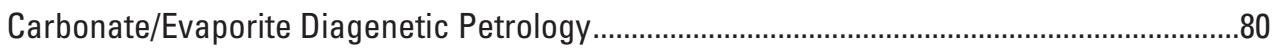

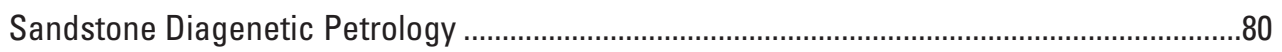

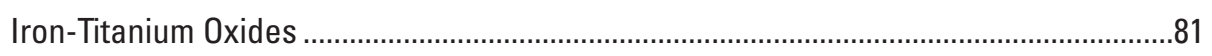

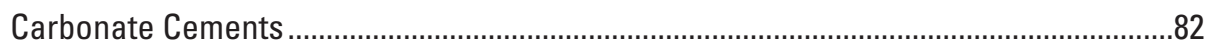

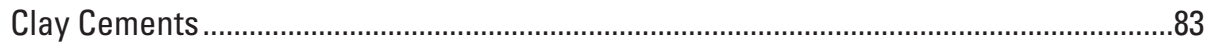

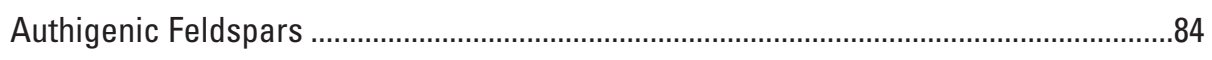

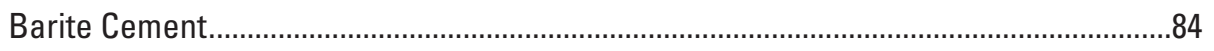

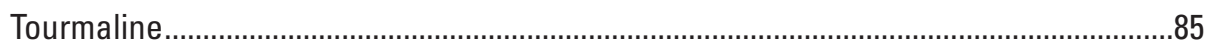

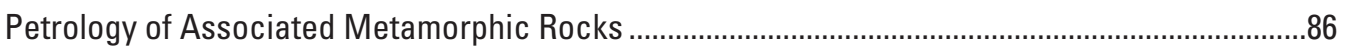

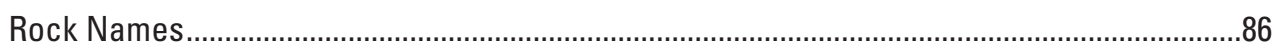

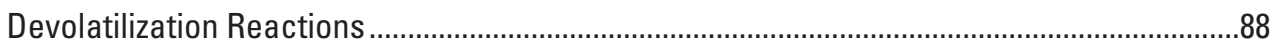

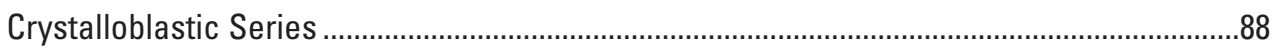

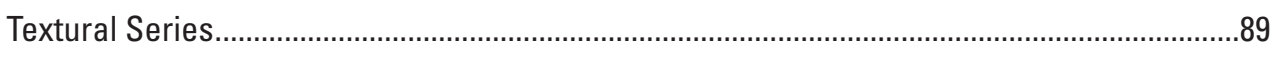

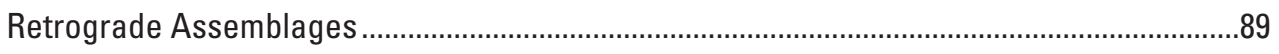




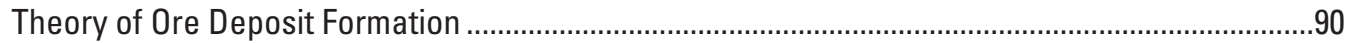

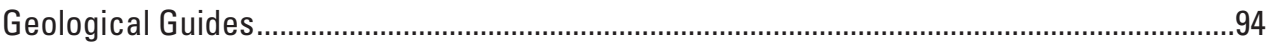

Mapping of Rock Types, Structural Geology, Minerals, Alteration, and Zoning ............94

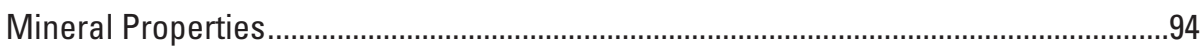

Distribution of Sulfide Minerals...................................................................................94

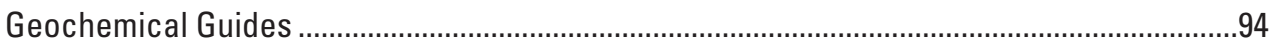

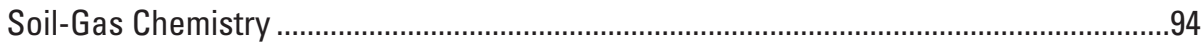

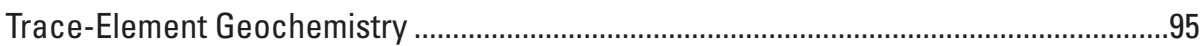

Supergene Enrichment and Leached Capping Characteristics......................................95

Cu-Oxide Minerals ..................................................................................................

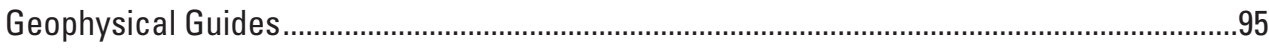

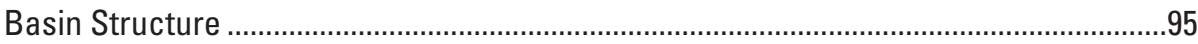

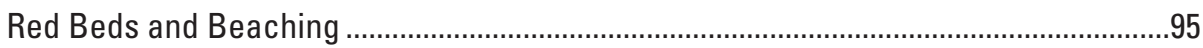

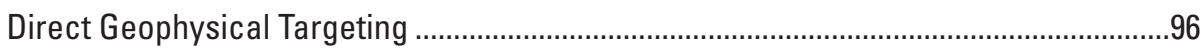

Attributes Required for Inclusion in a Permissive Tract....................................................96

Factors That Enable Favorability Zonation of Permissive Tracts...........................................96

Factors That Influence Undiscovered Deposits Estimates....................................................96

Geoenvironmental Features and Anthropogenic Mining Effects ...............................................97

Pre-Mining Baseline Signatures in Soil, Sediment, and Water .............................................98

Past and Future Mining Methods and Ore Treatment .........................................................98

Volume and Footprint of Mine Waste and Tailings....................................................................98

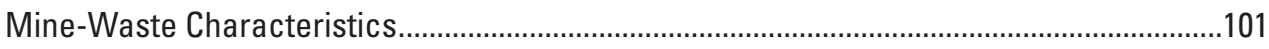

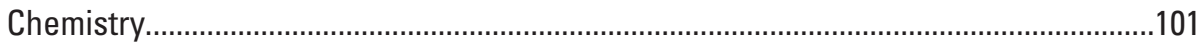

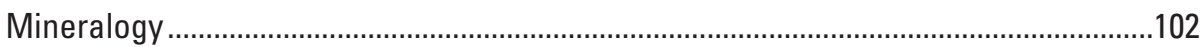

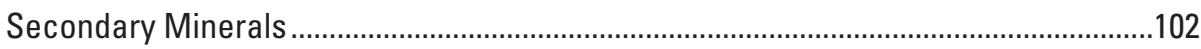

Acid-Base Accounting.........................................................................................102

Element Mobility Related to Mining in Groundwater, Surface Water, and Stream Sediments... 103

Reduced-Facies-Subtype Deposits ..........................................................................103

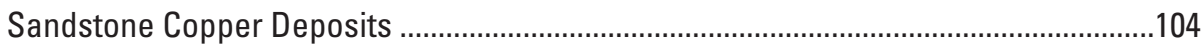

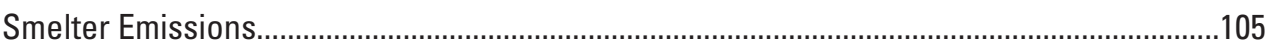

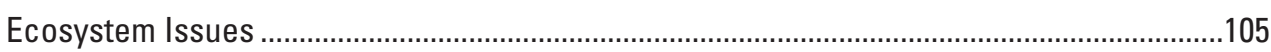

Climate Effects on Geoenvironmental Signatures ………...............................................106

Knowledge Gaps and Future Research Directions ......................................................................107

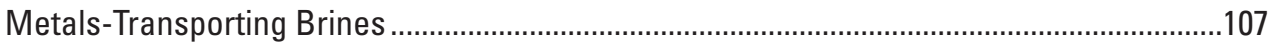

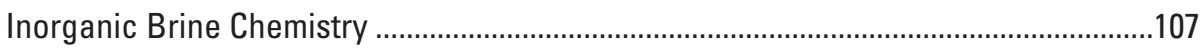

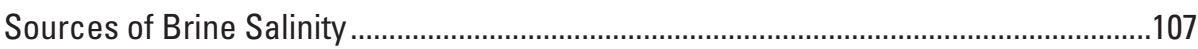

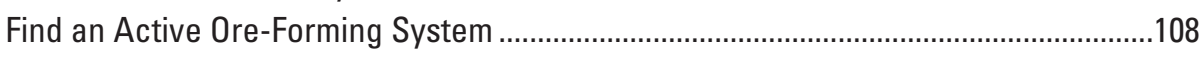

Hydrologic Drive(s) of Metals-Transporting Groundwater Flow...........................................108

Paleohydrologic Modeling of Metals-Transporting Groundwater Flow.........................108

Identifying Flow Paths for Metals-Transporting Brines .............................................109

Supergene Enrichment .....................................................................................................110

Changes to SSC Deposits with High-Grade Metamorphism ................................................110

Direct Sensing of Concealed Ore.................................................................................110

Observable Vectors for Narrowing the Search for Ore.......................................................111

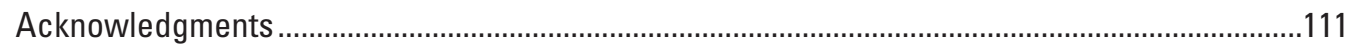

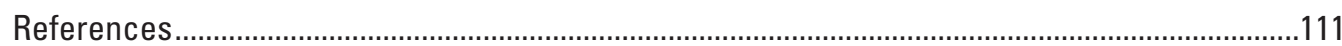

Appendix 1. Summary of Representative Sediment-Hosted Stratabound Copper Deposits .........137 


\section{Figures}

1. Map showing locations of sediment-hosted stratabound copper (SSC) prospects and deposits of the world presently known to the U.S. Geological Survey... .8

2. Map showing locations of known sediment-hosted stratabound copper prospects and deposits of the Central African Copperbelt, Democratic Republic of Congo and Zambia .9

3. Map showing locations of known sediment-hosted stratabound copper prospects and deposits of the Kupferschiefer in central Europe. 10

4. Diagram illustrating ore mineral zonation of the reduced-facies-type deposits of the White Pine deposit, Michigan, from White and Wright (1966) and Brown (1971) supplemented, in the cupriferous and hematitic zones from descriptions in Brown (1971), Hamilton (1967), and observations of the first author

5. Schematic cross section showing the mineral zonation related to the stratigraphy of the White PIne reduced-facies-type deposit, Michigan, modified from White and Wright (1966)...

6. Illustration showing mineral zones of the Spar Lake sandstone copper deposit, Montana, United States, from Hayes and others (2012).

7. Cross section showing mineral zonation in a cross section along the curving long axis of the Spar Lake sandstone copper deposit, Montana, United States, from Hayes and Einaudi (1986).

8. Photomicrographs showing denser than background concentrations of copper sulfides in a silt-sized lamination and in a medium-crystalline dolomite nodule within dolomitic mudstone from the Kamoto Principal deposit, Democratic Republic of Congo.

9. Graph showing relation between contained tonnes of copper metal in sedimenthosted stratabound copper deposits and the depositional age of host rocks, from Hitzman and others (2005)

10. Cross section of the Chambishi and Chambishi Southeast deposits and their relation to a basement high in the Zambian Copperbelt, from Garlick (1972)

11. Map showing deposit grade $X$ thickness contours related to basement highs and faults in the Chambishi Southeast deposit, Zambia, from Selley and others (2005)........25

12. Stratigraphic column and typical copper grades of each host unit, White Pine deposit, Michigan, United States, from Mauk and others (1992a)

13. Cross section of the Cashin sandstone copper deposit, Colorado, United States, from Thorson and MacIntyre (2005)

14. Sketch of a field relation in the White Pine deposit, Michigan, United States, from Mauk and others (1992b).

15. Distribution of ore in the Nchanga deposit, Zambia, in a vertically exaggerated schematic section that looks approximately downdip along the bedding, from McKinnon and Smit (1961)

16. A, Photomicrograph in transmitted, plane-polarized light; $B$, cathodoluminescent photomicrograph; and $C$, interpretive sketch of a rock from the bornite-calcite zone (fig. 6) of the Spar Lake sandstone copper deposit

17. Photograph showing exposure of a mine face underground at the Spar Lake sandstone copper deposit. 
18. A, Reflected-light photomicrograph in plane-polarized light of the margin of a compound pyrite clot, with a core of cementing pyrite surrounded by a continuous pyritic outer rim from the pyrite-calcite zone (fig. 6) at the Spar Lake sandstone copper deposit; $B$, part of the continuous outer rim of pyrite, also in reflected light; and $C_{r}$ "map" of cobalt characteristic X-rays from the electron microprobe of the same cubic grain shown in $B$.

19. $A$, Reflected-light photomicrograph in plane-polarized reflected light of a rock from the Spar Lake pyrite-calcite zone (fig. 6); $B$, photomicrograph in plane-polarized reflected light in oil immersion of a rock from the Spar Lake sandstone copper deposit bornite-calcite zone (fig. 6), along a heavy mineral lamination; and $C$, the same field of view as in $B$ shown in reflected cross-polarized light.

20. Sequence of authigenic minerals in the galena-calcite zone (fig. 6) of the Spar Lake sandstone copper deposit

21. Sequence of authigenic minerals in the bornite-calcite zone (fig. 6) of the Spar Lake sandstone copper deposit

22. Sequence of authigenic minerals in the bornite-calcite zone (fig. 6) of the Spar Lake sandstone copper deposit

23. Sequence of authigenic minerals in the chalcocite-chlorite zone (fig. 6) of the Spar Lake sandstone copper deposit.

24. Sequence of authigenic minerals in the chalcocite-chlorite zone (fig. 6) of the Spar Lake sandstone copper deposit..

25. Chalcocite-zone and Rote Fäule alteration-zone rocks from the Kupferschiefer mineralizing system on the Fore-Sudetic Monocline, Poland.

26. Photograph showing outcrop of albite zone quartzites (metasandstones) of the mineralizing system for the Revett Formation sandstone copper deposits (fig. 6), northwestern Montana, United States.

27. Photograph showing lavender hematitic banding in the Salib Arkosic Sandstone Formation in the Petra Archaeological National Park, Jordan.

28. Photomicrograph in reflected plane-polarized light of a vermicular (Bateman's [1930] "subgraphic") exsolution-textured grain of bornite and digenite from the Spar Lake sandstone copper deposit.

29. Patterns of weathering of different carbonate minerals in the Revett Formationhosted sandstone copper system (fig. 6), northwestern Montana and northern Idaho.

30. Graph showing populations of copper abundance in more than 3,500 wholerock analyses from the Blacktail Mountain greenbed copper occurrence from Connor and others (1981)

31. Graph showing populations of copper abundance in 110 whole-rock analyses from scattered samples of the Revett and Burke Formations that host the sandstone copper system in the Revett Formation, northwestern Montana and northern Idaho .......55

32. Graph showing relation between whole-rock copper and potassium/sodium in 45 samples of the Revett and Burke Formation quartzites, northwestern Montana and northern Idaho

33. Graph showing relation between whole-rock copper and a derived "metasomatic" variable in 45 samples of the Revett and Burke Formation quartzites, northwestern Montana and northern Idaho. 
34. Graph showing relation between whole-rock copper and whole-rock potassium in 236 samples from in and near the Konkola, Zambia, reduced-facies sedimenthosted stratabound copper deposit.

35. Graph showing relation between whole-rock copper and whole-rock sodium in 236 samples from in and near the Konkola, Zambia, reduced-facies sedimenthosted stratabound copper deposit.....

36. Graph showing relation between whole-rock copper and whole-rock potassium/ sodium in 16 Kupferschiefer reduced-facies ore-system samples, Fore-Sudetic Monocline, Poland

37. Graph showing relation between whole-rock copper and whole-rock potassium in eight samples from the Udokan sandstone copper system.

38. Graph showing map of the stratigraphic distribution of ores in the Zambian Copperbelt from Annels and Simmonds (1984)

39. Graph showing relation between copper and mercury in 61 samples from the Revett and Burke Formations in northwestern Montana and northern Idaho

40. Graph showing summary of fluid-inclusion microthermometry results from sandstone copper and reduced-facies sediment-hosted stratabound copper deposits of the Democratic Republic of Congo.

41. Graph showing fluid-inclusion homogenization temperatures from the Spar Lake sandstone copper deposit from Hayes (1990)

42. Ternary diagram showing water-carbon dioxide-methane compositions of Spar Lake sandstone copper deposit fluid inclusions compared with methane-rich inclusions from other metals depositing systems, with inclusions in pedogenic calcite, and with compositions of reservoired natural gas from Hayes and others (2012)

43. Maps of thermodynamically calculated temperature and $\log \mathrm{fO}_{2}$ of the Spar Lake sandstone copper deposit from Hayes and others (2012)

44. Graph showing sulfide sulfur-isotope distribution of the White Pine reduced-facies sediment-hosted stratabound copper deposit from Mauk and others (1992a)

45. Graph showing relation between total sulfide and $\delta^{34} S$ of sulfide from Kamoto reduced-facies type deposit, Democratic Republic of Congo, from Hoy and Ohmoto (1989)

46. Histograms of $\delta^{34} S$ values of sulfides and sulfates across the mineral zonation at the Spar Lake sandstone copper deposit, from Hayes and others (2012)

47. Graph showing sulfur-isotope values of the Spar Lake sandstone copper deposit and sulfur-isotope values of various sulfate, sulfide, and petroleum compounds in a typical petroleum-producing basin, the Amu-Dar'ya Basin, Turkmenistan and Uzbekistan

48. Graph showing relation between $\delta^{13} \mathrm{C}$ and $\delta^{18} 0$ of carbonates related to the Spar Lake sandstone copper deposit, from Hayes and others (2012)

49. Graph showing concentrations of copper $(\mathrm{Cu})$, zinc $(\mathrm{Zn})$, lead $(\mathrm{Pb})$, vanadium $(\mathrm{V})$, molybdenum (Mo), nickel (Ni), cobalt (Co), uranium (U), organic carbon $\left(\mathrm{C}_{\text {org }}\right)$ and carbonate carbon $\left(\mathrm{C}_{\text {carb }}\right)$, Rock Eval pyrolysis temperature $\left(\mathrm{T}_{\max }\right)$ and hydrogen index $(\mathrm{HI}), \delta^{13} \mathrm{C}$ of organic carbon, $\delta^{13} \mathrm{C}$ of calcite, and $\delta^{18} \mathrm{O}$ of calcite for a mineralized Kupferschiefer section from the Sieroszowice mine, Poland, from Bechtel and others (2002) 
50. Graph showing standard von Krevelin organics maturation diagrams for the samples of a Kupferschiefer section from the Sieroszowice mine, Poland, from Bechtel and others (2002).

51. Graph showing relation between $\delta^{34} S_{\text {Cu sulfide }}$ and $\delta^{13} C_{\text {carbonate }}$ for 18 samples where both were analyzed from the Spar Lake sandstone copper deposit

52. Graph showing authigenic minerals in Tertiary sandstones of the Gulf Coast, Texas, their sequence of appearance and relative abundance with depth and temperature (from Boles and Franks, 1979, and Boles, 1982)

53. Photomicrograph showing a typical detrital grain of ilmenomagnetite from red beds........82

54. Photomicrograph showing a typical detrital grain of ilmenohematite from red beds ........82

55. Photomicrograph showing calcite cementing a feldspathic sandstone .........................83

56. Photomicrograph showing grain-rimming "illite" cement...............................................83

57. Photomicrographs showing chlorite replacing muscovite along cleavages from the chalcocite-chlorite zone of the Spar Lake sediment-hosted stratabound copper sandstone deposit (fig. 6)

58. A, Photomicrograph in plane-polarized transmitted light of a replaced detrital plagioclase grain from the bornite-calcite zone of the Spar Lake sedimenthosted stratabound copper sandstone deposit (fig. 6). B, Cathodoluminscent photomicrograph of the same field of view and $C$, Interpretive overlay of the same field of view

59. Photomicrograph showing para-amphibolite, the metamorphosed equivalent of muddy dolomite, from the Ablah Group, southwestern Saudi Arabia

60. Photomicrograph showing the core of magnetite-sulfide clot from the Spar Lake sandstone copper deposit illustrating metamorphic crystalloblastic relations among magnetite, ankerite, bornite, and digenite

61. Photomicrograph showing retrograde(?) exsolution textures among bornite, chalcopyrite, and digenite

62. Photograph showing core samples contrasting siltite-argillite beds from remote from the Spar Lake RBA sandstone Cu deposit with the same kind of beds immediately beneath ore.....

\section{Tables}

1. Stratigraphy and lithology of the Damara Supergroup (Oamites Area) Correlated with the Katangan Supergroup, Zambian Copperbelt

2. Metamorphic rock types and their protoliths of the RBA copper deposit-hosting Ablah Group, southwestern Saudi Arabia

3. Concentrations of metals in stream, wetland, and lake sediment downstream from sediment-hosted Cu deposits

4. $\mathrm{pH}$ and dissolved metal content of waters from sediment-hosted copper deposits.

Drinking water and aquatic ecosystem guidelines also listed

5. Concentrations of elements (in milligrams per kilogram) in slag and flue dust from smelters in the Mansfield mining district (RF), Germany .101

6. Concentrations of metals (in milligrams per kilogram) in surface soils surrounding the Glogow and Legnica smelters, Poland 


\section{Conversion Factors}

\begin{tabular}{lll}
\multicolumn{1}{c}{ SI to Inch/Pound } & \multicolumn{1}{c}{ Multiply } & \multicolumn{1}{c}{ To obtain } \\
\hline & \multicolumn{1}{c}{ Length } & \\
\hline centimeter $(\mathrm{cm})$ & 0.3937 & inch (in.) \\
millimeter $(\mathrm{mm})$ & 0.03937 & inch (in.) \\
meter $(\mathrm{m})$ & 3.281 & foot (ft) \\
kilometer $(\mathrm{km})$ & 0.6214 & mile (mi) \\
\hline & Area & \\
\hline square kilometer $\left(\mathrm{km}^{2}\right)$ & 0.3861 & square mile $\left(\mathrm{mi}^{2}\right)$ \\
square kilometer $\left(\mathrm{km}^{2}\right)$ & 247.1 & acre \\
\hline & Mass & \\
\hline gram $(\mathrm{g})$ & 0.03527 & ounce, avoirdupois $(\mathrm{oz})$ \\
kilogram $(\mathrm{kg})$ & 2.205 & pound avoirdupois $(\mathrm{lb})$ \\
megagram, tonne $(\mathrm{Mg}, \mathrm{t})$ & 1.102 & ton, short $(2,000 \mathrm{lb})$ \\
megagram, tonne $(\mathrm{Mg}, \mathrm{t})$ & 0.9842 & ton, long $(2,240 \mathrm{lb})$ \\
\hline
\end{tabular}

Temperature in degrees Celsius $\left({ }^{\circ} \mathrm{C}\right)$ may be converted to degrees Fahrenheit $\left({ }^{\circ} \mathrm{F}\right)$ as follows:

${ }^{\circ} \mathrm{F}=\left(1.8 x^{\circ} \mathrm{C}\right)+32$

Temperature in degrees Fahrenheit $\left({ }^{\circ} \mathrm{F}\right)$ may be converted to degrees Celsius $\left({ }^{\circ} \mathrm{C}\right)$ as follows:

${ }^{\circ} \mathrm{C}=\left({ }^{\circ} \mathrm{F}-32\right) / 1.8$

Concentrations of chemical constituents in water are given either in milligrams per liter (mg/L) or micrograms per liter ( $\mu \mathrm{g} / \mathrm{L})$.

\section{Abbreviations}

$\begin{array}{ll}\mathrm{ppm} & \text { parts per million } \\ \mathrm{kg} / \mathrm{t} & \text { kilogram per tonne }(1 \mathrm{~kg} / \mathrm{t}=1000 \text { times } 1 \mathrm{ppm}) \\ \mathrm{ppb} & \text { parts per billion } \\ \mu \mathrm{m} & \text { micron }\end{array}$




\title{
Sediment-Hosted Stratabound Copper Deposit Model
}

\author{
By Timothy S. Hayes, Dennis P. Cox, Nadine M. Piatak, and Robert R. Seal, II
}

\section{Abstract}

This report contains a descriptive model of sedimenthosted stratabound copper (SSC) deposits that supersedes the model of Cox and others (2003). This model is for use in assessments of mineral resource potential. SSC deposits are the second most important sources of copper in the world behind porphyry copper deposits. Around 20 percent of the copper in the world is produced from this class of deposits. They are also the most important sources of cobalt in the world, and they are fourth among classes of ore deposits in production of silver. SSC deposits are the basis of the economies of three countries: Democratic Republic of Congo, Poland, and Zambia. This report provides a description of the key features of SSC deposits; it identifies their tectonic-sedimentary environments; it illustrates geochemical, geophysical, and geoenvironmental characteristics of SSC deposits; it reviews and evaluates hypotheses on how these deposits formed; it presents exploration and assessment guides; and it lists some gaps in our knowledge about the SSC deposits. A summary follows that provides overviews of many subjects concerning SSC deposits.

\section{Summary of Sediment-Hosted Stratabound Copper Deposit Model}

\section{Description of Key Features}

Sediment-hosted stratabound copper (SSC) deposits are bodies of disseminated, cementing, and lesser veinlet-hosted copper $(\mathrm{Cu})$ minerals that are peneconformable with their sedimentary or metasedimentary host rocks. These SSC deposits are characterized by strong zoning of the ore minerals laterally along and across the bedding, from pyrite, to chalcopyrite, to bornite, to chalcocite, and to hematite. Chalcocite and bornite zones are typically the ore zones.

SSC deposits occur in three subtypes divided by host lithology and by the corresponding type of reductant that precipitated sulfur $(\mathrm{S})$ and $\mathrm{Cu}$ from warm $\left(75-220^{\circ} \mathrm{C}\right)$, oxidized (hematite-stable), metals-transporting, sedimentary brines.
The three subtypes, their typical host lithologies, and their corresponding reductants are (1) reduced-facies type: black to gray to green shale, siltstone, mudstone, or carbonaceous dolosiltstone containing solid amorphous organic matter and pyrite; (2) sandstone-type: gray, well-sorted, fine- to coarsegrained sandstone containing petroleum, probably sour gas in most cases; and (3) red-bed type: gray, poorly to moderately sorted, and commonly conglomeratic fluvial sandstone containing carbonized plant fragments from silt-size up to whole logs. These black, gray, white, or green host rocks either lie atop or are enclosed within thick (greater than $300 \mathrm{~m}$ and commonly greater than $1 \mathrm{~km}$ ) sequences of red beds. The association with red beds is an important distinction from other $\mathrm{Cu}$ deposits found in sedimentary rocks.

Reduced-facies and sandstone $\mathrm{Cu}$ deposits can be quite large (tens of millions to more than a billion tonnes of ore), whereas red-bed-type deposits rarely have as much as 10 million tonnes of ore. Outside of the Central African Copperbelt, $\mathrm{Cu}$ grades of reduced-facies-type deposits average 1.38 percent $\mathrm{Cu}$; sandstone-type deposits average 1.08 percent $\mathrm{Cu}$; and red-bed-type deposits average 2.09 percent $\mathrm{Cu}$ (Parks and others, U.S. Geological Survey, written commun., 2012). Average grades of deposits in the Central African Copperbelt are higher: 2.59 percent $\mathrm{Cu}$ for reduced-facies-type deposits and 2.20 percent for sandstone deposits. SSC deposits are an important source of other metals, ranking first among all deposit types in world cobalt (Co) production and fourth among all deposit types in silver (Ag) production. Twentyfive percent of SSC deposits contain $\mathrm{Ag}$, grading between 2 and $200 \mathrm{~g} / \mathrm{t}$, and 14 percent of SSC deposits contain Co, grading between 0.05 and 0.5 percent in primary ores (Parks and others, U.S. Geological Survey, written commun., 2012). Those that contain byproduct Ag do not contain byproduct Co and vice versa; only the Kupferschiefer, which contains both byproduct metals, is an exception.

Deposits are confined to a limited package of sedimentary beds. Reduced-facies deposits have the geometry of sheets. Sandstone-type deposits are tabular to lens-like. Red-bedtype deposits are lenses of $\mathrm{Cu}$-bearing rock. The lateral extent of entire mineralizing systems is enormous, and because the $\mathrm{Cu}$ source rocks, typically within the red-bed packages, have nowhere been fully distinguished and mapped, the total dimensions are not known. 


\section{Regional Environment}

SSC deposits formed in sedimentary basins that now vary from virtually undeformed to intensely folded and thrust-faulted. These deposits are hosted by sedimentary-rock sequences that were deposited within 20 to 30 degrees of the paleo-equator, and thus associated with hot, dry climates that produced thick packages of red beds and commonly also produced evaporites (Kirkham, 1989). These thick packages of red beds were deposited in either proto-oceanic rifts or as post-collisional molasse. Ore-hosting lithologies for reducedfacies deposits are those that immediately mark the transgression in overall transgressive packages of rocks. Depositional environments of such beds include low sedimentation rate open marine shelves, coastal sabkhas, and subtidal carbonate shelves. Sandstone-type host rocks were deposited in subtidal nearshore, beach, eolian, and fluvial environments. The host rocks of red-bed-type deposits are fluvial or, in rare cases, deltaic sandstones. Faults at high angles to the host beds are found at many SSC deposits. Some of these faults may have been conduits along which warm metals-transporting brines moved upward across strata before spreading within permeable sandstone host beds or before spreading below impermeable reduced-facies host beds. Locations where reduced-facies host rocks onlap basement paleohighs are particularly favorable. Deposits at a few places appear to be within rocks that were deformed by strong halokinesis.

\section{Hypogene Ore and Gangue Characteristics and Alteration}

In unmetamorphosed SSC deposits, pyrite was replaced by chalcopyrite, which was replaced in turn by bornite, then by chalcocite. Further, pyrite was replaced by magnetite (rarely) or hematite (commonly). A fine dusting of authigenic hematite is found in parts of the chalcocite zone in all deposits. $\mathrm{Cu}$ sulfides also replaced carbonaceous materials in the sedimentary host rocks at essentially every scale. Where organic matter or organic carbon compounds were not directly replaced by the $\mathrm{Cu}$ sulfides, the organic materials were altered chemically and physically, changing from predominant alginite to predominant bitumen, or they were oxidized to dissolved carbonate species and precipitated as ore-stage carbonates. $\mathrm{Cu}$ minerals occur as disseminated 0.01 -to- $5 \mathrm{~mm}$ grains in clusters commonly following coarser grained laminae in the host sediment. Grains of $\mathrm{Cu}$ sulfide most commonly occur interstitially to detrital silicates or interstitially to carbonate allochems.

Some gangue minerals in SSC deposits are zonally arranged with their appearance boundaries parallel to the zonation of sulfides. As with the sulfides, most of these gangue minerals are cements of the sedimentary rocks and replacements of earlier detrital and cementing minerals. Pyrite is found in deposit-fringing zones. Iron (Fe)-rich calcite cements are found within pyritic zones of sandstone $\mathrm{Cu}$ deposits at
Spar Lake and Dzhezkazgan (Hayes, 1984, 1990; Gablina and Tsepin, 1975). Authigenic K-feldspar is found as overgrowths on pre-existing detrital $\mathrm{K}$-feldspar grains and as cements and replacements in ore zones of some reduced-facies and sandstone $\mathrm{Cu}$ deposits. In fine-grained dolomitic siltstones in the Democratic Republic of Congo and Zambia, authigenic quartz, $\mathrm{Cu}$ sulfides, and dolomite replaced crystals and nodules of anhydrite. Manganese (Mn) carbonates or oxides occur at fringes of SSC ores in some systems. Metasomatic tourmaline described from Zambia and the Democratic Republic of Congo is an unexpected mineral found as an ore-stage product in SSC deposits. Barite is found in some SSC ores, and it may be present continuing into altered rocks through which the $\mathrm{Cu}$ was transported.

The increasingly hematite- and albite-rich assemblages in the "upstream" direction for metals-transporting solutions (indicated by the passage from pyritic to $\mathrm{Cu}$-sulfide-rich to hematitic zones) at several SSC systems probably continue into rock where $\mathrm{Cu}$ is depleted rather than added. Such rock is comparable in position and genetic significance, although not in geometry, with the altered tongues of sandstone roll-front uranium (U) deposits. There are other sodic minerals that probably signal metals mobilization and depletion from altered rocks in some systems.

\section{Supergene Ore and Gangue Characteristics}

In the Central African Copperbelt, $\mathrm{Cu}$ probably undergoes locally significant supergene enrichment as chalcocite, covellite, and native copper (and probably djurleite, some anilite, and possible traces of low digenite) below a zone of leached capping typically 30 to $90 \mathrm{~m}$ thick extending from the surface and beneath a zone of oxide enrichment. The leached zone typically contains minor malachite and plancheite. The underlying oxide $\mathrm{Cu}$ zone has abundant malachite, azurite, other $\mathrm{Cu}$ oxides, and native copper, and extends to as much as a few hundred meters from the surface. Still deeper is a zone of secondarily enriched chalcocite-rich ore that may extend at least to $400 \mathrm{~m}$ depth and locally to as much as $800 \mathrm{~m}$. This enrichment extends far below the modern water table. Although it is clear that supergene enrichment as chalcocite has occurred in central Africa, the appearance, unchanged from the time of Bateman (1930), is that "perhaps the major part" of the chalcocite is hypogene.

Co in Central Africa is enriched residually within the zone of weathering, a different behavior than $\mathrm{Cu}$. "Cobalt caps" commonly extend from surface into the zone of $\mathrm{Cu}$ oxide enrichment. Co minerals in this environment are heterogenite-3R, kolwezite, sphaerocobaltite, cobaltoan dolomite, and cobaltoan calcite.

Outside of Central Africa, in most climates $\mathrm{Cu}$ is fixed in the weathering environment as malachite, brochanthite, beerbottle limonite, and other $\mathrm{Cu}$ oxides, and supergene enrichment is insignificant. 


\section{Geochemical Characteristics}

Major-element compositions of mineralized rocks and country rocks show major metasomatic effects from SSC mineralizing systems. The Konkola deposit, Zambia, and deposits of the Western Montana Copper Sulfide Belt, United States, record potassium $(\mathrm{K})$ enrichment accompanying $\mathrm{Cu}$ deposition. Both of those deposits also record barium (Ba) enrichment. In the altered hematitic rocks where metals were mobilized, the Western Montana Copper Sulfide Belt system shows sodium (Na) enrichment and extreme calcium (Ca) leaching. The major element, magnesium $(\mathrm{Mg})$, is anomalous in many SSC deposits. The minor element, boron (B), is anomalous in some of the SSC systems in Zambia. It appears that SSC deposit mineral zonations are comparable with chromatographic separations of elements so that small variations in solution concentrations, temperature, or host-rock conditions can shift the positions of a mineral or elemental front in one system relative to another or relative to a different place within the same system.

Many trace elements are found in anomalous concentrations in zonal arrangements near and in SSC deposits. $\mathrm{Ag}$ and $\mathrm{Co}$ are common byproduct metals from within zones of $\mathrm{Cu}$ ore. Ag is nearly totally confined to chalcocite- and bornitebearing zones, but Co extends to within pyritic zones. Also certainly among the trace elements enriched in deposit-related zonations are antimony $(\mathrm{Sb})$, arsenic $(\mathrm{As}), \mathrm{Ba}$, lead $(\mathrm{Pb})$, $\mathrm{Mn}$, mercury $(\mathrm{Hg})$, rhenium ( $\mathrm{Re})$, and zinc $(\mathrm{Zn})$. The trace elements, gold $(\mathrm{Au})$, palladium $(\mathrm{Pd})$, and platinum $(\mathrm{Pt})$, are found in anomalous concentrations, and the rock constitutes ore many places in a zone that parallels the sulfide zonation in a gentle cross through bedding along the footwall of Kupferschiefer $\mathrm{Cu}$ deposits in Poland. $\mathrm{U}$ and $\mathrm{V}$ may reach ore grades, either separately or together, in some red bed subtype deposits, and $\mathrm{U}$ also reaches ore grades in certain deposits of the Central African Copperbelt. Ferroan and manganoan carbonates of sandstone $\mathrm{Cu}$ deposits may be an identifier of mineralizing systems that extend well outside of the ore zones themselves. Some of these carbonates formed at the downstream fringes of a mixing and reaction zone between introduced metalliferous brine and reservoirs of natural gas (Hayes and others, 2012), and it is likely that they mark the locations of coupled redox reactions between $\mathrm{SO}_{4}{ }^{2-}$ of the metalstransporting brine and carbon in the reservoired methane $\left(\mathrm{CH}_{4}\right)$. Such a reaction could be expressed as:

$$
\begin{aligned}
\mathrm{Ca}^{2+} & +2 \mathrm{CuCl}_{0, \mathrm{aq}}+\mathrm{SO}_{4}^{2-}+\mathrm{CH}_{4}=\mathrm{Cu}_{2} \mathrm{~S} \\
& +\mathrm{CaCO}_{3}+2 \mathrm{Cl}^{-}+2 \mathrm{H}^{+}+\mathrm{H}_{2} \mathrm{O}
\end{aligned}
$$

The physical properties and compositions of hydrothermal fluids that formed SSC deposits were poorly known until recent years. From fluid-inclusion microthermometry studies, ore deposition in the Central African Copperbelt reduced-facies-type deposits took place in two stages. The first stage that deposited the main volume of disseminated and replacement sulfides produced only tiny liquid-vapor fluid inclusions with no solid daughter minerals; the second stage of veinlet-controlled sulfides produced large inclusions with multiple daughter minerals including halite and sylvite as well as several other daughters or trapped solids. At the early stage, saline fluids (typically in excess of 15 eq. wt. $\% \mathrm{NaCl}$ ) transported $\mathrm{Cu}$ at 130 to $220^{\circ} \mathrm{C}$. Deposition occurred partly by mixing with low-temperature less-saline groundwater, possibly just ordinary pre-ore groundwater, with salinity below 10 eq. wt. $\% \mathrm{NaCl}$. The result of the mixing was large ranges in homogenization temperatures and salinities. Later, probably during or after the Lufilian Orogeny, second-stage $\mathrm{Cu}$ mineralization took place from fluids with temperatures over 200 to as much as $415{ }^{\circ} \mathrm{C}$ and with salinities of 35 to 55 eq. wt. $\% \mathrm{NaCl}$. Sources of the fluids are not known for either stage, but with the extraordinary salinities of the second-stage (veinlet) fluids, dissolved evaporites are likely sources for that salinity. Second-stage (veinlet) mineralization probably does not contribute large portions of the total $\mathrm{Cu}$ endowment. From fluid-inclusion microthermometry studies of three sandstone $\mathrm{Cu}$ systems, mixing was more important than in reduced-facies deposits. Temperature and salinity ranges were similar to the earlier of the two stages in Central African reduced-facies deposits.

Compositions of main-stage fluid-inclusion volatiles are known for a single case. Quadrupole mass-spectrometric analysis of ore-stage inclusion fluids from the Spar Lake sandstone $\mathrm{Cu}$ deposit has demonstrated that mineralization took place where a metals-transporting brine at about $200{ }^{\circ} \mathrm{C}$ mixed and reacted with reservoired sour gas. The metalstransporting brine was an aqueous fluid lacking important amounts of dissolved $\mathrm{CO}_{2}, \mathrm{CH}_{4}$, or $\mathrm{H}_{2} \mathrm{~S}$. It entered the gas reservoir from below before spreading in the reservoir sandstones and reacting with cooler natural gas. Ore was deposited as the brine reacted with $\mathrm{CH}_{4}$ and $\mathrm{H}_{2} \mathrm{~S}$ in the natural gas toward lower $\mathrm{fO}_{2}$. Neither the metals-transporting brine nor the natural gas had any component of magmatic or subcrustal fluids.

Organic geochemical studies have been completed at two reduced-facies-type deposits. At White Pine, United States, Nonesuch Shale organic matter was thermally matured during mineralization. In the Kupferschiefer, Poland and Germany, various organic chemical measurements, organic petrologic studies, and the spectral fluorescence intensities of extracts indicate a high degree of oxidation as well as high thermal maturity in the basal section of mineralized shale, interpreted to be caused by maturation of organics in the shale by ascending, hot, oxidizing, metalliferous brine.

All studied reduced-facies-subtype deposits have large ranges of S-isotope values among their sulfides, and they have some sulfides that have light values of $\delta^{34} \mathrm{~S}$ reaching commonly below -10 per mil (\%o). This distribution is universally interpreted as evidence that $\mathrm{S}$ now found in $\mathrm{Cu}$ sulfides was bacteriogenically fractionated from seawater sulfate and deposited as Fe sulfides at a time shortly after host-rock sedimentation just below the sediment-seawater interface. This $\delta^{34} \mathrm{~S}$ distribution in $\mathrm{Cu}$ sulfides is probably because of replacement of early diagenetic pyrite without appreciable redistribution of S isotopes. Some studies have demonstrated addition of 
heavy $\delta^{34} \mathrm{~S}$ sulfides after precipitation of the early diagenetic pyrite, probably at ore-stage, and probably by thermochemical sulfate reduction (TSR).

Values of S isotopes from the Spar Lake sandstone $\mathrm{Cu}$ deposit, U.S.A., are remarkably similar to distributions through the full diagenetic history of petroleum producing basins (Hayes and others, 2012). The S-isotope distribution indicates an original derivation of all the $\mathrm{S}$ by bacterial sulfate reduction (BSR) of seawater sulfate, followed by sequestering of the sulfide in organic matter of petroleum source rocks. With burial, maturation of the organic matter produced petroleum with relatively homogeneous sulfide $\delta^{34} \mathrm{~S}$ values $15 \pm 5 \%$ less than the original seawater $\mathrm{SO}_{4}{ }^{2-}$. With further burial, thermal cracking produced $\mathrm{H}_{2} \mathrm{~S}$ with the same relatively homogeneous $\delta^{34} \mathrm{~S}$ that migrated and was emplaced in sour-gas reservoirs. Much of the ore-stage $\mathrm{Cu}$ sulfides simply precipitated that $\mathrm{H}_{2} \mathrm{~S}$, producing a favored small range of S-isotope values $15 \pm 5 \%$ lighter than the $\delta^{34} \mathrm{~S}$ of original seawater sulfate. There was an additional contribution of sulfide from later Thermochemical Sulfate Reduction (TSR) operating on formation water and (or) on sulfate of the metals-transporting brine in redox reactions with reservoired hydrocarbons (eqn. 1). The sulfide added by ore-stage TSR was typically isotopically heavier than the reservoired sour-gas $\mathrm{H}_{2} \mathrm{~S}$.

Carbon-isotope studies of ore-associated carbonate minerals from reduced-facies and sandstone $\mathrm{Cu}$ deposits include some low $\delta^{13} \mathrm{C}$ values. The low- $\delta^{13} \mathrm{C}$-carbonates reflect oxidation of solid organic matter or petroleum to provide $\mathrm{C}$ for deposition of the carbonates.

Integrated S-isotope, C-isotope, and organic geochemical studies along with elemental geochemical studies of the Kupferschiefer showed that total $\mathrm{C}_{\text {org }}, \mathrm{C} / \mathrm{S}$ ratios, and hydrogen indices of the organic materials are facies-related and do not correlate with $\mathrm{Cu}$ grade. Those parameters were established when pyrite was deposited, probably by BSR from seawater during earliest diagenesis. $\mathrm{Fe}-\mathrm{C}_{\mathrm{org}}-\mathrm{S}$ relations and ore microscopy indicated that, in parts of the Kupferschiefer bed with grades of 0.1 to as much as 6 percent $\mathrm{Cu}$, the pyrite was replaced by $\mathrm{Cu}-\mathrm{Fe}$-sulfides, and the isotopic composition of the replaced pyrite was inherited. With yet more intense mineralization in the lower part of the Kupferschiefer bed, there was (1) deposition of sparry calcite with $\delta^{13} \mathrm{C}$ values substantially lowered from the typical marine values found in the top of the shale, coupled with (2) reciprocal change of $\delta^{13} \mathrm{C}$ in kerogen and bitumen to heavier isotopic values, and (3) an addition of $\mathrm{Cu}$ sulfides with heavier $\delta^{34} \mathrm{~S}$ deposited by TSR of ore solution $\mathrm{SO}_{4}$ coupled with oxidation of the organic carbon to carbonate. $\mathrm{Cu}$ grades greater than 8 percent in the lowest layers of the shale are dominated by the thermochemically reduced S from late in the ore stage. At Spar Lake, the isotopically light distal-fringe carbonates are coupled with the sulfide that was themochemically reduced at ore-stage from $\mathrm{SO}_{4}$ in the metals-transporting brine, in redox reactions like equation 1 with the reservoired $\mathrm{CH}_{4}$. That sulfide from orestage thermochemical reduction is identified where samples have the combination of heavy $\delta^{34} \mathrm{~S}$ values in $\mathrm{Cu}$ (or $\mathrm{Pb}$ ) sulfides together with very light $\delta^{13} \mathrm{C}$ values in ore-stage calcite.
The ore processes at Sangerhausen and Spar Lake are similar. They simply use different reductants: solid organic material for the Kupferschiefer, $\mathrm{CH}_{4}$ for Spar Lake.

Isotopic age dating of SSC deposits has suffered from the lack of easily dateable minerals within the deposits themselves. A few direct dating attempts have been made with limited success. Re-Os ages of $\mathrm{Cu}$ sulfides from different Kupferschiefer deposits have varied from the same time as shale deposition (within isotopic age uncertainty), to 55 million years after shale deposition, to 19 million years after shale deposition at Lubin, Poland. The Re-Os age at Lubin is close to agreement with the paleomagnetic age of Rote Fäule alteration in that district. Re-Os dating of disseminated bornite and chalcopyrite from Konkola, Zambia, yielded an age of $816 \pm 62 \mathrm{Ma}$. That age is probably correct, but the large uncertainty, which resulted from high concentrations of common osmium in the sulfides, limits the utility of the dating. At White Pine, several age-dating studies have closely constrained the sequence and timing of ore-related events. Rapid deposition of more than a kilometer of Copper Harbor aquifer red beds and the lower Nonesuch reduced-facies host rocks and calcite diagenesis (interpreted as accompanying mainstage $\mathrm{Cu}$-sulfide mineralization) all took place over no more than 15 million years after deposition of an upper Portage Lake Lava andesite flow, probably within just 6 million years. Basin inversion, compressional tectonics, second-stage $\mathrm{Cu}$ mineralization at White Pine, and mineralization of the Keweenawan Native Copper district had all taken place within the next 30 to 70 million years after that. Aleinikoff and others (2012) obtained a ${ }^{207} \mathrm{~Pb} /{ }^{206} \mathrm{~Pb}$ age of $1,409 \pm 8 \mathrm{Ma}$ on ore-stage xenotime overgrowths on detrital zircons from Spar Lake. In host rocks that were deposited after 1,469 $\pm 3 \mathrm{Ma}$ and before $1,454 \pm 9 \mathrm{Ma}$, the xenotime-indicated mineralization age, 40 to 60 million years after host-rock deposition, is reasonable for the time at which a subsurface mineralizing brine would have reacted with reservoired sour gas.

\section{Petrology of Associated Sedimentary Rocks}

Common minerals in the sequence of diagenetic changes to sedimentary rocks are, for the host rocks of SSC deposits, important ore-stage gangue minerals. Most are not unusual or anomalous minerals in sedimentary diagenesis. Anhydrite that was replaced by quartz, dolomite, and sulfides in Zambian Copperbelt host rocks is an example. Just as in the changes seen in the diagenesis of anhydrite, the diagenetic changes seen in sandstone $\mathrm{Cu}$ deposits are all familiar in ordinary diagenesis, except, mainly, for the addition of $\mathrm{Cu}$ minerals. Every authigenic gangue mineral that is zonally distributed in the Spar Lake sandstone $\mathrm{Cu}$ deposit, with the exceptions of barite and $\mathrm{Ba}$ mica, has been found elsewhere as the product of ordinary diagenesis of sandstones. Many of the authigenic gangue minerals arranged zonally at Spar Lake have been found in the same paragenetic sequence as they appear at the deposit but with greater and greater burial depth and temperature in the Tertiary sandstones of the Gulf Coast in Texas. 


\section{Petrology of Associated Metamorphic Rocks}

Many SSC deposits were simply metamorphosed along with the rocks of their host sedimentary sequences. Metamorphic devolatilization reactions are of interest for SSC deposits and their host sections. One is simply, hematite $=$ magnetite $+\mathrm{O}_{2}$. This reaction has been demonstrated in the Belt Supergroup rocks, United States. The importance is that original red beds of SSC systems can be metamorphosed to magnetite-bearing quartzites. This reaction may have produced magnetite quartzites that are several kilometers thick in the Udokan Series in Russia. A second metamorphic devolatilization reaction is pyrite $=$ pyrrhotite $+S_{2}$. Almost all SSC deposit-bearing sequences that are at amphibolite grade have some pyrrhotite, and a few have abundant pyrrhotite. This pyrrhotite probably is a metamorphic product, not an orestage precipitate nor a pre-ore phase.

\section{Genetic Theory and Mineral Resource Potential Assessment}

SSC deposits require six elements to form. Evaluating the potential for SSC deposits using these six elements is analogous with evaluating a petroleum exploration "play." Petroleum plays are analyzed considering the elements: (1) source rocks, (2) maturation, (3) migration, (4) reservoir rocks, (5) trap, and (6) seal. In order to form a SSC deposit, there must be (1) $\mathrm{Cu}$ source rocks, (2) liberation (dissolution) of $\mathrm{Cu}$ from those source rocks by a hot (mature, typically greater than $100^{\circ} \mathrm{C}$ ) sedimentary brine, (3) migration of the $\mathrm{Cu}$-bearing brine, (4) non-oxidized, typically pyrite-bearing host rocks, (5) seal rocks (confining beds for the upward seeking metals-transporting brine), and (6) traps. The traps are physical and redox chemical traps.

A basin that contains $\mathrm{Cu}$ source rocks and host rocks is the fundamental unit that defines a permissive tract for exploration or assessments for SSC deposits. (1) The basin must contain some minimum, perhaps at least $300 \mathrm{~m}$, of oxidized, hematitestable permeable source rocks, probably red beds, with a small $\mathrm{Cu}$ content. Subaerial basaltic or other volcanic rocks are a positive factor as alternative $\mathrm{Cu}$ source rocks. (2) The basin must have undergone flow of hot (greater than $100^{\circ} \mathrm{C}$, and some places greater than $220^{\circ} \mathrm{C}$ ), briny, oxidized groundwater from an extensive catchment basin, cross-stratally upward toward host rocks. Because the metals-transporting solutions were brines, it is a positive factor if the basin contains or contained evaporites, either continental or marine. Evaporite presence either upsection or downsection relative to $\mathrm{Cu}$ source rocks and host rocks is permissive. It would be favorable if the basin has a history of halokinesis. (3) There must have been a flow system for transport of $\mathrm{Cu}$ in the sedimentary brines from source rocks to host rocks. Various types of flow systems with various hydrologic drives may have served, but the aquifers, at the time of mineralization, were confined so that brines were upwardseeking relative to stratigraphy. The flows probably had directions commensurate with dewatering the basin. (4) The basin must contain either organic-rich poorly permeable sedimentary beds that could provide solid organic matter as a reductant, permeable beds with reservoired petroleum vapor or liquids to act as reductant, or permeable beds with carbonized plant fragments to act as a reductant. (5) The basin must have had sufficient structural deformation to create traps. (6) The basin must have confining beds that are the upper parts of the reduced-facies host units, that overlie petroleum reservoirs, or that overlie sandstones containing carbonized plant fragments.

A permissive tract for SSC deposits is outlined by delineating an area on a geologic map that includes chemically reduced host rocks of any of the three types and generally stratigraphically lower red beds or former red beds and (or) flood basalts greater than or equal to $300 \mathrm{~m}$ thick. The exact thickness of source rocks needed to generate a metals-transporting brine is not known. A thickness of $300 \mathrm{~m}$ is considered to be near the minimum needed, and greater thicknesses can be considered more favorable. The tract may include known SSC deposits and prospects of any of the three subtypes. The tract outline approximately parallels the outline of the sedimentary basin, as depicted on the scale of the geologic map available for tract delineation. The presence of evaporite beds in the sequence and faults at high angles to bedding are particularly favorable.

\section{Environmental Geology and Effects of Mining}

Chalcocite group minerals and bornite in SSC deposits are fairly stable under oxidizing conditions. Pyrite is found only in trace amounts or not at all in the high-grade zones, but its content increases outward as $\mathrm{Cu}$ grade decreases. Therefore, environmental issues associated with the oxidation of pyrite can be minimized if mining avoids pyritic zones. The calcite and feldspar (or clays) present in some host rocks will help mitigate against the development of acid mine drainage. However, minerals such as $\mathrm{Pb}$-bearing galena, sphalerite, which commonly contains cadmium, and As minerals in such as tetrahedrite/tennantite and luzonite, found associated with these deposits, can be disturbed during mining or concentrated during ore processing and can potentially weather and release environmentally harmful trace elements.

Tailings from reduced-facies-subtype deposits consistently contain around 0.2 percent $\mathrm{Cu}$, but these have not proven to cause any major environmental problems (Sracek and others, 2010; E\&MJ, 1986b; U.S. Environmental Protection Agency, 1994; Williams and others, 2002). Secondary minerals on waste dumps include various $\mathrm{Cu}$-, $\mathrm{Zn}$-, and $\mathrm{Pb}$-sulfates, chlorides, and carbonates. Gypsum and poorly crystalline $\mathrm{Fe}$-oxides are reported as secondary phases in tailings. For tailings samples from the White Pine deposit, no acid-generating capacity was detected (Williams and others, 2002). The tailings of sandstone-subtype deposits from Montana contain low concentrations of metals like $\mathrm{Cd}$ and $\mathrm{Sb}$, contain some leachable $\mathrm{Pb}$, and contain $\mathrm{S}$ as sulfide ranging from 0.01 to 0.08 wt. $\%$, which results in acid production values of only 0.3 to $2.5 \mathrm{~kg} / \mathrm{t} \mathrm{CaCO}_{3}$. The net neutralization potentials of ore, waste rock, and tailings from Montana sandstone $\mathrm{Cu}$ deposits are reported as variable but generally low, from 2.8 to $10 \mathrm{~kg} / \mathrm{t}$ 
Sediment-Hosted Stratabound Copper Deposit Model

$\mathrm{CaCO}_{3}$. The favorable acid base accounting results are because of the low amounts of sulfides and presence of calcite in the tailings (U.S. Forest Service and others, 2009).

Overall, the metal mobility in mine-drainage waters from these deposits is low to moderate. Waters draining mines and tailings generally has near-neutral to moderately alkaline $\mathrm{pH}$ and low dissolved-metal contents. However, mining of Kupferschiefer deposits in Germany has locally contaminated stream sediments, soils, and surface water and groundwater with metals such as $\mathrm{Zn}, \mathrm{Pb}, \mathrm{Cu}$, As, and $\mathrm{Cd}$. The metals and $\mathrm{S}$ came predominantly from flue dust and slag from smelting (Schreck and Glaesser, 1998; Strauch and others, 2001; Schreck and others, 2005). In addition to the dissolution of metals from the flue dust, metals are dispersed into the environment as fine particles blown by the wind from waste or ore piles (Matheis and others, 1999).

Mining in the Central African Copperbelt in Zambia has led to elevated metal and sulfate concentrations in water that drained the mines and processing plants (Pettersson and others, 2000; Norrgren and others, 2000; Pettersson and Ingri, 2001). Though elevated concentrations of $\mathrm{Co}, \mathrm{Ni}$, and $\mathrm{Zn}$ are present, the concentrations do not exceed drinking water guidelines. Ore from Montana sandstone $\mathrm{Cu}$ deposits leached low concentrations of $\mathrm{Cu}(0.02-0.04 \mathrm{mg} / \mathrm{L})$ and $\mathrm{Mn}(0.03 \mathrm{mg} / \mathrm{L})$ and resulted in neutral $\mathrm{pH}$ water. Groundwater from monitoring wells frequently contains less than detectable dissolved metals concentrations. The $\mathrm{pH}$ of the groundwater is usually near neutral or slightly acidic (U.S. Forest Service and others, 2009).

Smelters are clearly the greatest environmental risks associated with mining SSC deposits. Soils within $1 \mathrm{~km}$ of the smelters in Poland contained elevated concentrations of $\mathrm{Cu}$, $\mathrm{Pb}, \mathrm{Cd}$, and Zn (Roszyka and Szerszen, 1988; Helios Rybicka and Jędrzejczyk, 1995). The concentrations of $\mathrm{Pb}$ and $\mathrm{Cd}$ in ground and surface water in the vicinity of the smelters exceed World Health Organization (WHO) guidelines for drinking water (World Health Organization, 2006).

Detailed ecological studies have been carried out along the Kafue River, which flows through the Central African Copperbelt in Zambia. $\mathrm{Pb}$ in a grass species, three species of fish, and the liver of the lechwe (antelope species) were all anomalously high. River sediment collected downstream from several mines and near a city with major ore-processing facilities was significantly more toxic to zebrafish and tilapia than sediment collected farther downstream (Mwase and others, 1998). Near the Glogow smelters of Kupferschiefer ores in Poland, the concentrations of metals in cultivated consumable plants correlated with nearness to the smelters and with the direction and strength of prevailing winds. Other studies identified high levels of metals in tissues, milk, and excrement of cattle in the region. Discharge from the White Pine mine area has not caused measureable effects on the basis of a lack of impact on the benthic community, minor increases in chloride from mine discharges, and a lack of detectable effects on local water intakes (U.S. Environmental Protection Agency, 1994).

\section{Knowledge Gaps}

The source(s) of the metals-transporting solutions for SSC deposits remain conjectural. Brine inorganic chemistry will help determine the source(s) of the metals-transporting solutions. LA-ICPMS (laser-ablation inductively coupled plasma mass-spectrometry) or PIXE (proton-induced X-ray emission) methods promise to be successful where fluid inclusions are large enough, and encapsulated crushing followed by leaching of ore-stage authigenic minerals can be used in other such studies. However, the most reliable way to define the source(s) of metals-transporting solutions for SSC deposits would be to sample the metals-transporting solutions from an ongoing (presently active) mineralizing system. An ongoing sandstone $\mathrm{Cu}$ mineralizing system can probably be found in a basin that has production of sour natural gas and that has petroleum source rocks overlain by more than $300 \mathrm{~m}$ (preferably over $1 \mathrm{~km}$ ) of red beds, overlain by intervals that contain gray or bleached sandstones. An ongoing reduced-facies-type mineralizing system may occur in a young rifting environment at low latitudes where organic-rich sabkha dolostone beds onlap basement highs and overlie thick sections of red beds. The search might be most productive in a young aulacogen like the Afar Rift or a young trans-tensional basin like the Gulf of California.

Mapping of alteration pathways over broad areas would limit the possible groundwater flow systems that could have produced ore. Certainly, high-angle faults and zones where pillars (water-escape structures) are densely distributed, both exposed downsectionward from mineralized rocks, are targets for study. From current knowledge, sodic minerals (albite, analcime, glauberite, riebekite, Na-illite, possibly scapolite), hematite, and possibly barite will mark the paths that fluids took between $\mathrm{Cu}$ source rocks and deposits. Better than either alteration mapping or paleohydrology studies, if an active ore system is found, its hydrologic drive could be straightforwardly observed and measured.

Several studies of smaller scope would also be useful. In the Central African Copperbelt, it is still unclear whether most of the chalcocite dates from supergene enrichment or whether it is hypogene. Knowledge of supergene enrichment is far advanced since the problem was last approached there, so new methods can be brought to bear. Insufficient knowledge of the changes caused in amphibolite-grade metamorphism of SSC deposits can be addressed at places like Aynak, Afghanistan, and the Ablah Group, Saudi Arabia. Such studies are economically important because high-grade metamorphism apparently makes the rock packages more amenable to geophysical exploration by IP (induced polarization) or MT (magnetotelluric) techniques. The most immediate payback from new studies will likely come from studies of exploration methods. Two methods that need testing are natural source induced polarization and soil gas chemistry. 


\section{Introduction}

This report is a review of the geological literature about SSC deposits written in order to serve the purposes of U.S. Geological Survey (USGS) assessments of mineralresource potential. SSC deposits are concentrations of $\mathrm{Cu}$ minerals that are disseminated as cements, replacements of clasts and earlier cements, and lesser veinlets within black, gray, green, or white sedimentary rocks within or atop sequences of red beds, which are typically many hundreds to thousands of meters thick. Such deposits have been mined far back into the 4th millennium B.C. in the Middle East (Weisgerber, 2006) and since A.D. 1199 in the Kupferschiefer in central Europe (Beck, 1905, p. 492). These deposits continue to be mined at a large scale, today, in the Central African Copperbelt, Poland, Khazakstan, China, and the United States, and a large deposit of this type in Russia will come into production soon.

The report has been written to be used for the Updated National Mineral Resource Assessment of 2012. It builds on earlier published models that were used in assessments of mineral-resource potential and mineral environmental assessments by the USGS. It is an update to the descriptive model(s) of the deposit type in Cox and others (2003). The report follows the organization and choice of subject matter determined by the leadership of the USGS National Mineral Assessment Program in order to be consistent with other oredeposits models.

The SSC deposits rank second in $\mathrm{Cu}$ production among the geologic deposit types of the world, behind porphyry $\mathrm{Cu}$ deposits. These deposits also produce important byproduct metals. They are the world's largest producing deposit type for Co. They are the fourth largest producing deposit type for $\mathrm{Ag}$, behind epithermal precious metal, porphyry $\mathrm{Cu}$, and sedex $\mathrm{Zn}$-Pb-Ag-barite deposits. SSC deposits form the base of the national economy for the Democratic Republic of Congo, Poland, and Zambia.

SSC deposits have been found on every continent except Antarctica (fig. 1), and they probably also exist in Antarctica should that continent ever be explored. However, just two districts account for 82 percent of all the currently known resources of $\mathrm{Cu}$ within SSC deposits (Parks and others, U.S. Geological Survey, written commun., 2012). These are the Central African Copperbelt in Zambia and the Democratic Republic of Congo (fig. 2) and the Kupferschiefer in Germany and Poland (fig. 3). Among the 47 SSC deposits in the world that contain more $\mathrm{Cu}$ than a median porphyry $\mathrm{Cu}$ deposit, 28 are in the Central African Copperbelt and 8 are in the Kupferschiefer in Central Europe. Nonetheless, the scattering of large SSC deposits worldwide can probably be taken as evidence that additional large deposits remain to be discovered outside the Kupferschiefer and the Central African Copperbelt.

\section{Deposit Type and Associated Commodities}

\section{Synonyms}

These deposits have been termed sediment-hosted stratiform $\mathrm{Cu}$, sedimentary rock-hosted stratiform $\mathrm{Cu}, \mathrm{Cu}$ shale, $\mathrm{Cu}$ sandstone, cupriferous sandstones, sandstone $\mathrm{Cu}$, red-bed $\mathrm{Cu}$, Kupferschiefer type $\mathrm{Cu}$, marine paralic type $\mathrm{Cu}$, reducedfacies $\mathrm{Cu}$, and Revett $\mathrm{Cu}$ deposits.

\section{Brief Description}

The SSC deposits are sedimentary rock-hosted peneconformable deposits typically dominated by chalcocite but strongly zoned laterally and vertically to bornite, then to chalcopyrite, and then to pyrite (figs. 4 to 7) (Kirkham, 1989; Cox and others, 2003). Some deposits also have a zone of native copper adjacent to the chalcocite zone and away from the bornite (figs. 4 and 5). However, where these are present, it is not necessarily clear that the native copper is a part of the same mineralizing event as the sulfides (for example; Mauk and others, 1992a; Brown, 2006), and it is unclear that the native copper is hypogene rather than supergene. The SSC deposits are hosted by gray, black, green, or white sedimentary rocks in sections otherwise dominated by or underlain by red beds, and the sections commonly contain evaporites, pseudomorphs of evaporites, or other indicators of aridity. Unmetamorphosed deposits of the class have a characteristic replacement paragenesis of sulfides and oxides within which pyrite was replaced by chalcopyrite, which was in turn was replaced by bornite and magnetite in some deposits, then by chalcocite and hematite in all deposits. The Cu-bearing sulfides formed where an advancing metalstransporting solution in equilibrium with hematite reacted with pre-existing pyrite and other detrital or pre-ore authigenic components of the host rocks and mixed and reacted with indigenous, probably sulfidic, pore fluids (Rentzsch, 1974; Hayes and others, 1989; Sutton and Maynard, 2005; Hayes and others, 2012). Depositional temperatures of ore varied from less than $90{ }^{\circ} \mathrm{C}$ to as much as $220^{\circ} \mathrm{C}$ (Touwaide, 1930; Brown, 1971; Lur’ye and Gablina, 1976; Nishioka, 1983; Morrison and Parry, 1986; Hayes and others, 1989; Annels, 1989; Hayes, 1990; Breit and Meunier, 1990; Arehart and others, 1990; Gray and others, 1996; Dewaele and others, 2006; El Desouky and others, 2009; Hayes and others, 2012). Many earlier papers describe deposits of this class or address aspects of deposit genesis. Hitzman and others (2005) provided a broad-ranging earlier review of SSC deposits. 


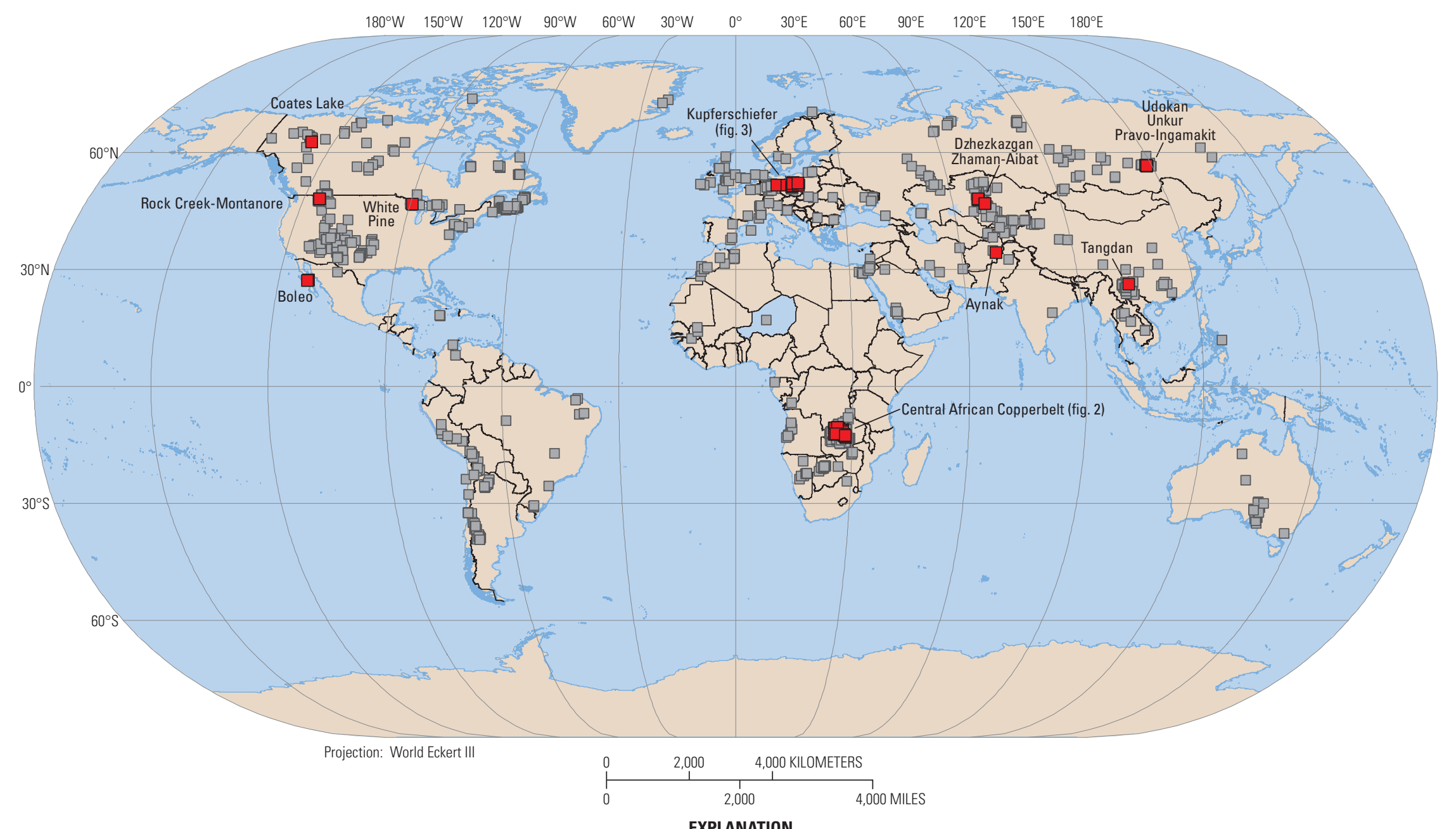

Total copper metal resources greater than 1.056 million metric tons

$\square$ Total copper metal resources less than 1.056 million metric tons

Figure 1. Locations of sediment-hosted stratabound copper (SSC) prospects and deposits of the world presently known to the U.S. Geological Survey. Deposits that have greater than 1.056 million metric tons of contained copper metal, the amount of the metal in a world median tonnage and world median grade porphyry copper deposit (Singer and others, 2008), are plotted in red. Thus, the deposits in red represent the largest and richest of the SSC deposits. Note that these are widely scattered worldwide, though the Kupferschiefer in central Europe and the Central African Copperbelt in the Democratic Republic of Congo and Zambia contain 36 of the 47 largest known SSC deposits (figs. 2 and 3). 


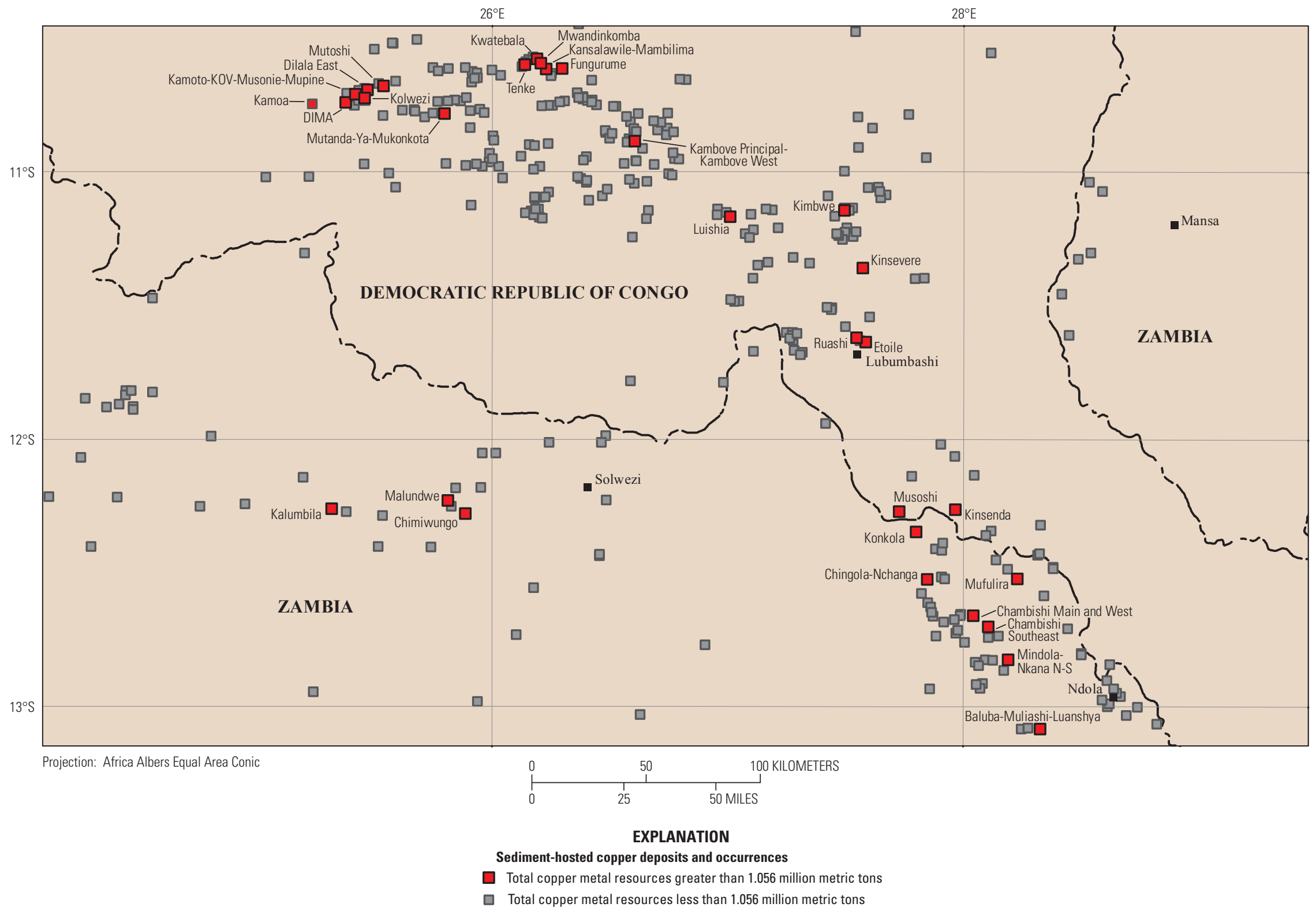

Figure 2. Locations of known sediment-hosted stratabound copper prospects and deposits of the Central African Copperbelt, Democratic Republic of Congo and Zambia. Those plotted in red have copper metal in excess of a world median grade and tonnage porphyry copper deposit. 


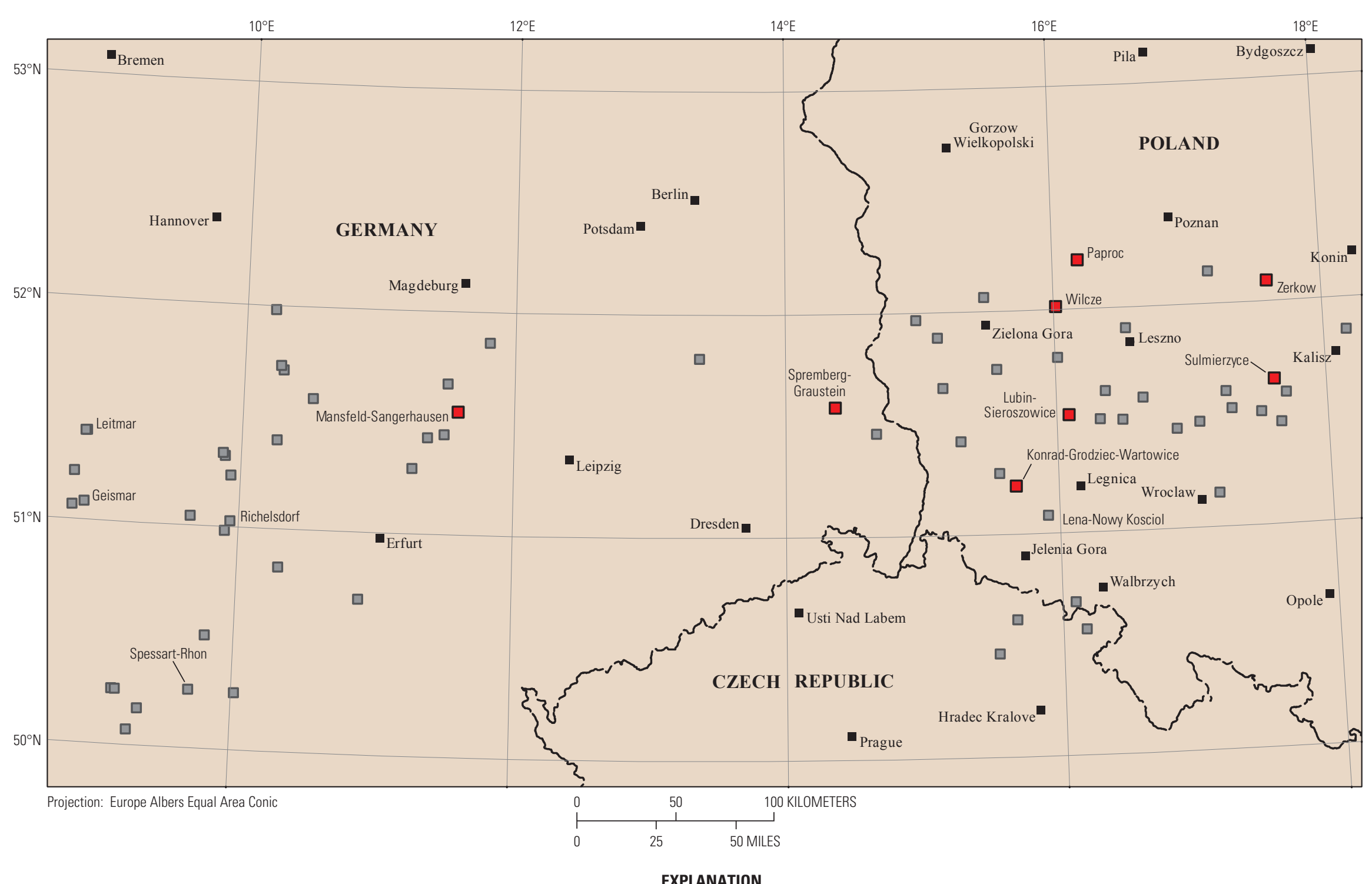

Sediment-hosted copper deposits and occurrences

Total copper metal resources greater than 1.056 million metric tons

Total copper metal resources less than 1.056 million metric tons

Figure 3. Locations of known sediment-hosted stratabound copper prospects and deposits of the Kupferschiefer in central Europe. Those plotted in red have copper metal in excess of a world median grade and tonnage porphyry copper deposit. 


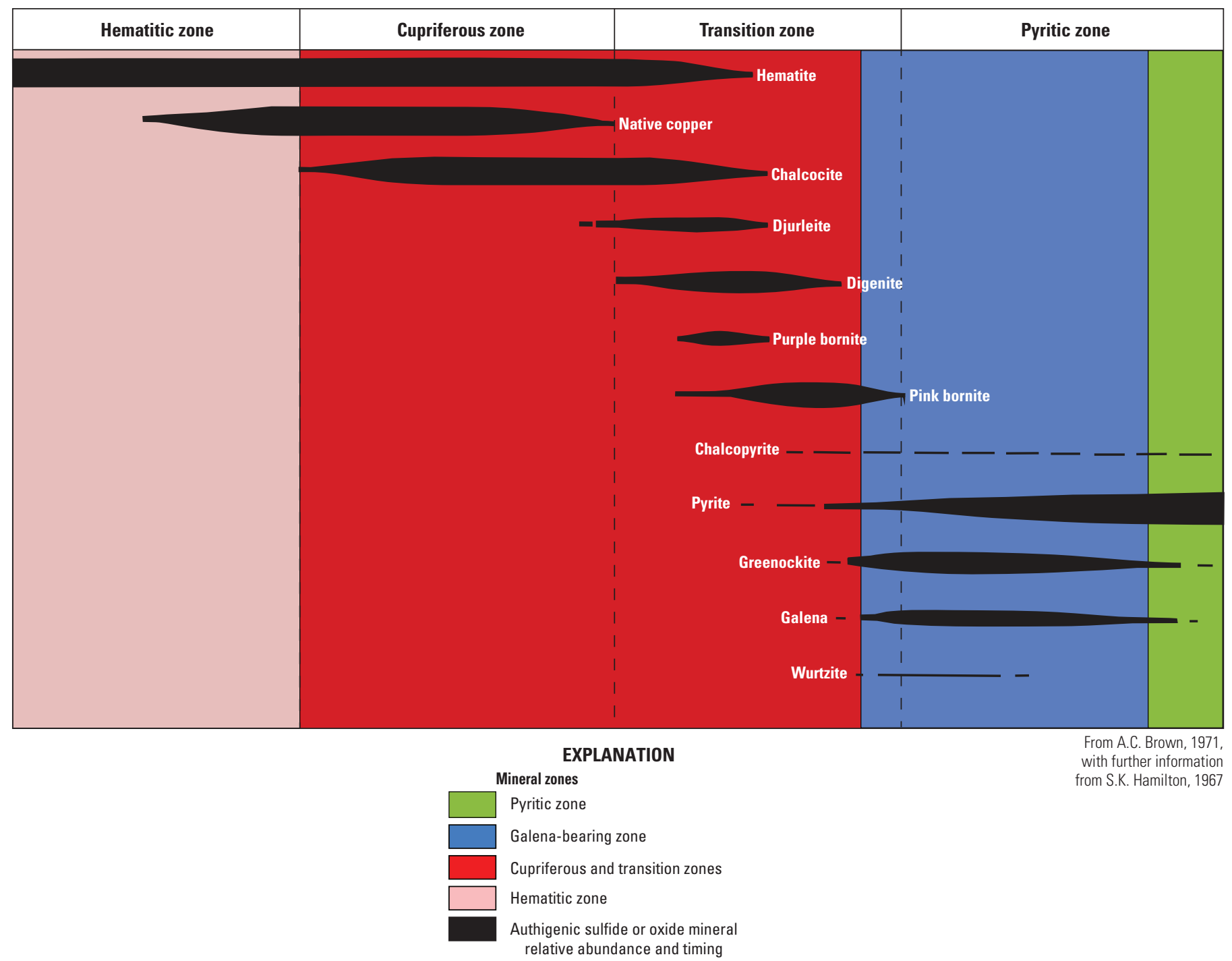

Figure 4. Ore mineral zonation of the reduced-facies-type deposits of the White Pine deposit, Michigan, from White and Wright (1966) and Brown (1971) supplemented, in the cupriferous and hematitic zones from descriptions in Brown (1971), Hamilton (1967), and observations of the first author. The diagram illustrates the distribution of authigenic minerals only in space, not in time. Colors match the mineral zones of the schematic cross section of the White Pine deposit, Michigan, shown as figure 5.

Deposits of this class are typically recognizable even where they have been metamorphosed to amphibolite or higher metamorphic grades because they still have sheetlike to tabular geometry mainly conformable with layering and have a diagnostic zonation along and across the layering of bornite to chalcopyrite to Fe sulfides. At grades of post-ore metamorphism exceeding upper greenschist, pyrrhotite may exceed or entirely displace pyrite in the zonation, and bornite commonly exceeds chalcocite.

SSC deposits are associated with red beds or former red beds where metamorphism has changed those rocks. The deposits are stratabound. That is, they are restricted to a particular stratigraphic interval within a sedimentary-rock sequence. However, the deposits do not perfectly follow sedimentary bedding. Association with red beds and stratabound character distinguish deposits of this class from other classes of sediment-hosted $\mathrm{Cu}$ deposits. For example, sediment-hosted $\mathrm{Cu}$ deposits at Mt. Isa, Australia, although they are stratabound, are not associated with red beds, occurring instead within dolostones near a facies change to black shales (Hitzman, 1983). Although $\mathrm{Cu}$ skarns are sediment-hosted, they are spatially and genetically associated with intermediate to acidic porphyries, and they are not stratabound. The popular synonymous class name, sediment-hosted stratiform $\mathrm{Cu}$ deposits (Brown, 1989), is rejected, because in detail, SSC deposits are not perfectly stratiform. In detail, even the very sheetlike reduced-facies SSC deposits (see below) cut bedding, with the deposit boundaries defined by sulfide mineral-zone boundaries rather than by bedding planes or by the lateral limits of the sedimentary host rocks (Brown, 1971; Rentzch, 1974). 


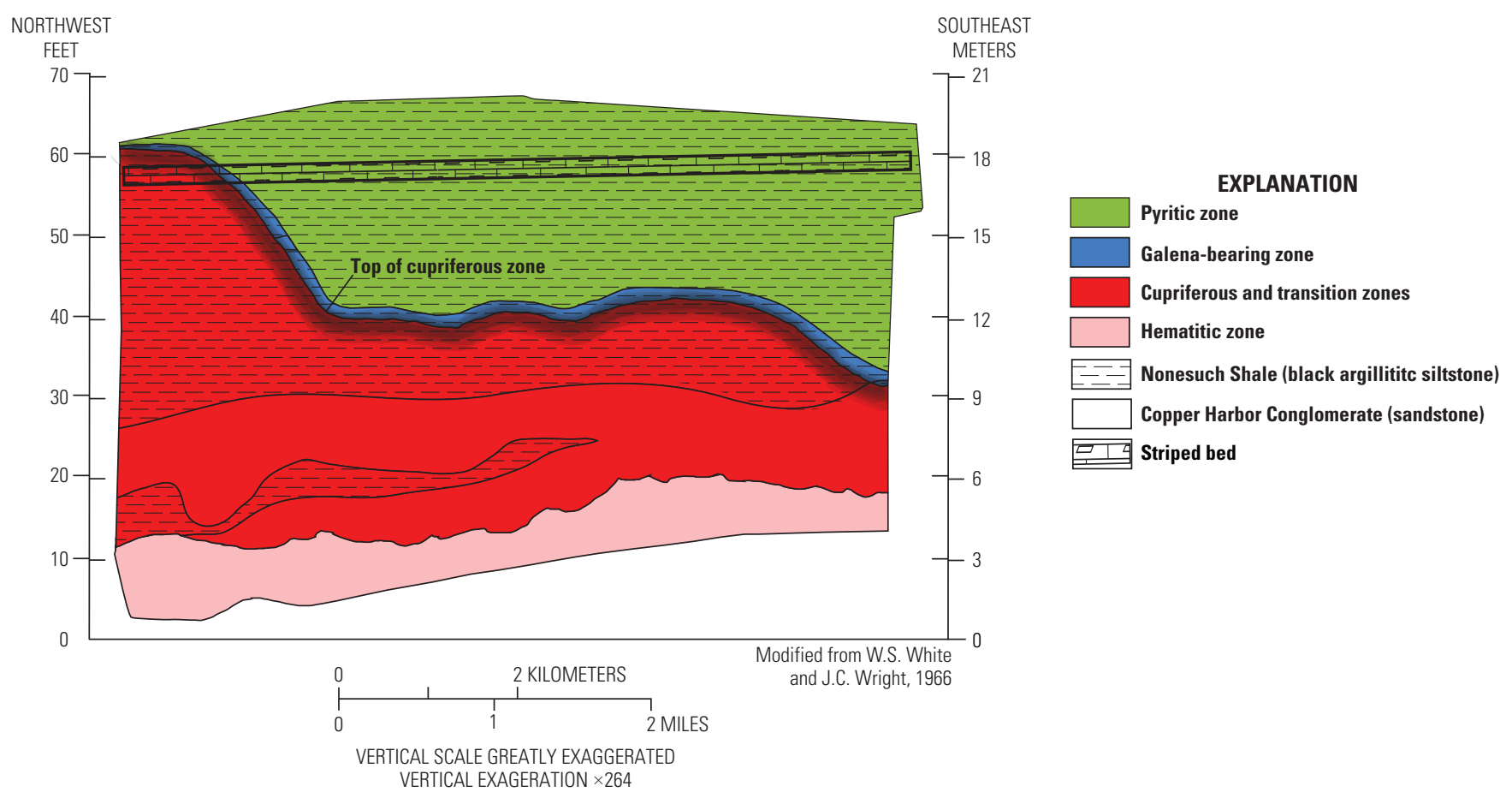

Figure 5. Schematic cross section showing the mineral zonation related to the stratigraphy of the White Pine reduced-facies-type deposit, Michigan, modified from White and Wright (1966). Colors match with figure 4. Rock with black patterning is Nonesuch Shale (black argilliitic siltstone), the most important host rock. Note the very large vertical exaggeration; the geometry of the cupriferous zone is actually like a sheet.

The universal association of the deposits with red beds also presents a constraint on the ages of deposits of this type. Red beds, and the associated SSC deposits, occur in the geologic record only since the Great Oxidation Event at about 2,400 Ma (Chandler, 1988; Bekker and others, 2004). Correspondingly, there are no Archean SSC deposits.

Host rocks and their corresponding reductants were used by Cox and others (2003) to divide the SSC deposits into three subclasses. In the "reduced-facies type" subclass (Kupferschiefer-type of Kirkham and others, 1994), in situ solid organic matter is the principal reductant for pre-ore, early diagenetic pyrite and ore-stage $\mathrm{Cu}$ sulfides. Deposits of this subclass include those associated with the Kupferschiefer, the White Pine deposit in Michigan, and the ores of the Central African Copperbelt that are hosted by the Roan Group "ore shale" (Zambia) or by the D Strat, RSF, and SDB beds of the Roan (Democratic Republic of Congo). The host rocks of deposits are marine-shelf shales, siltstones, and (or) impure dolostones immediately overlying a transgressive flooding surface (Oszczepalski, 1989; Cailteux, 1994; Selley and others, 2005). Immediately adjacent rocks, up- and down-section, may also be mineralized to ore grade. In SSC deposits, the host rocks are commonly, but not everywhere, parts of thicker, transgressive, vertical sequences (Hayes, 1991; Hitzman and others, 2005), and they mark the change up-section from proto-oceanic, rift-fill, nonmarine deposits, which are typically red beds, to marine-shelf deposits of rift- and passive-margin sequences
(Hoffman and others, 1974). In other places, the host rocks of reduced-facies SSC deposits are isolated gray or green beds within a thick stack of red beds (Smith, 1976). In "red-bed type" RBA-Cu deposits, the reductant is carbonized terrestrial plant matter, and the host rocks are fluvial sandstones or conglomerates (Cox and others, 2003). The reductant is more widely and diffusely distributed in "sandstone type" RBA-Cu deposits than in the red-bed type. Sandstone-type (often, hereafter, sandstone $\mathrm{Cu}$ ) is synonymous with the Revett $\mathrm{Cu}$ subclass of Cox and others (2003). Much as the "Kupferschiefer-type" of Kirkham and others (1994) was replaced with the generic "reduced-facies-type," here, the Revett-type is replaced with the generic, "sandstone Cu-type," using a class name that first appeared in Russia in the late 1950s (Satpaeva, 1958; Domarev and Bogdanov, 1959). Nearshore marine and beach sandstones, as well as some sandstones deposited in fluvial or eolian environments, host sandstone $\mathrm{Cu}$ ores (Cox and others, 2003). Host rocks for sandstone $\mathrm{Cu}$ deposits are the topset beds of deltaic sedimentary packages, including nonmarine and nearshore marine sandstones. The reductant for the Spar Lake sandstone $\mathrm{Cu}$ deposit in Montana was a reservoir of sour gas (Hayes and others, 2012), and the reductant was probably natural gas or another form of petroleum for other deposits of the subclass (Lur'ye and Gablina, 1978; Gablina, 1981; Hayes and Einaudi, 1986; Gablina, 1997; McGowan and others, 2003; Thorson and MacIntyre, 2005; Syusyura and Tyugay, 2008). 

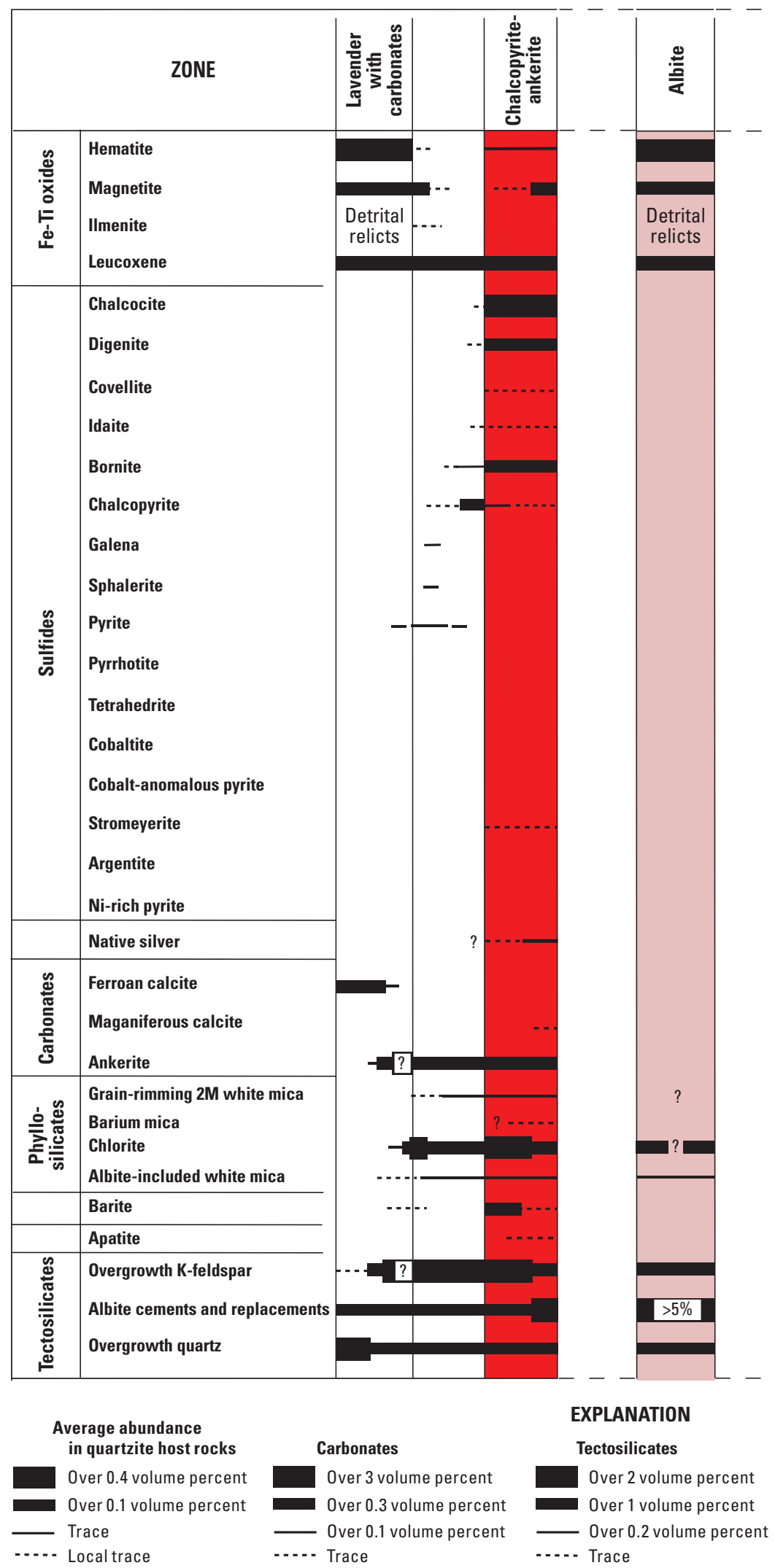
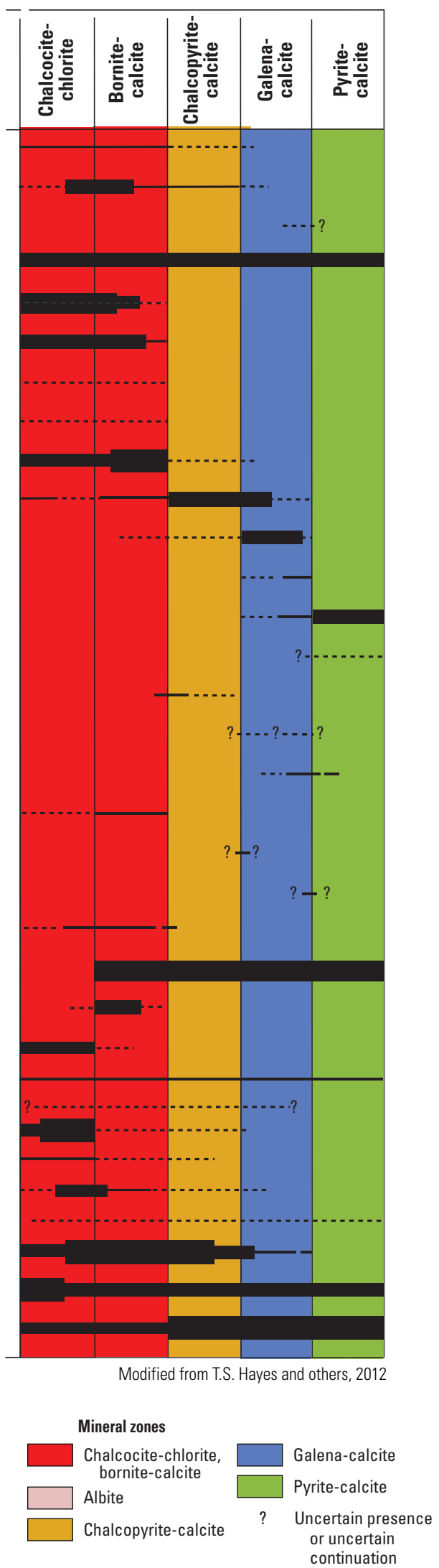

Figure 6. Mineral zones of the Spar Lake sandstone copper deposit, Montana, United States, from Hayes and others (2012). Mineral-zone colors match generally with figures 4 and 5 . The diagram illustrates the distribution of authigenic minerals only in space, not in time. Most changes in concentration of a mineral in space are gradual but are presented here as sharp to avoid confusion of this diagram with any paragenetic diagram. 


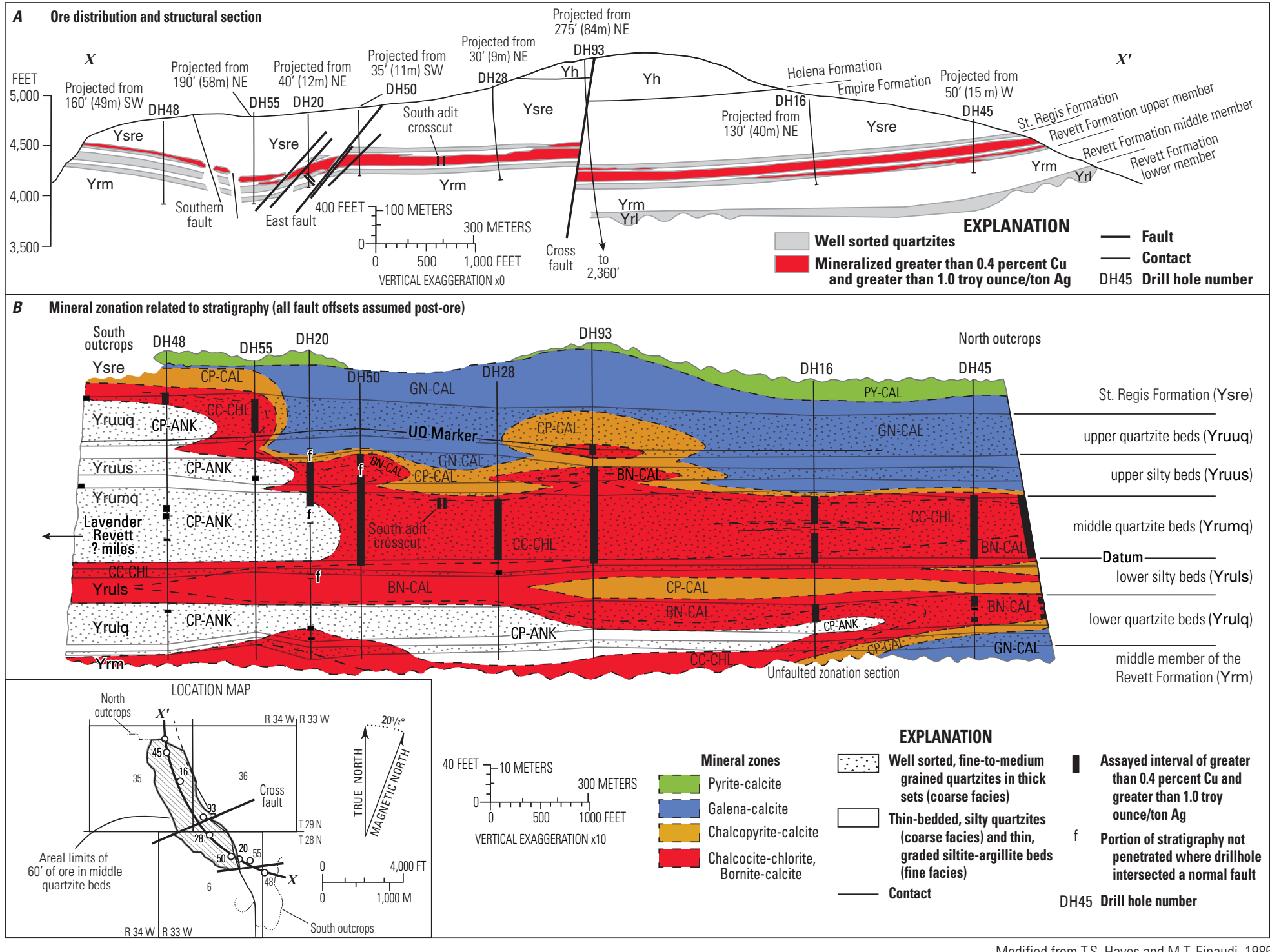

Figure 7. Mineral zonation along the curving long axis of the Spar Lake sandstone copper deposit, Montana, United States, from Hayes and Einaudi (1986). Mineral-zone colors match with figure 6 and match generally with figures 4 and $5 . A$, The distribution of ore without vertical exaggeration. $B$, The mineral zonation related to bedding with 10X vertical exaggeration from the same eight drill holes and two outcrop areas and with the assumption that all fault offset was post-ore. The assumption is true for the Cross Fault but not for the East Fault. However, only the southeastern end of this section would be affected, from drill hole 20 to the south outcrops. The change to correct the zonation section can be visualized. The bottoms of the high-grade ore intercepts, falling through section from southeast to north (black bars along the drill hole traces), were probably along a single gas/water interface of a gas reservoir at ore stage (Hayes and others, 2012). 
In preparing this revision to Cox and others (2003), the three subtypes were statistically tested to determine if they were discrete from one another in grade and tonnage characteristics; results of the statistical tests determined that they are discrete. That work first required rigorous definitions of the three subtypes, and those definitions are provided in detail in a separate publication on grade and tonnage models. The larger broad type of SSC deposit is, however, clearly distinct from all other types of $\mathrm{Cu}$-rich ore deposits everywhere in the world except, perhaps, in the Central African Copperbelt. In Central Africa, there appear to be multiple generations of economically important stratabound $\mathrm{Cu}$ deposits, the earliest of which have characteristics of SSC deposits, and the later ones with greater degrees of structural geologic control and, for some of them, distinct mineralogy (for example, Kansanshi and Lonshi; Broughton and others, 2002; Stephens, 2003; respectively). More is said on the distinction between early and late SSC deposits in a later section on Associated and Transitional Deposit Types.

The characteristic sulfide zonation of SSC deposits generally is accompanied by a parallel zonation of authigenic gangue minerals. Authigenic carbonates are generally peripheral to and extending into chalcocite-bearing rock from the pyritic zones, although the carbonates may be absent from highest grade ores where, instead, chlorite or illite are commonly present with authigenic hematite (Hamilton, 1967; Hayes, 1984; Michalik, 2001). Authigenic feldpars are present in many mineralizing systems, but their zonation is seldom documented. Authigenic K-feldspar is documented at deposits in Zambia (Annels, 1989; Sweeney and Binda, 1989; Selley and others, 2005) and at Spar Lake (Hayes, 1984; Hayes and Einaudi, 1986). Authigenic quartz also may accompany Cu-sulfide deposition in some deposits (Michalik, 2001, p. 50; Hayes, 1984). In some deposits, albite increases at the expense of K-feldspar in "upstream" directions for the metals-transporting solutions (for example, Oamites: Lee and Glenister, 1976; places in Zambia: Annels, 1989, p. 432 and p. 437-439; Sweeney and Binda, 1989; Selley and others, 2005; and Spar Lake: Hayes and Einaudi, 1986).

Similarly, the characteristic paragenesis of sulfides and oxides in SSC deposits is accompanied by parallel paragenesis of gangue minerals, many forming during the ore stage. Most of the ore and authigenic gangue minerals occur as cements (Hamilton, 1967; Anhaeusser and Button, 1973; Bartholomé, 1974; Hayes, 1984; Hayes and Einaudi, 1986; Hayes and others, 1989; Sawlowicz, 1990) and (or) they selectively replace certain clasts or earlier cements (Brown, 1971; Annels, 1974; Bartholomé, 1974; Banaś and others, 1982; Hayes and Einaudi, 1986). Replacement of early diagenetic pyrite occurred during deposition of ore-stage assemblages at many SSC deposits. Ore-stage cementation textures and preferential deposition of sulfides in coarser-grained beds or laminae in many deposits indicate that primary permeability was employed by ore solutions (fig. 8) (also, Hayes and Einaudi, 1986, fig. 5C; Borg and Maiden, 1989, p. 531-532 and 535; Richards and others, 1988a, p. 125).
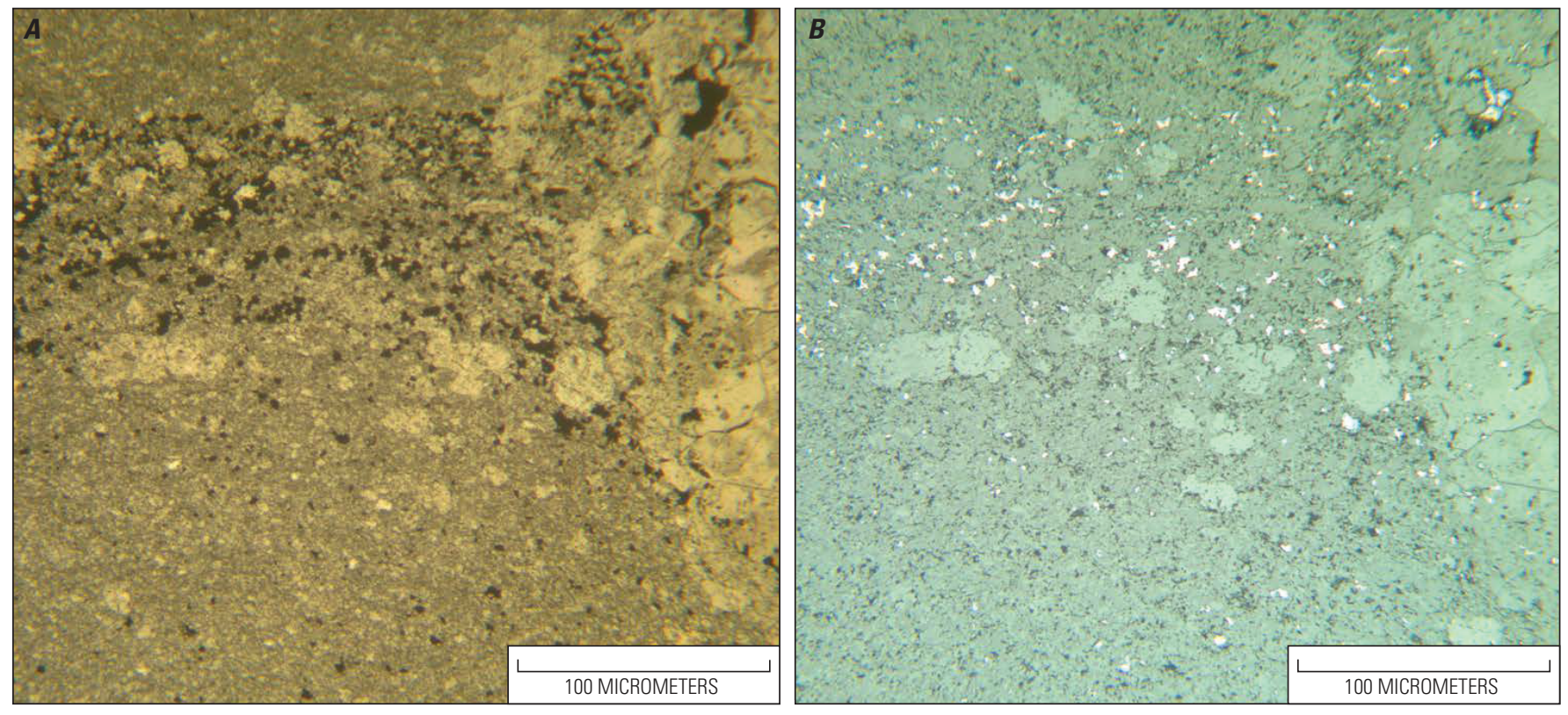

Figure 8. Photomicrographs showing denser than background concentrations of copper sulfides in a silt-sized lamination and in a mediumcrystalline dolomite nodule within dolomitic mudstone from the Kamoto Principal deposit, Democratic Republic of Congo. A, Transmitted light, plane polarized. $B$, Reflected light in air, plane-polarized. Bornite is lavender, and a chalcocite-group mineral is white. 


\section{Associated and Transitional Deposit Types}

A wide variety of mineral deposits may be associated with SSC deposits, but only two of these (basalt-hosted native $\mathrm{Cu}$ deposits and volcanic red-bed $\mathrm{Cu}$ deposits) appear to have genetic association. Others appear to merely share a common sedimentary-tectonic setting with SSC deposits.

The most clearly recognizable associate is native copper deposits within flood basalts, with the best example being the Keweenaw Native Copper district of the Upper Peninsula, Mich. (White, 1968; Jolly, 1974; Livnat, 1983; Bornhorst and others, 1986; Brown, 2006; 2009). Such native copper deposits formed at temperatures from $150^{\circ} \mathrm{C}$ to perhaps as much as $340^{\circ} \mathrm{C}$ (Livnat, 1983, p. 75-96) from fluids that may be viewed as formation waters of flood basalts. The fluids redistributed $\mathrm{Cu}$ from higher temperature zones, where the basalts were altering or metamorphosing through dehydration reactions to epidote, into lower temperature zones where the native copper was deposited with chlorite, quartz, pumpellyite, laumontite, and analcime, and the wallrocks were altered to pumpellyite, laumontite, and analcime (Stoiber and Davidson, 1959; Jolly, 1974). Native copper precipitated in quartz veins, in amygdules and autobrecciated zones of basalt flow tops, and within interflow conglomerates (Stoiber and Davidson, 1959; White, 1968; Bornhorst and others, 1986). The White Pine SSC deposit is just $75 \mathrm{~km}$ from the nearest part of the main Keweenawan native copper district, and minor native copper deposits are found as close as $29 \mathrm{~km}$ from White Pine (White, 1968, p. 305). The Portage Lake lavas underlie the White Pine deposit, so, conceptually; it is possible that the same fluids that created the native copper ores also mineralized the lower part of the Nonesuch Shale at White Pine. However, geologic constraints seem to favor, instead, that White Pine secondstage $\mathrm{Cu}$ mineralization, which is more localized in veins and consists mainly of native copper, correlates in time with the mineralization of the Keweenawan Native Copper district (Mauk and others, 1992c).

Another SSC deposit where native copper in flood basalts has been found nearby is Witvlei, Namibia, where native copper is hosted in basalts of the Opdam or Doornpoort Formation (Anhaeusser and Button, 1973; Borg and Maiden, 1989). A third deposit where native copper-bearing flood basalts occur nearby is Kurpandzhin, Russia (Ioganson, 1988).

Native copper deposits have been found in a number of additional basalts in the world, but without known association to SSC deposits. One such basalt is the ca. $1270 \mathrm{Ma}$

Coppermine River continental flood basalt on the Arctic coast of Canada, which is associated with the Muskox layered mafic to ultramafic intrusion as part of the Mackenzie large igneous province (Gilbert, 1931; Lang and others, 1976; Day, 2008). Others include the Late Precambrian Volynian volcanic rocks of northwestern Ukraine (Kvasnytsya and others, 2001), the Tongchanghe deposit in the Late Permian Emeishan flood basalts of Chengdu, in south-central China (Zhang and others, 2006), and the middle Cretaceous Seachondong basalts in east-central South Korea (Lee and Kim, 1970).
Some of these same basalt sequences that host native copper deposits also host deposits of $\mathrm{Cu}$ sulfides having mineralogy and paragenesis that resemble those of SSC deposits. In Northwest Territories, Canada, with the Coates Lake (Redstone) SSC deposit less than 1,000 m upsection, the mafic lava unit of the Little Dal Formation commonly contains chalcopyrite disseminated in amygdules and locally has a decimeter-scale layer at the top consisting entirely of sandsized chalcopyrite and detrital hematite grains together with lava pebbles and jasper and chalcedony clasts (Ruelle, 1982, p. 710). The Korean deposits in the Seachondong basalts also have chalcocite (Lee and Kim, 1970). Cu-sulfide deposits have been found in the Keweenawan volcanic rocks (Bornhorst and others, 1986, p. 24). The Cu sulfides are fairly widespread, although typically paragenetically later than the native copper deposits. The largest accumulation of $\mathrm{Cu}$ sulfides in the Keweenaw is at Mount Bohemia and has zonation and paragenesis of chalcocite, bornite, chalcopyrite, and pyrite like that of the SSC deposits (Robertson, 1975). Recent exploration at the 47 Zone deposit has discovered potentially economic $\mathrm{Cu}$-sulfide deposits in the Coppermine River basalts (Coronation Minerals, Inc., 2006) that are apparently quite similar to Mount Bohemia. The Sustut $\mathrm{Cu}$ deposit in central British Columbia, Canada, appears to be a related deposit type. It occurs in Triassic basaltic volcaniclastic rocks and consists of several tabular bodies each with a core of native copper zoned outward to chalcocite, then bornite, then chalcopyrite, and then pyrite (Wilton and Sinclair, 1988). The Kennecott deposits in eastern Alaska are probably also related to the volcanic red bed type deposits like those above (MacKevett and others, 1997). The Kennecott deposits, although having a relatively telescoped mineral zonation, have an identical paragenesis where pyrite was replaced by chalcopyrite, then by bornite, and then by chalcocite + djurleite. The Kennecott deposits occur as veins and prism-shaped replacements within brecciated limestone immediately above a contact between limestone and the Nickolai Greenstone. The Nickolai is another Large Igneous Province, and in the Kennecott vicinity, it is a sequence of subaerial basalt flows that is more than 1,800 m thick. Metalliferous fluids at Kennecott are interpreted to have formed during prehnite-pumpellyite metamorphism of the greenstone, where native copper and $\mathrm{Cu}$ sulfides also precipitated in small concentrations (Price and others, 2004).

The above volcanic-hosted or volcanic-associated deposits all fall within the volcanic red bed $\mathrm{Cu}$ deposit class of Kirkham (1984b) and Lefebure and Church (1996). Those authors also place within that class some of the volcanichosted peneconformable "manto" $\mathrm{Cu}-\mathrm{Ag}$ deposits of Chile, such as Mantos Blancos and El Soldado (Maksaev and Zentilli, 2002; Wilson and others, 2003). However, the Chilean manto deposits occur in the same region and generally within the same volcano-sedimentary sequence as iron oxide-coppergold (IOCG) deposits such as Candelaria, Manto Verde, and Punta del Cobre, so it is possible, instead, that the association of the Chilean manto deposits is really with IOCG deposits. 
In either case, there are many shared processes between the mantos and SSC deposits. The mantos have the same zonation from central chalcocite outward to bornite, chalcopyrite, and pyrite zones. They have the same paragenesis, where pyrite is replaced stepwise by chalcopyrite, bornite, and chalcocite. In addition, they have an abundance of pyrobitumen derived from degradation of oil where the petroleum was an ultimate reductant for $\mathrm{S}$, and perhaps $\mathrm{Cu}$, in forming the $\mathrm{Cu}$ sulfides (Wilson and Zentilli, 1999; Wilson and others, 2003). An apparent distinction is that the manto deposits were formed at higher temperatures of 200 to greater than $300{ }^{\circ} \mathrm{C}$ than are common for SSC deposits (Wilson and Zentilli, 1999).

Sandstone-hosted U deposits are a second deposit type associated with SSC deposits, particularly the tabular- or trend-type sandstone $\mathrm{U}$ deposits as are present in the Colorado Plateau. In fact, certain of the tabular U deposits in the Triassic Chinle Formation are hybrid types in that they are also red-bed-subtype stratabound $\mathrm{Cu}$ deposits (Hayes, 1982). Examples are in the Silver Reef district, southwestern Utah (Proctor, 1953), and include the Hide Out and Happy Jack deposits in the White Canyon district (Miller, 1955) and the Whirlwind deposit in the Monument Valley district (Isachsen and Evenson, 1955). Northrup and others (1990a, 1990b) demonstrated that the tabular V-U deposits of the Henry Basin, Utah, formed at an interface between fresh groundwater and a subsurface brine, where that interface crossed through fluvial sandstone host rocks with carbonized plant fossils. Hayes (1982) concluded that probably all other tabular- and trendtype sandstone-hosted V-U deposits were formed at subsurface groundwater interfaces where a freshwater/brine contact existed. Hayes further hypothesized that sandstone-hosted deposits that contain all three metals, $\mathrm{Cu}, \mathrm{U}$, and $\mathrm{V}$, were formed where the brine was the metals-transporting fluid for SSC deposits.

$\mathrm{U}$ is present in considerable abundances in some of the deposits of the Central African Copperbelt. For example, the Malundwe and Chimiwungo deposits in amphibolite-grade basement rocks underlying the Roan Group on the Mombezhi Dome have zones of recoverable U: Malundwe is estimated to have $9.9 \mathrm{Mt}$ of ore containing 0.087 percent $\mathrm{U}_{3} \mathrm{O}_{8}$ among its 161.7 Mt of 0.89 percent $\mathrm{Cu}$ ore, and Chimiwungo is estimated to have $2.2 \mathrm{Mt}$ of ore containing 0.056 percent $\mathrm{U}_{3} \mathrm{O}_{8}$ among its $739.6 \mathrm{Mt}$ of 0.66 percent $\mathrm{Cu}$ ore (Davis and others, 2008 , p. 20 and 22). The $U$ occurs as uraninite mainly at the hangingwall and footwall contacts of the $\mathrm{Cu}$ orebodies. The nearby Lubwe prospect also has substantial $\mathrm{U}$ grades. These, then, are a transitional type of deposit. Some of the reducedfacies-type SSC deposits of the Kolwezi klippe, Mutoshi, for example, also had recoverable U (Francois, 1996).

Two deposits in the Central African Copperbelt are atypical in that their hypogene ores are dominated by structurally controlled veinlets and replacements of chalcopyrite. These are Kansanshi (Broughton and others, 2002) and Lonshi (Stephens, 2003). These can be classed as post-orogenic stockwork and replacement deposits in order to distinguish them from the main ores of the Copperbelt, which are pre-orogenic stratabound disseminations. Kansanshi consists of veinlets and large veins of quartz-carbonate-chalcopyrite with alteration envelopes of albite and ferroan dolomite, cutting phyllites, schists, and marbles. Deposits of the Central African Copperbelt all have at least minor amounts of $\mathrm{Cu}$ sulfides localized in veinlets (Dewaele and others, 2006; El Desouky and others, 2009), but, in most deposits, the veinlet-hosted mineralization provides far less of the total $\mathrm{Cu}$ than the earlier $\mathrm{Cu}$ sulfides that cement the sedimentary rock and selectively replace clasts and diagenetic minerals. Post-orogenic stockwork and replacement deposits are not known in other SSC districts, although most deposits have later stages of vein $\mathrm{Cu}$ mineralization (examples are: Hayes and Einaudi, 1986, figs. 14B and 16; Jowett, 1987; Mauk and others, 1992b, 1992c), and the Kupferschiefer deposits in Germany are cut by Co-Ni-arsenide veins, called rücken, that occupy fault zones (Beck, 1905). A third atypical $\mathrm{Cu}$ deposit in the Copperbelt is Frontier. Frontier has classic mineral zonation from pyrite, to chalcopyrite, to bornite, to chalcocite, and to hematite. However, the zonation is distributed surrounding a fault at a low angle to bedding and in atypical host rocks (D. Jack, First Quantum Corp., oral commun., 2010). The fault is a probable feeder of oxidizing $\mathrm{Cu}$-transporting solutions to the deposit.

Kipushi-type carbonate-hosted $\mathrm{Zn}$ - $\mathrm{Pb}$-Cu-Ge deposits were listed as SSC deposit associates by Cox and others (2003), although that applied almost solely to the Central African Copperbelt where the Kipushi, Kengere, and Lombe deposits are present. These deposits are sited along faults and in breccia of Nguba Group carbonate rocks that are upsection from the Roan Group that contains the bulk of the SSC ore. The observation by Cox and others (2003) has since been further strengthened because SSC mineralization has been identified at Sebembere and Mufukushi near the Kabwe (formerly Broken Hill) Kipushi-type deposit in central Zambia (Kampunzu and others, 2009). Also, the second-best example of a Kipushi-type deposit is the Tsumeb deposit in northern Namibia, and a sandstone $\mathrm{Cu}$ deposit has been identified at Tschudi in the rocks immediately overlying the host rocks of Tsumeb (Kamona and Günzel, 2007). Tschudi is just $26 \mathrm{~km}$ west of Tsumeb.

Hydrothermal $\mathrm{U}$ orebodies may also be added to the list of SSC associates because the Shinkolbwe U deposit occurred between the Mombezhi Dome and the SSC deposits of the Kolwezi Klippe. Shinkolobwe was a "hypothermal" breccia and stockwork of veinlets cutting the SSC Cu host beds and consisted of uraninite, nickel- and Co-bearing sulfides, monazite, and molybdenite, with quartz and chlorite, within a magnesite alteration zone (Ridge, 1976). Other deposits along a west-trending belt from Shinkolobwe are U-rich post-orogenic stockworks (Francois, 1996).

Hoeve and Quirt (1989) suggested that unconformitytype $U$ deposits have a common diagenetic-hydrothermal origin with SSC deposits. However, to our knowledge, there are no examples of SSC deposits and spatially associated unconformity $\mathrm{U}$ deposits. 
IOCG deposits have spatial and temporal association to $\mathrm{SSC}$ deposits in several regions including, as above, the Coastal Cordillera of Chile, where volcanic-hosted mantos (for example, El, Soldado, Mantos Blancos) and sedimenthosted red-bed $\mathrm{Cu}$ deposits (for example, San Bartolo, Coloso; Flint, 1989) are located. Another region of spatial and age association is in South Australia where SSC deposits occur in Adelaidan rocks (Rowlands, 1974) and numerous giant IOCG deposits occur in the immediate Gawler Craton basement rocks. The IOCG deposits include Olympic Dam, Moonta, Acropolis, and Prominent Hill (Skirrow and others, 2002). A third area of associated SSC and IOCG is in the Lufilian Orogen (Hitzman, 2002). The clearest examples of IOCG mineralization in the Lufilian are in central-western Zambia where magnetite and $\mathrm{Cu}$ occurrences are associated with the late- to post-orogenic Cambrian Hook Granite. Equivalents of the Katanga Supergroup, host of the Central African Copperbelt SSC deposits, as well as older metasedimentary rocks, are mineralized and metasomatized with Fe oxides, $\mathrm{Cu}$ sulfides, and $\mathrm{Au}$ in areas near the Hook Granite intrusions, and SSC deposits, such as Sebembere and Mufukushi, are nearby (Kampunzu and others, 2009). The IOCG deposits include the Dunrobin and Matala Au deposits (Brown and others, 2008), the Mumbwa $\mathrm{Cu}-\mathrm{Au}$ prospect (Lobo-Guerrero, 2004), and prospects in the Kasempa area (Lobo-Guerrero, 2004).

Another associated ore-deposit type may be sedimenthosted stratabound $\mathrm{Cu}-\mathrm{Ni}(-\mathrm{Co})$ deposits. One is Kalumbila, in northwestern Zambia, in rocks that correlate with the Ore Shale of the Katangan Supergroup, a carbonaceous metapelite with disseminated to finely laminated to locally discordant pyrite, chalcopyrite, pyrrhotite, violarite, and siegenite (Steven and Armstrong, 2003). Early exploration results suggested high $\mathrm{Ni}(0.67$ percent $)$ and high Co (0.2 percent) with lesser $\mathrm{Cu}$ (0.11 percent), but as exploration progressed, the deposit became much larger and clearly $\mathrm{Cu}$-dominated and is now estimated at $340 \mathrm{Mt}$ of 0.78 percent $\mathrm{Cu}$ and 0.03 percent $\mathrm{Co}$ (Kiwara Resources, PLC, 2009). The possibly comparable deposit associated with the Udokan SSC deposit in Russia is Pravo Ingamakit (246.8 Mt of 0.88 percent $\mathrm{Cu}$ and $23.9 \mathrm{~g} / \mathrm{t} \mathrm{Ag}$ (V. Chechetkin, Committee on Geology and Utilization of Mineral Resources of the Chita Region, Russia, written commun., 2009). Pravo Ingamakit is less than $25 \mathrm{~km}$ from Udokan and hosted in the Udokan Supergroup, Chitkanda Formation, more than $3 \mathrm{~km}$ downsection from the Udokan deposit, which itself occurs in "terrigenous-carbonate rocks." The ores are "massive sulfide bodies surrounded by dissemination of pyrite and chalcopyrite" and, in detail, have stringer and stockwork/ breccia-fill structure. The additional metallic minerals are millerite, pentlandite, bravoite, clausthalite, hessite, and bohdanowiczite (trigonal $\mathrm{AgBiSe}_{2}$ ) (Gongalsky and others, 2007, p. 671-672). Others who work in the Udokan area do not agree that Pravo Ingamakit is different than other sandstone $\mathrm{Cu}$ deposits except in the near vicinity of its contacts with the Chinei layered mafic complex (V. Chechetkin, oral commun., 2009). A reasonable alternative to these Ni-rich stratabound $\mathrm{Cu}$ deposits being associates of SSC deposits is that they are
Ni-rich portions of ordinary SSC deposits, related to gabbroic intrusions. This is supported by the fact that the Chinei gabbroic complex lies between Udokan and Pravo Ingamakit, and the deposit is compared with "outer contact ore of the Chinei Massif" (Gongalsky and others, 2007); a suite of late Lufilian gabbros intrudes the metasedimentary rocks in the area of the Kalumbila deposit (Steven and Armstrong, 2003).

Last and possibly most important of all the mineral deposit types that are associated with SSC deposits are evaporite deposits including gypsum, halite, and potash. This association has long been recognized and has been discussed frequently, typically calling on dissolution of the evaporites to contribute to salinity and complexing capacity for a metalstransporting groundwater (Davidson, 1965; Rose, 1976; Thiede and Cameron, 1978; Hayes, 1983; Warren, 2000). Many different rock sequences that host SSC deposits also host evaporite deposits. The most familiar of these may be the Zechstein sequence in central Europe. The Kupferschiefer bed is the basal bed of the Zechstein sequence. Although millions of tons of salt (halite) have been produced from stratigraphically higher levels of the Zechstein, there is only a small area of the basin in central Germany where there was Kupferschiefer-hosted $\mathrm{Cu}$ production and production of salt from the overlying Zechstein evaporites. For the most part, the $\mathrm{Cu}$-producing part of the basin is along its southern margin, and the salt-producing part is to the north nearer the basin center. Many of the salt beds of the central basin are lower in elevation than the Kupferschiefer bed along the southern basin margin, so there remains a hydrologic problem in getting saline $\mathrm{Cu}$-transporting solutions from Zechstein evaporites for formation of the Kupferschiefer deposits. Brine is typically denser than other waters and would gravitate to the base of a pore water column, unless its density is lowered by anomalous heating. Some external hydrologic drive is required to move the brine to the higher basin edges (Hitzman and others, 2005).

The Central African Copperbelt deposits commonly contain anhydrite (Annels, 1974; Muchez and others, 2008), but far more evaporites may have existed in the Katangan Supergroup at some earlier time. Jackson and others (2003) have interpreted that the Roan Group of the Katangan Supergroup once had evaporites at four separate stratigraphic intervals. "Flakes, slices" (ecailles) of coherent, mineralized Mines Series rocks, 1 to $10 \mathrm{~km}$ scale, float within Roan 1 breccia, which may have once been predominantly halite and other salts that are now dissolved. Demesmacher and others (1963) and Jackson and others (2003) interpret that dêcollemants formed along those four salt intervals in producing the thrust stack that now exists in the Copperbelt in Democratic Republic of Congo. Given that hypersaline fluids have been documented in the ores of the Katangan (Dewaele and others, 2006; Heijlen and others, 2008; El Desouky and others, 2009), there is strong evidence for the involvement of evaporites in ore deposition.

An evaporitic source for the salinity in metalstransporting solutions is a very reasonable hypothesis. In only one case has the involvement of dissolved evaporites in ore genesis been directly tested, and the result indicates that 
they were likely involved. At Lisbon Valley, Utah, Breit and Meunier (1990) measured strontium isotope ratios of SSC orerelated fluid inclusions to be very radiogenic. They interpreted that gypsum and anhydrite of the Paradox Member of the Hermosa Formation that underlies the Lisbon Valley deposits by about $1-2 \mathrm{~km}$ was dissolved, contributing to the strontium of the inclusion fluids. Those fluids presumably dissolved $\mathrm{Cu}$ from the Cutler Formation arkoses that lie between, enroute to the stratabound $\mathrm{Cu}$ deposits.

\section{Primary Commodities}

$\mathrm{Cu}$ is the primary commodity in all SSC deposits. Co and $\mathrm{Ag}$ reach co-product concentrations in some, and $\mathrm{Au}$ and platinoids are produced from deposits of the Kupferschiefer in Poland, along with several minor metals (see below).

\section{By-Product Commodities}

The SSC deposits are the world's most important source of Co. Cobalt is produced from about 10 deposits in Zambia, from most, but not all of the deposits in the Democratic Republic of Congo, and as a byproduct from the Kupferschiefer deposits in Poland. Current plans for mining the Boléo deposit in Baha California, Mexico, call for recovery of $\mathrm{Co}$, which occurs there at an average grade of about $0.07 \mathrm{wt}$ \% $\%$ In 1990, for example, the Democratic Republic of Congo and Zambia produced 26,086 t of Co from SSC deposits, whereas the rest of the world combined produced only 9,736 t, mostly from other deposit types (calculated from http://minerals.usgs.gov/minerals/pubs/commodity/ cobalt/stat/tbl9.txt).

$\mathrm{Ag}$ is produced as a co-product metal from the Spar Lake deposit in Montana and as a byproduct metal from the Kupferschiefer deposits in Poland and the Dzhezkazgan deposits in Kazakhstan. As a Ag-producing deposit type, the SSC deposits rank fourth in the world, behind epithermal, porphyry $\mathrm{Cu}$, and sedex $\mathrm{Zn}-\mathrm{Pb}-\mathrm{Ag}$-barite deposits (as calculated from statistics presented in Brooks, 2010).

$\mathrm{Au}$, platinum $(\mathrm{Pt})$, and $\mathrm{Pd}$ are now recovered from the Kupferschiefer SSC deposits in Poland. They occur disseminated in a layer along the footwall of the $\mathrm{Cu}$ ore that parallels the mineral zonation of the $\mathrm{Cu}$ deposit slightly discordant to the bedding (Piestrzynski and others, 2002). Piestrzynski and others (2009) reported that the Au and platinoids deposit subjacent to Kupferschiefer $\mathrm{Cu}$ ore in the western part of the Polkowice mine averages $22 \mathrm{~cm}$ in thickness at $2.25 \mathrm{~g} / \mathrm{t} \mathrm{Au}$, $0.14 \mathrm{~g} / \mathrm{t} \mathrm{Pt}, 0.08 \mathrm{~g} / \mathrm{t} \mathrm{Pd}$, and 0.025 percent $\mathrm{Cu}$.

The Kupferschiefer deposits of Poland also yield $\mathrm{Pb}, \mathrm{Co}$, $\mathrm{Mg}$, nickel, selenium, and $\mathrm{S}$ for sulfuric acid (Pieczonka and others, 2001).

$\mathrm{U}$ and $\mathrm{V}$ were typically more valuable than $\mathrm{Cu}$ or $\mathrm{Ag}$ in some of the Triassic-hosted red-bed-type SSC deposits of the Colorado Plateau, United States (Miesch, 1963; Hayes, 1982). U is likely to be produced from the Malundwe and Chimiwungo deposits in Zambia (Davis and others, 2008).

\section{Trace Constituents}

$\mathrm{Mn}, \mathrm{Zn}, \mathrm{Pb}, \mathrm{Ba}, \mathrm{Re}, \mathrm{Hg}$, and As are present at anomalously high concentrations in some SSC deposits (Bakun and others, 1966; Nimry, 1973; Rentzsch, 1974; Seyfullin and others, 1974; Hayes and Nuckolls, Asarco, Inc., written commun., 1983; Sutton and Maynard, 2005), and are elements that were probably enriched together with $\mathrm{Cu}$ at ore stage. Example concentrations of these elements are given in the later section on trace-element geochemistry. Titanium is anomalous in numerous SSC deposits, but it is likely enriched in a detrital component of the host sedimentary rocks (Dimanche and Bartholomé, 1976). B is anomalously high in some Zambian Copperbelt deposits (Darnley, 1960, p. 160 and 162), where it is concentrated in authigenic tourmaline (Selley and others, 2005). Darnley (1960) concluded that the enrichment factor was about six times the B background in ore in Zambia. $\mathrm{Mg}$, found in chlorite in many deposits, and in magnesite in deposits of the Democratic Republic of Congo, is anomalous in some SSC deposits, though not at Konkola, Zambia (Sutton and Maynard, 2005).

\section{Example Deposits}

Cox and others (2003) reported grade and tonnage data for 101 well-explored deposits worldwide and used these data in their sediment-hosted $\mathrm{Cu}$ deposit grade and tonnage models. In addition to $\mathrm{Cu}$ grades, their compilation included $\mathrm{Co}$ and Ag grades. The compilation by Cox and others included 682 additional deposits and SSC mineral occurrences that lack reliable grade and tonnage data. Parks and others (written commun., 2011) contains summaries of more than 1,000 deposits and occurrences that highlight the diverse characteristics and settings of SSC deposits. It includes deposits newly described since Cox and others (2003), but a number of deposits were removed from the Cox and others compilation on the basis that they did not meet stricter definitions of the deposit type. Summaries of representative sediment-hosted stratabound copper deposits are discussed in Appendix 1:

A. Kupferschiefer, Lubin-Sieroszowice-PolkowiceRudna-Glogow Giboki-Przemyslowy-Bytom Odrzanski Retkow-Gaworzyse-Radnawice Zachody, Poland;

B. Kolwezi Klippe, Democratic Republic of Congo;

C. Creta, Okla., United States;

D. Udokan, Russia;

E. Spar Lake, Mont., United States;

F. Juramento, Argentina;

G. Corocoro, Bolivia;

H. Nacimiento, N. Mex., United States;

I. Happy Jack, Utah, United States. 


\section{History of Exploitation of Sediment- Hosted Stratabound Copper Deposits and History of Genetic Concepts}

\section{Archeometallurgy of Copper and of Sediment- Hosted Stratabound Copper Deposits}

SSC deposits were among the earliest types of metal deposits mined and processed at an industrial scale. Before mining occurred at an industrial scale, tools and jewelry items of smelted $\mathrm{Cu}$ were made at a household scale, and yet before that, native copper was used in similar ways. Archeometallurgy has competing claims for the oldest occurrences of each of these types of $\mathrm{Cu}$ usage, and $\mathrm{Cu}$ even has its own named archeological period, the Chalcolithic. This was the period when $\mathrm{Cu}$ was the most advanced material in use, between the Neolithic (new Stone Age) and the Early Bronze Age, when there first was a metals industry at a small industrial scale and when the first man-made alloys, tin-bronze and arsenicbronze, appeared. $\mathrm{Cu}$ was the first metal used for casting tools, probably because of its low melting temperature of $1,083{ }^{\circ} \mathrm{C}$.

Modern-day Turkey supplied the oldest known $\mathrm{Cu}$ artifacts, consisting of beads, pins, awls, and fishhooks dated to $8505 \pm 175$ B.C. from Çayönü Tepesi, Anatolia (Maddin and others, 1991; as recalculated in http://context-database.uni-koeln.de/). The source of the $\mathrm{Cu}$ for the Çayönü artifacts was almost certainly Ergani Maden, a Cyprus-type volcanogenic massive sulfide deposit (Yigit, 2009) about $20 \mathrm{~km}$ away. Several $\mathrm{Cu}$ beads were found at nearby Aşikli Höyük, Anatolia, dating from $7824 \pm 20$ B.C. (Esin, 1999). A single 6900 B.C. Cu bead was found at Ali Kosh in southwestern Iran (Smith, 1969). At 6000-5900 B.C., native copper was used to make a heavy mace head at Can Hasan, again in modern-day Turkey (Yalçin, 2000), and, by that time, native copper was in use in at least five sites in Iran (Thornton, 2009).

The claim to the earliest true $\mathrm{Cu}$ industry comes from eastern Serbia at Prokuplje, where evidence for smelting of $\mathrm{Cu}$ oxide ores and casting of a chisel, a 2-headed hammer, and an axe date to 5500 B.C. (Baird, 2007). A bonafide $\mathrm{Cu}$ industry has been proven nearby at Belovode, Serbia, that dates confidently to 5000 B.C., and that includes irrefutable evidence of smelting of ores, not merely melting of native copper fragments, associated with production of a variety of tools and jewelry (Radivojević and others, 2010). The specific source of the manganiferous and Co-bearing ore for Belovode has not been identified, but Belovode and Prokuplje are within a belt of porphyry $\mathrm{Cu}$ and epithermal $\mathrm{Cu}$-Au deposits (Berza and others, 1998). Perhaps spanning that same time is a small-scale $\mathrm{Cu}$ industry at Tal-i Iblis, Iran, dated from 5470 to 4250 B.C. (Evett, 1967; as explained in Thornton, 2009). Tal-i Iblis is about $125 \mathrm{~km}$ from the Sar Cheshmeh porphyry $\mathrm{Cu}$ deposit (Waterman and Hamilton, 1975), which could have supplied the $\mathrm{Cu}$.
Also at some time from 5266 to 3994 B.C. (Joffe and Dessel, 1995), there was artisanal use of $\mathrm{Cu}$ ore at Shiqmim, Israel, including crucible-scale smelting and casting. The ore for Shiqmim originated from SSC deposits near Feinan, Jordan, about $150 \mathrm{~km}$ to the south and east (Golden and others, 2001, p. 954). Ores used at Shiqmim are distinctive and identifiable as the "tile ores" of Feinan, from its Massive Brown Sandstone unit. Trace-element analyses also match the Shiqmim ore pieces with Feinan. Furthermore, a single ${ }^{14} \mathrm{C}$ date for a "Pottery Neolithic-aged" site at Wadi Feinan, which, in contrast, doesn't give evidence for a mining-centered lifestyle, is 5500 to 5270 B.C. (Hauptmann, 1989, p. 119), a near match to the earliest Shiqmim dates. Unless earlier sites are found, Feinan appears to be the first-used SSC deposit.

According to current archeological knowledge, Feinan is also the site of the earliest industrial-scale exploitation of a SSC deposit, with the actual demonstration being the smelting workshop village excavated at Wadi Fidan 4 with ${ }^{14} \mathrm{C}$ dates of 3630 to 2920 B.C. inclusive of uncertainties (Hauptmann, 2000, 2007; Weisgerber, 2006). Note, though, the apparent 1,600 year delay between artisanal and industrial-scale usage of the deposit, through a time interval during which industrial-scale $\mathrm{Cu}$ metal production and even early attempts at making tin-bronze and As-bronze alloys were proceeding in southeastern Europe, Anatolia, and Iran. The Feinan dates are, nonetheless, consistent with the appearance of objects made from $\mathrm{Cu}$ metal in Mesopotamia and Egypt. Written language appeared at nearly the same time. Cuneiform writing in Mesopotamia apparently arose around 3900 B.C. (Kramer, 1981), and hieroglyphic writing reached a useful development in Egypt at around 3300 B.C. (Mattesich, 2002). Not long after Feinan, though, the SSC deposits in Permian sedimentary rocks along the West Ural Foreland (Lur'ye and Gablina, 1972) were mined and smelted at a large area of archeometallurgical sites collectively called Kargaly that carry ${ }^{14} \mathrm{C}$ ages that cluster near 3000 B.C. (Chernykh, 2004; Chernykh and others, 2004). Ages like this (3600 to 3000 B.C.) in Iran (Thornton, 2009) and slightly younger ages marked the beginning of the Bronze Age across almost the entire Old World, including China (Linduff and Mei, 2009) and Pakistan/India (Hoffman and Miller, 2009). Feinan later became a large integrated mining and $\mathrm{Cu} /$ bronze metallurgical center that, along with Timna, Israel, which is probably a strike-slip offset segment of the same deposit located west across the Dead Sea Transform and a little more than $100 \mathrm{~km}$ to the south (Freund, 1965, p. 193), provided $\mathrm{Cu}$ for the Early Bronze Age rise to prominence of Egypt's Old Kingdom (Rothenberg and Merkel, 1995; Weisgerber, 2006), and probably also provided some $\mathrm{Cu}$ to the Sumerian civilization of present-day Iraq. Feinan continued producing into the days of Old Testament Biblical Judea, when it was known as Edom (Levy and others, 2004). It continued as a Cu mining and production center into the Roman era when it produced its largest tonnages (Weisgerber, 2006; Hauptmann, 2007). A considerable resource of ore remains present near Feinan in three separated prospect areas (Nimry, 1973; Rabb'a and Nawasreh, 2006), but the largest of those known resources is within Jordan's Dana Nature Reserve. 
The archeological dating shows that perhaps 3,500 years passed between man's first uses of $\mathrm{Cu}$ tools made from native $\mathrm{Cu}$ and the advent of the first primitive metals industry. Another 1,500 years passed before Egypt and Mesopotamia entered the Bronze Age using $\mathrm{Cu}$ from Timna and Feinan.

Turning back to the northern area of Bronze Age exploitation of SSC deposits, Kargaly was mined increasingly from 3000 to 2000 B.C. and hit a zenith of production about 1500 B.C. apparently contributing $\mathrm{Cu}$ metal for an enormous area of the Middle Asian steppes. The mining and $\mathrm{Cu}$ smelting then mysteriously and apparently abruptly ended about 1400 B.C. and did not return until about A.D. 1745 (Chernykh, 2004). Attempting to identify the cause of collapse of Kargaly is the subject of ongoing archeological research (Chernykh, 2004; Chernykh and others, 2004).

\section{Evolution of Concepts of SSC Deposit Genesis}

Jowett (1991) wrote a thorough earlier review of the history of genetic concepts for SSC deposits focused on the deposits of the Kupferschiefer in Germany and the deposits of the Zambian Copperbelt. The following draws heavily on that paper.

Earliest consideration of the genesis of the Kupferschiefer $\mathrm{Cu}$ ores favored a syngenetic origin, synchronous with the deposition of the shale. Mining of the Kupferschiefer at Mansfeld began in 1199 (Beck, 1905, p. 492). The first paper to discuss genesis of the Kupferschiefer deposits suggested that precipitation of $\mathrm{Cu}$ took place on the sea floor, essentially the first expression of a syngenetic theory (Lehman, 1756). From then through most of the 19th century, most scientists accepted a syngenetic origin as further evidenced, they thought, by the curled-up forms of fish fossils in the Kupferschiefer that were said to be poisoned by the metals-bearing seawater (Freiesleben, 1807-1817).

Epigenetic theory began first with the observation that $\mathrm{Cu}$ content was not uniform, varying even to barren Kupfershiefer outside the Mansfeld area (Beck, 1905, p. 491). Cross-cutting faults containing Co and nickel sulfides (Rücken) were called upon as feeders to the shale-hosted ores, and it was shown that curled fish fossils were found in other shales that lacked metal enrichments and even in recent sediments. Beyschlag and others (1916) observed that ore grades decreased upward within the shale and that grades did not follow the Kupferschiefer bed in dip and strike, but rather crossed it at a small oblique angle. Thus, through the early decades of the 20th century, opinion shifted to favor an epigenetic origin for deposits of the Kupferschiefer.

Schneiderhöhn (1923) led the next wave of syngeneticists when he interpreted the chalcopyrite microspheres of less than $0.2 \mu \mathrm{m}$ diameter in the Kupferschiefer as replaced bacteria. He then took his syngenetic theory to the Zambian Copperbelt, where comparisons of the sulfide paragenesis with Butte-style veins (Bateman, 1930) had earlier been used to support epigenetic theories. Schneiderhöhn (1932) observed that the Copperbelt granites were not intrusive into the Roan Formation host rocks, but rather they were in nonconformable contact, so the granites could not have provided epigenetic magmatic hydrothermal fluids to the Ore Shale. Garlick (1961b) developed his theory of syngenesis to produce the various sulfide zones with increasing distance from a paleoshoreline - chalcocite nearest the shore, then bornite, chalcopyrite, and pyrite farthest into the basin, as would be predicted by the relative solubility of those sulfides if $\mathrm{Cu}$ entered from the continentward side dissolved in river water. Vertical zonation of pyrite over the $\mathrm{Cu}$ sulfides could then be explained by transgression of an offshore pyrite-forming environment above the earlier nearshore chalcocite-depositing one. The elegance of the concept gave it great popularity that has not totally disappeared to this day. However, increasingly detailed study of the rocks and the application of better analytical tools do not support syngenesis.

Careful petrologic studies, some that also used geochemistry, started the movement toward today's preference for depositing SSC deposits during diagenesis. Darnley (1960) described metasomatic changes to the rocks accompanying ore in Zambia and their corresponding anomalous geochemical signatures. Bartholomé (1962) at Kamoto and Brown (1971) at White Pine recorded very detailed paragenetic sequences, and both concluded that mineralizing solutions had invaded the reduced-facies hosts from underlying red beds. Annels (1974) demonstrated that $\mathrm{Cu}$-rich sulfides in shale ores of Zambia replaced anhydrite, also favoring a diagenetic timing. Rentzsch (1974) integrated a number of different methods and, most importantly, demonstrated that Rote Fäule alteration zones were correlated to ore deposits of the Kupferschiefer, as well as being related to basin margins for underlying Rotliegendes red beds rather than to early Zechstein shorelines. In support of basinal brines from red-bed packages as metals-transporting solutions in diagenetic or epigenetic ore genesis, Rose (1976) demonstrated that chloride brines in equilibrium with hematite at intermediate oxidation states were capable of dissolving sufficient concentrations of $\mathrm{Cu}$ to act as ore solutions even at low temperatures.

Studies published in the 1980s continued to move away from syngenesis and, by the end of the decade, few economic geologists still held to that theory. Jowett and others (1987) demonstrated with a paleomagnetic study of Rote Fäule rocks of the Kupferschiefer in Poland that the ore-related zone had formed at ca. 240 to $230 \mathrm{Ma}$, affecting host rocks that were deposited at about $256 \mathrm{Ma}$, a strong demonstration of a nonsyngenetic origin for those deposits. Polar wandering curves have since been revised, moving the age of the Rote Fäule to 255 to $245 \mathrm{Ma}$ (Nawrocki, 2000), but dating of the deposition of the Kupferschiefer also improved, and it was deposited from 260.4 to $258 \mathrm{Ma}$ (Menning and others, 2006; Słowakiewicz and others, 2009). At Spar Lake, Mont., Hayes and others (1989) established with S-isotope geothermometry that the mineral zones had formed across a temperature gradient of as much as $100{ }^{\circ} \mathrm{C}$, with temperatures in chalcocite-depositing zones greater than $130^{\circ} \mathrm{C}$. If the sulfides formed during syngenesis, 
then they at least did not form as Garlick (1961b) envisioned at ambient temperatures. Diagenetic or epigenetic addition of isotopically heavy sulfide was shown for White Pine and Kamoto (Hoy and Ohmoto, 1989). Also, Annels (1989) reported ore-stage fluid-inclusion homogenization temperatures that averaged $130{ }^{\circ} \mathrm{C}$ at Chambishi Southeast and $147^{\circ} \mathrm{C}$ at Chambishi in Zambia. Ore-fluid salinities of 16 to 21 eq. wt. \% $\mathrm{NaCl}$ were measured. Breit and Meunier (1990) demonstrated, using Sr isotopes of fluid-inclusion fluids, that the Paradox evaporites were the most likely source for ore-fluid salinity in the origin of the sandstone $\mathrm{Cu}$ deposits at Lisbon Valley, Utah. Hayes (1990) studied fluid inclusions in quartz overgrowths and manganiferous calcite cements at Spar Lake and noted homogenization temperatures that varied dramatically across the mineral zonation. Homogenizations varied from 74 to $130{ }^{\circ} \mathrm{C}$ in galena-bearing rock, and in chalcocite- and bornite-bearing ore zones, homogenizations occurred from 130 to $184{ }^{\circ} \mathrm{C}$. The regularly varying homogenization temperatures and a large salinity range were interpreted to record mixing between hot, saline metals-transporting brines and cooler, dilute formation water. The salinities were from less than 5 eq. wt. $\% \mathrm{NaCl}$ to greater than 20 eq. wt. $\% \mathrm{NaCl}$, increasing toward the chalcocite- and bornite-bearing ore zones.

Since Jowett's (1991) summary of studies on genesis of SSC deposits, new studies have further helped to understand the origin of this deposit type. From the Central African Copperbelt, new fluid-inclusion microthermometric studies were reported by McGowan and others (2006) at Nchanga, Zambia; by Dewaele and others (2006) at Musonoi and Kamoto, Democratic Republic of Congo; by El Desouky and others (2008a) at Lufukwe prospect, Democratic Republic of Congo; by El Desouky and others (2008b) at Mwitapile prospect, Democratic Republic of Congo; and by El Desouky and others (2009) at Luiswishi and Kamoto, Democratic Republic of Congo. Referring only to results that did not come from syn- or post-orogenic veinlets, all these studies found large ranges in homogenization temperatures and in salinities, but with considerable consistency of the ranges. Diagenetic quartz that probably replaced anhydrite and that is found with $\mathrm{Cu}$ - and (or) Co-bearing sulfides precipitated at temperatures from $100{ }^{\circ} \mathrm{C}$ to $220^{\circ} \mathrm{C}$. Large ranges in salinities should probably be interpreted as mixing of saline metalliferous brines with relatively dilute pre-ore formation waters. Organic geochemical studies addressed the Nonesuch Shale of the White Pine deposit and the Kupferschiefer (Hieshima and Mauk, 1990; Ho and Mauk, 1996; Pratt and others, 1991; Püttmann and others, 1987; Püttmann and others, 1989; Sun and Püttmann, 1997; Bechtel and others, 2002). Nonesuch Shale ${ }^{\text {Pristane }} / \mathrm{n}-\mathrm{C}_{17}$ and ${ }^{\text {Phytane }} / \mathrm{n}-\mathrm{C}_{18}$ ratios at White Pine are lower within ore than outside of it, suggesting thermal maturation of the lower Nonesuch during mineralization. In the Kupferschiefer, a number of measures were found to indicate a higher degree of oxidation in the basal section interpreted to be caused by maturation and oxidation of organics in the shale by an ascending, oxidizing, metalliferous brine.
The 1990s and early 2000s saw the first attempts to isotopically date SSC mineralizing systems (Bechtel and others, 1996, 1999; Selley and others, 2005). These met with limited success. Illite K-Ar dates on Kupferschiefer mineralization were interpreted to indicate that mineralization occurred between 216 and $190 \mathrm{Ma}$, a rather long interval much different than the ages (for example, 255-245 Ma) estimated from a paleomagnetic study of the Rote Fäule (Jowett and others, 1987). Other dates on illite (Michalik, 1997) yielded ages as young as $188 \mathrm{Ma}$ and thus led to otherwise poorly supported hypotheses of multiple times of mineralization (Michalik and Sawłowicz, 2001). Isotopic dating in the Central African Copperbelt indicated veinlet-dominated mineralization formed after the Lufilian Orogeny at ca. $510 \mathrm{Ma}$ (Richards and others, 1988b; Selley and others, 2005, p. 983), but the earlier main stage of disseminated mineralization yielded an imprecise Re-Os age of $816 \pm 62 \mathrm{Ma}$ (Selley and others, 2005, p. 983).

\section{Regional Environment}

\section{Temporal and Secular Environment}

Kirkham (1989) described the temporal and secular environment of SSC deposits. He showed that among 820 deposits and occurrences, rocks of the Middle and Late Proterozoic (110) and the Permo-Carboniferous (290) contain the greatest numbers of deposits and occurrences. The distribution of deposits is strongly controlled by paleolatitude, with most deposits and associated evaporites located within 20 to 30 degrees of the paleo-equator at the times of host-rock deposition.

Hitzman and others (2005) showed that, by tonnage of contained $\mathrm{Cu}$, there are three maxima through geologic time in the distribution of ages of SSC deposit host rocks (fig. 9). Kirkham (1989) had earlier found three maxima in the number of deposits by age, duplicating the tonnage maximum from the Neoproterozoic but with maxima in the number of deposits in the Carboniferous and Cretaceous, rather than in the Permian and Tertiary as by contained metal. By comparison with continental drift maps (Smith and others, 1981; Scotese and McKerrow, 1990) and with knowledge of the sedimentary tectonic environments of SSC deposits (see below), the time distribution of host rocks is likely showing a correlation to the rifting apart of supercontinents, Pangea in the Permian and Rodinia in the Neoproterozoic. That correlation is further explained in the following section.

\section{Geotectonic Environment and Relations to Sedimentary Rocks}

If thick sections of red beds are classified strictly into sedimentary-tectonic environments, they fall into only two environments of classical Wilson cycles (Wilson, 1966; Hoffman and others, 1974), which are sediments deposited in protoceanic rifts and in post-collisional molasse. The SSC 


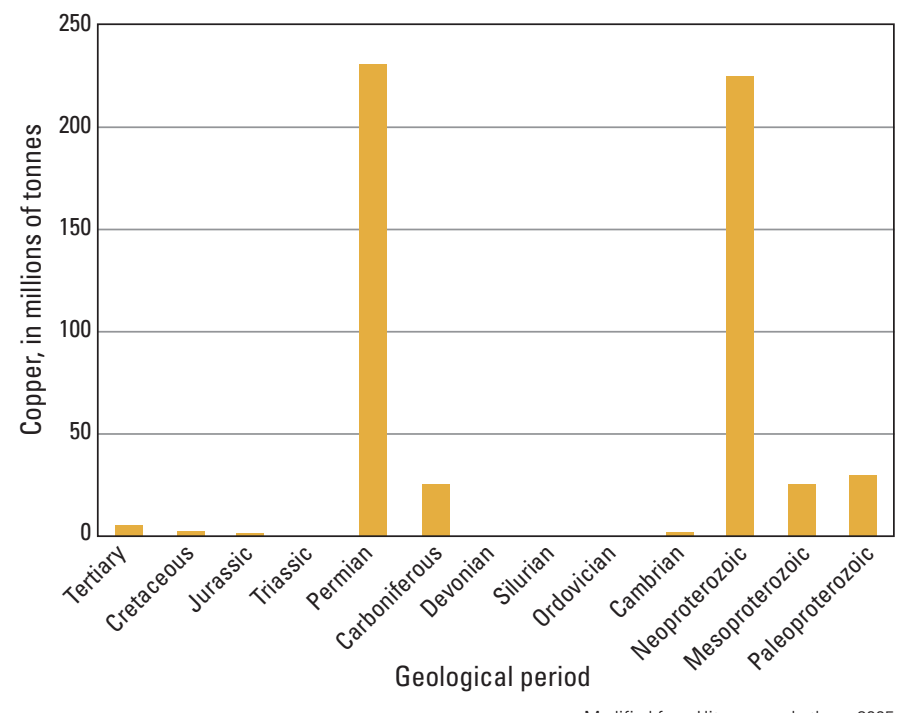

Modified from Hitzman amd others, 2005

Figure 9. Relation between contained tonnes of copper metal in sediment-hosted stratabound copper deposits and the depositional age of host rocks, from Hitzman and others (2005). Pt 1, 2, and 3, are Paleoproterozoic, Mesoproterozoic, and Neoproterozoic, respectively.

deposits are associated with the same two settings. In addition, thin packages of red beds are very widely distributed atop cratons and their margins, but economic SSC deposits are not associated with most of these red beds.

It is uncertain as to how thick a red-bed package needs to be to generate a mineralizing solution that transports $\mathrm{Cu}$ to SSC deposits. An approximate minimum appears to be red beds about $300 \mathrm{~m}$ thick. For most deposits and occurrences, the subjacent red-bed package is greater than $1 \mathrm{~km}$ thick. Importantly, though, favored sites for ore deposition in two of the most important SSC districts, the Kupferschiefer in central Europe and the Central African Copperbelt, are depositional paleohighs with only thin red-bed packages immediately subjacent or with the red-bed packages thinning over short distances beneath the host beds. Kupferschiefer ores in Germany are, at places, located immediately above late Paleozoic basement metamorphic rocks, with the Rotliegendes red beds that are elsewhere below the Kupferschiefer completely absent atop what is interpreted as a paleohorst block (Kulick and others, 1986, p. 34). The analogous geologic situation in several different parts of the Zambian part of the Copperbelt includes places where the subjacent coarse Mindola Clastics red beds are pinched out at onlaps against basement and where the paleoshoal localized stromatolitic carbonates as equivalents of the Copperbelt Orebody Member (formerly the Ore Shale) (fig. 10).

For reduced-facies-subtype SSC deposits, the host beds are particularly well defined in sedimentary-tectonic setting. The host beds are those whose base immediately marks a major transgression in the overall transgressive package of rocks. The transgressive packages are floored by fluvial red beds, which in some places include flood basalts and other alkaline volcanic rocks of variable thicknesses. The sequences change upwards through rocks deposited in nearshore marine environments to passive-margin shelf carbonates. Within such overall sequences, the rocks that host SSC deposits are the first non-red rocks upward in the package. Those fine-grained and generally carbonaceous rocks are typically marine siltstone, dolomitic siltstone, or shale. The base of the host beds is sharply erosional over subjacent coarse clastic rocks, and the erosional base represents a diastem within the sequence.

Evaporites may be present at three different levels of the overall transgressive sequence. Lacustrine evaporites can occur within the proto-oceanic rift-fill package. Anhydrite, particularly, can occur within the beds immediately above the transgressive erosional contact. Carbonaceous siltstone, shale, and dolostone with anhydrite nodules are the ore host rocks in the Central African Copperbelt, and they were probably deposited in coastal sabkhas (Renfro, 1974). In coastal sabkha host beds, such as the Copperbelt Orebody Member of Zambia and the RSF, RSC, and SDB beds of the Democratic Republic of Congo, there are thin intervals of anhydrite beds and more widespread disseminated crystals and nodules of anhydrite or pseudomorphs after anhydrite crystals and nodules (fig. 8) (Annels, 1974; Cailteux and others, 2005b; Muchez and others, 2008). However, coastal sabkha anhydrites are typically just a few meters thick, and more commonly, beds of anhydrite are not present. Rather, only nodules, discontinuous enteriolithic layers, or disseminated euhedral crystals are observed (Shinn, 1983). Thick beds of anhydrite, halite, and potash can occur farther upsection among the shelf carbonate parts of packages, including the Zechstein evaporites upsection from the Kupferschiefer. The lacustrine evaporites and the salts among the shelf carbonates can locally reach great thicknesses, and halokinesis may have occurred. Jackson and others (2003) have interpreted pre-ore salt horizons at three major and two minor levels in the ore-hosting Roan Group of the Central African Copperbelt and indicated that the salt first underwent extensive diapirism, then subsequently the salt defined the thrust planes of dêcollements, and finally the salt dissolved entirely, leaving heterolithic breccia.

The sandstone or carbonate grainstone host rocks of sandstone $\mathrm{Cu}$ deposits include coarse-grained rocks from a variety of depositional environments, although all can be generally grouped as being parts of deltaic topset beds. Hayes and Einaudi (1986) deduced that the lower quartzite beds of the upper member of the Revett Formation host rocks at Spar Lake were deposited in a prograding beach and bar nearshore environment and that the middle quartzite host rocks were deposited on subtidal bars and by laterally shifting subtidal channels. Dakota Formation host beds at the Lisbon Valley deposit were deposited in similar environments (Ridgley, 1990), but the underlying Burro Canyon Formation host rocks at Lisbon Valley were fluvial sandstones (Craig, 1982). Nearby, at the Cashin deposit, the Entrada Formation sandstone host rocks were eolian (MacIntyre, 2006). At several places in the Udokan district, Russia, the ore host beds are noted as being from the "submarine delta" facies (Bogdanov and others, 1966). At Mufulira, Zambia, van Eden (1974) recognized that the three host arenite sequences, each including 


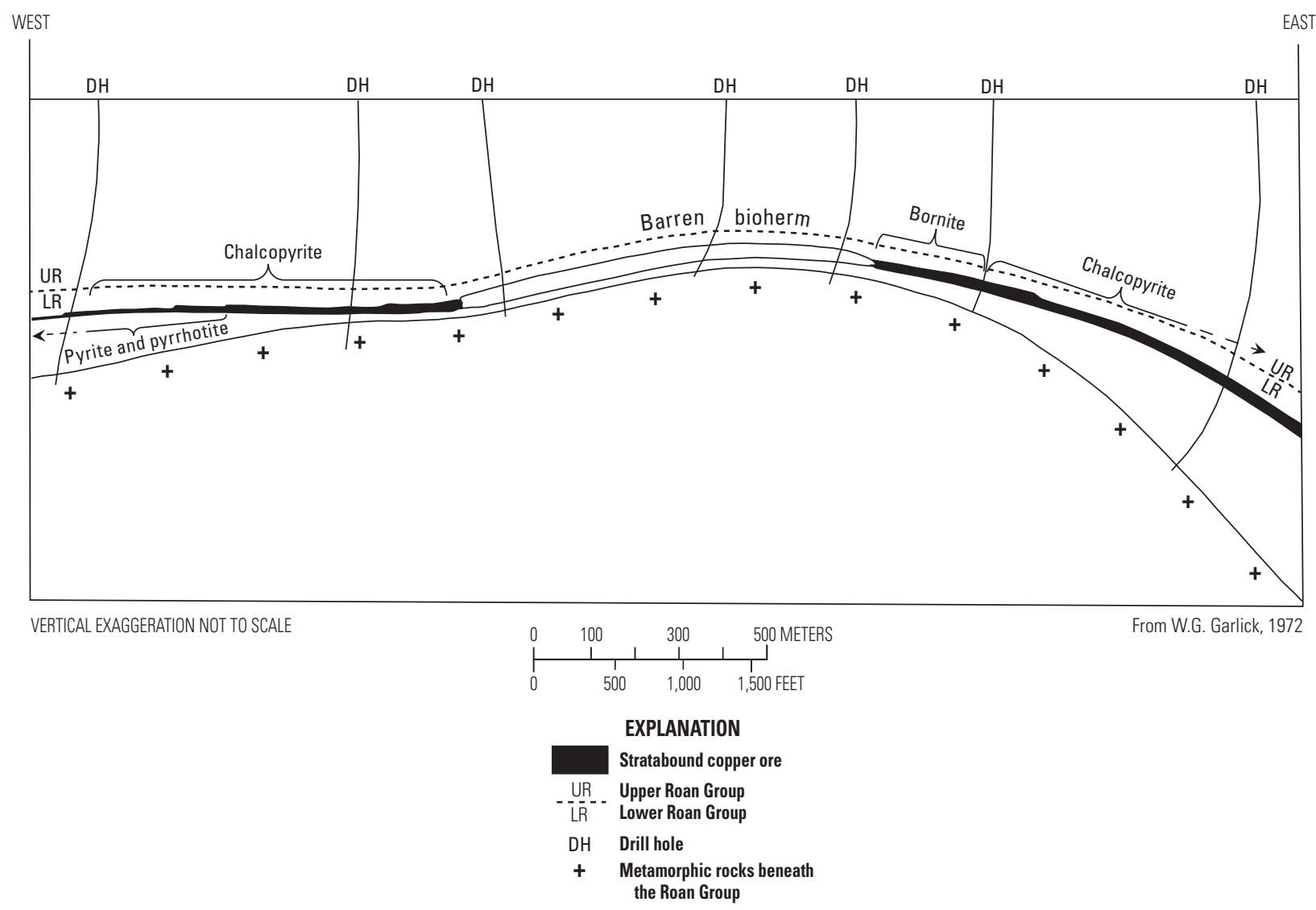

Figure 10. Cross section of the Chambishi (left) and Chambishi Southeast (right) deposits and their relation to a basement high in the Zambian Copperbelt, from Garlick (1972). The Copperbelt Orebody Member carbonaceous siltstone and shale changes facies over the high to stromatolitic dolostone, which is very poorly mineralized. The basal Mindola Clastics Member thins by onlap to a near-pinchout against the basement granite. Sulfide mineral zones parallel the margin of the basement high, the facies changes in the Ore Shale, and the pinchout of the subjacent coarse clastics, and they vary from bornite, adjacent to the high, to chalcopyrite and pyrite farther away.

some carbonaceous wacke where ore grades are highest, are separated by thin beds of coastal sabkha deposits. The sabkha mudrocks grade laterally into stromatolitic reef carbonates where the sequences onlap paleohighs. The host sandstones themselves logically were coastal and nearshore sand deposits.

Red-bed-subtype deposits are hosted by fluvial sandstones (Malan, 1968; Woodward and others, 1974; LaPoint, 1976; Flint, 1989) and less commonly by sandstones from deltaic environments (Smith, 1976). For these red-bed-subtype deposits, the host beds are commonly the only non-red rocks within thick sequences of red beds.

The most important feature of SSC host rocks is their content of reductants. These include plant or animal (cyanobacterial) fragments for the red-bed-subtype and reducedfacies-subtype deposits. The reductants were liquid or gaseous petroleum mixtures for the sandstone-subtype deposits. These reductants react with cuprous chloride and cuprous sulfate ions in oxidizing metals-transporting brines (Rose, 1976), reducing the sulfur and causing deposition of $\mathrm{Cu}$ sulfides.

\section{Structural Setting(s) and Controls}

The most important geometric aspect of SSC deposits is that they are sediment-hosted and peneconformable. Thus, they seem to be controlled almost entirely by bedding and lamination of their sedimentary host rocks. For each district, only one limited sequence of beds is mineralized to ore grades; in other words, the deposits are stratabound. Increasingly, however, it is being recognized that there are also important structural controls on locations of SSC deposits.

Faults at high angles to the host beds are found at many deposits. Many of the faults, however, simply cut and offset mineralized rocks. The importance of certain faults in ore genesis has been debated for years (for example, the White Pine fault at White Pine; Ensign and others, 1968; White, 1968), particularly in sandstone $\mathrm{Cu}$ deposits (for example, the East fault at Spar Lake; Hayes and Einaudi, 1986, p. 1927; Hayes, 1990, p. 27; Hayes and others, 2012). It can commonly be proven that the host beds are offset by faults that are suspected 
to have been genetically involved, but the timing of the offset relative to ore genesis is unclear, and the possibility that the faults were feeders for metals-transporting solutions cannot be discounted.

In the Kupferschiefer and Zambian Copperbelt deposits, faults at high angles to the host beds are present. They cut and offset the basement rocks but do not cut the host packages. These faults were the margins of subjacent grabens or halfgrabens (fig. 11).

\section{Relations to Igneous Rocks}

The SSC deposits are notable in their total lack of any clear genetic relation to igneous rocks. The sparse igneous rocks in the same sedimentary sequences with SSC deposits are typically mafic sills and rarely mafic lavas, and the economic $\mathrm{Cu}$ deposits have no relation to those igneous rocks. In the clearest example, from the Udokan deposit in Russia, the acidic igneous dikes or sills simply intrude the stratabound mineralization producing contact metamorphism of the ore, but only minor local depletion of the $\mathrm{Cu}$ grades in the sedimentary wallrocks (Bakun and others, 1966, p. 455; Bogdanov and others, 1966, p. 1312).

\section{Relations to Metamorphic Rocks}

A number of important SSC deposits are completely unmetamorphosed, but many SSC deposits have been metamorphosed along with their enclosing sedimentary-rock sequences. A simple conclusion drawn from that is that ore deposition tends to pre-date regional metamorphism. The deposits of the Central African Copperbelt are all at least lower greenschist facies and the metamorphic grade is upper greenschist for deposits from Nchanga southward in Zambia (Hitzman, 2000) reaching epidote-amphibolite facies in the Roan Basin (Mendelsohn, 1961b). Deposits of the Udokan Series are at lower greenschist grade, although the rocks have no schistocity, whereas the base of the series is upper greenschist grade and is schistose. Deposits in the Missoula and Ravalli Groups of Montana are at lower greenschist facies and at lower to upper greenschist facies, respectively. Greenschist facies metamorphism of SSC deposits has typically been noted to produce no important change to the deposits themselves.

A number of important deposits are at amphibolite or perhaps higher metamorphic grade. Aynak, Afghanistan, and other deposits along the enclosing belt of Neoproterozoic to Early Cambrian schist-, marble-, and quartzite-hosted deposits

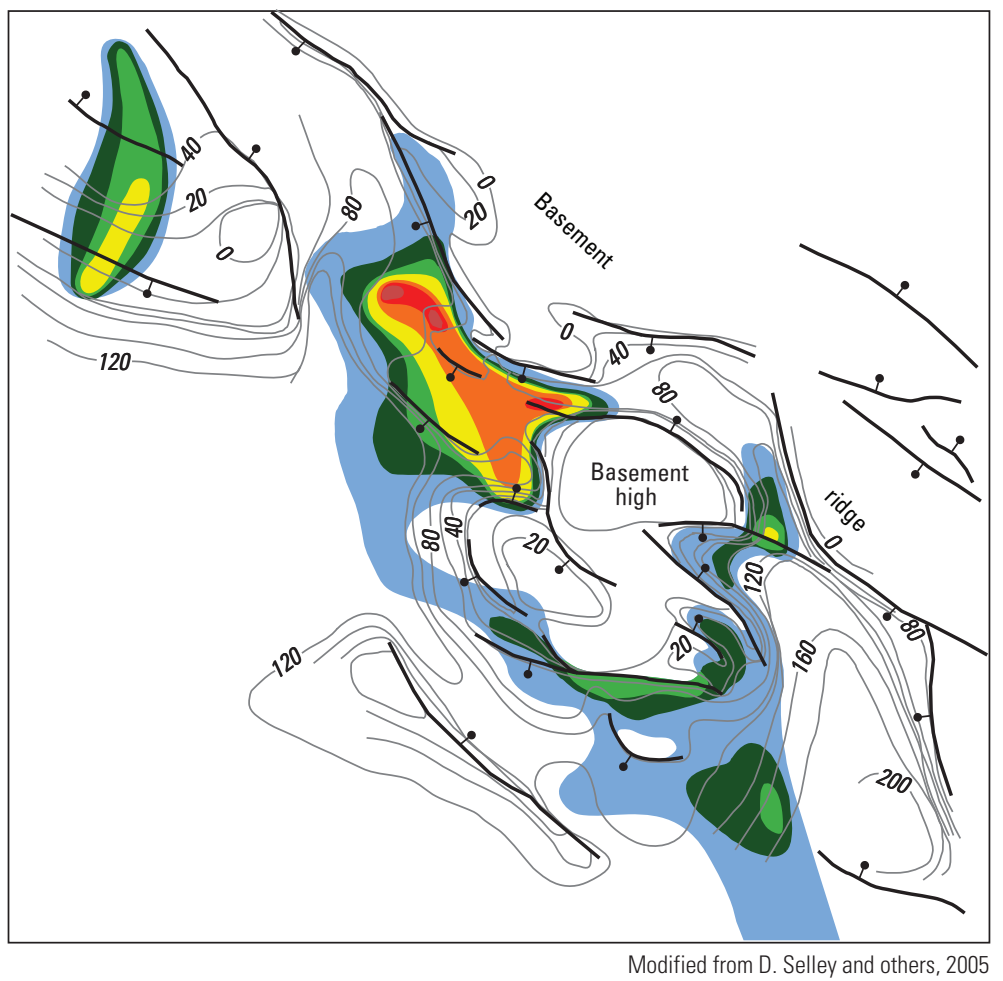

EXPLANATION

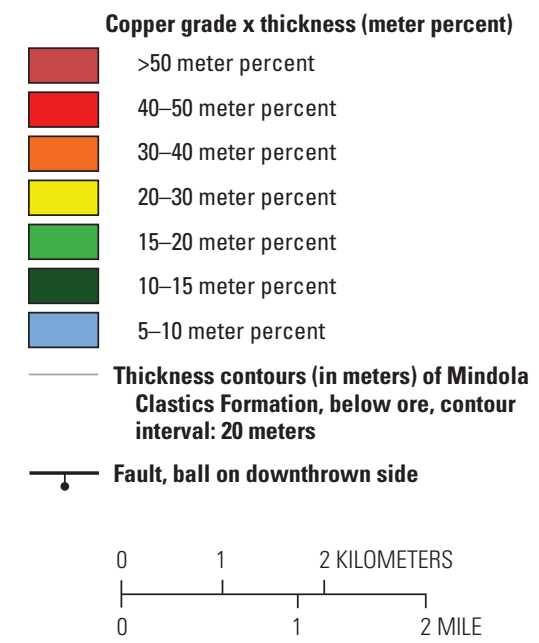

Figure 11. Deposit grade $X$ thickness contours related to basement highs and faults in the Chambishi Southeast deposit, Zambia, from Selley and others (2005). Fine black contours are the thickness in meters of the Mindola Clastics Formation beneath the Ore Shale host rocks (Copperbelt Orebody Member). Highest grade copper mineralization is underlain by pinchouts of the footwall clastics, comparable with the cross section of figure 10, and relates to fault zones (probably growth faults) that controlled sedimentation of the Mindola Clastics. 
are at amphibolite grade (Peters and others, 2007, p. 276). The deposits of the domes region west of the Zambian part of the Central African Copperbelt are also at amphibolite grade (Benham and others, 1976). In the deposits of the Domes Region, the main host rock was earlier interpretively correlated with the Copperbelt Orebody Member. The mineralized rock is now graphitic muscovite-phlogopite-kyanite schist, with feldspar-biotite schists that are interleaved. Feldsparbiotite gneisses and schists downsection, toward the core of the dome, were speculatively correlated with the red beds of the Mindola Clastics Formation. Rocks correlated with Roan impure stromatolitic dolomites are now para-amphibolites, although rocks correlated with purer carbonates of the Mwashya Formation, upsection, are dolomite marbles. Primary chalcocite is not present, and the ore sulfides are bornite and chalcopyrite. Formerly pyritic peripheral zones now contain pyrite and pyrrhotite. More recently, Davis and others (2008) have revised correlations within the Domes Region, and they suggest that the host rock formed as sheared, thrusted, and possibly nappe-folded zones within the Middle Proterozoic basement rocks beneath the Roan Group. The Oamites SSC deposit in Namibia, probably once a sandstonesubtype deposit, is metamorphosed to upper greenschist to probably lower amphibolite grade. In it, sandstone ore host rocks were metamorphosed to feldspathic-biotite-quartzite, and impure carbonate beds were metamorphosed to actinolitetremolite-biotite schists. Sulfide zonation appears to be almost completely preserved, and "sulfide facies boundaries are roughly parallel to the oxidized lithofacies/reduced lithofacies boundaries and cut across the lithozone contacts" (Lee and Glenister, 1976, p. 383).

\section{Physical Description of Deposits}

\section{Deposit Geometry}

The SSC deposits are confined to a limited sequence of sedimentary beds of each basin where they are found. Lateral dimensions are large relative to deposit thickness in all three deposit subtypes, dramatically so for the reduced-facies deposits.

Reduced-facies deposits have the geometry of sheets. Sandstone $\mathrm{Cu}$ deposits are tabular to lens shaped. Red-bed $\mathrm{Cu}$ deposits are lenses of $\mathrm{Cu}$-bearing rock.

Aerial extents and thicknesses of sediment-hosted $\mathrm{Cu}$ deposits have been described by Gustafson and Williams (1981). Reduced-facies and sandstone $\mathrm{Cu}$ deposits are the largest. Sizes of sediment-hosted $\mathrm{Cu}$ deposits are strongly affected by post-depositional faulting and erosion.

Reduced-facies-type deposits in Central Africa have strike lengths from 3,000 to $5,300 \mathrm{~m}$, widths from 550 to $2,000 \mathrm{~m}$, and ore thicknesses from 2 to $70 \mathrm{~m}$. The vertical extent perpendicular to bedding of the economically mineralized rocks in reduced-facies deposits is more commonly between 1 and $15 \mathrm{~m}$. The White Pine deposit occupies an area of $50 \mathrm{~km}^{2}$ constituting a single continuous ore layer 1 to $7 \mathrm{~m}$ thick. Within its chalcocite-bearing zone, individual beds have grades that vary only slightly over a distance of $10 \mathrm{~km}$ laterally (fig. 12). In noneconomic occurrences, which are very numerous in mineralized parts of basins, the thickness is commonly just centimeters.

\section{Dimensions and the Size of Hydrothermal Systems Relative to Extent of Economically Mineralized Rock}

The lateral extent of entire mineralizing systems may be enormous. Measured from the oxidized zone on the side towards the source of the metals-transporting fluids, the $\mathrm{Cu}$ ore zone can be tens of kilometers wide (for example, $25 \mathrm{~km}$ at Lubin, Poland). In the adjacent basin is a pyrite-bearing zone several hundred kilometers wide. The lateral dimensions are 100 to as much as 10,000 times greater than the thickness. Ore-stage hematite alteration (Rote Fäule) also extends tens to hundreds of kilometers in central Europe. Certainly, the total extent of altered rock is much larger than the economic zones of deposits, which may themselves be huge.

The economic parts of sandstone $\mathrm{Cu}$ deposits are tabular to lens-shaped, with maximum thicknesses of about $100 \mathrm{~m}$ and lengths and widths of kilometers to tens of kilometers. Deposit lateral dimensions are from 20 to 100 times the thicknesses. The largest sandstone $\mathrm{Cu}$ deposit is Udokan, Russia, which occupies a zone $10 \mathrm{~km}$ by $2.5 \mathrm{~km}$ that contains multiple ore lenses as large as $3 \mathrm{~km}$ long, $700 \mathrm{~m}$ wide, and several tens of meters thick. The middle quartzite beds hosted the Troy orebody at Spar Lake, Mont., were 2,500 by $540 \mathrm{~m}$ in area and 15 to $30 \mathrm{~m}$ in thickness. However, over about 90 percent of the area of the orebody, the thickness was consistent at 21 to $23 \mathrm{~m}$. For sandstone $\mathrm{Cu}$ deposits, the pyritic zones are as much as tens of kilometers parallel to bedding, but they probably do not reach $100 \mathrm{~km}$ in width. The extent of the hematitic zones is uncertain but may also be $100 \mathrm{~km}$ in width. The ore-related hematite zone extends into red beds where it is difficult to distinguish and has nowhere been fully mapped.

Red-bed deposits are smaller, commonly with lengths of a few tens of meters and thicknesses of less than $10 \mathrm{~m}$. For red-bed $\mathrm{Cu}$ deposits, the pyritic zones lacking $\mathrm{Cu}$ minerals are consistently less than $1 \mathrm{~km}$ parallel to bedding, and they are typically just tens of meters. Similar to the sandstone $\mathrm{Cu}$ deposits, the hematitic zones may reach $100 \mathrm{~km}$ and have nowhere been fully mapped.

\section{Source Rocks}

$\mathrm{Cu}$ source rocks are red-bed conglomerates, sandstones, siltstones, and mudstones of deltaic, fluviatile, eolian, lacustrine, or intertidal origin. The conglomerates and sandstones have cross bedding and cut and fill channels, and they had high original permeability. Detrital labile minerals, such as 
White Pine Deposit, Michigan, United States

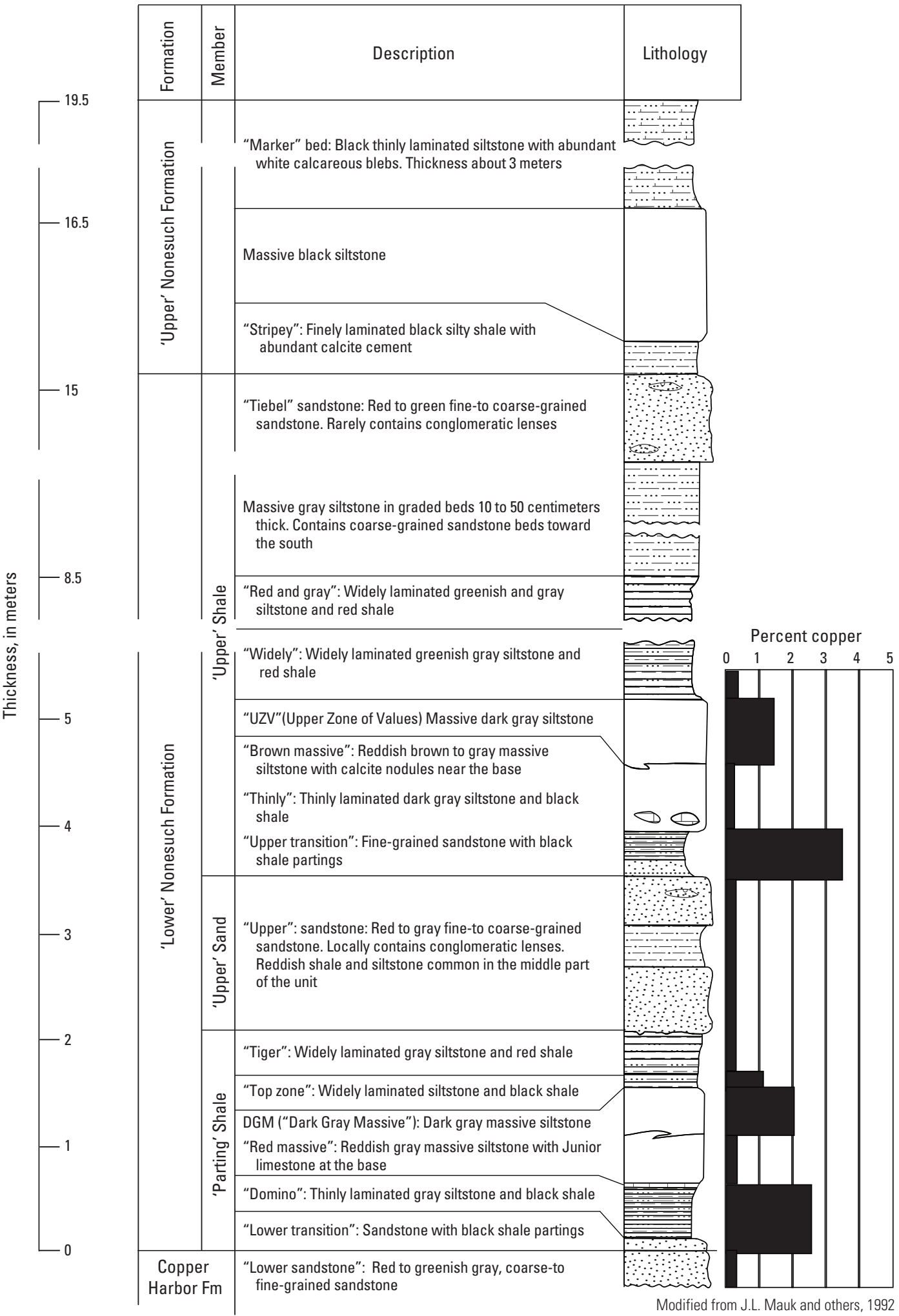

Figure 12. Stratigraphic column and typical copper grades of each host unit, White Pine deposit, Michigan, United States, from Mauk and others (1992a). Within the chalcocite-bearing zone, copper grades are remarkably consistent laterally within each bed across more than 10 kilometers laterally, and they correlate inversely with grain size of the host beds and directly with the content of organic carbon. Both relations are typical of reduced-facies-type deposits. 
amphibole, pyroxene, and plagioclase, probably acted as the ultimate sources of $\mathrm{Cu}$ (Walker and others, 1967; Walker, 1989; Lapoint, 1974). Zielinski and others (1983) demonstrated that in the process of early diagenetic reddening in red beds, the $\mathrm{Cu}$, and probably other metals, are "stored" in the earliest diagenetic ferric oxides. In hotter, deeper, more advanced conditions of diagenesis, the metals may be released to mineralizing solutions as the hydroxylated ferric oxides dehydrate to hematite. Goethite dehydroxylates to hematite at slightly above $125^{\circ} \mathrm{C}$ at atmospheric pressure (Posnjak and Merwin, 1919, p. 326-334). Observed mineralizing solutions are very saline (Annels, 1989; Hayes, 1990; Dewaele and others, 2006; El Desouky and others, 2009), so the process of releasing metals into a mineralizing solution is probably not simply because of aging and dehydration of the ferric-oxide grain coatings and is, instead, a chemical leaching by saline groundwater. The groundwater may have entered into the redbed sequence from outside, or it may have been indigenous to the red beds as an originally connate water. The $\mathrm{Cu}$ source rocks have been firmly identified only from the Redstone copperbelt in Canada (Lustwerk and Rose, 1983) and from the Western Montana Copper Sulfide Belt (Hayes, 1990).

Flood basalt packages may be alternative or additional source rocks for $\mathrm{Cu}$ in some districts and in the volcanic red-bed type of related deposits. Alteration of amphiboles and pyroxenes to epidote in those rocks appears to accompany $\mathrm{Cu}$ mobilization (Livnat, 1983; Borg, 1991). For these, also, the source of the mobilizing groundwater is unclear.

\section{Host Rocks}

Reduced-facies host rocks are commonly thin-bedded to very thinly laminated carbonaceous shale, siltstone, or very fine-grained sandstone, or they are similarly thin-bedded to very thinly laminated impure carbonaceous carbonate rocks. The Kupferschiefer shale is the deepest water marine rock in its local section, being a discrete transgressive bed commonly just 30 to $70 \mathrm{~cm}$ thick, with a top that typically grades upward into the overlying Werra carbonate and a bottom that is sharply erosional and underlain by a few centimeters to very rarely as much as $2 \mathrm{~m}$ of Zechstein conglomerate. In medieval times, only the Kupferschiefer shale bed itself was mined, and it typically averaged greater than 5 percent $\mathrm{Cu}$. Now, at places such as Lubin, Poland, and Sangerhausen, Germany, the Kupferschiefer bed is mined along with locally as much as $10 \mathrm{~m}$ of underlying mineralized Weissliegendes sandstones and with locally as much as $4 \mathrm{~m}$ of overlying mineralized Werra carbonates beds. The zone of ore-grade $\mathrm{Cu}$ mineralization cuts very gently across all three beds allowing various combinations to be economically mined but typically totaling 3 to $4 \mathrm{~m}$ in thickness at Lubin at an average grade of 2 percent $\mathrm{Cu}$.

The hosts of sandstone $\mathrm{Cu}$ deposits contrast with the reduced-facies deposit host rocks. Hosts of sandstone $\mathrm{Cu}$ deposits are medium- to very thickly bedded sandstones (bed thickness terminology of Ingram, 1954). These are typically well-sorted feldspathic to arkosic sandstones. Where conglomeratic, they typically have only mud intraclasts and are not polymictic.

The hosts for red-bed-type deposits are conglomeratic sandstone, typically feldspathic or arkosic. They are commonly polymictic.

The presence of plant or animal remains provides a carbonaceous host for $\mathrm{Cu}$ deposition for the reduced-facies and red-bed-type deposits. Where best studied in the Kupferschiefer, the organic remains were originally alginite, sporinite, liptodetrinite, and amorphous material, and they became bitumen and kerogen during mineralization (Nowak and others, 2001). In the Late Permian Creta Shale, the organic remains were Triletes spores, which were replaced pseudomorphically by chalcocite (Hagni and Gann, 1976). In red-bed $\mathrm{Cu}$ deposits, the organic remains were of higher vascular plants, and those were pseudomorphed by $\mathrm{Cu}$ sulfides, including chalcocite, bornite, and chalcopyrite (Tarr, 1910, p. 223; Richard, 1915, p. 640; Fath, 1915, p. 146; Miller, 1955, p. 161-162; Soulé, 1956, p. 16). Red-bed $\mathrm{Cu}$ deposits are well known for their $\mathrm{Cu}$-sulfide-pseudomorphed logs (at Nacimiento, N. Mex., for example; Woodward and others, 1974).

Some associated rocks are evaporite or sabkha beds. These provide a source of metals-transporting brine.

\section{Structural Setting(s) and Controls}

The SSC deposits occur in many different present-day structural settings. Host basins vary from early transtensional basins (for example, Boleo, Baja California, Mexico), through aulacogens and other general rifted settings (for example, Spar Lake; Kupferschiefer, central Europe), to post-orogenic molasse basins (for example, Dzhezkazgan, Kazakhstan; Tschudi, Namibia), and to fold-and-thrust belts (for example, Democratic Republic of Congo part of the Central African Copperbelt; Aynak, Afghanistan). They share, however, only two original sedimentary tectonic settings from the time of host-rock deposition. These are early oceanic rifted margins (for example, Kupferschiefer; Central African Copperbelt exclusive of post-orogenic veinlet-controlled deposits such as Kansanshi and Lonshi; Oklahoma and northern Texas postaulacogen setting; Juramento, Argentina) and late- to postorogenic molasse basins (for example, Dzhezkazgan; Tschudi, Lisbon Valley).

The mineralizing process, however, in SSC deposits is controlled mostly by sedimentary lithology and not by structure. However, faults may have been important in other ways. Areas where faulting or folding have caused favorable beds to be uplifted and exposed, but not destroyed by erosion, are highly prospective. For certain sandstone $\mathrm{Cu}$ deposits, faults or fault zones may have fed oxidizing metalliferous basinal brines from red beds into favorable host rocks. This is suggested by the geometry of the Cashin deposit in the Paradox Basin, Colo. (fig. 13) (Thorson and MacIntyre, 2005; MacIntyre, 2006), and it may be the case for many other 


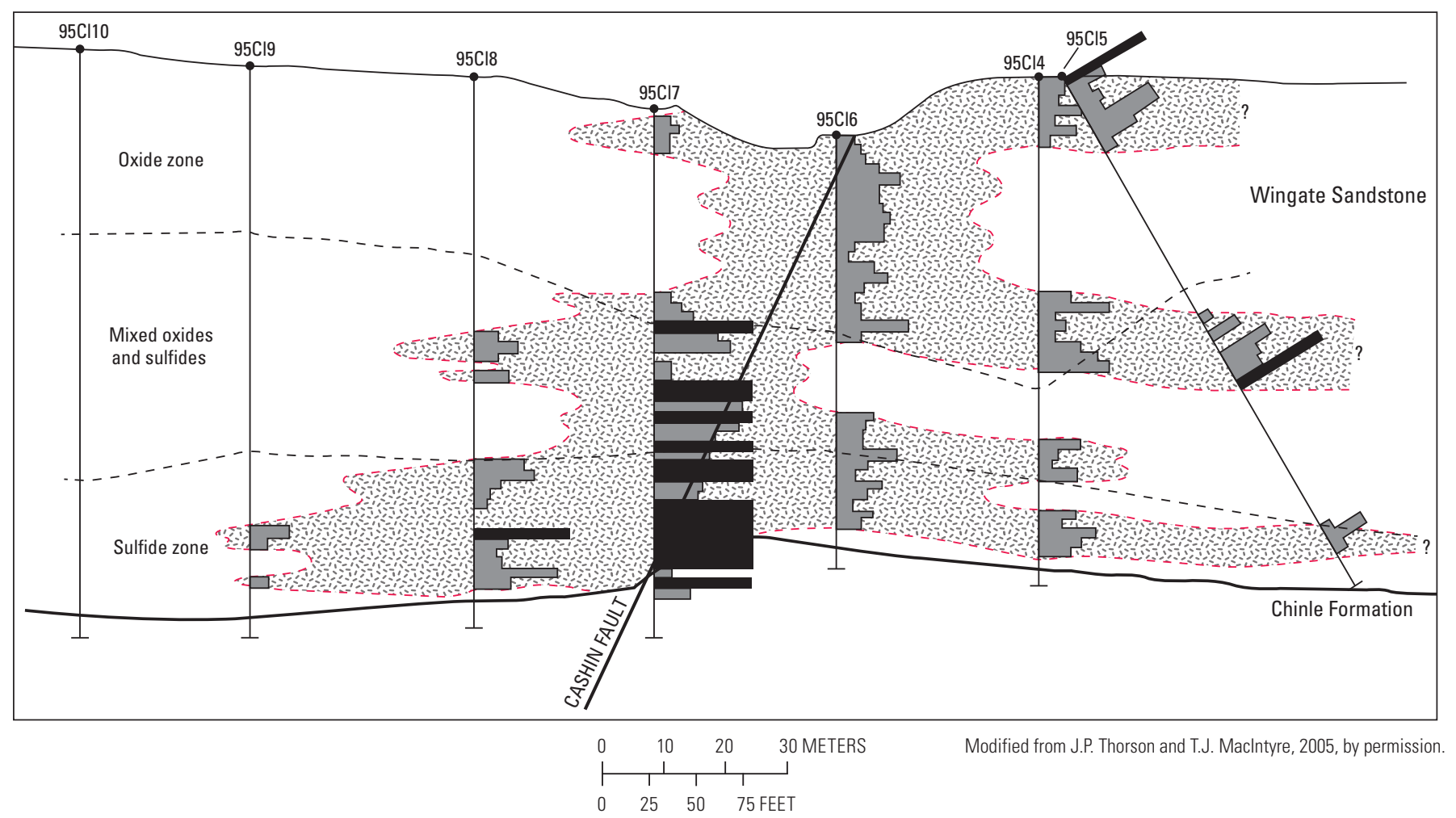

EXPLANATION

Contact
Stratigraphic
Uncertain presence or uncertain continuation
$\quad$ Borehole (with borehole ID)

$\quad$ Copper assay values
\[ 0.1 \% \]

Figure 13. Cross section of the Cashin sandstone copper deposit, Colorado, United States, from Thorson and Maclntyre (2005). The section is perpendicular to the strike of the Cashin fault and to the long axis of the deposit. The zone of greater than 0.1 percent copper (within the heavy red dashed line) is an irregular zone distributed grossly symmetrically surrounding the fault, although with values controlled strongly along bedding within the Wingate Sandstone host rocks and decreasing away from the fault. Mineralizing fluids are inferred to have ascended along the fault before migrating outward from it along permeable beds.

sandstone $\mathrm{Cu}$ deposits. Those in the Revett Formation in the Belt Supergroup each have one or more possible feeder faults, such as the East Fault at Spar Lake. It is still uncertain whether the East Fault did or did not feed metalliferous basinal brines into the host beds, although it is certain that metalliferous fluids had to come upward across section into the ore zone before spreading within those permeable beds.

In Kazakhstan, geologists recognize two types of sandstone Cu deposits: Dzhezkazgan-type (for example, Dzhezkazgan, Zhaman-Aibat) and Zhilandy-type (for example, Itauz, SaryOba, Kipshakpai, Karashoshak). The Dzhezkazgan-type form concentric rings along the flanks of anticlinal structures, with pyritic zones interior to each ring and chalcocite being exterior. The Zhilandy-type instead has a concentric zonation centered on an elongate central chalcocite zone, which is generally a fault (B. Syusyura, oral commun., 2009). As defined above, Cashin, Lisbon Valley, Spar Lake, Rock Creek, and Montanore are all similar to the Zhilandy-type deposits.

Reduced-facies-subtype deposits may also be affected and localized by faults. At White Pine, Mauk and others (1992b) showed a number of relations between compressional fault features and second-stage $\mathrm{Cu}$ mineralization. First stage constituted most of the finely disseminated chalcocite-dominated mineralization that replaced pyrite in the Nonesuch Formation and that produced a chalcocitebornite-chalcopyrite-pyrite fringe (Brown, 1971). Second stage included (1) bedding-plane seams of native copper, (2) bedding-plane seams of chalcocite, (3) stockwork veins 
of chalcocite localized adjacent to thrust faults, (4) cementing native copper occurring together with pyrobitumen in the top of the Copper Harbor Conglomerate, (5) slickensided sheets of native copper along bedding, (6) bedding-plane seams of native copper that pass laterally into seams of chalcocite, (7) mineralogically zoned disseminations developed as halos adjacent to thrust faults, and (8) disseminations that are mineralogically zoned, chalcocite to bornite to chalcopyrite to pyrite over centimeters above and below bedding-plane seams of chalcocite. A feature that compellingly demonstrates $\mathrm{Cu}$ mineralization during compressional faulting is a thrust fault that offset bedding by $90 \mathrm{~cm}$ but that offset a bedding-plane vein of native $\mathrm{Cu}$ by only $60 \mathrm{~cm}$ (fig. 14). The bedding-plane vein contained native copper deposited after offset began on the thrust fault and was then, itself, offset by later movement on the thrust. Second-stage mineralization at White Pine is dominated by native copper, although it does include minor chalcocite, whereas first-stage mineralization is Cu-sulfidedominated, although it does include minor native copper. With its relation to compressional faulting and native copper dominance, the second-stage mineralization seems likely to correlate with the time of native copper mineralization in the Portage Lake Lava Series to the northeast in the Keweenawan Native Copper district. Brown $(2006,2008)$ interpreted that the second-stage mineralization was from a brine similar

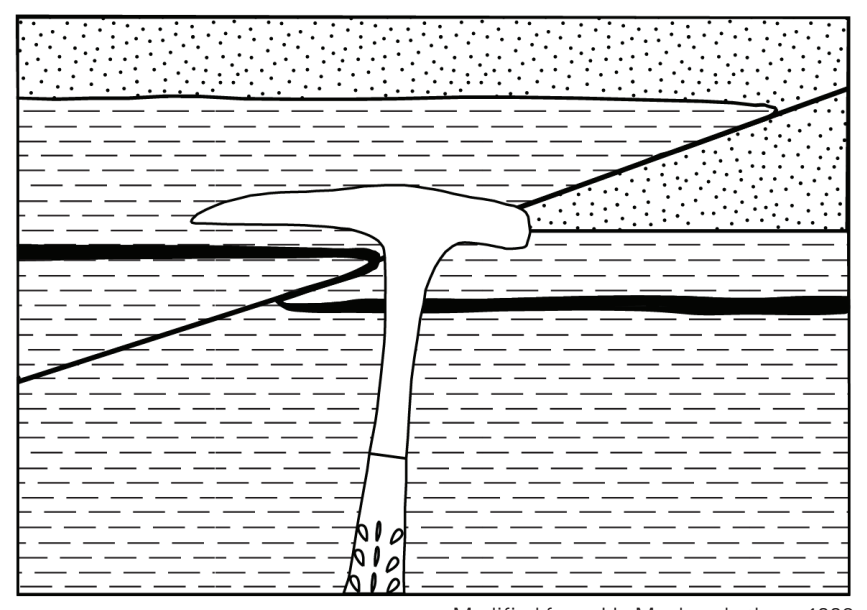

Modified from J.L. Mauk and others, 1992
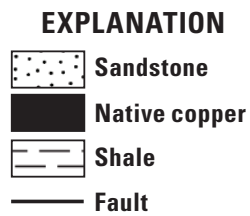

Figure 14. Sketch of a field relation in the White Pine deposit, Michigan, United States, from Mauk and others (1992b). A rock hammer is sketched for scale. The thick black line in the shale is a seam of native copper parallel with bedding. It was offset by the small reverse fault but not so much as the bedding contact was. The mineralization in the seam must have been deposited during the period of compressional faulting. It is part of the second-stage mineralization at White Pine. to that from the first, disseminated stage, but the sulfide in the host rocks had been used by the first stage, such that the second was dominated, in the basal ore section, by native copper. Brown correlated each stage with a stage of highland recharge to the $\mathrm{Cu}$ source rocks, and he correlated the second stage, which included mineralized veins, amygdular and brecciated flow tops, and conglomerates in the Portage Lake lavas, to compressional features at White Pine caused by late Mesoproterozoic Grenvillian deformation.

Another frequent type of control of reduced-facies deposits by faults is where such deposits are localized above the flanks of basement horst blocks, a relation demonstrated by several different deposits in the Zambian Copperbelt (fig. 11). Zambia also has deposits where the mineralized arenite beds are truncated against faulted basement (fig. 15).

\section{Geophysical Characteristics}

\section{Regional-Scale Geophysics}

There has been an increasing recognition that SSC deposits occupy recognizable settings within basins. This lends itself to all geophysical methods that can help determine basin geometry.

Reduced-facies-subtype deposits tend to occur above the flanks of basement horsts or generally above the flanks of basins. Gravity and magnetic methods can map characteristics of basement rocks through sedimentary sections, which themselves have much lower specific gravity and much lower magnetic susceptibility than the crystalline basement. Airborne magnetic surveys are fast, inexpensive, and easily combined with additional electromagnetic methods that could be effective in limited circumstances at deposit-scale (see below, the discussion of induced polarization, IP, methods). Faults, especially those that affect basement but not the overlying sedimentary rocks, can be mapped on first- and second-derivative maps of the gravity and magnetic signatures.

Because halite and sylvite have low specific gravities ( 2.16 and $1.99 \mathrm{~g} / \mathrm{cm}^{3}$, respectively), gravity maps and particularly microgravity maps can identify salt structures. These may be associated with SSC deposits (examples are Lisbon Valley, Utah, and Corocoro, Bolivia).

Obviously, either or both seismic-reflection and seismicrefraction surveys can help identify basement structure and overall basin geometry.

\section{Deposit-Scale Geophysics}

Earlier models for SSC deposits (Kirkham, 1984a; Cox, 1986; Cox and others, 2003) made no mention of any geophysical methods applicable to exploration for this type of deposit. Some methods are, however, effective, particularly where the sedimentary section generally lacks conductive rock types. 


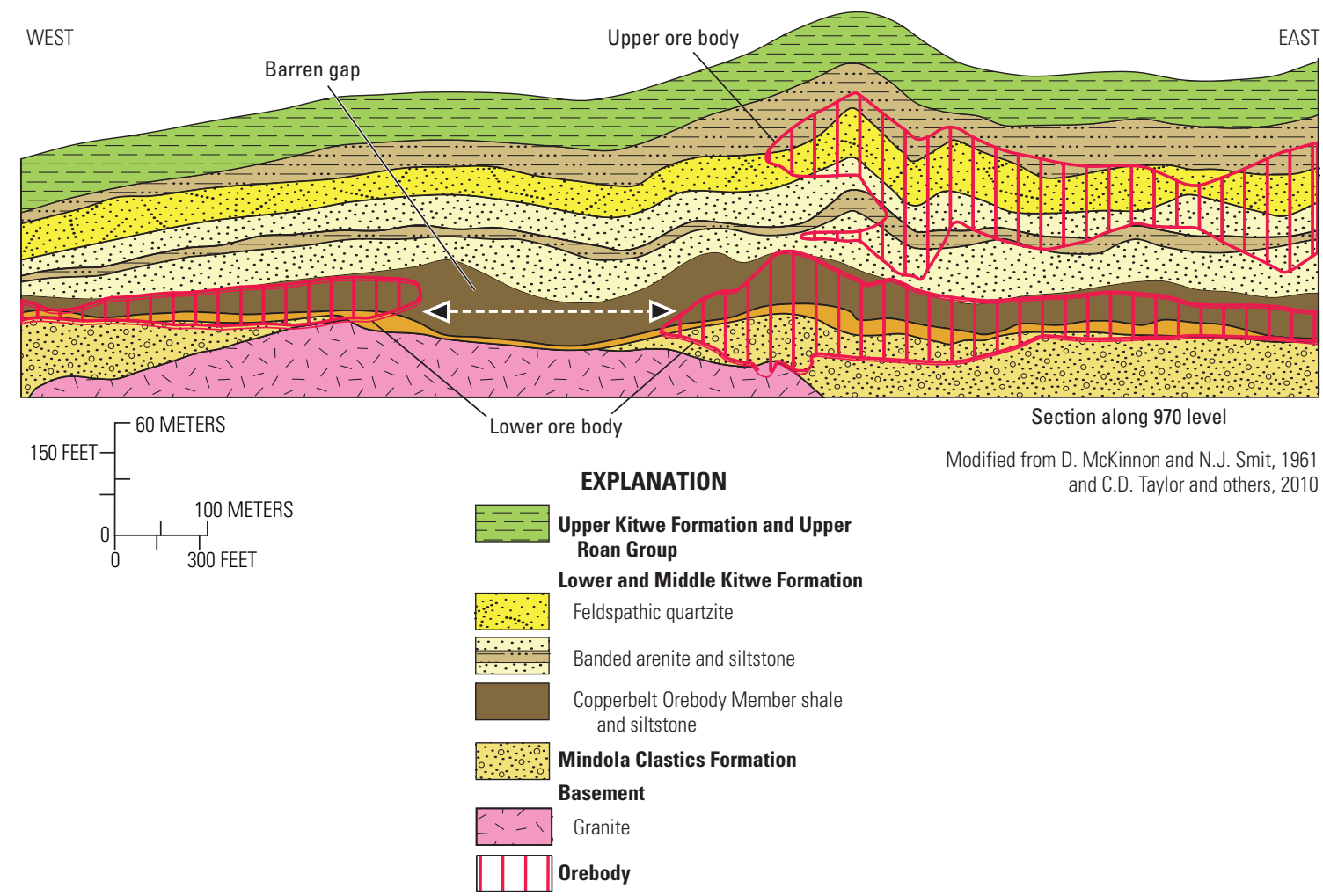

Figure 15. Distribution of ore in the Nchanga deposit, Zambia, in a vertically exaggerated schematic section that looks approximately downdip along the bedding, from McKinnon and Smit (1961). Comparable with figures 10 and 11. The distribution of ore is controlled by the pinchouts of the Mindola Clastics Formation against the basement high, subjacent to the major ore host, the Copperbelt Orebody Member. Note that the sandstone pinchouts against basement would constitute an updip pinch-out stratigraphic trap in a petroleum province.

Vector induced polarization was first tested over the premining Spar Lake sandstone Cu deposit (Van Voorhis, Asarco, Inc., written commun., 1970), and following successful demonstration of the utility of the method, it was widely applied in the area by Kennecott Exploration Services. Between 1970 and 1975, they conducted induced polarization (IP) surveys along 18 crisscrossing lines in the area of the deposit and to its north. In addition to the known deposit, three anomalous areas were found, although one of these was downsection from any Revett Formation potential ore host rocks. The better of the remaining two anomalies, the Fairway Creek prospect, was drilled and resulted in discovery of a zone of anomalous pyrite concentrations with minor galena disseminated in upper member quartzites of the Revett Formation. Lying along trend with the elongation of the Spar Lake deposit and also along the East Fault, the Fairway Creek prospect, which has no outcrop exposure, may be the northwest distal continuation of the Spar Lake mineral zonation (fig. 7).

Van Voorhis (Asarco, Inc., written commun., 1970) noted that the rocks of the Spar Lake area generally had extremely high resistivity so that even with less than 1 volume $\%$ total sulfides (and about $0.1 \mathrm{v} \%$ magnetite) in the orebody, there was a well-defined anomaly. For the dipole-dipole survey that passed over the orebody looking through about $300 \mathrm{~m}$ of cover, modeled resistivity of the ore was 2,600 to about
3,300 ohm-meters, whereas the surrounding country rocks generally exceeded 5,000 ohm-meters. Orebody calculated metal factors were 8 to 10 milliradians, whereas country rock metal factors were everywhere 6 or less milliradians and were 0 to 3 milliradians at all distances greater than $1 \mathrm{~km}$ from the deposit boundaries. Responses over the Fairway Creek prospect sulfide-anomalous body were nearly identical for a cover thickness that was also about $300 \mathrm{~m}$.

IP has also proven very effective in recent prospecting near the Malundwe and Chimiwungo deposits (Lumwana mine) in Zambia. The setting there is grossly similar in having very resistive rocks everywhere surrounding the deposits. Those deposits occur in highly sheared "mylonitized, recrystallized muscovitephlogopite-quartz-kyanite schists," with quartz-feldspar-biotite gneisses above and below the sulfide-mineralized schists (Davis and others, 2008, p. 27-28). The schists are interpreted as zones of thrusting and possible nappe folding that were mineralized with bornite, chalcopyrite, and distal pyrite. The Chimiwungo North orebody was discovered in 2004 by drill testing an IP chargeability anomaly, which then led to completing greater than $150 \mathrm{~km}^{2}$ of IP coverage nearby over the next few years. The work identified 27 IP chargeability anomalies. Two of those (Kanga and Kababisa prospects) had received initial drill testing by June 2008, and both drill programs had intersected significant $\mathrm{Cu}$ sulfides (Davis and others, 2008, p. 27 and 31-34). 
The success of IP for deposit-scale prospecting for SSC deposits will probably be limited to areas that lack other conductive rock types, such as pyritic black shales or graphitic schists. Nonetheless, the method could be effective in additional areas. The Udokan region of Transbaikalian Russia is similar to the Belt Supergroup, composed almost entirely of resistive rocks, so IP promises to be a useful deposit-scale prospecting technique in that area. In the Democratic Republic of Congo, most orebodies are found in the Roan-2 stratigraphic interval within stratigraphically coherent "ecailles" (French: flakes) floating within chaotic breccia. Additional ecailles orebodies might be effectively located with limited-area IP surveys. The IP can expect only limited success where the surveys go beyond the areas of outcropping Lower Roan Group and breccia, onto upsection areas underlain by rocks of the Dipeta and Mwashya Groups and the Grand Conglomerate. Those rocks upsection all have substantial intervals of black shale. But within the Lower Roan exposure, where ore-bearing "ecailles" may be covered beneath breccia only meters below the surface without any surface expression, IP promises to be effective.

Application of seismic methods was mentioned above with reference to helping determine basin geometry. Seismic studies have also been used in deposit-scale prospecting in the Chu-Sarysu Basin, Kazakhstan. The blind Zhaman-Aibat and Taskura deposits were discovered by drilling on the geologically mapped Zhaman-Aibat anticline beginning in the 1920s (Japan International Cooperation Agency and Metal Mining Agency of Japan, 1997), using the analogy of that structure to the Dzhezkazgan brachyanticline. Having concluded that the sandstone $\mathrm{Cu}$ deposits of the Chu-Sarysu Basin are associated with accumulations of hydrocarbons (Syusyura and Tyugay, 2008), explorationists have since focused on seismically indicated positive structural closures, with several additional prospects successfully identified in recent years (B. Syusyura, oral commun., 2009). Hayes and others (2012) have confirmed that sandstone $\mathrm{Cu}$ deposits form in association with hydrocarbon accumulations. They found that Spar Lake formed where oxidizing $\mathrm{Cu}$-transporting brines mixed and reacted with a reservoir of sour gas. Obvious next steps are (1) to start prospecting for former stratigraphic and combination traps in productive basins such as the Chu-Sarysu; and (2) to apply the thinking and mineral-exploration methods to other basins that host known SSC-mineralizing systems and that have known sour gas accumulations and seismic data, such as central Kansas, western Oklahoma, and northern Texas, United States.

\section{Remote Sensing of Sediment-Hosted Stratabound Copper Deposits}

Two possible applications of remote sensing may be of use in exploration for SSC deposits. First, $\mathrm{Cu}$ clearings were wellknown and widely searched for using air photos in the early days of exploration in Zambia and the Democratic Republic of Congo (Ellis, 1961, p. 175-177). Even 100 years after their first recognition, similar features may still await discovery. In other climates with other specific types of vegetation, different types of vegetation anomalies may accompany outcropping SSC deposits, and the vegetation anomalies may be visible using remotely sensed spectral data. Second, bleaching of red beds is easily mapped by remote sensing (Beitler and others, 2003) either using simple color mapping or mapping of $\mathrm{Fe}$ oxides using Landsat, AVIRIS (Airborne Visible/Infrared Imaging Spectrometer), or ASTER (Advanced Spaceborne Thermal Emission and Reflection Radiometer) imagery. Current thinking holds that sandstone $\mathrm{Cu}$ deposits can mineralize only the bleached sandstones of such systems (Thorson, 2005; B. Sysyura, oral commun., 2009). Assumedly, the red sandstones would not be mineralized because they were in equilibrium with the hematite-stable metals-transporting brines, whereas some of the bleached sandstones would contain petroliferous fluids that would be reactive with the metalstransporting brines. If true, then only bleached sandstones would be prospective in regions such as the Colorado Plateau, United States, the Chu Sarysu Basin, Kazakhstan, and the Western Montana Copper Sulfide Belt, United States.

\section{Hypogene Ore Characteristics}

\section{Grade}

Because of the high $\mathrm{Cu}$ content of chalcocite, digenite, bornite, and djurleite, which characterize SSC deposits, $\mathrm{Cu}$ grades of this class of deposits average 2.1 percent, compared to porphyry $\mathrm{Cu}$ deposits ( 0.44 percent $)$ or Kuroko massive sulfide deposits (1.3 percent) where chalcopyrite is the main $\mathrm{Cu}$ mineral. Less than 20 percent of SSC deposits contain substantial Ag, grading between 2 and $200 \mathrm{~g} / \mathrm{t}$, or Co, grading between 0.15 and 0.5 percent in primary ores (Mosier and others, 1986, p. 207-208). Co, in particular, is present at much higher grades locally in supergene, residually enriched ores in the Central African Copperbelt.

A platinoid metal and Au orebody has been identified and described, paralleling the zonation of $\mathrm{Cu}-, \mathrm{Pb}-$, and $\mathrm{Zn}$ bearing sulfides and lying from 0 to $0.5 \mathrm{~m}$ below the $\mathrm{Cu}$ ore of the Kupferschiefer mineralizing system on the Fore-Sudetic Monocline in Poland. The deposit of precious metals averages $0.22 \mathrm{~m}$ in thickness, with grades of $2.25 \mathrm{~g} / \mathrm{t} \mathrm{Au}, 0.138 \mathrm{~g} / \mathrm{t} \mathrm{Pt}$, and $0.082 \mathrm{~g} / \mathrm{t} \mathrm{Pd}$, although no tonnage has been announced (Piestrzynski and others, 2002, p. 517). However, economically recoverable ore does not form a continuous layer beneath the $\mathrm{Cu}$ ore. For example, about 30 percent of the area of the Polkowice deposit is underlain with a greater than $20 \mathrm{~cm}$ thickness of greater than $1 \mathrm{~g} / \mathrm{t} \mathrm{Au}$. Given, however, that the deposits of the Fore-Sudetic monocline total an area of more than $410 \mathrm{~km}^{2}$ (S. Osczcepalski, oral commun., 2008), this may be the largest Au deposit in Europe. Unfortunately, the $\mathrm{Au}$ and platinoid concentrations were not identified until after large tonnages of $\mathrm{Cu}$ ore had already been mined, and many workings have collapsed, which may render the Au resource unprofitable to mine in those areas (Z. Sawlowicz, oral commun., 2001). 


\section{Ore Mineralogy and Assemblages}

Sulfide mineralogy and its zonation are well-defined for SSC deposits. They were briefly described earlier in the report and illustrated in figures 4, 5, 6, and 7 .

Most SSC deposits contain chalcocite, digenite, bornite, and chalcopyrite. Some, such as Boleo, contain monoclinic (pseudo-orthorhombic) chalcocite crystals (Touwaide, 1930, p. 134-135), demonstrating that the main ore zone of the deposit formed at less than $103.5^{\circ} \mathrm{C}$ (Roseboom, 1966). Others, such as White Pine and Dzhezkazgan, contain hypogene djurleite (Brown, 1971, p. 556; Lur'ye and Gablina, 1976, p. 72; respectively). However, statements by Brown (p. 565) and Lur'ye and Gablina (p. 73), that the presence of djurleite limits the temperature of ore deposition to $93{ }^{\circ} \mathrm{C}$ or less are incorrect unless more conditions are met. The maximum thermal stability of djurleite is $93{ }^{\circ} \mathrm{C}$ (Roseboom, 1966). The djurleite composition can, however, be reached by exsolution on cooling from a higher temperature solid solution with composition within the high digenite solid solution (Roseboom, 1966, p. 648). Djurleite would be a demonstration of origin at less than $93{ }^{\circ} \mathrm{C}$ only if it occurred in its own euhedral crystals (analogous with the monoclinic chalcocite of Boleo), or if it occurred in large, monomineralic masses in the ores (Roseboom, 1966). Also, the presence of X-bornite (Cu-deficient, S-rich bornite, "orange bornite") does not limit the origin of Dzhezkazgan, Kazakhstan, ores to $75^{\circ} \mathrm{C}$ or less as was claimed by Lur'ye and Gablina (1976, p. 76) and repeated several times since. X-bornites, when heated, exsolve to chalcopyrite and stoichiometric ("brown") bornite. So presence of X-bornite at Dzhezkazgan in the local absence of both chalcopyrite and brown bornite was taken to indicate that Dzhezkazgan had formed below $75^{\circ} \mathrm{C}$, the temperature by which the exsolution took place in some X-bornites from redbed-type deposits of the Colorado Plateau in heating experiments (Brett and Yund, 1964). However, X-bornites have varying thermal stabilities (Brett, 1962; Brett and Yund, 1964; Yund and Kullerud, 1966). Other X-bornites from Colorado Plateau deposits did not exsolve chalcopyrite and brown bornite until they were heated to $100^{\circ} \mathrm{C}$ (Brett and Yund, 1964), and synthetic X-bornite did not exsolve until heated to greater than $140{ }^{\circ} \mathrm{C}$ (Yund and Kullerud, 1966). Lur'ye and Gablina would have had to do heating experiments with the Dzhezkazgan X-bornites, themselves, to establish a minimum temperature provided by the X-bornite there, or claim only the conservative temperature estimate, that the deposit formed at $140{ }^{\circ} \mathrm{C}$ or less. Native silver is present in a number of deposits within rocks that also contain chalcocite and (or) bornite (Woodward and others, 1974; Jung and Knitzschke, 1976; Hayes and Einaudi, 1986, p. 1910 and 1916-1917; Volodin and others, 1994, p. 18). Stromeyerite is present as well in the Kupferschiefer and at Spar Lake. In those SSC deposits where $\mathrm{Ag}$ is found in concentrations of tens of grams per tonne, that Ag is sited mostly in solid solution in chalcocite, digenite, and (or) bornite (for example, Witvlei: Anhaeusser and Button, 1973, p. 292; Spar Lake: Hayes, 1983, Appendix II;
Kupferschiefer: Sawlowicz, 1990, p, 264; Udokansk: Volodin and others, 1994, p. 18). At Spar Lake, each of those three sulfides typically carries about 0.1 wt. \% Ag.

Sulfide minerals in the fringing zones host recoverable metals in many SSC deposits. Some deposits in Zambia and the Democratic Republic of Congo contain carrollite (Darnley, 1960, p. 154; Oosterbosch, 1962, p. 118), and some in the Democratic Republic of Congo and Zambia also have Co-rich pyrite (Brown and Bartholomé, 1972; Bartholomé and others, 1976). Galena and sphalerite are common in the zones fringing the $\mathrm{Cu}$ orebodies, between ore and pyritic zones.

The dominant sulfides and associated oxides in the Kupferschiefer system vary from zone to zone and include (1) hematite with only scant traces of any sulfides (Rote Fäule); (2) covellite with idaite, chalcopyrite, and trace magnetite; (3) chalcocite with digenite, covellite, and pyrite; (4) chalcocite with bornite, digenite, and pyrite; (5) bornite with chalcocite, chalcopyrite, sphalerite, galena, and pyrite; (6) bornite with chalcopyrite, pyrite sphalerite, and galena; (7) chalcopyrite and pyrite with sphalerite, galena, and tennantite; (8) pyrite, sphalerite, galena, and chalcopyrite; (9) pyrite, sphalerite, and galena with chalcopyrite; and (10) pyrite with only scant traces of any base-metal sulfides (Jung and Knitzshke, 1976). There is a zonation of metals varying from a zone devoid of base metals other than $\mathrm{Fe}$ (\#1 above), to $\mathrm{Cu}$ zones (\#2-6), to a $\mathrm{Pb}$ zone (\#7), to a $\mathrm{Zn}$ zone (\#8), and to another zone nearly devoid of base metals other than Fe (\#10) (Jung and Knitzschke, 1976; Oszczepalski and Rydzewski, 1997). Ore grades of $\mathrm{Cu}$, typically greater than 1 percent, are developed only in zones with bornite, chalcocite, or covellite as a predominant sulfide. The single exception is in Central Africa, where the chalcopyrite zone can reach ore grades and is attractive, as well, because it may have high concentrations of Co. Examples are the Kambove West deposit, Democratic Republic of Congo (Cailteux, 1994) and the Nkana South orebody, Zambia (Brems and others, 2009).

In each one of the other deposits of the reduced-facies and sandstone subtypes, there is a similar sulfide zonation, which progresses from a chalcocite or a bornite side to a pyrite side, although with local variations. Spar Lake, for example, has a chalcopyrite-only zone that is $1-3 \mathrm{~m}$ wide between galena-bearing rock and bornite-bearing rock, and pyrite nowhere coexists with bornite or chalcocite. The galena-dominant zone at Spar Lake has, in places, a thickness of greater than $20 \mathrm{~m}$ and a width of several hundred meters. At White Pine, the transition from rock with chalcocite as the dominant sulfide to rock with pyrite as the dominant sulfide is just a few centimeters wide, where that "transition fringe" passes through fine-grained lithologies. The transition fringe at White Pine contains minor amounts of the cadmiumsulfide mineral greenockite (Brown, 1971). Greenockite is also present at Happy Jack and other red-bed-type $\mathrm{Cu}-\mathrm{U}$ deposits, Utah (Weeks and others, 1959), and the Sustut, British Columbia, volcanic red-bed-type deposit (Wilton and Sinclair, 1988). 
Many other sulfides have been identified, each with a limited extent. Tetrahedrite in small concentrations is found between rock with bornite and rock with galena at Spar Lake and at Juramento, Argentina (Durieux and Brown, 2007, p. 890), but is not typically present within Kupferschiefer system deposits. Tennantite is found, instead, in approximately the same zonal position. In Kupferschiefer deposits, linnaeite is present at places in rock with pyrite, galena, sphalerite, and chalcopyrite in about equal abundances. Linnaeite is found together with chalcopyrite and pyrite in deposits of the Central African Copperbelt, but galena and (or) sphalerite are extremely rare in Zambian deposits (Notebaart and Vink, 1972). Altogether, more than 115 different ore minerals have been identified in the Kupferschiefer deposits (Pieczonka and others, 2001), but most of those occur only as traces yet may still contribute to geochemical signatures (for example, see Bechtel and others, 2002, p. 17-24).

$\mathrm{U}$ - and $\mathrm{V}$-oxide and silicate minerals may be present in some red-bed-subtype deposits, as in the Colorado Plateau region, United States, and in Argentina east of the Andes in Cretaceous host rocks (Brodtkorb and Brodtkorb, 1984; Ferreyra and Lardone, 1990). In red-bed-subtype deposits, $\mathrm{Cu}$-sulfide zonation is typically telescoped relative to the other subtypes. There may be no rock with only chalcocite, and there may be no rock with only pyrite. $\mathrm{U}$ in coffinite (tetragonal $\left.\mathrm{U}\left[\mathrm{SiO}_{4},(\mathrm{OH})_{4}\right]\right)$ is predominantly in pyritic assemblages that may entirely lack $\mathrm{Cu}$ minerals or contain chalcopyrite. $\mathrm{V}$ sited in either $\mathrm{V}$ illite or $\mathrm{V}$ chlorite is also present mostly in the pyritic assemblages. $\mathrm{U}$ as uraninite (isometric $\mathrm{UO}_{2}$ ) and $\mathrm{V}$ as montroseite (orthorhombic [ $\mathrm{V}, \mathrm{Fe}] \mathrm{O}[\mathrm{OH}]$ ) are more typically found in copper-bearing assemblages, particularly with chalcopyrite, and somewhat less commonly with bornite or chalcocite (Miller, 1955; Phillips, 1960; Tschanz and others, 1958). The result is that $\mathrm{Cu}$-poor variants of the $\mathrm{Cu}-\mathrm{U}-\mathrm{V}$ sandstone-hosted deposits of the Colorado Plateau region are the ones that typically contain coffinite and $\mathrm{V}$ phyllosilicates whereas $\mathrm{Cu}$-rich variants more typically have uraninite and montroseite (Hayes, 1982).

\section{Paragenesis and Zoning}

$\mathrm{Cu}$ minerals in SSC deposits and their $\mathrm{Cu}$ to $\mathrm{S}$ molar ratio can be listed in their paragenetic order and zonation as follows:
- Chalcopyrite $\left(\mathrm{CuFeS}_{2}\right)$
0.5
- Bornite $\left(\mathrm{Cu}_{5} \mathrm{FeS}_{4}\right)$
- Digenite $\left(\mathrm{Cu}_{9} \mathrm{~S}_{5}\right)$
1.80
- Djurleite $\left(\mathrm{Cu}_{31} \mathrm{~S}_{16}\right)$
- Chalcocite $\left(\mathrm{Cu}_{2} \mathrm{~S}\right)$
2.0

Minerals at the low-Cu end of the list form a zone next to the reduced, pyritic zone in the deposits. Minerals at the $\mathrm{Cu}-$ rich end are found in zones next to the hematitic rock on the side from where the high salinity, metals-transporting fluids entered the systems (for example, Bechtel and others, 2001). In unmetamorphosed deposits, pyrite is replaced by chalcopyrite, which is replaced in turn by bornite and then by chalcocite (Brummer, 1955; Brown, 1971; Anhaeusser and Button, 1973; Bartholomé and others, 1976; Lur'ye and Gablina, 1976; Chartrand and others, 1989). Furthermore, pyrite is replaced rarely by magnetite or commonly by hematite within the zones of Rote Fäule associated with Kupferschiefer deposits (Jung and Knitzschke, 1976; Schmidt, 1987), and hematite accompanies chalcocite in replacements of pyrite at White Pine (Brown, 1971, p. 556) and Witvlei (Anhaeusser and Button, 1973, p. 292).

Continuing centimeters to meters into the Rote Fäule of the Kupferschiefer mineralizing systems in the Fore-Sudetic monocline, Poland, some important additional minerals are deposited. Rote Fäule (literally translated: red rot) is rock that is spotted or streaked with hematite and that lacks any important concentrations of $\mathrm{Cu}$ sulfides. The important minerals in the near-ore edge of the Rote Fäule zone rocks are (1) native gold of high purity associated with hematite and covellite, and (2) mercurian electrum with an assemblage of chalcocite, digenite, bornite, and minor clausthalite (isometric $\mathrm{PbSe}$ ), tetraauricupride (tetragonal $\mathrm{CuAu}$ ), spionkopite (rhomobohedral $\mathrm{Cu}_{39} \mathrm{~S}_{28}$ ), yarrowite (rhombohedral $\mathrm{Cu}_{9} \mathrm{~S}_{8}$ ), and tiemmannite (isometric $\mathrm{HgSe}$ ). Native platinum $(\mathrm{Pt})$ and palladium (Pd) occur together with the above. The result is an Au- and platinoid-bearing orebody from 0 to $0.5 \mathrm{~m}$ below the $\mathrm{Cu}-\mathrm{Ag}$ orebody (Piestrzynski and others, 2002).

Some deposits contain carrollite and Co-pyrite in the near-ore part of the pyrite zone. These may extend for hundreds of meters parallel to bedding or for meters perpendicular to bedding and, for carrollite, into the chalcocite-bearing zone in the Central African Copperbelt reduced-facies deposits.

$\mathrm{Cu}$ sulfides in the deposits have been observed to replace carbonaceous materials of every type in the sedimentary host rocks of SSC deposits at essentially every scale. At the Creta reduced-facies-subtype deposit, many chalcocite grains are replacements of 100 to $200 \mu \mathrm{m}$ diameter ovoid spores of the genus, Triletes (Hagni and Gann, 1976). At the Nacimiento red-bed-subtype deposit, whole fossil logs were replaced by pyrite and later $\mathrm{Cu}$ sulfides, such that the deposit was essentially a replaced logjam within fluvial sandstone paleochannels (Woodward and others, 1974).

Where organic matter or organic carbon compounds were not directly replaced by the $\mathrm{Cu}$ sulfides in forming SSC deposits, the organics were altered chemically and physically, or they were oxidized to carbonate species and precipitated as ore-stage carbonates. In mineralized Kupferschiefer, oresolution sulfate was thermochemically reduced to sulfide utilizing the carbon in organic matter as the reductant. This resulted in oxidative alteration of the solid organic matter, 
whose carbon was then incorporated into epigenetic, ore-stage carbonate minerals with $\delta^{13} \mathrm{C}$ values that are shifted downward compared with the typical marine values of the carbonates just tens of centimeters upsection. Some of the relict organic matter was altered to solid bitumen in the process, and the bitumen, as well as the kerogen, in well-mineralized Kupferschiefer has $\delta^{13} \mathrm{C}$ values reciprocally heavier than the original organic matter (Bechtel and others, 2001). Toward and into the Rote Fäule, the rocks became increasingly calcified, with a higher $\mathrm{Ca} / \mathrm{Mg}$ molar ratio. Dolostone of the Werra (Zechstein 1) carbonate was altered to limestone in the Rote Fäule zone (Rentzsch, 1974, p. 411), and the thin Boundary Dolomite at the base of the Kupferschiefer bed is also altered to limestone. Original liptinite group macerals of the Kupferschiefer bed, including alginite, sporinite, collinite, and amorphous organic macerals, were altered to increased concentrations of inertinite and solid bitumen (Nowak and others, 2001). The reflectance of Kupferschiefer vitrinite increased correspondingly, from $\mathrm{R}_{0}$ of $0.72-0.86$ percent in $\mathrm{Cu}$-poor reduced rocks, to $0.72-1.13$ percent in $\mathrm{Cu}$-rich rocks, and to 1.03-1.10 percent in Rote Fäule-altered Kupferschiefer (Oszczepalski and others, 2002). The various organic petrologic indicators show that Rote Fäule-altered Kupferschiefer has seen a maximum temperature of about $130{ }^{\circ} \mathrm{C}$ in the Fore-Sudetic monocline district in Poland, corresponding to source rock within the window of oil generation (Nowak and others, 2001). Accompanying the petrographic alterations to the Kupferschiefer organic matter, the chemistry of the organic matter was also substantially altered (Püttmann and others, 1987). The content of saturated hydrocarbons was diminished, and the content of heteroaromatic compounds containing oxygen and $\mathrm{S}$ was increased by reaction with the metalstransporting brine. Cu-mineralized and Rote Fäule-altered Kupferschiefer rocks are enriched in polycyclic aromatic hydrocarbons, such as dibenzofuran, dibenzothiophene, fluoranthene, pyrene, and chrysene. Non-methylated phenanthrene in the organic matter increased, an indication of a greater degree of oxidation, assumedly from reaction with metals-transporting brines and greater maturity. The organic matter became more carbonized by the process with a lowering of $\mathrm{H} / \mathrm{C}$ ratios, albeit with an increase in $\mathrm{O} / \mathrm{C}$ ratios, corresponding to an increase in rank from flamecoal to gascoal (Rentzsch, 1974, p. 409; Oszczepalski and others, 2002).

\section{Forms and Textures}

$\mathrm{Cu}$ minerals occur as disseminated 0.05 to $5 \mathrm{~mm}$ grains randomly scattered through the host sediment or commonly localized in the coarser part of individual sedimentary laminations (fig. 8), or in any other coarser-grained sedimentary or pre-lithification feature. The typical $\mathrm{Cu}$-sulfide grain occurs interstitially to detrital silicates or carbonates. The $\mathrm{Cu}$ sulfides are most consistently in grain contact with a syntaxial quartz overgrowth on detrital quartz or a syntaxial overgrowth of K-feldspar on detrital K-feldspar, with the overgrowths appearing to precede deposition of the sulfide, and with the sulfide appearing to form the ultimate filling of the former pore (fig. 16) (Hayes, 1984; Sweeney and Binda, 1989, fig. 6). However, given that K-feldspar and quartz overgrowths are, themselves, zonally more abundant in the zones richest in $\mathrm{Cu}$ sulfides (fig. 6), that apparent paragenesis possibly needs interpretation. If an epigenetic ore solution entered a clastic rock and was supersaturated with respect to chalcocite and $\mathrm{K}$-feldspar and a substrate $\mathrm{K}$-feldspar detrital grain is present, then the texture described above would form and could indicate simultaneous precipitation of chalcocite and the K-feldspar overgrowth.

Many unique textures occur among the disseminated sulfides, as well as among the zonally distributed authigenic gangue minerals of SSC deposits. A common texture in sandstone $\mathrm{Cu}$ deposits has been termed a bedform dissemination (Hayes and Einaudi, 1986), where the sulfide or authigenic gangue minerals are densely disseminated along a primary sedimentary structure, such as cross laminae (fig. 17). Sulfides along large-scale cross laminae at Mufulira were once (Garlick, 1972, p. 295) interpreted as a detrital distribution of sulfides, but at Spar Lake, careful grain-size analysis shows that the sulfide-rich bedform disseminations occupy coarser grained laminae than adjacent sulfide-poor laminae, simply repeating the generality (fig. 8) that every slightly coarser grained primary sedimentary feature becomes a locus of sulfide deposition, assumedly because metals-transporting fluid flux was proportional to permeability (T.S. Hayes, unpub. data, 1985).

A common special texture in reduced-facies-subtype deposits is a coarser grained (than the background) sulfide nodule that is either spherical or slightly flattened within the bedding. This texture constitutes a substantial proportion of the disseminated $\mathrm{Cu}$ sulfides (perhaps 10-15 percent) in reduced-facies host rocks in the Kupferschiefer, in Zambia, in the Democratic Republic of Congo, and at White Pine. In the African examples, the nodule or lens is also the site of coarse-grained quartz or dolomite (fig. 8), which hosts the fluid inclusions interpreted as being from the initial ore stages (Annels, 1989; Dewaele and others, 2006; El Desouky and others, 2009).

Localization of ore sulfides in water-escape structures is also recognized in many SSC deposits. Lustwerk and Wasserman (1989) described the classification of water-escape structures and the localization of $\mathrm{Cu}$ sulfides within the structures at the Redstone, Canada, reduced-facies-subtype deposit.

In red-bed-subtype deposits, the $\mathrm{Cu}$ sulfides may be concentrated surrounding plant remains, and they commonly replace the carbonized wood, preserving or pseudomorphing the wood cells in great detail. For example, at Nacimiento, N. Mex., the wood cells are filled with pyrite and later chalcocite, and the cell walls are replaced by bornite (Woodward and others, 1974, fig. 4). In these deposits, where the sulfide is pyrite, it is commonly the case that the cellular structure has not been collapsed by compaction. That may or may not be so 

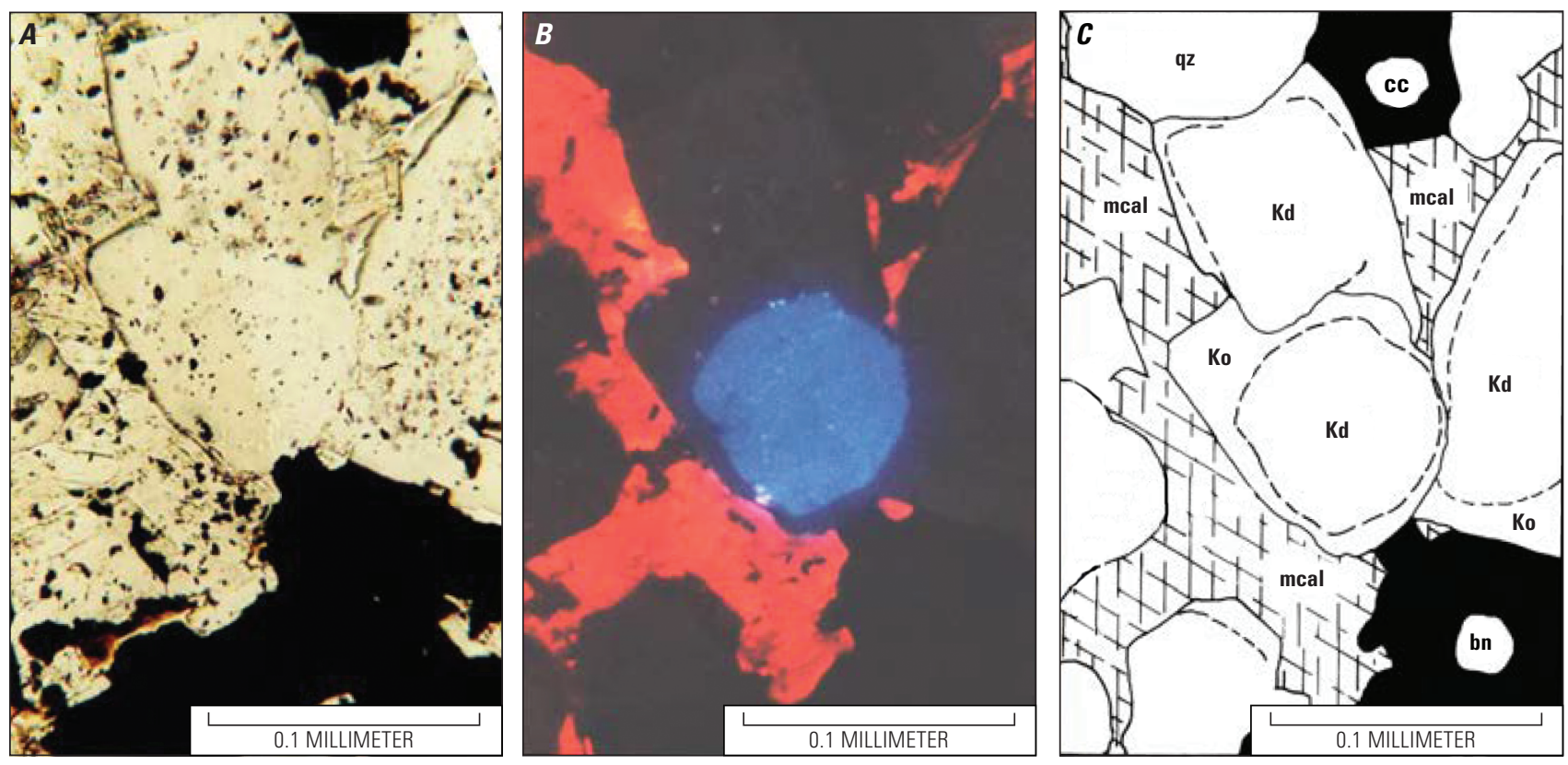

Figure 16. $A$, Photomicrograph in transmitted, plane-polarized light; $B$, cathodoluminescent photomicrograph; and $C$, interpretive sketch of a rock from the bornite-calcite zone (fig. 6) of the Spar Lake sandstone copper deposit. First and most important, cathodoluminescent petrography is extremely valuable in studying ore deposits in sedimentary rocks. The figure shows an apparent paragenetic sequence of (1) detrital quartz and K-feldspar (Kd) grains, (2) syntaxial quartz and K-feldspar overgrowth (Ko) on detritus, and (3) manganiferous calcite (mcal), bornite (bn), and chalcocite (cc) pore-filling cements. The K-feldspar overgrowths are found in great abundance in the galena-calcite, chalcopyrite-calcite, and bornite-calcite zones on the fringe of the deposit (figs. 6 and 7), as is the manganiferous calcite, so those minerals would appear to be uniquely deposit-related, thus probably early ore-stage in timing. In other thin sections, copper sulfides partially replace the manganiferous calcite. Two authigenic minerals in contact may be deposited at the same time if a solution, saturated with respect to both is introduced. If a growth substrate is present for one, then that mineral will deposit syntaxially (in crystallographic continuity) with the substrate, and could yield an apparent time sequence such as first the K-feldspar overgrowth, then the calcite and sulfides, although all of the authigenic mineral precipitations might be taking place at the same time.

where a $\mathrm{Cu}$ sulfide fills the lumens. For uncollapsed lumens, some mineral, perhaps only pyrite, had mineralized the wood relatively soon after sedimentation. Where pyritized wood has uncollapsed lumens but $\mathrm{Cu}$ sulfide-bearing lumens are partially collapsed (Phillips, 1960, p. 47), the texture indicates that the $\mathrm{Cu}$ sulfides formed later than the pyrite, the usual paragenesis of SSC deposits.

\section{Hypogene Gangue Characteristics and Alteration}

Modern mines that exploit SSC deposits typically mine by bulk methods, generally open pit or underground room and pillar. With typical grades of 0.5 to 3 percent $\mathrm{Cu}$, the bulk of the rock from these mines consists of waste minerals. The waste minerals include detrital components, such as quartz, feldspars, carbonates, and clays, and authigenic gangue minerals. Detrital components vary with the host depositional environments from clay-rich, to carbonate-rich, and to quartz-feldspar-rich. The authigenic gangue minerals are also an integral part of the mineralizing system, and unlike for vein deposits where vein-fill is easily separable from wallrock alteration, there are only mineral appearance/disappearance boundaries in SSC mineralized systems, and such boundaries are seldom macroscopically visible in outcrops or mine faces.

The following sections adopt a division in which "alteration" is restricted to those minerals distributed in space in zones up the hydrologic gradient from ore and extending into ore. For most SSC deposits, upgradient is in a downsectionward direction, taken to indicate that the aquifers through which the $\mathrm{Cu}$ was transported were confined; that is, artesian pressure was driving the metals-transporting brines. By this division, gangue minerals are the other authigenic waste minerals found within orebodies. This convention views the "alteration" minerals as those that occur most abundantly in the rocks from which the $\mathrm{Cu}$ came, or in rocks through which $\mathrm{Cu}$ was transported enroute to the deposits. The convention aids in distinguishing the conditions of $\mathrm{Cu}$ transport from the conditions of $\mathrm{Cu}$ deposition, and, as with other hydrothermal ores, the alteration minerals are useful in understanding metals-transporting and metals-depositing conditions (Meyer and Hemley, 1967; Einaudi, 1979). 


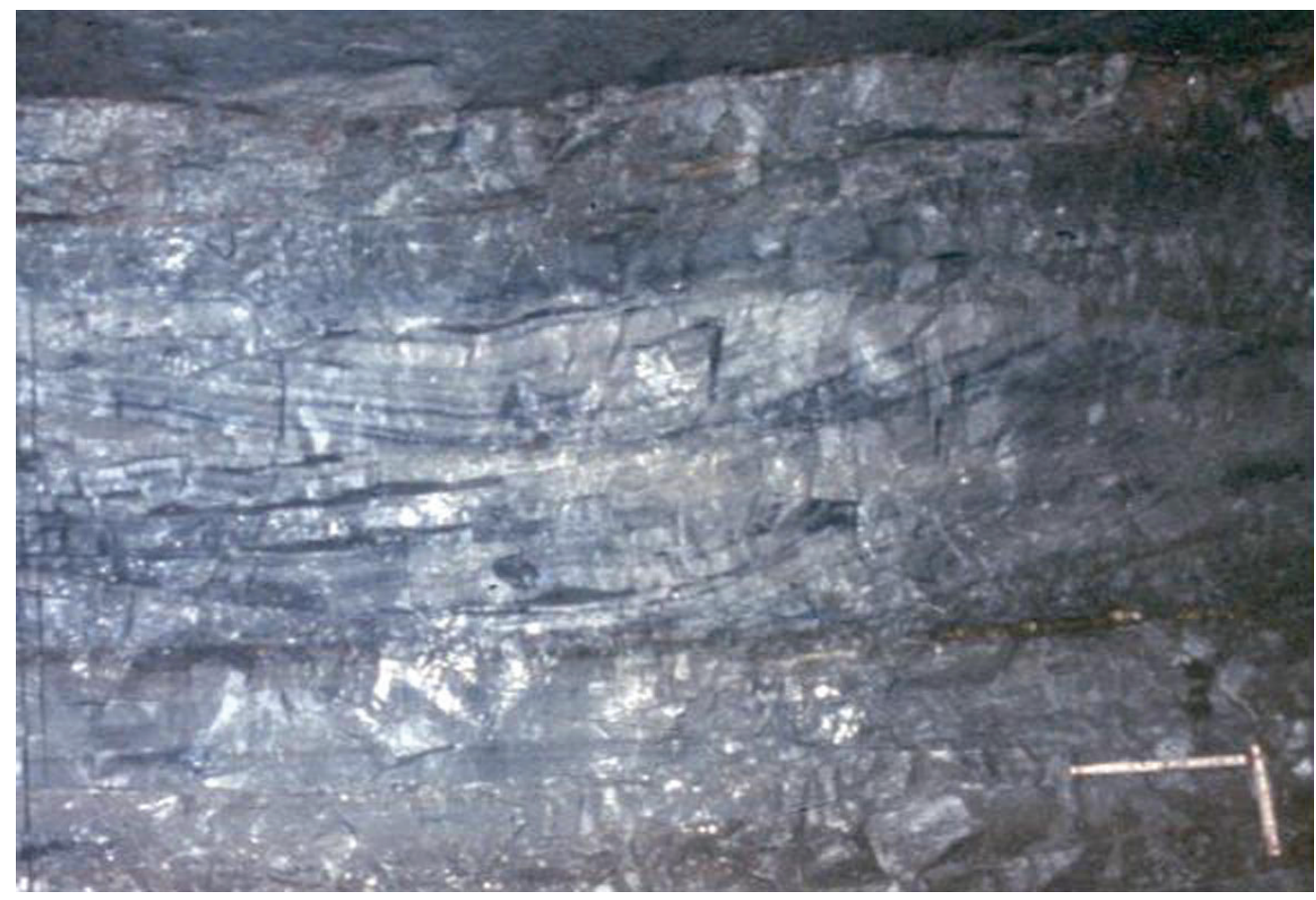

Figure 17. Exposure of a mine face underground at the Spar Lake sandstone copper deposit. The scale at lower right is 60 centimeters long horizontally and 30 centimeters vertically. Photograph by Norm Lutz of Bear Creek Mining about 1972. The photograph shows thick to very thick sets of trough-crossbedded metasandstone. Blue colors along foresets and set boundaries are dense disseminations of chalcocite-digenite-bornite. The copper-sulfide-rich foresets are termed "bedform disseminations" (Hayes and Einaudi, 1986). Microscopic examination of samples from the face revealed that the detrital grain sizes of copper-sulfide-rich laminae are slightly coarser than adjacent copper-sulfide-poor rock. The relation is completely comparable with that in figure 8 .

\section{Gangue Mineralogy, Paragenesis, and Zoning}

Similar to the deposit-defining Cu-sulfide minerals, the gangue minerals of SSC deposits are zonally arranged; their appearance/disappearance boundaries parallel the zonation of the sulfides. The ore-stage and pre-ore gangue minerals are cements of the sedimentary rocks and replacements of earlier detrital and cementing minerals.

Pyrite is an important gangue mineral in downgradient deposit-fringing pyritic zones, although there are probably two generations of pyrite in many deposits. Pre-ore, first-stage pyrite is commonly framboidal in reduced-facies-type deposits (Brown, 1971, fig. 25; Oszczepalski, 1989, plate II, fig. 5). In coarser host rocks, the pre-ore pyrite is a cementing mineral. In red-bed-type deposits, pre-ore pyrite commonly replaces carbonized wood fragments (Woodward and others, 1974, fig. 4; Thaden and others, 1964, fig. 16). In the reduced-facies deposits in the Democratic Republic of Congo, a secondstage cobaltiferous pyrite is probably from the ore-stage (Bartholomé and others, 1971), and that pyrite typically contains 4 wt. \% Co. In Zambian rocks, concentrations of as much as 42 wt. \% Co in pyrite were measured (Riley, 1968; Brown and Bartholomé, 1972). Ore-stage, Co-anomalous pyrite, typically about $0.015 \mathrm{wt}$ \% Co, is recognized, as well, in the Spar Lake sandstone $\mathrm{Cu}$ deposit (Hayes, 1984) where it coats earlier cementing pyrite, overgrows the cementing pyrite, and replaces detrital quartz and feldspar of the framework to form cubic crystals or clots of cubic crystals with mutually interfering growth (fig. 18).

Iron-rich calcite cements are found within pyritic zones of sandstone $\mathrm{Cu}$ deposits at Spar Lake and Dzhezkazgan (Gablina and Tsepin, 1975; Hayes, 1984, 1990). The Spar Lake ferroan calcite has as much as 3.5 mole $\% \mathrm{FeCO}_{3}$, and it typically has more than 2 mole \%. Fe-rich carbonates are found in approximately the same zonal position in the Cashin and Lisbon Valley deposits in the Paradox Basin, United States.

All mineral zones of SSC deposits contain leucoxene that pseudomorphs former ilmenite in exsolution-created, trellis-textured ilmeno-magnetite detrital grains or the ilmenite plates of exsolution-created, stacked-plate-textured ilemnohematite detrital grains (fig. 19). The magnetite and hematite of the original detritus is destroyed, and sulfide minerals, which incorporate Fe that earlier may have been within the detrital magnetite, hematite, and ilmenite, are commonly in close association (Dimanche and Bartholomé, 1976; Hayes, 1983; Hayes, unpub. observations from Rock Creek, Mont.; Paoli, Okla.; Farwan no. 1 occurrence, Saudi Arabia; and Jabal Muryyii deposit, Saudi Arabia; 1980; 1988; 1999; and 2000, respectively). 

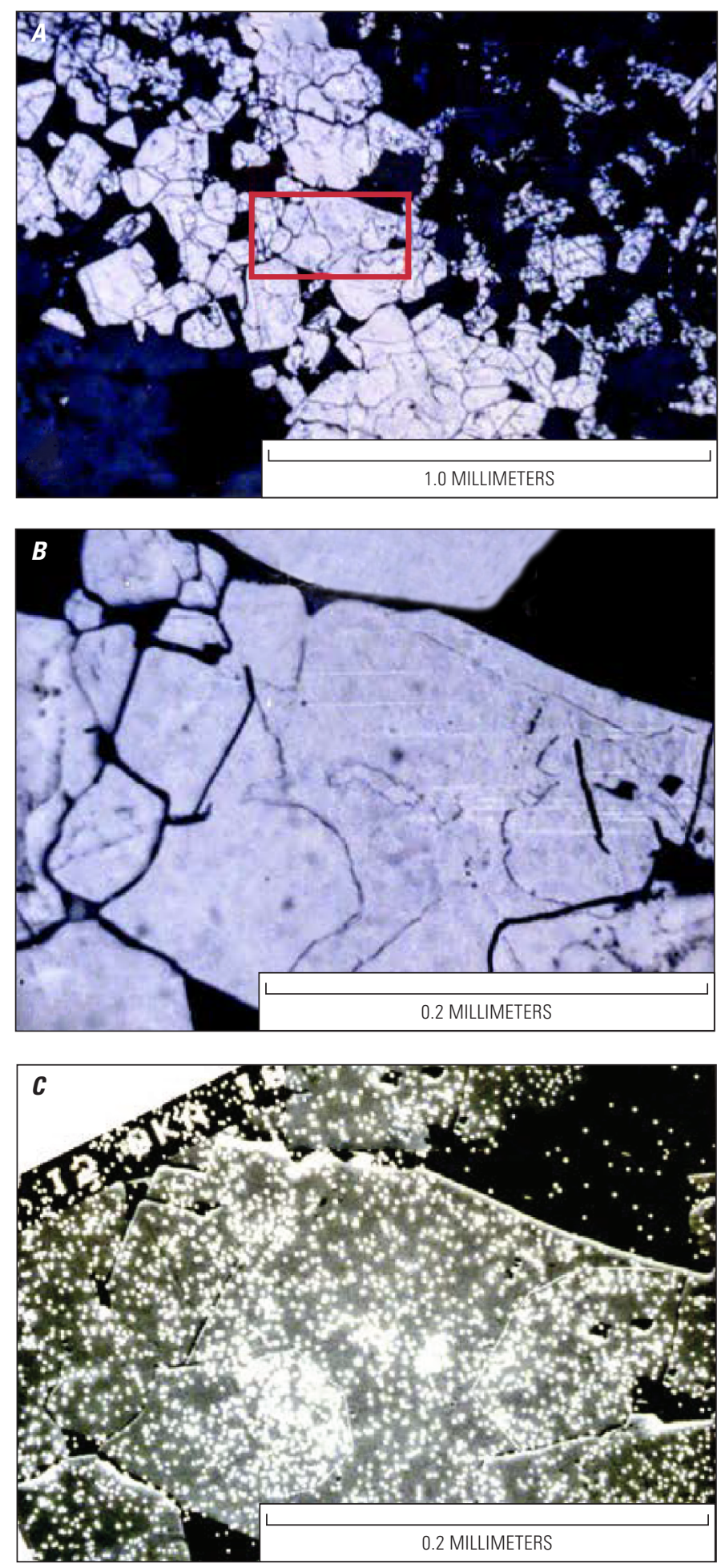

Galena- and sphalerite-bearing peripheral zones of SSC deposits also contain calcite or ferroan calcite. In fine-grained host rocks, chlorite may appear in these zones. At the Spar Lake deposit, K-feldspar and quartz overgrowths on detrital substrates are prominent in this zone but have not been found in zones with only pyrite (fig. 20). The K-feldspar overgrowth has also been described from the Kafufya Formation (Mindola Clastics), within and underlying ore at Konkola, Zambia
Figure 18. $\quad A$, Reflected-light photomicrograph in plane-polarized light of the margin of a compound pyrite clot, with a core of cementing pyrite surrounded by a continuous pyritic outer rim from the pyrite-calcite zone (fig. 6) at the Spar Lake sandstone copper deposit. The red-outlined box identifies the field of view of $B$ and $C$. $B$, Part of the continuous outer rim of pyrite, also in reflected light. The section has been etched for 1 minute in concentrated $\mathrm{HNO}_{3^{\prime}}$ followed by 10 seconds in concentrated $\mathrm{HCl}$ to enhance any internal textures within the pyrite. A cuspate internal shape is within one of the cubic pyrite grains forming the continuous outer rim of the clot. The cuspate shape is similar to pyrite grains found cementing quartz grains in the interior of the clot. $C$, "Map" of cobalt characteristic X-rays from the electron microprobe of the same cubic grain shown in $B$. The parts of the pyrite cube outside of the cuspate interior shape are anomalous in cobalt. The pyrite clot formed in two steps; first a cementation between detrital quartz grains by ordinary pyrite, and then replacement of detrital quartz in the outer rim by cobalt-rich pyrite, overgrowing the cementing pyrite to form a continuous outer pyrite rim. The cobalt-rich pyrite precipitated later than the ordinary pyrite.

(Sweeney and Binda, 1989, plates I, II, and III; Sutton and Maynard, 2005, figs. 4 and 7). Quartz overgrowth on detrital quartz grains is prominent at Spar Lake and has the same kinds of textural relations to sulfides and carbonates that the $\mathrm{K}$-feldspar overgrowths do (see below discussion of barite).

In fine-grained dolomitic siltstones in the Democratic Republic of Congo and Zambia, authigenic quartz replaced crystals and nodules of anhydrite. Annels (1974) documented widespread replacement of anhydrite nodules by calcite and sulfides, by pyrite of peripheral non-ore zones and the $\mathrm{Cu}$ sulfides of the ores at Nkana North Limb. Annels showed direct proportionality between $\mathrm{Cu}$ grades and abundance of "carbonate lenticles," that is, anhydrite nodules that had been replaced. In the Democratic Republic of Congo, quartz, sufides, and dolomite have replaced anhydrite (Dewaele and others, 2006). Some of the quartz and dolomite is pseudomorphic after anhydrite nodules and anhydrite crystals, and anhydrite relicts are found at places within the authigenic minerals (Muchez and others, 2008). Additionally, given the fluid-inclusion microthermometric results from inclusions hosted in such quartz-after-nodularanhydrite, with homogenization temperatures of 105 to $192{ }^{\circ} \mathrm{C}$ (Annels, 1989; Dewaele and others, 2006), some of such quartz is probably ore stage, not from early diagenesis.

Authigenic tourmaline locally makes up 4 percent of the rock in the Central African Copperbelt (Darnley, 1960, p. 147; Selley and others, 2005), but it is not known if it has a zonal distribution.

Hematite, Mn-bearing minerals, and barite accompany bornite in the sulfide assemblages at Spar Lake. A fine dusting of pore-lining and pore-filling hematite (fig. 19C) and fine pigmenting hematite have been described at White Pine (Brown, 1971, p. 555), Kamoto (Dimanche and Bartholomé, 1976, p. 195), Witvlei (Anhaeusser and Button, 1973, p. 292), and Seboruco, Venezuela (Dimanche and Bartholomé, 1976, p. 199). 

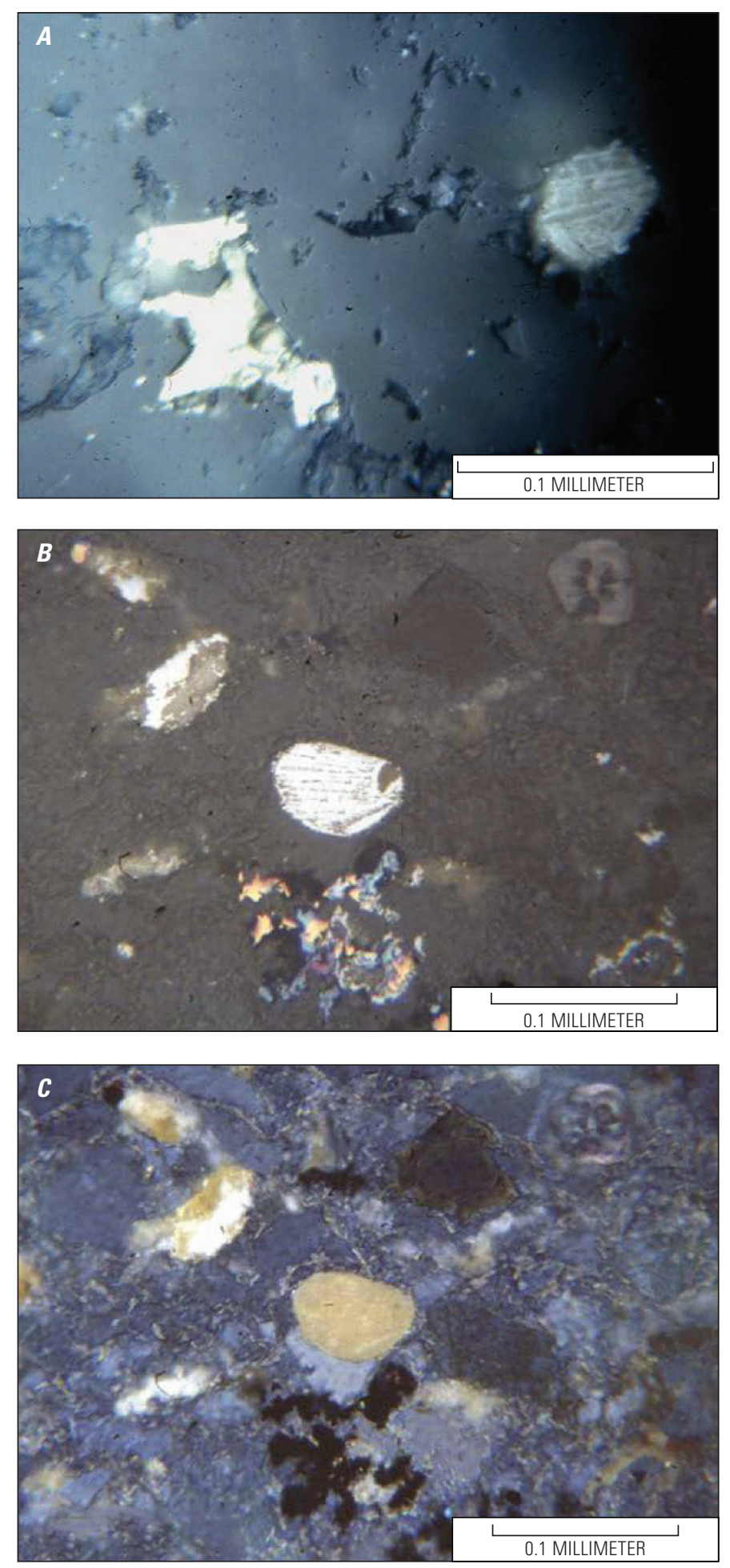

This is ore-stage hematite and should not be confused with the early diagenetic hematite or other ferric oxyhydroxides formed in early diagenesis of red beds. This earliest variety of hematite common to all red beds is recognizable because it ubiquitously rims and outlines detrital grains of those red beds (Turner, 1980, p. 316-317). Multiple hematite dust rims are found in some bornite- and chalcocite-bearing ore zone rocks at Spar Lake, separated by overgrowth quartz or K-feldspar, and second-rim
Figure 19. $A$, Reflected-light photomicrograph in plane-polarized reflected light of a rock from the Spar Lake pyrite-calcite zone (fig. 6). In the upper right is a trellis-textured array of leucoxene needles each a few to 10 microns wide and as much as 60 microns long. The leucoxene is pseudomorphic after ilmenite in a nowdissolved detrital (note the rounded shape of the leucoxene trellis) former grain of ilmeno-magnetite. The reflecting grain about 0.15 millimeters to the left of the leucoxene trellis is pyrite. The array of tiny leucoxene needles could not have been transported as such, so the grain was transported and deposited as an ilmenomagnetite grain, although some alteration may have occurred to ilmenite and magnetite by then. $B$, Photomicrograph in planepolarized reflected light in oil immersion of a rock from the Spar Lake sandstone copper deposit bornite-calcite zone (fig. 6), along a heavy mineral lamination. Orange and blue cuspate-shaped grains are bornite and digenite cements, respectively. Central to the field of view is a stacked-plate-textured array of plates of leucoxene, each plate about 5 microns thick and as much as 60 microns long. The leucoxene is pseudomorphic after the ilmenite in a now-dissolved detrital ilmeno-hematite grain. The array of tiny leucoxene platelets could not have been transported as such, so, as above, the grain was transported and deposited as an ilmeno-hematite grain. Additional authigenic leucoxene rims detrital grains in the lower right. $C$, The same field of view as in $B$ shown in reflected cross-polarized light. Leucoxene has bright yellow internal reflection. The area at lower right near the leucoxene grain rims also has intergranular authigenic hematite with crimson-red internal reflection. Hematite was unstable and dissolved from the detrital ilmeno-hematite grain after transport and sedimentation, during pre-ore diagenesis. Hematite became stable again and was deposited as a pore-filling cement, with orestage copper sulfides. Above and slightly right of the leucoxenestacked plates is a grain of tourmaline with nearly rectangular shape. In $C$, there is a difference in pleochroism of the central detrital core of tourmaline (purplish) and the grain's authigenic overgrowth (yellow brown).

hematite is probably from the ore stage (fig. 21). Near the bornite appearance at Spar Lake, manganiferous calcite, with as much as 12 percent $\mathrm{MnCO}_{3}$, is later than ferroan calcite (fig. 22) (Hayes, 1990). Spar Lake Cu sulfides typically appear to be ultimate pore fillings, deposited after quartz- and K-feldspar overgrowths and with paragenetic position similar to the calcite cements (fig. 16). Weathered rocks with greater than 20 percent $\mathrm{Mn}$ are present in SSC deposits at Feinan, Jordan. The Mn may be sited within carbonates in the unweathered equivalents. Hypogene Mn-bearing oxides are found in great abundance, together with chalcocite, in the mineralized layers of Boléo, Mexico (Conly and others, 2006). Barite generally appears near the same place that bornite does in Spar Lake ore. It occurs as a cement that fills pores apparently after quartz and K-feldspar have formed overgrowths on detritus (fig. 23). It shares former pores with chalcocite or bornite, with no clear paragenetic relation to the sulfides. It increases in abundance in the central chalcocite-chlorite zone. It is rarely found in rocks with galena or chalcopyrite but has not been found co-existing with pyrite. Barite has also been described 

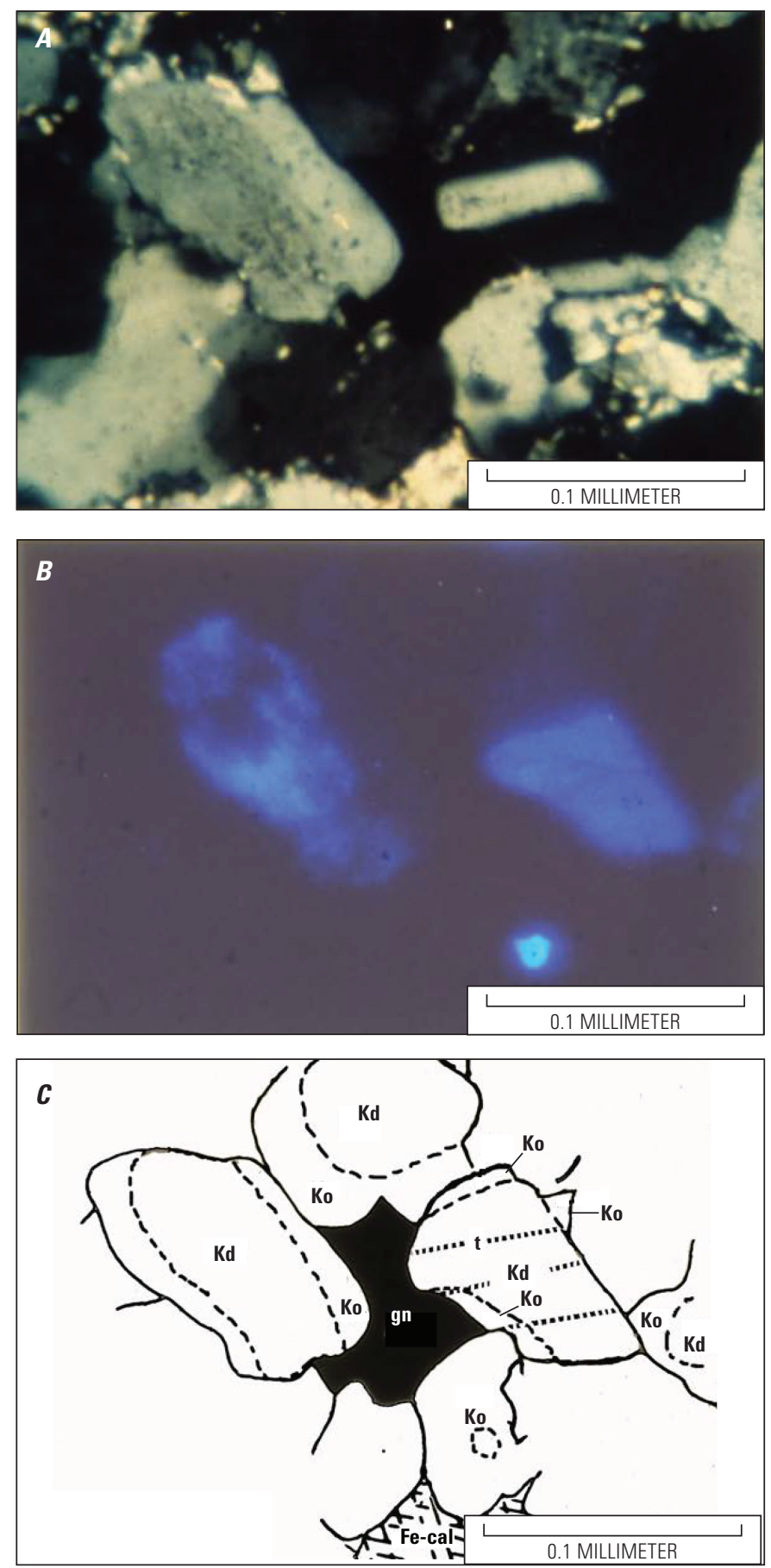

at Konkola, Zambia (Sutton and Maynard, 2005), in several different red-bed-type deposits in New Mexico and Utah (Phillips, 1960), in Weissliegendes sandstones, some ore-bearing, in Poland (Michalik, 2001), and it probably occurs in many other deposits together with bornite and chalcocite. Barite and albite form the paragenetically latest pore-filling cements at Spar Lake, along with the $\mathrm{Cu}$ sulfides.

Chlorite occurs as a pore-lining cement towards the centers of former pores that have overgrowths of quartz or K-feldspar but with chalcocite, digenite, and bornite still more central to the former pores at Spar Lake. Abundant Fe-rich chlorite is probably ore stage at White Pine (Hamilton, 1967; A. Brown, École
Figure 20. Sequence of authigenic minerals in the galenacalcite zone (fig. 6) of the Spar Lake sandstone copper deposit. $A$, Photomicrograph in cross-polarized transmitted light. $B$, Cathodoluminescent photomicrograph of the same field of view. Potassium feldspar detrital grain cores are luminescing blue. $C$, Image made by drawing grain boundaries and identifying mineral grains on an overlay of the upper and middle images. Mineral abbreviations: Kd - K-feldpar detritus, Ko - K-feldspar overgrowth, gn - galena, Fe-cal - ferroan calcite, $t$-albite law twinning plane within K-feldspar. The apparent sequence is: (1) detrital quartz and K-feldspar, (2) syntaxial K-feldspar overgrowth on detrital cores, and (3) pore-filling cementation by galena and ferroan calcite. As discussed, a reasonable interpretation is that $\mathrm{K}$-feldspar overgrowth, galena, and ferroan calcite are partly synchronous.

Polytechnique de Montreal, written commun., 2011). Additionally, authigenic chlorite is found in ore at Witvlei (Anhaeusser and Button, 1973), at Kamoto (Bartholomé and others, 1976, p. 34), and from the deposits in Zambia (Darnley, 1960). Spar Lake chlorite is Fe-rich, as much as $39 \mathrm{wt} \% \% \mathrm{FeO}$ and typically greater than 30 wt. \%. This requires siting $\mathrm{Fe}$ as both $\mathrm{Fe}^{2+}$ and $\mathrm{Fe}^{3+}$ (Foster, 1962; Brown and Bailey, 1962), and such Fe-rich chlorites are typically formed in advanced, deep burial diagenesis or by hydrothermal processes, not during metamorphism (Brown and Bailey, 1962; Curtis and others, 1985). At Spar Lake, the manganiferous calcite of the bornite-calcite zone disappears abruptly at an easily mappable mineralogical boundary (Hayes and Einaudi, 1986, fig. 17D, p. 1922) with the chalcocite-chlorite zone of that deposit. Amounts of carbonate minerals change from about $5 \mathrm{v} \%$ at the inner edge of the bornite-calcite zone to only $0.3 \%$ disseminated ankerite inward of that boundary.

Distribution of chlorite and calcite is similar to that of Spar Lake at other deposits where both have been observed, although details of their distributions are not as well known. At White Pine, the rocks are calcareous through all the zones from pyritic into and including most of the chalcocite-bearing rocks, but the calcite is not present in parts of the Lower Sandstone (Copper Harbor Conglomerate) underlying the ore. Some of the footwall Copper Harbor rocks have calcite and chlorite as sandstone cements, and others have only chlorite (Hamilton, 1967).

\section{Alteration}

The increasingly albite-rich assemblages in the "upstream" direction for metals-transporting solutions at such places as Spar Lake and Oamites probably continue into rock where $\mathrm{Cu}$ is depleted. With no $\mathrm{Cu}$ sulfides and the presence of authigenic hematite, such rock is analogous with the altered tongue of sandstone-hosted roll-front $U$ deposits. In the Revett Formation surrounding Spar Lake, such rock typically has less than $5 \mathrm{ppm}$ $\mathrm{Cu}$ compared with $20 \mathrm{ppm}$ within rock totally unaffected by any mineralizing system processes (Hayes, 1990). Such rock almost certainly represents the source for $\mathrm{Cu}$ in the stratabound deposits. It is actually, however, quite difficult to recognize as 

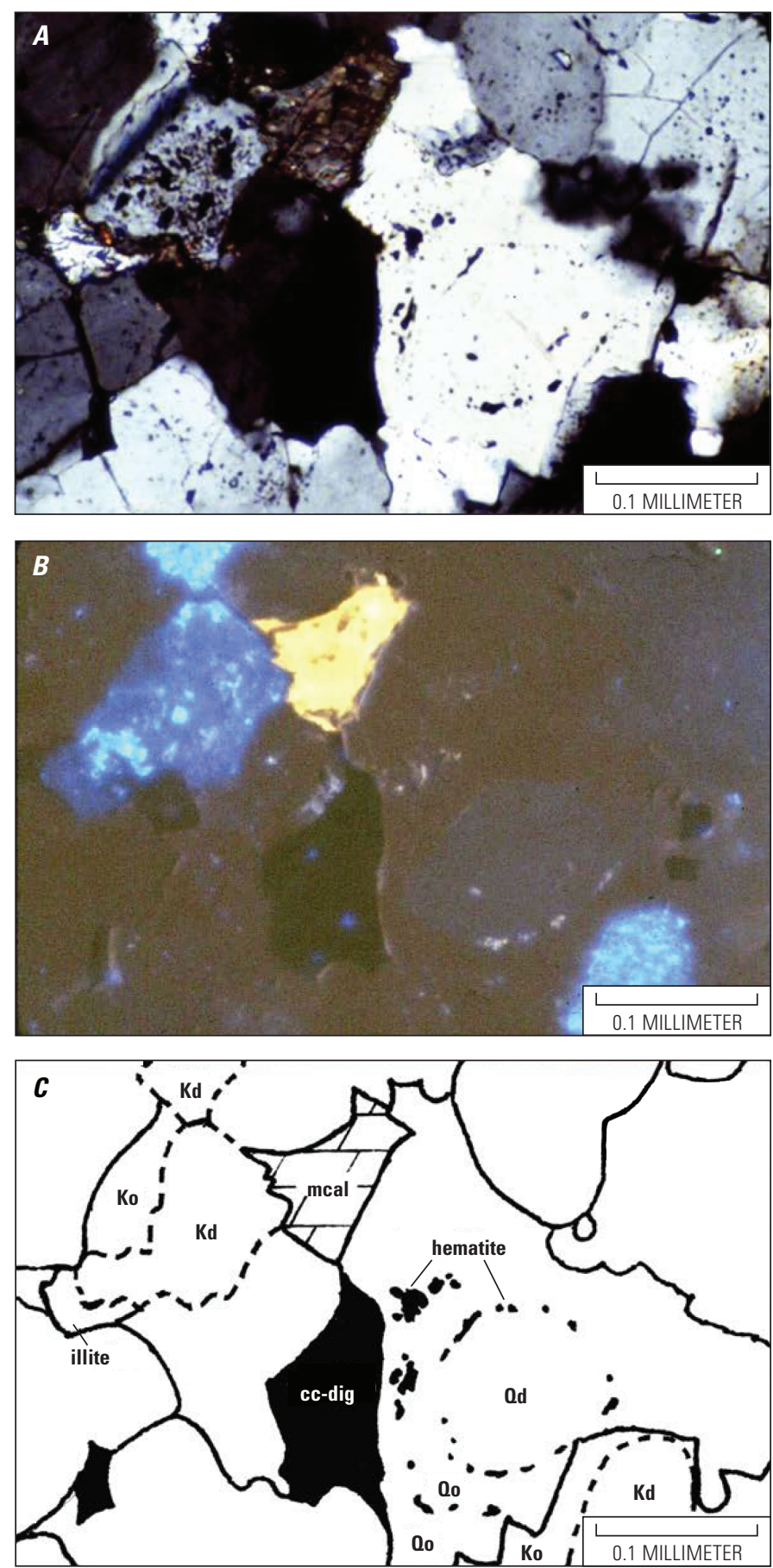

altered rock, because it occurs distant from $\mathrm{Cu}$-mineralized rock and because the albite is finely disseminated through the rock. The albite has the appearance of being detrital at hand specimen or hand lens scale, and it is only at the scale of the petrographic microscope that the albite is seen to replace all the detrital plagioclase and occur as a pore-filling cement (fig. 24). Whole-rock composition, however, identifies this rock as dramatically unusual. In a (meta)clastic rock with 15 percent total feldspars, and 12 percent of that being plagioclase, these rocks typically have less than $300 \mathrm{ppm} \mathrm{Ca}$ after albitization. Albitic alteration in cross-stratal zones is widespread in the Central African Copperbelt (Selley and others, 2005) and in
Figure 21. Sequence of authigenic minerals in the bornitecalcite zone (fig. 6) of the Spar Lake sandstone copper deposit. $A$, Photomicrograph in cross-polarized transmitted light. $B$, Cathodoluminescent photomicrograph of the same field of view. Detrital K-feldspar grains luminesce bright blue. Some detrital quartz grains luminesce dull blue gray while all authigenic quartz and feldspar luminesce dull red-brown. Manganiferous calcite luminesces bright orange. $C$, Image made by drawing grain boundaries and identifying mineral grains on an overlay of the upper and middle images. Mineral abbreviations: Kd - detrital K-feldspar, Ko - K-feldspar overgrowth, qd - detrital quartz, qo - quartz overgrowth, mcal - manganiferous calcite, cc-dig chalcocite-digenite. The apparent sequence is (1) detrital quartz and K-feldspar, (2) hematite dust rims on detrital cores, (3) quartz and K-feldspar overgrowths on detrital cores, (4) a second stage of hematite dust rims deposited on quartz overgrowths, (5) a second stage of quartz overgrowth, and (6) pore-filling copper sulfides and manganiferous calcite. The manganiferous calcite may have started growing any time after (1), as could have the chalcocite-digenite, but the final growth of both had to postdate the second generation of hematite and probably the final stage of quartz overgrowth.

the Udokan sedimentary complex that hosts the giant Udokan deposit. However, the albitization in the Udokan complex has not been related directly to the deposits but has been shown to be zonally related to faults (Abramov and Chernyshova, 2001; Abramov, 2008).

Albite is the sodic mineral that can be directly correlated with $\mathrm{Cu}$ source zones near several SSC deposits, but other sodic minerals may signal metals mobilization and depletion. In the Redstone (Coates Lake) system in Canada, the footwall red beds contain abundant glauberite (monoclininc $\mathrm{NaCa}\left(\mathrm{SO}_{4}\right)_{2}$ ) (R. Lustwerk, oral commun., 1985). In rocks of the Salib Arkosic Sandstone Formation, which are the footwall to SSC mineralization in the Burj Formation at Feinan and Wadi Abu Kushaiba, Jordan, the sodic phase is probably paragonitic illite (T. S. Hayes, unpub. data, 2001). Near the Dzhezkazgan deposits in Kazakhstan, mudstones upsection from the mineralized Dzhezkazgan Formation have been massively altered to riebekite $\left(\mathrm{Na}_{2}\left[\mathrm{Fe}^{\mathrm{II}}, \mathrm{Mg}\right]_{3} \mathrm{Fe}_{2}{ }_{2}{ }^{\mathrm{II}} \mathrm{Si}_{8} \mathrm{O}_{22}[\mathrm{OH}]_{2}\right)$ (B. Syusyura, oral commun., 2009). Similar alteration is known from the area surrounding Tenke-Fungurume in the Democratic Republic of Congo (M. W. Hitzman, oral commun., 2010). In the Agadez area, Niger, where there are many red-bed-type copper occurrences, analcime (monoclinic $\mathrm{Na}\left(\mathrm{AlSi}_{2}\right) \mathrm{O}_{6} \cdot \mathrm{H}_{2} \mathrm{O}$ ), the sodium zeolite, is remarkably abundant in the coarse arkosic red beds underlying the three separated strata that host copper mineralization (Imreh and Nicolini, 1962). That rock is locally named "analcimolite." Thus, sodic minerals characteristically mark $\mathrm{Cu}$ source rocks for SSC deposits.

A second mineral that characterizes metal source areas for SSC deposits is hydrothermal hematite, which is the direct analogy of the ferric oxides of the altered tongue of a sandstone-hosted roll-front $\mathrm{U}$ deposit. Hematite in such a zonal arrangement is best known from the mineralizing systems 

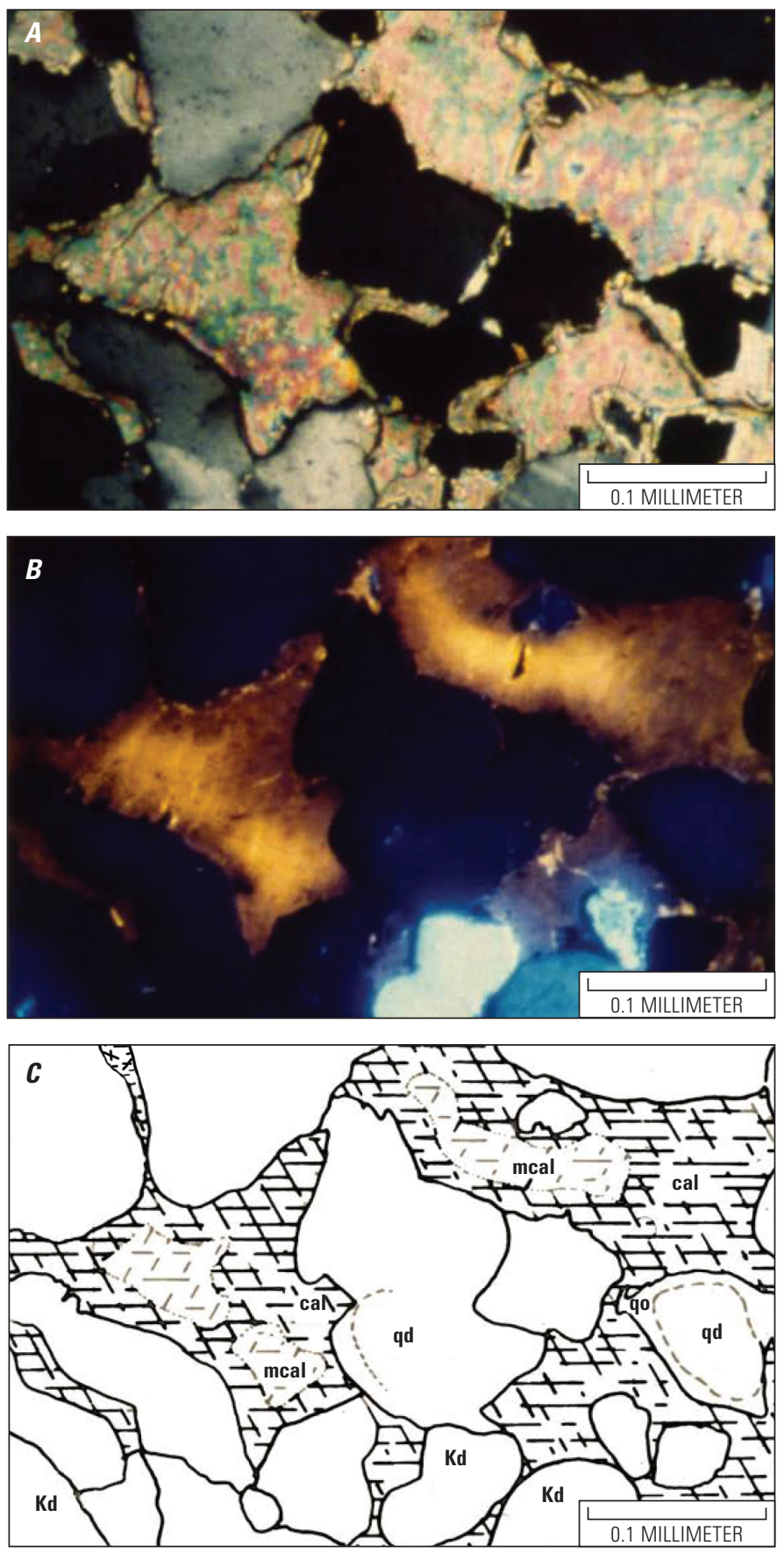

of the Kupferschiefer, where it is called Rote Fäule (figs. 4 and 5). Rote Fäule, where it is present in rocks that lacked hematite prior to the ore event, appears as red spots that are centimeters to tens of centimeters in scale (fig. 25). Because it occurs as discrete, large spots or streaks, it is easily identified within the Weissliegendes, Kupferschiefer, and Werra Carbonate stratigraphic units (fig. 25). There is no description of Rote Fäule alteration within the Rotliegendes Formation red beds that lie downsection from the mineralized stratigraphic interval, and the downsection Rotliegendes rocks have assumedly been red beds since earliest diagenesis, so a second, later stage of hematite from the ore-stage either does not exist or it may not be identifiable.
Figure 22. Sequence of authigenic minerals in the bornitecalcite zone (fig. 6) of the Spar Lake sandstone copper deposit. $A$, Photomicrograph in cross-polarized transmitted light. $B$, Cathodoluminescent photomicrograph of the same field of view. Detrital K-feldspar luminesces bright blue. Some detrital quartz luminesces very dull blue gray. Calcite luminesces in shades of orange with brightness proportional to manganese concentration in the calcite. $C$, Image made by drawing grain boundaries and identifying mineral grains on an overlay of the upper and middle images. Mineral abbreviations: $\mathrm{Kd}$ - detrital K-feldspar, qd - detrital quartz, qo - quartz overgrowth, cal - mildly manganiferous calcite, and $\mathrm{mcal}$ - very manganiferous calcite. The apparent sequence is (1) detrital quartz and K-feldspar, (2) quartz and probably k-feldspar overgrowth on detrital cores, (3) mildly manganiferous calcite, and (4) very manganiferous calcite. Increase in manganese within the calcite over the time of precipitation is obvious and probably occurs as well at the scale of the whole deposit.

In the sandstone $\mathrm{Cu}$ deposit at Paoli, Okla., hematite is clearly identifiable in a zone through which metals have been transported to form an SSC deposit. The deposit, itself, has a roll front geometric form (Shockey and others, 1974). The altered tongue sandstone is mottled red and light gray, and the hematite lends a brick-red color to Garber Sandstone host rocks that are pastel green in color where they are $\mathrm{Cu}$ - and $\mathrm{Ag}$-mineralized or non-oxidized containing trace pyrite. Mudstones that occur upsection and downsection from the mineralized sandstones are ordinary red beds, although they are pastel green for a few centimeters at their contacts against the sandstone beds. The pastel green host sandstones also have red-mud intraclasts within them that have green rims; the type B pillars (Lustwerk and Wasserman, 1989) consist of pale green sandstone cutting red mudstone. The sandstones lack any carbonaceous plant fossils. These observations suggest that the pastel green color is a secondary feature: the sandstones were reddened during early diagenesis, then bleached prior to the ore event, and, finally, oxidizing metals-transporting solutions infiltrated the sandstones and deposited the chalcocite and native silver, and produced the red hematitic mottling in the altered tongue.

It remains speculative as to whether barite also characterizes zones of metals mobilization (fig. 6). Calculations in Hayes (1983, p. 221-230) suggest that barite would be stable in such rocks, and there are occurrences of barite disseminated in red-bed sandstones in several places in Oklahoma, near SSC deposits such as Paoli and Creta, and even within the altered tongue sandstones of Paoli. Barite in the Garber Sandstone in this zonal position at Paoli forms barite "roses," and barite roses are found over more than $100 \mathrm{~km}$ along the outcrop belt in the Garber in central Oklahoma (Ham and Merritt, 1944). However, it is unclear whether such rocks have lost $\mathrm{Cu}$ to the hydrothermal systems. Barite is also found in considerable abundances within the ore system at Konkola, Zambia (Sutton and Maynard, 2005), but the barite may not take a single regular place within the mineral zonation; it is found within ore, below ore, and (or) above ore, and it is found in footwall clastic rocks of the Copperbelt Orebody Member, or even in the shale with grit that overlies that member. 

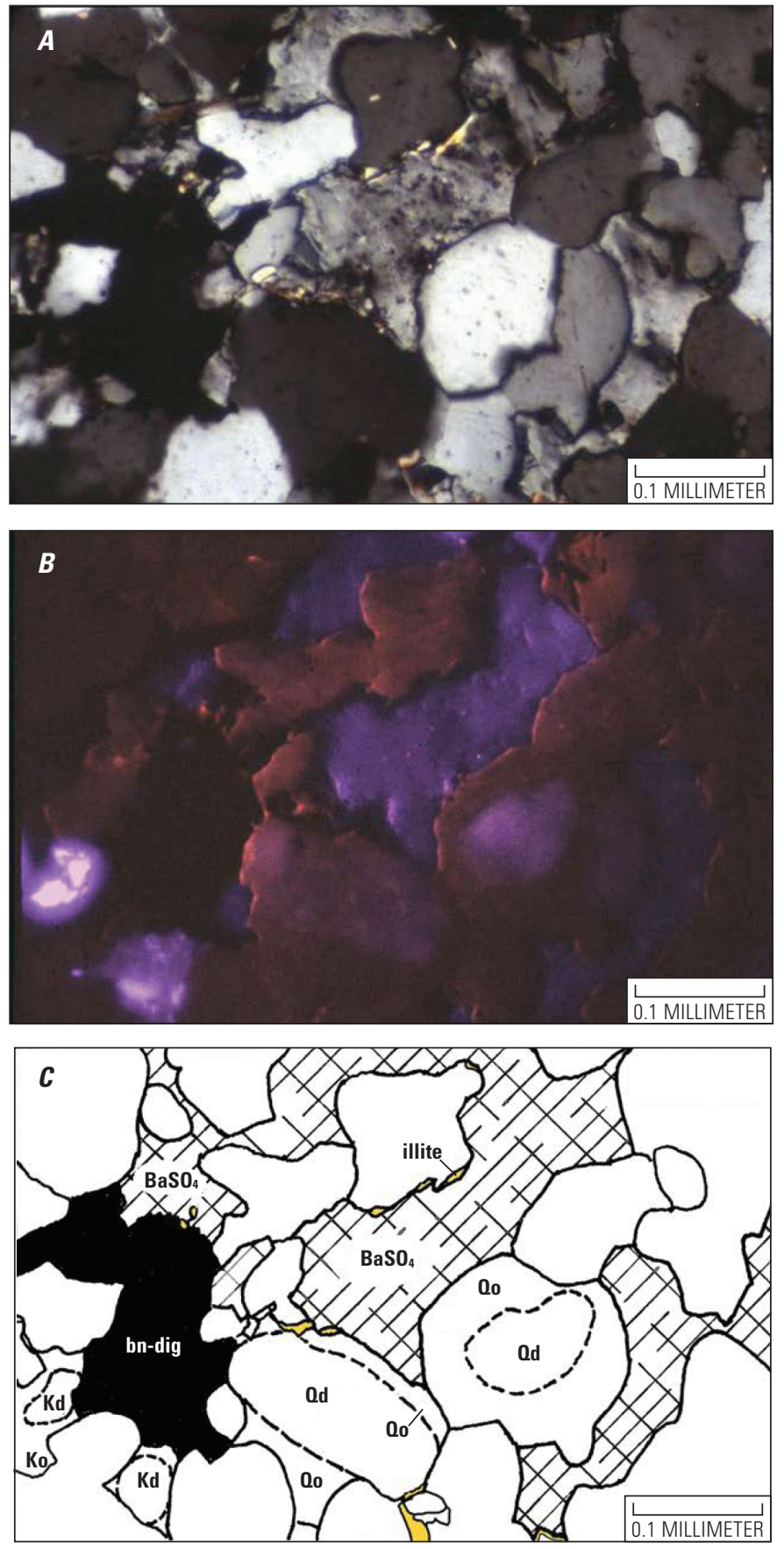

\section{Textures and Grain Sizes of Hypogene Gangue}

The reason that alteration is seldom discussed in the literature of SSC deposits is that the grain sizes and textures of the alteration and gangue minerals, such as albite and hematite, are not different than other minerals in these altered rocks. As such, this alteration is not distinguished in appearance except where it forms nearly total replacements of the other minerals of the rock or unless it occurs in disconformable bodies. In two mineralizing systems, however, there are specific rock textures that distinguish the hematization where $\mathrm{Cu}$ is depleted. Related to deposits of the Revett Formation, Montana, and to those of
Figure 23. Sequence of authigenic minerals in the chalcocitechlorite zone (fig. 6) of the Spar Lake sandstone copper deposit. $A$, Photomicrograph in cross-polarized transmitted light.

$B$, Cathodoluminescent photomicrograph of the same field of view. Detrital k-feldspar luminesces bright blue. Some detrital quartz luminesces dull blue gray. Barite appears to luminesce blue with recessed polishing relief, but the color is probably just internal reflection of K-feldspar luminescence. Overgrowth quartz and $\mathrm{K}$-feldspar luminesce dull red. $C$, Image made by drawing grain boundaries and identifying mineral grains on an overlay of the upper and middle images. Mineral abbreviations: Kd - K-detrital K-feldspar, Od - detrital quartz , Ko - K-feldspar overgrowth; 0o - quartz overgrowth, illite - high-birefringent white mica, now $2 \mathrm{M} 1$, but probably originated as a clay cement, $\mathrm{BaSO}_{4}-$ barite, bn-dig - bornite-digenite. The apparent sequence is (1) quartz and $\mathrm{K}$-feldspar detritus, (2) quartz and $\mathrm{K}$-feldspar overgrowth on detrital cores, (3?) illite, and (4) barite and bornite-digenite porefilling cements.

the Burj Formation at Wadi Dana and Wadi Abu Kusheiba, Jordan, there is an unusual, cross-laminar, swirled banding of hematite in sodically altered $\mathrm{Cu}$ source rocks (fig. 26). The banding has the appearance of Leisegang banding, but the bands are pervasive through the rock volume rather than confined to a joint or fracture plane. Microscopically, the hematite in this texture is not distinguishable from the hematite of other red beds; it forms rims outlining detrital grains and is enclosed in later cements, commonly occurring between quartz detritus and quartz overgrowths. The banding in the Salib Formation interpreted source beds in Jordan is well exposed in the archeological ruins at Petra (fig. 27).

Although swirled hematitic banding characterizes altered rock of these two systems, such banding occurs in many other sandstone units where it has no relation to SSC deposits. For example, many different sandstone units of the Colorado Plateau, United States, show such banding.

\section{Lateral and Vertical Dimensions}

The lateral and vertical dimensions of alteration and $\mathrm{Cu}$ source areas related to a SSC system is uncertain, in part because there are only a few systems in the world where the alteration is recognized. Nonetheless, it can be stated that the dimensions of whole systems are enormous, apparently nearly the scale of whole basins. In the Spar Lake and associated deposit area, only a zone about $100 \mathrm{~km}$ long and $50 \mathrm{~km}$ wide has any Revett Formation rocks that are suitable host rocks, those which are white, gray, or green. These rocks in the Western Montana Copper Sulfide Belt (Harrison, 1972) average $0.5 \mathrm{~km}$ in thickness. To the west and east of the Copper Sulfide Belt, rocks of the Revett Formation are lavender gray and are entirely albitized and depleted in $\mathrm{Cu}$. Downsection rocks of the Burke Formation and upsection rocks of the St. Regis Formation, both within the $\mathrm{Cu}$-sulfide belt and to its west and east, are almost entirely albite-altered and depleted in Cu. Albitized rocks of the Ravalli Group continue westward for about $70 \mathrm{~km}$ 

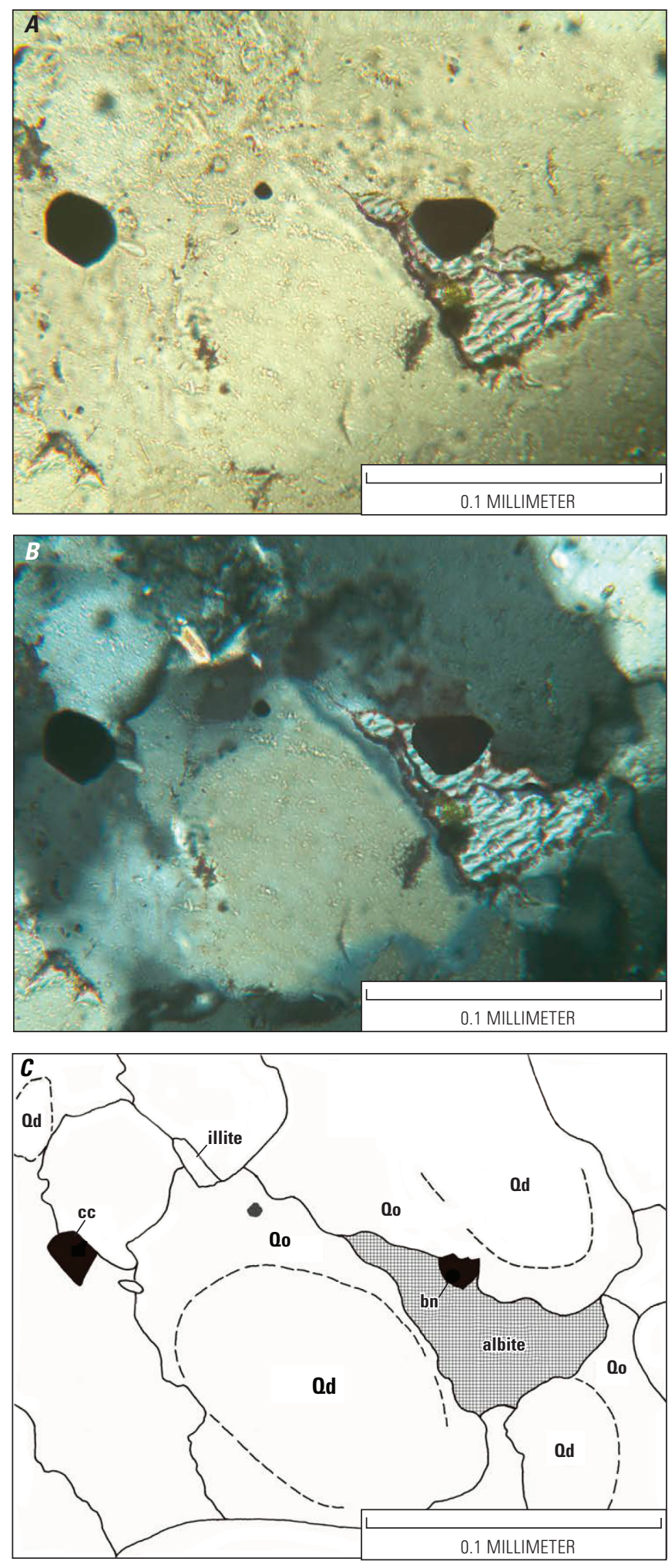

and eastward for almost $200 \mathrm{~km}$ from the boundaries of the $\mathrm{Cu}$-sulfide belt and have a typical total thickness of about $3 \mathrm{~km}$. Thus, as a rough estimate, the Western Montana Copper Sulfide Belt consists of about 2,500 $\mathrm{km}^{3}$ of white, gray, or green Ravalli Group rocks. To its west and east and interlayered within those white gray or green rocks, there is about $80,000 \mathrm{~km}^{3}$ of $\mathrm{Cu}-$ stripped albite-altered Ravalli Group rock.
Figure 24. Sequence of authigenic minerals in the chalcocitechlorite zone (fig. 6) of the Spar Lake sandstone copper deposit. $A$, Photomicrograph in transmitted, plane-polarized light. $B$, Photomicrograph in transmitted, cross-polarized light. $C$, Image drawn by tracing grain boundaries on the first two. The section has been etched for 90 seconds in the vapors above concentrated HF acid. It has then been stained sequentially by sodium cobaltinitrite and Amaranth solutions by the method of Gabriel and Cox (1929), as subsequently modified by Keith (1939), Chayes (1952), and Rosenblum (1956). Using this method, K-feldspar stains bright yellow, and calcium-bearing plagioclase stains magenta colors with intensity of the color increasing with calcium concentration in the plagioclase. Pure albite etches but takes no stain color. Mineral abbreviations are: $0 d$ - detrital quartz, 00 - quartz overgrowth, bn - bornite, and cc- chalcocite. The apparent sequence is (1) detrital quartz, (2) quartz overgrowth, (3) chalcocite, bornite, illite, and albite, and (4) albite (the central pore-filling of albite probably formed after the bornite ceased growing).

It is unlikely that from the vast volumes of albitized Ravalli Group rocks to the west and east of the Western Montana Copper Sulfide Belt, the $\mathrm{Cu}$ moved hundreds of kilometers laterally to orebodies within the belt. Mineralizing solutions probably did not migrate laterally for more than $100 \mathrm{~km}$ and perhaps not even for tens of kilometers. It is likely, instead, that the $\mathrm{Cu}$ moved mainly upward across stratification. In the areas to the west and east of the $\mathrm{Cu}$ sulfide belt, the $\mathrm{Cu}$ probably was deposited in the laterally persistent, although thin "greenbed" occurrences described by Harrison (1974), such as the Blacktail Mountain occurrence at the contact of the Spokane and Empire Formations (Harrison and Reynolds, 1979).

\section{Weathering and Supergene Ore and Gangue Characteristics}

The weathering of SSC deposits has received little attention from geologists in recent years, although it was the subject of debate at earlier times. In part, the lack of recent attention is because changes to $\mathrm{Cu}$ grade because of supergene processes are not particularly great for most combinations of deposit subtype and weathering conditions. In part, the lack of attention is because the geometry of an SSC deposit is rarely conducive to much supergene enrichment. These deposits tend to be sheetlike to tabular, so they generally have limited areas exposed in outcrop, and only shallow bedding attitudes lend themselves to making an extensive enrichment "blanket." Steep bedding attitudes can also lend themselves to enrichment, although not with a blanket geometry, so the enrichment is not easily detected. Supergene enrichment, however, may be important in some deposits, particularly in the Democratic Republic of Congo and Zambia. This section will first discuss the mainly earlier work on supergene enrichment for the deposits of the Central African Copperbelt. It will then turn to descriptions of mineralogy and associations in leached cappings, oxide $\mathrm{Cu}$ zones, and enriched $\mathrm{Cu}$-sulfide zones of SSC deposits in central Africa and elsewhere. 


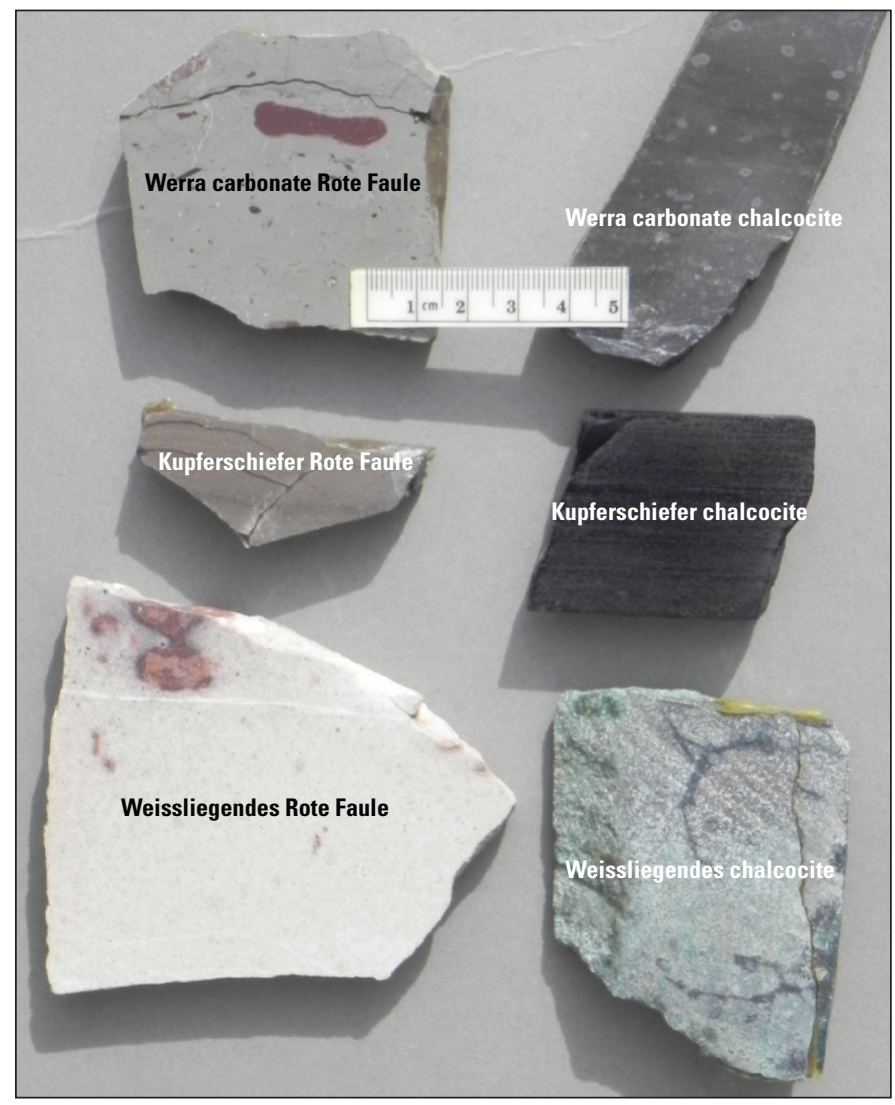

Figure 25. Chalcocite-zone and Rote Fäule alteration-zone rocks from the Kupferschiefer mineralizing system on the ForeSudetic Monocline, Poland. Rocks are aligned horizontally along stratigraphy. Chalcocite-zone rocks (ores) are on the right, and Rote Fäule zone rocks are on the left. Chalcocite-zone hand specimens are from the Rudna mine. Rote Fäule zone hand specimens are from the updip part of the Polkowice mine. Small scale divisions are 1 millimeter.

\section{Enrichment or the Lack of it in the Central African Copperbelt}

Climate is always an important variable in the process of weathering and supergene enrichment. Supergene effects in the Central African Copperbelt may differ from the world's other SSC districts because of its climate. The Copperbelt climate is warm and relatively humid, with 120 to $140 \mathrm{~cm} / \mathrm{yr}$ of rain. Lateritic soils are developed locally along the Copperbelt, but the lateritization nowhere produces a soil profile with economic Fe or aluminum concentrations. Weathering is relatively deep over much of the area; average depths to bedrock are $4 \mathrm{~m}$ (Maree, 1961, p. 65). Among the world's known SSC districts, only Seboruco, Venezuela, and Bahia, Brazil, share a similar latitudinal zone with the Central African Copperbelt, and even within a latitudinal zone, rainfall, a first-order control on supergene enrichment processes, can vary greatly.

Hitzman and others (2005, p. 627) stated that "supergene processes appear to be responsible for forming much of the chalcocite" of Zambian Copperbelt deposits and that "the

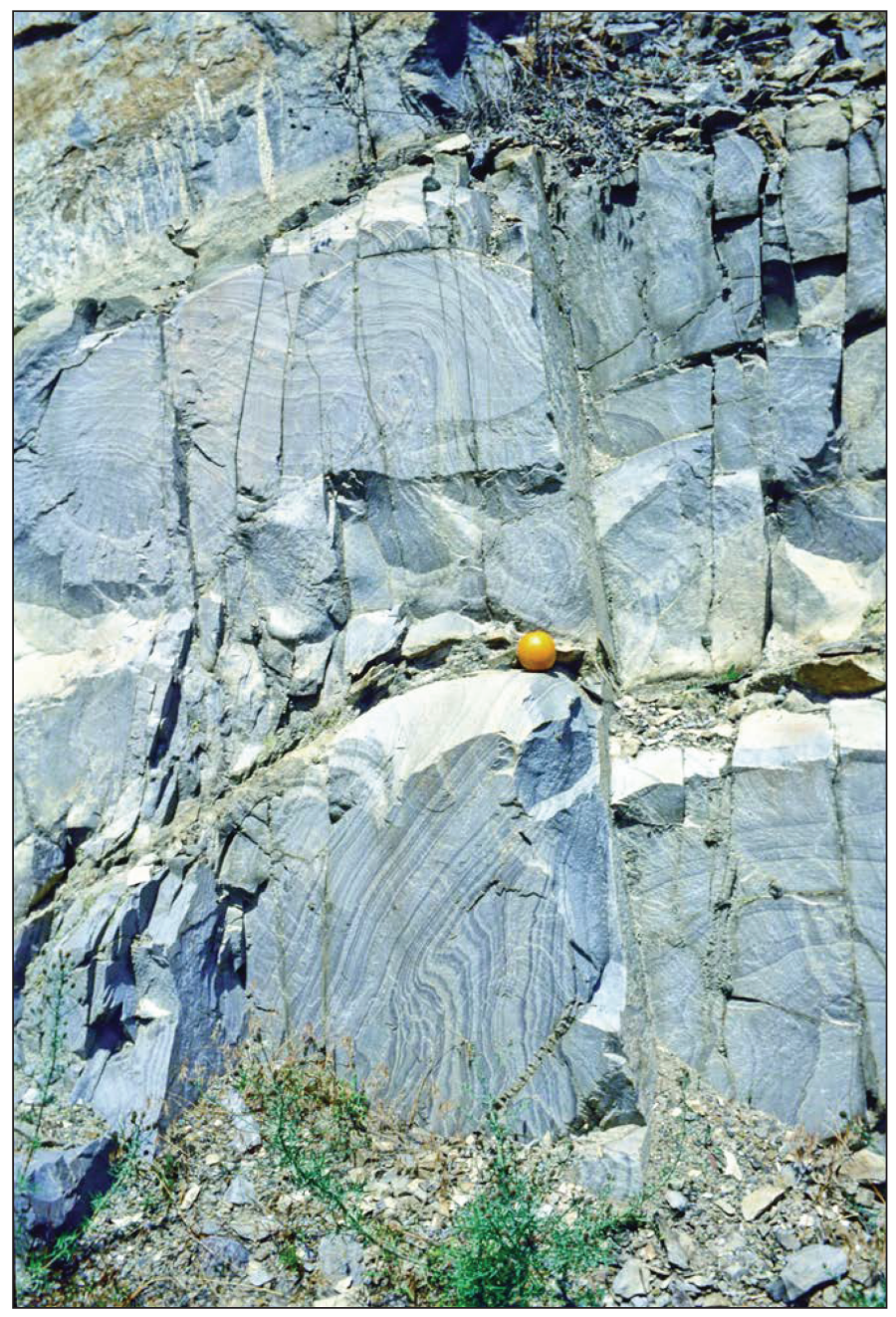

Figure 26. Outcrop of albite zone quartzites (metasandstones) of the mineralizing system for the Revett Formation sandstone copper deposits (fig. 6), northwestern Montana, United States. Bedding dips about 15 degrees from upper right to lower left. An orange is a standard for scale and color. The purplish gray bands consist of zones of dense dissemination of dust-rimming hematite like that of figure 21, and areas between the purplish gray bands have a lesser abundance of hematite dust rims. The rock has more than 15 volume percent feldspars including K-feldspar (approximately 3 percent) and albite (approximately 12 percent) but totally lacking any calcium plagioclase and totally lacking any carbonate minerals. Albite in the rock has replaced all calcium-bearing plagioclase and mostly replaced detrital and overgrowth K-feldspar. The rock has less than 300 parts per million calcium despite having more than 15 percent total feldspars.

high grade of many orebodies in Zambia and probably Congo, relative to other sediment-hosted stratiform $\mathrm{Cu}$ deposits may be due in large part to supergene alteration." However, it is likely that where the host rock is finely laminated, carbonaceous dolosiltstone, as is the case for most of the deposits of the Democratic Republic of Congo, the chalcocite contained therein is mostly hypogene, because supergene chalcocite is deposited from acidic shallow groundwater solutions. At $\mathrm{pHs}$ of about 3.5 , typical of those forming supergene chalcocite 

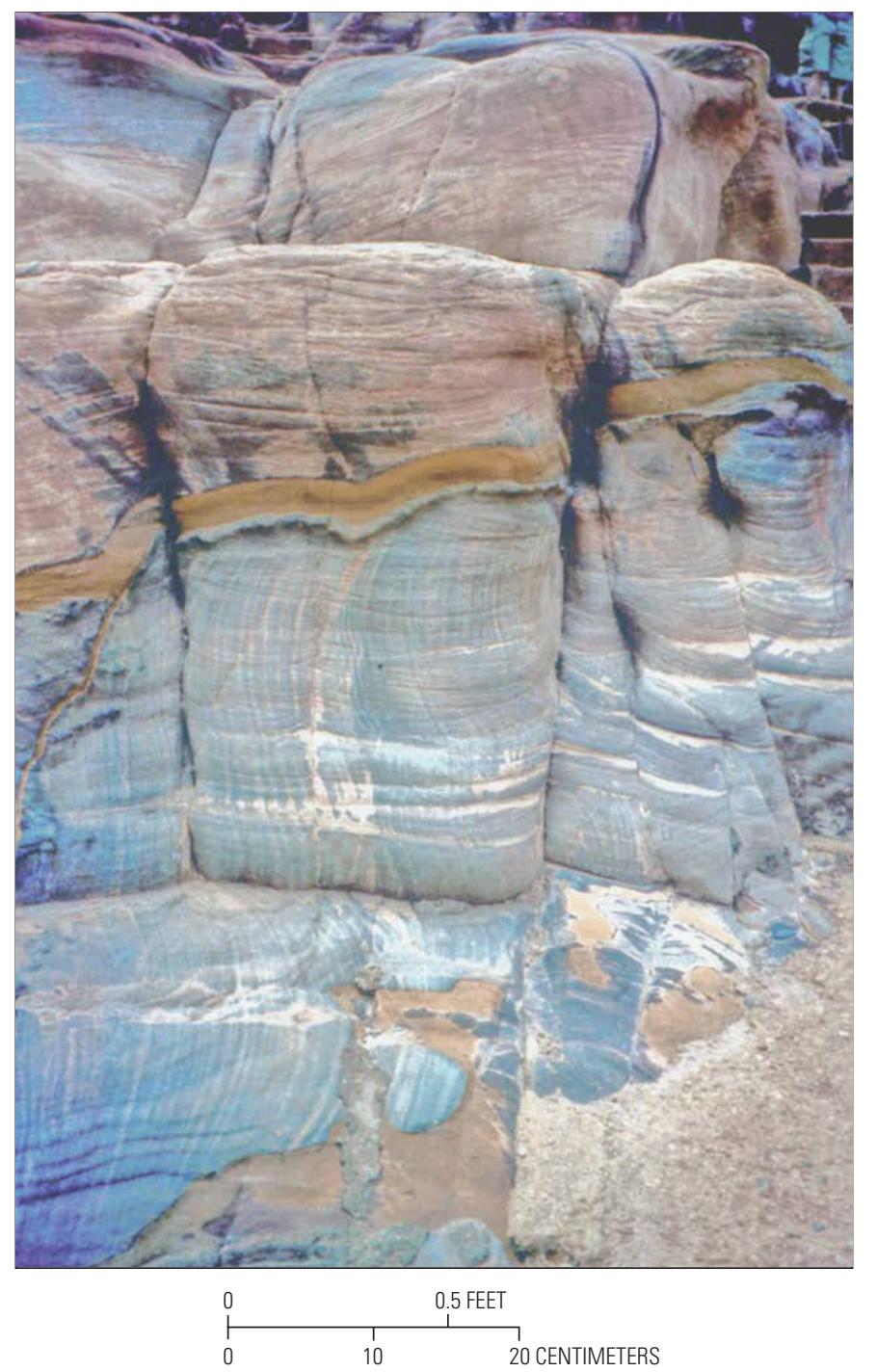

Figure 27. Lavender hematitic banding in the Salib Arkosic Sandstone Formation in the Petra Archaeological National Park, Jordan. The rock is close in stratigraphic position laterally to the Wadi Abu Kushayba sediment-hosted stratabound copper deposit that is about 15 kilometers west from this outcrop. Samples of similar sandstone collected nearby from the same formation and rock type contain sodium believed to be mainly in paragonitic illite grain rims deposited atop quartz and K-feldspar detritus and overgrowths, and an analyzed whole-rock sample contained just 2 parts per million copper and 100 parts per million calcium (the lower detection limit of the analytical method) by inductively coupled plasma mass spectrometry. Copper-depleted rocks like these are probably the copper source for the sediment-hosted stratabound copper deposit. Photograph from Peter Johnson.

blankets (Titley and Marozas, 1995; Enders and others, 2006), the dolomite would not have survived to coexist with chalcocite in large volumes of rock, and the $\mathrm{pH}$ of vadose-zone water would never have become acidic enough for transporting $\mathrm{Cu}$ over major distances downward to form extensive supergene chalcocite blankets. Conversely, wherever there is chalcocite of supergene origin, leaching of the dolomite is likely.
Chalcocite group minerals, including chalcocite, djurleite, digenite, and anilite, though, are the only $\mathrm{Cu}-, \mathrm{Co}-$, or $\mathrm{Ag}-$ bearing minerals in these deposits whose hypogene versus supergene origin can be strongly questioned.

The origin of chalcocite in Zambian and Democratic Republic of Congo SSC deposits was the subject of lively debate in the 1920s through the 1950s (Bateman, 1930; Schneiderhöhn, 1932; Oosterbosch, 1951; Garlick, 1961a). The debate seemed to resolve itself with the widespread acceptance of Garlick's (1961b) syngenetic hypothesis of deposit genesis, but with that hypothesis now mainly viewed as incorrect, the primary or supergene origin of most of the chalcocite needs to be better addressed. Certainly, some of the older observations still apply. The literature that addresses supergene or hypogene origin of chalcocite group minerals in Central Africa all dates from before 1965.

Bateman (1930) specifically addressed the problem and did so from extensive ore microscopy ("one hundred or so representative sulphide ore specimens," p. 388). His most important conclusion was that there was both hypogene and supergene chalcocite, but that (p. 404) "perhaps the major part of the Rhodesian chalcocite is of hypogene origin." Bateman's work pre-dated much of the present-day knowledge of the phase relations among the chalcocite-group minerals. At the time, there was recognition from work on supergene blankets at porphyry $\mathrm{Cu}$ deposits in the American Southwest, of two phases, termed white chalcocite and blue chalcocite, on the basis of their apparent colors in reflected light where they occur together. The chalcocite with composition, $\mathrm{Cu}_{2} \mathrm{~S}$, had a low-temperature polymorph that was thought to be probably orthorhombic, and the high temperature one was thought to be isometric.

Buerger (1942) found that the "blue chalcocite" was a separate mineral that he named digenite, that it was isometric, that it formed solid solutions at high temperatures over a range of compositions between $\mathrm{Cu}_{9} \mathrm{~S}_{5}$ and $\mathrm{Cu}_{2} \mathrm{~S}$, and that at low temperature it had a much more restricted composition range near $\mathrm{Cu}_{9} \mathrm{~S}_{5}$ and had non-isometric crystallography. Djurle (1958) found another phase of composition $\mathrm{Cu}_{1.96} \mathrm{~S}$ that had optical properties near those of chalcocite, and djurleite was soon found in numerous natural assemblages, notably including supergene blankets and SSC deposits (Butte, Mont., and Tsumeb, Namibia: Roseboom, 1962; Kennecott, Ala.,: Roseboom, 1966; Copiapó district, Chile: Sillitoe and Clark, 1969; White Pine, Mich.: Brown, 1971). Roseboom (1966) defined most of the phase relations among these and found that chalcocite (pure $\mathrm{Cu}_{2} \mathrm{~S}$ ) had high temperature hexagonal and high pressure tetragonal polymorphs, the latter being quite rare, as well as a low-temperature monoclinic, pseudo-orthorhombic polymorph. Morimoto and others (1969) identified anilite (orthorhombic $\mathrm{Cu}_{7} \mathrm{~S}_{4}$ ) as yet one more phase intermediate in composition between chalcocite and covellite. Sillitoe and Clark (1969) almost immediately identified anilite as a key component in the "sooty" chalcocite, which is widespread in supergene enrichment blankets, together with covellite, djurleite, and monoclinic chalcocite. 
Morimoto and Kato (1970) then redefined the low-temperature phase relations among chalcocite, djurleite, digenite, anilite, and covellite, including finding a eutectic of $70{ }^{\circ} \mathrm{C}$ between anilite and djurleite below which temperature digenite would not form. This digression into sulfide phase relations is needed to evaluate which among Bateman's (1930) findings about Zambian "chalcocite" remain valid and which do not.

Bateman (1930, p. 394-395) described "subgraphic" intergrowths of bornite and "chalcocite" (fig. 28) and noted that they are common in Zambian ores and that he had never seen them in chalcocite of supergene origin. With the understanding that the chalcocite of the intergrowths is probably digenite, the conclusion stands that these types of exsolution intergrowths are probably hypogene. In fact, where they have the phase proportions of 0.33 to 1.00 bornite component, these intergrowths mark the unmixing of a solid solution that was stable at temperatures certainly greater than $82^{\circ} \mathrm{C}$ and, across most of that range of compositions, greater than $180^{\circ} \mathrm{C}$ (Grguric and others, 2000). Such a grain with molar proportions of 0.56 bornite and 0.44 digenite is prominent in figure 28. Bateman (1930, p. 396-401) also found (1) needle-thin octahedral intergrowths of bornite in "chalcocite," (2) lamellar intergrowths of blue and white "chalcocite," (3) triangular pseudo-eutectic textures of unmixed bornite and "chalcocite" within triangular arrays of "chalcocite" blades, and (4) triangular-patterned lattice intergrowths of bornite and "chalcocite" in Zambian ores. Bateman reasoned that all these marked a formerly isometric crystal system for the "chalcocite," and he attributed the textures to hypogene origins at greater than $91{ }^{\circ} \mathrm{C}$, which was thought to be the thermal maximum stability of lowtemperature monoclinic, pseudo-orthorhombic chalcocite. In fact, each of the textures indicating a former isometric crystal system was an exsolution of digenite and either bornite or chalcocite starting from a higher temperature digenite solid solution (Roseboom, 1966), and all these did originate at higher temperatures, thus suggesting hypogene origin. They could have, however, been deposited as low-temperature composite sulfide grains indicating replacement, then have been ramped up to high temperature and homogenized in the digenite solid solution compositional field, and then exsolved as they returned to lower temperature. But if that was how they formed, then other textures (see below) would also have gone through that history. Finally, Bateman (1930) observed rim-pattern and mesh-pattern textures where chalcocite replaced bornite or chalcopyrite, commonly also containing traces of covellite, and these he attributed to supergene origin. In short, knowing now about digenite, djurleite, and anilite, Bateman's (1930) conclusion should be accepted that Zambian chalcocite-group minerals are of both hypogene and supergene origin and, if his distribution of samples was representative, that "perhaps the major part" of the chalcocite is hypogene.

Oosterbosch (1951) described mineral distributions at Fungerume, Democratic Republic of Congo, well enough to start further conjecture about weathering and enrichment,

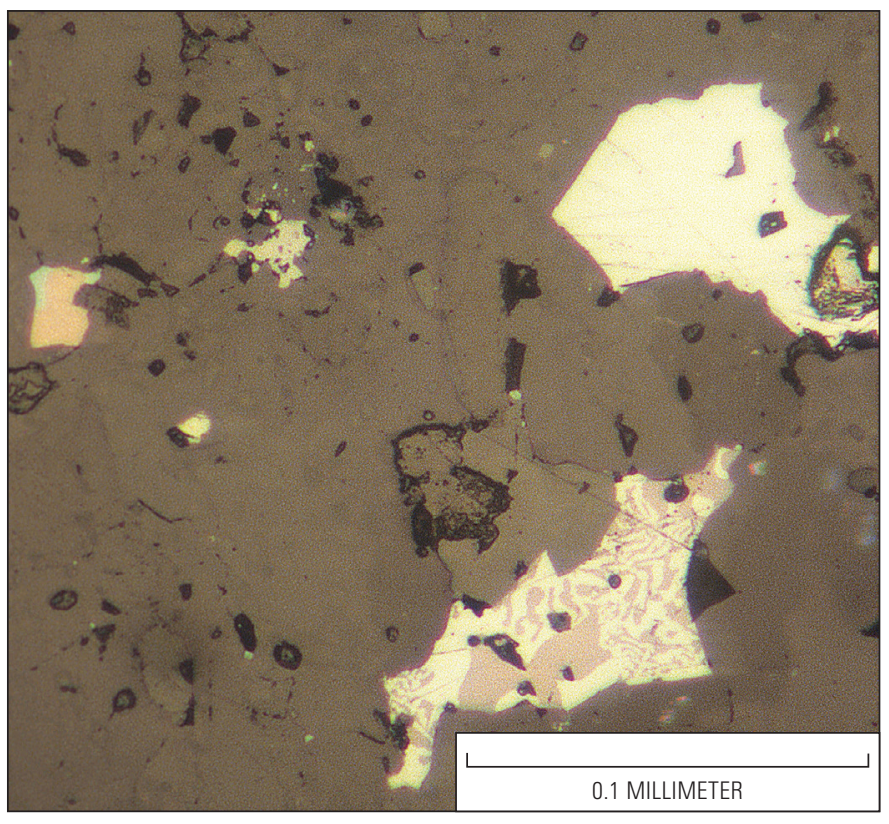

Figure 28. Photomicrograph in reflected plane-polarized light of a vermicular (Bateman's [1930] "subgraphic") exsolutiontextured grain of bornite and digenite (in the lower right) from the Spar Lake sandstone copper deposit. Note that it and other reflecting grains have cuspate outlines that probably indicate they are intergranular to detrital grains and earlier cements. This proportion of each bornite (purple) and digenite (very light gray) would have come from a homogeneous solid solution with its solidus at $317^{\circ} \mathrm{C}$, providing that the composite grain shown acted as a closed system as temperatures fell from maximum metamorphic temperatures. In the upper left in orange is sulfur-rich (X-)bornite; digenite is blue. In the upper right is a homogeneous grain of digenite.

yet came to the conclusion that all the "chalcocite" had the same supergene origin. $\mathrm{He}$ (p. 131) stated that there is a zone of malachite and $\mathrm{Cu}$ silicates from surface to $100 \mathrm{~m}$ depth, underlain by a zone of chalcocite and "green salts" to a depth of $250 \mathrm{~m}$, underlain by sulfides only, although with only scant traces of chalcopyrite. He found limonite and local occurrences of native copper to the greatest depths they had then drilled, $990 \mathrm{~m}$, and noted that the top of sulfides was only "slightly related" to the present water table. With digenite then known, he noted digenite only below $250 \mathrm{~m}$, and he found evidence for pre-existing cubic structure in the chalcocite only at those levels. Oosterbosch wrote (p. 142):
"The upper sulfide zone [that lying stratigraphically above the RSC beds] in which the chalcocite domi- nates contains 6 to 8 percent copper; the surficial oxidation causes the grade to drop on the average to 5.5 to 6 percent. Marked impoverishment appears to start only above a depth of $100 \mathrm{~m}$ [that is, impov- erishment within the malachite and copper silicates zone as described above]." 
Finally, Oosterbosch (1951) gave the distribution of grades of chalcocite orebodies stratigraphically below the RSC beds. Average grade at $100 \mathrm{~m}$ depth was 5.99 percent $\mathrm{Cu}$, at the top of his non-cubic, low-temperature chalcocite lacking earlier cubic structure, with green salts zone, totally lacking digenite. At $400 \mathrm{~m}$ depth, it was 8.93 percent $\mathrm{Cu}$, in a zone containing some digenite and formerly cubic chalcocite. At $680 \mathrm{~m}$, it was 5.43 percent $\mathrm{Cu}$, and at $715 \mathrm{~m}$, it was 5.58 percent $\mathrm{Cu}$, with both from zones having some digenite and formerly cubic chalcocite.

Together, these data probably indicate some supergene enrichment of copper as low temperature (monoclinic, pseudoorthorhombic) chalcocite at depths extending from $100 \mathrm{~m}$ to somewhat below $400 \mathrm{~m}$ depth at Fungurume. Nearly all of the chalcocite between 100 and $250 \mathrm{~m}$ depth is supergene, because none in that interval has cubic (digenite solid solution field) parentage. Everywhere below $250 \mathrm{~m}$, some hypogene chalcocite is certainly present and came from the cubic, high-temperature solid solution with digenite as further evidenced by the presence of digenite that is absent everywhere above $250 \mathrm{~m}$.

For the case of Roan Antelope, Brummer (1955, p. 288-290) observed digenite, white chalcocite, and sooty chalcocite. He attributed the sooty chalcocite, which was more abundant in upper levels and was associated with cuprite and malachite, to supergene origin. He stated that sooty chalcocite does not furnish any appreciable tonnage of ore at that mine, which is now called the Luanshya deposit.

Weathering effects on the ores of the Zambian Copperbelt were discussed in Mendelsohn (1961a), and the various statements reflected the lack of consensus about the importance of supergene effects. First, in general, Mendelsohn wrote (p. 129):

"In the southern part of the Copperbelt west of the Kafue anticline, below a narrow layer of mixed sulphide and oxide with some enrichment there is clean sulphide ore with little or no enrichment. Farther north there has been more supergene activity. At Nchanga a considerable part of the mineralization is of supergene origin and there has probably been much enrichment; ... At Bancroft [now called Konkola] there has been leaching and redeposition of the copper to a depth of many hundreds of feet. The areas in which the orebody was leached and those that were enriched are related to the fold structure. At Mufulira there was supergene enrichment in all three orebodies in the higher levels... The main supergene minerals are malachite, chalcocite, cuprite, chrysocolla, and vermiculite, and lesser minerals are tenorite and native copper. The vermiculite is an alteration product of biotite, or possibly in places other micas, and contains copper both as inclusions between the plates of the mica and as part of the crystal lattice."
Those who described individual deposits in 1961 found what they considered to be varying effects of weathering and supergene enrichment across the Copperbelt. Mendelsohn (1961a, p. 400) said that "most of the oxidation appears to consist in the fixing of the $\mathrm{Cu}$ in new minerals with little or no migration."

Important but localized enrichment took place at Chibuluma. Winfield (1961, p. 339) wrote:

"A gossany sandstone forms the entire sub-outcrop of the orebody and extends to between 200 and 270 feet below surface. The sulphides in this zone have been leached out and replaced by limonite. Malachite and chrysocolla are absent except near the abrupt change to sulphide at the upper edge of the orebody. The ore below the gossany sandstone has been enriched down to the 350-foot level, chalcocite and covellite commonly replacing the primary sulfides."

The ore continued to more than 2,500 ft below surface. Because most of the ore at Chibuluma was chalcopyrite, with bornite found only in western and eastern extremes, the supergene origin of the chalcocite and covellite was obvious below the leached capping and the thin malachite-chrysocolla (oxide $\mathrm{Cu})$ zone.

At Nkana, the distribution of supergene versus hypogene chalcocite has never been clearly described. However, native copper is known to depths as great as 2,700 $\mathrm{ft}$ in the Porous Sandstone [that overlies the Copperbelt Orebody member], and sulphides extend to a depth of at least 6,000 ft (Jordaan, 1961, p. 323).

Farther north, Nchanga is one of the two places where supergene $\mathrm{Cu}$-bearing vermiculites were first identified (Bassett, 1958). Cu-vermiculite mineralization extends down along the $20^{\circ}$ dips in sandstones to depths of greater than $800 \mathrm{ft}$, but it gives out below that, apparently having formed in weathering from earlier phlogopitic biotite. Notably, the pre-mining water table was nowhere more than $40 \mathrm{ft}$ below surface. Features like this and the ones at Fungurume have led workers to repeatedly suggest a Mesozoic to Tertiary period of deep supergene oxidation (Selley and others, 2005) assumedly dating from a time when the water table was much deeper than it presently is. McKinnon and Smit (1961) noted that masses of cuprite commonly form a border around chalcocite layers. They stated that sulfuric-acid solutions have reacted with the aluminous minerals leaving kaolinite as a residual product. The arkose in the footwall of the orebody is particularly kaolinized.

For the Konkola area, although weathering effects were profound, Schwellnus (1961, p. 228) wrote that, "in any area, the total number of copper units will remain the same regardless of their distribution by supergene solutions." This indicates that the migration of $\mathrm{Cu}$ for the most recent supergene minerals was over only small distances. On a map (p. 229), Schwellnus showed the zone of malachite with lesser chalcocite and chrysocolla extending irregularly to a 
depth of nearly $1,900 \mathrm{ft}$, and with lesser malachite occurrence extending below probably $2,100 \mathrm{ft}$. He (p. 234) described heavily leached ore sections where carbonate minerals had been removed to produce "a porous mass of chalcocite, goethite, and Mn wad in cavities parallel to the bedding." He also showed major-element data (p. 224) that documented prominent leaching of the carbonates from the ore horizon [Copperbelt Orebody Member] in upper levels of the mine, corroborating our earlier statement about the likelihood that dolomite would dissolve in and above zones where supergene chalcocite is deposited.

At Mufulira, the identification of a leached capping was entirely straightforward. Brandt and others (1961, p. 450) reported that leaching of sulfides of the three orebodies was general to a depth of $200 \mathrm{ft}$ from surface and sporadic below that depth, extending within some Footwall quartzites and grits to $2,000 \mathrm{ft}$ or more. Near the surface, the ore beds were leached and porous in contrast to the solid and fresh unweathered orebody quartzites, and they contained $\mathrm{Cu}$ as noneconomic malachite, chrysocolla, cuprite, and native copper. It was simply assumed that all the chalcocite was supergene in origin, probably a correct assumption for the small amounts of chalcocite with some cuprite and malachite in porous quartzites adjacent to the $\mathrm{Cu}$ orebody that elsewhere consists only of bornite and chalcopyrite. Where $200 \mathrm{ft}$ of quartzite leached capping with subeconomic $\mathrm{Cu}$ oxides is found, and the rock below contains ore grades as chalcocite, it follows that supergene enrichment as sulfides probably occurred. Notably, though, four different textures illustrated by Bateman (1930) indicating "chalcocite" that had formed earlier in isometric crystals came from Mufulira. As above, the "chalcocite" with isometric heritage was probably hypogene and originated as the high digenite solid solution.

\section{Mineralogy and Mineral Associations in Weathered and Enriched Zones}

From the above, in the Central African Copperbelt, $\mathrm{Cu}$ undergoes locally significant enrichment as chalcocite and covellite, and probably djurleite and anilite, below a zone of leached capping that is highly variable in thickness but appears to extend downward for a few to $90 \mathrm{~m}$ from surface. The capping is followed downward by a zone of oxide $\mathrm{Cu}$ minerals and native copper that appears to typically extend from the base of leached capping to as much as a few hundred meters from the surface. Further below is a zone of supergene enriched chalcocite ore that extends at least to $400 \mathrm{~m}$ depth (Fungurume) and probably more likely to at least $800 \mathrm{~m}$ depth (Nkana, Nchanga, and possibly Konkola). Yet, Bateman's (1930) principal conclusions stand, and the statement of Hitzman and others (2005) does not appear well supported: there are "chalcocites" of both supergene and hypogene origin in the Central African Copperbelt, and the major part is probably hypogene.
Co in Central Africa has a different behavior than $\mathrm{Cu}$ in the zone of weathering. Co is residually enriched within the zone of weathering and oxidation. The behavior is known but has not been studied systematically. Gauthier and Deliens (1999) described a well-developed "cobalt cap" at the Musonoi deposit in the Kolwezi klippe and in the nearby K.O.V. deposit.

The following sections describe, as well as possible, the minerals in the leached capping, the oxide $\mathrm{Cu}$ zone, and the chalcocite enrichment zone in Central Africa and elsewhere. Obviously, there are still major gaps in our understanding of these.

\section{Leached Capping}

In the Central African Copperbelt, mineralized arenites, where they have been leached of their $\mathrm{Cu}$ content near the surface, are porous, friable, and "gossany," and the only two minerals that are clearly formed in the zone of weathering are goethite and kaolinite, on the basis of the descriptions from Chibuluma (Winfield, 1961), Konkola (Schwellnus, 1961), and Mufulira (Brandt and others, 1961). The source of the $\mathrm{Fe}$ for the goethite could be earlier $\mathrm{Cu}$ - and Fe-rich sulfides, ferroan dolomite (Darnley, 1960, p. 148), or both. Original carbonate and anhydrite cements have been leached from the capping.

The Fe oxide described in Central African leached cappings is goethite and not hematite. The richest leached cappings overlying chalcocite enrichment blankets of southwestern United States porphyry $\mathrm{Cu}$ deposits contain hematite, specifically called red hematite because of its blood-red streak (Titley, 2007). Red hematite was first described as a distinct component of porphyry $\mathrm{Cu}$ deposit leached cappings by Anderson (1982), who noted that at temperatures of formation below the dehydration temperature of goethite, the stable oxide should be goethite, not hematite. He (p. 279) suggested that the specific oxidation mechanism of chalcocite somehow stabilizes the hematite structure at low temperatures. Hayes (unpub. data) has found red hematite in a second low-temperature environment, as the cement of upgradient ferricretes of exotic $\mathrm{Cu}$ deposits, wherein the hematite certainly did not form as an oxidation product of chalcocite, but it did form from solutions that had a high concentration of dissolved $\mathrm{Cu}$. So, it is notable if red hematite is not the Fe oxide found in leached cappings in central Africa.

Co caps, described by Gauthier and Deliens (1999) and Decrée and others (2010), where $\mathrm{Cu}$ has been preferentially removed leaving Co residually enriched in the product, are a special form of leached capping in central Africa, although typically the Co oxides are accompanied by minor malachite and other $\mathrm{Cu}$ oxides. The $\mathrm{Co}$ oxides and malachite are found to depths locally hundreds of meters below the surface and commonly tens of meters. Co minerals in this environment, in order of relative abundance, 
are heterogenite-3R (rhombohedral $\mathrm{CoO}[\mathrm{OH}]$ ), kolwezite (triclinic $[\mathrm{Cu}, \mathrm{Co}]_{2} \mathrm{CO}_{3}[\mathrm{OH}]_{2}$ ), sphaerocobaltite (rhombohedral $\mathrm{CoCO}_{3}$ ), cobaltoan dolomite (rhombohedral $[\mathrm{Ca}, \mathrm{Co}]$ $\mathrm{Mg}\left[\mathrm{CO}_{3}\right]_{2}$ ), cobaltoan calcite (rhombohedral $[\mathrm{Ca}, \mathrm{Co}] \mathrm{CO}_{3}$ ), comblainite (rhombohedral $\mathrm{Ni}_{6} \mathrm{Co}_{2} \mathrm{CO}_{3}[\mathrm{OH}]_{6} \cdot 4 \mathrm{H}_{2} \mathrm{O}$ ), oursinite (orthorhombic $[\mathrm{Co}, \mathrm{Mg}]\left[\mathrm{UO}_{2}\right] \mathrm{Si}_{2} \mathrm{O}_{7} 6 \mathrm{H}_{2} \mathrm{O}$ ), and juliënite (monoclinic $\mathrm{Na}_{2} \mathrm{Co}[\mathrm{SCN}]_{4} \cdot 8 \mathrm{H}_{2} \mathrm{O}$ ). Comblainite and oursinite have been found only in the oxidized $\mathrm{Cu}$ - and $\mathrm{Co}$-rich $\mathrm{U}$ ores of Shinkolobwe, and juliënite has been found only at the surface at Shamitumba, where its crystallization is known to be bacterially mediated and ongoing (Schoep and Billiet, 1935). Of these, heterogenite is by far the most important, occurring in black microgranular kidney-shaped nodules, in botryoidal masses with shiny black surfaces at places in concentric superposed layers in outcrop, as earthy encrustations, and as stalactites, draperies, and oolites. Implicit in those occurrences is open space in the vadose zone, which then demands that there has been major dissolution, assumedly of the host-rock dolomite, within the residually enriched Co-oxide ores. Kolwezite commonly occurs in some of the same rocks with heterogenite, and it forms pale tan, powdery to velvety reniform crusts and mammillary surfaces. Sphaerocobaltite occurs mainly in the transition from carrollite-bearing or linnaeite-bearing primary sulfides to the zone of Co oxides, which, itself, is typically well down within the zone of $\mathrm{Cu}$ sulfides where the carrollite weathers much more readily than coexisting $\mathrm{Cu}$ sulfides. Sphaerocobaltite forms rose-red to purple layers directly replacing carrollite, it occurs as microscopic inclusions vividly coloring the dolomite, it occurs as drusy aggregates, and rarely it occurs as deep rose to deep-red crystals or rosettes associated with cobaltoan dolomite or calcite. Most of the cobaltoan dolomite occurs as vividly pink druses on joint faces, but some cobaltoan calcite occurs as large scalenohedrons or hexagonal prisms that are also vividly pink. Finally, some of the malachite of Democratic Republic of Congo oxide zones contains as much as $6 \mathrm{wt}$. \% Co, thus forming a limited solid solution with kolwezite.

Except for central Africa, no known rock is associated with SSC deposits that would properly be termed leached capping. But, similar features probably occur in other places.

\section{Oxide Copper Zones}

The major minerals of the oxide $\mathrm{Cu}$ zone in the Central African Copperbelt are malachite, chrysocolla, cuprite, native copper, tenorite, $\mathrm{Cu}$ wad, and $\mathrm{Cu}$ vermiculite. Pseudomalachite [monoclinic $\mathrm{Cu}_{5}\left(\mathrm{PO}_{4}\right)_{2}(\mathrm{OH})_{4}$ ], libethenite, cornetite [orthorhombic $\mathrm{Cu}_{3} \mathrm{PO}_{4}(\mathrm{OH})_{3}$ ], dioptase [rhombohedral $\mathrm{CuSiO}_{3}$. $\mathrm{H}_{2} \mathrm{O}$ ], shattuckite[orthorhombic $\mathrm{Cu}_{5}\left(\mathrm{SiO}_{3}\right)_{4}(\mathrm{OH})_{2}$ ], planchéite [orthorhombic $\mathrm{Cu}_{8}\left(\mathrm{Si}_{4} \mathrm{O}_{11}\right)_{2}(\mathrm{OH})_{4} \mathrm{H}_{2} \mathrm{O}$ ], chalchanthite [triclinic $\mathrm{CuSO}_{45} \mathrm{H}_{2} \mathrm{O}$ ], brochanthite [monoclinic $\mathrm{Cu}_{4} \mathrm{SO}_{4}(\mathrm{OH})_{6}$ ], and antlerite [orthorhombic $\mathrm{Cu}_{3} \mathrm{SO}_{4}(\mathrm{OH})_{4}$ ] are also important locally (Notebaart and Vink, 1972). Many additional secondary $\mathrm{Cu}$ minerals have been identified but only in trace quantities. Among the weathering-zone $\mathrm{Cu}$ minerals, there is a good deal of predictability in occurrence on the basis of the hostrock types and depth within the weathering and enrichment profiles. Some description is provided below.

Gangue minerals within the oxide $\mathrm{Cu}$ zones have nowhere been thoroughly described. They could provide some important information if they had been. Two minerals can be predicted in this zone. The obvious one is kaolinite, which is described in the overlying leached cappings and accompanying supergene chalcocite-enrichment profiles. Secondary $\mathrm{Co}$ - and $\mathrm{Cu}$-bearing carbonates are present, so another mineral predicted in the oxide zone or possibly in the supergene sulfide zone of the profiles is calcite. It is fairly likely that "dedolomite" will occur. Dedolomite is known from other locations where surface recharge or other freshwaters alter dolostones. Dedolomite is a replacement of the dolomite in dolostones occurring in a recognizable texture, namely that of mediumcrystalline, mosaic-textured masses of pure calcite with intergranular residues of the trace elements that were found in the original dolomite (Braddock and Bowles, 1963, fig. 84.1-E, p. C97; Evamy, 1967; Lyle, 1977, fig. 9B, p. 431; Kenny, 1992, p. 140-141). Typical intergranular residues include Fe as goethite and Mn as pyrolusite, ramsdellite, birnessite, or cryptomelane. A study of the weathering and enrichment profiles in the Central African Copperbelt is likely to encounter dedolomite, which will then aid in identifying the base of the chalcocite enrichment.

Within the $\mathrm{Cu}$-oxide zones, the available anions from the wallrocks provide an important control on the oxide minerals that form. In the Democratic Republic of Congo, where finely laminated carbonaceous dolostones are the host rocks, malachite is the predominant oxide $\mathrm{Cu}$ mineral. Although most of the malachite is finely disseminated, the massive botryoidal coatings of malachite that line open spaces are widely recognized among mineral collectors around the world. In more siliceous parts of the section, such as the RSC beds, chrysocolla is abundant, and planchéite, dioptase, and shattuckite are also found. Chrysocolla is abundant at Nchanga, interlayered with chalcedony. These silicates are also more common in the oxide zones of arenite-hosted ores. Planchéite was identified at Nchanga and Mufulira (Notebaart and Vink, 1972). Contrasting with that, the secondary phosphates are more common in oxide zones of the Zambian shale-hosted ores. Pseudomalachite is common in the Chambishi open pit and at Mindola, although it is widespread in minor amounts in all Copperbelt oxide ores. Libethenite is widespread but not abundant and also best known from the shale-hosted ores such as Mindola (Notebaart and Vink, 1972). Cornetite is known from Bwana Mkubwa and Nchanga and was first described in specimens from L'Étoille, Democratic Republic of Congo (Cesàro, 1912).

Cuprite and native copper are widespread near the transition to sulfides, and, as above, these can be found to depths far below the present-day water table. Cuprite in Zambia and the Democratic Republic of Congo is far more abundant than cuprite in oxide zones of most SSC deposits. In mapping 
of more than $1.8 \mathrm{~km}$ of underground workings of the Spar Lake deposit, through all of which the rocks were either fully weathered or weathered along several hundreds of fractures, cuprite was identified along only two fractures through sulfidebearing wallrock (T. Hayes, unpub. data).

The $\mathrm{Cu}$ vermiculites of Central Africa's oxide $\mathrm{Cu}$ zones are unique to that region. Bassett (1958) studied these and found hematite and goethite microscopically associated with them. He rejected the hypothesis that chlorite was actually interlayered in these on the basis of the differential thermal analyses and concluded that the $\mathrm{Cu}$ vermiculites formed from biotite in the unweathered rocks when $\mathrm{Cu}$ entered the exchangeable intersilicate layers. However, Jebson (AngloAmerican Corp., Central Africa, Ltd., Lubumbashi, D.R.C., written commun., 1970) disagreed and concluded instead that the cupriferous micas were composed of regularly interstratified layers of biotite and cupriferous chlorite (Notebaart and Vink, 1972). Their supergene origin is fully agreed upon, though, and they have been found in abundance at Nchanga, Chingola, and Roan Antelope (now Luanshya) and in lesser quantities in the oxide zones of all the other Zambian deposits in the Copperbelt.

In other regions, oxide $\mathrm{Cu}$ zones constitute the outcrops of orebodies and extend, at most, $60 \mathrm{~m}$ into the subsurface. Malachite is typically the most common $\mathrm{Cu}$ mineral in the weathered rocks. In sandstone $\mathrm{Cu}$ deposits, the malachite commonly is disseminated throughout the host rock, but in red-bed-type deposits, it can be concentrated, with azurite, on the carbonized plant material. Azurite is subordinate but notable in oxide zones of sandstone $\mathrm{Cu}$ deposits. At Lisbon Valley, it forms spherical concretions up to $2 \mathrm{~cm}$ in diameter. In the weathered rocks in the sandstone $\mathrm{Cu}$ deposits of the Belt Supergroup, United States, and the Udokan, Russia, malachite is not the dominant $\mathrm{Cu}$ phase. The climate is temperate to cool and total precipitation is moderate in these two areas, and they have brochanthite as the principal disseminated $\mathrm{Cu}$-oxide mineral in outcropping ore (V. Chechetkin, oral commun., 2009; T. Hayes, unpub data). In Belt Supergroup deposits joint and fracture surfaces commonly contain malachite from hypogene carbonate-bearing zones, brochanthite from hypogene carbonate-free zones, and black oxides that are probably $\mathrm{Cu}$ wad from either. The $\mathrm{Cu}$ wad forms prominent dendritic growths.

Deposits of the Belt Supergroup weather differently on the sunny southern exposures than they do on northern exposures. The $\mathrm{Cu}$ sulfides persist in outcrop on the northern exposures, but they rarely do on south-facing outcrops. Beerbottle limonite, also called glassy limonite or $\mathrm{Cu}$ pitch, forms pseudomorphs of the finely disseminated $\mathrm{Cu}$ sulfides and is the most common $\mathrm{Cu}$ phase in south-facing outcrops. In these southern exposures, the $\mathrm{Cu}$ grade is typically decreased by about one-half from its unweathered values. The beer-bottle limonite forms after chalcocite, digenite, bornite, or chalcopyrite. Galena is generally leached from southern outcrops.
By comparison, malachite- or brochanthite-bearing northern outcrops with some remnant sulfides commonly keep 75 to 90 percent of their unweathered $\mathrm{Cu}$ grade. Galena is perhaps the most resistant of all sulfides to weathering in north-facing outcrops.

In south-facing outcrops, pyrite is pseudomorphed by dense medium- to dark-brown goethite in cubes or in clots. Pyrite may persist or it may be similarly pseudomorphed in north-facing outcrops.

To a greater degree in south-facing than in north-facing outcrops, the Fe- and Mn-bearing carbonates of the primary ore in the Belt Supergroup are leached, although they leave distinctive pseudomorphs. The Fe-rich calcites may leave leached porous zones in the pattern of bedform disseminations, as well as a fairly dense intergranular network of dendritic-like chocolatebrown goethite (fig. 29). Even at depths of greater than $500 \mathrm{~m}$, the chocolate-brown goethite-after-ferroan carbonates can fill and envelope fractures. Ankerite of the central chalcocite-chlorite zone or the chalcopyrite-ankerite zone leaves discrete, randomly disseminated, tiny freckles of bright orange limonite (fig. 29). Partial weathering of the same ankerite sites may produce small amounts of calcite intergrown with the bright orange limonite. Ankerite sites from the unweathered rock do not effervesce in 1.5 percent $\mathrm{HCl}$, but the same sites, where they are turned orange in the partly weathered rock, effervesce from the $1 \mathrm{~mm}$ limonitic fleck in the weak acid. Where fully weathered, carbonate is completely gone from the orange limonite. Similarly weathering carbonates occur in the Paradox Basin deposits.

An additional group of supergene products is present at the red-bed-type $\mathrm{Cu}$ deposits of Silver Reef, Utah. These are the silver halide minerals, such as chlorargyrite (cubic $\mathrm{AgCl}$ ), bromargyrite (cubic $\mathrm{AgBr}$ ), and embolite $(\mathrm{Ag}[\mathrm{Cl}, \mathrm{Br}])$. These are generally spatially separated from but locally together with malachite and azurite. Chalcocite and pyrite were present below the water table, and an unidentified Ag-sulfide species was reported as well. As in other red-bed-type deposits, these ore minerals were found as replacements of carbonized plant fossils (Proctor, 1953). Although Ag grades were as high as those at Silver Reef in the sulfide-zone ores of Paoli, Okla. (Shockey and others, 1974), the Ag halides are not known in the weathered ore at Paoli, so a difference in climate is the likely explanation for the different weathering products.

\section{Copper-Sulfide Enrichment Zone}

In the Central African Copperbelt, distinguishing sulfideenrichment zones from primary hypogene chalcocite zones is not possible without extensive ore microscopic study, except where there is accompanying native copper or covellite of supergene origin. Those two minerals almost certainly signal some degree of supergene origin for the chalcocite. Kaolinite probably also is an indicator of supergene processes. Macroscopic bleaching of the silt- and clay-size gangue assemblages indicates some uncertain mineralogical change, which could include oxidation and leaching of organic matter and changes to the phyllosilicate assemblage. 


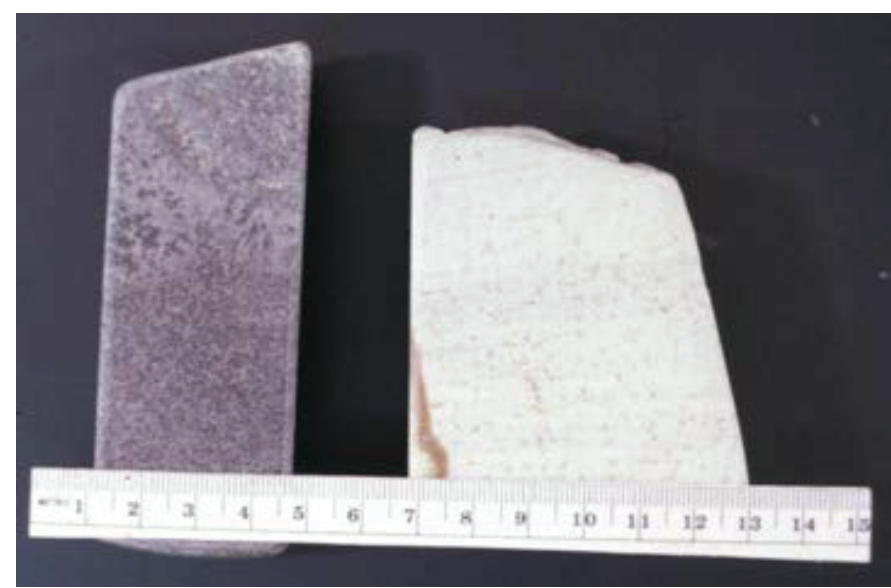

Figure 29. Patterns of weathering of different carbonate minerals in the Revett Formation-hosted sandstone copper system (fig. 6), northwestern Montana and northern Idaho. On the left, ferroan and manganiferous calcite of the pyrite-calcite, galena-calcite (pictured), chalcopyrite-calcite, and bornite-calcite zones (fig. 6), where weathered completely, leave intergranular chocolatebrown goethite in a dendritic-looking pattern. Where most abundant, leached cavities, lined with the dark goethite, occur at the sites of the former calcite. On the right, ankerite of the chalcocite-chlorite and chalcopyrite-ankerite (pictured) zones leaves discrete, tiny pseudomorphs of bright orange limonite at each ankerite site.

\section{Geochemical Characteristics}

Geochemical characteristics of SSC deposits are relatively straightforward. Description of geochemical characteristics can be categorized by the type of analyses performed: (1) majorelement rock geochemistry, (2) minor and trace-element rock geochemistry, (3) mineral compositions, (4) fluid-inclusion geochemistry, (5) organic geochemistry, (6) stable-isotope geochemistry, and (7) radiogenic-isotope geochemistry.

\section{Major-Element Rock Geochemistry}

Major-element compositions of mineralized rocks and country rocks have been determined for relatively few SSC deposits. In fact, only the rocks of the Udokan mineralizing system in Russia, the Kupferschiefer mineralizing system in Germany and Poland, the Konkola deposit of the Central African Copperbelt, and the Revett mineralizing system in the United States have such data. Results from this limited amount of work show substantial major-element changes associated with ore-forming events.

The limited amount of major-element geochemical data from the Revett Formation sandstone $\mathrm{Cu}$ mineralizing system is the best understood of the various data. The data are from 110 samples collected over the period from 1965 through about 1975 from the Burke and Revett Formations, Belt Supergroup, Montana and Idaho (Harrison and Grimes, 1970; Harrison and others, 1986a, 1986b). The dataset included five (meta)sandstone samples that were visibly mineralized with $\mathrm{Cu}$ sulfides or malachite, including three samples from the Spar Lake sandstone $\mathrm{Cu}$ deposit and one from the Snowstorm deposit. The samples were otherwise regionally distributed and widely scattered.

Changes in major-element chemistry that occur related to the Revett sandstone $\mathrm{Cu}$ ore system are best recognized when related to the $\mathrm{Cu}$ geochemistry. For that reason, it is important to first understand some aspects of $\mathrm{Cu}$ geochemistry in Belt Supergroup SSC mineralizing systems. Some such understanding came from earlier work at Blacktail Mountain, one of the many "greenbed" $\mathrm{Cu}$ occurrences of Harrison (1974).

Blacktail Mountain $\mathrm{Cu}$ occurs at the contact of the Empire Formation with the underlying Spokane Formation. Over an area of several thousand square kilometers in the central Belt Basin, the transitional contact from the Spokane Formation to the overlying Empire Formation has at least a trace of stratabound $\mathrm{Cu}$ mineralization. The Empire Formation consists of about $200 \mathrm{~m}$ of lenticular bedded, white, calcitecemented siltite within green argillite. The Spokane is a sequence as much as $1 \mathrm{~km}$ thick of purple to red argillite and siltite with much lesser coarse-grained quartzite, all in medium to very thin beds. The Blacktail Mountain occurrence is within a transition zone between the Spokane and Empire Formations where green and purple beds alternate over a thickness of about $30 \mathrm{~m}$, and each of the several green beds within the transition is $\mathrm{Cu}$ mineralized to varying degrees (thereby "greenbed" Cu occurrences). Green beds numbers 3 and 5 have grades at places over 1 percent $\mathrm{Cu}$ but only over thicknesses of 0.2 to $1.5 \mathrm{~m}$. From more than 3,500 rock geochemical analyses for $\mathrm{Cu}$ at the Blacktail Mountain occurrence, Connor and others (1981) identified four lognormal populations of $\mathrm{Cu}$ concentrations (fig. 30). These were, in order of decreasing $\mathrm{Cu}$ concentration, (1) a population of ore-mineralized rocks with a geometric mean of $1,500 \mathrm{ppm} \mathrm{Cu},(2)$ an uninterpreted population of mildly enriched rocks with a geometric mean of $100 \mathrm{ppm} \mathrm{Cu}$, (3) a background population of rocks with a geometric mean of $22 \mathrm{ppm} \mathrm{Cu}$ that they interpreted had seen no effects at all from the mineralizing processes, and (4) a depleted population that had lost most of its $\mathrm{Cu}$, with a geometric mean of $1.9 \mathrm{ppm} \mathrm{Cu}$. It was notable that over 70 percent of the total number of samples analyzed fell within the "depleted" population. Connor and others (1981) interpreted that the relatively large volume of depleted rocks had sourced the $\mathrm{Cu}$ now found in the small volumes of mineralized and enriched rocks. All four abundance populations were found in a $30-\mathrm{m}$ section in an area of $2 \mathrm{~km}^{2}$, so the entire ore process required to produce a greenbed deposit involved only a small total volume of rock. The thin, layer-form mineralized layers with interlayered depleted intervals several meters thick suggest the possibility of groundwater convection cells that are flat within the bedding with dominant lateral flow. A process where the composition of source rocks is changed by subtraction of one or more elements, and the composition of sink rocks is changed by the addition of those same elements, can be termed "bi-metasomatic." Where there are bi-metasomatic distributions of $\mathrm{Cu}$, it might be expected that there would also be bi-metasomatic distributions of major elements as well. 


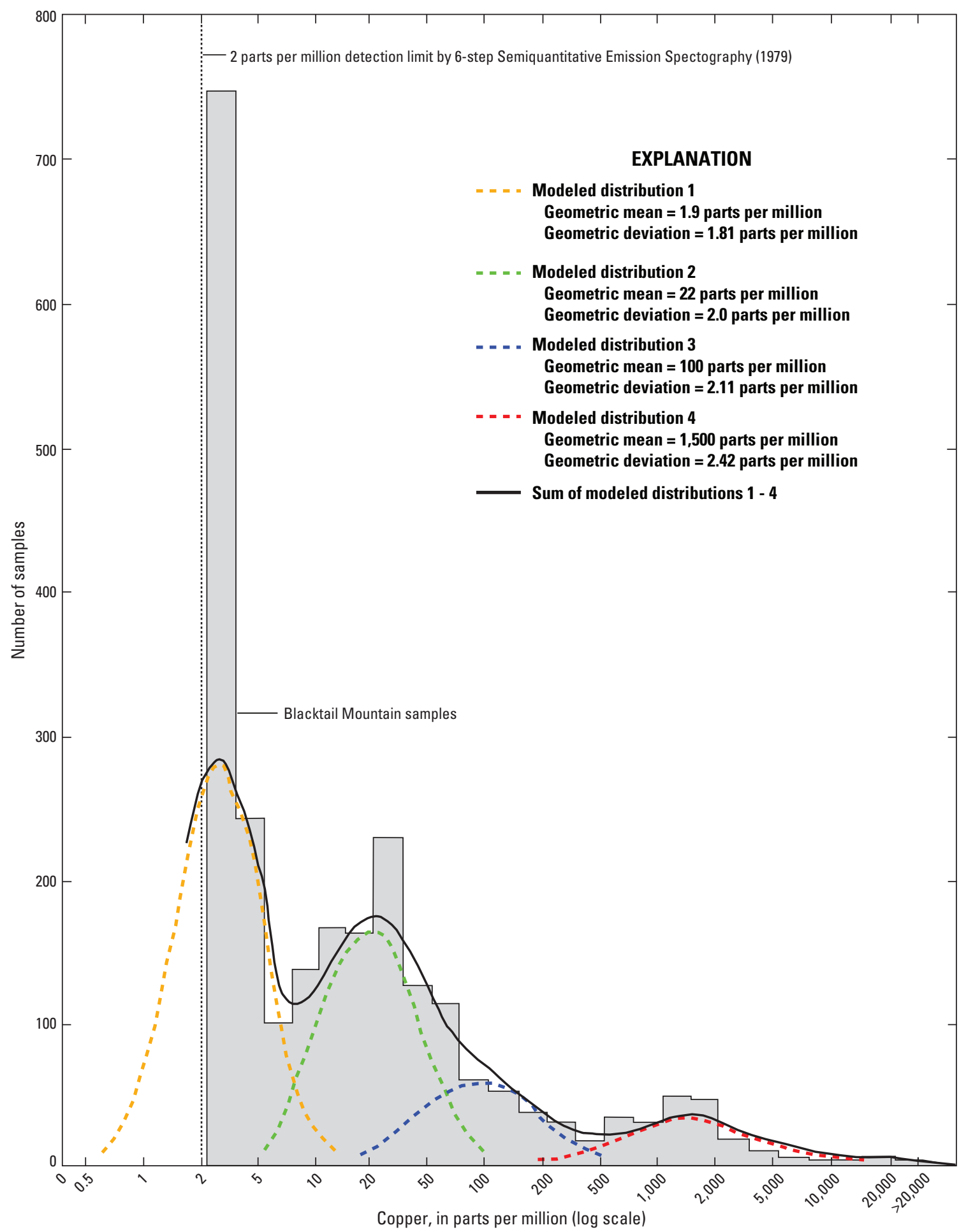

Modified from J.J. Connor and others, 1981

Figure 30. Populations of copper abundance in more than 3,500 whole-rock analyses from the Blacktail Mountain greenbed copper occurrence from Connor and others (1981). 
The dataset from Harrison samples (fig. 31) also appears to fit into the same four lognormal populations of $\mathrm{Cu}$ abundance that were expressed in the much larger dataset from Blacktail Mountain. From the additional descriptive information on the Harrison samples, ore mineralized and enriched rocks include no lavender (colored by pervasive hematite) samples at all, and background and depleted populations are dominated by lavender samples (former red beds) including quartzites (metasandstones), siltites, and argillites. The bulk of the hematite in lavender rocks occurs as dust rims on detrital grains. A bi-metasomatic process was suggested for the Revett Formation mineralizing system as well, and bi-metasomatic distributions of the major elements were suspected on the basis of the $\mathrm{Cu}$ distribution. However, drillhole data demonstrated that flat groundwater convection cells were not likely in the Revett where sandbodies tens of meters thick are mineralized and where certain drill holes remained in enriched rock for thicknesses of more than $500 \mathrm{~m}$ (Hayes and Einaudi, 1986, fig. 4).

The relation between alkali metals and $\mathrm{Cu}$ concentrations confirmed that the metasomatic effects could be seen in Harrison's major-element data (fig. 32). Detailed petrologic examination of more than 250 polished thin sections, mostly from the Spar Lake deposit in the Revett but including some from Harrison's collection, lent explanation to the behavior of the alkali metals. The covariance of $\mathrm{Cu}$ and $\mathrm{K}$ is because of an anomalous abundance of $\mathrm{K}$ feldspar overgrowth on detrital $\mathrm{K}$ feldspar grains within the $\mathrm{Cu}$-ore zones (figs. 6, 7, 20, 21, and 22). Albite, in contrast, is more abundant in certain carbonatefree lavender quartzites in areas far removed from the ore than within the ore zones (Hayes and Einaudi, 1986, fig. 15). In the ore itself, albite postdates the overgrowth K-feldspar and, in part, it postdates the $\mathrm{Cu}$ sulfides (fig. 24).

A variable was constructed from the Harrison data (Hayes, 1990) to be tested as a measure of the bimetasomatism (fig. 33). The constructed metasomatic variable consists of the logarithm of $\mathrm{K}$ abundance plus the quantity, $1+$ the $\log$ of $\mathrm{Ba}$ abundance, that sum divided by the logarithm of $\mathrm{Na}$ abundance. $\mathrm{Ba}$, a minor element, was given sufficient weight in the variable by adding one order of magnitude to its raw value. That measures the increased barite in the ore zones (figs. 6, 7, and 23). Forming a ratio of the two elements metasomatically enriched in the rocks where $\mathrm{Cu}$ is enriched, $\mathrm{K}$ and $\mathrm{Ba}$, divided by the element, $\mathrm{Na}$, that is enriched instead where $\mathrm{Cu}$ is depleted, has the effect of emphasizing contrasts in the major- and minor-element data. The graph of the results from the Ravalli Group rocks clearly shows the bi-metasomatism within the major- and minor-element geochemical data.

This rock metasomatism is the inverse of changes that would have occurred in the metals-transporting solutions, and it likely is a reflection mainly of the temperature of those solutions. In ordinary deep burial diagenesis, as temperatures increase (with deeper and deeper burial), $\mathrm{K}$ feldspars dissolve and albite precipitates (Boles, 1978; Boles and Franks, 1979; Boles, 1982; see fig. 53). The K concentrations in the groundwater increase, the Na concentrations decrease, and the rocks are sodically altered. $\mathrm{Ba}$ (from the altering K-feldspar) is probably released to the groundwater as well. White (1965, p. 358-360) observed the variation in molar $\mathrm{K} / \mathrm{Na}$ ratios in geothermal waters, and from this, he proposed a crude geothermometer where the measured ratio in produced geothermal water predicted the last temperature of equilibration of the water with feldspathic rock. That geothermometer was later improved upon by Fournier and Truesdell (1973) who added the effects known from $\mathrm{Ca} / \mathrm{Na}$ exchange with changing temperature.

In the Revett bi-metasomatic system, $\mathrm{Cu}$ deposition is accompanied by local $\mathrm{K}$ - and Ba-metasomatism, now known to have occurred over a zone of falling temperature (shown below, in the section on Fluid-Inclusion Geochemistry; Hayes, 1990), whereas $\mathrm{Cu}$ depletion is accompanied by Na-metasomatism, occurring locally in the zone of greater temperature and interpreted regionally to indicate zones that reached higher temperature.

Sutton and Maynard (2005, figs. 4, 5, 6, and 9, tables 1 and 2) observed intense K-metasomatism accompanying mineralization at Konkola North. Their data have been used to construct figure 34 , showing effects very similar to those observed in the Belt Supergroup. Of note, the sampled rocks from Konkola are notably different than those that provided Harrison's data from the Belt Supergroup. The Konkola rocks were sampled from nine core holes along a fence of drill holes stretching just $8.2 \mathrm{~km}$ with the cores representing a stratigraphic interval of only $162 \mathrm{~m}$, all those rocks at or near the sites of Cu-ore deposition. Harrison's samples sparsely covered an area $225 \mathrm{~km}$ by $170 \mathrm{~km}$ and a vertical stratigraphic interval of almost $4 \mathrm{~km}$. The difference shows clearly in the relation between $\mathrm{Na}$ and $\mathrm{Cu}$. The rocks sampled by Sutton and Maynard (2005) do not necessarily appear to include any from a zone of $\mathrm{Cu}$ mobilization (fig. 35) even though the analyses included many samples where $\mathrm{Cu}$ was below the detection limit of $2 \mathrm{ppm}$.

Datasets of major-element data from the Kupferschiefer system of mineralized rocks include Oszczepalski and others (2002) and Hammer and others (1990). However, the Hammer and others (1990) dataset reported only the ranges of values so it was not possible to crossplot elements sample by sample. The data from Oszczepalski and others (2002) do not seem to indicate $\mathrm{K}$ metasomatism in the $\mathrm{Cu}$-enriched rocks like that seen in the Belt Supergroup and at Konkola. However, when the $\mathrm{K} / \mathrm{Na}$ ratio is plotted in relation to $\mathrm{Cu}$ (fig. 36), the regression line is similar to the regression from the same plot from the Belt Supergroup (fig. 32), but the scatter among the data from the Kupferschiefer discourages much confidence in the result. Individual sample numbers from the Oszczepalski and others (2002) dataset are included on figure 36, which allows a little more understanding. Samples from the S2 sample subset (a Sieroszowice area borehole fence) plot across the high-K part of the figure, and samples from the PZ19 sample subset (a Polkowice mine underground lateral section) plot across the low-K part of the figure. Trends of those subsets parallel the fitted linear regression of the total dataset with ore-grade $\mathrm{Cu}$ samples on the right (additionally labeled $\mathrm{Cu}_{2} \mathrm{~S}$ ), samples transitional from $\mathrm{Cu}$-sulfide-rich to Rote Fäule in the middle 
Modes of modeled populations of copper abundance from Blacktail Mountain

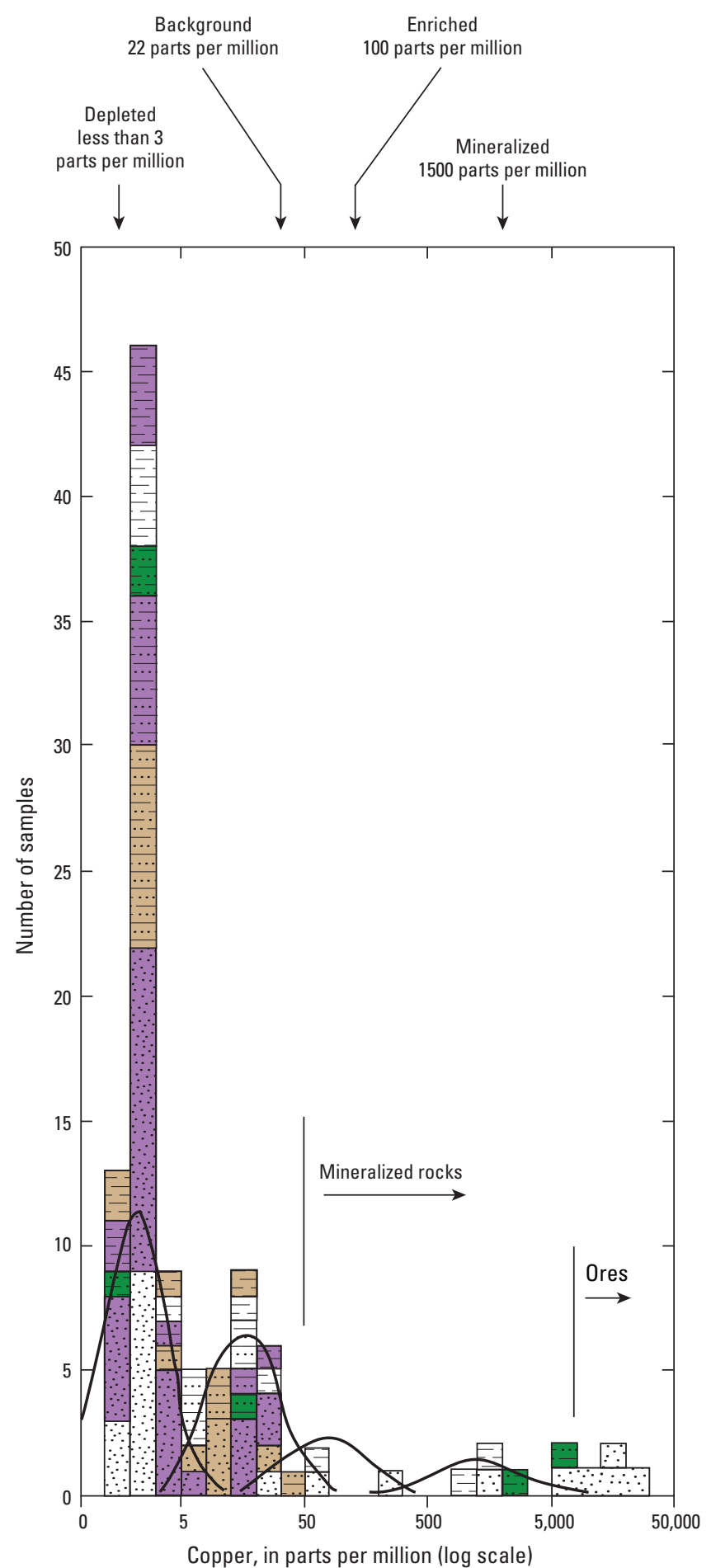

EXPLANATION

Rock colors and grain sizes

Green

$\square$ Lavender

$\square$ White or gray

$\square \quad$ Other colors including tan and brown

F Argillite

Siltite

Quartzite

Other symbology

Modeled distributions of Blacktail Mountain copper values from J.J. Conner and others, 1981

Figure 31. Populations of copper abundance in 110 whole-rock analyses from scattered samples of the Revett and Burke Formations that host the sandstone copper system in the Revett Formation, northwestern Montana and northern Idaho. Analyses provided by J.E. Harrison, U.S. Geological Survey, written commun., 1985. 


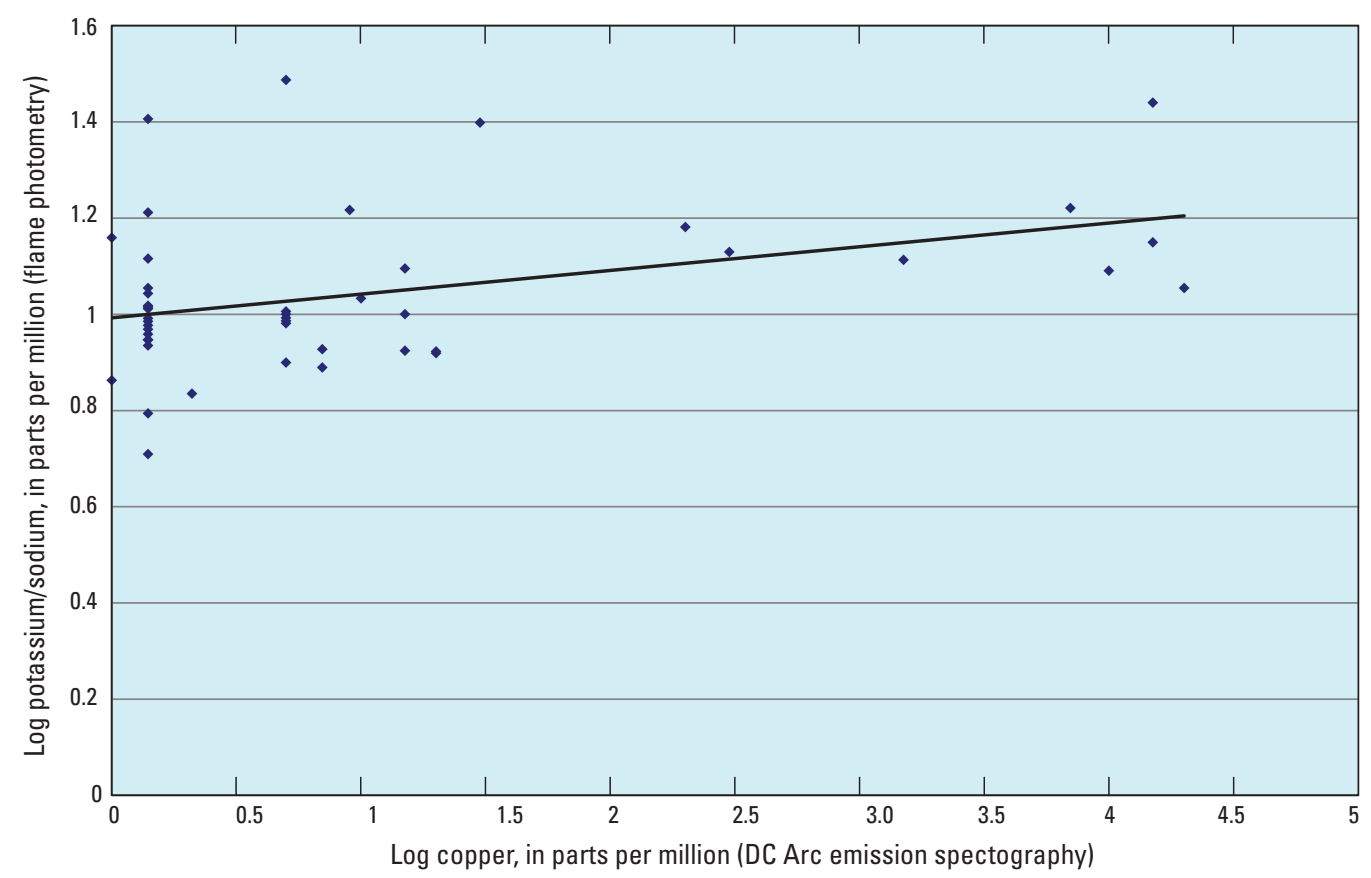

Figure 32. Relation between whole-rock copper and potassium/sodium in 45 samples of the Revett and Burke Formation quartzites, northwestern Montana and northern Idaho. Analyses provided by J.E. Harrison, U.S. Geological Survey, written commun., 1985. The plot is made from a subset of the 110 samples graphed in figure 31 .

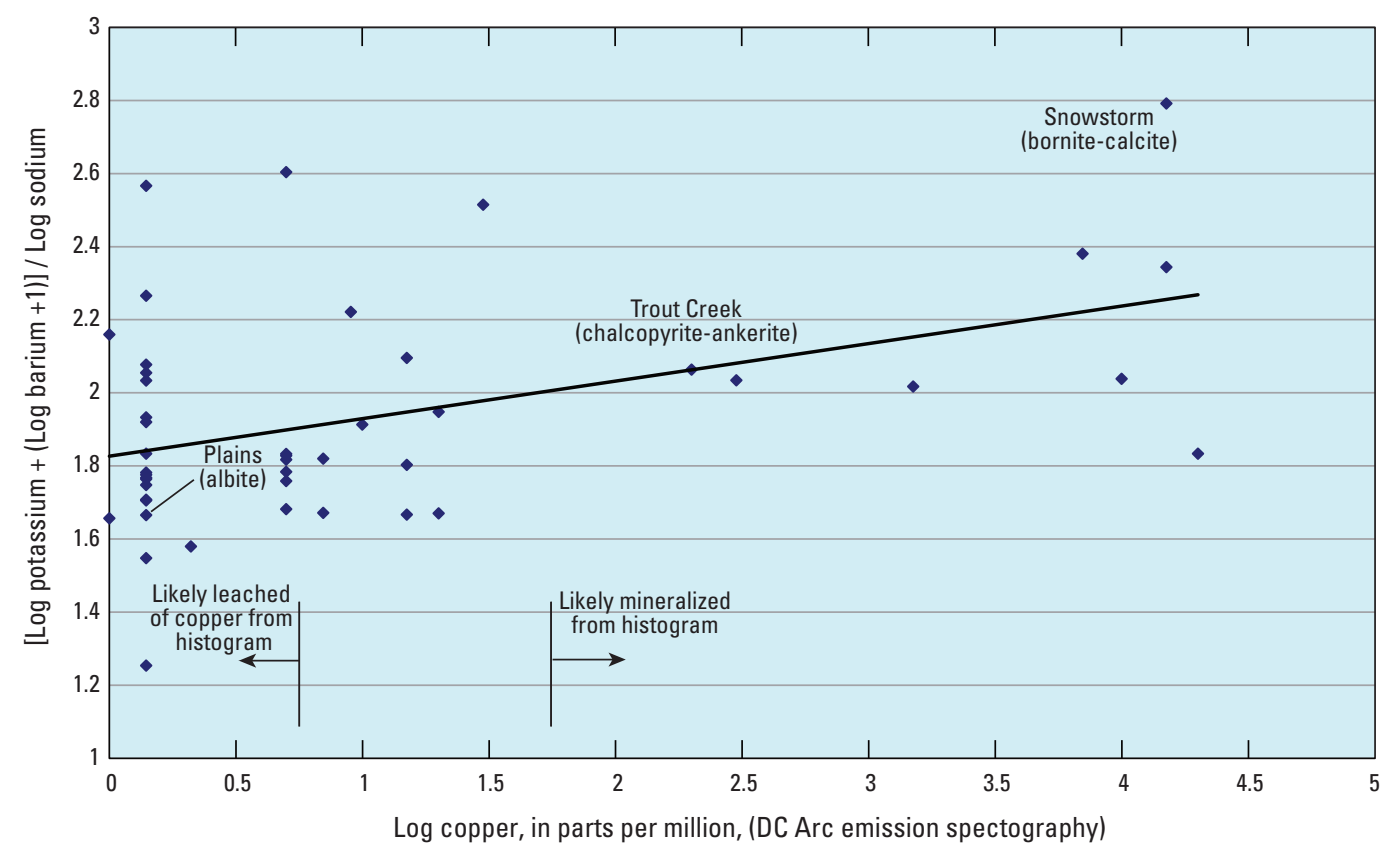

Figure 33. Relation between whole-rock copper and a derived "metasomatic" variable in 45 samples of the Revett and Burke Formation quartzites, northwestern Montana and northern Idaho. Analyses provided by J.E. Harrison, U.S. Geological Survey, written commun., 1985. A linear regression line has been fitted to the log-transformed elemental data. Three quartzite samples of identical grain size and primary sedimentary structure are identified with their mineral-zone names from figure 6 . The divisions of "likely leached of copper" and "copper-mineralized" are from figure 31. 
(additionally labeled trans), and Rote Fäule samples on the left (RF), and each subset yields results quite comparable with the Belt Supergroup data. Viewed as individual areas, the two datasets are confidently comparable with the Belt Supergroup data. The total-alkali metals vary with the different areas of sampling. Each area is then affected by the metasomatism in like manner starting from the different total-alkali values.

The sample values on figure 36 provide another increment of understanding. On that plot, the highest $\mathrm{K} / \mathrm{Na}$ values from the S2Pk57, 58, 59-61 data subset are from the transitional zone between ore-grade $\mathrm{Cu}$ samples and Rote Fäule samples, but the highest K/Na values from the Pz19 data subset are in the ore (sample Pz19Pk6 Cu $\mathrm{Cu}_{2} \mathrm{~S}$ ). The Polowice dataset appears to be fully comparable with the Belt Supergroup data, but the Sieroszowice S2Pk 57-61 dataset is slightly different. The data of Hammer and others (1990) from near Sangerhausen, FDR, is slightly different from all three; it appears to indicate K-metasomatism of the Rote Fäule rocks, rather than K-metasomatism in the $\mathrm{Cu}$ ore or in the transitional rocks. It appears that SSC deposit mineral zonations are comparable with chromatographic separations of elements in which small variations in solution concentrations, temperature, or host-rock conditions can shift the relative positions of a mineral or elemental enrichment zone in one system relative to another system, or relative to a different place in the same system. Using the example of pyrite-chalcopyrite-bornitechalcocite mineral zone boundaries, Ripley and others (1985) demonstrated that different mineral-zone arrangements could be the result of small differences in temperature or activity of any of several different components in solution including fugacity of oxygen and activity of $\mathrm{Cu}, \mathrm{Fe}$, and $\mathrm{S}$. Furthermore, various mineral-zone arrangements could also be the result of varying flow rates of metals-transporting solutions, themselves controlled by permeability and head. Mineral dissolution can then produce yet more variability by causing variation in porosity, thus permeability.

Major-element chemical work on Udokan includes some old data generated using FSX methods (Bakun and others, 1966) and some more recent data for which the analytical methods were not specified (Volodin and others, 1994). The data from Volodin and others, though it is sparse, representing average analyses of quartzite groups with variable cementation, was treated the same as with the other major-element datasets (fig. 37). There is a relatively weak suggestion of potassium metasomatism accompanying ore deposition broadly similar to other systems.

\section{Minor- and Trace-Element Geochemistry}

Many minor and trace elements are found in anomalous concentrations in zonal arrangements near and in SSC deposits. The element signatures vary considerably from district to district, and they vary as well among the different deposit subtypes.

The Central African Copperbelt stands apart in having high concentrations of $\mathrm{Co}$ in its ores, although some Co metasomatism occurred as well at Boleo, Mexico, and in the Kupferschiefer deposits. The Co enrichment is not uniform, though, even in central Africa. In Zambia, for the most part, only the ores of the Copperbelt Orebody Member

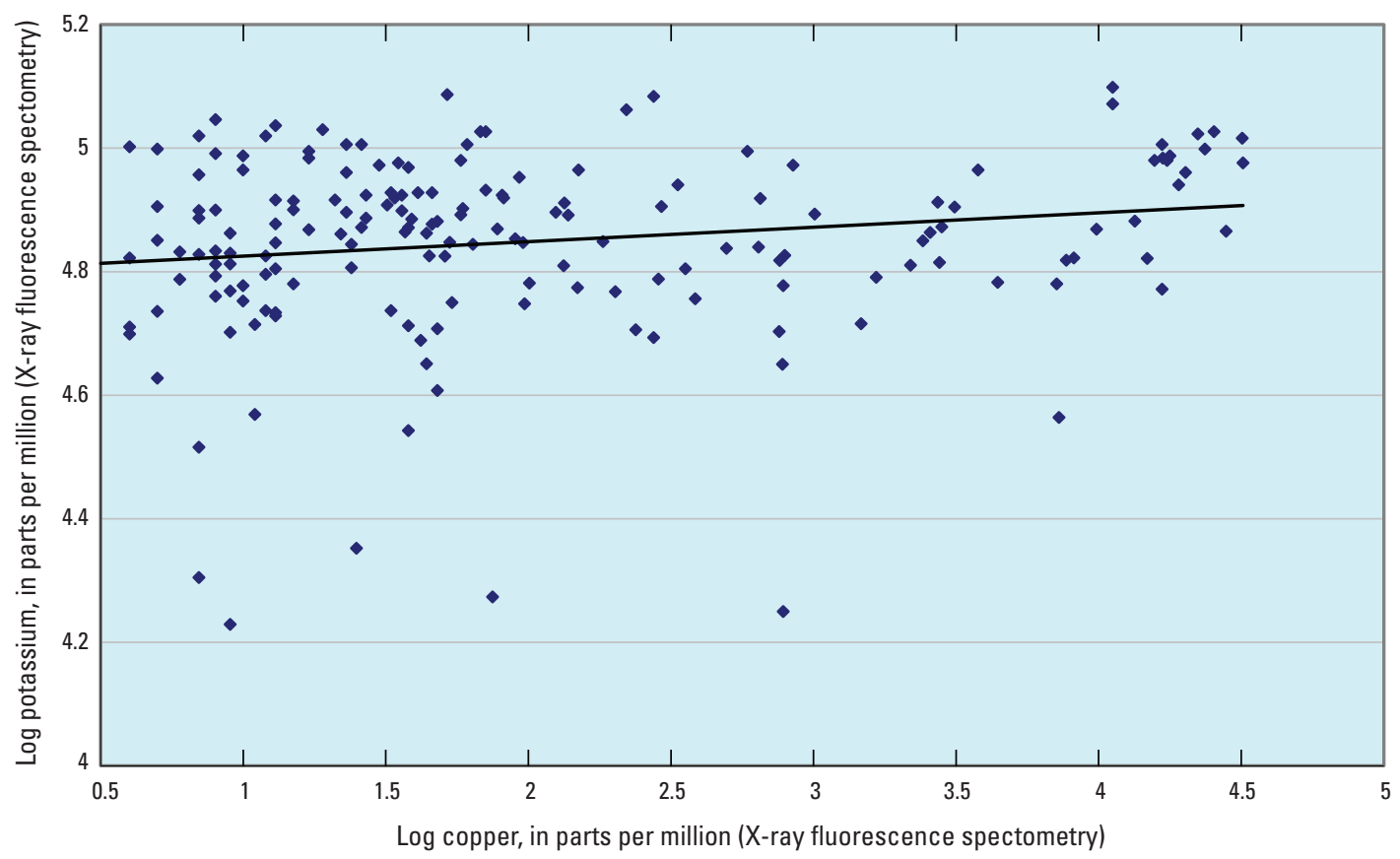

Figure 34. Relation between whole-rock copper and whole-rock potassium in 236 samples from in and near the Konkola, Zambia, reduced-facies sediment-hosted stratabound copper deposit. Data from Sutton and Maynard (2005). Compare with figure 32. A linear regression line has been fit to the log-transformed elemental data. 


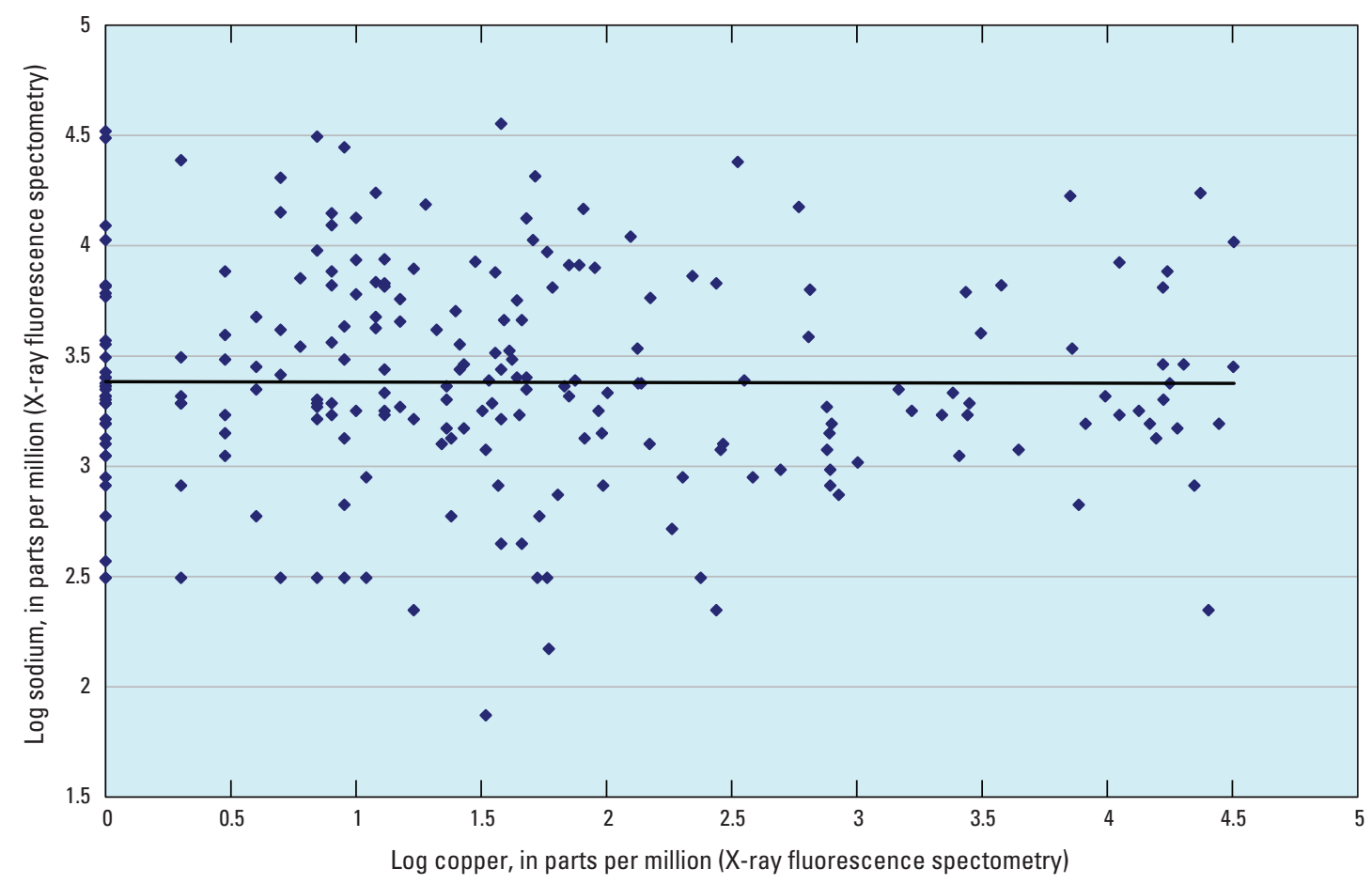

Figure 35. Relation between whole-rock copper and whole-rock sodium in 236 samples from in and near the Konkola, Zambia, reduced-facies sediment-hosted stratabound copper deposit. Data from Sutton and Maynard (2005). A linear regression line has been fit to the log-transformed elemental data. Compare with figures 32 and 33 .

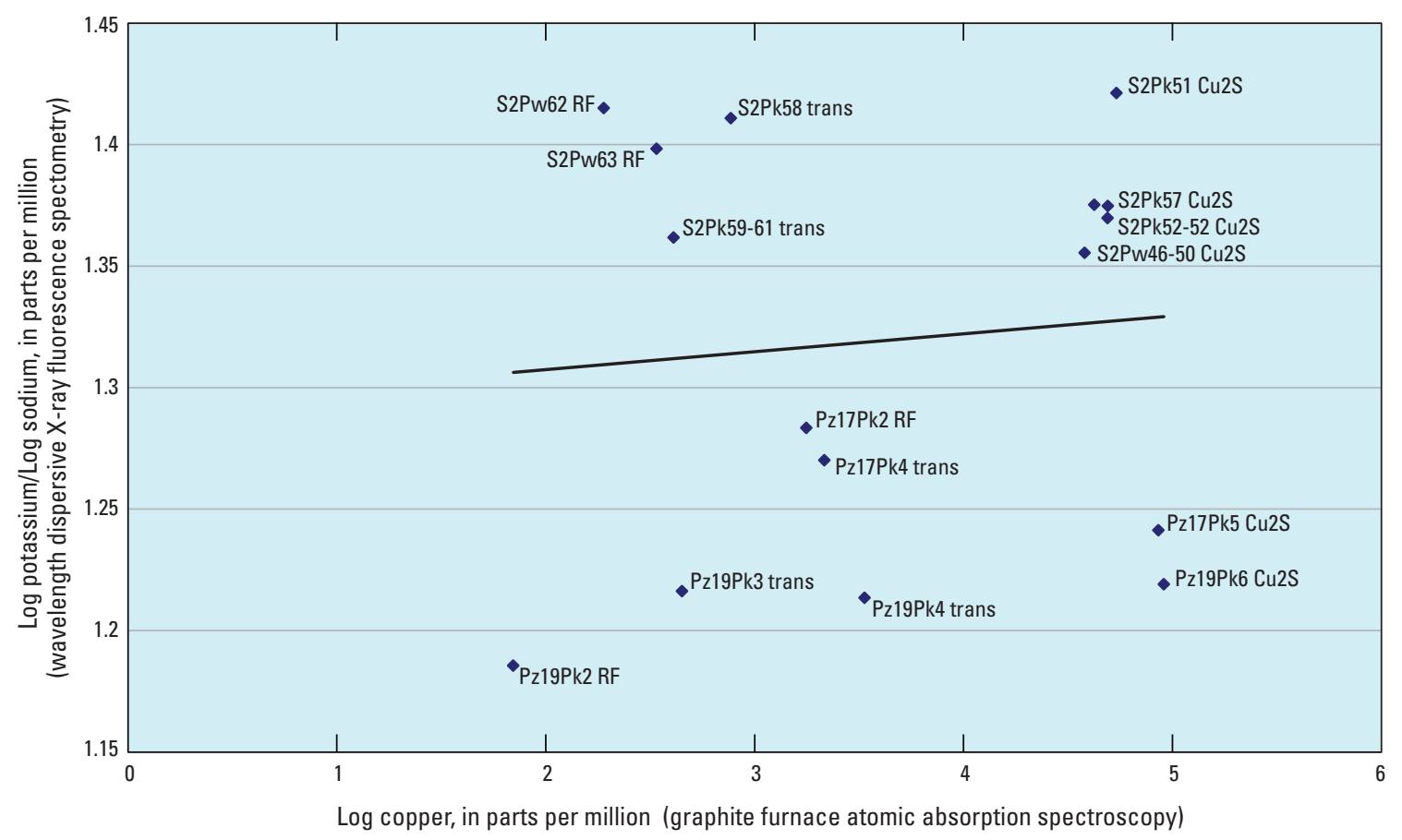

Figure 36. Relation between whole-rock copper and whole-rock potassium/sodium in 16 Kupferschiefer reducedfacies ore-system samples, Fore-Sudetic Monocline, Poland. Analyses from Oszczepalski and others (2002). A linear regression line has been fit to the log-transformed data (despite the great scatter among the points). Compare with figures 32 and 33 and see the text discussion. 
(formerly the Ore Shale) produce byproduct Co (fig. 38), at average grades of about 2.74 percent $\mathrm{Cu}$ and 0.19 percent Co (weighted average calculated from the database of Parks and others, written commun., 2011). Attempts at explanation of the Co distribution in Zambian Copperbelt ores (Annels and Simmonds, 1984) first recognized several different possible positions in mineral zonation for Co-enriched rock, and recognized that Co was found at high grades locally even in sandstone deposits, albeit in a position outboard of bornite and chalcocite toward pyritic rock. In the sandstone deposits in Zambia, carrollite commonly co-exists only with chalcopyrite and pyrite, thus not in rock economic to mine for $\mathrm{Cu}$. Annels and Simmonds (1984) eventually suggested that the source of Co most likely for Zambian ores was the mafic sills, now amphibolites, that lie upsection from the ores by at least $100 \mathrm{~m}$. Such mafic sills are unavailable as source rocks at other deposits in the world like the Kupferschiefer and Spar Lake where cobalt is anomalous and in ore-stage mineral sitings (fig. 18), so Annels and Simmonds conclusions are not sufficient explanation for the involvement of cobalt in SSCmineralizing systems. In Democratic Republic of Congo as in Zambia, only the reduced-facies-type deposits produce $\mathrm{Co}$, at average grades of about 3.39 percent $\mathrm{Cu}$ and 0.27 percent $\mathrm{Co}$ (weighted average calculated from the database of Parks and others, written commun., 2011). However, it is likely that the average grade of $\mathrm{Cu}$ and $\mathrm{Co}$ in the Democratic Republic of Congo reflects the effects of supergene enrichment, whereas the average grade for the Ore Shale belt deposits of Zambia does not. No other deposits known in the world possess such high Co grades. However, Co may be recoverable from the remaining ores at Boleo. The Co grade at Boleo is reported at 0.05 percent (Yeo and others, 2007). Co is recovered from the ores of Kupferschiefer system in Poland, but an average grade of Co has not been reported. The average Co grade in eight ore samples, averaging 5.67 percent $\mathrm{Cu}$, reported by Oszczepalski and others (2002) was 0.005 percent (50 ppm). Seven of those samples were from the Kupferschiefer bed, typically considerably higher in $\mathrm{Cu}$ grade than overlying Werra carbonate ore or underlying Weissliegendes sandstone ore.

Co may be anomalous and even economic in reducedfacies-type SSC deposits but not generally in sandstone $\mathrm{Cu}$ deposits nor in red-bed-type $\mathrm{Cu}$ deposits. In a study of minor and trace elements of the Spar Lake deposit (Hayes and Nuckolls, Asarco, Inc., written commun., 1983), among 205 samples collected from all parts of the mineral zonation, only a single sample had greater than $10 \mathrm{ppm}$ Co. The sample had $110 \mathrm{ppm} \mathrm{Co}$, and it came from a rock with traces of chalcopyrite, galena, and pyrite in the galena-calcite zone (fig. 6). This relative lack of anomalous Co at Spar Lake came despite the fact that a generation of Co-anomalous pyrite is known from the galena-calcite and inboard part of pyrite-calcite zones of the deposit (fig. 18). Microprobe analyses indicate that 17 Spar Lake Co-anomalous pyrites have average concentrations of about 160 ppm Co. The Co-anomalous pyrite is not known in concentrations of as much as $0.1 \mathrm{v} . \%$ in any of the Spar Lake rocks. None of the rocks at Udokan were reported to have more than 100 ppm $\mathrm{Co}$, and massive Udokan $\mathrm{Cu}$ ores were reported to have no more than 10 ppm Co (Bakun and others, 1966, p. 461).

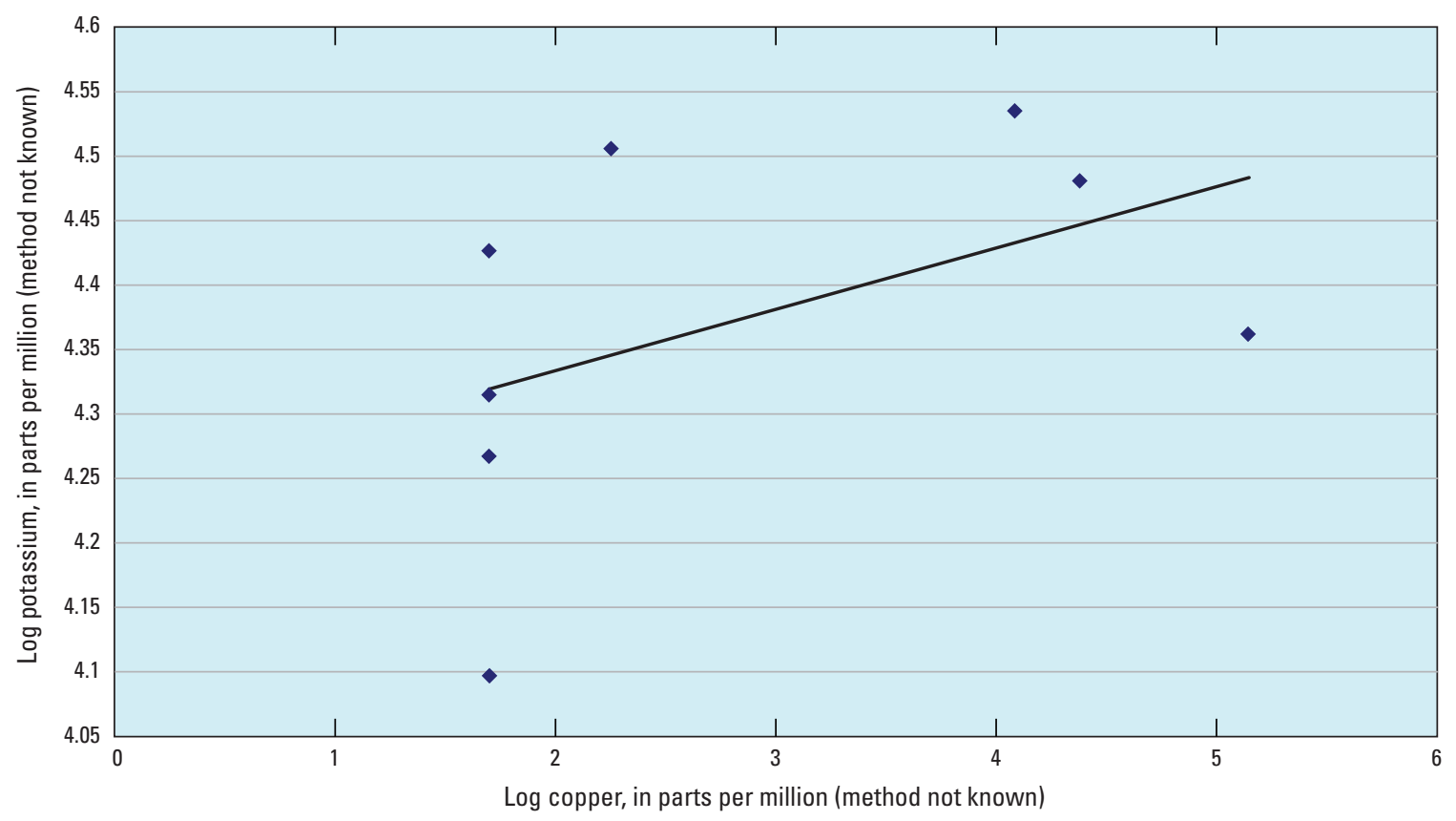

Figure 37. Relation between whole-rock copper and whole-rock potassium in eight samples from the Udokan sandstone copper system. Analyses from Bakun and others (1966) and Volodin and others (1994). A linear regression line has been fit to the log-transformed elemental data. Compare with figure 34. 


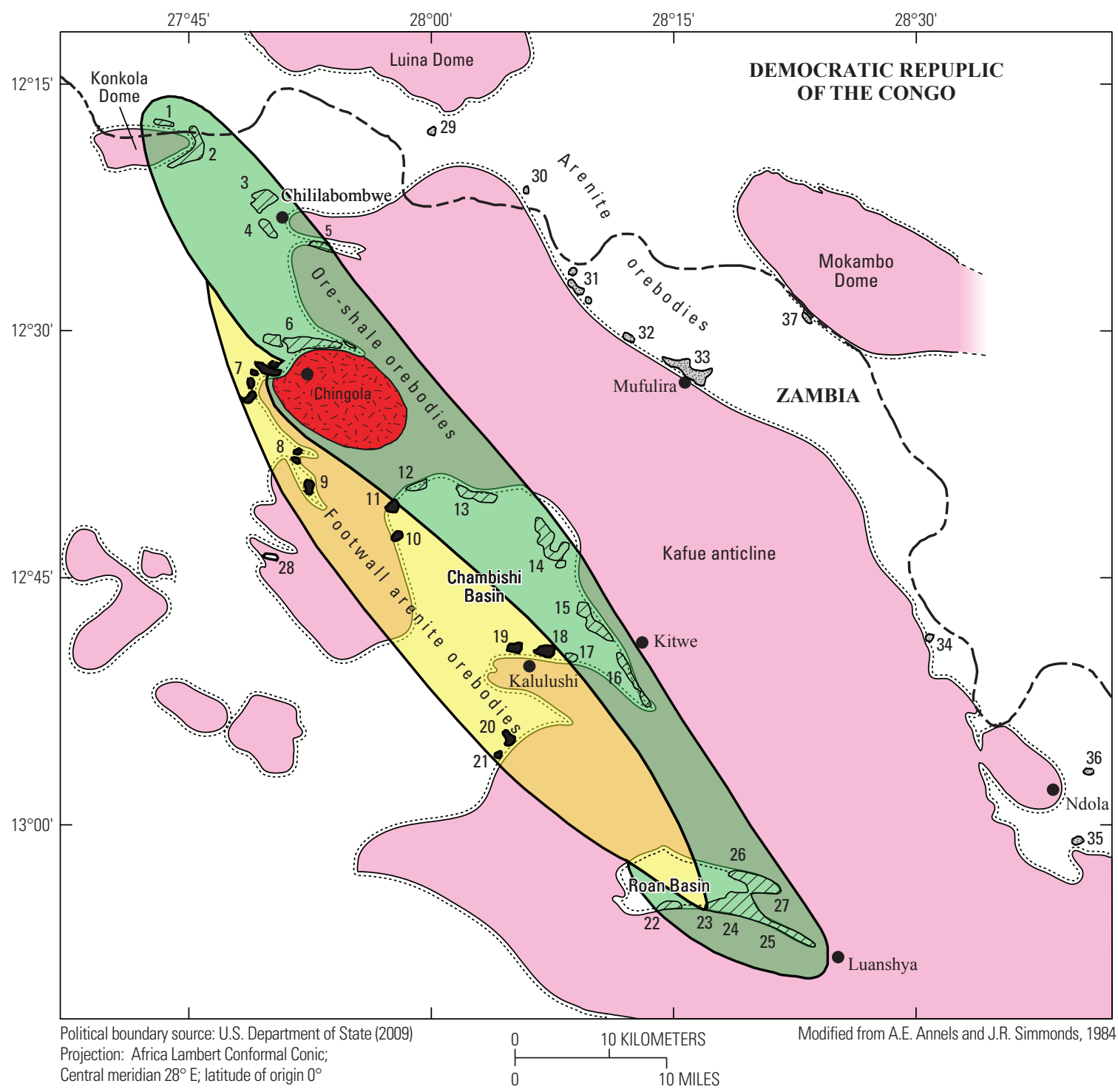

\section{EXPLANATION}

\section{Map units}

Roan Group in the area of footwall arenite orebodies, inferred

Roan Group in the area of ore shale orebodies, inferred

Roan Group in the area of footwall arenite orebodies

Roan Group in the area of ore shale orebodies

Neoproterozoic Nchanga red granite basement to the Roan

Mesoproterozoic basement rocks to the Roan Group

$\begin{array}{ll}\text { 1. Musoshi } & \text { 7. Chingola Orebodies } \\ \text { 2. Konkola } & \text { 8. Mimbula I and II } \\ \text { 3. Kirilabombwe North } & \text { 9. Fitula } \\ \text { 4. Kirilabombwe South } & \text { 10. Mwambashi B } \\ \text { 5. Fitwaola } & \text { 11. Pitanda South } \\ \text { 6. Nchanga } & \text { 12. Pitanda }\end{array}$

Stratigraphic position of orebodies

Lower roan Group arenite

Ore shale (Copperbelt Orebody Member)

Footwall arenite (Mindola Clastics Formation)

Basement schists derived from porphyritic igneous rocks of quartzite monzonite to granodiorite composition
Geologic boundaries

Basement-Lower Roan Group nonconformity (dotted toward Lower Roan Group)

Contact (dashed where uncertain)

Limit of area with orebodies in a particular host type and stratigraphic position

Limit of area with orebodies in a particular host type and stratigraphic position, inferred

Political boundary

\section{Deposits and Prospects}

$\begin{array}{ll}\text { 13. Chambishi } & \text { 19. Chimbuluma West } \\ \text { 14. Chambishi SE } & \text { 20. Kalulushi East } \\ \text { (Nkana North Limb) } & \text { 21. Chifupu } \\ \text { 15. Mindola } & \text { 22. Lufubu South } \\ \text { 16. Nkana (Rhokana) } & \text { 23. Muliashi South } \\ \text { 17. Nkana South Limb } & \text { 24. Roan Extension } \\ \text { 18. Chibuluma } & \end{array}$

31. Kasaria
32. Luansobe
33. Mufulira
34. Mwekera
35. Bwana Mkubwa
36. Itawa
37. Mokambo 26. Baluba 27. Baluba East 28. Samba

29. Kinsenda 30. Lubembe

Figure 38. Stratigraphic distribution of ores in the Zambian Copperbelt from Annels and Simmonds (1984). Only the ores hosted by the Ore Shale (now called the Copperbelt Orebody Member) host economically recoverable concentrations of cobalt. 
The other metal that is commonly economic in SSC deposits is Ag. The Ag occurs typically in native silver and in solid solution in chalcocite, digenite, and bornite (and perhaps others like djurleite and X-bornite). Scant traces of stromeyerite occur in a few deposits. For 1769.7 Mt of the Kupferschiefer ores on the Fore-Sudetic Monocline in Poland, the average $\mathrm{Ag}$ content is $57.5 \mathrm{~g} / \mathrm{t}(57.5 \mathrm{ppm}) \mathrm{Ag}$ at an average $\mathrm{Cu}$ grade of 2.02 percent (KGHM Polska Midź, S.A., 2009). Ores of the Spar Lake deposit average $46 \mathrm{ppm}$ Ag at an average $\mathrm{Cu}$ grade of 0.63 percent. The most Ag-rich of all is Paoli, Okla., where the average of 46 unweathered trench samples was $156 \mathrm{ppm} \mathrm{Ag}$ at an average $\mathrm{Cu}$ grade of 0.68 percent (Thomas and others, 1991). These are among the most Ag-rich deposits, but many deposits have some recoverable Ag. White Pine has $40 \mathrm{ppm}$ at an average $\mathrm{Cu}$ grade of 1.2 percent $\mathrm{Cu}$ (Kirkham and others, 1994). Udokan has $12.6 \mathrm{ppm} \mathrm{Ag}$ at an average $\mathrm{Cu}$ grade of 1.45 percent (Volodin and others, 1994). The belt of recently discovered deposits in Botswana typically have $15-20 \mathrm{ppm} \mathrm{Ag}$ at 1.2 to 1.5 percent $\mathrm{Cu}$ (Discovery Metals, Ltd., 2011), and Juramento, Argentina, has 21.8 ppm $\mathrm{Ag}$ at a $\mathrm{Cu}$ grade of 0.8 percent (Durieux and Brown, 2007). All three subtypes of SSC deposits may have anomalous Ag concentrations. The Nacimiento, N. Mex., red-bed-type deposit had $2.4 \mathrm{ppm} \mathrm{Ag}$ at 0.67 percent $\mathrm{Cu}$, and Stauber, N. Mex., had $5.5 \mathrm{ppm} \mathrm{Ag}$ at $2.57 \% \mathrm{Cu}$. Red-bed-type deposits are not generally low in Ag-Corocoro, Bolivia, had $106 \mathrm{ppm}$ $\mathrm{Ag}$ at $7.1 \% \mathrm{Cu}$ from ore that was probably hand-sorted.

However, Co-rich SSC deposits do not typically have economic concentrations of Ag, and Ag-rich SSC deposits do not typically have economic concentrations of Co. The exception to this is the Kupferschiefer, which has recoverable concentrations of both. Published data with analyses for $\mathrm{Co}$ and $\mathrm{Ag}$ are rare from Co-producing districts. Only the work of Darnley (1960) from the Zambian Copperbelt, Wilson (1955) from Boleo, Mexico, and Jung and Knitzschke (1976) for the Kupferschiefer in Germany are known. Darnley analyzed rocks from Mufulira, Mokombo, and Chibuluma mines in Zambia. All three of these are sandstone $\mathrm{Cu}$ orebodies in which most of the ore occurs in the "sericitic quartzite" class that Darnley established, and the results were only published graphically, not with individual analyses for single samples. Of these, only Chibuluma produced $\mathrm{Co}$, at metal grades of 3.71 percent $\mathrm{Cu}$ and 0.21 percent Co (Selley and others, 2005). Among Darnley's 30 analyzed sericitic quartzite samples from Zambia, 27 had 5,000 ppm Cu or greater. Among the same 30 samples, the Co concentrations averaged $331 \mathrm{ppm}$ including 2 samples that had 5,000 ppm Co or greater. Among the same 30 samples, Ag concentrations ranged from less than 1 to a high of 15 ppm (no mean Ag concentration was given). Wilson (1955) stated that the average $\mathrm{Cu}$ grade of all ore mined at Boleo from 1886 to 1947 was 4.81 percent. For 126 high-grade ore samples Wilson collected throughout the district, the average Co concentration was 1,200 ppm, considerably greater than the $500 \mathrm{ppm}$ in the currently remaining ore, reported by Yeo and others (2007), above. For four high-grade ore samples, Wilson (1955) measured an average Ag concentration of just 9 ppm. Jung and Knitzschke (1976) give the grades of Kupferschiefer shale-hosted ores in the German Democratic Republic (formerly East Germany, dominated by the Mansfeld and Sangerhausen deposits) at 1.15 percent $\mathrm{Cu}$, $68.5 \mathrm{ppm} \mathrm{Co}$, and $72.7 \mathrm{ppm} \mathrm{Ag}(2.1 \mathrm{oz} / \mathrm{t})$. Completing the comparison with some more Ag-rich ores, a set of 12 samples with greater than 0.4 wt. \% Cu from the Revett Formation sandstone $\mathrm{Cu}$ system in Montana and Idaho had mean $\mathrm{Cu}$ of 1.13 percent, $4.5 \mathrm{ppm} \mathrm{Co}$, and $70.3 \mathrm{ppm} \mathrm{Ag} \mathrm{(2.1} \mathrm{oz/t).} \mathrm{Note} \mathrm{the}$ great similarity between Revett and Kupferschiefer $\mathrm{Cu}$ and $\mathrm{Ag}$ grades, whereas the Kupferschiefer shale Co grade is at least an order of magnitude greater than the Co in the Revett sandstonetype ores.

Recoverable Re occurs in the Dzhezkagan deposits, where it reaches concentrations in ore of about $100 \mathrm{ppm}$ and occurs in the mineral dzhezkazganite (isometric $\mathrm{ReMoCu}_{2} \mathrm{PbS}_{6}$ ?) (Gustafson and Williams, 1981). Re is also economically recoverable in the Kupferschiefer, where it averages $21 \mathrm{ppm}$ at Mansfeld and Sangerhausen (Jung and Knitzschke, 1976).

Many deposits have peripheral zones toward their pyritic sides with anomalous $\mathrm{Pb}$ as galena and $\mathrm{Zn}$ as sphalerite. Locally, these can reach ore grades, and at Boléo, $\mathrm{Cu}$ ore has $\mathrm{Zn}$ grades that are considered economic for recovery as a byproduct. The $\mathrm{Zn}$ grade at Boléo is reported at 0.62 percent in 277.1 million tonnes of remaining ore containing 0.70 percent $\mathrm{Cu}$ (Yeo and others, 2007, p. 3). Jung and Knitzschke (1976) reported an average of 0.57 percent $\mathrm{Pb}$ and 1.10 percent $\mathrm{Zn}$ in Kupferschiefer bed-hosted $\mathrm{Cu}$ ore from Mansfeld and Sangerhausen that had 1.15 percent $\mathrm{Cu}$. Twenty-one samples from the peripheral Galena-Calcite zone quartzites of the Spar Lake sandstone $\mathrm{Cu}$ deposit averaged 2,176 ppm $\mathrm{Pb}$. The same 21 samples averaged just $9.1 \mathrm{~g} / \mathrm{t} \mathrm{Ag}$, whereas the $\mathrm{Cu}$ orebody at 6,300 ppm Cu averages $46 \mathrm{~g} / \mathrm{t} \mathrm{Ag}$, showing the zonal segregation of $\mathrm{Pb}$ from $\mathrm{Cu}-\mathrm{Ag}$.

$\mathrm{Au}, \mathrm{Pt}$, and $\mathrm{Pd}$ are recovered from the Kupferschiefer SSC mines in Poland. These precious metals occur in the footwall of the $\mathrm{Cu}$ ore in a zone that parallels the mineral zonation of the deposit in a gentle cross through the bedding (Piestrzynski and others, 2002). Total tonnages and average grades of Kupferschiefer-associated Au-platinoid ores have not been released, but oxidized (Rote Fäule) and transitional near$\mathrm{Cu}$-ore samples reported by Oszczepalski and others (2002) averaged $4.74 \mathrm{~g} / \mathrm{t}(\mathrm{ppm}) \mathrm{Au}, 0.45 \mathrm{~g} / \mathrm{t} \mathrm{Pt}$, and $0.29 \mathrm{~g} / \mathrm{t}$ Pd. Given the enormous size of the Lubin-Sieroszowice-PolkowiceRudna(-Glogow Giboki-Przemyslowy-Bytom OdrzanskiRetkow-Gaworzyse-Radnawice Zachody) deposit, there are certainly tens of millions of tonnes of this type of precious metals ore.

The Lubin-Sieroszowice-Polkowice-Rudna mines in Poland also produce $\mathrm{Pb}, \mathrm{Co}, \mathrm{Mg}$, nickel (Ni), selenium (Se), and S (Pieczonka and others, 2001). Pb and Co grades were discussed above. Eight samples of Kupferschiefer ore that averaged 5.7 percent $\mathrm{Cu}$ also averaged $125 \mathrm{ppm} \mathrm{Ni}$ (Oszczepalski and others, 2002). Jung and Knitzschke (1976) reported an average of $91 \mathrm{ppm} \mathrm{Ni}$ for Kupferschiefer bed $\mathrm{Cu}$ ore that averaged 1.15 percent $\mathrm{Cu}$. They also reported an average of $23.7 \mathrm{ppm}$ Se for the same Mansfeld and Sangerhausen 
Kupferschiefer ores. Clausthalite (isometric $\mathrm{PbSe}$ ) and tiemannite (isometric $\mathrm{HgSe}$ ) were reported by Piestrzynski and others (2002) from Rote Fäule-altered rocks, but mineralogic siting of Se in non-hematitic rocks of the Kupferschiefer system has not been reported.

Among the trace elements associated with reducedfacies SSC deposits, the Kupferschiefer bed ores of MansfeldSangerhausen also contain an average of $281 \mathrm{ppm} \mathrm{V,}$ 1,812 ppm As, 158 ppm molybdenum (Mo), 19 ppm cadmium (Cd), 9 ppm thallium (Tl), 8 ppm germanium (Ge), 3 ppm tellurium (Te), $15 \mathrm{ppm} \mathrm{Sb}, 3 \mathrm{ppm} \mathrm{Hg}$, and 2 ppm bismuth (Bi) (Jung and Knitzschke, 1976). The V, Se, and Mo may not be enriched because of the ore system but could be, instead, a syngenetic lithogeochemical enrichment in the euxinic black shale. These elements are probably sited with the carbonaceous matter in the shale (Wedepohl, 1964). The As may or may not be ore-associated and could, instead, also be a product of the euxinic depositional environment. However, its concentration is strongly correlated with the concentration of $\mathrm{Cu}$ (Jung and Knitzschke, 1976), and As is anomalous in parts of other SSC systems (see below), so most likely the As is part of the ore system and inherently elevated in the black-shale environment. Each of the other elements may be ore-related. The $\mathrm{Hg}$ almost certainly is because Piestrzynski and others (2002) identified $\mathrm{Hg}$-bearing electrum and tiemannite in the Au mineralized rock at Polkowice, and Piestrzynski and Pieczonka (1997) measured 0.20 to 0.69 wt. \% Hg in Polkowice chalcocite. Finally, Hg is known to be anomalous in other SSC ore systems (see below).

In the Colorado Plateau region, United States, redbed-subtype stratabound $\mathrm{Cu}$ deposits have locally economic concentrations of associated $\mathrm{U}$ and $\mathrm{V}$. At other deposits with similar geometry and even some in the same stratigraphic host sandstones, there are $\mathrm{U}-\mathrm{V}$ deposits lacking $\mathrm{Cu}$ or $\mathrm{U}$ deposits lacking both $\mathrm{Cu}$ and $\mathrm{V}$. The Happy Jack mine in the Red Canyon district has produced about 600,000 short tons of 0.74 percent $\mathrm{Cu}, 0.25$ percent $\mathrm{U}_{3} \mathrm{O}_{8}$, and 0.047 percent $\mathrm{V}_{2} \mathrm{O}_{5}$. The Mi Vida mine, also in the Chinle Formation and just $103 \mathrm{~km}$ away from Happy Jack, produced ore with only 0.007 percent $\mathrm{Cu}(70 \mathrm{ppm}), 0.38$ percent $\mathrm{U}_{3} \mathrm{O}_{8}$, and 0.91 percent $\mathrm{V}_{2} \mathrm{O}_{5}$ (analysis of a single mill shipment from Al Miesch [U.S. Geological Survey, retired, written commun., 1980]). Hayes (1982) concluded that all these tabular sandstonehosted deposits were formed by subsurface interaquifer mixing of two distinct types of groundwater, one saline and the other much less saline, and that the chemical composition of each of the two types of groundwater varied in geologic time depending on climate and rocks through which the groundwater traveled. The deposition from two groundwater types, one briny and the other less saline, was confirmed in the Henry Mountains U-V deposits by Northrop and others (1990a, 1990b) and Goldhaber and others (1990). Hot, arid climates of the Permian and pre-Permian yielded oxidizing briny groundwater that, later in the Mesozoic, at places, transported $\mathrm{Cu}$ up from below. This was the typical mineralizing groundwater for SSC deposits. However, in the subtropical but more humid Late Jurassic through Early Cretaceous, most of the groundwater moving upward was not $\mathrm{Cu}$-bearing and yielded $\mathrm{U}-\mathrm{V}$ deposits that almost completely lack $\mathrm{Cu}$. In the time from Late Triassic through Early Cretaceous, relatively fresh shallow groundwater was not strongly oxidizing because of swampy organic-charged recharge areas and the shallow recharge transported the $\mathrm{U}$ and $\mathrm{V}$ to mix in the subsurface with $\mathrm{Cu}$-bearing saline groundwater at some places but with $\mathrm{Cu}-$ poor saline groundwater at others. There appear to be red-bedtype and possibly sandstone-type $\mathrm{Cu}$ deposits in the Neuquén and Salta Basins, Argentina, that also have all three elements, $\mathrm{Cu}, \mathrm{U}$, and $\mathrm{V}$, in deposits, all in Cretaceous sandstone host rocks, but with a variety of elemental ratios (Angelelli, 1956; Brodtkorb and Brodtkorb, 1984; Ferreyra and Lardone, 1990).

Trace and minor elements associated with sandstone $\mathrm{Cu}$ subtype deposits were defined at Spar Lake by Hayes and Nuckolls (1983). Using highly selective sampling of rock features in 205 samples from core holes from opposite sides of the mineral zonation, they defined a full suite of mobile elements concentrated across the zonation. The full suite included only $\mathrm{Cu}, \mathrm{Ag}, \mathrm{Pb}, \mathrm{Ba}, \mathrm{Mn}$, and As. It probably also included $\mathrm{Sb}$, but the XRF analyses had a detection limit of $20 \mathrm{ppm}$ that produced no $\mathrm{Sb}$ detections even though the detected $\mathrm{As}$ anomalies were later traced to tetrahedrite (not tennantite nor enargite). The tetrahedrite occurs in a relatively narrow zone from the outboard bornite-calcite through the inboard galena-calcite zone (figs. 6 and 7). $\mathrm{Cu}$ and $\mathrm{Ag}$ are found in the ore-bearing chalcocite-chlorite and bornite-calcite zones predominantly in chalcocite, digenite, and bornite but also in traces of native silver and stromeyerite. $\mathrm{Pb}$ is sited in galena of the galena-calcite zone as well as within traces of tetrahedrite. $\mathrm{Ba}$ is in barite, Ba-rich $\mathrm{K}$-feldspar overgrowths on detrital $\mathrm{K}$-feldspar grains, and in trace cymrite (labeled Ba mica on fig. 6), found from the inboard galena-calcite zone through the chalcocite-chlorite zone. $\mathrm{Mn}$ is found in carbonates of the Spar Lake zonation. There are far more abundant carbonates within the pyrite-calcite, galena-calcite, chalcopyrite-calcite, and bornite-calcite zones of the deposit than within the chalcocitechlorite, chalcopyrite-ankerite, and albite zones. Additionally, the calcite of the bornite-calcite is notably Mn-rich in the near vicinity of that mineral's disappearance boundary against the chalcocite-chlorite zone (see below). Notably, though sphalerite was identified as part of the mineral zonation in the galenacalcite zone, $\mathrm{Zn}$ was not found in greater concentrations in that mineral zone, indicating probably that the element had taken a new mineralogical siting rather than being part of the transported elemental suite. $\mathrm{Zn}$ and several other elements varied only with lithology, being more abundant in argillaceous host rocks than in metasandstones. Exactly the same was true of cadmium, which was probably also sited in the sphalerite. The same was true of Fe despite the high abundance of ore-stage ferroan and manganiferous calcite found in the bornite-calcite, chalcopyrite-calcite, galena-calcite, and pyrite-calcite zones. Those elements were apparently sited in chlorite and ankerite in the chalcocite-chlorite and chalcopyrite-ankerite zones of the deposit. The study also identified a fully immobile suite of elements including zirconium, yttrium, and titanium, which all occur in heavy minerals within the (meta)sedimentary rocks. 
Almost certainly also anomalous within Revett sandstone $\mathrm{Cu}$ deposits is $\mathrm{Hg}$ (fig. 39). Though the absolute concentrations are small (everywhere at $1 \mathrm{ppm}$ or less), there is a strong positive correlation between $\mathrm{Cu}$ and $\mathrm{Hg}$ in the data collected from Harrison's samples.

B metasomatism expressed in anomalous abundances of tourmaline was discussed earlier as demonstrated in the work of Darnley (1960) and Selley and others (2005). It is clear that B metasomatism accompanying ore processes in Zambia is intense. That contrasts strongly with results from Burnie and others (1972) at White Pine, the only other place where B contents were documented. They found that the Nonesuch Formation siltstones and shales at White Pine were generally low in B, averaging 47, 66 , and $81 \mathrm{ppm}$ in three different mineralized shale or silt beds, but they further analyzed the clay and the chlorite contents of their samples. From that they concluded that the clay component of the Nonesuch Formation is more B rich than typical marine sediments but that the overall low B values reflected a low clay content. They showed that the B and the chlorite content of the rocks increase upsectionward within the Nonesuch, which is generally the inverse of the variation in $\mathrm{Cu}$ content.

\section{Mineral Compositions}

In reduced-facies and sandstone $\mathrm{Cu}$ deposits, $\mathrm{Ag}$ is sited predominantly in chalcocite, digenite, and bornite. At the Spar Lake sandstone $\mathrm{Cu}$ deposits, each of those three sulfides averages greater than $0.1 \mathrm{wt}$ \% Ag. Twenty chalcocites analyzed by electron microprobe had a range from 0.002 wt. \% to 1.62 wt. $\% \mathrm{Ag}$, and a mean of 0.30 wt. \% Ag. Twenty-five digenite grains contained from non-detectable concentrations to 0.625 wt. $\%$ Ag, with a mean of 0.14 wt. \% Ag. Eight analyzed bornite grains contained from non-detectable concentrations to 0.61 wt. \% Ag and averaged 0.22 wt. \% Ag (Hayes, T.S., unpub. data, 1988). The Ag concentrations in the $\mathrm{Cu}$ sulfides of the Kupferschiefer are similar. Sawlowicz (1990) found a mean Ag concentration of 0.25 wt. \% in 58 analyzed grains. From the corresponding Fe concentrations, these were all chalcocitegroup minerals with $\mathrm{Cu} / \mathrm{S}$ molar ratios from 1.78 (anilite) to 2.0 (chalcocite). Piestrzynski and others (2009) reported a measured range of $\mathrm{Ag}$ concentrations in $\mathrm{Cu}$ sulfides from 0.15 to 7.11 wt. $\%$, and they tabulated eight bornite analyses with mean Ag concentrations of 0.175 wt. \%. Spar Lake and the deposits of the Kupferschiefer also contain lesser abundances of native silver and traces of stromeyerite (fig. 6).

The most notable other co-product metal of SSC deposits is Co. Most of the Co in deposits in Zambia and the Democratic Republic of Congo occurs in carrollite [isometric $\left.\mathrm{Cu}(\mathrm{Co}, \mathrm{Ni})_{2} \mathrm{~S}_{4}\right]$, which forms a solid solution with linnaeite $\left[\mathrm{Co}_{3} \mathrm{~S}_{4}\right]$. Linnaeite has also been reported at a number of the deposits in Zambia (Notebaart and Vink, 1972). The carrollite in these deposits occurs in relatively coarse grains, in fact, typically in grains that are much larger than the disseminated pyrite or the disseminated $\mathrm{Cu}$ sulfides. Co also occurs in some pyrite in these deposits, and where unmetamorphosed, the Corich pyrite is a later stage than the earliest pyrite. At Kamoto, Democratic Republic of Congo, the Co-rich pyrite forms rims that complete idiomorphic crystals surrounding earlier generations of pyrite (Bartholomé, 1974).

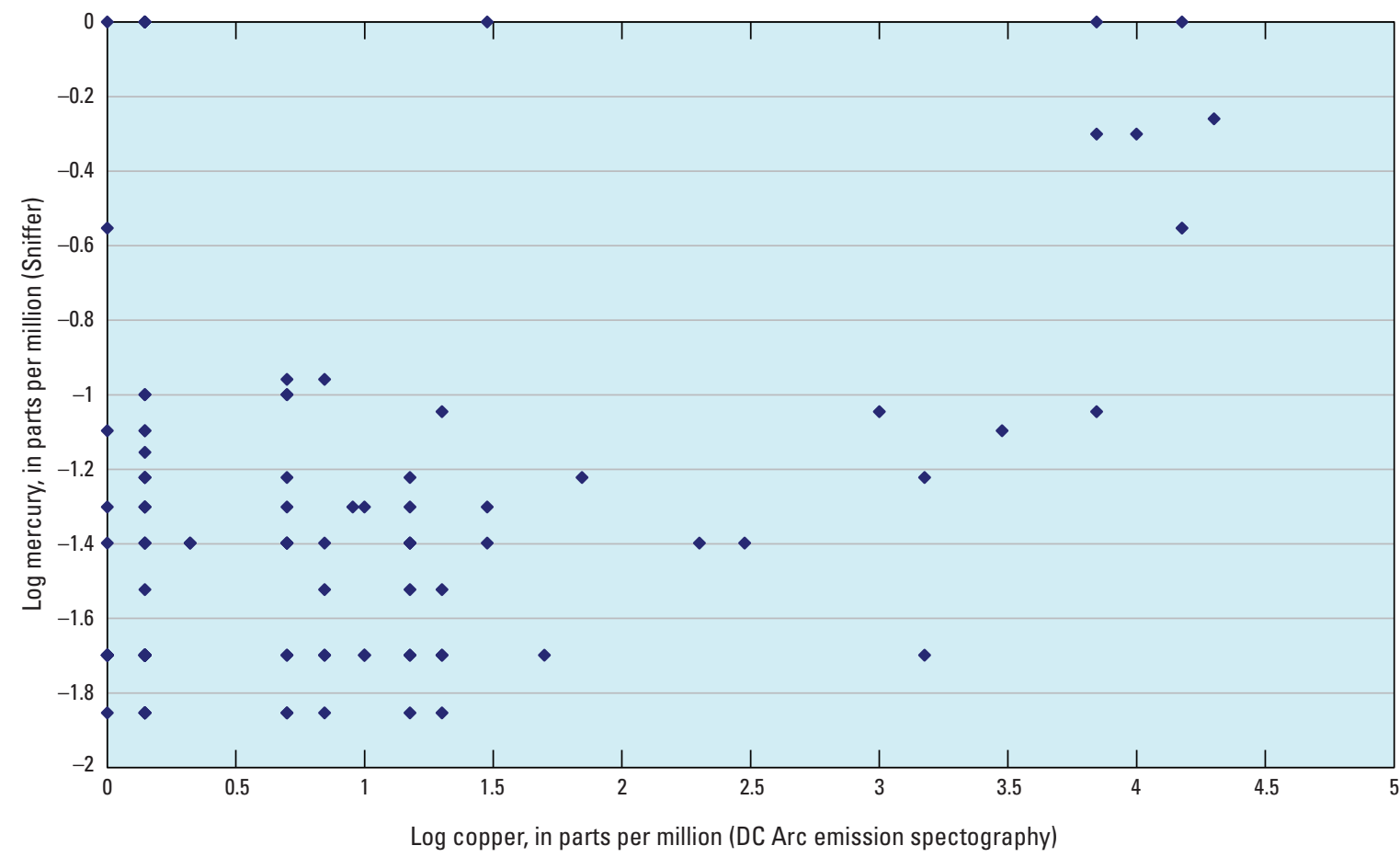

Figure 39. Relation between copper and mercury in 61 samples from the Revett and Burke Formations in northwestern Montana and northern Idaho. Analyses provided by J.E. Harrison, U.S. Geological Survey, written commun., 1985. The plot is made from a subset of the 110 samples graphed in figure 31 . 
Ferroan and manganoan carbonates surrounding sandstone $\mathrm{Cu}$ deposits may be found in 100s of meter- to kilometer-scale halos fringing the deposits, and these could be exploration indicators of the deposits. Ferroan calcites have been identified at Dzhezkazgan (Gablina and Tsepin, 1975) and Spar Lake (Hayes and Einaudi, 1986). Mn contents of the calcite and ankerite at Spar Lake also vary zonally across that deposit (fig. 22). The ferroan and particularly the manganoan carbonates of the Spar Lake deposit have anomalously low $\delta^{13} \mathrm{C}$ attributable to organic carbon (see below). Because these carbonates were forming at the fringes of a mixing zone between a metalliferous brine and reservoired natural gas (Hayes and others, 2012), it is likely that they mark the locations of coupled redox reactions between $\mathrm{SO}_{4}{ }^{2-}$ of the metalstransporting brine and carbon in the reservoired $\mathrm{CH}_{4}$. Such a reaction could be expressed as:

$$
\begin{aligned}
\mathrm{Ca}^{2+} & +2 \mathrm{CuCl}_{0, \mathrm{aq}}+\mathrm{SO}_{4}^{2-}+\mathrm{CH}_{4}=\mathrm{Cu}_{2} \mathrm{~S} \\
& +\mathrm{CaCO}_{3}+2 \mathrm{Cl}^{-}+2 \mathrm{H}^{+}+\mathrm{H}_{2} \mathrm{O}
\end{aligned}
$$

\section{Fluid-Inclusion Geochemistry}

The physical properties and compositions of hydrothermal fluids that formed SSC deposits were poorly known until recent years. Syngenetic theories of origin for this deposit type, which were popular until the 1970s or early 1980s, probably delayed the application of fluid-inclusion studies. There still remains an opportunity for major contributions from fluidinclusion studies of SSC deposits, particularly for determining fluid-inclusion compositions in attempts to identify the source(s) of metals-transporting groundwater(s).

\section{Fluid-Inclusion Microthermometry}

On the basis of fluid-inclusion microthermometry studies, fluids that formed SSC deposits varied relatively narrowly in composition, from low-salinity vapor, to dilute liquid, and to high-salinity brine.

Fluid-inclusion studies in the Central African Copperbelt have shown the complexity of $\mathrm{Cu}$-Co mineralization in the region. All reports noted the small size of the inclusions, generally less than $5 \mu \mathrm{m}$. The earliest study of fluid inclusions in the Democratic Republic of Congo was by Pirmolin (1970). He studied the fluid inclusions within dolomite "porphyroblasts" within the RSC beds, between the upper and lower orebodies, at Kamoto. The observed two-phase liquid-vapor inclusions were too small to work with by microthermometry at that time. Larger inclusions with diameters of 9 to $50 \mu \mathrm{m}$ were observed to be of two types: randomly distributed (probably primary) and "parallel to cleavages" (probably secondary). The primary inclusions all had from one to four solid daughter minerals or trapped phases, none of which were opaque, as well as small gas bubbles commonly occupying 2 percent of the inclusion volume. More recent observations (Richards and others, 1988b; El Desouky and others, 2009) show that these large inclusions with multiple solid daughter minerals date from a second stage of $\mathrm{Cu}$ mineralization at Kamoto. In heating runs, five of the Pirmolin's large, complex inclusions homogenized by disappearance of the gas phase at between 140 and $150^{\circ} \mathrm{C}$, with, as well, dissolution of some solid phases at varying temperatures. Some parallelepiped-shaped solids dissolved at temperatures as low as $55-60^{\circ} \mathrm{C}$, additional parallelepiped solids dissolved at temperatures between 120 and $145^{\circ} \mathrm{C}$, and spheroidal solids dissolved, finally, between 200 and $240{ }^{\circ} \mathrm{C}$, by which temperature all five inclusions that had earlier lost their gas bubbles between 135 and $150{ }^{\circ} \mathrm{C}$ had decrepitated. All seven of the inclusions where the gas bubble did not disappear were noted to have undergone "slight opening of the cleavages around $130^{\circ} \mathrm{C}$." That is, they leaked during the heating run.

Pirmolin (1970) also applied XRF studies that allowed $\mathrm{x}$-ray beam penetrations of 25 to $30 \mu \mathrm{m}$ into some inclusions. This remains, even to this day, the only direct measurement of inorganic compositions of the fluids involved in forming SSC deposits. Pirmolin identified $\mathrm{Ca}, \mathrm{K}, \mathrm{Si}, \mathrm{Cl}, \mathrm{Cu}, \mathrm{Fe}, \mathrm{Pb}, \mathrm{Mn}, \mathrm{Sn}$, $\mathrm{Co}, \mathrm{Ti}$, and $\mathrm{S}$ in the inclusion fluids but could make no attempt at quantification. $\mathrm{He}$ attributed $\mathrm{Cu}, \mathrm{Co}$, and $\mathrm{Pb}$ to the mineralizing process and $\mathrm{Ca}, \mathrm{Fe}, \mathrm{Mn}$, and $\mathrm{Si}$ were attributed to interaction with the siliceous dolomite host rocks. He concluded that the $\mathrm{K}, \mathrm{Cl}$, S, and some $\mathrm{Na}$ formed the solid daughter minerals, and from that he deduced that the solids included halite, sylvite, and anhydrite. With some further understanding of the petrology of the Democratic Republic of Congo host rocks, it is now known that the dolomite whose inclusions Pirmolin (1970) studied was an ore-stage or later pseudomorph of original anhydrite. It is that fact that validates the coarse crystalline quartz and dolomite in Zambian and Congolese ores as a host for ore-stage fluid inclusions and that validates fluid inclusion microthermometry results from Pirmolin (1970), Annels (1989), Dewaele and others (2006), and El Desouky and others (2009).

Returning to the study of Pirmolin (1970), and with the assumption that anhydrite was replaced in depositing the dolomite that hosted the inclusions, a highly saline system of $\mathrm{NaCl}, \mathrm{KCl}$, and water, with high concentrations of $\mathrm{Cu}$ and $\mathrm{Co}$, is accepted as the mineralizing fluid. The three component $\mathrm{NaCl}-\mathrm{KCl}-\mathrm{H}_{2} \mathrm{O}$ system was illustrated by Roedder (1984, p. 245). With the temperatures and solid behaviors above, the dissolution of the first solid, definitely $\mathrm{KCl}$, at less than $60{ }^{\circ} \mathrm{C}$ allows only fluid compositions with $15-20 \mathrm{~mol} . \% \mathrm{KCl}$ for the three inclusions that had two parallelepiped-shaped solids. With dissolution of the second solid at 120 to $130{ }^{\circ} \mathrm{C}$, the $\mathrm{NaCl}$ molarity is also closely limited and must be between 28 and $30 \mathrm{~mol} . \% \mathrm{NaCl}$. The fluid is, therefore, saline- 15 to $20 \mathrm{~mol} . \% \mathrm{KCl}$ and 28 to $30 \mathrm{~mol} . \% \mathrm{NaCl}$, and thus 43 to 50 eq. mol. $\% \mathrm{NaCl}$ total. The behavior in heating runs indicates homogenization temperatures of 135 to $150{ }^{\circ} \mathrm{C}$ probably are minimum temperatures for the deposition of the dolomite at a time probably many millions of years later than main-stage $\mathrm{Cu}$-Co-sulfide deposition. 
Richards and others (1988b) studied veinlet-controlled mineralization accompanied by montmorillonitic vein envelopes and quartz-hematite-rutile-barite-calcite vein centers cutting footwall clastic rocks at Musoshi, Democratic Republic of Congo. Fluid inclusions in the vein quartz were studied microthermometrically. The inclusions had multiple daughters certainly including halite and sylvite and probably including anhydrite, hematite, and other solids in certain inclusions. These inclusions homogenized with a systematically different sequence than those observed by Pirmolin (1970), by dissolution of first, sylvite, then the gas bubbles, and finally, halite, at temperatures between 247 and $300{ }^{\circ} \mathrm{C}$ for distal-veinlet zones and between 391 and $413{ }^{\circ} \mathrm{C}$ for influx-zone veins. Minimum salinities were $39 \mathrm{wt}$ \% $\mathrm{NaCl}$ plus 15 wt. $\% \mathrm{KCl}$, and thus 50.75 eq. wt. $\% \mathrm{NaCl}$ total. Finally, Richards and others (1988b) $\mathrm{Pb}-\mathrm{Pb}$ dated the rutile of the veinlets at $514 \pm 2 \mathrm{Ma}$ and thus interpreted the fluid as a late, post-ore overprint from the Lufilian Orogeny relative to the main disseminated ore-stage.

Annels (1989) studied fluid inclusions in coarse crystalline nodular quartz, probably pseudomorphic after anhydrite, and in vein quartz at Chambishi and Chambishi East. He measured 138 to $180^{\circ} \mathrm{C}$ homogenization temperatures and determined salinities of 10.5 to 16 eq. wt. $\% \mathrm{NaCl}$ for pyrite- and carrolliteassociated inclusions at Chambishi, 137 to $170{ }^{\circ} \mathrm{C}$ homogenization temperatures and 16 to 21 eq. wt. $\% \mathrm{NaCl}$ salinities in chalcopyrite-associated quartz, and 118 to $150{ }^{\circ} \mathrm{C}$ homogenization temperatures and 16 to 20 eq. wt. $\% \mathrm{NaCl}$ salinities in bornite-associated quartz. These results were discussed by Annels (1989), who noted the shift in paragenetic time from high temperature and low salinity to lower temperature at greater salinity. In these fluids that all date from the main stage of disseminated sulfides, with salinities varying from 10.5 to 21 eq. wt. $\% \mathrm{NaCl}$, mixing of two solutions seems likely, although it was not discussed. Late-stage veins with homogenization temperatures from $297^{\circ} \mathrm{C}$ to $425^{\circ} \mathrm{C}$ with the same salinities were interpreted by Annels (1989) to be related to late intrusion of mafic sills. This work was the first to deal with inclusions from the early, main-stage disseminated mineralization for the Central African deposits. Its homogenization temperatures are generally lower than temperatures from the overprinted veinlet stage, as are its salinities.

McGowan and others (2006) at the Nchanga deposit in Zambia examined inclusions in quartz veins from the Mines Sequence but did not report on the smaller inclusions in the stratabound ores. They found homogenization temperatures ranging from 140 and $180{ }^{\circ} \mathrm{C}$ and salinities between 31 and 38 eq. wt. $\% \mathrm{NaCl}$. Compared with other studies, it is clear that McGowan and others (2006) recorded results only from second-stage mineralization probably related to the Lufilian Orogeny (by comparison with Richards and others, 1988b; El Desouky and others, 2009).

Dewaele and others (2006) studied small inclusions in coarse-crystalline quartz, which probably replaced anhydrite, from stratabound ores from the Musonoi and Kamoto deposits in the Copperbelt in the Democratic Republic of Congo. Homogenization temperatures were between 127 and $192{ }^{\circ} \mathrm{C}$ at Kamoto and 105 and $188^{\circ} \mathrm{C}$ at Musonoi, with salinities between 9.4 and 15.3 equivalent (eq.) wt. \% $\mathrm{NaCl}$ at Kamoto and 8.4 and 18.4 eq. wt. $\% \mathrm{NaCl}$ at Musonoi. These, clearly, were all related to the pre-orogenic main stage of sulfide mineralization, and, as with Annels' (1989) results, mixing of two solutions is suggested by the large ranges in temperatures and salinities.

El Desouky and others (2009) conducted petrographic and microthermometric studies of borehole samples from Kamoto and Luiswishi deposits and found evidence for two distinct mineralizing phases. In the first, $\mathrm{Cu}$ and $\mathrm{Co}$ minerals are found in layers and nodules of dolomite accompanied by quartz (both minerals probably pseudomorphic after anhydrite). Inclusion homogenization temperatures ranged from 117 to $220^{\circ} \mathrm{C}$. Salinities were calculated from 11.3 to 20.9 eq. wt. $\% \mathrm{NaCl}$ (fig. 40). In the second phase, ore minerals are found in stratabound veins and breccias, and fluid inclusions have homogenization temperatures between 270 and $385^{\circ} \mathrm{C}$ and salinities from 35 to 45.5 eq. wt. $\% \mathrm{NaCl}$. El Desouky and others (2009) concluded that the early main phase of sediment-hosted ore was enriched by a synorogenic second phase at the later time of the Lufilian Orogeny.

El Desouky and others (2008b) studied fluid inclusions in the Mwitapile sandstone $\mathrm{Cu}$ deposit in the Lufilian Foreland in Democratic Republic of Congo and compared the results with earlier studies at Lufukwe sandstone $\mathrm{Cu}$ deposit of the same region that had been studied by El Desouky and others (2008a). At Mwitapile, arkosic, calcareous sandstone shows a first generation of quartz overgrowths. Dissolution of the calcite produced cavities occupied by pyrite, chalcopyrite, bornite, chalcocite, and a second generation of quartz. Microthermometry on inclusions in the early overgrowth quartz yielded homogenization temperatures between 111 and $182{ }^{\circ} \mathrm{C}$ and salinities between 22 and 25.5 eq. wt. $\% \mathrm{CaCl}_{2}$. These results were comparable with the results from Lufukwe (El Desouky and others, 2008a). Inclusions in the secondphase quartz associated with the main ore stage had temperatures between 120 and $280^{\circ} \mathrm{C}$ and salinities between 2.4 and 19.8 eq. wt. \% NaCl. The higher temperatures were associated with higher salinities. Mineralization was interpreted to be related to mixing of the high temperature, high salinity, metals-transporting fluid with the lower temperature, reduced, first-phase fluids. It is not clear whether or not the main stage at Mwitapile correlates with the main stage from deposits at Kamoto, Musonoi, and Luiswishi (Dewaele and others, 2006; El Desouky and others, 2009).

In summary, ore deposition in the Central African Copperbelt SSC deposits took place in two separate stages. The first stage produced only small liquid-vapor fluid inclusions, with no solid daughter minerals; the second stage produced large inclusions, with multiple daughter minerals including halite, sylvite, and other possible solids. At the early stage, saline fluids, typically in excess of 15 eq. wt. $\% \mathrm{NaCl}$ and greater than 20 eq. wt. \% $\mathrm{NaCl}$ in a few locations, 


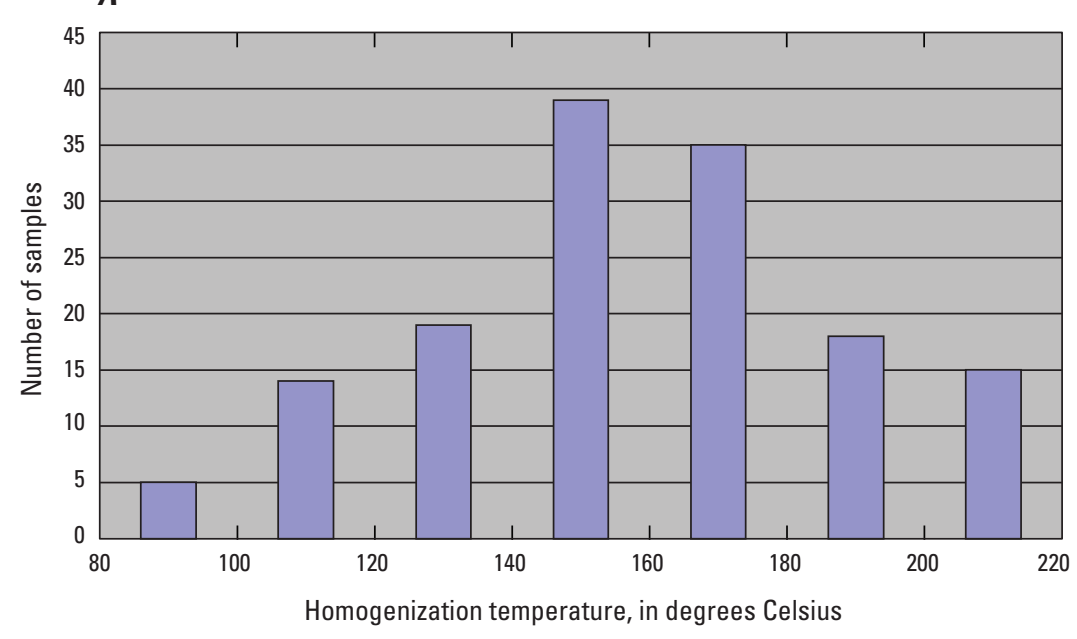

$c$

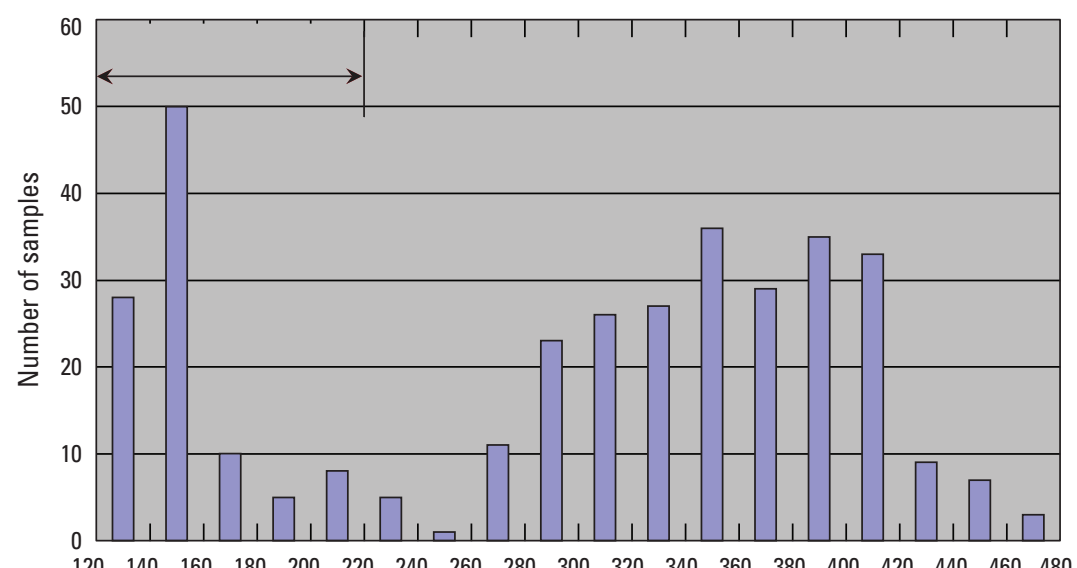

Homogenization temperature, in degrees Celsius

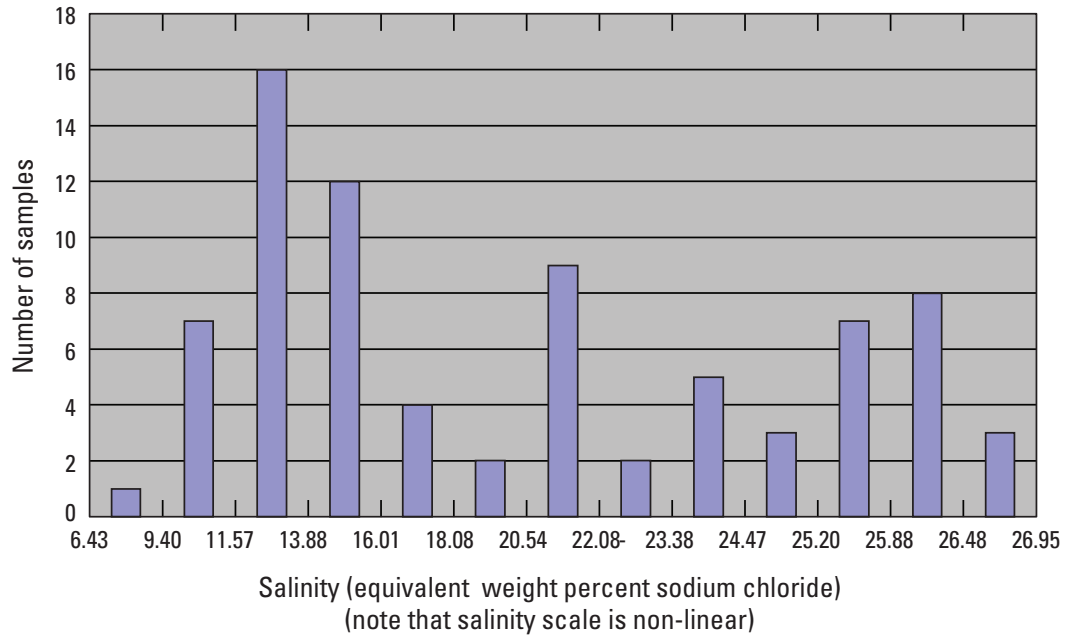

D

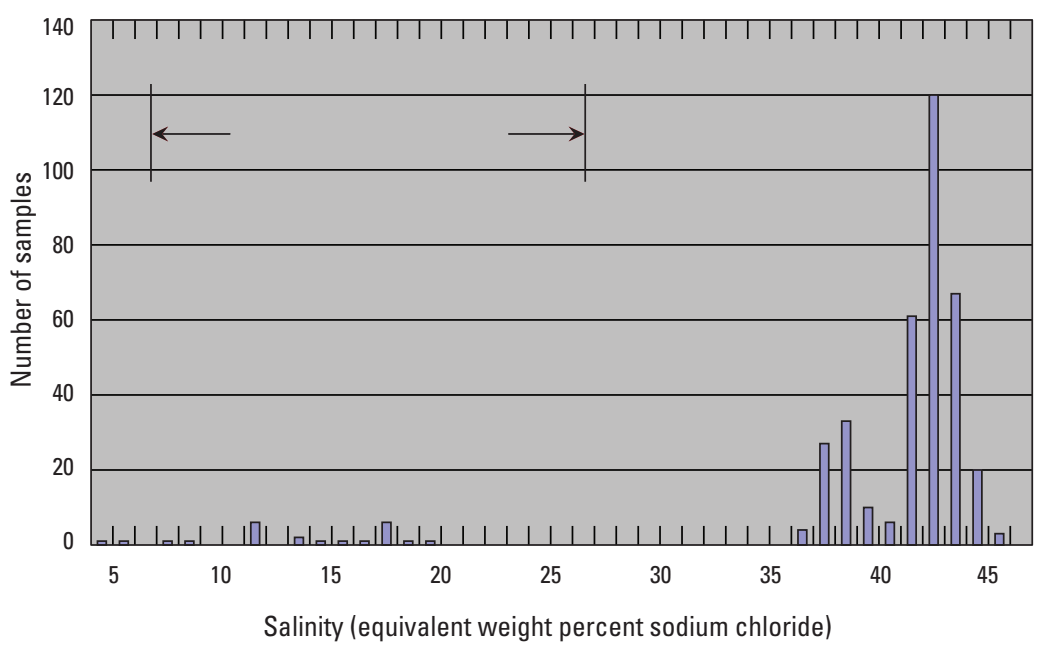

Figure 40. Summary of fluid-inclusion microthermometry results from sandstone copper and reduced-facies sediment-hosted stratabound copper deposits of the Democratic Republic of Congo. Histograms compile the results from primary inclusions, only, from Dewaele and others (2006) from the Kamoto and Musonoi reducedfacies deposits, from El Desouky and others (2008a) from the Lufukwe sandstone copper prospect, from El Desouky and others (2008b) from the Mwitapile sandstone copper prospect, and from El Desouky and others (2009) from the Kamoto and Luiswishi reduced-facies sediment-hosted stratabound copper deposits. Graphs $A$ and $B$ are homogenization temperatures and salinities from the early disseminated stage, and graphs $C$ and $D$ are from the later veinlet stage. Assignment of certain inclusions from Mwitapile to the late stage by El Desouky and others (2008b) (their second authigenic quartz phase) may be erroneous. Results from those inclusions are very similar in homogenization temperatures and salinities to early-stage inclusions from the other four deposits. Rather than occurring in veinlets, this authigenic quartz occurs as overgrowths on detrital quartz grains that are encased within copper-sulfide clots. The results from quartz overgrowths at Mwitapile are demarcated by the arrowed brackets in $C$ and $D$. 
transported $\mathrm{Cu}$ at temperatures of about 130 to greater than $220^{\circ} \mathrm{C}$. Ore deposition occurred partly by mixing with lower temperature and less saline groundwater, probably just the preore groundwater with a salinity less than 10 eq. wt. $\% \mathrm{NaCl}$. The result was large ranges in homogenization temperatures and salinity. Later, probably during or after the Lufilian Orogeny, a second stage of $\mathrm{Cu}$ mineralization took place from fluids with temperatures greater than 200 to $415^{\circ} \mathrm{C}$ and with salinities of 35 to 55 eq. wt. $\% \mathrm{NaCl}$. The second-stage $\mathrm{Cu}$ mineralization was dominantly vein-controlled, whereas the early $\mathrm{Cu}$ mineralization was disseminated through host rocks. Sources of the fluids are not known for either stage, but particularly given the extraordinary salinities of the secondstage fluids, dissolved evaporites, likely even potash salts, are probably significant. Descriptions to date (Selley and others, 2005, p. 965-966; Dewaele and others, 2006, p. 455) suggest that the second-stage mineralization did not contribute large parts of the total $\mathrm{Cu}$ mineralization except at a few places, such as Kansanshi, Lubembe, and Frontier (Doug Jack, oral commun., 2010).

Fluid-inclusion studies were important in understanding the origin of the Spar Lake sandstone $\mathrm{Cu}$ deposit. Fluidinclusion studies (Hayes, 1990) were aimed partly at understanding the zonal pattern of ore and gangue cements. Only primary inclusions from within quartz overgrowths on detrital quartz grains or from pore-filling calcite cements were studied by microthermometry, and these were all small, between 2 and $7 \mu \mathrm{m}$ in greatest dimension, with most less than $5 \mu \mathrm{m}$. All were 2-phase liquid-vapor inclusions. Six inclusion homogenization temperatures from the galena-calcite zone were from 72 to $126^{\circ} \mathrm{C}$, four from the chalcopyrite-calcite zone were from 150 to $164{ }^{\circ} \mathrm{C}$, seven from the bornite-calcite zone were from 130 to $172{ }^{\circ} \mathrm{C}$, and eight from the chalcocite-chlorite zone were from 143 to $184{ }^{\circ} \mathrm{C}$ (fig. 41). Those results demonstrated increasing temperatures from pyrite-calcite toward chalcocitechlorite, corroborating earlier S-isotope geothermometry (Hayes and others, 1989). Two homogenizations from chalcopyrite-ankerite zone rocks were $145^{\circ} \mathrm{C}$ and $169.5^{\circ} \mathrm{C}$, and those, in being equal to or lower than the temperatures in the adjacent chalcocite-chlorite zone, demonstrated that the chalcopyrite-ankerite zone was not a feeder zone to the deposit. Salinity calculations ranged widely and correlated poorly with homogenization temperatures, although freezing runs generally indicated lower salinities in the peripheral chalcopyrite- and galena-bearing zones. The salinities varied from 5 to 22.5 eq. wt. $\% \mathrm{NaCl}$. Those results were interpreted to indicate mixing of a high temperature, high salinity, metalstransporting fluid with cooler, less saline pre-ore fluids.

\section{Chemical Compositions of Mineralizing Fluids}

Exclusive of Pirmolin (1970) described above, the only work that has determined compositions of inclusion fluids of any SSC deposit was a study of the Spar Lake deposit (Hayes and others, 2012). In that study, quadrupole mass spectrometry was used to determine fluid-inclusion volatile compositions. Inclusion fluids were released from samples of separated carbonates, separated $\mathrm{Cu}$ sulfides, or crushed whole rocks by thermal decrepitation at $180^{\circ} \mathrm{C}$ for periods of as much as one hour in order to accumulate enough gas from the small and sparse inclusions in ore-stage authigenic cements. The low temperature was chosen to avoid decrepitating any higher-temperature inclusions trapped in detrital grains at times earlier in those grains geologic histories. The results demonstrated that mineralization at Spar Lake took place where a metals-transporting brine at greater than $200^{\circ} \mathrm{C}$ mixed and reacted with sour gas (natural gas containing $\mathrm{H}_{2} \mathrm{~S}$ ) reservoired in sandstones. The metals-transporting brine was an aqueous fluid lacking any important amounts of dissolved $\mathrm{CO}_{2}, \mathrm{CH}_{4}$, or $\mathrm{H}_{2} \mathrm{~S}$ (fig. 42). Systematic arrangement of fluidinclusion volatiles across the ore deposit was reflected in $\mathrm{H}_{2}$ and other hydrocarbon gases, as well as in $\mathrm{CH}_{4} / \mathrm{CO}_{2}$ ratios. The metals-transporting brine entered the gas reservoir from below at a temperature of at least $200{ }^{\circ} \mathrm{C}$ and reacted with cooler natural gas. The brine was apparently oxidizing, and the ore was deposited as it reacted to lower $\mathrm{fO}_{2}$ conditions with the $\mathrm{H}_{2} \mathrm{~S}$ and $\mathrm{CH}_{4}$ in the reservoired natural gas (fig. 43). Neither the metals-transporting brine nor the natural gas give any indication of involvement of magmatic or subcrustal fluids; Spar Lake fluid-inclusion volatiles also have low helium $\mathrm{R} / \mathrm{R}_{\alpha}$ values ranging from 0.236 to 0.995 , also indicating no involvement of mantle or magmatic fluids.

\section{Organic Geochemistry}

The earliest studies of organic geochemistry at a SSC deposit were at White Pine (Eglinton and others, 1964; Meinschein and others, 1964; Barghoorn and others, 1965). Their purpose was limited, however, to demonstrating and analyzing the forms of early life in the Mesoproterozoic Nonesuch Shale host rocks. The studies, nonetheless, demonstrated the presence of in situ-generated oil; of macerals of plant, possibly algal, remains; of an odd-carbon-preference distribution of alkane compounds in organic matter extracts; of pristine and phytane typical of those produced from diagenesis of plant materials; and of vanadyl porphyrins in extracts from the rock organic matter probably derived from chlorophyll (Barghoorn and others, 1965).

More recent organic geochemical studies have addressed the Nonesuch Shale of the White Pine deposit and the Kupferschiefer, including a number of studies designed to glean understanding of the mineralizing process from the organics and to determine the effects of the mineralizing process on the organics (Hieshima and Mauk, 1990; Ho and Mauk, 1996; Pratt and others, 1991; Püttmann and others, 1987, 1989; Sun and Püttmann, 1997; Bechtel and others, 2002). Work at White Pine found that Nonesuch Shale ${ }^{\text {Pristane }} / \mathrm{n}-\mathrm{C}_{17}$ and ${ }^{\text {Phytane }} / \mathrm{n}-\mathrm{C}_{18}$ ratios are lower within ore than outside of it, suggesting thermal maturation of the lower Nonesuch during mineralization. Yet the temperatures experienced in the ore were insufficient to destroy the pristine and phytane. In the Kupferschiefer, in the bottom section of mineralized 


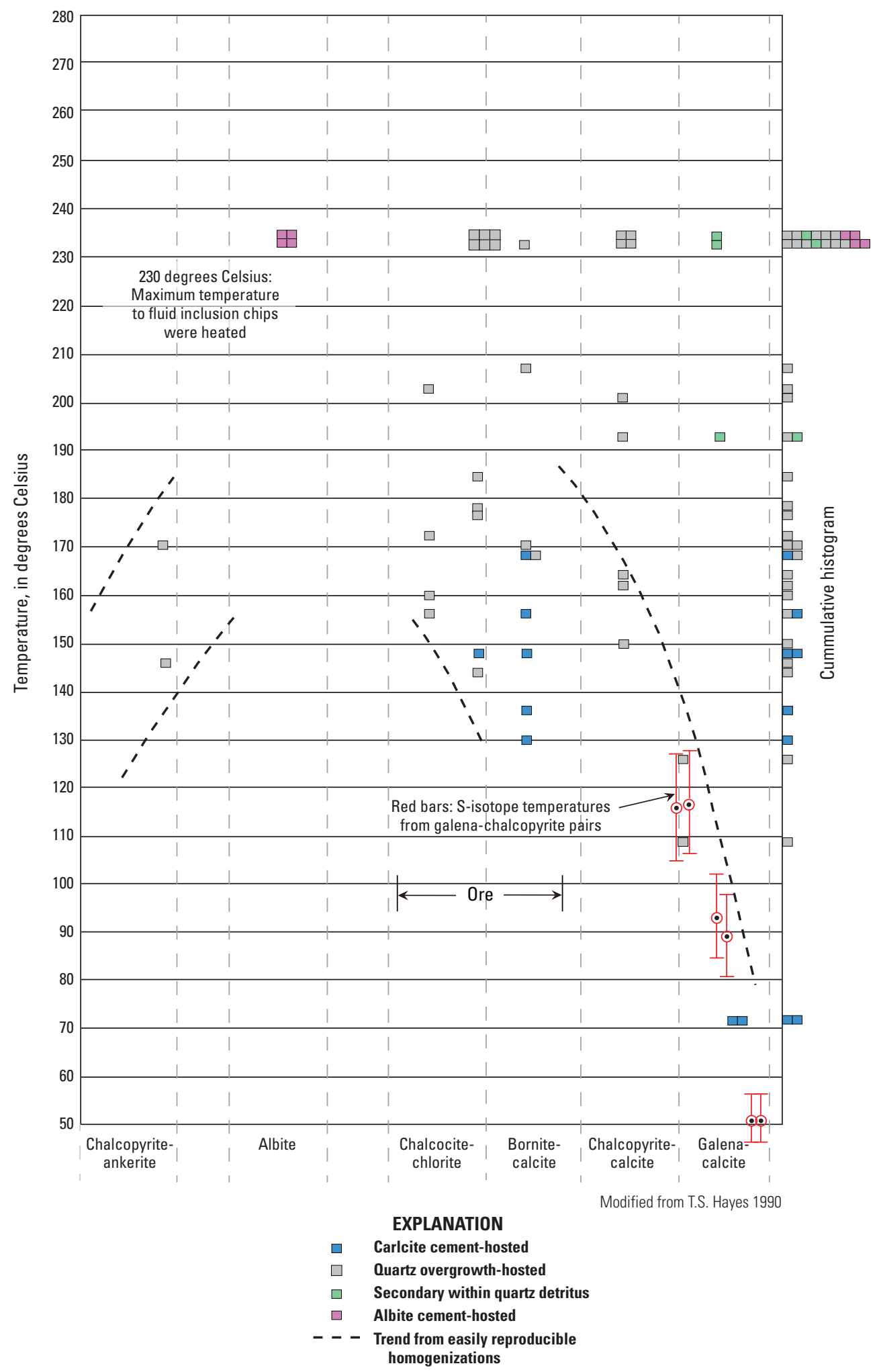

Figure 41. Fluid-inclusion homogenization temperatures from the Spar Lake sandstone copper deposit from Hayes (1990). Gray filled square symbols are for inclusions in quartz overgrowths on detrital quartz substrates (figs. 20, 21, 22, and 23). Blue square symbols are for inclusions from ore-stage manganiferous or ferroan calcite cements (figs. 20,21, and 22). There is a gradient in the homogenization temperatures of as much as $100^{\circ} \mathrm{C}$ from the galena-bearing fringing zone to the core of the chalcocite-bearing ore zone. That gradient occurs over typically about 300 meters laterally and 50 meters vertically. Nonetheless, the ore-depositing system was clearly a geothermal anomaly. Using this and salinity data, Hayes (1990) interpreted that hot, saline metals-transporting groundwater mixed with cooler, dilute formation waters in depositing ore. 
shale, saturated hydrocarbons are diminished and heteroaromatic systems containing oxygen and $\mathrm{S}$ are substantially enriched, compared with the less-mineralized shale just tens of centimeters upsection. The ratio of phenanthrene/sum of methylphenanthrenes is greatest in the richly mineralized basal part of the shale, and there are increased spectral fluorescence intensities of extracts relative to samples higher in the shale. All these measurements indicate a higher oxidation state in the basal section, interpreted to be caused by maturation and oxidation of organics in the shale by an ascending, oxidizing, metalliferous brine. Probably most important of all were studies of the Kupferschiefer that combined organic geochemical studies with studies of stable isotope systematics (discussed below).

\section{Stable-Isotope Geochemistry}

There have been numerous studies of $\mathrm{S}$ isotopes in sulfides of SSC deposits, and there have been several studies of $\mathrm{C}$ isotopes in carbonates of SSC deposits. Measurements of $\mathrm{C}$-isotopes in organic materials in the Kupferschiefer and at White Pine were also conducted in recent years. A few studies also document values of $\mathrm{O}$-isotopes of the carbonate minerals. The first study to document $\mathrm{S}$ and $\mathrm{O}$ isotopes in ore-stage sulfates was Hayes and others (2012).

\section{Sulfur Isotopes}

All reduced-facies-subtype deposits that have been studied have large ranges of S-isotope values among their sulfides, and they have some sulfides that have $\delta^{34} \mathrm{~S}$ values much lower than -10 per mil (\%) Dechow and Jensen, 1965; Marowsky, 1969; Burnie and others, 1972; Sawlowicz, 1989; Branam and Ripley, 1990). The White Pine deposit is fairly typical of this (fig. 44), with a total range in $\delta^{34} \mathrm{~S}$ values of $70 \%$ and values as low as $-29 \%$. This characteristic is evidence that sulfide now found in $\mathrm{Cu}$ sulfides was bacteriogenically fractionated from seawater sulfate. The Kupferschiefer has even lower values of $\delta^{34} \mathrm{~S}$ because the Kupferschiefer is in Permian host rocks, from a time when the $\delta^{34} \mathrm{~S}$ of seawater sulfate was at its lowest known value in geologic history (Claypool and others, 1980). Kupferschiefer $\delta^{34} \mathrm{~S}$ values are as low as $-44 \%$. Interpretations of the great spread in pyrite and $\mathrm{Cu}$ sulfide $\delta^{34} \mathrm{~S}$ values and some light values have varied. Marowsky (1969) interpreted that both types of values indicated "syngenetic" sulfides, although actually referring to early diagenetic sulfide formation just below the seawater-sediment interface. Burnie and others (1972) recognized that the distribution indicated either earliest diagenetic mineralization or an earliest diagenetic distribution of pyrite values followed by replacement by

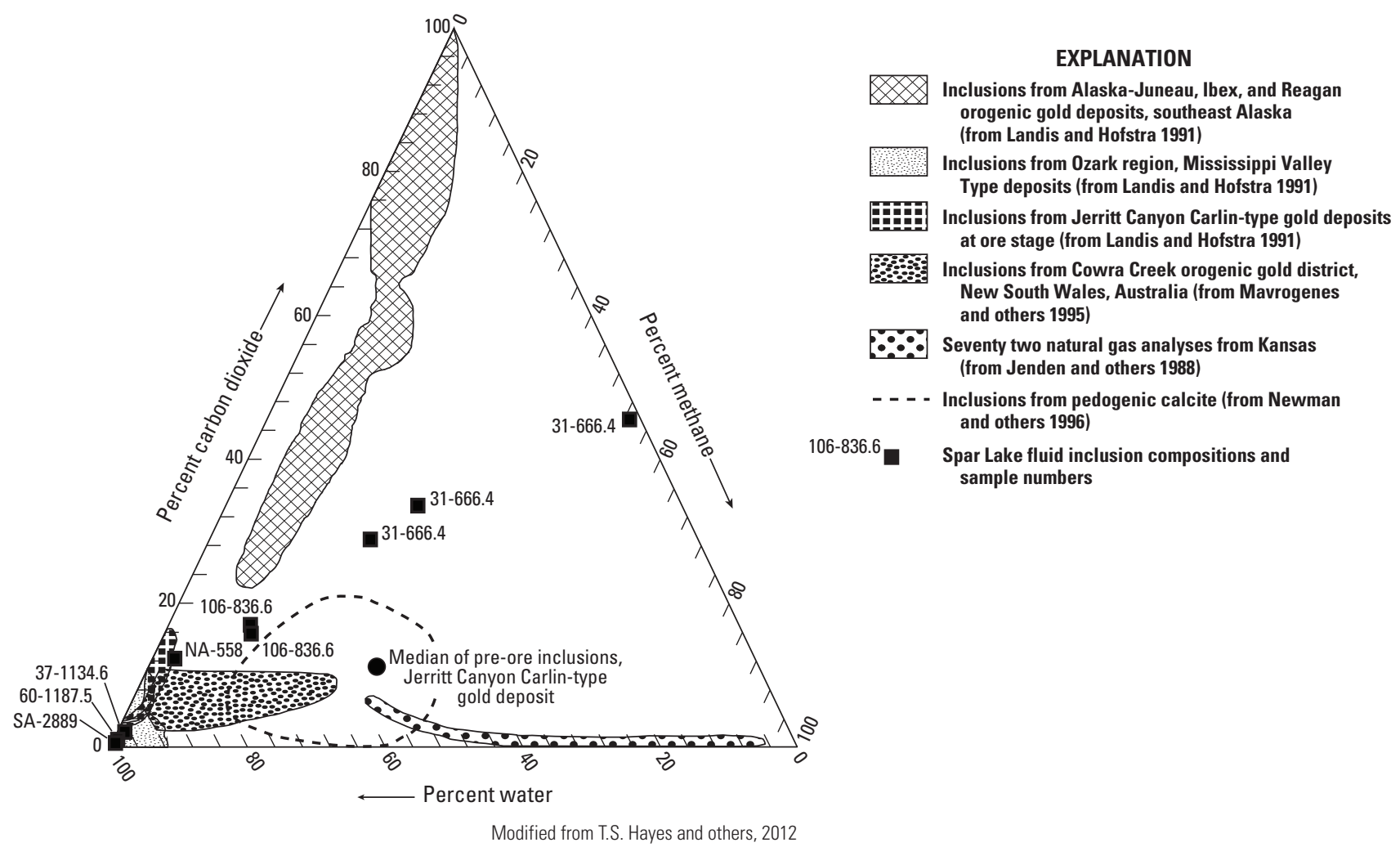

Figure 42. Water-carbon dioxide-methane compositions of Spar Lake sandstone copper deposit fluid inclusions compared with methane-rich inclusions from other metals depositing systems, with inclusions in pedogenic calcite, and with compositions of reservoired natural gas from Hayes and others (2012). Spar Lake inclusions include some that are more methane-rich than inclusions from any other studied metals deposit. Inclusions are more water-rich toward the center of the chalcocite-bearing deposit interpreted to indicate that hot metals-transporting groundwater lacking important concentrations of either methane or carbon dioxide mixed and reacted with reservoired natural gas to deposit ore, oxidizing some of the methane to carbon dioxide in the process. 


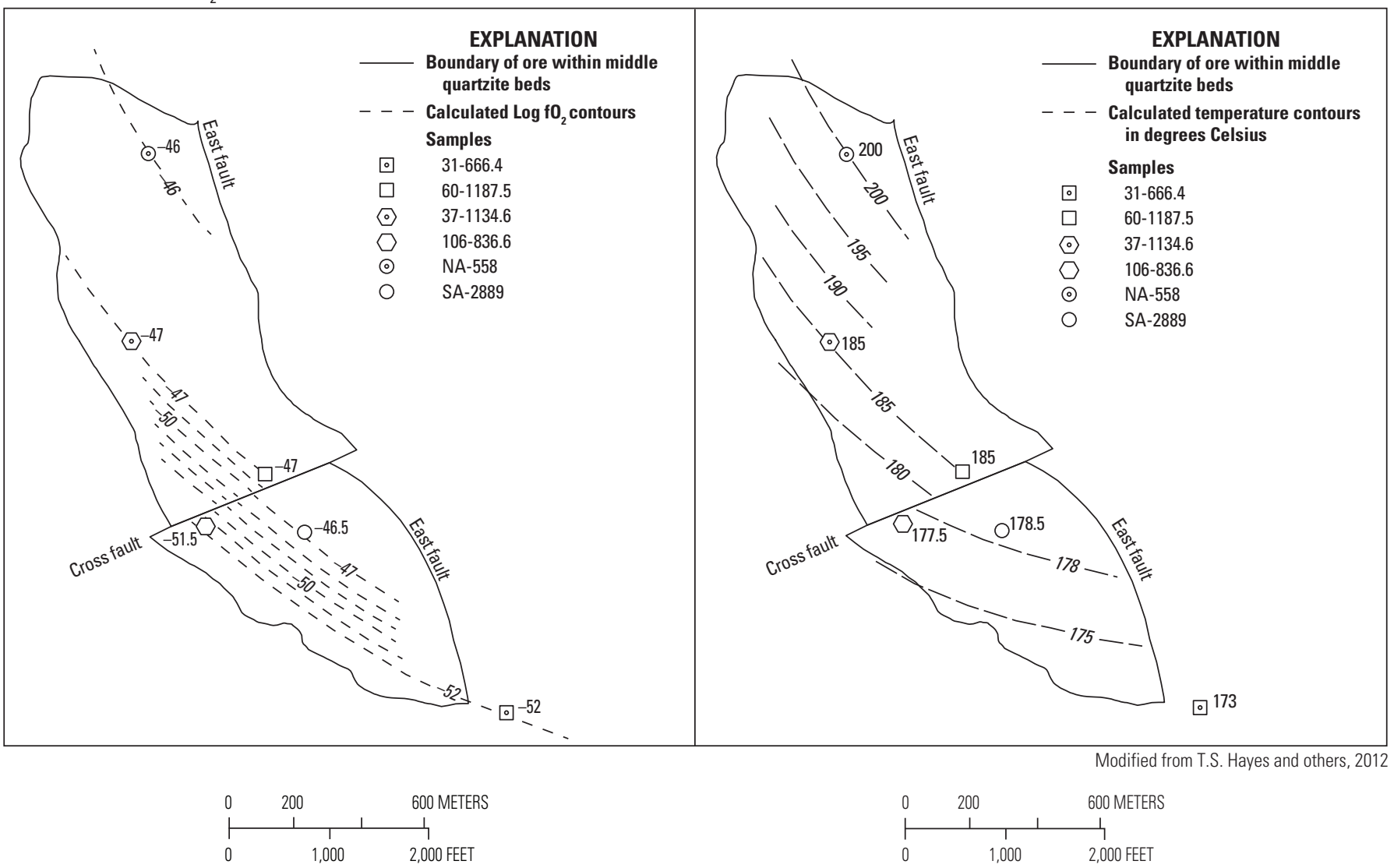

Figure 43. Maps of thermodynamically calculated temperature and $\log \mathrm{fO}_{2}$ of the Spar Lake sandstone copper deposit from Hayes and others (2012). Calculations were made from measurements of fluid-inclusion concentrations of hydrogen $\left(\mathrm{H}_{2}\right)$, water $\left(\mathrm{H}_{2} \mathrm{O}\right)$, methane $\left(\mathrm{CH}_{4}\right)$, and carbon dioxide $\left(\mathrm{CO}_{2}\right) \cdot \log \left(\mathrm{CH}_{4} / \mathrm{CO}_{2}\right)=\left(4625 / \mathrm{T}\left[{ }^{\circ} \mathrm{K}\right]\right)-10.4$, and $\log f \mathrm{O}_{2}=5.30-\left(25552 / \mathrm{T}\left[{ }^{\circ} \mathrm{K}\right]\right)-2 \mathrm{R}_{\mathrm{H}}$, where $\mathrm{R}_{\mathrm{H}}=\log \left(\mathrm{H}_{2} / \mathrm{H}_{2} \mathrm{O}\right)$ (Giggenbach, 1997). Fluid temperature and oxygen fugacity declines from the axis of the deposit (or from the northeast) towards its southwest fringe. This is interpreted to indicate that a hot, oxidized metals-transporting groundwater was introduced along the axis of the deposit (or perhaps from the northeast), and it mixed and reacted with reservoired natural gas, becoming more reduced, as it spread southwestward in the permeable sandstone reservoir.

chalcocite without appreciable redistribution of S-isotopes. Later workers have been far more definite in preferring replacement of pyrite without appreciable redistribution of $\mathrm{S}$ isotopes. Hoy and Ohmoto (1989) argued that $\mathrm{Cu}$ sulfides incorporating $\mathrm{S}$ with heavy $\delta^{34} \mathrm{~S}$ were added at ore-stage to White Pine and Kamoto (fig. 45). The $\delta^{34} \mathrm{~S}$ of the added sulfide at ore stage was about $+1.5 \%$ at White Pine, but it was as heavy as $+9 \%$ at Kamoto (Hoy and Ohmoto, 1989). The timing of that sulfide addition was constrained only as being sometime after the early diagenetic establishment of a wide distribution of values in pyrite.

The timing was better constrained in recent integrative studies of the Kupfershiefer at Sangerhausen of $\mathrm{S}$ isotopes of $\mathrm{Cu}$ sulfides, $\mathrm{C}$ isotopes of pre-ore and ore-stage carbonates, organic geochemistry, and C isotopes of organic matter (Bechtel and others, 2001). Those studies will be described below in the section on Integrated Isotopic Studies.

S-isotope values at sandstone $\mathrm{Cu}$ deposits differ dramatically from those at reduced-facies deposits in that they have no notably negative $\delta^{34} \mathrm{~S}$ values, although they share the characteristic of having broad distributions of values. Spar Lake sulfide values spread from +2.1 to $+29.1 \%$ (fig. 46). From S-isotopic studies at Spar Lake, there was an approach to thermal S-isotope equilibrium between pyrite, galena, and chalcopyrite of the distal zones. Tie lines connecting those three minerals (fig. 46) generally parallel one another. However, S-isotope equilibrium between the base-metal sulfides and barite was not attained or approached. Tie lines connecting the base-metal sulfides with barite generally do not parallel one another (fig. 46) and many cross one another.

About one-half of the total sulfides at Spar Lake are in large seepage pillars, a type of water-escape structure, locally called ore rods, and all the ore-rod sulfides have $\delta^{34} \mathrm{~S}$ values from +3.9 to $+10.7 \%$ (fig. 47 ). The $\delta^{34} \mathrm{~S}$ values of ore-stage barite vary from +18.8 to +28.9 (fig. 46 ), and together with the sulfide S-isotopes, the overall distribution is remarkably similar to the distribution of positive S-isotope values of sulfide minerals and petroleum in the Amu-Dar'ya petroleum-producing basin in Turkmenistan and Uzbekistan (Belenitskaya and others, 1981) (fig. 47). The Spar Lake deposit formed where Cu-transporting brines mixed and reacted with reservoired sour gas. The 


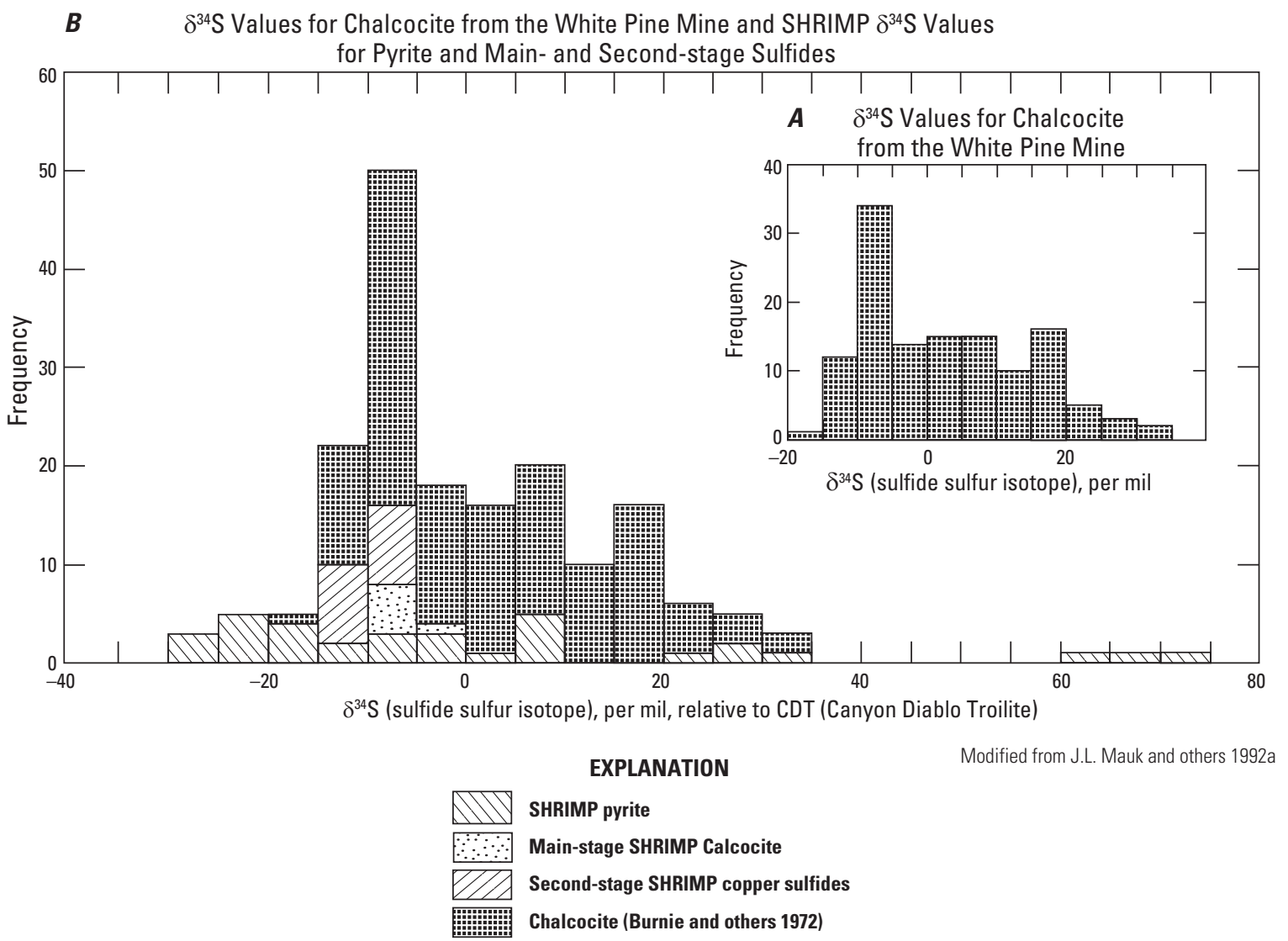

Figure 44. Sulfide sulfur-isotope distribution of the White Pine reduced-facies sediment-hosted stratabound copper deposit from Mauk and others (1992a).

full history of the S found in Spar Lake sulfides is interpreted as follows and can be followed on the diagram of the similar history of the Amu-Dar'ya basin (fig. 47). The bulk of the Spar Lake $\mathrm{S}$ was derived by bacterial sulfate reduction of seawater sulfate having $\delta^{34} \mathrm{~S}$ slightly higher than $+20 \%$, followed by sequestering of the sulfide in organic matter of down-section source rocks in the Prichard Formation. Maturation of the organic matter later produced petroleum with relatively homogeneous sulfide with $\delta^{34} \mathrm{~S}$ of about $+6 \%$. Thermal cracking then produced $\mathrm{H}_{2} \mathrm{~S}$ with relatively homogeneous sulfide also having $\delta^{34} \mathrm{~S}$ closely distributed about $+6 \%$ in sour gas. There was an additional contribution of sulfide from later TSR operating on formation water with $\delta^{34} \mathrm{~S}$ of +20 to $+29 \%$. That TSR probably occurred during the entire time interval from initial trapping of petroleum through ore deposition. Additional sulfide was thermochemically reduced at ore-stage from sulfate $\left(\mathrm{SO}_{4}\right)$ in the metals-transporting brine in redox reactions like equation 1 with the reservoired $\mathrm{CH}_{4}$. The $\mathrm{SO}_{4}$ in the metals-transporting brine was also deposited in ore-stage barite having that distribution of $\delta^{34} \mathrm{~S}$ values of about +19 to $+29 \%$. Knowledge of the fate of $\mathrm{S}$ and its isotopes in petroleum was documented by Thode and Monster $(1965,1970)$ and Krouse (1977).

Thus, the overall difference between $\mathrm{S}$ isotopes found in reduced-facies-subtype deposits and those found in sandstone $\mathrm{Cu}$ deposits is explained by the $\mathrm{S}$ being resident in different reductants. The deposit subtypes share the addition of ore-stage, isotopically heavy sulfide from the thermochemical reduction of sulfate $\left(\mathrm{SO}_{4}\right)$ from the metals-transporting brines as will be shown below in the sections on Carbon Isotopes and Integrated Isotopic Studies.

\section{Carbon Isotopes}

Markowsky (1969) analyzed 105 Kupfershiefer bed samples for $\delta^{13} \mathrm{C}$ in dolomite or calcite and 103 samples for $\delta^{13} \mathrm{C}$ in organic matter. The values in organic matter were typical of bituminous shale, with a unimodal distribution centered surrounding $-27.5 \%$ relative to $\mathrm{PDB}$ and with a narrow range from only -25 to $-30 \%$. The distributions of calcite and dolomite $\delta^{13} \mathrm{C}$ values were also typical. The calcite had a mode at about $+2.5 \%$, with a fairly large range from -5.5 to $+4.5 \%$. The range of values in dolomite was also fairly large, from +6.5 to $-2.5 \%$. Many of Marowsky's (1969) samples came from areas of barren pyritic Kupferschiefer from northern Germany. He noted the occurrence of light carbonates of biogenic origin above zones of sulfide accumulation but interpreted that it indicated bacterial involvement in syngenetic precipitation of the sulfides.

Earliest reported C-isotope studies in Zambia were from the work of Annels (1989). Only nine samples were analyzed. Stromatolitic reef dolomites were relatively close to typical 


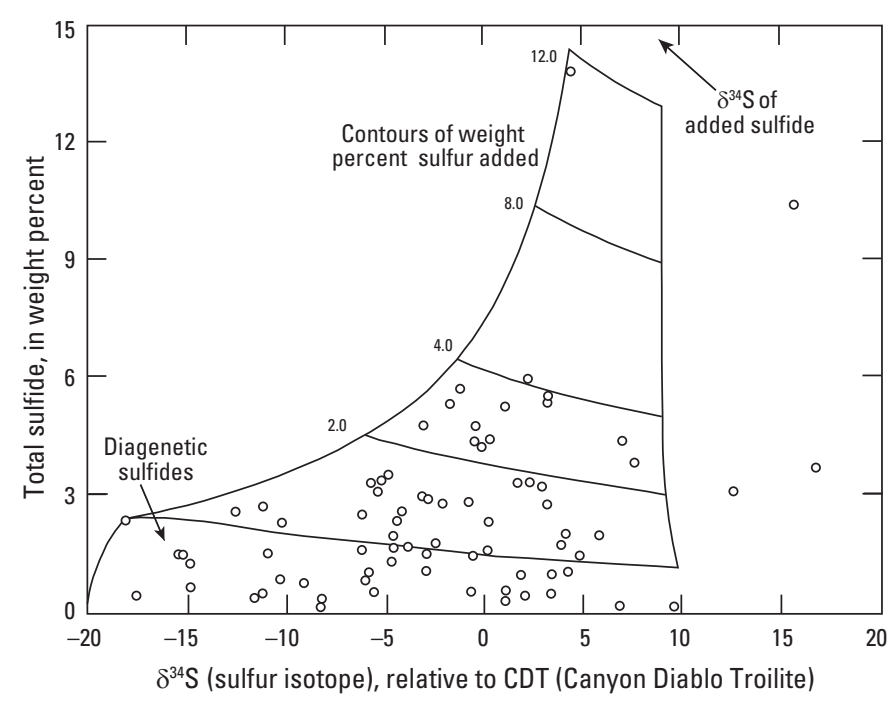

Modified from L.D. Hoy and H. Ohmoto, 1989

Figure 45. Relation between total sulfide and $\delta^{34} S$ of sulfide from Kamoto reduced-facies type deposit, Democratic Republic of Congo, from Hoy and Ohmoto (1989). At this and other reducedfacies sediment-hosted stratabound copper deposits, a broad distribution of sulfur-isotope values inherited from early diagenetic pyrite was augmented by an additional ore-stage supply of sulfide for copper sulfides. Modeling such an addition results in a parabolic triangular envelope of $\delta^{34} S$, total sulfide, values that then approximates, at its apex, the $\delta^{34} S$ sulfide value of the sulfide added at ore stage.

Neoproterozoic marine values of -1 to $+10 \%$ o $\delta^{13} \mathrm{C}_{\mathrm{PDB}}$ and -4 to $-10 \%{ }_{0}^{18} \mathrm{O}_{\text {PDB }}$ (Halverson and others, 2005; Santos and others, 2000; Chu and others, 2007; Corsetti and others, 2007; Giddings and Wallace, 2009). Two dolomite nodules associated with $\mathrm{Cu}$ - and Co-bearing sulfides had $\delta^{13} \mathrm{C}$ of -14.8 and $-25.2 \%$. Two calcite nodules were -14.8 and $-19.4 \%$. These are extremely depleted values that indicate a large proportion of organic carbon in the minerals. Sweeney and Binda (1989) reported dolomite lenticles with $\delta^{13} \mathrm{C}$ values of -8.5 to $-21 \%$ from the Ore Shale at Konkola, layered dolomite from unit $\mathrm{C}$ of the Ore Shale at $-12.5 \%$, and Ore Shale calcite at $-17 \%$. They interpreted these depleted values as related to fresh groundwater, and the heavier values in the footwall clastics were interpreted as related to marine transgression. Values from carbonates in the footwall clastic rocks varied from -4.5 to $-9.5 \%$. Sweeney and Binda (1989) stated these $\delta^{13} \mathrm{C}$ values indicated that "organic matter was oxidized during carbonate formation." The Ore Shale values are far too low to have been due merely to continental groundwaters. These low $\delta^{13} \mathrm{C}$ values of ore-related carbonates are indicators of the oxidation of organic carbon accompanying sulfide mineralization. Hitzman and others (2005) suggested that low $\delta^{13} \mathrm{C}$ in carbonates within specific rock volumes would serve as proxy for the presence of mobile reductants (that is, petroleum). The carbonates also had $\delta^{18} \mathrm{O}$ values that were low compared with contemporary marine carbonate values and that could be interpreted to be because of either involvement of fresher, less saline water in their precipitation or to relatively high temperatures of precipitation. Obviously, given Annels' (1989) fluid-inclusion homogenization temperatures from some of these same samples, the low values were because of elevated hydrothermal temperature.

Sandstone $\mathrm{Cu}$ deposits, such as Spar Lake, also reflect the oxidation of organic carbon-bearing reductants in orestage products. The isotopically lightest carbon of the entire Belt Supergroup measured to date is found in ore-stage calcite and ankerite cements from the distal fringes of the Spar Lake deposit (fig. 48).

\section{Integrated Isotopic Studies}

The most valuable of the studies of stable isotopes are those that have integrated studies of both $\mathrm{S}$ and $\mathrm{C}$ isotopes or integrated isotopic studies with other geochemical methods.

Bechtel and others (2001), studying samples from

Sangerhausen, Germany, integrated S-isotope, C-isotope, organic geochemical, and elemental geochemical data. They showed that total $\mathrm{C}_{\text {org }}, \mathrm{C} / \mathrm{S}$ ratios, and hydrogen indices of the organic materials were facies related and did not correlate with $\mathrm{Cu}$-enriched beds. Values of these parameters indicate where pre-ore pyrite was deposited by bacterial sulfate reduction from seawater. Then, with $\mathrm{Fe}-\mathrm{C}_{\mathrm{org}}-\mathrm{S}$ relations and ore microscopy, they showed that in parts of the Kupferschiefer bed with grades of 0.1 to 6 percent $\mathrm{Cu}$, the pyrite was replaced by $\mathrm{Cu}$ - and Fe-bearing sulfides, and the isotopic signature of the replaced pyrite was inherited. With higher grade (greater than 8 percent $\mathrm{Cu}$ ) mineralization, in the lower part of the Kupferschiefer bed, there was (1) deposition of sparry calcite with $\delta^{13} \mathrm{C}$ values substantially lowered relative to the typical marine values found in the top of the shale, (2) reciprocal changes of values of $\delta^{13} \mathrm{C}$ in kerogen and bitumen to heavier isotopic values remaining in those organic residues, and (3) an addition of $\mathrm{Cu}$ sulfides with heavier $\delta^{34} \mathrm{~S}$ deposited by thermochemical reduction of ore solution $\mathrm{SO}_{4}$ coupled with oxidation of the organic carbon.

In studying the Polish Kupferschiefer, Bechtel and others (2002) combined C-isotope, Rock-Eval pyrolysis, and elemental geochemistry data. Just as in Germany, as the $\delta^{13} \mathrm{C}$ of epigenetic calcite shifts to lower values with higher $\mathrm{Cu}$ grades, the $\delta^{13} \mathrm{C}$ of residual kerogen and bitumen shift to heavier isotopic values (fig. 49). The hydrogen indices of the same samples shift to lower, more matured values, and the pyrolysis $\mathrm{T}_{\max }$ values increase. Over the same trends, the oxygen indices increase, seemingly altering the organic matter to entirely different kerogen types and crossing sharply across the ordinary burial maturation pathways for organic matter (fig. 50).

At Spar Lake (Hayes and others, 2012), the isotopically light distal-fringe carbonates are coupled with the sulfide that was thermochemically reduced at ore-stage from $\mathrm{SO}_{4}$ in the metalstransporting brine. The sulfide from ore-stage thermochemical reduction is identifiable where samples have heavy $\delta^{34} \mathrm{~S}$ values in $\mathrm{Cu}$ - or Pb-bearing sulfides and light $\delta^{13} \mathrm{C}$ values in ore-stage calcite from the distal fringes of the deposit (fig. 51). 
Chalcopyrite-ankerite zone, chalcopyrite

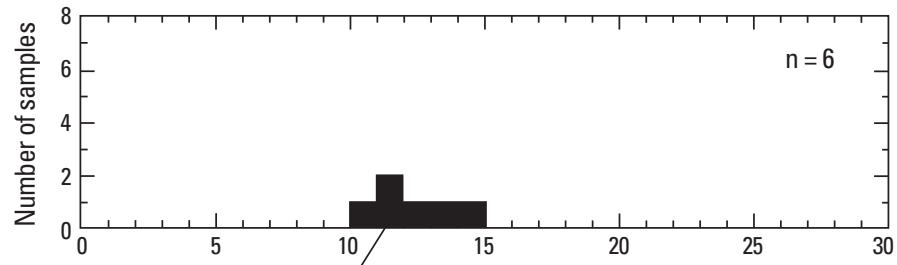

Chalcopyrite ankerite zone, digenite

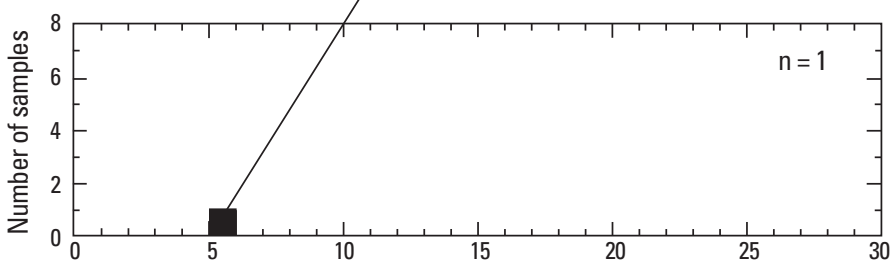

Bornite-diginite chalcocite, mixtures
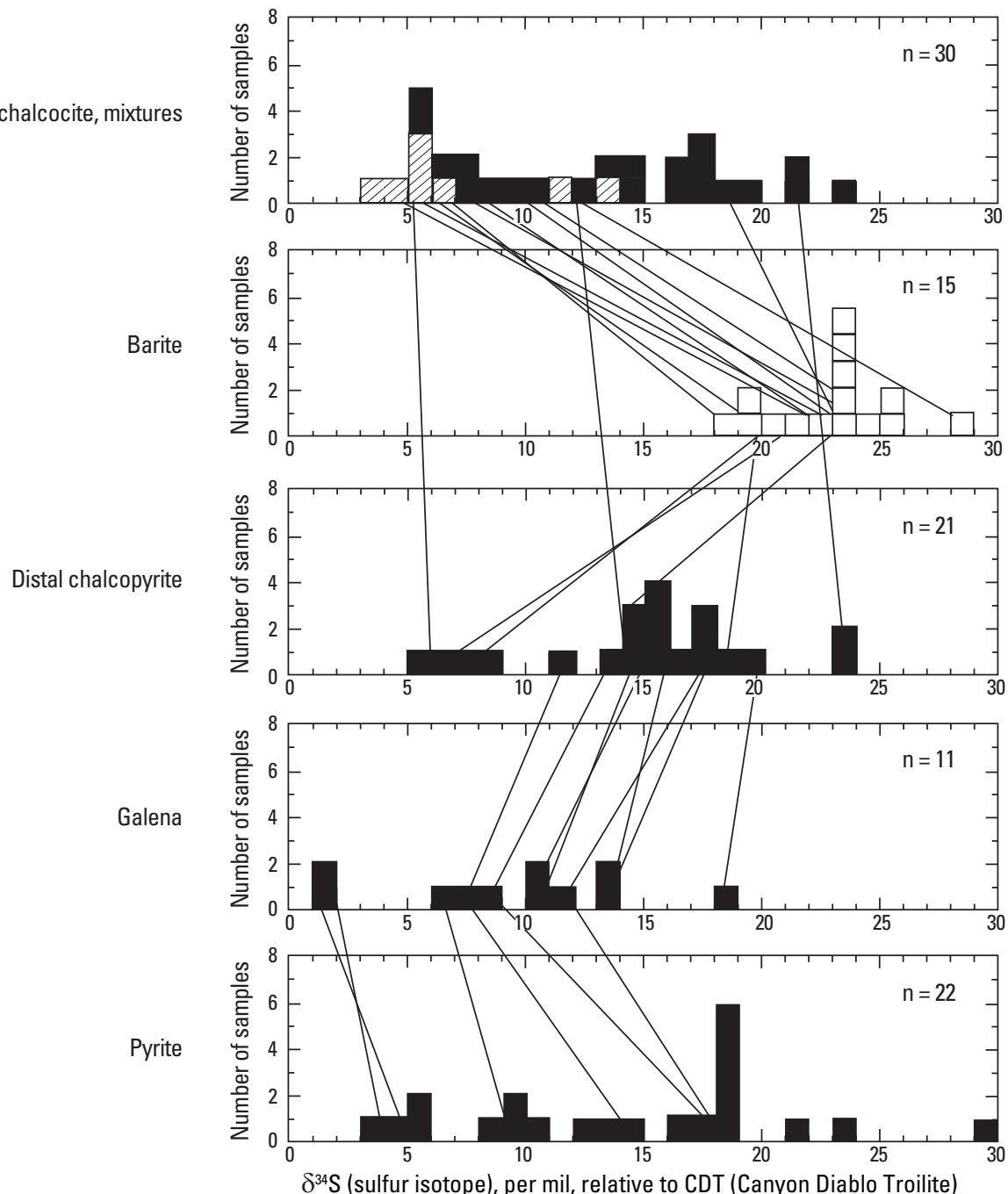

Modified from T.S. Hayes and others, 2012

EXPLANATION

One sulfide sulfur isotope value

$\square$ Ore rods sulfide sulfur isotope value

Barite sulfate sulfur isotope value

Figure 46. Histograms of $\delta^{34} S$ values of sulfides and sulfates across the mineral zonation at the Spar Lake sandstone copper deposit, from Hayes and others (2012). 


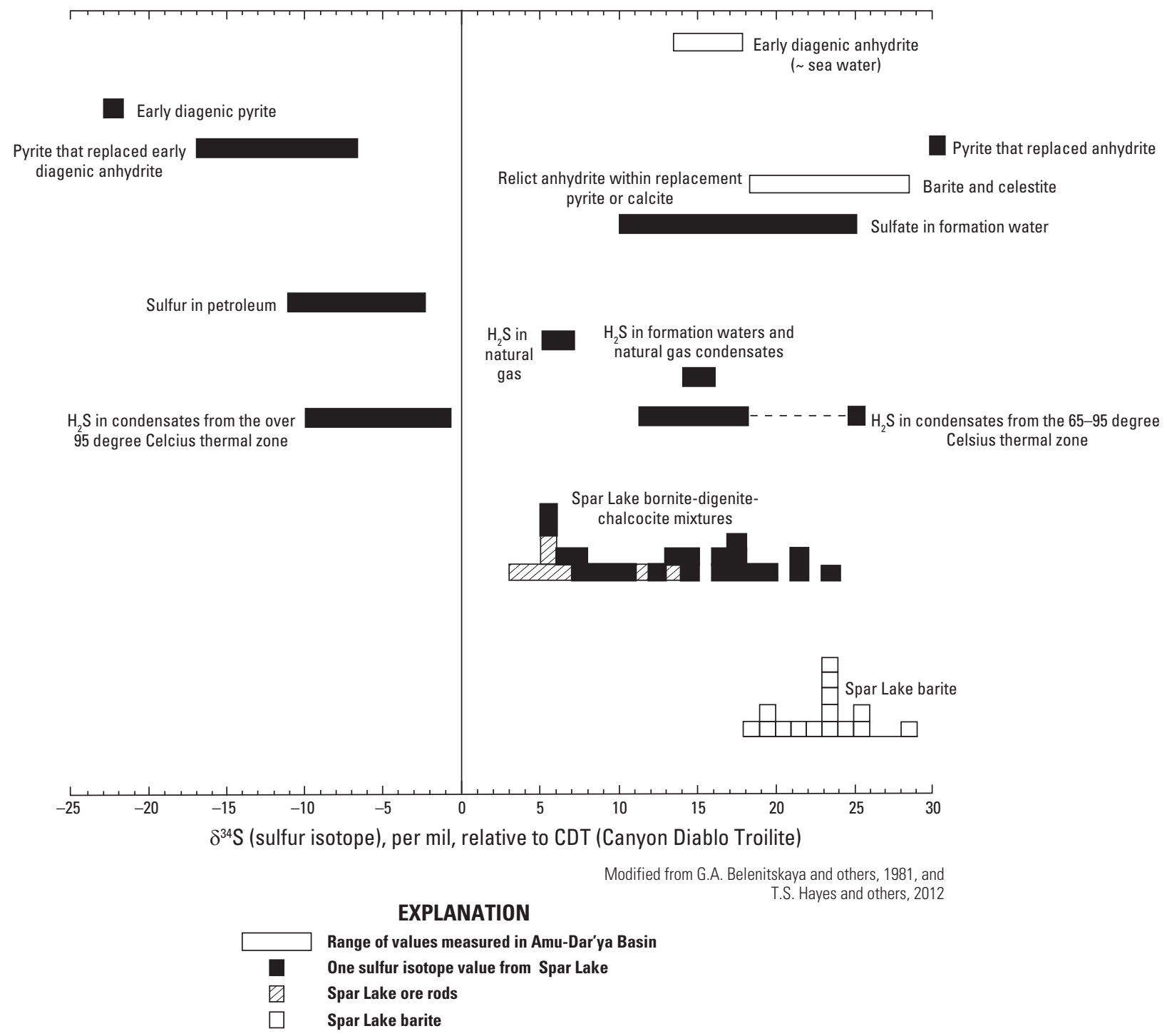

Figure 47. Sulfur-isotope values of the Spar Lake sandstone copper deposit and sulfur-isotope values of various sulfate, sulfide, and petroleum compounds in a typical petroleum-producing basin, the Amu-Dar'ya Basin, Turkmenistan and Uzbekistan. Amu-Dar'ya values are from Belenitskaya and others (1981). The bars extend across the full ranges of values for each particular form of sulfur in the Amu-Dar'ya Basin (the bars are not histograms of individual values). Spar Lake coppersulfide and barite values are shown as histograms.

\section{Isotopic Dating and Radiogenic Isotope Geochemistry}

Isotopic dating of SSC deposits has suffered from the lack of easily dateable minerals within the deposits. Thus, most age constraints have been established by dating interlayered volcanic rocks, tuffs, and the basement rocks beneath the sedimentary-host sections. A few direct dating attempts have been made with limited success.

Earliest dating attempts examined $\mathrm{Pb}$-isotopes, particularly because galena was a part of the mineralization. $\mathrm{Pb}$-isotope studies have been used in attempts to date SSC mineralization and to determine sources of the metals for these deposits. Wedepohl and others (1978) studied whole-rock(?)
$\mathrm{Pb}$-isotopes from Kupferschiefer samples scattered over a large area of central and northern Germany, as well as individual samples from Holland, England, and Poland. The accepted depositional age of the Kupferschiefer is from 260.4 to $258 \mathrm{Ma}$ (Menning and others, 2006; Słowakiewicz and others, 2009), which sets a maximum age for mineralization. Eight of Wedepohl's samples were from Germany; two were ores of $\mathrm{Cu}$, five were from $\mathrm{Pb}$-rich zones, and one sample was from the pyrite zone. The samples were fitted to a line on the cross plot of ${ }^{207} \mathrm{~Pb} /{ }^{204} \mathrm{~Pb}$ and ${ }^{206} \mathrm{~Pb} /{ }^{204} \mathrm{~Pb}$ that intersected the Stacey and Kramers 2-stage terrestrial $\mathrm{Pb}$ evolution curve at $250 \mathrm{Ma}$ and $1750 \mathrm{Ma}$. The interpretation was that these defined a secondary isochron. The former age is obviously close to the depositional age of the Kupferschiefer, and Wedepohl 


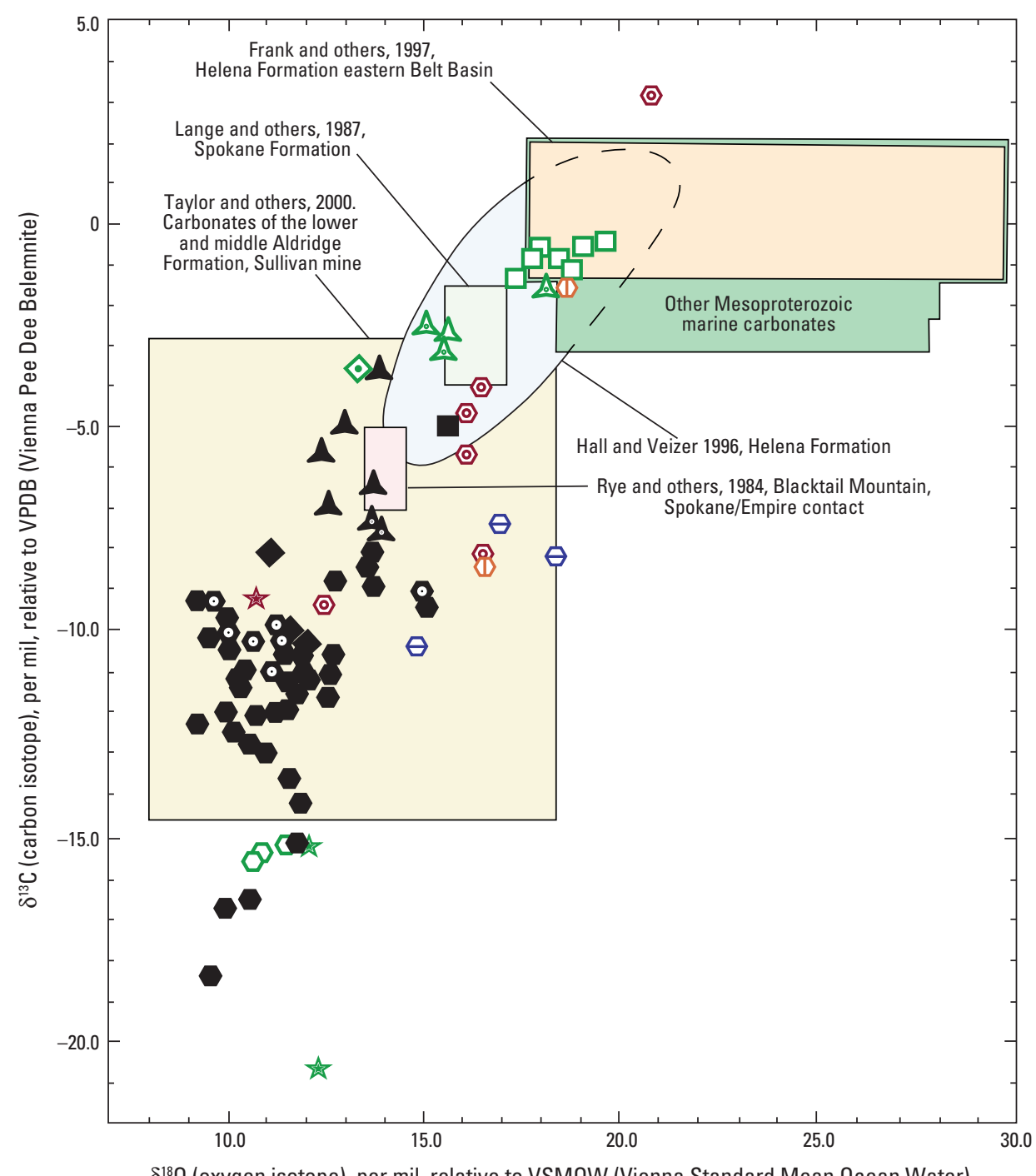

$\delta^{18} \mathrm{O}$ (oxygen isotope), per mil, relative to VSMOW (Vienna Standard Mean Ocean Water)

Modified from T.S. Hayes and others 2012

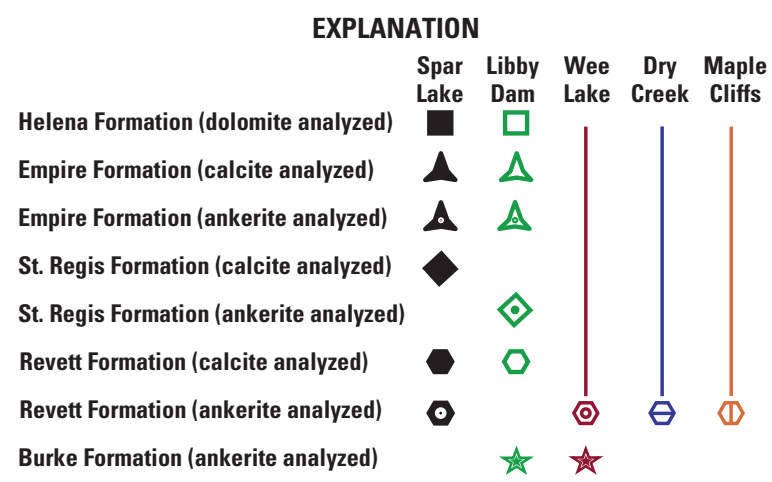

Figure 48. Relation between $\delta^{13} \mathrm{C}$ and $\delta^{18} 0$ of carbonates related to the Spar Lake sandstone copper deposit, from Hayes and others (2012). Isotope values for carbonates about 50 kilometers northeast of Spar Lake are within the lowest part of the range of such values for the Helena Formation and for Mesoproterozoic carbonates elsewhere in the world. Values for the Helena Formation overlying the ore at Spar Lake are lower in $\delta^{13} \mathrm{C}$ and $\delta^{18} 0$, interpreted to indicate that those carbonates derive partly from the carbon in thermally cracked hydrocarbons from a Revett Formation-hosted natural-gas reservoir, below. Values of calcite and ankerite cements in the Revett ores and distal galena and pyrite zones are lighter in $\delta^{13} \mathrm{C}$, particularly, including many values less than -12 per mil. These are interpreted to have employed carbon from ore-stage oxidation of methane of the pre-ore natural gas reservoir in redox reactions coupled with the reduction of ore-fluid sulfate to sulfide in precipitating the copper- and base-metal sulfides. 


\begin{tabular}{|ll} 
Stratigraphy & Metallic \\
& Facies \\
& $\mathrm{Cu}$ \\
& \\
$\mathrm{Ca} 1$ & $\mathrm{Cu}$ \\
& \\
& $\mathrm{Cu}$ \\
& \\
& $\mathrm{Cu}$ \\
& $\mathrm{Cu}$ \\
$\mathrm{T} 1$ & $\mathrm{Cu}$ \\
& $\mathrm{Cu}$ \\
& $\mathrm{Cu}$ \\
$\mathrm{S} 1$ & $\mathrm{Trans}$ \\
& $\mathrm{RF}$
\end{tabular}
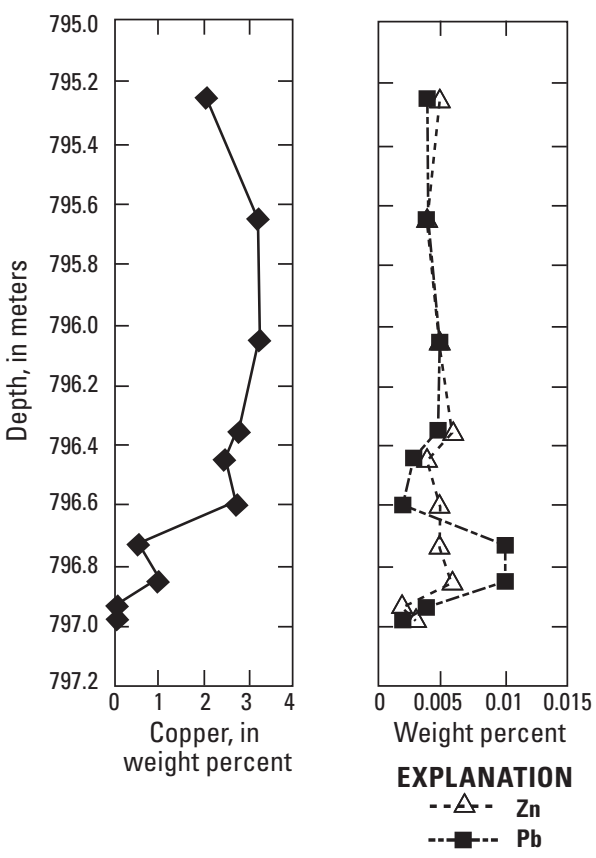

Drill site S 204
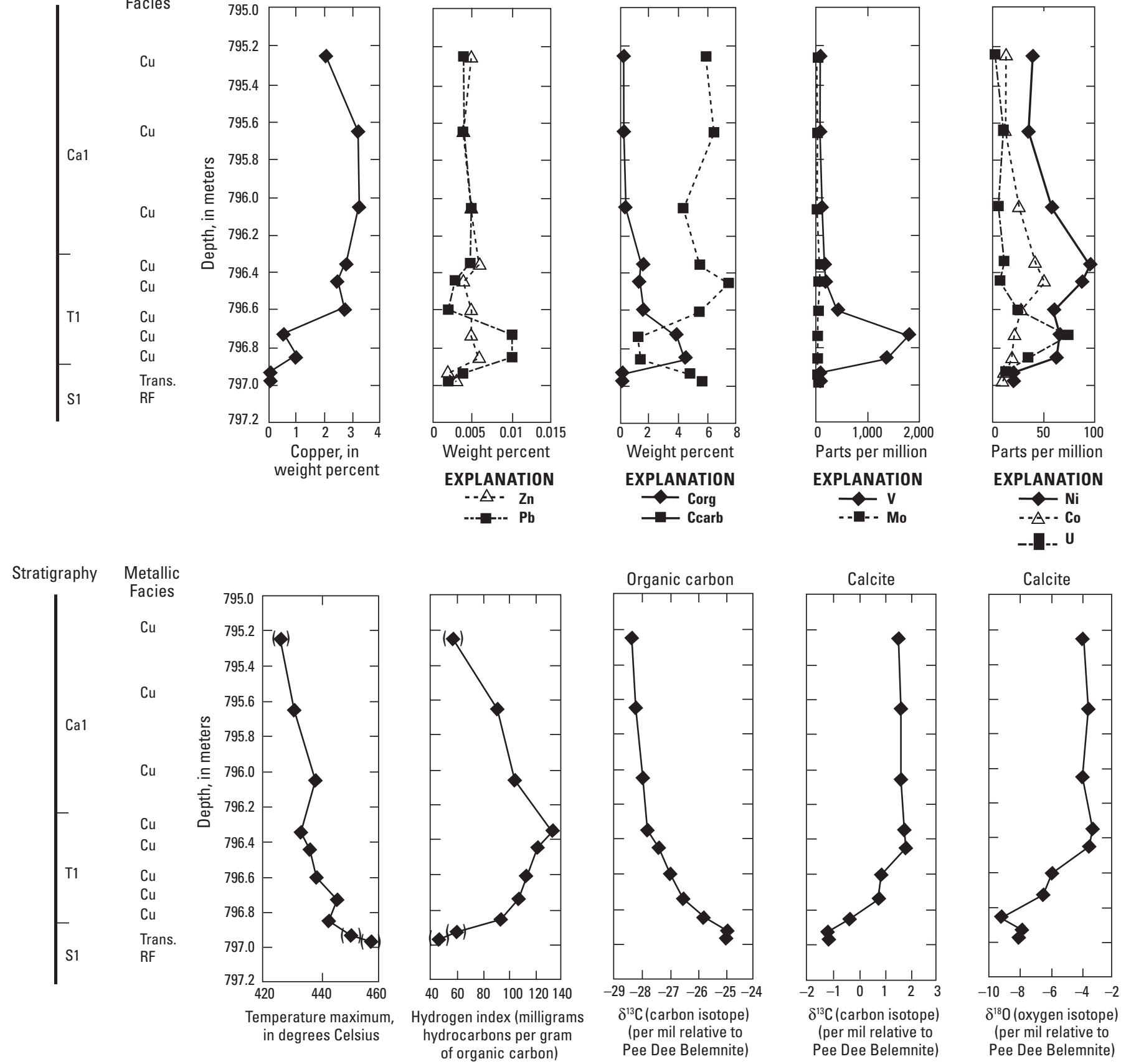

Modified from A. Bechtel and others 2002

Figure 49. Concentrations of copper (Cu), zinc ( $\mathrm{Zn}$ ), lead (Pb), vanadium (V), molybdenum (Mo), nickel (Ni), cobalt (Co), uranium (U), organic carbon $\left(\mathrm{C}_{\text {org }}\right)$ and carbonate carbon $\left(\mathrm{C}_{\text {carb }}\right)$, Rock Eval pyrolysis temperature $\left(\mathrm{T}_{\max }\right)$ and hydrogen index $(\mathrm{HI}), \delta^{13} \mathrm{C}$ of organic carbon, $\delta^{13} \mathrm{C}$ of calcite, and $\delta^{18} \mathrm{O}$ of calcite for a mineralized Kupferschiefer section from the Sieroszowice mine, Poland, from Bechtel and others (2002). Stratigraphic divisions (ascending order): S1 - Weisslilegendes sandstone, T1 - Kupferschiefer shale bed, $\mathrm{Ca} 1$ - Zechstein 1 (Werra) carbonate. $\mathrm{Pb}, \mathrm{U}, \mathrm{V}$, and $\mathrm{Zn}$ are highest where $\mathrm{C}_{\text {org }}$ is highest within the Kupferschiefer black shale, but $\mathrm{Co}$ and $\mathrm{Ni}$ are highest where $\mathrm{Cu}$ is highest in this section. The distribution of $\mathrm{U}$ and $\mathrm{V}$ probably reflects only the black-shale depositional environment, but $\mathrm{Co}$ and $\mathrm{Ni}$ are clearly enriched in the sediment-hosted stratabound copper-mineralizing process. The Rock Eval $\mathrm{T}_{\max }$ climbs steadily downsectionward, indicating more exposure to hot mineralizing brines in that direction. $\mathrm{HI}$, however, correlates with $\mathrm{Cu}$ grade indicating hydrocarbon generation correlated with mineralization intensity. Solid-phase $C_{\text {org }}$ increases steadily in $\delta^{13} \mathrm{C}$ downward while calcite carbon does the reverse. With increasing exposure to hot metals-transporting brines downsectionward, $\mathrm{C}_{\text {org }}$ was oxidized to carbonate, which was precipitated as calcite with low $\delta^{13} \mathrm{C}$, leaving the residual $C_{\text {org }}$ with higher $\delta^{13} \mathrm{C}$. Plotted points enclosed in parentheses contained less than 0.2 weight percent organic carbon at which concentration the analytical values are questionable. 

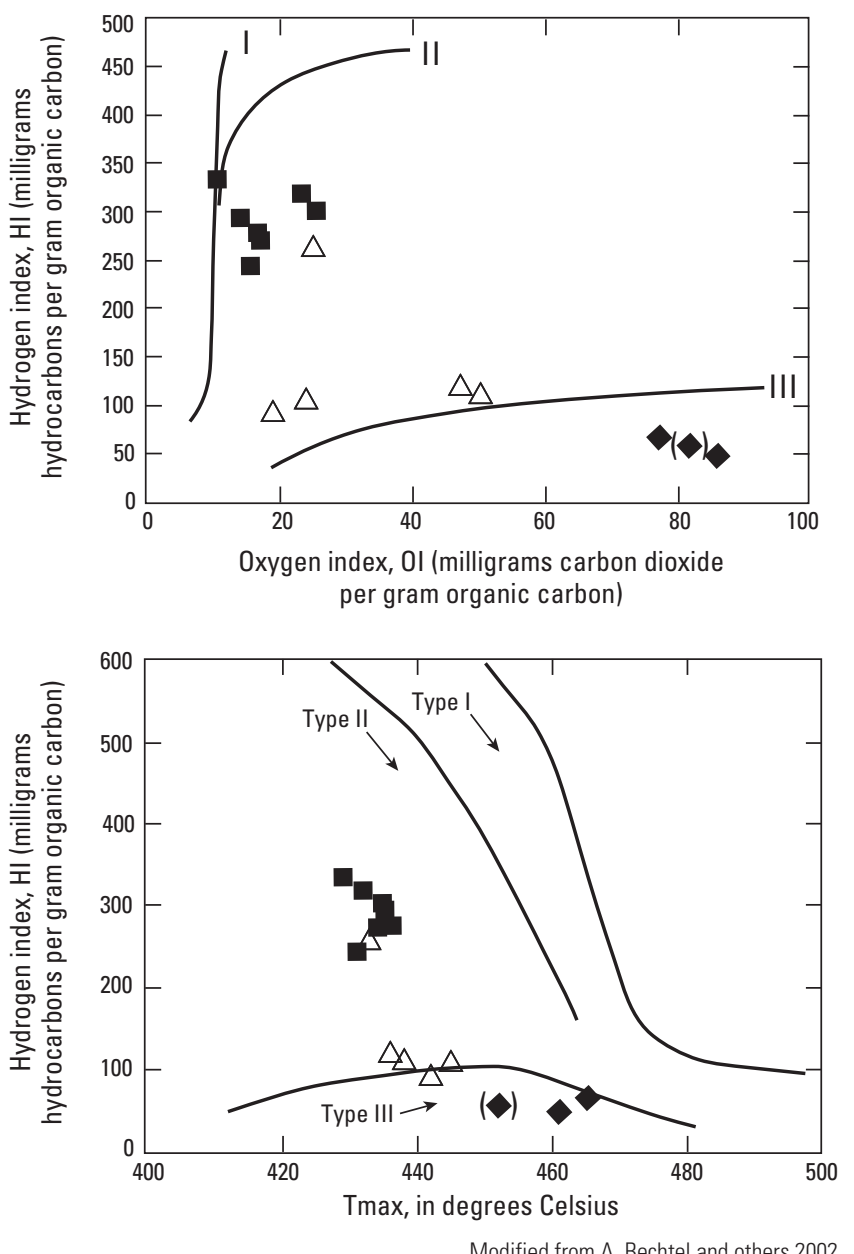

EXPLANATION

$\checkmark$ Rote Faule

$\triangle$ Copper

- Lead/zinc

Figure 50. Standard von Krevelin organics maturation diagram for the samples of a Kupferschiefer section from the Sieroszowice mine, Poland, from Bechtel and others (2002). With a position more and more proximal to the source of hot mineralizing solutions, lead/zinc zone to copper zone to Rote Fäule zone, the Rock Eval pyrolysis maximum temperature $\left(T_{\text {max }}\right)$ climbs steadily, but the hydrogen index (HI) and oxygen index (OI) cross sharply across ordinary organic maturation pathways. The mineralizing process differs from ordinary maturation most obviously in being a chemical oxidation process. Plotted points enclosed in parentheses contained less than 0.2 weight percent organic carbon at which concentration the analytical values are questionable.

stated that it indicated syngenetic origin of the mineralization. The latter age was interpreted to be the age of the source $\mathrm{Pb}$ derived either from Precambrian basement of northern Europe or from clasts derived from that basement. Notably, the other three Kupferschiefer samples (Dutch, British, and Polish) plotted well off the secondary isochron. The $250 \mathrm{Ma}$ age is difficult to interpret, including, as it does, the barren sample as well as any $\mathrm{Pb}$ within unreplaced early diagenetic pyrite, but the source age $(1750 \mathrm{Ma})$ is reasonable and suggests origin of the $\mathrm{Pb}$ in the Precambrian continental basement rocks or from (Rotliegendes?) clasts derived from those basement rocks.

Bechtel and others (1996) attempted to indirectly date the Kupferschiefer mineralization using K-Ar on illite from Kupferschiefer shale samples collected from barren pyritic, $\mathrm{Zn}-\mathrm{Pb}, \mathrm{Cu}-\mathrm{Zn}-\mathrm{Pb}, \mathrm{Cu}$, and Rote Fäule zones. Initial results indicated a Middle Triassic age of mineralization in agreement with the paleomagnetic age from Jowett and others (1987). Bechtel and others (1999) attempted to further refine the illite K-Ar ages using only mineralized samples and extrapolating the arrays of $\mathrm{K}$-Ar ages in illite to 0 percent of the $2 \mathrm{M}_{1}$ polytype of illite, of assumedly detrital origin, trying to date only $1 \mathrm{M}$ and $1 \mathrm{M}_{\mathrm{d}}$ illite polytypes of probable diagenetic, authigenic origin. Results varied from 216 to $190 \mathrm{Ma}$. The wide range in extrapolated ages renders the results uncertain and has led to hypotheses of multistage mineralization, where Weissliegendes sandstone-hosted ore formed at a time later than Kupferschiefer shale-hosted ore (Michalik and Sawłowicz, 2001). Multi-stage mineralization for the disseminated (non-veinlet) ore is not convincing because sulfide-zone boundaries cross gently and continuously with no steep perturbations through all the different rock types.

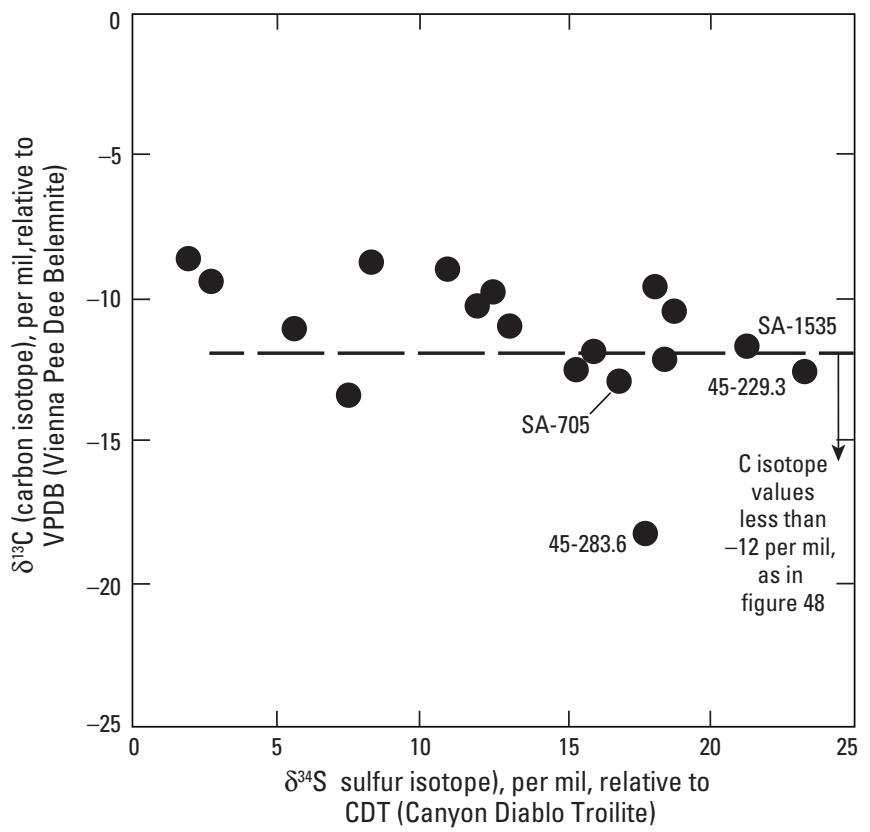

Figure 51. Relation between $\delta^{34} S_{\text {Cu sulfide }}$ and $\delta^{13} C_{\text {carbonate }}$ for 18 samples where both were analyzed from the Spar Lake sandstone copper deposit. Samples having the combination, high $\delta^{34} S_{\text {cu sulfide }}$ and low $\delta^{13} \mathrm{C}_{\text {carbonate }}$ probably indicate ore-stage coupled redox processes where carbon from methane (natural gas) was oxidized, precipitating as calcite, coupled with reduction of ore solution sulfate to sulfide, precipitating as copper sulfides. Four such samples are labeled. Figure 48 showed that much of the $\delta^{34} S_{\text {sulfide }}$ in Spar Lake ore was probably from sour gas $\mathrm{H}_{2} \mathrm{~S}$, so $\delta^{34} \mathrm{~S}$ values much higher than that (greater than 6 permil) reflect increasing contributions of heavy sulfur at ore stage by thermochemical sulfate reduction, made clearer yet where the high $\delta^{34} S$ values are accompanied by carbonates with light (organic-sourced) carbon. 
The Re-Os direct dating of Kupferschiefer mineralization has been tried at several places and the results have been inconsistent. Pätzold and others (2002) found an age of $204.3 \pm 0.5 \mathrm{Ma}$ for Cu-sulfides at Mansfeld and argued for an epigenetic origin of the mineralization. Brauns and others (2003) measured and reported an isochron from several samples from the Sangerhausen deposit with an age of $257 \pm 1.6 \mathrm{Ma}$, leading them to suggest syngenetic origin. Pašava and others (2007b) reported an age of $240 \pm 3.8 \mathrm{Ma}$ from whole-rock samples of $\mathrm{Cu}$-rich mineralization from Lubin mine. Pašava and others (2007a) reported an "altered" age of $279 \pm 14 \mathrm{Ma}$ from the Au-Pt-Pd-rich zone within Rote Fäule rocks of the Polkowice mine. Details on samples and the materials separated and dated for these various studies are not available. Consistency of the methods can be questioned. All these results can be compared with the results from illite dating (above) and with the results from paleomagnetic dating of the Rote Fäule by Jowett and others (1987). The paleomagnetic dating of Rote Fäule hematite initially yielded dates of 250 to $220 \mathrm{Ma}$. Those dates were later refined to 255 to 245 Ma by Nawrocki (2000) on the basis of improved polar wander paths. Only the Re-Os age of $240 \pm 3.8 \mathrm{Ma}$ on $\mathrm{Cu}$-rich rocks from Pašava and others (2007b) is close to agreement with the paleomagnetic dating.

It remains unclear what the age of the main stage(s) of $\mathrm{Cu}$ mineralization is (are) for Kupferschiefer deposits. Although it is possible that different ages of mineralization could apply to distantly separated Kupferschiefer districts, it seems unlikely that, across the basin, the principal mineralizing events could have been spread from the age of host rock deposition in the Late Permian all the way through the Early Jurassic in rocks that have never seen a post-ore orogeny.

The SSC deposit with the best-constrained mineralization age is White Pine. In the Midcontinent Rift-fill rocks, the Portage Lake lavas were extruded between 1,096 \pm 1.8 and $1,094 \pm 1.6 \mathrm{Ma}$ (U-Pb on zircon; Davis and Paces, 1990). These were followed upward by the Copper Harbor Conglomerate, coarse clastic red beds, with an interleaved andesite flow that was dated at $1,087 \pm 1.6 \mathrm{Ma}$ (U-Pb on zircon; Davis and Paces, 1990). In the White Pine deposit, the Junior Limestone bed has been dated at $1,081 \pm 9 \mathrm{Ma}$ by a ${ }^{207} \mathrm{~Pb} /{ }^{206} \mathrm{~Pb}$ isochron $(\mathrm{Ohr}$, 1993). The Junior Limestone of the deposit has greater concentrations of $\mathrm{U}$, parent of the radiogenic $\mathrm{Pb}$, than does a sample of the same bed from outside of mineralization. The age is that for diagenesis of the calcite in the limestone, which is considered to overlap with the early diagenetic main-stage $\mathrm{Cu}$-sulfide mineralization. The U-Pb isochron is corroborated by a ${ }^{87} \mathrm{Rb}-{ }^{86} \mathrm{Sr}$ isochron of 1,093 $\pm 15 \mathrm{Ma}$ on 11 shale and siltstone samples, mineralized and unmineralized, from the deposit area. A second stage of $\mathrm{Cu}$ mineralization at White Pine consists of veinlets and disseminations associated with compressional tectonic features and dominated by native copper (Mauk and others, 1992b). The ${ }^{147} \mathrm{Sm} /{ }^{144} \mathrm{Nd}$ age of two calcite samples from such veinlets is $1,043 \pm 40 \mathrm{Ma}(\mathrm{Ohr}, 1993)$ and the ${ }^{87} \mathrm{Rb} /{ }^{86} \mathrm{Sr}$ model age for the veinlets is $1,020 \pm 18 \mathrm{Ma}(\mathrm{Ohr}, 1993)$. Those ages overlap within uncertainties with each other and with ${ }^{87} \mathrm{Rb}-{ }^{86} \mathrm{Sr}$ ages of 1,060 to $1,047 \pm 20 \mathrm{Ma}$ on microcline, calcite, epidote, and chlorite alteration minerals associated with native copper veins, amygdule fillings, and conglomerate cements from the Keweenaw native copper district about $100 \mathrm{~km}$ to the northeast (Bornhorst and others, 1988). Thus, rapid deposition of more than a kilometer of Copper Harbor aquifer red beds and the lower Nonesuch reduced-facies host rocks and calcite diagenesis accompanying main-stage $\mathrm{Cu}$-sulfide mineralization all took place over no more than 15 million years after deposition of the andesite flow and probably within just 6 million years. Basin inversion, compressional tectonics, second-stage $\mathrm{Cu}$ mineralization at White Pine, and mineralization of the native copper district all occurred within the next 30 to 70 million years.

Selley and others (2005) reported results of Re-Os dating on $\mathrm{Cu}$ sulfides in the Zambian deposits. They reported a six-point Re-Os isochron on disseminated chalcopyrite and bornite from Konkola with a slope age of $816 \pm 62 \mathrm{Ma}$. The age is probably correct for main-stage diagenetic disseminated, but not veinlet, mineralization. The host rocks were deposited after $883 \pm 10 \mathrm{Ma}$ because that is the age of basement Nchanga red granite (Armstrong and others, 2005). However, the large uncertainty limits the utility of the reported age. The large uncertainty resulted from relatively high concentrations of common Os in the sulfides. Richards and others (1988a) studied $\mathrm{Pb}$ isotopes of the $\mathrm{Cu}$-sulfides from Musoshi in the Copperbelt in Democratic Republic of Congo. They found, from 15 analyses of 3 samples that were free of veinlets and least recrystallized, as well as free from coarse biotite, a secondary isochron on the ${ }^{207} \mathrm{~Pb} /{ }^{204} \mathrm{~Pb}$ versus ${ }^{206} \mathrm{~Pb} /{ }^{204} \mathrm{~Pb}$ plot defining an age of $645 \pm 15 \mathrm{Ma}$. Other, more recrystallized samples and veinlets were scattered below the two-stage model age line. They recognized two possible interpretations: (1) the deposit formed at $645 \pm 15 \mathrm{Ma}$, or (2) the Pb isotopes of the deposit homogenized at that time in a pre-existing orebody, by a process that also introduced $\mathrm{U}$ and thorium into the deposit. In either case, the age is a minimum age for the disseminated deposit. Because the result is 100 million years after the youngest age allowed within the uncertainties from Selley and others (2005) (above), who also used Konkola disseminated sulfides, the second appears to be the proper interpretation; that is, $645 \mathrm{Ma}$ is the age of homogenization of the $\mathrm{Pb}$ isotopes and it post-dates the age of mineralization. The results entirely eliminated the possibility of a contribution of mantle- or mafic-rock $\mathrm{Pb}$ to the $\mathrm{Cu}$ sulfides. This negates the hypothesis of Annels and Simmonds (1984) that the Co of the Ore Shale belt of deposits in Zambia came from metagabbro intrusions along the belt.

Selley and others (2005) also reported a 7-point Re-Os isochron with a slope age of $576 \pm 41$ Ma for disseminated and veinlet chalcopyrite and bornite from the Nkana-Mindola and Chibuluma West deposits and from carrollite from the upper orebody at Nchanga. The age corresponds to the early stages of basin inversion and post-dates deposition of the Petit Conglomerate at about $635 \mathrm{Ma}$. The Nkana-ChibulumaNchanga isochron also falls within the range of ages for Roan Group metamorphic monazites from the Chambishi 
basin. Those metamorphic ages are $592 \pm 22,531 \pm 12$, and $512 \pm 12 \mathrm{Ma}$ (Rainaud and others, 2005), and the latter two of those overlap as well with ages from veinlet mineralization.

Dating the later vein/veinlet-controlled mineralizing events in the Central African Copperbelt has proven relatively simple. For example, Richards and others (1988b) obtained an age of $514 \pm 2 \mathrm{Ma}$ by U-Pb for rutile in quartz-hematite( \pm microcline-biotite-rutile) veins, with late calcite, siderite, anhydrite, and barite that cut stratiform $\mathrm{Cu}$ ore at Musoshi. Barra and others (2004) measured an age of $525.7 \pm 3.4$ Ma by Re-Os on molybdenite from a chalcopyrite-bearing vein that cuts stratiform mineralization at Nkana-Mindola. Richards and others (1988a) confirmed the late overprinting vein event with a U-Pb date of $514 \pm 3 \mathrm{Ma}$ on uraninite from a veinlet that cut the Ore Shale at Musoshi. Postpeak-metamorphic veinlet $\mathrm{Cu}-\mathrm{U}-\mathrm{Mo}$ mineralization at Kansanshi is dated at $512-502 \mathrm{Ma}$ (Torrealday and others, 2000).

Uplift and cooling in the Central African Copperbelt have also proven relatively simple to date (Rainaud and others, 2005). The ${ }^{40} \mathrm{Ar} /{ }^{39} \mathrm{Ar}$ ages from Luanshya biotite give an age of $586 \pm 1.7 \mathrm{Ma}$, coinciding with the oldest metamorphic monazite age from the Chambishi Basin to its north. Biotite and muscovite plateau ages from the Chambishi basin and Konkola range from $496.6 \pm 0.6$ to $483.6 \pm 1.1 \mathrm{Ma}$. Microcline ${ }^{40} \mathrm{Ar} /{ }^{39} \mathrm{Ar}$ ages from Musoshi range from $467 \pm 2.7$ to $405.8 \pm 3.8 \mathrm{Ma}$. The data indicate that uplift proceeded from south to north in the southeastern segment of the Copperbelt.

Aleinikoff and others (2012) obtained a ${ }^{207} \mathrm{~Pb} /{ }^{206} \mathrm{~Pb}$ age of $1,409 \pm 8 \mathrm{Ma}$ on xenotime overgrowths on detrital zircons from Spar Lake, attempting to indirectly date the ore deposition. The xenotime overgrowths are closely associated with $\mathrm{Cu}$ sulfides in such a way that they had to be either ore-stage, or dating from between host-rock deposition and the ore stage. Spar Lake host rocks were deposited after 1,469 $\pm 3 \mathrm{Ma}$ (Sears and Price, 2003) and before 1,454 $\pm 9 \mathrm{Ma}$ (Evans and others, 2000), and the ore was deposited where an oxidized metalliferous brine reacted with reservoired natural gas. The 1,409 \pm 8 Ma age is, within uncertainties, the same age as deposition of the Libby Formation of the upper part of the Belt Supergroup, about $5 \mathrm{~km}$ upsection from the Spar Lake host rocks (Evans and others, 2000), thus predicting $5 \mathrm{~km}$ as the approximate depth of burial at the time of mineralizing the natural-gas reservoir.

\section{Petrology of Associated Sedimentary Rocks}

The rocks of SSC deposits have sedimentologic and petrologic features common to the same kinds of sedimentary sequences and rock types that lack the ore minerals. That simple observation is what has made the application of ordinary methods of sedimentology and sedimentary petrology effective means of understanding the genesis of these deposits.

\section{Depositional Environments}

Various depositional environments are represented in the host rocks of SSC deposits. Reduced-facies types and some sandstone $\mathrm{Cu}$ types have host rocks that are parts of overall large-scale transgressive sequences that may total several hundreds of meters in thickness. They feature open-shelf marine carbonate rocks overlying coastal marine rocks that are overlying fluvial coarse clastic rocks.

The Copperbelt Orebody Member of Zambia, as well as D.Strat., RSF, and SDB host beds of Democratic Republic of Congo, are deposits of coastal sabkhas (Illing and others, 1965; Kinsman, 1969; Renfro, 1974; Shinn, 1983). These are coastal marine deposits of thinly laminated carbonaceous gypsiferous mudstone and siltstone or of thinly laminated carbonaceous gypsiferous dolostone. The sabkha beds overlie coastal eolian sandstones, fluvial sandstones, or intertidal mud flat siltstones and mudstones.

The most obvious of all the sabkha environment host rocks for SSC deposits are the Cu-bearing gray to green shale beds of the otherwise red Late Permian Flowerpot Shale in southwestern Oklahoma and the Texas panhandle. Each of the beds is overlain by rock gypsum beds in vertical sequences of lithologies and sedimentary structures of sabkha depositional environments (Smith, 1976). Gypsum textures in particular identify the coastal sabkhas (Shinn, 1983).

The Kuperschiefer bed is the deepest marine rock of its local section, deposited during a maximum transgression of Zechstein time and below storm-wave base on an open shelf. It is not a coastal sabkha deposit. It has massive, bioturbated (dysaerobic), and laminated (anaerobic) facies. At the southern margin of the Zechstein Basin, however, the Kupferschiefer bed changes facies to deposits 3 to $5 \mathrm{~m}$ thick of a shallower water carbonate bank, with medium and thin alternation of marl and fossiliferous limestone packstones. The overlying Zechstein limestone consists of three shoaling upward sequences, 0.2 to $20 \mathrm{~m}$ thick, with open marine, sub-wave base burrowed carbonate mudstone or wackestone at the base, changing upwards to ooidal packstones and grainstones, and locally upward again to small-scale hemispheroidal stromatolitic, but probably subtidal beds.

Underlying the Kupferschiefer are the Weissliegendes sandstone beds that are considered to be eolian at the base and shallow marine, wave-dominated at the top (Peryt, 1989). Laterally, the Weissleigendes sandstone beds change to different depositional lithofacies. Pryor (1971) rejected an eolian origin for the Weissliegendes in parts of Germany and concluded that they were deposited on a shallow, offshore marine sea floor beyond the surf zone. Those environments are similar to the environments of deposition of the favored host rocks for sandstone $\mathrm{Cu}$ deposits (see below).

Host rocks for sandstone $\mathrm{Cu}$ deposits were deposited in a variety of environments. Ores are hosted by subtidal, highenergy nearshore marine rocks (deposits of longshore bars or tidal channels) where the host-rock depositional environments are best known at Mufulira (van Eden, 1974) and Spar Lake (Hayes and Einaudi, 1986). These are fine- to medium-grained, 
well-sorted sandstones. Beach and nearshore sandstones also host some ore at Spar Lake. Those rocks are very fine- to finegrained, well-sorted sandstones with an abundance of heavy mineral laminae in their uppermost several meters.

However, the depositional environment of the lensshaped bodies of the highest grade rock at Mufulira, termed carbonaceous wacke and mottled sandstone, remain enigmatic. These are poorly sorted, in sharp contrast with other Mufulira quartzites (above), and they have a wider range of grain sizes, with their modes finer than other footwall and orebody quartzites. The sand grains are also less rounded (van Eden, 1974). It is likely that many of the observed features of the carbonaceous wackes attributed by van Eden (1974) to a low-energy depositional environment are actually the product of diagenesis in a petroleum reservoir that was then overprinted by the $\mathrm{Cu}$ mineralization.

\section{Carbonate/Evaporite Diagenetic Petrology}

Sedimentary rocks record the diagenetic changes that occur through time in sequences of cements and replacements. Changes include those because of increased heat and pressure from burial and changes because of introduction of groundwater of different composition. The latter are far more important in genesis of an SSC deposit, although metalstransporting solutions were apparently also hot (see earlier sections on fluid inclusions). For SSC deposits, the diagenetic changes are paragenetic sequences of ore and gangue minerals that record changes in pore-fluid chemistry before mineralizing fluids arrive, when mineralizing fluids are present, and after mineralization.

Some minerals that are typically precipitated during diagenesis of sedimentary rocks are, for the host rocks of SSC deposits, one and the same as important ore-stage gangue minerals. For the most part, these are not unusual or anomalous minerals in sedimentary diagenesis. There is no better illustration of this than with the quartz and carbonate minerals that replace the crystalloblasts (Oosterbosch, 1951, fig. 16) and the nodules of gypsum and anhydrite in silty or muddy carbonate rocks, such as in the D.Strat, RSF, and SDB beds of the Copperbelt in the Democratic Republic of Congo (fig. 8) (Muchez and others, 2008).

There is extensive literature recording the diagenetic replacement of gypsum or anhydrite by silica minerals (Folk and Pittman, 1971; Levandowski and others, 1973; Milner, 1976; Siedlecka, 1976; Chowns and Elkins, 1974; Milliken, 1979; Young, 1979; Geeslin and Chafetz, 1982; Ulmer-Scholle and others, 1993; Luebking and others, 2001; Henchiri and Slim-S'himi, 2006). In most cases, morphology of former anhydrite nodules is recognized in nodules now consisting of quartz and (or) chalcedony. In the midcontinent area of the United States, the knobby, irregularly shaped silica nodules had earlier been termed "cauliflower chert" (Chowns and Elkins, 1974). In some, coarse-crystalline calcite is also present in the pseudomorphed anhydrite. Relicts of anhydrite are locally present. In one case (Ulmer-Scholle and others, 1993), pyrite is encapsulated within the replacement quartz, and oil occurs as fluid inclusions. In one case (Milner, 1976), pyrite is found as a rim surrounding gypsum in unreplaced nodules in the subsurface, whereas in two cases, hematite interpreted as weathering-zone pseudomorphs of subsurface pyrite is found as rims surrounding silica-replaced anhydrite nodules (Milner, 1976; Young, 1979). In one place where silica minerals are not found as a replacement of anhydrite nodules, coarse calcite replaces the anhydrite (Shearman and Fuller, 1969).

Dewaele and others (2006) described the entire diagenetic sequence of minerals in the orebodies at Kamoto and Musonoi, making effective use of cathodoluminescent petrology, although their main purpose in doing so appears to have been to determine generations of fluid inclusions. Nonetheless, they identified that the earliest diagenetic minerals were pyrite, anhydrite, and a first generation of dolomite. These were followed by quartz, chalcopyrite, bornite, digenite, and chalcocite that replaced most of the anhydrite and replaced pyrite everywhere except at the tops of orebodies. The earliest generation of ore minerals was followed by luminescing and therefore probably Mn-rich, dolomite and additional chalcocite and digenite. Later veinlet mineralization included growth-zoned, strongly luminescing, coarse dolomite, with chalcocite, digenite, and hematite. All these were followed by supergene alteration with malachite, azurite, chrysocolla, cuprite, and heterogenite.

\section{Sandstone Diagenetic Petrology}

There is more detailed reference material on sandstone petrology because petroleum geologists have extensively studied the petrology of reservoir rocks. Just as in the changes seen in the diagenesis of sulfate-bearing evaporites, the diagenetic changes seen in sandstone $\mathrm{Cu}$ deposits are all typical of any diagenesis, except, mainly, for presence of the $\mathrm{Cu}$ minerals. Every authigenic gangue mineral that is zonally distributed in the Spar Lake sandstone $\mathrm{Cu}$ deposit, with the exceptions of barite and $\mathrm{Ba}$ mica, has been found elsewhere as the product of ordinary diagenesis of sandstones.

Much of the paragenesis of the authigenic gangue minerals at Spar Lake was illustrated earlier in the section on Hypogene Gangue Minerals. This section will be used to provide references about deposition of the same authigenic minerals in unmineralized sedimentary rocks remote from SSC deposits, followed by some further description of these minerals within SSC ores.

Many of the authigenic gangue minerals arranged zonally at Spar Lake (fig. 6) have been found in the same paragenetic sequence as at the deposit, but across a gradient in burial depth and temperature in the Tertiary sandstones of the Gulf Coast in Texas (fig. 52; Boles, 1978, 1982; Boles and Franks, 1979). It is not being suggested that the Spar Lake deposit formed at the same burial depths at which the various minerals appeared on the Gulf Coast. Instead, the suggestion is that fluids from such depths, in equilibrium with albite-ankerite-chlorite, migrated to lower-temperature environments to mix with cooler fluids to deposit ore. 


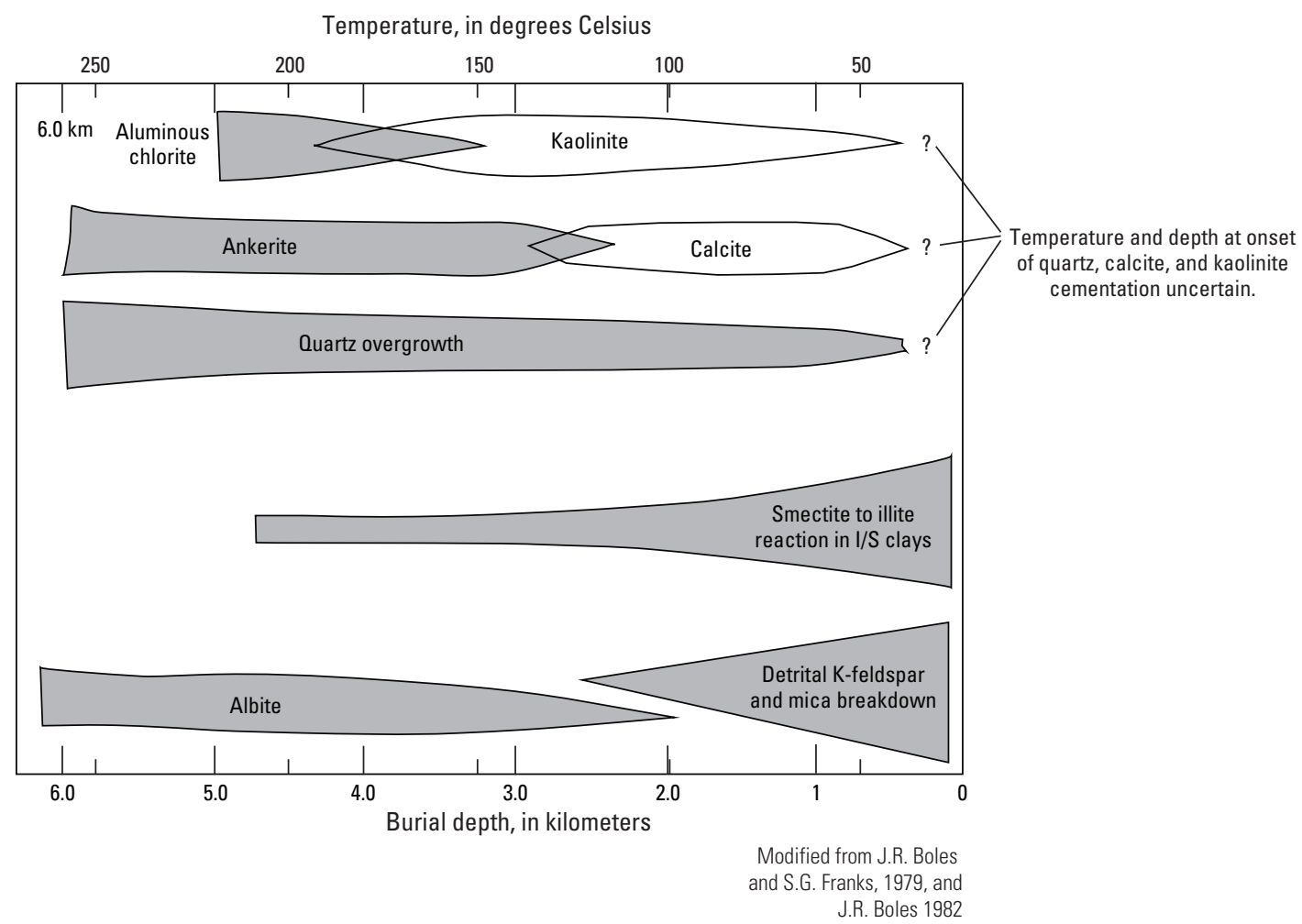

Figure 52. Authigenic minerals in Tertiary sandstones of the Gulf Coast, Texas, their sequence of appearance and relative abundance with depth and temperature (from Boles and Franks, 1979, and Boles, 1982). Among these minerals, quartz overgrowth, calcite, albite, ankerite, and chlorite occur within the same zonal and paragenetic sequence in moving from the fringes to the center of the Spar Lake sediment-bound stratabound copper sandstone deposits (fig. 6).

The discussions of petrology in sandstone $\mathrm{Cu}$ deposits, below, follow the sequence of mineral groups in figure 6, top to bottom. The section makes liberal use of cathodoluminescent photomicrographs to show cementation sequences (orestage paragenesis), and that serve to demonstrate the utility of using the luminoscope in studies of sedimentary rocks.

\section{Iron-Titanium 0xides}

Iron-titanium (Fe-Ti) oxides are minor constituents of most siliciclastic sedimentary rocks, and their authigenesis in such rocks has been studied with reference to sandstone U deposits (Adams and others, 1974; Reynolds and Goldhaber, 1978), to heavy mineral sand deposits (Bailey and others, 1956; Lind, 1961; Temple, 1966), and to SSC deposits (Dimanche and Bartholomé, 1976). These papers that describe changes to Fe-Ti oxide minerals after sedimentation all draw fundamentally on knowledge of Fe-Ti oxides in the source areas for the sediments (Haggerty, 1976).

The Fe-Ti oxides are useful in studying SSC deposits because they are sensitive indicators of redox states and redox histories. Parts of the redox histories are common between all three of the deposit types mentioned above. Two types of $\mathrm{Fe}$-Ti oxide grains are useful starting materials. The first are grains that were originally of the ulvöspinel-magnetite solid solution, which typically alter subsolidus, but still in magmatic rocks, to grains of ilmeno-magnetite. The ulvöspinelmagnetite solid solutions exsolve on cooling, with ilmenite forming rod-shaped grains along the magnetite isometric crystal axes. Cuts through the grains have the appearance of trellises of ilmenite within magnetite (Haggerty, 1976) (fig. 53). The second useful starting materials are ilmeno-hematite grains typical, instead, within Fenner reaction series igneous rocks. They consist of platelets of ilmenite within hematite, the ilmenite occurring along $\{0001\}$ rhombohedral planes in the hematite (fig. 54), and these ilmenite platelets are also typically just a few to $10 \mu \mathrm{m}$ thick (Haggerty, 1976). Both types of common Fe-Ti exsolution grains typically survive weathering, transport, and deposition, and remain mostly stable through all red-bed diagenesis, although alteration to produce fine, red, hematite pigment is typical in red beds (fig. 53) (Turner, 1980). In red beds, these two types of Fe-Ti oxide clasts continue to be stable throughout burial diagenesis (Turner, 1980) (for example, fig. 54).

In non-red sediments, however, the diagenetic history of both types of Fe-Ti exsolution detrital grains can be complex, and, for the case of SSC-deposit host rocks, it is complex (Dimanche and Bartholomé, 1976; Hayes, 1983, 1984). In reducing early diagenesis, the $\mathrm{Fe}$ of the magnetite, hematite, and ilmenite dissolves. However, the Ti of the ilmenite does 


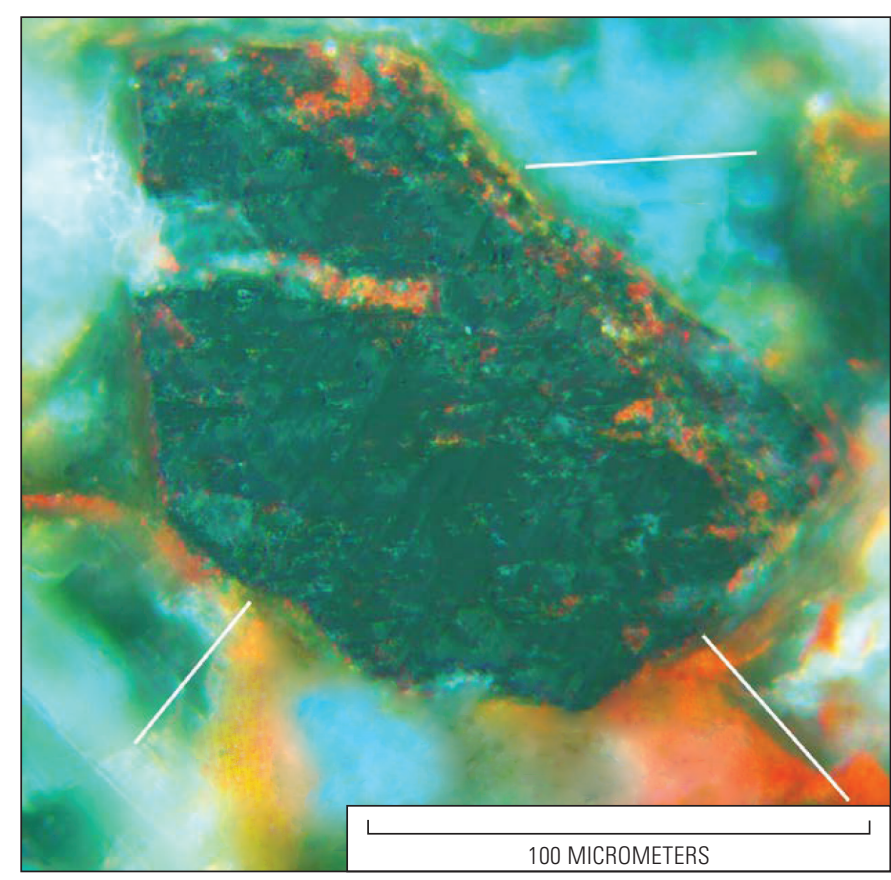

Figure 53. A typical detrital grain of ilmenomagnetite from red beds. Photomicrograph in reflected, cross-polarized light of a sample from the Permian Cutler Formation, southeastern Utah. Bright red internal reflections are from authigenic hematite that partly alters the ilmenomagnetite and ubiquitously rims detrital grains as a first cementing mineral. The grain-rimming hematite is typical of all red beds. Magnetite is black, and ilmenite is blue-green. The ilmenite forms exsolved rods along the three octahedral directions of the host magnetite, parallel with the directions of the three superimposed white lines. Thus, ilmenite forms a 3-dimensional trellis of grains within the host magnetite.

not. Instead the ilmenite needles or platelets become pseudomorphed by $\mathrm{TiO}_{2}$ phases, typically leucoxene, but probably in places, either rutile or anatase (figs. 19A and 19B). Trellis or stacked-plate leucoxene aggregates are far too delicate to have survived erosion and transport as they are found now. Instead, they had to be eroded and transported as grains that still consisted mainly of magnetite or hematite, and the alteration of exsolved ilmenite to leucoxene happened during diagenesis. There is typically also a hand-lens to microscopic scale association of the leucoxene trellises or stacked-plate aggregates with pyrite or another Fe-bearing sulfide. Dissolution and pseudomorphing can apparently take place early, the typical case for reduced-facies host rocks, or may take place somewhat later in sandstone $\mathrm{Cu}$ hosts, perhaps because of reducing fluids, such as petroleum, during their migration into reservoir rocks. In reduced-facies and sandstone $\mathrm{Cu}$ hosts, orestage replacement of pyrite by $\mathrm{Cu}$ sulfides accompanied by an ore-stage generation of hematite pigment (fig. 19B and 19C; Dimanche and Bartholomé, 1976, fig. 11C) is a final step.

\section{Carbonate Cements}

Calcite is one of the commonest of all cementing minerals in all types of sandstones (Dapples, 1971; Folk, 1974; Fuchtbauer, 1972; Jonas and McBride, 1977). It can occur in many different places in a diagenetic sequence of cements and temporally from early to late (fig. 55; Blanche and Whitaker, 1978). As a cement, it has micritic or sparry textures. Folk (1974) emphasizes that the micritic cements typically precipitated from saline pore waters, and the sparry cements typically precipitated from dilute groundwater. In marine settings, calcite cements can precipitate early, such that grain-to-grain contacts of detrital grains are rarely intersected by the plane of the thin section.

The calcite of the Spar Lake sandstone $\mathrm{Cu}$ deposit and probably that of Dzhezkazgan (Gablina and Tsepin, 1975) is not early. It likely replaces parts of adjacent detrital quartz and feldspar grains. It is poikilotopic, enclosing a number of individual detrital $0.1-\mathrm{mm}$ silicate grains in optically continuous crystals of several millimeters. Although it is sparry, it did not precipitate from dilute groundwater, as demonstrated by fluid inclusions with greater than 10 eq. wt. $\% \mathrm{NaCl}$. Possibly, the elevated temperatures and deep burial at the time of its deposition has made it an exception to Folk's (1974) generalities about micritic versus sparry calcite cements. It has unique composition with high Fe through the pyrite-calcite,

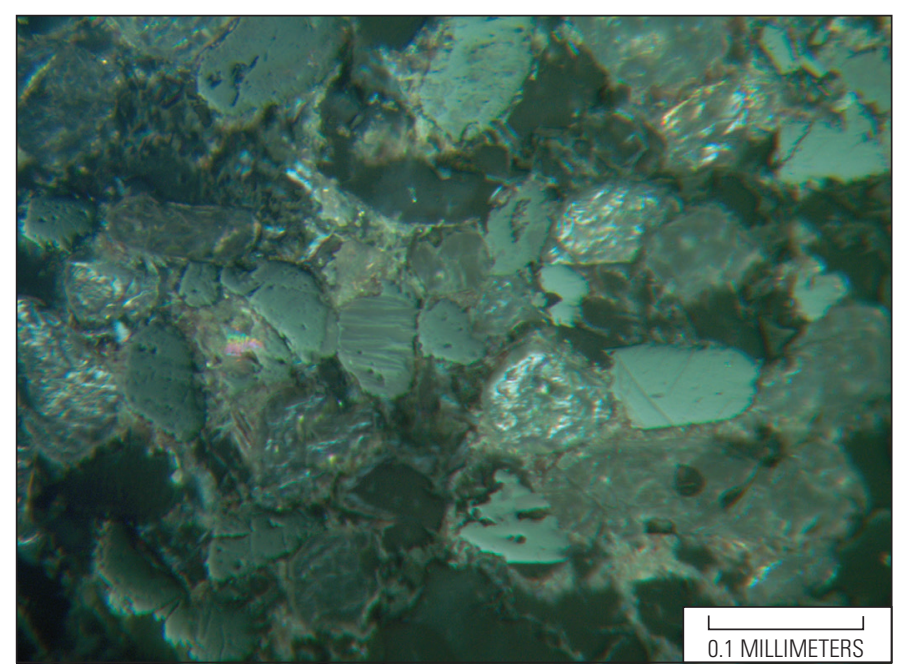

Figure 54. A typical detrital grain of ilmenohematite (center left, horizontally striped) from red beds. Photomicrograph in reflected, cross-polarized light of a sample from the Mesoproterozoic Revett Formation near Plains, Mont. Hematite is light blue-gray, and ilmenite is medium gray. Detrital silicates are dark gray to black, and transmitting heavy minerals like zircon and apatite have a mottled appearance due to internal reflections. Ilmenite and hematite occur in an exsolved, stacked-plate array within the detrital grain that was later overgrown with hematite forming protrusions outward from the ovoid detrital core. 


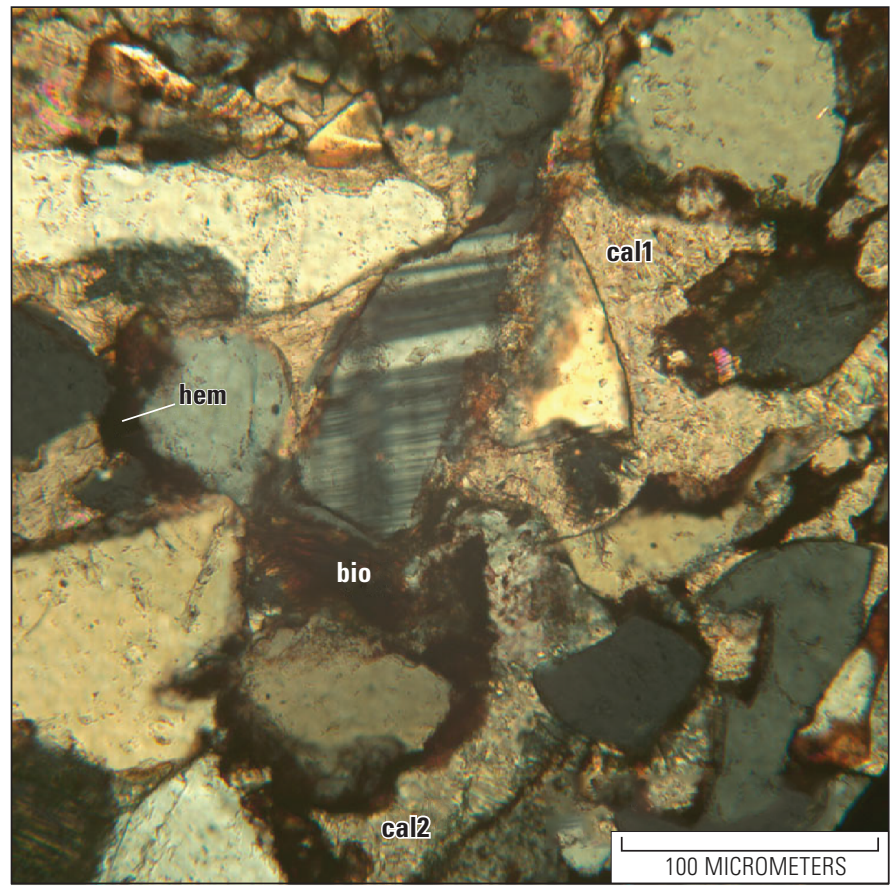

Figure 55. Photomicrograph showing calcite cementing a feldspathic sandstone. Photomicrograph in transmitted, crosspolarized light. Quartz is various shades of gray in rounded to subrounded grains. A grain of twinned albite is at center. The first stage of cements is hematite (hem, reddish brown) rimming detritus and altering biotite (bio) along cleavages. The second is sparry calcite (cal) in a poikilotopic texture (large calcite crystal enclosing multiple detrital grains - calcite grain 1 encloses 13 detrital grains within the field of view). Sample from the Permian Cutler Formation, southeastern Utah.

galena-calcite, and chalcopyrite-calcite zones and with high Mn near its disappearance at the boundary between bornitecalcite and chalcocite-chlorite zones (fig. 22). At many places at Spar Lake, $\mathrm{Cu}$ sulfides replace calcite. The interpretation is that a more distal, early ore-stage mineral was replaced by a more proximal, later ore-stage mineral. Ankerite, ferroan dolomite, or siderite is common in sandstones that have undergone relatively deep burial (Boles, 1978; Macaulay and others, 1993; Hendry and others, 2000) or that have undergone diagenesis under reducing conditions (Tye and Hickey, 2001).

\section{Clay Cements}

Authigenic clay cements are common in sandstones (Füchtbauer, 1974; Wilson and Pittman, 1977). The clay minerals that commonly form as cements in sandstone are illite, kaolinite, and chlorite, and smectite is common in graywackes and lithic sandstones. The first three minerals have diagnostic textures where they grow authigenically as sandstone cements (Wilson and Pittman, 1977). Kaolinite forms books or vermiform books. Illite bridges pores in arching sheets. Chlorite coats detrital grains with crystals standing on edge, with the c-axis tangential to rounded grain boundaries and its cleavages "edgeon." Only the smectites have poorly defined crystals.

The high birefringent phyllosilicates zonally distributed in quartzites at Spar Lake are found coating quartz or K-feldspar grains but do not coat every grain completely, allowing some to develop long contacts with adjacent quartz grains (fig. 56). Rarely, the mica occurs inside quartz or K-feldspar overgrowths, possibly originally as a clay coating on detritus that is now recrystallized. Hayes (1983, Appendix I) showed such grain-coating white micas are Barich within bornite-calcite and chalcocite-chlorite zones.

Chlorite is common as a sandstone cement in many settings (Wilson and Pittman, 1977; Curtis and others, 1985). Authigenic chlorite is present in a number of SSC deposits. The chlorite in Spar Lake's chalcocite-chlorite zone has typical textures with the chlorite crystals edge-on forming grain coatings. However, everywhere quartz or K-feldspar overgrowths are present, the chlorite is not in direct contact with the detrital grains; rather, it is found farther toward the centers of former pores, coating overgrowths, not detritus. Chalcocite or bornite locally occurs along cleavages of the chlorite, either replacing chlorite or growing synchronously with it. The chlorite also partially replaces detrital muscovite in that zone of the deposit (fig. 57). As stated earlier, the Spar Lake sandstone-cementing chlorite of the chalcocite-chlorite zone is an extraordinarily Fe-rich chamosite, which is unlike the chlorite cement found in typical sandstone diagenesis and certainly not metamorphic.

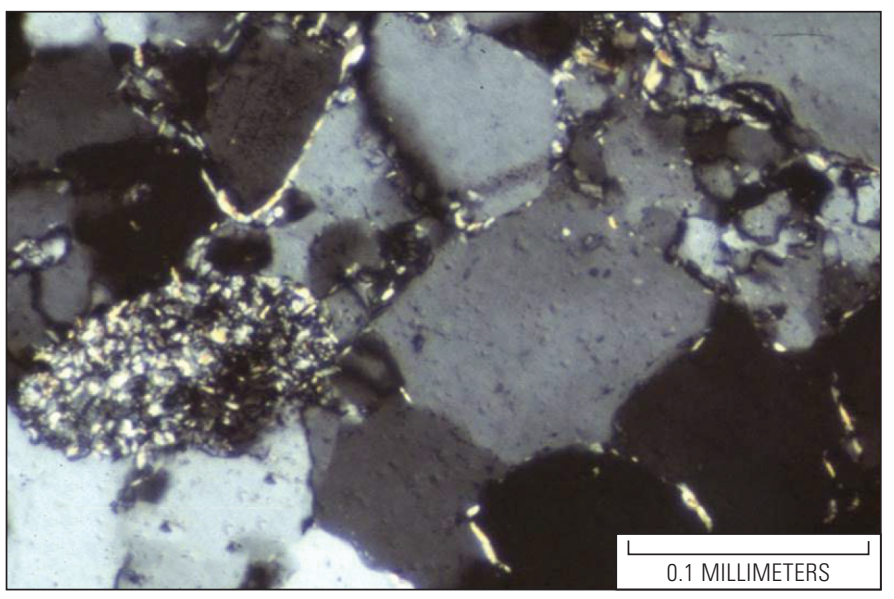

Figure 56. Photomicrograph showing grain-rimming "illite" cement. Photomicrograph in transmitted, cross-polarized light. According to X-ray diffraction, the highly birefringent mineral that coats detrital grains is a $2 \mathrm{M} 1$ white mica, but it probably originated as smectite or illite clay coatings, prior to burial metamorphism. Note that where the detrital grains were coated, no quartz overgrowth occurred, but where they were not coated, syntaxial overgrowth on detrital quartz cores did occur. Sample from the Mesoproterozoic Revett Formation, northwestern Montana. 

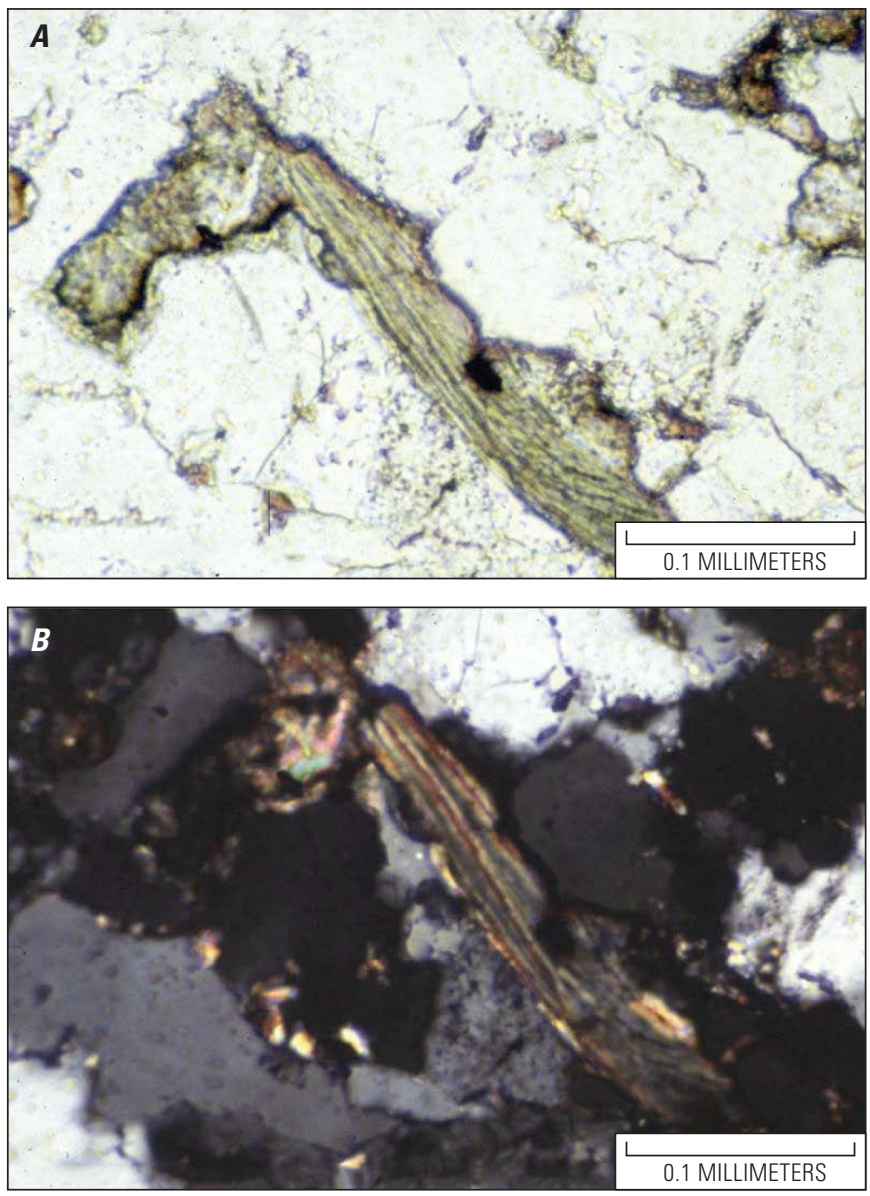

Figure 57. Photomicrographs of chlorite replacing muscovite along cleavages from the chalcocite-chlorite zone of the Spar Lake sediment-hosted stratabound copper sandstone deposit (fig. 6). A, Photomicrograph in transmitted, plane-polarized light. Chlorite is limy green. Muscovite appears yellowish. $B$, Photomicrograph in transmitted, cross-polarized light. Muscovite has high birefringence colors of yellow and red. Chlorite is very low birefringent with blue-gray appearance. A detrital muscovite grain was bent during loading and compaction of the sand. Chlorite partly replaced the muscovite along its cleavages.

\section{Authigenic Feldspars}

Authigenic feldspars in sedimentary rocks are widespread and common in many different environments (Baskin, 1956; Kastner and Siever, 1979). Authigenic albite is more common in carbonates, and K-feldspar is more common in siliciclastics. The authigenic K-feldspar occurs most commonly as syntaxial overgrowth on detrital feldspar cores. Albite, instead, appears to commonly replace detrital Ca-bearing plagioclase or forms euhedral grains within carbonate rocks.

Albite increases at the expense of detrital K-feldspar and detrital Ca-plagioclase with depth in Gulf Coast sandstones in Texas (Land and Milliken, 1981; Boles, 1982). These changes parallel other changes at depth that include the increase in illite at the expense of smectite, increasing cementation of ankerite, increasing quartz overgrowths, and the appearance and breakdown of kaolinite to chlorite (fig. 52). For some of these mineral reactions, there is a local source of needed elements. For example, the smectite conversion to illite can provide Fe and $\mathrm{Mg}$ for replacing calcite with ankerite and for the authigenic chlorite, and it can provide silica for detrital quartz overgrowths. It can release aluminum for kaolinite and later chlorite formation. But other elements must be newly introduced by solution. For albite, introduced $\mathrm{Na}$ is needed, and possibly accompanying that, chloride is needed to convert the relatively fresh groundwater at shallow depth to briny groundwater at the depths of precipitation of authigenic albite, chlorite, and ankerite. Land and Milliken (1981) calculated that $\mathrm{Na}$ for the albitization from seawater buried with the sediment was insufficient and suggest that dissolution of halite is needed.

Authigenic K-feldspar and authigenic quartz at Spar Lake occur as overgrowths on detrital K-feldspar and quartz grains, respectively, and their textures have been shown in figures 16, 20, 21, 22, and 23. Authigenic albite forms final pore-filling cements (fig. 24), and it replaces earlier detrital and overgrowth K-feldspar. Albite also accompanies other cements, including apatite and $\mathrm{Cu}$ sulfides, in replacing detrital Ca-bearing plagioclase (fig. 58). Albite or another authigenic mineral has replaced all the detrital Ca-plagioclase in Spar Lake rock (Hayes, 1983, Appendix I).

\section{Barite Cement}

Barite is common as a trace authigenic constituent in sedimentary rocks, most frequently observed in gray and black shales (Johnson and others, 2009). Barite as a sandstone cement is much less widespread but is known from Germany, Italy, England, northeastern Africa, Egypt, and Oklahoma, United States (Tarr, 1933). It has been best studied from Oklahoma, where it is abundant in the upper half of the Early Permian Garber Sandstone. The barite forms concretions in sandstone and most prominently forms "barite roses." A barite rose is a sand-barite crystal, where sand grains are cemented by and enclosed in large $(0.5$ to $10 \mathrm{~cm})$ cementing crystals with poikilotopic texture. The barite crystals are multiply twinned on the b axis, with as much as 20 individual crystals sharing the same $b$ axis and with the crystal axes of individual crystals spraying in acute angles to one another. In the sandbarite crystals, barite has partially replaced quartz and other detrital minerals such that most detrital grains are now angular, whereas outside the sand-barite crystal, the detrital grains are moderately to well rounded, each with a hematite dust rim. Hematite dust rims within the barite rose, similar to the sand grains themselves, are partially replaced, such that the color of the inside of the barite rose is red-gray rather than red-orange (Tarr, 1933; Ham and Merritt, 1944).

Sandstones within the Garber are host to the Paoli and other nearby sandstone $\mathrm{Cu}$ occurrences (Shockey and others, 1974). Cu-Ag mineralization at Paoli occurs along mineral appearance fronts between mottled hematitic sandstone and pastel green sandstone, with ore grades as chalcocite and native silver developed in the pastel green sandstone adjacent to the 

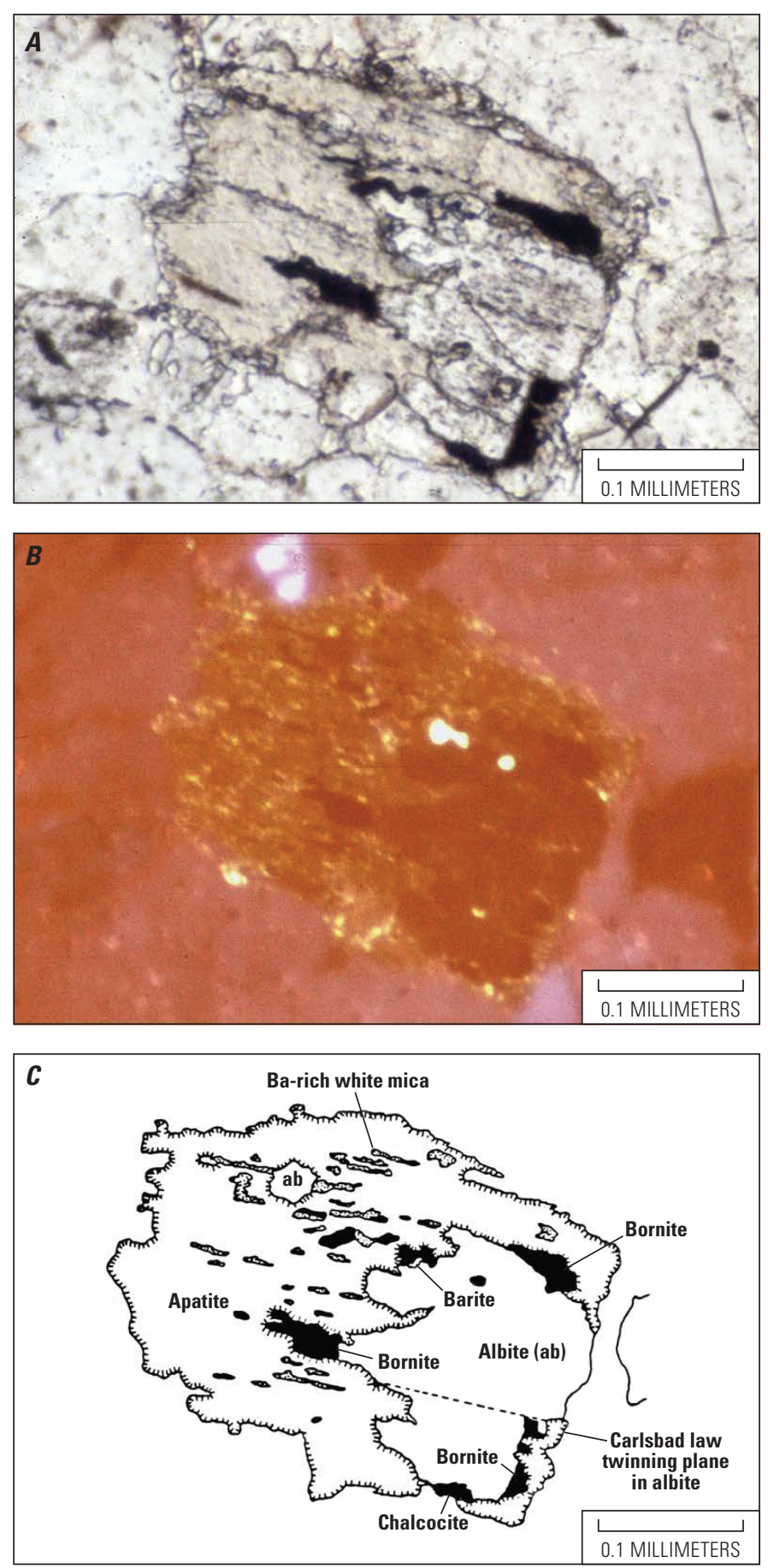

front. The mottled hematitic sandstone occupies the interiors of paleochannels of sandstone within the otherwise muddy Wellington Formation. Although comparable in zonal geometry, the mottled hematitic sandstone is not comparable in color with the altered tongues of roll front $U$ deposits. The hematitic parts at Paoli are deep red, nearing brick-red in color, whereas roll front $\mathrm{U}$ deposit altered tongues are grayish yellow (Shirley Basin, Wyo.; Harshman, 1972) or pink to grayish pink (Powder River Basin, Wyo.; Davis, 1969; Dahl and Hagmaier, 1976). The host sandstones are also notably different. The sandstones that are host to Paoli $\mathrm{Cu}-\mathrm{Ag}$ mineralization are pastel green, and they
Figure 58. $\quad A$, Photomicrograph in plane-polarized transmitted light of a replaced detrital plagioclase grain from the bornitecalcite zone of the Spar Lake sediment-hosted stratabound copper sandstone deposit (fig. 6). B, Cathodoluminscent photomicrograph of the same field of view. Apatite has high relief in $A$ and luminesces yellow in $B$. $C$, Interpretive overlay of the same field of view. A detrital plagioclase grain has been completely replaced by authigenic minerals including apatite, barite, barium-rich white mica, albite, bornite, and chalcocite.

lack carbonaceous plant material; those that host roll front $\mathrm{U}$ deposits in Wyoming are, instead, gray and contain conspicuous amounts of carbonized plant debris. The mottled gray and red sandstone interior to the paleochannels and between $\mathrm{Cu}-\mathrm{Ag}$ mineralization fronts also contains barite roses.

The barite concretions and barite roses of Oklahoma relate spatially, at least, to RBA $\mathrm{Cu}$ occurrences and deposits in the Permian rocks of the region. They may be more specifically within the $\mathrm{Cu}$ source rocks, the "altered" rocks of the usage in this report.

Spar Lake barite occurs as pore-filling cement that has grown toward centers of former pores from quartz or K-feldspar overgrowths (fig. 23). Most sulfide grains show the same textural relation. However, if a solution was introduced into a sandstone and was simultaneously saturated with respect to barite and K-feldspar, and K-feldspar detrital grains are present, the K-feldspar would precipitate as a syntaxial overgrowth, probably at the same time that barite precipitated, yet resulting in the appearance that overgrowth preceded barite filling the pores. Thus, it is likely that the barite grew at the same time as the K-feldspar overgrowths. The same textural observation and the same logic hold for most bornite-digenite-chalcocite, chalcopyrite, galena, calcite, and chlorite. $\mathrm{Cu}$ sulfides and galena share former pores with barite, and there is no evidence that either replaced the other (fig. 23).

Barite cements have also been found (1) in the Mindola Clastics below ore and within the Copperbelt Orebody Member ore at Konkola, Zambia (Sutton and Maynard, 2005), (2) in a single sample of Weissliegendes Sandstone below mineralized Kupferschiefer on the Fore-Sudetic Monocline, Poland (Michalik, 2001), (3) within the Udokan deposits, Russia (Volodin and others, 1994), and (4) in red-bed-type deposits near Nacimiento and Tularosa, New Mexico (Lindgren and others, 1910). Barite is clearly an important gangue phase related to many SSC deposits.

\section{Tourmaline}

Among the most unexpected of the minerals found as an ore-stage product in SSC deposits is the metasomatic tourmaline described from Zambia (Darnley, 1960; Selley and others, 2005) and Democratic Republic of Congo (Oosterbosch, 1951). Tourmaline is not a mineral commonly formed during diagenesis. Yet, Gautier (1979) found authigenic, pore-occluding tourmaline crystals, as well as overgrowths on detrital grains, in the Late Cretaceous Eagle Sandstone reservoir rocks of the 
Tiger Ridge gas field in north-central Montana. The Spar Lake deposit also has tourmaline overgrowths on detrital tourmaline cores (fig. 19C) and the Spar Lake host rocks were also, prior to the arrival of hot briny $\mathrm{Cu}$-transporting solutions, a gas reservoir (Hayes and others, 2012).

\section{Petrology of Associated Metamorphic Rocks}

It is common that SSC deposits are metamorphosed along with the rocks of their host sedimentary packages. This allows the conclusion that, everywhere that that is observed, the SSC deposits are pre-metamorphic. Veins and stockworks that post-date metamorphism or accompanied metamorphism occur as well, particularly within the Central African Copperbelt, and those are described and modeled separately. They are described in the section on Associated and Transitional Deposit Types. All examples of that type of deposit, syn- or post-orogenic veinlet controlled, have been removed from the accompanying database and from the grade and tonnage models.

Features of metamorphism observed in silicate and carbonate assemblages are also found in metamorphosed sulfidebearing rocks. Among these are metamorphic devolatilization reactions, crystalloblastic series, 'textural series' that include polygonization, annealing, and recrystallization, and retrograde assemblages.

\section{Rock Names}

Only a few terranes that contain SSC deposits cross sufficiently through metamorphic isograds to allow directly equating protolith sedimentary rock types and their metamorphosed equivalents. These include the Central African Copperbelt, the Kalahari Copperbelt of Botswana and Namibia, and the Ablah Group in southwestern Saudi Arabia. A number of other deposit-bearing belts cross between different metamorphic facies, but sufficient descriptions of those have not been found.

Lee and Glenister (1976) attempted correlation of the Damara Supergroup of the Oamites deposit area in Namibia with the Katangan Supergroup in Katanga (table 1). In these Precambrian rocks, all the correlations are lithostratigraphic, so the metamorphosed rock type and protolith equivalency that they propose has no fossil-age control and only broad absolute-age control. The correlation is on what they believe to be an equivalent of the Petite Conglomerate, the Marinoan aged tillite, marking the separation, in Katanga, of the Nguba Group (formerly Lower Kundulungu) from the Upper Kundulungu Group, which is the uppermost correlated tillite of the table. Notable equivalents that they propose are (1) basal arenitic sections (correlated with Mindola Clastics
Group) are metamorphosed to sericitic quartzite with lesser biotitic schist, phyllite, and metaconglomerate with schistose biotitic matrix; (2) carbonaceous argillitic dolomites correlate with biotitic schist and amphibolitic schist; (3) carbonaceous shale/argillite correlates with graphitic schist; and (4) dolomite correlates with dolomitic marble. Strong support for their sedimentary to metamorphic rock-type correlations comes from the Central African Copperbelt and the Ablah Group of Saudi Arabia.

The Katangan Supergroup of Democratic Republic of Congo is defined entirely by sedimentary rock names, although even the earliest workers recognized that all but the Upper Kundulungu rocks had been metamorphosed to lower greenschist facies or higher. Extrapolating from rocks with better described metamorphic minerals and fabric from the south would indicate that some chlorite and some white mica are of metamorphic origin in the rocks in Congolese deposits. Francois (1992) stated that, $90 \mathrm{~km}$ south of Kolwezi, metamorphism reaches "lower mesozone" grade with the formation of garnet and green amphibole. The border between Zambia and Democratic Republic of Congo is just $10 \mathrm{~km}$ beyond that greenschist/amphibolite isograd. Farther eastward, in the Zambian part of the Copperbelt, Mendelsohn (1961b) described the metamorphism and stated that the metamorphic grade in Katangan rocks increased from northeast to southwest, from the Mokambo concession to the Roan-Muliashi Basin. Hitzman (2000) showed isograd boundaries extending from the northwest to southeast such that a lower to middle greenschist isograd passes between the Nchanga and Mimbula deposits (fig. 38 for locations), with all the Chambishi Basin at middle greenschist facies. He showed a middle greenschist to lower amphibolite facies isograd passing between Chibuluma and the Roan-Muliashi Basin. Correspondingly, the metamorphism at Konkola, farthest north of the belt of shale ores, is said to "rarely reach the chlorite facies" (Schwellnus, 1961); the Ore Shale is described as a biotite-quartz-argillite at Chambishi (Garlick, 1961a); and the Ore Shale consists mainly of tremolite and biotite, with local scapolite and clinozoisite in the RoanMuliashi Basin (Mendelsohn, 1961b). Mendelsohn labels the metamorphism as epidote-amphibolite facies and he notes the presence of epidote and actinolite in carbonate-rich quartzites. He states that tremolite is locally abundant near the base of the Ore Shale, a unit that is commonly also crenulation-folded with strong development of axial-plane cleavage. The scapolite is found only in the Ore shale and occurs as porphyroblasts with inter-inclusion textures of the silicates but, interestingly, not of the sulfides. Cu sulfides are expelled in scapolite porphyroblast growth and they rim each porphyroblast. Actinolite characterizes the impure dolomites, but tremolite occurs in the purer dolomites and in the basal section of the Ore Shale.

Rock-type equivalents from lowermost greenschist to upper amphibolite are well known in the Ablah Group of southwestern Saudi Arabia. The rocks can be walked in 
Table 1. Stratigraphy and lithology of the Damara Supergroup (Oamites Area) Correlated with the Katangan Supergroup, Zambian Copperbelt. ${ }^{1}$

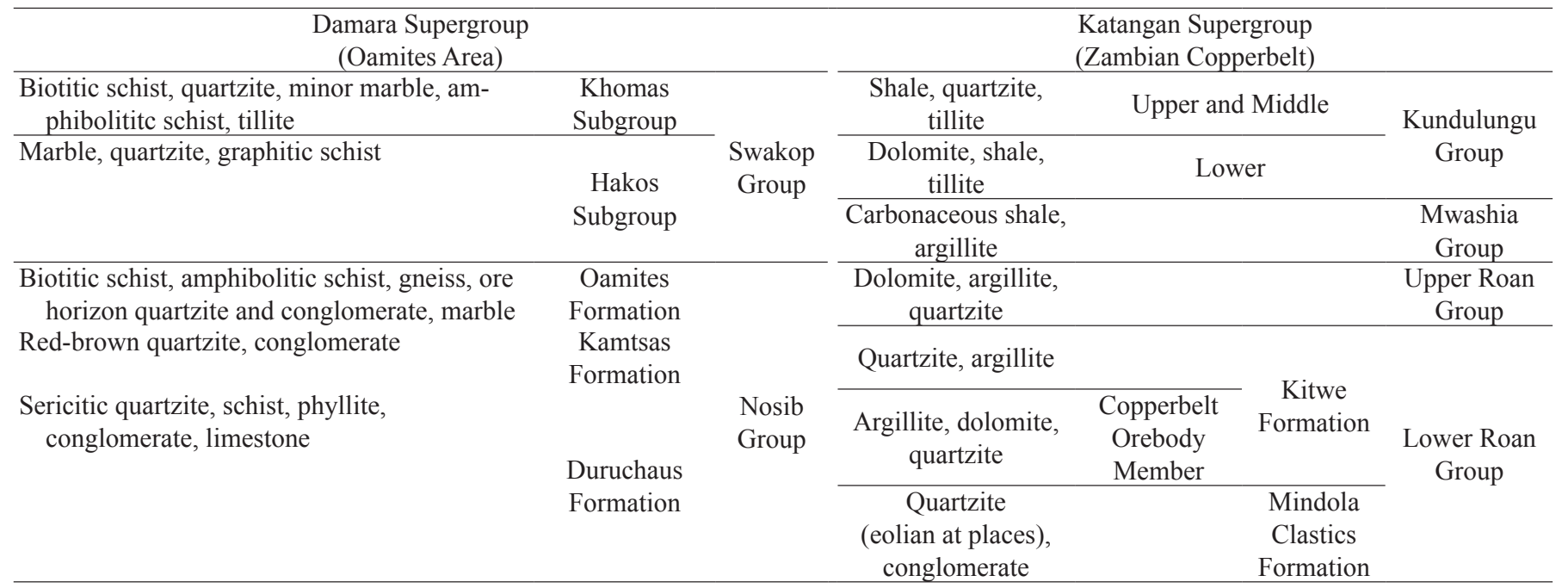

${ }^{1}$ Katangan stratigraphic nomenclature updated with reference to Selley and others (2005).

nearly continuous outcrop exposure from lowest greenschist facies into upper amphibolite facies along several individual lithostratigraphic units along a distance of about $15 \mathrm{~km}$. Equivalents are shown in table 2 from Sanders (1983). The (para-) amphibolite that Sanders lists is a conspicuous rock type. It has sprays of tremolite crystals commonly 2 to $3 \mathrm{~cm}$ long, with the crystal spray flattened within the schistocity, and the rock otherwise consisting of granoblastic mosaic of equant $0.5 \mathrm{~mm}$ grains of quartz, oligoclase, and biotite, with traces of relict dolomite (fig. 59).

Additional details about the Ablah Group rocks are worthwhile to the discussion of metamorphic rock types and their protoliths. The Al Mehdadah prospect was earlier hypothesized to be a volcanogenic massive sulfide occurrence in metavolcanic host rocks that were basement to the Ablah Group metasediments. Sanders (1983) indicated, instead, that Al Mehdadah was an amphibolite-grade metamorphosed SSC occurrence. Other lateral changes of note in rocks of the sequence are that red beds change laterally along the $15 \mathrm{~km}$ to magnetite-bearing, still hematite-bearing, flat-gray-colored phyllitic albitic quartzites, and eventually to quartz-oligoclase-orthoclase-muscovite-magnetite schist near Al Mehdadah. The para-amphibolite unit correlates with argillitic dolomitic phyllite in the lower greenschist zone and overlies the lowermost section of former red beds. The Al Mehdadah prospect, itself, has footwall rocks of intensely magnetite-rich quartzites that originated as red beds. Within these is a crosscutting zone of rocks composed of 75 v. \% magnetite and 25 v. \% quartz ending against the footwall of the $\mathrm{Cu}-$ sulfide-rich conformable layer, grading from 1 to 2 percent $\mathrm{Cu}$ (as chalcopyrite where cut in core holes). The magnetite-quartz rock is interpreted as a pre-metamorphic stockwork of hematite veinlets cutting footwall red beds, originally a hematitic feeder zone to the deposit.
Table 2. Metamorphic rock types and their protoliths of the RBA copper deposit-hosting Ablah Group, southwestern Saudi Arabia.

\begin{tabular}{|c|c|c|}
\hline $\begin{array}{l}\text { Sedimentary } \\
\text { protolith }\end{array}$ & & $\begin{array}{l}\text { Amphibolite grade } \\
\text { metamorphic rock type }\end{array}$ \\
\hline $\begin{array}{c}\text { Impure dolomite } \\
\text { Shale }\end{array}$ & $\begin{array}{c}\text { Transgressive } \\
\text { upwards }\end{array}$ & $\begin{array}{c}\text { Para-amphibolite } \\
\text { Chlorite schist }\end{array}$ \\
\hline Siltstone & and grain size & Biiotite-quartz schist \\
\hline Arenite & fines upwards & Sericite-quartz schist \\
\hline $\begin{array}{l}\text { Coarse arenite } \\
\text { (original grit) }\end{array}$ & & $\begin{array}{l}\text { Sericite-quartz schist } \\
\text { with quartz clasts }\end{array}$ \\
\hline
\end{tabular}

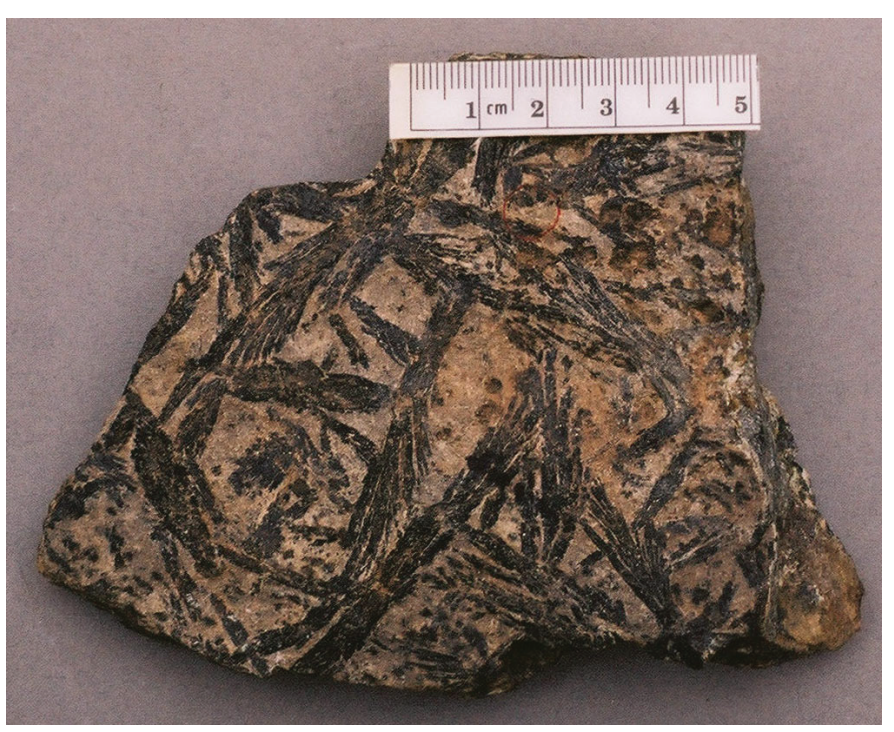

Figure 59. Para-amphibolite, the metamorphosed equivalent of muddy dolomite, from the Ablah Group, southwestern Saudi Arabia. In the metasedimentary sequences that host sedimenthosted stratabound copper deposits at amphibolite and higher grades, this is a relatively common rock type. 


\section{Devolatilization Reactions}

Prograde metamorphic reactions are commonly devolatilization reactions that liberate water $\left(\mathrm{H}_{2} \mathrm{O}\right)$, carbon dioxide $\left(\mathrm{CO}_{2}\right)$, or other gases as temperatures and (or) pressures increase. Metamorphic reactions can illustrate, for example, the formation of tremolite in the dolomitic basal ore shale of Zambia or in the para-amphibolite of the Al Mehdadah vicinity, Saudi Arabia, as follows:

$$
\begin{gathered}
\text { dolomite }+ \text { quartz }+ \text { talc } \\
=\text { tremolite }+\mathrm{CO}_{2}(\text { Kerrick, 1974) } \\
2 \mathrm{CaMg}\left(\mathrm{CO}_{3}\right)_{2}+4 \mathrm{SiO}_{2}+\mathrm{Mg}_{3}\left(\mathrm{Si}_{4} \mathrm{O}_{10}\right)(\mathrm{OH})_{2} \\
=\mathrm{Ca}_{2} \mathrm{Mg}_{5}\left(\mathrm{Si}_{8} \mathrm{O}_{22}\right)(\mathrm{OH})_{2}+4 \mathrm{CO}_{2}
\end{gathered}
$$

A couple of specific devolatilization reactions are of interest for SSC deposits and their host sections. These are a redox reaction and a desulfidation reaction.

In the Belt Supergroup, Jack Harrison (oral commun., 1979) observed that Ravalli Group rocks of the eastern Belt Basin were red and hematitic, but that in the western Belt Basin, many of the stratigraphically correlated Ravalli Group rocks were lavender gray and contained small $(0.3-1.0 \mathrm{~mm})$ octahedra of magnetite (Kleinkopf and others, 1972). Harrison (oral commun., 1979) proposed that the magnetite was a burial metamorphic product from consumption of hematite. Harrison observed that western Belt rocks reached biotite grade of regional burial metamorphism while the eastern Belt was at a maximum of chlorite grade (Harrison, 1972; Maxwell and Hower, 1967). The redox reaction would be:

$$
\begin{aligned}
\text { hematite } & =\text { magnetite }+\mathrm{O}_{2} \\
6 \mathrm{Fe}_{2} \mathrm{O}_{3} & =4 \mathrm{Fe}_{3} \mathrm{O}_{4}+\mathrm{O}_{2}
\end{aligned}
$$

Nadoll and others (2012) have recently demonstrated that Harrison was correct, using oxygen-isotope geothermometry. Quartz-magnetite and calcite-magnetite mineral pairs from the Spar Lake deposit were shown to have formed at temperatures from 359 to $437^{\circ} \mathrm{C}$. Compared with temperatures derived from S-isotope studies (50 to $116^{\circ} \mathrm{C}$ in galena-calcite zone; Hayes and others, 1989), fluid-inclusion microthermometry $\left(74^{\circ} \mathrm{C}\right.$ in galena-calcite zone to $178^{\circ} \mathrm{C}$ or more in chalcocite-chlorite zone; Hayes, 1990), and fluid-inclusion volatiles $\left(165-200{ }^{\circ} \mathrm{C}\right.$ in chalcocite-chlorite and bornite-calcite zones; Hayes and others, 2012), these oxygen-isotope temperatures cannot be temperatures of ore deposition. However, they correspond well with temperatures of burial metamorphism from studies of the biotite-forming reaction at Spar Lake (Hayes, unpub. data). The Spar Lake magnetite is also thus probably burial metamorphic.

Other metamorphosed SSC deposits and their host sections also show this metamorphic magnetite including the Ablah Group of Saudi Arabia and probably Udokan, Russia. In the Udokan series, the ore-bearing Upper Sakukan Formation is underlain by 1,000 to $1,700 \mathrm{~m}$ of "magnetite-carrier sandstones" of the Lower Sakukan Formations and by 1,100 to $1,400 \mathrm{~m}$ of magnetite-bearing sandstones and siltstones of the Talakan Formation (Bogdanov and others, 1966). Magnetite also occurs in the chalcocite- and bornite-bearing ore but not in the peripheral chalcopyrite and pyrite zones (Volodin and others, 1994). Little is made of it, but magnetite is common in the Zambian Copperbelt. It occurs predominantly in footwall sediments (the Mindola Clastics Formation), at Chibuluma (Winfield, 1961), in the Roan-Muliashi Basin (Lee-Potter, 1961), and at lower metamorphic grade at Luansobe (Groen, 1961, p. 406-407) and Mufulira (Brandt and others, 1961). In the lower greenschist facies rocks of Luansobe and Mufulira, there is also the possibility that the magnetite is detrital and typical of red beds (see fig. 53).

The other metamorphic devolatilization reaction type of interest is desulfidation. The one that is locally common is the desulfidation of pyrite to form pyrrhotite:

$$
\begin{gathered}
\text { pyrite }=\text { pyrrhotite }+\mathrm{S}_{2} \\
2 \mathrm{FeS}_{2}=2 \mathrm{FeS}+\mathrm{S}_{2}
\end{gathered}
$$

With the exception of Baluba (Lee-Potter, 1961), every SSC deposit that is at amphibolite metamorphic grade and has published detailed information on sulfide assemblages contains some pyrrhotite. These include Oamites, Namibia (Lee and Glenister, 1976); Roan Antelope, Zambia (Mendelsohn, 1961b); Nkana North Limb, Zambia (Annels, 1974); Nkana South, Zambia (Notebaart and Vink, 1972; Brems and others, 2009); Al Mehdadah, Saudi Arabia (Sanders, 1983), and Malundwe and Chimiwungo, Zambia (Benham and others, 1976). Traces of pyrrhotite are reported at Spar Lake, at the biotite isograd of greenschist facies (Hayes, 1983), and pyrrhotite is present at Chambishi East, Chambishi West, and Pitanda, Zambia, at middle to upper greenschist facies (Annels, 1989). However, pyrrhotite is not reported from deposits in the Central African Copperbelt that are at lower greenschist facies, not even where the same (Copperbelt Orebody Member) host rock is mineralized (Richards and others, 1988a; Sutton and Maynard, 2005; McGowan and others, 2006). Pyrrhotite is, however, found in vein ores in the Democratic Republic of Congo and Zambia and is relatively abundant at Kansanshi (Broughton and others, 2002).

Because traces of pyrrhotite occurs in unmetamorphosed Kupferschiefer ore and unmineralized host rocks in Germany (Jung and Knitzschke, 1976), it is not certain that all the pyrrhotite in metamorphosed SSC deposits is formed by devolatilization of pyrite.

\section{Crystalloblastic Series}

Sulfides of SSC deposits form parts of a crystalloblastic series, together with silicate and carbonate minerals that form a crystalloblastic series of their own. Only parts of the crystalloblastic series are known because of the probable disappearance of certain minerals from metamorphosed products. As an example, at White Pine, which is unmetamorphosed, pyrite relicts are found coated by chalcocite, digenite, or bornite (Brown, 1971, figs. 16, 22, 23). In contrast, at Spar Lake, 
which has been post-ore metamorphosed to biotite grade of greenschist facies, pyrite is not found in microscopic contact with any $\mathrm{Cu}$ sulfide except chalcopyrite. Chalcopyrite would be an intermediate composition between, for example, bornite and pyrite. It is likely that, at ore-stage at Spar Lake, relicts of pyrite once occurred within bornite or chalcocite, but that post-ore metamorphism homogenized the composition of the composite sulfide grains to a chalcopyrite + pyrite grain. Similarly, at Spar Lake, chalcopyrite has not been found in grain contact with either primary digenite or primary chalcocite.

In the list below, the minerals (sulfides and others) are listed top to bottom in sequence of their tendency to form euhedral crystals with increasing metamorphic grade. Where the exact positioning is uncertain, typically because the minerals do not occur in grain contact, a line is placed between the two.

$$
\begin{gathered}
\text { Myrite, Garnet, Tourmaline } \\
\text { Amphibole (Tremolite) } \\
\text { Kyanite } \\
\text { Ankerite, Ferroan Dolomite, Siderite } \\
\text { Biotite, Muscovite, Chlorite } \\
\hline \text { Albite in Carbonate Rock } \\
\text { Calcite }
\end{gathered}
$$

Biotite, Muscovite, Chlorite

Quartz, K-feldspar, Albite in siliciclastic rock Galena, Chalcopyrite, Bornite, Digenite, Chalcocite

The types of petrographic relations that were observed in assembling the above list are shown in figure 60. The intergrowth of digenite and bornite has neither mineral imparting a euhedral boundary against the other. Ankerite clearly forms a rhomb-shaped crystal with its euhedral boundaries imparted against the two sulfides, but magnetite imparts euhedral boundaries against the ankerite and the sulfides. Clots of sulfides with recrystallized magnetite, carbonates, and silicates are minor at Spar Lake. Most of the ore has not annealed or recrystallized after diagenesis, and the majority of the rock still has cementation textures like those in many earlier photomicrographs.

Perhaps the most important observation of the above crystalloblastic series, as it affects SSC deposits, is that all the common $\mathrm{Cu}$ sulfides of these deposits have the lowest of all crystalloblastic strengths. After metamorphism, the $\mathrm{Cu}$ sulfides appear interstitial to all the minerals with higher crystalloblastic strengths, which include all other mineral groups in the rocks. Thus, a strongly metamorphosed SSC ore has all sulfides, except pyrite, in sites interstitial between quartz, feldspar, mica, and carbonate grains, and the $\mathrm{Cu}$ sulfides occur only in anhedral grain shapes. They are anhedral particularly against metamorphic minerals such as garnet, tremolite, and tourmaline.

\section{Textural Series}

Annealing and recrystallization textures are observed in SSC deposits at upper greenschist and higher grades facies, and they can be used to distinguish between minerals of metamorphic and detrital and diagenetic origin. Many

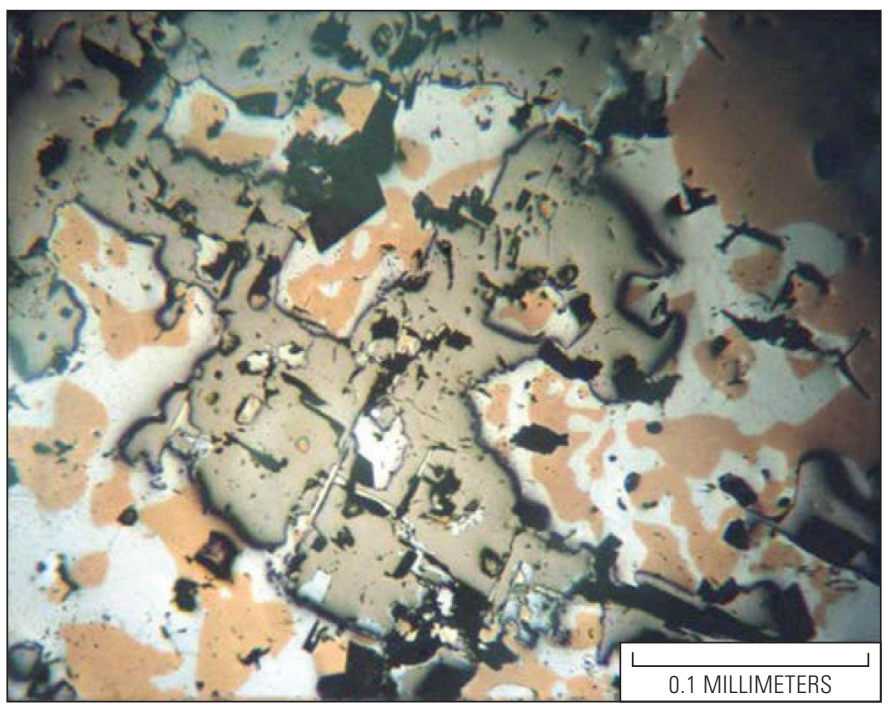

Figure 60. Photomicrograph from the core of magnetite-sulfide clot from the Spar Lake sandstone copper deposit illustrating metamorphic crystalloblastic relations among magnetite (dark graybrown with high polishing relief), ankerite (black), bornite (orange), and digenite (light blue gray). Photomicrograph in reflected planepolarized light in oil immersion. Magnetite imposes its cubic crystals against any of the other minerals including the rhombs of ankerite, but ankerite imposes its rhombohedral crystals against the bornite and digenite.

sedimentary and diagenetic mineral grains are distinguished by subtle discontinuities. For example, detrital quartz and feldspar grains are commonly crowded with fluid inclusions, whereas grain-rimming syntaxial overgrowth cements are not. Among carbonate minerals, diagenetic-aged cements commonly grow with crystal terminations towards the centers of pores or former pores. Where annealing and recrystallization have occurred, such discontinuities are erased, and the product is a mosaic of even-grained quartz-feldspar-mica-carbonate with or without porphyroblasts. Triple-point textures are common. Where sulfides other than pyrite were involved in the annealing and recrystallization, and the sulfides are less than about $10 \mathrm{v} . \%$, the sulfides are interstitial to the other mineral groups and anhedral. Where the $\mathrm{Cu}$ sulfides constitute more than about 10 percent of the rock, they go through textural series with advancing deformation and metamorphic grade. This includes grain growth, dislocation, polygonization, and recrystallization (for example, the Al Mehdadah prospect, Saudi Arabia).

\section{Retrograde Assemblages}

Retrograde metamorphic minerals are found in metamorphosed SSC deposits and do not differ from the retrograde minerals of other metamorphic rocks of similar bulk composition. Chlorite that is retrograde after garnet or tremolite is a common example.

Retrograde sulfide assemblages and textures, however, are common in metamorphosed SSC deposits with some interesting details. The incoherent exsolution texture of bornite 
that unmixed from the high-temperature solid solution with digenite (fig. 28) is ubiquitous in metamorphosed deposits. The same incoherent exsolution of bornite and digenite is absent from unmetamorphosed deposits, such as the Polish Kupferschiefer, the Paoli deposit, Lisbon Valley, and White Pine. Additional details can be seen in samples from Spar Lake (fig. 28). First, the grain of exsolved bornite and digenite grain has none of its own crystal boundaries. The grain boundaries are against detrital (rounded) and diagenetic quartz and calcite, rather than metamorphic phases. The calcite is porefilling relative to the detrital and overgrown quartz. Other $\mathrm{Cu}-$ sulfide grains have mostly cuspate grain boundaries, suggesting all originated as cements. The quartz-feldspar framework is detrital with cementation and remains unmetamorphosed. Individual sulfide grains or composites are cementing, yet one sulfide has a clearly retrograded texture where the higher temperature bornite-digenite solid solution has unmixed. A secondary electron image of the bornite-digenite exsolution grain (a gray-scale image) was determined to have mole proportions of 43.8 percent bornite and 56.2 digenite. Then, following the assumption that a grain of bornite-digenite solid solution of that composition exsolved as a closed system, and that the solid solution cooled to intersect the solvus of Grguric and others (2000), the solvus would have been intersected at about $177^{\circ} \mathrm{C}$. Other incoherent exsolution-textured bornitedigenite grains have mole proportions of as high as 91 percent bornite and 9 percent digenite. That composition intersects the solvus at $237^{\circ} \mathrm{C}$. This latter temperature is $37^{\circ} \mathrm{C}$ higher than the highest temperature determined for the ore stage at Spar Lake by S-isotope geothermometry (Hayes and others, 1989), fluid-inclusion microthermometry (Hayes, 1990), or gas-phase equilibria using fluid-inclusion compositions (Hayes and others, 2012). It is $53{ }^{\circ} \mathrm{C}$ higher than the highest fluidinclusion homogenization temperature determined from the bornite-calcite zone, the mineral zone that the sample comes from. The preferred explanation is that an earlier composite sulfide grain, perhaps chalcocite + chalcopyrite, homogenized by melting to the $\mathrm{bn}_{0.91} \mathrm{dig}_{0.09}$ composition as a closed system, then retrograded by unmixing as temperatures decreased from peak metamorphism at greater than $430{ }^{\circ} \mathrm{C}$ to less than $237^{\circ} \mathrm{C}$. The bornite-digenite textures of figure 60 are probably the same type of exsolution.

Bornite-digenite is one of at least three types of $\mathrm{Cu}$-sulfide exsolution textures described from SSC ores. This incoherent exsolution type has been described from Spar Lake, Roan Antelope in Zambia (Bateman, 1930; Brummer, 1955, fig. 25), and Fungurume in Democratic Republic of Congo (Oosterbosch, 1951). Coherent exsolutions of digenite from chalcocite indicating isometric parentage have been illustrated from Mufulira, Zambia (Bateman, 1930), Roan Antelope (Brummer, 1955, fig. 30), and Witvlei, Namibia (Anhaeusser and Button, 1973, fig. 11). Coherent exsolutions of chalcopyrite and digenite along cubic crystallographic directions from bornite (fig. 61) are recognized at Spar Lake, the Snowstorm mine also in the Western Montana Copper Sulfide Belt, Fungurume (Oosterbosch, 1951, fig. 25), and White Pine (Brown, 1971, fig. 27).

\section{Theory of Ore Deposit Formation}

There are six requirements in order for SSC deposits to form. Evaluating potential for SSC deposits using these six requirements is fully analogous with the thinking commonly applied to evaluate a petroleum exploration "play." Petroleum plays are conceptually analyzed considering (1) source rocks, (2) maturation, (3) migration, (4) reservoir rocks, (5) trap, and (6) seal rocks (Ulmishek, 1986; Bird, 1986; Magoon, 1988). In order to form a SSC deposit, it is generally agreed that there must be (1) $\mathrm{Cu}$ source rocks, (2) liberation of $\mathrm{Cu}$ from those source rocks by a hot sedimentary brine, (3) migration of the $\mathrm{Cu}$-bearing brine, (4) host rocks, (5) trap, and (6) seal rocks that are confining beds for the upward seeking metals-transporting brine. The trap must be a chemical redox trap and a physical trap.

$\mathrm{Cu}$ source rocks are generally red beds, and they should contain labile or chemically unstable minerals with a small amount of $\mathrm{Cu}$. The labile minerals, such as hornblende or pyroxene, dissolve during early red-bed diagenesis. The $\mathrm{Cu}$ is relocated within ferric-oxide coatings, which hold the $\mathrm{Cu}$ until the coatings recrystallize to hematite or until brine moves into the source rocks and mobilizes the $\mathrm{Cu}$. Alternative source rocks are flood basalts, such as with the Keweenawan section of northern Michigan and the Rotliegendes volcanics in the Kupferschiefer. Additional alternative source rocks can be the basement rocks of the basins containing the deposits.

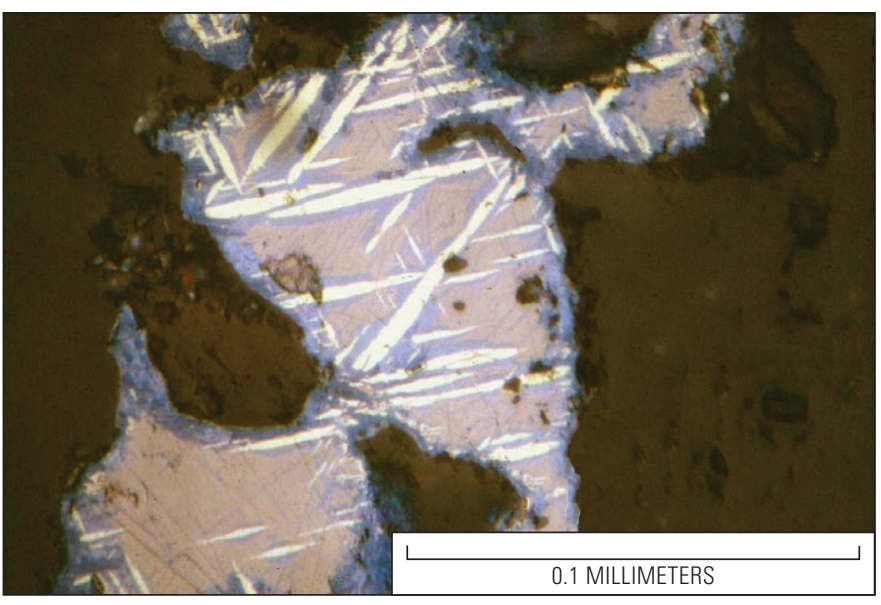

Figure 61. Retrograde(?) exsolution textures among bornite (pink), chalcopyrite (light yellow), and digenite (purplish gray). Chalcopyrite and digenite form exsolved laminae along bornite cubic crystal directions, and there is an outer continuous rim of digenite on the bornite grains. Royal blue color is later supergene covellite. Sample is from the Snowstorm sandstone Cu deposit, Idaho. Photomicrograph in reflected plane-polarized light in oil immersion. The identical texture has been observed at Fungurume, Democratic Republic of Congo, and White Pine. Grace and Putnis (1976) produced chalcopyrite and digenite from formerly homogeneous bornite by simple heating, and Kosyak (1969) produced similar chalcopyrite laminae in bornite on the electron microprobe adjacent to where he used high beam currents in analyzing formerly homogeneous bornite, so retrograde metamorphic origin is uncertain. 
Liberation by dissolution of $\mathrm{Cu}$ is by hot sedimentary brines. The $\mathrm{Cu}$ in the ferric-oxide coatings is mobilized as chloride complex ions (Rose, 1976). These brines have been observed in fluid inclusions in the Central African Copperbelt and at Spar Lake in ore-stage authigenic gangue minerals (Annels, 1989; Hayes, 1990; Dewaele and others, 2006; El Desouky and others, 2008a, 2008b, 2009). The brines had salinities of at least 18 to 25 eq. wt. $\% \mathrm{NaCl}$ and transported $\mathrm{Cu}$ at temperatures from greater than $220^{\circ} \mathrm{C}$ to as low as perhaps $100{ }^{\circ} \mathrm{C}$. Because the deposits are found associated only with thick packages of red beds, typically greater than $1 \mathrm{~km}$, the heat is likely supplied by deep burial of the source rocks. There is no reason to think that magmatic heat is involved in any way; Hayes and others (2012) found that fluid inclusion volatiles from the ore stage at Spar Lake, particularly helium isotopes, $\mathrm{HCl} / \mathrm{HF}$ ratios, and nitrogen/argon ratios, "give no evidence of magmatic or mantle involvement." Rose (1976, 1989) suggested that the subsurface brines are hematite-stable albeit with intermediate oxidation states. The source(s) of salinity for the brine is known, with certainty, probably only for Lisbon Valley, where it was dissolved Paradox evaporites (Breit and Meunier, 1990). Elsewhere, the salinity sources are not known, although they too were probably dissolved evaporites. However, it is also possible that lacustrine connate brines, particularly the Great Salt Lake-type of Hardie and Eugster (1970), or Kupferschiefer-type of Eugster (1985, 1989), could act as sources of salinity for metals-transporting solutions. The Great Salt Lake-type brines are near saturation with respect to Na-sulfate salts such as glauberite or thenardite (Hardie, 1968). Brines with chemistry similar to these are the possible metals-transporting solutions for the Kupferschiefer and, particularly, for Redstone (Northwest Territories, Canada), where glauberite has been identified in footwall red beds (R. Lustwerk, oral commun., 1986). Lustwerk and Rose (1983) demonstrated the same footwall red beds, the Redstone River Formation, to be greatly depleted in $\mathrm{Cu}$, with many samples having concentrations less than or equal to $2 \mathrm{ppm} \mathrm{Cu}$.

Transport of the $\mathrm{Cu}$ occurs under artesian heads (that is, by confined aquifer flow), because zoning and paragenesis indicate that $\mathrm{Cu}$-rich, hematite-stable brines have entered the host rocks from below. Almost every other aspect of fluid and metal migration remains conjectural. Hitzman and others (2005) listed possible causes for the migration as (1) purely compaction-driven groundwater flow, (2) topographically driven groundwater flow (Brown, 2005, 2009), (3) topographically driven flow with convection or forced convection, and (4) thermohaline (buoyancy)-driven free convection induced by salt dissolution (Hanor, 1987; Evans and Nunn, 1989; Gvirtzman and others, 1997). In addition, there is also the possibility of pure thermally driven free convection (Raffensperger and Garven, 1995a, 1995b). Thermally driven free convection induced by igneous intrusion (Norton and Knight, 1977) can probably be eliminated from consideration because there appears to be no association between SSC deposits and intrusive rocks. Also to be added to the above is the fluid flow system that has been proposed for the Kupferschiefer by Blundell and others (2003), which is termed "seismic pumping."

Considerable disagreement exists on what type of groundwater flow system may have driven $\mathrm{Cu}$-transporting groundwater to the deposits. An early paleohydrologic model for transporting $\mathrm{Cu}$ to the White Pine deposit was constructed by White (1971), and it was later supported by and expanded upon by Brown $(2005,2009)$. White (1971) favored topographically driven groundwater flow to the deposit site at the time of the inversion of the Midcontinent Rift basin about 30 to 50 million years after deposition of the Nonesuch Formation reduced-facies host rocks. Brown (2009) also called upon topographically driven groundwater flow, but he believes that it took place earlier in the geologic history, essentially at the time of diagenetic deposition of $\mathrm{Fe}$ oxides to produce the Copper Harbor red beds and within a few million years after deposition of the Nonesuch Formation host rocks. Jowett (1986a) suggested that thermally driven free convection operated over the Early to Middle Triassic to move $\mathrm{Cu}$ from the Rotliegendes source red beds to mineralize the Late Permian reduced-facies host rocks of the Polish Kupferschiefer. Alternatively, Blundell and others (2003) offered their seismic pumping model to drive $\mathrm{Cu}$-transporting brines out of basement fractures toward the Polish Kupferschiefer deposits. Perhaps the best of the paleohydrologic models to date is that of Swenson and others (2004) for the White Pine deposit. They demonstrated that a compaction-driven groundwater flow system during sedimentational loading during the deposition of as much as $4 \mathrm{~km}$ of Freda Formation atop the Nonesuch Formation host rocks, focused by a zone of thinning of the Copper Harbor red-bed aquifer, could have produced the White Pine deposit. The likely timing would have been 10 to 15 million years after Nonesuch Formation reducedfacies host rock deposition essentially during the sag stage of the Keweenawan rift basin, and the $\mathrm{Cu}$ concentrations in the brines could have been less than or equal to $50 \mathrm{ppm} \mathrm{Cu}$. Hitzman and others (2010) contended that the supergiant SSC districts, the Kupferschiefer, the Central African Copperbelt, and Udokan, were probably formed over long geologic periods with repeated groundwater flow and mineralization episodes. However, the model of Swenson and others (2004) for White Pine appears to succeed with only the compactiondriven single-pass groundwater flow event. Nonetheless, a compaction-driven system, such as that modeled at White Pine, would, in many other districts, be followed by changing tectonic setting with likelihood of additional groundwater flow systems that could transport and deposit additional $\mathrm{Cu}$. In Central Africa, for example, an early compaction-driven system that mineralized the reduced-facies host rocks would logically be followed by deep burial and emplacement of sour gas in arenites, which would later be mineralized to form the sandstone $\mathrm{Cu}$ deposits of the belt. Subsequent compressional tectonics accompanying Lufilian Orogeny might have produced the veinlet-localized stratabound $\mathrm{Cu}$ deposits and increased the grade of the pre-existing deposits. 
The conduits or pathways followed by hot, metalstransporting brines have rarely been recognized. At local scales, they certainly include various water-escape structures (pillars) (fig. 62). At deposit scale, they probably include faults, such as at Cashin (fig. 13) and possibly Spar Lake. For the largest reduced-facies-type deposits, conduits at the deposit scale have not been identified because they probably include large volumes of coarse, siliciclastic rocks lying along the entire footwall of the orebodies. The "conduit" rocks have not been differentiated from ordinary red beds. In order to be differentiated, the subtle alteration must be recognized and mapped.

Host rocks are relatively well known, and three major variants correspond with each of the reduced-facies, sandstone $\mathrm{Cu}$, and red-bed subtypes. Reduced-facies-type hosts are black shale (Kupferschiefer), dark gray to black siltstone (White Pine), dark gray dolosiltstone (Roan 2-hosted ores of Democratic Republic of Congo and Ore Shale-hosted deposits of Zambia), gray shale (Creta, Okla.), or locally, green shale or siltstone (Belt Supergroup "green bed" occurrences). In reduced-facies hosts, the major reductant is probably solid organic material. A pre-ore step in most is to create early diagenetic pyrite, which becomes a second reductant and sulfide source at the expense of some organic material.

Sandstone $\mathrm{Cu}$ host rocks are typically well-sorted siliciclastic sandstones from a variety of deltaic topset environments, from subtidal to coastal to eolian and to fluvial. Carbonate grainstones can act the role as well (for example, Juramento, Argentina; Durieux and Brown, 2007), and grain sizes vary

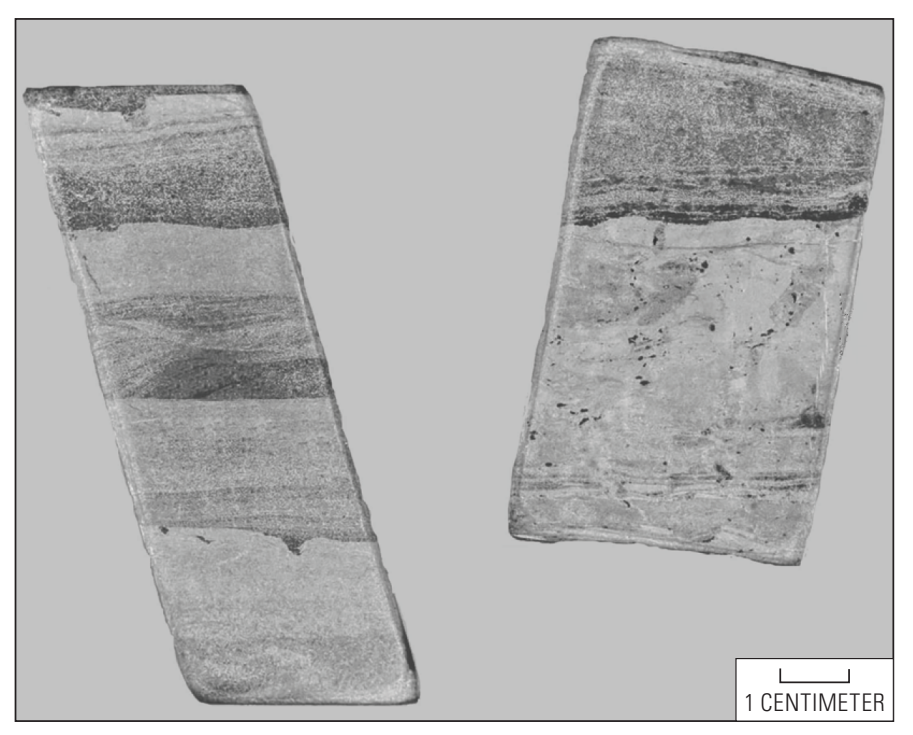

Figure 62. Core samples contrasting siltite-argillite beds from remote from the Spar Lake RBA sandstone Cu deposit (left) with the same kind of beds immediately beneath ore (right). In both cores light gray is argillite and darker gray is siltite. Very dark patches from $0 . x$ to $1 \mathrm{~mm}$ on the right are coarse-grained patches of quartz-chlorite-bornite-digenite-chalcocite. Mineralized type B water escape structures are abundant beneath ore, but they are nearly absent over large areas nearby. from conglomerate to very fine sand. Critically, these rocks at the time of arrival of the metals-transporting brine were probably reservoir rocks for petroleum, and they were gray, green, or white in color but not, at that time, red. In many places, the petroleum was probably sour gas and, in general, the petroleum was the reductant during ore deposition (equation 1). Because petroleum in some form was present in the host rocks before arrival of metals-transporting brines, some pre-ore diagenetic pyrite had probably formed, and it acted as another reductant and second sulfide source for the ore.

Host rocks for red-bed-subtype deposits were fluvial sandstones, commonly conglomeratic and containing carbonized plant fragments sized from silty partings up to logs. The plant fragments were the reductant for this deposit subtype. Because the fluvial sandstones contained the plant fragments at deposition, their early diagenesis was probably reducing, and pyrite was probably formed in proximity to the plant fragments before arrival of the metals. The pyrite, once more, was an additional reductant and sulfide source during ore deposition.

SSC deposits are found at the sites of traps that are both chemical and physical. The host rocks for SSC deposits were the chemical redox traps. Reductants in the host rocks acted as a chemical barrier for $\mathrm{Cu}$ moving in hot, briny, oxidizing groundwater. Physical traps for some reduced-facies deposits were the pinchouts of the sub-ore red-bed aquifers (fig. 15), where the coarse clastics onlapped basement rocks and were confined beneath the argillaceous reduced-facies host rocks. For sandstone $\mathrm{Cu}$ deposits, Dzhezkazgan and other deposits of the Chu-Sarysu Basin demonstrate that anticlines are a favored type of trap. However, stratigraphic or combination traps could also localize sandstone $\mathrm{Cu}$ deposits. Maiden (1989) recognized additional types of traps for South Australian SSC deposits. For the red-bed $\mathrm{Cu}$ deposits, the host rocks are classically comparable with "shoestring" sands of popular oilfield terminology. In a "shoestring" sandstone reservoir, seal rocks and a structural closure or stratigraphic trap are required, and the same is probably true of the rocks that host red-bed $\mathrm{Cu}$ deposits.

Outflow zones include the galena, sphalerite, and, for some, pyrite zones of deposits, particularly where there is abundant pyrite or Co-bearing pyrite. For the sandstone $\mathrm{Cu}$ deposits and, perhaps, red-bed $\mathrm{Cu}$ deposits, there may also be former red beds that are now altered to gray, green, or white in the hanging walls of the deposits. Where such rocks contain pyrite, perhaps with sphalerite and galena, they are probably outflow zone rocks.

Seal rocks or confining beds are necessary for forming SSC deposits. The seal rocks for the reduced-facies deposits are commonly the ore host rocks themselves, or, in the Kupferschiefer, the overlying Zechstein I Anydrite unit. Seal rocks for sandstone $\mathrm{Cu}$ deposits are typically shales or argillites. It is likely that these are now gray or green, but prior to petroleum entrapment, they may have been red. Seal rocks for red-bed $\mathrm{Cu}$ deposits are also typically shale, and the same color history may be probably true for them, but in several examples the confining shales are still red. 
Flow of oxidized metals-transporting brine through any rocks that were not hematitic prior to ore stage causes oxidation and reddening by hematite deposition in the rock (for example, Rote Fäule). When the groundwater contacts the reductants in black, gray, green, or white beds, $\mathrm{Cu}$ is deposited as sulfides by replacing pre-ore pyrite and in coupled redox reactions of the transporting solution's sulfate, and possibly dissolved oxygen, with the reductants of the host rock and pore fluid. With flow farther into the host rocks, accompanied by further reaction with the host rock reductants, the lateraland vertical-zoned arrangement of chalcocite, then bornite, then chalcopyrite, and then pyrite is produced.

The preceding paragraphs in this section pertain only to the hypogene genetic features of red-bed SSC deposits. Supergene enrichment of SSC deposits as chalcocite group minerals certainly occurs, but with chalcocite occurring as a common hypogene sulfide in this class of deposits, it is at places difficult to separate supergene from hypogene features. It is less difficult to recognize supergene enrichment where it takes the form of residual enrichment in Co-rich oxide zones and probably Ag-chloride zones, for example, Silver Reef, Utah.

The SSC deposits have spatial affiliations with several other types of mineral deposits. The clearest affiliations are with native copper deposits in flood basalts. Other affiliations are with the volcanic red-bed-type $\mathrm{Cu}$ deposits of Kirkham (1984b), sandstone-hosted U deposits, evaporite deposits, Kipushi-type $\mathrm{Zn}(-\mathrm{Ge}-\mathrm{Cu}-\mathrm{Pb} \pm \mathrm{Ag})$ deposits, certain types of hydrothermal U-Ni-Se deposits such as Shinkolobwe, and, in places with Fe oxide- $\mathrm{Cu}-\mathrm{Au}$ deposits. Among the above, the associations with deposits of native copper in flood basalts, with volcanic red-bed-type $\mathrm{Cu}$ deposits, and with sandstonehosted U deposits may be associations that share some aspects of deposit genesis. The association with evaporites is assumed to stem from dissolving the evaporites to produce the high salinities for metals-transporting brines. The associations with Fe oxide-Cu-Au, Kipushi-type, and U-Ni-Se deposits are, instead, probably just shared sedimentary tectonic settings.

Exploration and resource assessments have purposes that are partly in common, finding mineral resources or noting the probable existence of mineral resources. The objective of resource assessments by government is to identify prospective terrain (1) as an aid to exploration groups, (2) as a way to assess the potential mineral endowment of the country for strategic purposes, including whether the country will be dependent on external sources of critical and strategic minerals, and (3) for land-use planning that determines whether land should be held open for multiple uses including mineral exploration and development or used in ways not compatible with mineral development. The sole objective of mineral exploration is to make a discovery of a potentially economic deposit. Although these two objectives differ in detail, the techniques employed in the initial stages of mineral exploration are similar to the techniques of resource assessment.

Kirkham (2001) and Hitzman and others (2005, p. 635) have discussed the main factors in exploration and assessment. In our own analysis (above) a SSC system must have (1) source rocks, (2) mobilization by hot sedimentary brines, (3) transport of those brines, (4) host rocks, (5) traps, both chemical and physical, and (6) seal rocks to confine the upward migrating brine. All these factors relate to the stratigraphy and history of sedimentary basins. A basin that contains source rocks and host rocks is the fundamental unit that defines a permissive tract for exploration or assessment. (1) The basin must contain a minimum of perhaps $300 \mathrm{~m}$ of oxidized, hematite-stable permeable source rocks, probably red beds, with a small $\mathrm{Cu}$ content. Flood basalts or other volcanic rocks are a positive factor as alternative $\mathrm{Cu}$ source rocks. (2) The basin must have undergone flow of groundwater equilibrated with hematite from an extensive catchment basin, and the groundwater must have traveled upward across strata and toward host rocks. It is a positive factor if the basin contains or contained evaporites, either continental or marine. Having the evaporites downsection from the source rocks and the host rocks is clearly favorable (as at Lisbon Valley), but with the possibility of basin inversion, evaporite presence anywhere in the section relative to source rocks and host rocks is permissive. It would be favorable if an examination of the geologic history of a basin suggests a history of halokinesis. It would be more direct to be able to document phases that mark pathways of metalliferous brine migration by the presence of alteration phases, including hematite in rocks that were not earlier red, albite, analcime, Na-sulfate minerals, riebeckite, paragonite, epidote, perhaps barite, and perhaps chlorine-bearing illite (Michalik, 1997), and it would be particularly favorable if the rocks containing the alteration phases now had low $\mathrm{Cu}$ contents. (3) There must have been a groundwater flow system that drives the $\mathrm{Cu}$-bearing sedimentary brines from source rocks to host rocks. Various types of flow systems with various hydrologic drives are possible, but the flow system apparently had to, at the time of mineralization, operate within confined aquifers so that brines were upward-moving relative to stratigraphy. Alternatively, the brines were sourced in rocks hot enough that the density of the brines was less than the density of the resident groundwater of the rocks immediately downsection from the host rocks. Flow probably had a directional sense of dewatering the basin. Basins where there were never flows that met those criteria are unfavorable for SSC deposits. Such infertile basins are probably common. (4) The basin must contain either organic-rich impermeable sedimentary beds that could provide solid organic matter as a reductant, permeable beds with reservoired petroleum vapor and (or) liquids to act as reductant, or permeable beds with carbonized plant fragments to act as a reductant. Obviously, a basin would be most favorable if some such rocks contained local $\mathrm{Cu}$ mineral occurrences. (5) The basin should have had sufficient structural deformation to create traps. Minimally, that might constitute sagging of basin or sub-basin centers such that an onlap of reduced-facies host beds onto a basement high would become a stratigraphic trap. The traps could vary from that up to complex combination traps produced by pre-ore folding and faulting. (6) The basin should have had confining beds that either constitute the reduced-facies host rocks or that stratigraphically, or perhaps structurally, overlie petroleum reservoirs. This last criterion is met by nearly every studied basin. 


\section{Geological Guides}

\section{Mapping of Rock Types, Structural Geology, Minerals, Alteration, and Zoning}

Mapping is by far the most important procedure in assessing the location, volume, and attributes of altered and (or) mineralized rocks and in determining the relative position of exposures of those altered or mineralized rocks within a SSC system. In exploration and assessment, all available geologic mapping is used. Where prior mapping is not available, explorationists will commonly conduct the required geologic mapping at least at reconnaissance scale. Resource assessment may require new geologic mapping in order to produce any reasonably accurate assessment.

Reconnaissance-scale geologic mapping may suffice in initial stages of exploration or assessment, and the mapping may need only identify major lithostratigraphic packages. It can be guided by the purposes of identifying the necessary elements of a SSC mineralizing system: $\mathrm{Cu}$ source rocks; sources for hot metals-transporting brines; conduits for metalstransporting brine migration, such as basin margins, largescale alteration pathways, and faults; $\mathrm{Cu}$ host rocks; traps; and seals.

Alteration mapping may become increasingly useful, although alteration may be extremely subtle. Where wholescale replacement by albite occurs, as it does at places in the Central African Copperbelt and the Udokan system in Russia, albitic alteration is easily mapped. However, although the albite zone can now be mapped in the Western Montana Copper Sulfide Belt (fig. 6), this has not proved useful in exploration to date. In frontier exploration areas, with the concept of alteration marking the path of migrating metalstransporting brines, identification of the characteristics of alteration may be a useful early task, and alteration mapping could then be quite productive. Even in better-explored systems, identification of the characteristics of alteration along migration pathways may prove useful.

\section{Mineral Properties}

A few mineral properties have emerged that can be mapped at a reconnaissance exploration or assessment scale. A notable one for sandstone $\mathrm{Cu}$ deposits is carbonate compositions and abundances. There is an anomalous concentration of calcite in the distal-fringe zones of the Spar Lake and other Revett Formation-hosted stratabound $\mathrm{Cu}$ deposits. Those calcite cements are Fe-rich through the pyrite-calcite, galena-calcite, and chalcopyrite-calcite zones of deposits. An associated $\mathrm{Cu}$ deposit will already have been located by the time an explorationist narrows the search enough to observe the Mn-rich calcites of the bornite-calcite zone of a deposit. The bleached rocks of chalcopyrite-ankerite zone of mineralizing systems have very sparse disseminations of ankerite that weathers much differently than the Fe-rich calcites (fig. 29).
For deposits in sandstone or siltstone host rocks, carbonate abundance, not just composition, should also be a guide if the carbonates result from oxidation of reactant natural gas, as is suspected.

Weathering products from different hypogene sulfide zones of sandstone $\mathrm{Cu}$ deposits can also be used to narrow the search for locating deposits. Brochanthite, as opposed to malachite, is a strong indicator of the central highest-grade parts of such systems. The occurrence of $\mathrm{Cu}$ in $\mathrm{Cu}$ wad in black oxides distributed on joints and fractures is an indicator of a mineralizing system from farther away, perhaps kilometers along bedding, from centers of mineralization.

\section{Distribution of Sulfide Minerals}

Sulfide minerals in fresh rocks or their pseudomorphs in weathered outcrops are the best mappable mineralogical indicators for exploration or assessment. The strong sulfide zonation of reduced-facies SSC deposits and sandstone $\mathrm{Cu}$ deposits makes the sulfides and their zoning useful. The sulfides of distal-fringe zones vary a little with the subtype of the deposits.

Sandstone $\mathrm{Cu}$ deposits have large volumes of bleached rock (Chalcopyrite-Ankerite zone of fig. 6), which extend the greatest distances surrounding orebodies. The bleached rock haloes can extend several tens of kilometers from the ore. Because the bleaching may have been caused by unrelated events, such as petroleum migration and emplacement, bleaching alone is not a vector to ore. It may, though, be a necessary effect preparatory to later ore events. Sparsely disseminated pyrite in strata that are elsewhere red beds can yield a broad halo that may extend as much as $10 \mathrm{~km}$ laterally along bedding from ore. The sandstone $\mathrm{Cu}$ deposits also have large galena- and (or) sphalerite-bearing inner halos that extend for $1-2 \mathrm{~km}$ laterally from ore.

For reduced-facies SSC deposits, the lateral extent of the different sulfide zones is even greater. The $\mathrm{Pb}-\mathrm{Zn}$ zones of the Kupferschiefer are halos several tens of kilometers wide adjacent to the target $\mathrm{Cu}$ zones and separating the $\mathrm{Cu}$ zones from barren, pyritic zones (fig. 4) (Oszczepalski and Rydzewski, 1997). If a favored reduced-facies host bed is identified, sulfide mineral zonation, or the trace-metal chemistry that results from the sulfide mineral zonation, can lead to the $\mathrm{Cu}$ deposits from very great distances. The Central African Copperbelt systems unfortunately do not appear to have $\mathrm{Pb}$ - and $\mathrm{Zn}$-enriched zones, and Co is also fairly narrowly distributed. Co does, though, form an outermost distal-fringe halo that extends $1 \mathrm{~km}$ or more away from ore along bedding.

\section{Geochemical Guides}

\section{Soil-Gas Chemistry}

With knowledge that sandstone $\mathrm{Cu}$ deposits occur where oxidizing, hot, metals-transporting brines mix and react with $\mathrm{H}_{2} \mathrm{~S}$-bearing natural gas (Hayes and others, 2012), soil-gas chemistry might be a powerful exploration 
method in the search for such deposits. Fluid inclusions in ore-stage authigenic minerals of the Spar Lake deposit contained high concentrations of $\mathrm{CH}_{4}$ and hydrogen in the distal fringe, and they contained high concentrations of sulfur dioxide in rich ore. It is suspected that fluid inclusions in more distal minerals might contain even higher concentrations of $\mathrm{CH}_{4}$, as well as anomalous concentrations of $\mathrm{H}_{2} \mathrm{~S}$ that constitute unreacted or only slightly reacted sour gas. All these gases can be measured in soil gases (McCarthy and Reimer, 1986). Carbon disulfide $\left(\mathrm{CS}_{2}\right)$, which might occur at detectable concentrations within unreacted sour gas, and $\mathrm{Hg}$ vapor may also be substantial (fig. 39). Weathering of ores destroys the hypogene carbonate and sulfide minerals that host the gas-filled inclusions. Localization of ores along faults, with locally deep weathering to depths of greater than $600 \mathrm{~m}$, provides conduits for escape of the gases liberated from the fluid inclusions.

\section{Trace-Element Geochemistry}

From geochemical surveys of soil and stream sediment, it is well known that $\mathrm{Cu}$, itself, is an excellent pathfinder element for these deposits in many different weathering and climatic conditions (for example, Payne, 1971). Additional ore elements are $\mathrm{Ag}$ and $\mathrm{Co}$. Ag is useful in the sandstone $\mathrm{Cu}$ mineralizing system of the Revett Formation, because anomalies with $\mathrm{Cu}$ and $\mathrm{Ag}$ are distinguishable as a SSC system as distinct from anomalies associated with other types of deposits (Harrison and others, 1986a). Other potential pathfinder elements include $\mathrm{Pb}, \mathrm{Zn}, \mathrm{As}, \mathrm{Hg}, \mathrm{Mn}$, and $\mathrm{Ba}$. Soil geochemical surveys have proven effective in Botswana even where the bedrock that hosts the deposits are covered by tens of meters of Kalahari sands (Van Der Heever and others, 2009).

\section{Supergene Enrichment and Leached Capping Characteristics}

In many climatic zones, supergene enrichment is negligible for SSC deposits, and either $\mathrm{Cu}$-oxides or relict sulfides are found in weathering-zone outcrops of deposits.

In central Africa, heterogenite with or without lesser malachite, forms "Co caps" (Gauthier and Deliens, 1999). In Co caps, the amounts of heterogenite make it unmistakable as an earthy to dense, botryoidal black oxide. Leached cappings in central Africa have been only poorly described, although it is clear, particularly where carbonates or anhydrite with $\mathrm{Cu}$-sulfides formerly cemented sandstones, that highly porous, brown, goethitic(?) sandstone results from weathering. Red hematite and beer-bottle limonites are not described from this rock, but kaolinite is a major component.

Weathered deposits with rich concentrations of malachite are known from the Democratic Republic of Congo, and specimens of malachite from these occurrences are famous worldwide. Some such deposits do not overlie sulfide deposits.
Some are known to have been below Roan 2-hosted stratabound $\mathrm{Cu}$ ore, but others occur below thrust faults with Roan 2-hosted ore within the allochthonous plate (for example, within Kundulungu beneath the Kolwezi klippe) or associated with extrusion faults (probably halokinetic). Some occur randomly within tectonic or halokinetic breccias stratabound (Francois, 1992). Supergene enrichment is obvious in these cases. Native copper and covellite are additional common supergene zone products in the Central African Copperbelt, but they probably do not constitute major enrichments to hypogene grades.

\section{Cu-0xide Minerals}

Malachite is the most widespread $\mathrm{Cu}$-oxide mineral from the weathering of SSC deposits. In middle-latitude temperate, relatively humid climates, brochanthite predominates instead, as the weathering product of the richest ore zones. Chrysocolla is generally present in low abundances with either of the above. Copper wad may be present in associated black oxides, discretely along joint faces, or as weathered veinlets. Beerbottle limonite is the most common of $\mathrm{Cu}$-oxide minerals in sunny exposures where it commonly directly pseudomorphs earlier grains of disseminated sulfide cements.

\section{Geophysical Guides}

\section{Basin Structure}

Basin margins, where reduced-facies host rocks onlap basement rocks (fig. 10), are favorable sites for ore deposition. These can be detected by magnetic and gravity surveys and, most reliably, by seismic surveys. Regional-scale magnetic and gravity surveys are first-order geophysical methods in exploration for reduced-facies-type deposits. They are also first-order data for assessments wherever target stratigraphic intervals are covered.

In basins that have not been dramatically deformed post-ore and where SSC systems are already recognized (for example, Chu-Sarysu Basin, Kazakhstan; Permian rocks of Kansas-Oklahoma-Texas, United States), seismic reflection or refraction surveys in search of anticlines, stratigraphic traps, and combination traps, combined with more commonly used mineral exploration methods, should be effective at finding additional sandstone $\mathrm{Cu}$ deposits.

\section{Red Beds and Beaching}

Bleaching of red beds detectable by remote sensing of colors using Landsat imagery or of ferric oxides using ASTER or AVIRIS imagery can narrow the search for sandstone $\mathrm{Cu}$ deposits or limit the areas for assessments. Only the bleached former red beds can be mineralized by later ore systems (MacIntyre, 2006). 


\section{Direct Geophysical Targeting}

Induced Polarization (IP) may be effective in direct sensing of deposits. The conductive sulfide signature of sandstone $\mathrm{Cu}$ deposits can be found with IP for rocks that contain no carbonaceous or very pyritic shales. The key to success of the method is that the unmineralized, non-graphitic and nonsulfidic rocks will be extremely resistive, whereas areas of $\mathrm{SSC}$, though they may not be truly conductive, will be relatively non-resistive. The IP can be effective for exploration in local situations, such as in the Democratic Republic of Congo part of the Central African Copperbelt, where the sulfide orebodies may be shallowly covered by heterogeneous breccias that crop out between exposures of Kundulungu Group. However, in areas with Kundulungu sediments in the subcrop, IP will likely be ineffective at seeing through the thick intervals of carbonaceous and pyritic shale cover.

\section{Attributes Required for Inclusion in a Permissive Tract}

At the broadest level, permissive tracts for SSC deposits can be defined to include the presence of carbonaceous and (or) pyritic beds, and (or) beds containing trapped petroleum, or beds that formerly contained trapped petroleum. These host rocks should be located upsection from red beds thicker than $300 \mathrm{~m}$ or a former red-bed unit and (or) flood basalts, or laterally within $10 \mathrm{~km}$ of that thickness of $\mathrm{Cu}$ source rocks. A permissive tract for SSC deposits is outlined by delineating a geographic area on a geologic map that includes chemically reduced host rocks and generally stratigraphically lower red beds or former red beds and (or) flood basalts that are a minimum of $300 \mathrm{~m}$ thick. A thickness of $300 \mathrm{~m}$ is considered the approximate minimum needed to generate the required metals-rich brine, and greater thicknesses can be considered more favorable. The tract may include known SSC deposits and prospects of any of the three subtypes. Current economics of metal production will define a maximum allowable thickness of cover rocks overtop the host rocks. The tract outline approximately parallels the outline of the sedimentary basin, as depicted on the scale of the geologic map available for tract delineation. The presence of evaporite beds in the sequence and faults at high angles to bedding are particularly favorable. Tracts should include only those areas underlain by chemically reduced host rocks, provided that there is good knowledge of any downsection source rocks that demonstrates that no bleached former red beds are present.

\section{Factors That Enable Favorability Zonation of Permissive Tracts}

Areas with known SSC deposits within a permissive tract define locations having distinctly better favorability than other parts of that tract. As above, faults at steep angles to sedimentary layering define more favorable parts of tracts. Any parts of a basin where reduced-facies host beds onlap basement rocks are favorable. In terrains that have known sandstone $\mathrm{Cu}$ deposits, anticlines, areas with known stratigraphic traps, and those with known combination traps are more favorable than other parts of the tract (for example, Hitzman and others, 2005, fig. 8; the Paradox Basin). Areas of natural-gas production are also more favorable within basins that have known sandstone $\mathrm{Cu}$ deposits.

Basin margins are more favorable than basin centers (see, for example, Hitzman and others, 2005, fig. 6B showing the Zechstein Basin). Structurally high areas within central basins are more favorable than their surroundings, such as the structural high with Rote Fäule alteration near the Pommeranian Coast of the Zechstein basin (Oszczepalski and Rydzewski, 1997, Plate XVI). This structurally high zone probably extends westward across southern Denmark and northernmost Germany as the Ringkobing-Fyn High, then into the North Sea to become the mid-North Sea High defined from petroleum exploration.

In basins with reduced-facies-type mineralization, areas where host beds contain only pyrite, or even contain $\mathrm{Zn}$ - or $\mathrm{Pb}$-bearing sulfides, are unfavorable, although a transition from $\mathrm{Pb}$-rich rock to $\mathrm{Cu}$ ore can occur over a short distance In basins with reduced-facies-type mineralization, areas where host beds are known to be secondarily hematized or otherwise altered in ways analogous with sandstone roll front $\mathrm{U}$ deposit alteration; that is, rocks where $\mathrm{Cu}$ is depleted relative to background are unfavorable. Again, however, a transition from altered rock to $\mathrm{Cu}$ ore can occur over a short distance.

Burial histories derived from petroleum exploration such as Lopatin modeling can help subdivide permissive tracts into more favorable and less favorable areas. Only those areas within and adjacent to parts of the tract that underwent rapid subsidence and burial are favorable. Parts of basins that subsided slowly and are distant from fast subsiding parts, the shallow platforms, are unfavorable.

\section{Factors That Influence Undiscovered Deposits Estimates}

Different basins typically have characteristic distributions of $\mathrm{Cu}$ grades in their deposits, especially for deposits of the same subtype. For example, Mesoproterozoic-hosted reducedfacies deposits in south-central China have grades that average 1.04 percent (six deposits). The ores hosted in Neoproterozoic shale of the Zambian Copperbelt average 2.11 percent $\mathrm{Cu}$ (13 deposits or prospects, all within the Copperbelt Orebody Member). It is unlikely a 2.1 percent shale-hosted orebody will be found in the south-central China province, except if considering only a small tonnage. $\mathrm{Cu}$ grades are consistent from deposit to deposit within a basin, although they are different from one basin to the next. Similarly, sandstone $\mathrm{Cu}$ deposits of the Udokan sequence are higher grade than sandstone $\mathrm{Cu}$ deposits of the Revett Formation in the Belt Supergroup. It cannot be expected that a new Revett-hosted orebody will have 1.3 percent $\mathrm{Cu}$, which characterizes the Udokan. Together, Spar Lake, Rock Creek, and Montanore, 
in the Revett, average 0.75 percent $\mathrm{Cu}$ (Boleneus and others, 2006). The same observations hold for byproduct metals, Co and Ag. It cannot be expected that the next-discovered Udokan Series-hosted orebody will have $40 \mathrm{~g} / \mathrm{t} \mathrm{Ag}$. Udokan contains $12.6 \mathrm{~g} / \mathrm{t} \mathrm{Ag}$ (Vladimir Chechetkin, Committee on Geology and Utilization of Mineral Resources of the Chita Region, Russia, written commun., 2009). But, in the Revett, the Spar Lake, Rock Creek, and Montanore deposits have 46, 73, and 75 g/t, respectively, and together they average $68 \mathrm{~g} / \mathrm{t}$ (Boleneus and others, 2006). It can be expected that the next-discovered economic Revett-hosted deposit will have an $\mathrm{Ag}$ grade of more than $40 \mathrm{~g} / \mathrm{t}$. Providing that existing grade data permits it, basin-unique grade distribution models should be used in assessments. The statements above hold only as depositscale observations. Within deposits, there is commonly a bed-by-bed grade variation. The average grade of the White Pine deposit is 1.2 percent $\mathrm{Cu}$, but the average grade of the "Domino" and "Lower Transition" beds within the deposit is 2.5 percent (fig. 12). Deposit average grades, particularly for reduced-facies-type deposits, may reflect the need for dilution with waste rock in order to extract a minimum thickness that can be mined underground by a large-tonnage method. Actual mineralized intercepts may be considerably higher grade, but the average reflects blending that rock with nearly barren waste rock to attain a mineable thickness. Within reducedfacies-type deposits particularly, individual sample grades can be quite high, but the challenge may be to find a sufficient thickness to mine.

Tonnage distributions are not similarly basin-unique. These distributions are geologically controlled and not simply an artifact from reporting only open-pit resources. The tonnages probably have more geologic cutoffs, such as structural geologic boundaries and outcrop boundaries.

Deposit densities are nearly impossible to estimate for reduced-facies-type SSC deposits. Minor continuations of mineralization are so widespread that it becomes an almost totally arbitrary decision where one deposit ends and the next begins (see the maps of Oszczepalski and Rydzewski, 1997). Therefore, deposit-density modeling methods as a control on undiscovered deposit number estimates do not work with these layer-form ores.

Reported tonnages, particularly, are probably incompletely representative of entire deposits. Geological limits, such as structural geologic boundaries or grade cutoff boundaries, would result in larger tonnages than are reported for many active mines and for many prospects. Instead, many of the reported tonnages from Democratic Republic of Congo, in particular, are only the tonnages considered accessible in an open-pit mine. Geologically, the deposits continue to greater depth, which is beyond the economic limit of mining and where the continuity of the deposit is not known. Nonetheless, through time, reserve growth is likely. This holds as well for certain deposits of the Kupferschiefer, where the Lubin-Sierozowice mining complex has reported larger total resources through time by mining the same single deposit to greater and greater depth as new technology and $\mathrm{Cu}$ prices allowed. The Lubin-Sierozowice-Polkowice-Rudna mines have reached depths of 1,250 m without encountering any limitations on their room-and-pillar methods because of the depth, and there appear to be no important difficulties in continuing farther down-dip. Either wallrock temperature or the saline and corrosive groundwater may eventually limit the operation (A. Piestrzyński, oral commun., 2001).

The degree of structural disruption of the rocks is a critical geologic factor in exploring for SSC deposits. Even small-offset faults can substantially influence the economics, because, in these layer-form ores, the faults cause considerable tonnages of waste rocks to be mined, diluting the grades. Dips between about 15 and 40 degrees are problematic because rubber-tired underground equipment struggles or fails to climb the dips (Derek Feeback, oral commun., 2007), and the broken ore will not gravity-feed in a sublevel stoping or a block caving operation. Deposits that are nearly flat-lying and undisrupted are at a great economic advantage. The Creta reducedfacies-type deposit was an example of that. The ore was typically just $21 \mathrm{~cm}$ thick (Dingess, 1976) at an average grade of 1.9 percent $\mathrm{Cu}$, but the beds dip less than $2^{\circ}$ and the topographic relief is low. Also, blasting was seldom required in the generally soft sedimentary rocks. These factors resulted in an area of more than $8 \mathrm{~km}^{2}$ being strip-mined before overburden thicknesses and $\mathrm{Cu}$ prices forced the closure of the mine.

\section{Geoenvironmental Features and Anthropogenic Mining Effects}

All SSC deposits contain zones of chalcocite and other $\mathrm{Cu}_{2} \mathrm{~S}$ minerals, bornite, chalcopyrite, pyrite, and subordinate galena and sphalerite. The chalcocite and bornite in the highgrade zone are fairly stable under oxidizing conditions. Pyrite is typically found only in trace amounts in the high-grade zone, but its content increases outward as $\mathrm{Cu}$ grade decreases. Therefore, environmental issues associated with the oxidation of pyrite and the subsequent potential production of acid mine drainage and leaching of metals can be minimized if mining plans avoid the outboard pyrite-containing zones. Two types of host rocks are associated with these deposits: lowenergy marine or lacustrine siltstones, shales, and carbonate rocks; and high-energy continental sandstones, arkoses, and conglomerates (Cox and others, 2003) corresponding to the reduced-facies and sandstone $\mathrm{Cu}$ subtypes. The calcite present in some host rocks will help mitigate against the development of acid mine drainage. In addition to pyrite as a potential environmental concern, minerals such as galena, sphalerite that commonly contains $\mathrm{Cd}$ substituting for $\mathrm{Zn}$, and As-bearing minerals such as tennantite, enargite, luzonite, and arsenopyrite can be disturbed during mining or concentrated during ore processing and potentially weather and release harmful trace elements into the environment. The geoenvironmental characteristics of sediment-hosted $\mathrm{Cu}$ deposits have been previously addressed by Lindsey and others (1995). 


\section{Pre-Mining Baseline Signatures in Soil, Sediment, and Water}

Mine permitting requires an estimate of the pre-mining natural background conditions to serve as a goal for postmining reclamation. For all three subtypes of SSC deposits, soil and stream sediments may contain anomalous abundances of $\mathrm{Cu}, \mathrm{Pb}, \mathrm{Ag}$, and possibly $\mathrm{As}, \mathrm{Hg}$, and $\mathrm{Zn}$ in the vicinity of the deposits (Lindsey and others, 1995). For example, in the vicinity of SSC deposits in the Democratic Republic of Congo and Zambia, soils are $\mathrm{Cu}$-rich such that $\mathrm{Cu}$-resistant and $\mathrm{Cu}-$ accumulating plants have replaced normal vegetation (Reilly, 1967; Reilly and Stone, 1971; Malaisse and others, 1978).

Upper canopy trees cannot grow in the $\mathrm{Cu}$-rich soils yielding "copper clearings." Stream sediments collected in the Kafue River upstream from mining contain between 15 and 146 ppm $\mathrm{Cu}$ (specify the element), some of which are just below the probable effect concentration (PEC) of $149 \mathrm{ppm}$ (table 3) (MacDonald and others, 2000; Pettersson and others, 2000; Pettersson and Ingri, 2001). Soil and sediment associated with some Revett deposits in Montana contain as much as 2,000 $\mathrm{ppm} \mathrm{Cu}$, greater than $150 \mathrm{ppm} \mathrm{Pb}$, and greater than $500 \mathrm{ppb}$ Ag (Cazes and others, 1981; Wells and others, 1981).

In contrast to some of the sediment and soils with anomalous metal concentrations, background surface waters of the Kafue River, upstream from the mining area in Zambia, contain low $\mathrm{Cu}$ (less than or equal to $3 \mu \mathrm{g} / \mathrm{L}$ ) and other trace elements (table 4) (Norrgren and others, 2000; Pettersson and Ingri, 2001). Also, the draft environmental impact statement for the Montanore Project, a proposed mine in the Rock Creek-Montanore sandstone Cu-type deposit in Montana, states that surface-water quality in streams and lakes near the proposed mine is excellent. The concentrations of total suspended solids, total dissolved solids, major ions, nutrients, and metals are generally low and frequently at or below detection limits even downstream from the deposit. The surface waters generally contain $\mathrm{Fe}, \mathrm{Cu}$, and $\mathrm{Ag}$ in low concentrations, well below environmental guidelines. The surface waters tend to be slightly acidic likely from organic acids and dissolved carbon dioxide. The hardness values in streams are commonly less than $30 \mathrm{mg} / \mathrm{L}$ (U.S. Forest Service and others, 2009).

\section{Past and Future Mining Methods and Ore Treatment}

Most reduced-facies-subtype deposits are developed by underground mining methods, predominantly by roomand-pillar to depths of $1,000 \mathrm{~m}$, although in a few old mines, longwall methods were used. Ore is processed by grinding and flotation and the concentrate is smelted (E\&MJ, 1979a, 1986a, 1986b). In the Mansfeld district in Germany, the volatile compounds and fine particles produced by smelting ore were recovered by suspending the material in water, followed by filtering and dewatering (Matheis and others, 1999). The resulting flue dust material was called 'Theisenschlamm,' and at times, it was reprocessed to recover metals. In addition to underground mining, ore such as in Zambia has been mined by open-pit methods and processed by a combination of flotationsmelting and solvent-extraction electrowinning (SX-EX) methods (E\&MJ, 1979a). As for underground mining, at least one mine in Zambia performs acid leaching of the ore underground (Sracek and others, 2010). Also, in situ bioleaching was proposed as an effective means of recovering $\mathrm{Cu}$ from chalcocite ores from White Pine and Kona, Mich. (Johnson and others, 1988). To date, the bioleaching of these ores has taken place only at lab-bench scale.

Large red-bed-subtype deposits are mined by open-pit methods, whereas smaller deposits are generally mined by underground methods via adits, inclines, and shafts. Ore is processed by grinding and flotation, and the concentrate is shipped to smelters (Soule, 1956; Talbott, 1974). Future processing of ore may occur by heap leach-SX-EW on site (Mining Record, 1995).

Sandstone $\mathrm{Cu}$ deposits are mined by underground roomand-pillar methods with ore processed by grinding and flotation near the mine site and concentrates shipped to smelters (E\&MJ, 1979b, 1982; U.S. Forest Service and others, 1992). Deposits in the Lisbon Valley district in Utah have been mined by open-pit operations in addition to underground methods. Modern ore processing was done by SX-EW leaching (Krahulec, 2006).

\section{Volume and Footprint of Mine Waste and Tailings}

The volume of mine waste and tailings produced from a deposit depends on the deposit size, depth, and geometry; the ore grade; and mining method. Reduced-facies-type deposits are generally high tonnage (median, outside of the Central African Copperbelt, 27 million tonnes) with a high $\mathrm{Cu}$ grade (median 1.38 percent) compared to other subtypes and are mined mostly underground (Lindsey and others, 1995; Cox and others, 2003). The amount of waste produced by deposits is exemplified by the Mansfeld district in Germany. Each tonne of ore in the Mansfeld district yielded 35-38 kg of metal, $740 \mathrm{~kg}$ of silicate slag, $20 \mathrm{~kg}$ of flue dust, and approximately $1,500 \mathrm{~m}^{3}$ of furnace-top gas (Matheis and others, 1999). Waste rock and slag from the Mansfeld district were piled in large heaps up to $9,000,000 \mathrm{~m}^{3}$ (Schubert and others, 2003). Strauch and others (2001) estimated that approximately 2,000 heaps of mining and smelting waste of mainly low-grade ore, host rock, and slag occur in this former mining district. After metal recovery from the flue dust ceased in 1978, more than 300,000 $t$ of the material were deposited on the heaps of slag and mining debris (Matheis and others, 1999). One disposal site for flue dust in the same district is approximately $225,000 \mathrm{~m}^{3}$ (Schubert and others, 2001, 2003). The flue dust is considered the most important source of pollution in the Mansfeld district because of its elevated concentrations of $\mathrm{As}, \mathrm{Cd}, \mathrm{Cr}, \mathrm{Cu}, \mathrm{Pb}$, and $\mathrm{Zn}$ (table 5) (Strauch and others, 2001). 
Table 3. Concentrations of metals in stream, wetland, and lake sediment downstream from sediment-hosted Cu deposits.

$[R F$, reduced-facies-type deposit; Al, aluminum; As, arsenic; Cd, cadmium; Co, cobalt; Cr, chromium; Cu, copper; Fe, iron; Ni, nickel; Pb, lead; S, sulfur; Zn, zinc; \%, percent; mg/kg, milligrams per kilogram; - , no data; $<$, less than]

\begin{tabular}{|c|c|c|c|c|c|c|c|c|c|c|c|c|c|c|}
\hline $\begin{array}{c}\text { Mining area } \\
\text { (deposit model) }\end{array}$ & Source & Description & $\begin{array}{c}\text { Al } \\
(\%)\end{array}$ & $\begin{array}{c}\text { As } \\
(\mathrm{mg} / \mathrm{kg})\end{array}$ & $\begin{array}{c}\text { Cd } \\
(\mathrm{mg} / \mathrm{kg})\end{array}$ & $\begin{array}{c}\text { Co } \\
(\mathrm{mg} / \mathrm{kg})\end{array}$ & $\begin{array}{c}\mathrm{Cr} \\
(\mathrm{mg} / \mathrm{kg})\end{array}$ & $\begin{array}{c}\mathrm{Cu} \\
(\mathrm{mg} / \mathrm{kg})\end{array}$ & $\begin{array}{l}\mathrm{Fe} \\
(\%)\end{array}$ & $\begin{array}{c}\mathrm{Ni} \\
(\mathrm{mg} / \mathrm{kg})\end{array}$ & $\begin{array}{c}\mathrm{Pb} \\
(\mathrm{mg} / \mathrm{kg})\end{array}$ & $\begin{array}{c}\mathbf{S} \\
(\%)\end{array}$ & $\begin{array}{c}\mathrm{Zn} \\
(\mathrm{mg} / \mathrm{kg})\end{array}$ & Reference \\
\hline $\begin{array}{l}\text { Chambishi mine, } \\
\text { Zambia (RF) }\end{array}$ & stream & $\begin{array}{l}\text { upstream of mining } \\
\text { area (Kafue River) }\end{array}$ & $5.5-5.9$ & - & - & $30-46$ & - & $15-146$ & $2.4-4.9$ & - & - & $0.35-0.65$ & - & $\begin{array}{l}\text { Pettersson and others (2000); } \\
\text { Pettersson and Ingri (2001) }\end{array}$ \\
\hline $\begin{array}{l}\text { Chambishi mine, } \\
\text { Zambia (RF) }\end{array}$ & stream & $\begin{array}{l}\text { mining area } \\
\text { (Kafue River) }\end{array}$ & $9.0-9.7$ & - & - & $789-1,030$ & - & $11,028-12,855$ & 3.8 & - & - & $0.20-0.80$ & - & Pettersson and Ingri (2001) \\
\hline $\begin{array}{l}\text { Chambishi mine, } \\
\text { Zambia (RF) }\end{array}$ & stream & $\begin{array}{c}\text { mining area } \\
\text { (Mwambashi } \\
\text { River) }\end{array}$ & 4.9 & - & - & 374 & - & 1,250 & 1.9 & - & - & - & - & Pettersson and Ingri (2001) \\
\hline $\begin{array}{l}\text { Chambishi mine, } \\
\text { Zambia (RF) }\end{array}$ & wetland & $\begin{array}{l}\text { within wetland } \\
\text { (New Dam) }\end{array}$ & $1.7-2.3$ & - & $<0.1-0.8$ & $42-8,439$ & $9-130$ & $109-12,112$ & - & $3-220$ & $9-75$ & $0.10-1.05$ & $7-125$ & von der Heyden and New (2004b) \\
\hline $\begin{array}{l}\text { Mansfield district, } \\
\text { Germany (RF) }\end{array}$ & stream & $\begin{array}{l}\text { downstream of } \\
\text { Helbra smelter }\end{array}$ & - & 487 & - & - & 121 & 198 & 5.1 & 0 & 567 & - & 6,429 & Schreck and others (2005) \\
\hline $\begin{array}{l}\text { Mansfield district, } \\
\text { Germany (RF) }\end{array}$ & stream & $\begin{array}{l}\text { downstream of } \\
\text { Eisleben smelter }\end{array}$ & - & 56 & - & - & 92 & 1,054 & 2.9 & 56 & 1,034 & - & 3,796 & Schreck and others (2005) \\
\hline $\begin{array}{l}\text { Mansfield district, } \\
\text { Germany (RF) }\end{array}$ & lake $^{1}$ & $\begin{array}{l}\text { downstream of } \\
\text { mining and } \\
\text { smelting district }\end{array}$ & $5.1-7.6$ & $2-1,800$ & $<2-55$ & $11-47$ & $65-92$ & $21-2704$ & $2.2-3.6$ & $36-71$ & $27-4,017$ & $0.4-2.3$ & $88-35,500$ & Becker and others (2001) \\
\hline $\begin{array}{l}\text { Probable Effect } \\
\text { Concentrations } \\
\text { (PEC) }\end{array}$ & & & - & 33 & 4.98 & - & 111 & 149 & - & 48.6 & 128 & - & 459 & MacDonald and others (2000) \\
\hline
\end{tabular}

${ }^{1}$ Range in typical concentrations for samples between 0 and 510 centimeter depths. 
[RF, reduced-facies-type deposit(s); SS, sandstone copper-type deposit(s); Al, aluminum; Cd, cadmium; Co, cobalt; Cr, chromium; Cu, copper; Fe, iron; Mn, manganese; Mo, molybdenum; Ni, nickel; Pb, lead; $\mathrm{S}$, sulfur; $\mathrm{Zn}$, zinc; $\mu \mathrm{g} / \mathrm{L}$, micrograms per liter; <, less than; -, not reported or not analyzed; m, meters; km, kilometers; $\mathrm{mg} / \mathrm{L}$, milligrams per liter; $\mathrm{Al}$, Fe, and $\mathrm{pH}$ are non-priority pollutants]

\begin{tabular}{|c|c|c|c|c|c|c|c|c|c|c|c|c|c|c|c|c|}
\hline $\begin{array}{c}\text { Mining area } \\
\text { (deposit model) }\end{array}$ & $\begin{array}{l}\text { Water } \\
\text { type }\end{array}$ & $\begin{array}{l}\text { Water } \\
\text { source }\end{array}$ & pH & $\begin{array}{c}\text { Al } \\
(\mu \mathrm{g} / \mathrm{L})\end{array}$ & $\begin{array}{c}\mathrm{Cd} \\
(\mu \mathrm{g} / \mathrm{L})\end{array}$ & $\begin{array}{c}\text { Co } \\
(\mu \mathrm{g} / \mathrm{L})\end{array}$ & $\begin{array}{c}\mathrm{Cr} \\
(\mu \mathrm{g} / \mathrm{L})\end{array}$ & $\begin{array}{c}\mathrm{Cu} \\
(\mu \mathrm{g} / \mathrm{L})\end{array}$ & $\begin{array}{c}\mathrm{Fe} \\
(\mu \mathrm{g} / \mathrm{L})\end{array}$ & $\begin{array}{c}\mathrm{Mn} \\
(\mu \mathrm{g} / \mathrm{L})\end{array}$ & $\begin{array}{c}\text { Mo } \\
\text { ( } \mu \mathrm{g} / \mathrm{L})\end{array}$ & $\begin{array}{c}\mathrm{Ni} \\
(\mu \mathrm{g} / \mathrm{L})\end{array}$ & $\begin{array}{c}\mathrm{Pb} \\
(\mu \mathrm{g} / \mathrm{L})\end{array}$ & $\underset{(\mathrm{mg} / \mathrm{L})}{\mathrm{S}}$ & $\begin{array}{c}\mathrm{Zn} \\
(\mu \mathrm{g} / \mathrm{L})\end{array}$ & Reference \\
\hline $\begin{array}{l}\text { White Pine, Michigan, } \\
\text { USA (RF) }\end{array}$ & $\begin{array}{l}\text { surface } \\
\text { water }\end{array}$ & $\begin{array}{c}\text { tailings basin, } \\
\text { smelter slag, and mine }\end{array}$ & 7.2 & - & - & - & - & - & - & - & - & - & - & - & - & Lindsey and others (1995) \\
\hline $\begin{array}{l}\text { Spar Lake, Montana, } \\
\text { USA (SS) }\end{array}$ & $\begin{array}{l}\text { surface } \\
\text { water }\end{array}$ & mine & $7.2-7.6$ & - & $<1$ & - & - & $10-280$ & - & - & - & - & 10 & - & $10-40$ & $\begin{array}{l}\text { U.S. Forest Service and others } \\
\text { (1992) }\end{array}$ \\
\hline $\begin{array}{l}\text { Spar Lake, Montana, } \\
\text { USA (SS) }\end{array}$ & $\begin{array}{l}\text { surface } \\
\text { water }\end{array}$ & mine & $7.5-8$ & - & $<1$ & - & - & $<10$ & - & - & - & - & $<10$ & - & $10-20$ & $\begin{array}{l}\text { U.S. Forest Service and others } \\
\text { (1992) }\end{array}$ \\
\hline $\begin{array}{l}\text { Spar Lake, Montana, } \\
\text { USA (SS) }\end{array}$ & $\begin{array}{l}\text { surface } \\
\text { water }\end{array}$ & settling pond & $7.7-10.9$ & - & $<1$ & - & - & $<10-20$ & - & - & - & - & $<10$ & - & $<20-50$ & $\begin{array}{l}\text { U.S. Forest Service and others } \\
\text { (1992) }\end{array}$ \\
\hline $\begin{array}{l}\text { Spar Lake, Montana, } \\
\text { USA (SS) }\end{array}$ & $\begin{array}{l}\text { surface } \\
\text { water }\end{array}$ & $\begin{array}{l}\text { tailings } \\
\text { impoundment outflow }\end{array}$ & 7.5 & - & 2 & - & - & 40 & 50 & 430 & - & - & 15 & 8 & 20 & $\begin{array}{l}\text { U.S. Forest Service and others } \\
\text { (2009) }\end{array}$ \\
\hline $\begin{array}{l}\text { Montanore, Montana, } \\
\text { USA (SS) }\end{array}$ & $\begin{array}{l}\text { surface } \\
\text { water }\end{array}$ & $\begin{array}{l}\text { tailings impoundment } \\
\text { outflow }\end{array}$ & 7.5 & - & - & - & - & - & - & - & - & - & - & 4 & - & $\begin{array}{l}\text { U.S. Forest Service and others } \\
\text { (2009) }\end{array}$ \\
\hline $\begin{array}{l}\text { Chambishi mine, } \\
\text { Zambia (RF) }\end{array}$ & $\begin{array}{l}\text { ground } \\
\text { water }\end{array}$ & tailings pile & 7.5 & - & - & 12 & - & 6 & 70 & 13 & - & - & - & 600 & - & Sracek and others (2010) \\
\hline $\begin{array}{c}\text { Chambishi mine, } \\
\text { Zambia (RF) }\end{array}$ & $\begin{array}{l}\text { surface } \\
\text { water }\end{array}$ & $\begin{array}{l}\text { wetland inflow } \\
\text { (tailings outflow) }\end{array}$ & $7.3-8.5$ & - & - & $<10-470$ & - & $<10-380$ & - & - & - & - & - & $<30-510$ & - & von der Heyden and New (2005) \\
\hline $\begin{array}{c}\text { Chambishi mine, } \\
\text { Zambia (RF) }\end{array}$ & $\begin{array}{l}\text { surface } \\
\text { water }\end{array}$ & wetland outflow & $7.2-7.8$ & - & - & $<10-940$ & - & $<10-50$ & - & - & - & - & - & $100-290$ & - & von der Heyden and New (2005) \\
\hline $\begin{array}{c}\text { Chambishi mine, } \\
\text { Zambia (RF) }\end{array}$ & $\begin{array}{l}\text { ground } \\
\text { water }\end{array}$ & tailings basin & $6.0-6.2$ & $20-50$ & $1-2$ & $24-26$ & $1-6$ & $2-19$ & $1,680-2,420$ & $990-1,070$ & - & $5-10$ & $0.3-0.4$ & - & $40-91$ & von der Heyden and New (2004a) \\
\hline $\begin{array}{l}\text { Chambishi mine, } \\
\text { Zambia (RF) }\end{array}$ & $\begin{array}{l}\text { ground } \\
\text { water }\end{array}$ & $\begin{array}{l}150 \text { m downgradient } \\
\text { of tailings basin }\end{array}$ & $6.1-6.5$ & $20-50$ & $2-3$ & $<50-206$ & $1-5$ & $3-24$ & $220-7,830$ & $80-510$ & - & $3-16$ & $0.2-2$ & - & $17-133$ & von der Heyden and New (2004a) \\
\hline $\begin{array}{l}\text { Copperbelt district, } \\
\text { Zambia (RF \& SS) }\end{array}$ & $\begin{array}{l}\text { surface } \\
\text { water }\end{array}$ & $\begin{array}{c}\text { Kafue River } \\
\text { upstream of mining }\end{array}$ & $7.2-8.1$ & $3-8$ & - & $0.2-2$ & - & $1-3$ & $78-254$ & $6-17$ & ND & $0.1-1$ & - & $1-2$ & - & $\begin{array}{l}\text { Pettersson and Ingri (2001), } \\
\text { Pettersson and others (2000) }\end{array}$ \\
\hline $\begin{array}{l}\text { Copperbelt district, } \\
\text { Zambia (RF \& SS) }\end{array}$ & $\begin{array}{l}\text { surface } \\
\text { water }\end{array}$ & $\begin{array}{l}\text { Kafue River } \\
\text { upstream of mining }\end{array}$ & - & 2 & - & 0.3 & - & 2 & 6 & 32 & NR & $<0.02$ & $<0.02$ & NR & 38 & Norrgren and others (2000) \\
\hline $\begin{array}{l}\text { Copperbelt district, } \\
\text { Zambia (RF \& SS) }\end{array}$ & $\begin{array}{l}\text { surface } \\
\text { water }\end{array}$ & $\begin{array}{l}\text { Kafue River } \\
\text { mining area }\end{array}$ & $7.2-8.0$ & $5-76$ & - & $4-25$ & - & $18-144$ & $24-132$ & $86-132$ & $2-5$ & $2-4$ & - & $14-82$ & - & $\begin{array}{l}\text { Pettersson and Ingri (2001), } \\
\text { Pettersson and others (2000) }\end{array}$ \\
\hline $\begin{array}{l}\text { Copperbelt district, } \\
\text { Zambia (RF \& SS) }\end{array}$ & $\begin{array}{l}\text { surface } \\
\text { water }\end{array}$ & $\begin{array}{l}\text { Kafue River downstream } \\
\text { of mining area }\end{array}$ & - & 21 & - & 54 & - & 15 & 18 & 122 & 6.8 & 7.6 & 0.5 & NR & 53 & Norrgren and others (2000) \\
\hline Glogow, Poland (RF) & $\begin{array}{l}\text { ground } \\
\text { water }\end{array}$ & $2.0 \mathrm{~km}$ from smelter & - & - & $2-13$ & - & - & $16-62$ & - & - & - & - & $37-72$ & - & $91-804$ & Pilc and others (1999) \\
\hline Glogow, Poland (RF) & $\begin{array}{l}\text { surface } \\
\text { water }\end{array}$ & $2.0 \mathrm{~km}$ from smelter & - & - & $1-7$ & - & - & $7-31$ & - & - & - & - & $17-62$ & - & $16-92$ & Pilc and others (1999) \\
\hline Glogow, Poland (RF) & $\begin{array}{l}\text { surface } \\
\text { water }\end{array}$ & $5.5 \mathrm{~km}$ from smelter & - & - & $1-8$ & - & - & $5-16$ & - & - & - & - & $26-40$ & - & $24-120$ & Pilc and others (1999) \\
\hline $\begin{array}{l}\text { Mansfeld district, } \\
\text { Germany (RF) }\end{array}$ & $\begin{array}{l}\text { surface } \\
\text { water }\end{array}$ & mine & $6.9-7.7$ & - & - & - & - & - & - & - & - & - & - & - & - & Knitzschke and Kahmann (1990) \\
\hline $\begin{array}{l}\text { Mansfeld district, } \\
\text { Germany (RF) }\end{array}$ & $\begin{array}{l}\text { surface } \\
\text { water }\end{array}$ & flue dust sludge pond & - & 18,000 & 3,300 & - & 3 & 19,000 & $<50$ & 16,000 & - & - & 2,400 & - & $2,111,000$ & Schubert and others (2003) \\
\hline $\begin{array}{l}\text { Drinking water } \\
\text { guideline }\end{array}$ & - & - & - & & 3 & - & 50 & 2,000 & - & 400 & 70 & 70 & 10 & - & - & $\begin{array}{l}\text { World Health Organization } \\
\text { (2006) }\end{array}$ \\
\hline $\begin{array}{l}\text { Aquatic ecosystem } \\
\text { acute toxicity }^{2}\end{array}$ & - & - & - & 750 & 2 & - & 570 & 13 & - & - & - & 470 & 65 & - & 120 & $\begin{array}{l}\text { U.S. Environmental } \\
\text { Protection Agency (2006) }\end{array}$ \\
\hline $\begin{array}{l}\text { Aquatic ecosystem } \\
\text { chronic toxicity }^{2}\end{array}$ & - & - & $6.5-9$ & 87 & 0.25 & - & 74 & 9 & 1,000 & - & - & 52 & 2.5 & - & 120 & $\begin{array}{l}\text { U.S. Environmental } \\
\text { Protection Agency (2006) }\end{array}$ \\
\hline
\end{tabular}

${ }^{1}$ Dissolved concentrations were calculated from total concentration and percent suspended.

${ }^{2}$ Freshwater criterion for $\mathrm{Cd}, \mathrm{Cr}$ (assume $\mathrm{Cr}(\mathrm{III})$ ), $\mathrm{Cu}, \mathrm{Pb}, \mathrm{Ni}$ and $\mathrm{Zn}$ are hardness dependent and calculated based on a hardness of $100 \mathrm{mg} / \mathrm{L} \mathrm{CaCO}$. 
Table 5. Concentrations of elements (in milligrams per kilogram) in slag and flue dust from smelters in the Mansfield mining district (RF), Germany.

[RF, reduced-facies-type deposit; As, arsenic; $\mathrm{Cd}$, cadmium; $\mathrm{Cr}$, chromium; $\mathrm{Cu}$, copper; Fe, iron; $\mathrm{Pb}$, lead; $\mathrm{Zn}$, zinc; <, less than; NR, not reported]

\begin{tabular}{lrrrrrrrr}
\hline \multicolumn{1}{c}{ Sample type } & As & Cd & Cr & Cu & Fe & Pb & Zn & Source \\
\hline Slag & 3 & 1 & 233 & 1,636 & 13,708 & 172 & 2,788 & Jahn and others (1997) \\
Slag & 5 & $<3$ & 230 & 1,600 & NR & 200 & 2,800 & Matheis and others (1999) \\
Flue dust (fresh) & 3,800 & 435 & 130 & 13,200 & 12,700 & 143,000 & 193,000 & Weiss and others (1997) \\
Flue dust (weathered) & 6,674 & 451 & 201 & 10,117 & 14,722 & 95,772 & 83,182 & Jahn and others (1997) \\
Flue dust (mean concentration) & NR & 8,100 & NR & 15,500 & 12,900 & 15,900 & 9,900 & Schubert and others (2003) \\
Flue dust (ground) & 4,080 & 360 & 890 & 14,100 & 30,850 & 122,000 & 163,000 & Morency and others (1998) \\
flue dust & 6,300 & 980 & $<10$ & 9,200 & NR & 12,400 & 15,900 & Matheis and others (1999) \\
flue dust & 215 & 450 & 18 & 10,100 & NR & 9,600 & 8,300 & Matheis and others (1999) \\
\hline
\end{tabular}

In contrast to the Mansfeld district, the White Pine mine included $26.3 \mathrm{~km}^{2}$ of tailings in three surface impoundments (Williams and others, 2002). In 1991, White Pine generated 5.0 million tonnes of tailings and 182,000 $t$ of reverberatory furnace slag (U.S. Environmental Protection Agency, 1994). During the 1970s and during periods of low production rates in the 1990s, slag was crushed and underwent beneficiation to recover Cu (U.S. Environmental Protection Agency, 1994).

Red-bed-subtype deposits are generally low tonnage (median 1.2 million tonnes) with intermediate $\mathrm{Cu}$ grade (median 1.2 percent) and are mined either on the surface or underground. The volume of mine waste and tailings is expected to be lower for the red-bed deposits compared to the other subtypes of deposits because of their overall smaller size.

The sandstone $\mathrm{Cu}$ deposits are intermediate tonnage (median, outside of the Central African Copperbelt, 7.2 million tonnes) but lower $\mathrm{Cu}$ grade (median 1.08 percent). The Troy mine in Montana produced 2.9 million tons of tailings each year (U.S. Environmental Protection Agency, 1994). The mine was in operation from 1981 to 1993, and it re-opened in 2004 and has operated continuously since then. Because of the intermediate tonnage of these deposits, the amount of waste produced is intermediate between the red-bed-subtype and the reduced-facies-subtype deposits.

\section{Mine-Waste Characteristics}

Common mine waste produced by the processing of sedimentary-hosted $\mathrm{Cu}$ deposits includes flotation mill tailings, flue dust concentrated by spraying water into the smelter process gases, and silicate slag. These types of waste can be characterized on the basis of their chemical composition, mineralogy, and acid-generating potentials.

\section{Chemistry}

Reduced-facies-type.-The mining of reduced-facies deposits has produced tailings, slag, and flue dust as waste products. Tailings from two deposits, Chambishi and Nkana, in Zambia in the Central African Copperbelt generally contain 1 to 4 wt. $\% \mathrm{Fe}, 0.1-0.3$ wt. $\% \mathrm{Cu}$, and 300 to $800 \mathrm{mg} / \mathrm{kg}$ Co. A hardpan layer in one tailings pile contains substantially higher concentrations of these three metals (Sracek and others,
2010). Tailings from the Rudna, Polkowice, and Lubin mines in Poland are all dumped in a common tailings pond. The tailings from the Rudna mine are reported to contain approximately 0.2 percent $\mathrm{Cu}$ (E\&MJ, 1986b). Tailings from the White Pine mine in the United States contain comparable concentrations; $\mathrm{Cu}$ ranges from less than detection to $0.17 \mathrm{wt}$. \% (U.S. Environmental Protection Agency, 1994; Williams and others, 2002). The concentrations of $\mathrm{Cu}$ for tailings from all three countries are consistent.

Slag and flue dust from smelting in the Mansfeld mining district contains significant concentrations of $\mathrm{Cu}, \mathrm{Pb}, \mathrm{Zn}$, $\mathrm{Cd}$, and As (table 5); the flue dust is highly enriched in As, $\mathrm{Cd}, \mathrm{Cu}, \mathrm{Pb}$, and $\mathrm{Zn}$ compared to the slag (Jahn and others, 1997; Matheis and others, 1999; Wennrich and others, 2001). The flue dust is extremely fine-grained and contains major concentrations of metals with as much as $193,000 \mathrm{mg} / \mathrm{kg} \mathrm{Zn}$, $143,000 \mathrm{mg} / \mathrm{kg} \mathrm{Pb}, 8,100 \mathrm{mg} / \mathrm{kg} \mathrm{Cd}$, and 6,674 mg/kg As (Wennrich and others, 2001; Schubert and others, 2003) (table 5). This material was reprocessed from 1904 to 1978 to extract $\mathrm{Zn}, \mathrm{Pb}, \mathrm{Ag}, \mathrm{Re}, \mathrm{Se}, \mathrm{Sn}, \mathrm{Tl}$, and $\mathrm{Ge}$ (Matheis and others, 1999).

Waste slag from the Glogow smelters in Poland contains between 0.5 and 0.7 percent $\mathrm{Cu}(\mathrm{E} \& \mathrm{MJ}, 1986 \mathrm{a})$. These are higher concentrations than reported for the Mansfeld district slag (0.16 wt. 5, table 5). Kucha and Cichowska (2001) report 6 and $40 \mathrm{mg} / \mathrm{kg} \mathrm{Ag}$, and 0.008 and $0.009 \mathrm{mg} / \mathrm{kg} \mathrm{Au}$ in shaft and converter slags from Legnica. Pt and Pd were not detected at detection limits of $0.002 \mathrm{mg} / \mathrm{kg}$ (Kucha and Cichowska, 2001).

Sandstone Cu-type.-Mine waste from deposits hosted by the Revett Formation in Montana has low concentrations of trace elements. The orebody contains very little pyrite, and levels of $\mathrm{Cd}, \mathrm{Sb}$, and other metals are low. Copper occurs predominantly as $\mathrm{Cu}$ and $\mathrm{Cu}-\mathrm{Fe}$ sulfides and $\mathrm{Ag}$ occurs as native $\mathrm{Ag}$ and in solid solution in $\mathrm{Cu}$ minerals. There are broad halos of galena-rich rock, much greater than $100 \mathrm{~m}$ in width and several tens of meters thick, surrounding the ore and, farther outboard, pyrite. The Pb-rich rock has been shown to leach $\mathrm{Pb}$ in considerable concentrations but can be avoided when mining (E\&MJ, 1989; U.S. Forest Service and others, 2009). Tailings for the Revett deposits contain low $\mathrm{S}$ concentrations, ranging from 0.01 to 0.08 wt. \%, presumably mainly as $\mathrm{Cu}$ sulfides. However, if the $\mathrm{S}$ were in pyrite, it would equate to an acid-generating potential value of 0.3 to $2.5 \mathrm{~kg} \mathrm{CaCO}_{3} / \mathrm{T}$ (U.S. Forest Service and others, 2009). 


\section{Mineralogy}

SSC deposits contain zones of chalcocite and other minerals near $\mathrm{Cu}_{2} \mathrm{~S}$ in composition, as well as bornite, chalcopyrite, pyrite, and subordinate galena and sphalerite in order outward from the oxidized source of $\mathrm{Cu}$. Native copper and native silver may also be present. The chalcocite and bornite in the high-grade zone are fairly stable under oxidizing conditions, but the oxidation of pyrite can generate acid and cause environmental issues depending on its abundance. The overall concentrations of sulfide minerals are typically low for these deposits and only make up less than or equal to $10 \mathrm{wt}$. \% of the processed ore. Because of the overall low sulfide content, the mine-waste mineralogy is dominantly a reflection of the host-rock mineralogy, which does vary between the subtypes of SSC deposits. For reduced-facies-type deposits, host rocks are marine or lacustrine rocks and approximately 30 percent of deposits are hosted by limestone, dolomite, or marl according to Cox and others (2003). The tailings produced from processing these deposits are more likely to contain higher abundances of carbonates that can mitigate acid generation. In contrast, about 3 percent of red-bed-type deposits and 4 percent of sandstone-type deposits are hosted by carbonates, although nearly all deposits contain at least a minor amount of carbonates. The majority of the red-bed ( 85 percent) and sandstone $\mathrm{Cu}$ deposits (77 percent) are hosted by sandstone or conglomerate (Cox and others, 2003). Therefore, tailings generated by processing ores of the various subtypes will be composed of silicate, carbonate, and (or) oxide phases from the host rocks, with only minor to trace amounts of sulfides. This is consistent with the finding of Sracek and others (2010), who report the primary mineralogy of tailings from the Zambian Copperbelt as quartz, muscovite, amphibole tremolite, orthoclase, calcite, and, at some sites, dolomite. The sulfide $\mathrm{S}$ at various depths within the tailings piles in the Zambian Copperbelt is only between 0.03 and 0.5 wt. \%; pyrite and chalcopyrite were identified by electron microscopy. Also, inorganic $\mathrm{C}$, which likely equates to calcite or dolomite, ranges from 0.4 to $3.1 \mathrm{wt}$. $\%$ (Sracek and others, 2010).

Several studies have focused on characterizing the mineralogy of flue dust from Germany and slag from Poland, both from reduced-facies-type deposits. First, flue dust from the Mansfeld district consists mainly of amorphous sulfidic particles containing $\mathrm{Pb}, \mathrm{Zn}, \mathrm{Cu}$, and $\mathrm{Fe}$ (Schubert and others, 2003). The predominant mineral phases are sphalerite/wurzite and galena, with poorly developed lattice structures and extensive ionic substitutions and secondary anglesite (Weiss and others, 1997; Morency and others, 1998). Substantial amounts of amorphous material are also present (Weiss and others, 1997). The mineralogy of various types of slag (shaft, converter, and suspension) from the Legnica and Glogow smelters in Poland includes, as the main component, a glass phase that contains abundant small oval aggregates of metallic $\mathrm{Cu}$, sulfides, $\mathrm{Fe}-\mathrm{Co}$ alloys, $\mathrm{Pb}-\mathrm{Ag}$ alloys, spinels, sphalerite, arsenate phases, and less commonly olivine, pyroxene, and amphibole crystals (Kucha and Cichowska, 2001). Silver generally occurs as small metallic inclusions in metallic $\mathrm{Cu}$, metallic $\mathrm{Pb}$, and sulfides. $\mathrm{Au}$ is generally found with metallic $\mathrm{Cu}$, metallic $\mathrm{Ag}$, metallic $\mathrm{Pb}$, and $\mathrm{Pb}-\mathrm{Ag}$ alloys (Kucha and Cichowska, 2001).

\section{Secondary Minerals}

Secondary minerals form on mine-waste dumps, slag heaps, and flue-dust piles. Data on the secondary mineralogy of mine waste from deposits are discussed below.

Gordaite (hexagonal $\left.\mathrm{Na}(\mathrm{Zn}, \mathrm{Cu})_{4}\left(\mathrm{SO}_{4}\right)(\mathrm{OH})_{6} \mathrm{Cl} \cdot 6 \mathrm{H}_{2} \mathrm{O}\right)$ has been identified on the surface of mine-waste dumps in the Mansfeld district occurring with connellite (hexagonal $\mathrm{Cu}_{19}\left(\mathrm{SO}_{4}\right)(\mathrm{OH})_{32} \mathrm{Cl}_{4} 3 \mathrm{H}_{2 \mathrm{O}}$ ), anglesite (orthorhombic $\mathrm{PbSO}_{4}$ ), and chlorine bromargyrite (cubic $\mathrm{Ag}(\mathrm{Br}, \mathrm{Cl})$ ) (Jahn and Witzke, 1999). Jahn and Witzke (1999) report secondary gypsum $\left(\mathrm{CaSO}_{4} \cdot 2 \mathrm{H}_{2} \mathrm{O}\right)$ and malachite (monoclinic $\mathrm{Cu}_{4}\left(\mathrm{CO}_{3}\right)$ $(\mathrm{OH})_{2}$ ), as well as an amorphous $\mathrm{Zn} \mathrm{Pb}$ sulfate, on the surface of dumps. Matheis and others (1999) reported secondary minerals form from weathering of ores and flue dust as relatively soluble $\mathrm{Zn}$-dominated amorphous phases and more stable $\mathrm{Cu}$ and $\mathrm{Pb}$-bearing carbonates and sulfates. After mining stopped in the Mansfeld district in 1990, the water that covered the flue-dust piles dried up, allowing oxidation and formation of secondary minerals, particularly sulfates, that have various solubilities. When exposed to rainfall, soluble secondary minerals are washed into the surrounding environment (Schubert and others, 2001, 2003).

Gypsum, hematite, and poorly crystalline Fe oxides are reported as secondary phases in tailings from the Zambian part of the Central African Copperbelt, mostly forming hardpan layers within the piles. The sulfate S reaches nearly $5 \mathrm{wt}$ \% at one location at depth because of the formation of a gypsum hardpan; the sulfate $\mathrm{S}$ contents of the remaining samples are generally less than $1 \mathrm{wt}$ \% (Sracek and others, 2010).

The secondary mineral, gordaite, was reported in small cavities together with sphalerite $(\mathrm{ZnS})$, boléite (cubic $\left.\mathrm{KPb}_{26} \mathrm{Ag}_{9} \mathrm{Cu}_{24}(\mathrm{OH})_{48} \mathrm{Cl}_{62}\right)$, and gypsum within slags of the Mansfeld district (Witzke and Pöllmann, 1996). These secondary minerals found on waste dumps and slag heaps indicate the reactive nature of these materials.

\section{Acid-Base Accounting}

The abundance of carbonate minerals and minerals that weather at intermediate rates, principally chlorite- and epidotegroup minerals, define the acid-neutralizing capacity of these deposits, whereas the acid-generating potential is defined by the abundance of sulfides such as pyrite and chalcopyrite. The net neutralization potential is the acid-neutralizing capacity minus the acid-generating capacity; the neutralization potential ratio is the acid-neutralizing capacity divided by the acid-generating capacity. Many deposits contain substantial carbonate minerals in the ore or host rock, which neutralize acidity generated by the sulfides. Nacimiento, N. Mex., is an exception among the red-bed deposits and contains as 
much as $1 \mathrm{v} . \%$ carbonate minerals (LaPoint, 1974). As for acid-generating sulfides, the ore for all three subtypes contain low pyrite contents. Host-rock pyrite content varies with greater than or equal to $1 \mathrm{v}$. \% pyrite in host-rock shale and siltstone of the reduced-facies subtype and approximately 0.1 to $0.2 \mathrm{v} . \%$ pyrite in the peripheral pyrite-bearing zones of sandstone Cu-type deposits in the Revett Formation (Hayes and Einaudi, 1986).

Sulfide minerals have zonal distributions in these ore deposits, which need to be considered when evaluating potential environmental effects. The high-grade ore zone contains chalcocite and bornite, which are fairly stable under oxidizing conditions. This zone contains pyrite in trace amounts or none at all. In contrast to the high-grade ore zone, the low-grade zone consists of pyrite and chalcopyrite; pyrite abundance increases outward as $\mathrm{Cu}$ grade decreases (Cox and others, 2003). Therefore, the low-grade zone has a higher potential to create acid mine drainage but is not the target of the mining. The acid-base accounting methods commonly used assume the source of $\mathrm{S}$ is acid-generating pyrite. This overstates the potential for acid generation by the $\mathrm{Cu}$-sulfide minerals. Therefore, the acid-generating potential may be overestimated by this method.

Limited acid-base accounting data have been reported in the literature for SSC deposits. Acid-base accounting data for waste from three reduced-facies-type deposits are given below. For tailings, no acid-generating capacity is detected for samples from the White Pine mine (Williams and others, 2002) and high acid-neutralizing capacities and neutral to alkaline conditions are reported for samples from Zambia in the Central African Copperbelt. For the Zambian tailings, neutralization potential ratios are between 3.4 and $84 \mathrm{~kg} \mathrm{CaCO}_{3} / \mathrm{T}$; most samples at depth have values greater than 20 . The highest values are for the leached surface materials (Sracek and others, 2010). The acid-neutralizing capacity of flue dust from the Mansfeld district was approximated at only $45 \mathrm{~kg} \mathrm{CaCO}_{3} / \mathrm{T}$ (900 $\mathrm{mmol} \mathrm{H}^{+} / \mathrm{kg}$ ) (Paschke and others, 2001).

The net neutralization potentials of ore, waste rock, and tailings from the sandstone $\mathrm{Cu}$ deposits, including Montanore, Rock Creek, and Spar Lake (Troy mine), were summarized by the U.S. Forest Service and others (2009). Ore from the Montanore deposit has an average net neutralization potential of $-4 \mathrm{~kg} \mathrm{CaCO}_{3} / \mathrm{T}$, with values ranging from -24 to $11 \mathrm{~kg} \mathrm{CaCo}_{3} / \mathrm{T}$. Values for Rock and Troy ore samples average 5.1 and $7.6 \mathrm{~kg} \mathrm{CaCO}_{3} / \mathrm{T}$, respectively. The mean net neutralization potentials for tailings from these sandstone $\mathrm{Cu}$ deposits range from 2.8 to $10 \mathrm{~kg} \mathrm{CaCO}_{3} / \mathrm{T}$. Humidity cell tests on tailings resulted in leachates with near-neutral $\mathrm{pH}$ and low levels of metals (U.S. Forest Service and others, 2009). The acid-base accounting results are because of low sulfide concentrations in the tailings. The mean net neutralization potentials for mine waste from these deposits range from 3.6 to $15 \mathrm{~kg} \mathrm{CaCO}_{3} / \mathrm{T}$, although the waste-rock net neutralization potential is highly variable. For example, net neutralization potentials range from -20 to $54 \mathrm{~kg} \mathrm{CaCO}_{3} / \mathrm{T}$ for the Burke and Prichard Formations, which would be penetrated by an adit in order to access the Montanore deposit, and from 3.2 to $6.0 \mathrm{~kg} \mathrm{CaCO}_{3} / \mathrm{T}$ for the lower Revett Formation host rocks of the deposit. These ranges indicate highly variable potential to generate acid from various layers within the host stratigraphic section of a deposit.

\section{Element Mobility Related to Mining in Groundwater, Surface Water, and Stream Sediments}

The potential for acid drainage and the release of metals associated with these deposits is minimized by the widespread presence of carbonate minerals in ore and waste rock and by low pyrite and chalcopyrite contents. Overall, the metal mobility from these deposits is low to moderate in water draining mines. Waters draining mines and tailings generally have near-neutral to moderately alkaline $\mathrm{pH}$ and low dissolvedmetal contents (table 4). However, the concentrations of some metals, including $\mathrm{As}, \mathrm{Cd}, \mathrm{Cr}, \mathrm{Cu}, \mathrm{Hg}$, and $\mathrm{Pb}$, may be elevated downstream from mining and milling operations relative to upstream concentrations.

Metals from mining waste can be immobilized by natural processes such as precipitation, sedimentation, and sorption. The presence of carbonate rock can mitigate the acidic water that may drain from tailings and waste rock. Metals in surface water may be sorbed by Fe or Mn oxyhydroxides or may form less-soluble metal carbonates, hydroxides, and oxides. Lakes and wetlands can act as a trap for particulates. Metals may be removed by filtration through soil or by plant uptake.

\section{Reduced-Facies-Subtype Deposits}

The mining of deposits in the Mansfeld district has contaminated stream sediments, soils, and surface water and groundwater with metals such as $\mathrm{Zn}, \mathrm{Pb}, \mathrm{Cu}, \mathrm{As}$, and $\mathrm{Cd}$. The source of the metals and $\mathrm{S}$ has been shown to be predominantly low-grade ore from mining and flue dust and slag from smelting (Schreck and Glaesser, 1998; Strauch and others, 2001; Schreck and others, 2005). Strauch and others (2001) stated that the flue dust is the most important source of pollution in this mining district. Metals were recovered from the flue dust until 1978, after which the material was deposited in open basins in piles or on slag or mining debris (Matheis and others, 1999). The flue dust is extremely fine-grained being micrometer to submicrometer in size adding to the weathering potential of the material. Wennrich and others (2001) demonstrated on the basis of laboratory extraction procedures that most metals in the flue dust have a high mobilization potential under simulated natural conditions. Paschke and others (2001), using a standard leaching test with distilled water as well as tests that simulated drainage from sludge ponds and acid-rain deposition on flue dust, showed $\mathrm{Zn}, \mathrm{Pb}, \mathrm{Ni}$, and $\mathrm{Cd}$ were leached in concentrations that exceeded environmental limits. Matheis and others (1999) performed outdoor 
leaching experiments to expose material to local climatic conditions and found substantially higher concentrations of metals in leachates from flue dust compared to slag and host rock. Waters from the base of a flue-dust disposal site contain extremely high concentrations of $\mathrm{Zn}(2,000 \mathrm{mg} / \mathrm{L})$ and lesser amounts of $\mathrm{Pb}(2.4 \mathrm{mg} / \mathrm{L}), \mathrm{Cu}(19.2 \mathrm{mg} / \mathrm{L})$, and $\mathrm{Cd}(3.3 \mathrm{mg} / \mathrm{L})$ (table 4; Schubert and others, 2003). Matheis and others (1999) reported seepage waters from the base of flue dust and slag heaps containing as much as $2,500 \mathrm{mg} / \mathrm{L} \mathrm{Zn}$. Zinc was shown to be highly mobile from flue dust weathering occurring in soluble $\mathrm{Zn}$-dominated amorphous phases, whereas $\mathrm{Cu}$ and $\mathrm{Pb}$ form relatively stable secondary carbonates and sulfates (Matheis and others, 1999). In addition to the dissolution of metals from the flue dust, metals are dispersed into the surrounding environment through the wind-borne dispersion of the fine-grained particles (Matheis and others, 1999).

Mining in the Zambian Copperbelt, which includes reduced-facies $\mathrm{Cu}$ deposits and sandstone $\mathrm{Cu}$ deposits, has led to elevated metal and sulfate concentrations in water in the areas draining the mines and ore-processing plants (Pettersson and others, 2000; Norrgren and others, 2000; Pettersson and Ingri, 2001). On the basis of Pettersson and Ingri (2001) and Pettersson and others (2000), mining-impacted water of the Kafue River contains as much as $82 \mathrm{mg} / \mathrm{L} \mathrm{S}, 25.3 \mu \mathrm{g} / \mathrm{L} \mathrm{Co}$, and $144.4 \mu \mathrm{g} / \mathrm{L} \mathrm{Cu}$ (table 4). Norrgren and others (2000) report elevated concentrations of metals, such as Co $(54 \mu \mathrm{g} / \mathrm{L})$, $\mathrm{Cu}(15 \mu \mathrm{g} / \mathrm{L})$, and $\mathrm{Ni}(7.6 \mu \mathrm{g} / \mathrm{L})$, downstream from the industrial area compared to an upstream location (table 4).

A groundwater plume that extends 500-700 m downstream from the tailings impoundment at the Chambishi mine in the Zambian Copperbelt was investigated by von der Heyden and New (2004a). They reported elevated $\mathrm{Co}, \mathrm{Ni}$, and $\mathrm{Zn}$ concentrations in the effected groundwater (table 4). Although elevated, the concentrations of metals are generally low and do not exceed drinking-water guidelines because of processes of attenuation resulting from the high buffering capacity of the tailings and bedrock (von der Heyden and New, 2004a). The low concentrations of metals in the plume are consistent with the low metal content of groundwater within the tailings pile at Chimbashi reported by Sracek and others (2010) (table 4). The plume presently does not represent a major environmental risk.

The chemistry of stream sediment downstream from smelters that process reduced-facies $\mathrm{Cu}$ ore is exemplified by samples from the Mansfeld district (Helbra and Eisleben smelters) (table 3). Sediments in a lake downstream from the mining and smelting district act as a sink for metals and contain as much as $5 \mathrm{wt}$ \% $\mathrm{Zn}, 5,000 \mathrm{ppm} \mathrm{Pb}, 4,500 \mathrm{ppm} \mathrm{Cu}$, and 2,000 ppm As (Becker and others, 2001). The ranges for typical concentrations of selected elements for lake sediments between 0 and $510 \mathrm{~cm}$ depths are given in table 3 (Becker and others, 2001). In Zambia in the Central African Copperbelt, stream sediment from an area impacted by mining along the Kafue River locally contains as much as 0.8 wt. \% S, $12,855 \mathrm{ppm} \mathrm{Cu}$, and 1,030 ppm Co (table 3) (Pettersson and others, 2000; Pettersson and Ingri, 2001).
In addition to stream and lake sediment, wetland sediment can also become contaminated downstream from oreprocessing facilities. At the Chambishi mine in the Zambia, effluent from ore processing eventually flows through a natural wetland. The ranges in concentrations of various elements in wetland inflow, which is downstream from a tailings impoundment and chemically comparable to tailings outflow, and wetland outflow in the Chambishi-mine catchment are reported in table 4 (von der Heyden and New, 2005). This natural wetland system substantially improves the quality of the water by retaining potentially toxic metals, such as $\mathrm{Cu}$ and $\mathrm{Co}$, and diluting some conservative pollutants, such as sulfate (von der Heyden and New, 2005). Von der Heyden and New (2004b) estimated that the wetland has accumulated 150 tonnes of $\mathrm{Cu}$ and 100 tonnes of $\mathrm{Co}$ in the upper $1 \mathrm{~m}$ of wetland sediment. The wetland has been receiving metal-laden effluent for between 40 and 50 years. The range in concentrations of $\mathrm{Cu}$ and $\mathrm{Co}$ in wetland sediment is shown in table 3. Von der Heyden and New (2004b) suggest that the sediment is a potential source of pollutants to the downstream ecosystem. Their work demonstrates that under conditions of lowered surface-water metal concentrations, the metals in the sediment may be released to the water; this may be the condition once mining operations have ceased, and the wetland no longer receives effluent (von der Heyden and New, 2004b). Von de Heyden and New (2003) also stress that the benefit to the downstream ecosystem from the filtering effect of the wetland is offset by the severe pollution of the wetland itself.

\section{Sandstone Copper Deposits}

Several environmental impact statements for sandstone $\mathrm{Cu}$ deposits in Montana discuss the mobility of trace elements to surface water. Tailing effluent and mine-water chemistries for the Spar Lake (Troy) mine are given in table 4 (U.S. Forest Service and others, 1992, 2009). The concentrations of Cd, $\mathrm{Cu}$, and $\mathrm{Pb}$ in the tailings outflow exceed the guidelines for aquatic ecosystems. The potential mobility of trace elements from tailings and waste rock generated from mining the Rock Creek and Montanore deposits was assessed on the basis of standard leaching tests. Ore from the Rock Creek and Montanore deposits leached low concentrations of $\mathrm{Cu}$ $(0.02-0.04 \mathrm{mg} / \mathrm{L})$ and $\mathrm{Mn}(0.03 \mathrm{mg} / \mathrm{L})$ and resulted in neutral $\mathrm{pH}$ water on the basis of a humidity cell test. On the basis of the Toxicity Characteristic Leaching Procedure, tailings and waste rock leached low amounts of metals such as $\mathrm{Ba}, \mathrm{Cr}, \mathrm{Cu}$, $\mathrm{Fe}, \mathrm{Pb}, \mathrm{Mn}$, and $\mathrm{Zn}$ (U.S. Forest Service and others, 2009). Waste rock from some parts of the deposit has the potential to generate acid, whereas other parts do not. Groundwater from monitoring wells in tailings impoundment sites and disposal areas in Montana contain low total dissolved solids and frequently non-detectable dissolved metals. The $\mathrm{pH}$ of the water is typically near-neutral or slightly acidic (U.S. Forest Service and others, 2009). 


\section{Smelter Emissions}

Ore from SSC deposits is either smelted on site or shipped off site. Smelters may emit particulates, metals, nitrogen oxide, sulfur dioxide, carbon monoxide, and (or) hydrocarbons. Atmospheric dusts collected in the vicinity of the Glogow smelters in Poland contain sulfides and arsenides of $\mathrm{Cu}, \mathrm{Pb}, \mathrm{Zn}$, and $\mathrm{Ni}$, and alloys of $\mathrm{Pb}, \mathrm{Pb}-\mathrm{Cu}$, and precious metals (Muszer, 2004). Numerous studies on the soil surrounding the Glogow and Legnica smelters report high metal concentrations, particularly for $\mathrm{Cu}$ and $\mathrm{Pb}$, because of dust emissions; most studies document that concentrations in soils depend on the dominant wind direction and distance from the smelter (table 6) (Roszyk and Szerszen, 1988; Helios Rybicka and Jędrzejczyk, 1995; Karczewska, 1996; Pilc and others, 1999; Grzebisz and others, 2001; Kabala and Singh, 2001). Soils within $1 \mathrm{~km}$ of the smelters contained 250-10,000 ppm $\mathrm{Cu}, 90-18,000$ ppm Pb, 0.3-10.9 ppm Cd, and 55-4,000 ppm Zn (Roszyka and Szerszen, 1988; Helios Rybicka and Jędrzejczyk, 1995). Kabala and Singh (2001) examined soils between 1 and $6 \mathrm{~km}$ from the smelters and reported distinctly lower concentrations of 97-426 ppm Cu, 65-130 ppm Pb, and 45-92 ppm Zn in soils. Grzebisz and others (2001) also found $\mathrm{Cu}$ concentrations (26-330 ppm) within $10 \mathrm{~km}$ of the smelter that were comparable to those reported by Kabala and Singh (2001) (table 6). Overall, the concentrations of $\mathrm{Cu}$ and $\mathrm{Pb}$ determined in these studies were substantially higher than typical values for agricultural soils (Kabata-Pendias and Pendias, 1992). According to Kabala and Singh (2001), the relative mobility of $\mathrm{Cu}, \mathrm{Pb}$, and $\mathrm{Zn}$ increased with an increase in their total-metal content and decreased with an increase in the clay content of the soil. Pilc and others (1999) examined soils 2.0 and $5.5 \mathrm{~km}$ from the smelters and found concentrations of $\mathrm{Cu}, \mathrm{Pb}$, and $\mathrm{Zn}$ that were comparable to those reported by Kabala and Singh (2001) (table 6). Pilc and others (1999) found the highest metal concentrations in soils that had been fertilized intensely with manure, suggesting natural fertilizers may also introduce substantial amounts of pollutants to the soils. The concentrations of metals in groundwater and surface water in the vicinity of the smelters are given in table 4 (Pilc and others, 1999). The concentrations of $\mathrm{Pb}$ and $\mathrm{Cd}$ in many of these waters exceed the World Health Organization guidelines for drinking water (World Health Organization, 2006). As with the soil samples, the substantially higher metal concentrations in the groundwater may result from fertilization with manure.

Flue dust from the Mansfeld district has been documented to release metals into the environment through deflation, erosion, and leaching (Schreck and Glaesser, 1998). The flue dust not only contains large quantities of metals such as $\mathrm{Pb}$ and $\mathrm{Zn}$ but contains substantial amounts of organic compounds (that is, polycyclic aromatic hydrocarbons, polychlorinated dibenzo-p-dioxin) and high concentrations of radionuclides. The extremely fine-grained nature of the material and high solubility for some of the substances promote the release of these materials into surface water, groundwater, and soils (Weiss and others, 1997). (See section on "Element Mobility Related to Mining").

In 1990, the smelter at White Pine emitted approximately 900 short tons of particulates and 225 tons of metal. Metal outputs include 198 ton/yr Cu, 25 ton/yr Pb, 9 ton/yr As, 1.8 ton/yr Cd, and less than 1 ton/yr each of $\mathrm{Cr}, \mathrm{Hg}$, and $\mathrm{Ni}$ (Lindsey and others, 1995).

\section{Ecosystem Issues}

Potential impacts to aquatic ecosystems near a mine site may be grouped into the following categories: changes in sedimentation and water quantity, changes in water quality, changes in toxic metal concentrations in fish tissues, and effects on threatened, endangered, or sensitive species. First, sedimentation rates in streams may increase because of mine construction and mine activities. Aquatic habitats could be affected by changes in flow because of various mechanisms such as changes in stream base flow because of mine and adit inflows, infiltration from disposal sites into shallow groundwater systems and then downgradient streams, diversion of precipitation intercepted by tailings impoundments for mill use, increased storm-water runoff from mine facilities, and increased peak flows affected by vegetation clearing for roads and mining facilities (U.S. Forest Service and others, 2009). Aquatic life can also be affected by high concentrations of metals and nutrients in streams. The effects

Table 6. Concentrations of metals (in milligrams per kilogram) in surface soils surrounding the Glogow and Legnica smelters, Poland.

[Cd, cadmium; $\mathrm{Cu}$, copper; $\mathrm{Pb}$, lead; $\mathrm{Zn}$, zinc; km, kilometers; ND, not detected]

\begin{tabular}{lcccccl}
\hline \multicolumn{1}{c}{ Smelters } & $\begin{array}{c}\text { Distance } \\
\text { from smelters }\end{array}$ & Cd & Cu & Pb & Zn & Source \\
\hline Glogow & Within $1 \mathrm{~km}$ & $0.3-10.9$ & $250-10,000$ & $90-18,000$ & $55-4,000$ & Roszyk and Szerszen (1988) \\
Glogow & Within 6 km & ND & $97-426$ & $65-130$ & $45-92$ & Kabala and Singh (2001) \\
Glogow & Within $5.5 \mathrm{~km}$ & $0.75-1.58$ & $88-510$ & $55-255$ & $68-207$ & Pilc and others (1999) \\
Glogow & Within $10 \mathrm{~km}$ & ND & $26-330$ & ND & ND & Grzebisz and others (2001) \\
Glogow & "near" the smelter & ND & $42-298$ & ND & ND & Grzebisz and others (1997) \\
Glogow \& Legnica & Within $2.5 \mathrm{~km}$ 1 & ND & $7.4-1,710$ & $11-460$ & $6.4-153$ & Karczewska (1996) \\
Legnica & $0.2 \mathrm{~km}$ & 4 & 7,400 & 1,960 & 675 & Helios Rybicka and Jędrzejczyk (1995) \\
\hline
\end{tabular}

${ }^{1}$ Includes A and B soil horizons. 
depend on the hardness of the water for metals such as Zn, $\mathrm{Cu}, \mathrm{Pb}$, and $\mathrm{Cd}$. The hardness of waters in the vicinity of the $\mathrm{Cu}$ deposits can vary depending on the presence and abundance of certain host rocks such as limestone. The greater the hardness, the less toxic the metal is to the ecosystem. Also, air quality may be affected by emissions from smelting and other processing facilities, and surface disturbances may result from open pits and leaching facilities. Lake levels may be disturbed if underground workings intersect fractured rock beneath lakes.

Detailed ecological studies have been carried out along the Kafue River, which flows through the Zambian part of the Central African Copperbelt. Syakalima and others (2001) analyzed water, grass, fish, and lechwe (antelope) liver for $\mathrm{Pb}$; these samples were collected downstream from the miningimpacted areas from two national parks. This study found concentrations of $\mathrm{Pb}$ in water between 0.29 and $0.36 \mathrm{mg} / \mathrm{L}$ compared to the World Health Organization drinking-water guideline of $0.01 \mathrm{mg} / \mathrm{L}$. In a grass species commonly grazed by wildlife and livestock, $\mathrm{Pb}$ concentrations are between 26.0 and $48.0 \mathrm{mg} / \mathrm{kg}$ dry weight. Three species of fish contained between 23.0 and $33.0 \mathrm{mg} / \mathrm{kg}$ dry weight $\mathrm{Pb}$, and the liver of the lechwe contained between 7.0 and $25.0 \mathrm{mg} / \mathrm{kg}$ dry weight $\mathrm{Pb}$ (Syakalima and others, 2001). Overall, this study reported that $\mathrm{Pb}$ has the potential to bioaccumulate in this ecosystem and may cause adverse effects (Syakalima and others, 2001).

Other studies focused on effects of metals in Kafue River on tropical fish toxicity. Stream sediment collected downstream from several mines and near a city that has a major ore-processing facility was substantially more toxic to zebrafish and tilapia than sediment collected further downstream (Mwase and others, 1998). The toxicity was directly related to the contamination of sediments by the mining activities (Mwase and others, 1998). The results of another study showed tilapia exposed in situ to Kafue River water for 2 weeks bioaccumulated trace elements (that is, $\mathrm{Cd}, \mathrm{Co}, \mathrm{Cu}$, $\mathrm{Cr}$, and $\mathrm{Ni}$ ) in experiments downstream from mining activities and other industrial point sources (Norrgren and others, 2000).

Several studies have been carried out on plants growing in the vicinity of the Glogow smelters in Poland (Pilc and others, 1999; Grzebisz and others, 2001). Grzebisz and others (2001) studied nonconsumable crops and found higher amounts of $\mathrm{Cu}$ in flax plants than in oil-seed rape. The concentrations of metals in cultivated consumable plants, including corn, carrots, red beets, and beans, correlated with the distance from the source of smelter emission and with the direction and strength of winds blowing most frequently in the region, indicating the plant pollution is a result of the dust emissions and not the concentrations of metals in the soils (Pilc and others, 1999). Pilc and others (1999) referred to other studies that identified high levels of metals in blood, milk, liver, kidneys, bones, hair, and excrement of the cattle grazing the region. Other studies used sequential extraction schemes on soils to assess the distribution of metal species in operationally defined fractions to gain insight into potential mobility and bioavailability (Helios Rybicka and others, 1994; Grzebisz and others, 1997; Karczewska, 1996).

The growth of plants on waste material is an indication of ecosystem health. Vegetation establishment was attempted in the 1960s on tailings from the White Pine mine. In general, the vegetation died after 2 to 3 years because of factors including the sand-blasting effect of wind blowing the tailings, the physical nature of the material, and possibly the chemical and nutrient imbalances. Nearly all $\mathrm{Cu}$ in the tailings was loosely bound and is considered available for uptake by plants. In 1997, a reclamation goal was set to revegetate the tailings to help stabilize them. Greenhouse and field tests were conducted in 1999 and 2000; large test plots were treated. As reported in 2002, the treated areas were self-sustaining and green (William and others, 2002).

The results of a study to assess the local and long-term effects on Lake Superior from the discharge from the White Pine mine was conducted in 1991. The study showed that discharge from the mine area was not causing measureable effects on the basis of a lack of impact on the benthic community, insignificant increase in chloride from mine discharges, and a lack of detectable effects on local water intakes (U.S. Environmental Protection Agency, 1994). USEPA (1994) referred to the Surface Water Quality Division of the Michigan Department of Natural Resources saying that a diverse fish community exists in the nearby Mineral River that receives drainage from the mine. They reported a reduced macroinvertebrate community downstream from the mine drainage compared to upstream in the river (U.S. Environmental Protection Agency, 1994). This reduction may be because of major physical and natural stream-quality differences in the White Pine area (U.S. Environmental Protection Agency, 1994). Biomonitoring of mine drainage conducted in 1991 showed acute and chronic toxicity for discharge collected in August but not for discharge collected in April, June, or October (U.S. Environmental Protection Agency, 1994).

\section{Climate Effects on Geoenvironmental Signatures}

The effects of various climatic settings on the geoenvironmental signatures of these deposits are not well documented. In general, the environmental impact associated with sulfide-mineral-bearing deposits is greater in humid to temperate climates in comparison to arid climates. Acidity and total-metal concentrations in mine drainage are generally higher in arid environments because of evaporation, which results in the storage of metals and acidity in highly soluble metal-sulfate-salt minerals. However, the lack of surface-water drainage inhibits the mobility of the acidity and metals. In contrast, in more tropical environments, the leaching of metals is exacerbated (Lindsey and others, 1995). 


\section{Knowledge Gaps and Future Research Directions}

There are many different knowledge gaps in studies of SSC deposits, offering outstanding opportunities for usefully directed research. Some of these are discussed below.

\section{Metals-Transporting Brines}

\section{Inorganic Brine Chemistry}

Although it is clear from places that have been studied that the ore-forming groundwater for SSC deposits was briny and it mixed with a second, more dilute solution, the source(s) of the metals-transporting solutions remain somewhat conjectural. In only two places, source rocks have been found that have been depleted of their original $\mathrm{Cu}$ (Coates Lake deposit, Northwest Territories, Canada: Lustwerk and Rose, 1983; Western Montana Copper Sulfide Belt: Hayes, 1990). As known to date, only Coates Lake has continuous exposure of rock between depleted rocks and the $\mathrm{Cu}$ deposit.

The research tools needed to answer questions about the brine source(s) are in place. Brine inorganic chemistry will go a long way toward determining the source(s) of the metals-transporting solutions. In general, two methods, either macro-chemical or micro-chemical, have been used on other ore-deposit types. Both might be employed in studies of the fluid inclusions of SSC deposits.

Viets and others (1996) conducted ion chromatography studies of fluid inclusions in sphalerite or massive ore from Mississippi Valley-type $\mathrm{Pb}-\mathrm{Zn}$ deposits. With ionic compositions of the fluids, various ionic ratio cross plots were constructed and compared with seawater composition, seawater residual brine compositions from evaporite precipitation sequences, and re-dissolved evaporite compositions, allowing conclusions about the origin of the fluids and their pre-ore and ore-stage history. The ore-depositing system of MVTs is a broadly similar interaquifer groundwater mixing process to that of SSC deposits (Plumlee and others, 1994, 1995). In detail, it is doubtful that the two deposit types have metals-transporting brines that are of similar origin, but it does seem likely that the metals-transporting brines of both became strongly saline by dissolving evaporites. Ion chromatography (Viets and others, 1996) would also be the choice for analysis of the anions of SSC-deposit brines. This method would probably be best applied to pure sulfide mineral separates, although it might also provide interesting comparisons from co-existing carbonates and sulfates, for example, from Kupferschiefer ores. It would be best applied to an unmetamorphosed deposit. For fine-grained SSC ores, hand picking and crushing minerals would probably seriously contaminate the ore-stage signature with fluid-inclusion fluids from the detritus, but an approach that thermally decrepitates the inclusions could still succeed (Hayes and others, 2012).

Multiple new techniques for microanalyses of fluid inclusions include laser-ablation inductively coupled plasma mass-spectrometry (LA-ICPMS) (Heinrich and others, 2003), proton-induced X-ray emission (PIXE) (Kurosawa and others, 2003), and synchrotron X-ray fluorescence (SXRF) (Bassett and Brown, 1990). These methods have been successfully used to define composition of inclusion fluids in ore-deposit studies of porphyry $\mathrm{Cu}$, molybdenum, and tungsten deposits (Heinrich and others, 1992; Vanko and others, 2001; Klemm and others, 2007, 2008), Fe oxide-Cu-Au deposits (Baker and others, 2008), epithermal precious-metals deposits (Wallier and others, 2006), volcanogenic massive sulfide deposits (Moura, 2008), intrusion-related Au deposits (Baker and others, 2006), banded Fe formations (Brown and Oliver, 2002), and Mississippi Valley-type Pb-Zn deposits (Stoffel and others, 2008). The LA-ICPMS or PIXE methods promise to be very successful in studies of SSC deposits but only if fluid inclusions are large enough. Most inclusions from SSC-deposit main stages are less than $10 \mu \mathrm{m}$ in size, and such inclusions are too small for LA-ICPMS, PIXE, or SXRF study. Coarser grained host rocks would generally yield coarser grained minerals from the main-stage ore (cements), and those ore-stage minerals might have larger fluid inclusions than finer grained ores, but that has not yet been demonstrated. The LAICPMS, PIXE, and SXRF methods are well-suited to studying second-stage veinlet-hosted stages of SSC deposits.

\section{Sources of Brine Salinity}

In only one place has the source of salinity in a metalstransporting brine been strongly constrained for an SSC deposit. Breit and Meunier (1990) determined the strontiumisotope ratios of barite cements, dolomite cements, and barite in feeder veins for the Lisbon Valley sandstone $\mathrm{Cu}$ deposit. Such isotope determinations can also constrain the sources of the brines and the sources of their salinity. The study used chemical leaching methods to free the strontium, and it used samples of fine crystalline sandstone cements from the sandstone $\mathrm{Cu}$ deposit and other sandstones nearby and coarse crystalline material from feeder veins. The chemical leaching method could be applied to ore-stage gangue minerals of any grain size, although petrographic and microthermometric examination of the fluid inclusions in the minerals should be performed to yield a clearer understanding of the inclusions that host the fluids with saline-sourced elements and isotopes. Because so many SSC deposits occur in stratigraphic sections that contain evaporites, there is little doubt that evaporites have contributed to the salinity of metals-transporting solutions in most districts (Kirkham, 1989). Details that could be valuable in understanding deposit genesis may, nonetheless, be available from additional studies focused on the sources 
of brine salinity. In a few districts (for example, Udokan, Belt Supergroup, Cambrian of Israel and Jordan) the connection to evaporites is not obvious.

\section{Find an Active Ore-Forming System}

The most reliable results in attempting to define the source(s) of metals-transporting solutions for an SSC deposit would be to sample the metals-transporting solutions from a present-day active mineralizing system. In years past, finding an active system would have been considered impossible, but this does not appear to be the case now.

Sandstone $\mathrm{Cu}$-type.-An active sandstone $\mathrm{Cu}$ mineralizing system can probably be found in a basin that has petroleum source rocks overlain by greater than $300 \mathrm{~m}$, and preferably greater than $1 \mathrm{~km}$, of red beds, overlain by intervals that contain gray or bleached sandstones, and that has production of sour natural gas. Groundwaters with around $10 \mathrm{ppm} \mathrm{Cu}$ in that setting are the target brines. A sampling target may already be identifiable; Lebedev and Nikitina (1968, p. 181) sampled and analyzed a brine from "aquifer 11" of the Cheleken oil and gas field and iodine-bromine deposit that was a sodium-calciumchloride brine with dissolved $\mathrm{Fe}^{3+}$ exceeding $\mathrm{Fe}^{2+}$ and with $8.34 \mathrm{ppm}$ dissolved $\mathrm{Cu}$. The geologic setting of the Cheleken field is remarkably similar to what the setting of the ore-stage Dzhezkazgan sandstone $\mathrm{Cu}$ district must have been. However, further details on Cheleken aquifer 11 are not available.

Reduced-facies-type.-An active reduced-facies-type stratabound $\mathrm{Cu}$ mineralizing system may be locatable but is not so straightforward to find as the sandstone Cu-type system. One should be looking in a young rifting environment at low latitudes and looking for reduced-facies host rocks (for example, organic-rich sabkha dolostone beds such as the Central African Copperbelt host rocks or transgressive organic-rich shales or sedimentary breccias such as the Kupferschiefer or the hosts of Boléo, respectively), particularly where they onlap basement highs. There is a good chance that the search would be most productive in a young aulacogen or rift. The constraints suggest that examination of drill holes near the mouth of the East African Rift Valley into the Red Sea/Gulf of Aden has a fair chance of finding an active reduced-faciestype mineralizing system. An alternative approach would be to start near the youngest known reduced-facies-type deposit (Boléo, Baja California, Mexico) and look to where similar geology might be found nearby in even younger host rocks. In the gradually opening Gulf of California Basin that geology would be to the north of Boleo, in the subsurface, an area that was earlier suggested by Brown and Ledesma (2005). With Boléo as the example, the search for an ongoing reducedfacies system might be, for example, aimed at the subsurface below seafloor gas vents with precipitates of barite and pyrite along the Wagner Fault in the southern part of the Colorado River delta area (Canet and others, 2010).

\section{Hydrologic Drive(s) of Metals-Transporting Groundwater Flow}

\section{Paleohydrologic Modeling of Metals- Transporting Groundwater Flow}

A number of attempts have been made to model the groundwater flow systems that produced SSC deposits. These were by White (1971), Jowett (1986a), Cathles and others (1993), Person and Garven (1994), Blundell and others (2003), Swenson and others (2004), and Brown $(2005,2009)$.

Person and Garven (1994) examined the general case of groundwater flow in the protoceanic rift and open-ocean sag stages of passive margins. At full development of the sag phase, rapid deposition near the basin axis would result in two groundwater flow systems separated by the fine-grained impermeable beds deposited in the transgression between the protoceanic rift- and the sag-basin stages. A gravity-driven flow system would set up within the coarse-grained beds deposited atop the transgressive beds, and a system driven toward basin margins would be established below those transgressive beds driven by compactive loading along the basin axis.

The Kupferschiefer in Poland has seen a succession of three modeling attempts. Cathles and others (1993) tested an earlier hypothesis offered by Jowett (1986a) that Polish Kupferschiefer ore formed when thermally driven free convection of groundwater in the sub-ore Rotliegendes red beds occurred, confined beneath the Kupferschiefer bed and Zechstein evaporites, and confined laterally by basement rocks of horst blocks. The hypothesized thermal drive was provided by a generally high geothermal gradient accompanying recurrent rift tectonics. Mass balances for such a flow system succeeded only if dissolved $\mathrm{Cu}$ concentrations were at least $127 \mathrm{ppm}$, a concentration higher than in any known sedimentary brine. Blundell and others (2003) started with the observation that normal faulting drives a pulse of groundwater outward away from extensional fractures. They considered deriving metals-transporting groundwater from basement fractures by that means during extensional tectonics through the Early and Middle Triassic. In their model, a localized heat-flow anomaly would provide buoyant fluid coming from the basement fractures, and permeable eolian Weissliegendes sandstones would provide a connection and allow rapid groundwater flow upward and laterally along the footwall of the Kupferschiefer bed. With these conditions met, normal faulting with a 100 - to 200-year recurrence interval could provide enough groundwater to create the Lubin-Sieroszowice deposit with solution concentrations of $60 \mathrm{ppm} \mathrm{Cu}$ over a period of 12 million years. This model could be called seismic pumping. Its likelihood depends on localized thermal anomalies along the floors and flanks of the rift basin.

The White Pine reduced-facies deposit has also seen a succession of paleohydrologic modeling studies. White (1971) tested the feasibility of forming the deposit solely from 
groundwater expelled by compaction of the sub-ore Copper Harbor red-bed aquifer assuming that the water of compaction contained $50 \mathrm{ppm}$ dissolved $\mathrm{Cu}$ and that all the $\mathrm{Cu}$ that reached the Nonesuch Formation host rocks precipitated. He found that the deposit could be formed in that way, but only if there was a convergence of flow paths focused to the White Pine area, not just uniform flow away from the basin axis. Swenson and others (2004) applied modern finite-element groundwater flow modeling at White Pine. Their modeling indicated that there would be the convergence of flow paths needed by White (1971), to the White Pine area, caused by the thinning of the Copper Harbor aquifer over a bulge in the basement where the Porcupine Mountain volcanics sit atop the Portage Lake lavas. Following the findings of Person and Garven (1994), they modeled that compactive groundwater flow away from the axis of the Midcontinent Rift basin would occur within the Copper Harbor red-bed aquifer at the time of deposition of Freda Formation sandstones atop the Nonesuch host rocks and confining beds. They showed that the focused groundwater flow in the area of the Porcupine volcanics would push groundwater upward and into the Nonesuch particularly in that area along the basin flank. Elsewhere along the basin flank, where a similar thickness and lateral fetch of Copper Harbor source rocks are available, the immediate base of the Nonesuch would be slightly mineralized, but mineral-zone boundaries would not rise up across the Nonesuch, and chalcopyrite would not be replaced, stepwise, to chalcocite, because most of the groundwater would simply exit the basin through thick sections of coarse-grained basin-margin sediments. The modeled advective heat transfer was an excellent match to known geothermometry constraints on the White Pine deposit. The timing of mineralization, within 10 to 15 million years after Copper Harbor deposition, fell within the times allowable from isotopic age dating. Swenson and others (2004) also modeled $\mathrm{Cu}$ concentrations in groundwater with varying high chloride concentrations in equilibrium with possible "alteration assemblages" in the Copper Harbor, at two different buffered oxygen fugacities. The greatest theoretical $\mathrm{Cu}$ solubility was found buffered by native $\mathrm{Cu}$-cuprite in equilibrium with a laumontite-paragonite-kaolinite-quartz assemblage, but assemblages with albite or prehnite, instead, also provided sufficient $\mathrm{Cu}$ concentrations, typically many tens of parts per million $\mathrm{Cu}$ at reasonable transport temperatures of 100 to $120 \mathrm{oC}$. Cu solubility increased with increasing chloride concentrations and increasing temperature for all alteration and buffer assemblages. Brown $(2005,2009)$ proposed that only a gravity-driven system of groundwater recharge and flow from the northern side of the Midcontinent Rift basin would be consistent with optimal conditions for low-temperature $\mathrm{Cu}$ dissolution and transport. The "dynamic footwall reddening" model of Brown (2005) suggested "that $\mathrm{Cu}$ mobilization should follow early diagenetic reddening, in both time and space." That is, Brown proposed that $\mathrm{Cu}$ is mobilized while oxygenated recharge water is precipitating grain-coating ferric oxides in the source red beds and while $\mathrm{Cu}$ mineralization is precipitating in the Nonesuch farther along the flow path.
Brown suggested that only this early diagenetic timing allows the proper conditions of oxidation potential for large-scale $\mathrm{Cu}$ transport and for a large-scale flux of oxygenated groundwater.

The combination of paleohydrologic and solution chemical modeling by Swenson and others (2004) is considered to be the most realistic of such modeling to date. Importantly, that work demonstrates that a single pass of compactive groundwater flow is sufficient to create reduced-facies $\mathrm{Cu}$ deposits. It has long been recognized that reduced-facies deposits in Zambia are localized adjacent to basement highs (figs. 10, 11, and 15), and this modeling explains the hydrology of the localization. It also explains the expanses of tracemineralized reduced-facies host rocks between the deposits.

The "dynamic footwall reddening" model (Brown, 2005, 2009) is a feasible alternative to compactive groundwater flow for the White Pine deposit. However, there are reasonable alternatives to dissolved oxygen as an oxidizing agent, so proximity to recharge from the surface really is not a serious limitation on $\mathrm{Cu}$ mobilization. $\mathrm{S}+6$ in sulfate for example can yield conditions for cuprous $\mathrm{Cu}$ solubility. Evaporite brines are typically rich in chloride and sulfate. Maximum $\mathrm{Cu}$ transport temperatures that were generally greater than $180^{\circ} \mathrm{C}$ for Kamoto and Musonoi, Democratic Republic of Congo (El Desouky and others, 2009), and greater than $200{ }^{\circ} \mathrm{C}$ for Spar Lake (Hayes and others, 2012) are notably higher than would be found in dynamic footwall reddening. Isotopic dating does not allow $\mathrm{Cu}$ mobilization by dynamic footwall reddening at Spar Lake, because the source red beds were already buried by more than $5,000 \mathrm{~m}$ of overburden when mineralization occurred (Aleinikoff and others, 2012).

Additional paleohydrologic modeling studies of SSC deposits would be valuable particularly if they are well constrained by isotopic and stratigraphic ages. Sandstone $\mathrm{Cu}$ deposits have not been modeled, and they may have formed generally later in basin histories than reduced-facies deposits. Later in the basin histories, gravity-driven groundwater flow seems more probable. The Paradox Basin has a wealth of oilfield data available and a generally well-known geologic history (Nuccio and Condon, 1996). Once ore deposition has been dated, it would be a good place to study sandstone $\mathrm{Cu}$ deposit paleohydrology.

\section{Identifying Flow Paths for Metals-Transporting Brines}

Although paleohydrologic studies have proven effective where they could be combined with isotopic dating of ore systems (for example in some Mississippi Valley-type deposits: Bethke, 1986; Brannon and others, 1992; and in the reduced-facies $\mathrm{Cu}$ deposit at White Pine: Swenson and others, 2004), the paleohydrology is only testable in theory. Although paleohydrologic modeling studies should be encouraged, studies that attempt to map rock features promise to be more conclusive to identifying the hydrologic drive(s) of mineralizing systems. 
Metals transport can be mapped if alteration along the flow path can first be recognized and if exposure is adequate either in outcrops or drill holes. Mapping of alteration pathways could greatly limit the possible flow systems that may have produced ore. Certainly, high-angle faults and zones where pillars are densely distributed, both that are exposed downsection from mineralized rocks, are specific targets.

Alteration.-From current knowledge, sodic minerals (albite, glauberite, analcime, riebekite, paragonite, and possibly scapolite), hematite, and possibly barite will mark the paths taken between $\mathrm{Cu}$ source rocks and deposits. Epidote is a mineral associated with $\mathrm{Cu}$ mobilization from volcanic rocks (Livnat, 1983; Borg, 1991) and is to be expected as well in altered rocks with volcaniclastic components. Albite is possibly the most common alteration mineral, but glauberite is the one identified within $\mathrm{Cu}$-depleted rocks of the Redstone River Formation below the Coates Lake deposit (R. Lustwerk, oral commun., 1985). Starting at a deposit in the Kupferschiefer, it should, with careful examination of rock sequences such as the Rotliegendes in central Europe, be possible to identify and then map alteration paths.

In young mineralizing systems, it would be expected that alteration might also be marked by an anomalously mature ferric-oxide assemblage in the sourcing red beds, such as well crystallized hematite coating the grains of $\mathrm{Cu}$-depleted rocks versus amorphous ferric oxides or poorly crystallized hematite in rocks that have not lost their $\mathrm{Cu}$. A study testing this is suggested near Boléo.

Metals sources.-The source rocks for $\mathrm{Cu}$ in SSC deposits are marked as rocks with $\mathrm{Cu}$ concentrations depleted relative to rocks that were never affected by the mineralizing systems. In both examples where depleted red beds were identified, the background $\mathrm{Cu}$ concentrations of the source rocks were about $20 \mathrm{ppm}$ and depleted values were typically below 4 ppm (Lustwerk and Rose, 1983; R. Lustwerk, oral commun., 1985; Hayes, 1990). The source rocks for the Revett Formation-hosted deposits are also remarkably depleted of their $\mathrm{Ca}$; quartzites with greater than $15 \mathrm{v}$. \% total feldspars have less than $400 \mathrm{ppm}$ Ca in whole rocks (T. Hayes, unpub. data, 1989). They are discernibly depleted in $\mathrm{Pb}$, as well. Each element that is depleted in the altered rock is found elsewhere at anomalously high concentrations within the zoned mineralogic systems of the deposits. Cu-depleted rock can be expected to have authigenic minerals unique to a zone of mobilization and including some of the minerals listed above.

\section{Supergene Enrichment}

In the Central African Copperbelt, it is still unclear whether most of the chalcocite is formed during supergene enrichment or whether it is hypogene. Since the times of Bateman (1930) and Oosterbosch (1951), much has been learned about the process of supergene enrichment of $\mathrm{Cu}$ deposits. Many new tools have been developed. Just one example is the isotopic age dating of supergene phases such as Mn oxides, which may be directly applicable to heterogenite in the Democratic Republic of Congo. But even if it is only possible to use detailed mineralogy and mapping, better understanding can be gained. The porous sandstones overlying Mufulira ore together with the chalcocite-rich parts of that deposit are a good target for study. Working downward from a Co cap into hypogene ore at a deposit in the Democratic Republic of Congo is a second good target. Understanding the process of enrichment in the climate of the Central African Copperbelt promises to quickly provide value in central Africa and the rest of the world.

\section{Changes to SSC Deposits with High-Grade Metamorphism}

The knowledge of the mineralogic and textural changes in amphibolite-grade and granulite-grade metamorphism of SSC deposits is insufficient. There are also opportune places to address related questions, such as in Aynak, Afghanistan, and in the Ablah Group occurrences in Saudi Arabia. There is immediate value in increased understanding of the subject, because high-grade metamorphism may leave the rock sequences more amenable to geophysical exploration by induced polarization and magneto-telluric methods.

\section{Direct Sensing of Concealed Ore}

The most immediate and highest payback on new studies will likely come from developing exploration methods. Methods that need testing are natural-source induced polarization and soil-gas chemistry. Both methods attempt to directly sense the presence of ore or ore-related features in the subsurface.

A test of the natural-source IP method was started with field data collection at the Rock Creek sandstone $\mathrm{Cu}$ deposit in the Western Montana Copper Sulfide Belt in 2009. Data analysis is ongoing.

Knowing that sandstone $\mathrm{Cu}$ deposits form where hot, metals-transporting brines mixed and reacted with $\mathrm{H}_{2} \mathrm{~S}$-bearing natural gas, a test using soil-gas chemistry as an exploration method for sandstone $\mathrm{Cu}$ deposits is needed. Obviously, a $\mathrm{CH}_{4}$ anomaly can be hypothesized. But it is possible that an anomalous signature might be a combination of different pathfinder gases, including $\mathrm{CH}_{4}$, carbon disulfide, and $\mathrm{Hg}$ (fig. 39). A test of soil-gas chemistry in exploration could take place in the Western Montana Copper Sulfide Belt over a known but unmined deposit or it could take place in the Paradox Basin where the Flying Diamond deposit, southeast of the Lisbon Valley deposit, is an outstanding candidate for further study. Flying Diamond was earlier studied by an integrated set of exploration techniques including $\mathrm{CO}_{2}-\mathrm{O}_{2}$ soil-gas geochemistry (Adkins and others, 2010). 


\section{Observable Vectors for Narrowing the Search for Ore}

Further study is needed to find exploration guides that may narrow the search for new ore. One such guide may be composition of carbonate minerals of sandstone $\mathrm{Cu}$ systems. Work has started to see if there is a quantifiable relation between $\mathrm{Fe}$ and $\mathrm{Mn}$ contents in calcites and ankerites and their zonation surrounding sandstone $\mathrm{Cu}$ deposits of the Western Montana Copper Sulfide Belt (Hayes, unpub. data, 1986). Fe-rich calcites have also been described in association with the Dzhezkazgan deposits (Gablina and Tsepin, 1975). Together with these, there is a suggestion from the observation of clearly hydrothermal dolomite in association with the Paoli, Okla., sandstone $\mathrm{Cu}$ deposit (Thomas and others, 1991) that carbonate minerals of anomalous composition may occur in many systems.

Vectors that may narrow the search for new ore may exist at many scales. Because our current understanding suggests that only basins with thick packages of red beds that were deposited relatively quickly develop SSC systems, Lopatin timetemperature models (Lopatin, 1971; Waples, 1980) of basins could be a vectoring technique comparing one basin to another or comparing different parts of the same basin. Lopatin modeling is designed to address thermal maturity of petroleum source rocks (Davey, 1985). It calculates time-temperature indices (TTIs) on the basis of absolute age and burial histories of rock units. The minimum TTI necessary for the onset of oil generation, for peak oil generation, and for the end of oil generation are known from experience (Waples, 1980). The TTIs calculated for source rocks also constrain the time-temperature histories of red beds in the same basins that might source metals-transporting brines, and it is now known that such units probably reached temperatures of $120^{\circ} \mathrm{C}$ or greater to source a SSC-mineralizing brine. Thus, Lopatin modeling may be able to distinguish prospective red-bed-bearing basins from non-prospective ones. It could identify large prospective areas within a red-bed-bearing basin. The data needed for Lopatin modeling are widely available from essentially all basins in the world that have undergone some level of exploration for petroleum. Stratigraphic analysis and Lopatin modeling can then guide the early steps of exploration, selecting basin-scale or sub-basin-scale targets. Alteration mapping and geochemical patterns within basins with identified systems might be a medium-scale vectoring technique.

\section{Acknowledgments}

An earlier draft of this report was reviewed by Murray W. Hitzman and A.C. Brown who both suggested many useful revisions. Professor Brown probably spent many days in this effort, and we thank him, especially. Both reviewers are experts on SSC deposits who are known worldwide, so we note, particularly, that any conclusions drawn herein are our own, and they do not necessarily reflect the views of Hitzman or Brown. The greatest help on this report came, however, from our colleague, Rich Goldfarb, who edited a second draft in great detail and otherwise worked long and hard in trying to make this model as useful as possible.

We also thank the following individuals for their discussions over many years: Rod Kirkham, Marco Einaudi, Jack Harrison, Dean Kleinkopf, Jeff Mauk, Brian White, Joe Whelan, Gary Landis, Bob Rye, Michael Zientek, Dave Leach, Murray Hitzman, Alan Wallace, Tom Chadwick, Russ Smith, Larry Appelgate, Nancy Joseph, Gregor Borg, Dave Broughton, and Jon Thorson.

A final acknowledgement is due John Wallis, our technical illustrator contracted to the Spokane office of USGS. He brought 59 of the 62 figures of this report admirably into compliance with the requirements for figures in a Scientific Investigations Report.

Subjects covered in this report were determined by the leadership of the Updated National Mineral Resource Assessment of 2012 Project in order to provide consistency with models of other ore-deposit types. For some subjects that were to be covered, for example, hypogene gangue characteristics and major-element rock geochemistry, the Spar Lake deposit was among only a few SSC deposits where the subject had been specifically addressed. An unanticipated effect of the standardized coverage of subjects then became that examples from Spar Lake were used in most sections. Spar Lake examples were at hand because that deposit has been the subject of studies by the first author and colleagues at several times over the past 30 years. We apologize for what may seem an over-emphasis on Spar Lake.

\section{References}

Abramov, B.N., 2008, Petrochemistry of the Paleoproterozoic Udokan copper-bearing sedimentary complex: Lithology and Mineral Resources, v. 43, p. 37-43.

Abramov, B.N., and Chernyshova, N.A., 2001, Processes of sodic metasomatism associated with general Precambrian mineralization in the Kodar-Udokan Zone (East Siberia): Izvestiya Vysshikh Uchebnykh Zavedenii, Geologiya i Razvedka, no. 2, p. 52-58.

Adams, S.S., Curtis, H.S., and Hafen, P.L., 1974, Alteration of detrital magnetite-ilmenite in continental sandstones of the Morrison Formation, New Mexico, in Formation of uranium deposits: Vienna, International Atomic Energy Agency, p. 219-253.

Adkins, A.R., Thorson, J.P., and Geiger, Faye, 2011, Integrated exploration techniques for sediment-hosted copper, lower Lisbon Valley, Utah, in Steininger, Roger, and Pennell, Bill, eds., Geological Society of Nevada Symposium, 2012, Great Basin evolution and metallogeny: Lancaster, Pa., DEStech Publications, p. 585-607. 
Aleinikoff, J.N., Hayes, T.S., Evans, K.V., Mazdab, F.K., Pillers, R.M., and Fanning, C.M., 2012, SHRIMP U-Pb ages of xenotime and monazite from the Spar Lake red bedassociated $\mathrm{Cu}-\mathrm{Ag}$ deposit, western Montana: Implications for ore genesis: Economic Geology, v. 107, p. 1251-1274.

Alexander Mining, 2005, Regulatory announcement, Alexander Mining PLC, Operations: Leon copper/silver project, Salta Province, NW Argentina, available at http//www. londonstockexchange.com/LSECWS/IFSPages MarketNewsPoppup. aspx $? \mathrm{id}=1045802 \&$ source $==$ RNS.

Anderson, J.A., 1982, Characteristics of leached capping and techniques of appraisal, in Titley, S.R., ed., Advances in geology of the porphyry copper deposits: Tucson, Ariz., The University of Arizona Press, p. 275-295.

Angelelli, V., 1956, Distribution and characteristics of the uranium deposits and occurrences of the Argentine Republic: Proceedings of the International Conference on the Peaceful Uses of Atomic Energy: New York, United Nations, p. 63-74.

Anhaeusser, C.R., and Button, A., 1973, A petrographic and mineragraphic study of the copper-bearing formations in the Witvlei area, Southwest Africa: Transactions of the Geological Society of South Africa, v. 76, part 3, p. 279-299.

Annels, A.E., 1974, Some aspects of the stratiform ore deposits of the Zambian Copperbelt and their genetic significance, in Bartholomé, P., ed., Gisements stratiformes et provinces cuprifères: Société Géologique de Belgique, Liège, Belgium, p. 235-254.

Annels, A.E., 1989, Ore genesis in the Zambian Copperbelt with particular reference to the northern sector of the Chambishi Basin, in Boyle, R.W., Brown, A.C., Jefferson, C.W., Jowett, E.C., and Kirkham, R.V., Sediment-hosted stratiform copper deposits: Geological Association of Canada, Special Paper 36, p. 427-452.

Annels, A.E., and Simmonds, J.R., 1984, Cobalt in the Zambian Copperbelt: Precambrian Research, v. 25, p. 75-98.

Arehart, G.B., O’Neil, J.R., and Mauk, J.L., 1990, Stable isotope compositions of fluid inclusions in native copper from White Pine, Michigan [abs.]: Geological Society of America Abstracts with Programs, v. 22, p. A250.

Armstrong, R.A., Master, S., and Robb, L.J., 2005, Geochronology of the Nchanga Granite, and constraints on the maximum age of the Katanga Supergroup, Zambian Copperbelt: Journal of African Earth Sciences, v. 42, p. 32-40.

Bailey, S.W., Cameron, E.N., Spedden, H.R., and Weege, R.J., 1956, The alteration of ilmenite in beach sands: Economic Geology, v. 51, p. 263-279.
Baird, W.D., 2007, The Early Minoan colonization of Spain: accessed February 22, 2010, at http://www.minoanatlantis. com/Minoan_Spain.php.

Baker, T., Ebert, S., Rombach, C., and Ryan, C.G., 2006, Chemical compositions of fluid inclusions in intrusionrelated gold systems, Alaska and Yukon, using PIXE microanalysis: Economic Geology, v. 101, p. 311-327.

Baker, T., Mustard, R., Fu, B., Williams, P.J., Dong, G., Fisher, L., Mark, G., and Ryan, C.G., 2008, Mixed messages in iron oxide-copper-gold systems of the Cloncurry district, Australia - insights from PIXE analysis of halogens and copper: Mineralium Deposita, v. 43, p. 599-608.

Bakun, N.N., Volodin, R.N., and Krendelev, F.P., 1966, Genesis of the Udokansk cupriferous sandstone deposit (Chitinsk Oblast): International Geology Review, v. 8, no. 4, p. 455-466.

Banaś, M., Salamon, W., Piestrzyński, A., and Mayer, W., 1982, Replacement phenomena of terrigenous minerals by sulfides in copper-bearing Permian sandstones in Poland, in Amstutz, G.C., El Goresy, A., Frenzel, G., Kluth, C., Moh, G., Wauschkuhn, A., and Zimermann, R.A., eds, Ore genesis - State of the Art: Berlin, Springer-Verlag, Society of Geology Applied to Mineral Deposits Special Publication 2, p. 3-9.

Barghoorn, E.S., Meinschein, W.G., and Schopf, J.W., 1965, Paleobiology of a Precambrian shale: Science, v. 148, p. 461-472.

Barra, F., Broughton, D., Ruiz, J., and Hitzman, M., 2004, Multi-stage mineralization in the Zambian Copperbelt based on Re-Os isotope constraints [abs.]: Geological Society of America Abstracts with Programs, v. 36, p. 516.

Bartholomé, P., 1962, Les minerais cupro-cobaltifères de Kamoto (Katanga-Ouest). I Pétrographie: Studia Universitatis "Lovanium," Faculté des Sciences, Léopoldville (Kinsasha), v. 14, 40 p. (In French).

Bartholomé, P., 1974, On the diagenetic formation of ores in sedimentary beds with special reference to the Kamoto copper deposit, Shaba, Zaire, in Bartholomé, P., ed., Gisements stratiformes et provinces cuprifères: Société Géologique de Belgique, Liège, Belgium, p. 203-214.

Bartholomé, P., Evrard, P., Katekesha, F., Lòpez-Ruiz, J., and Ngongo, M., 1976, Diagenetic ore-forming processes at Kamoto, Katanga, Republic of Congo, in Amstutz, G.C., and Bernard, A.J., eds., Ores in sediments: Berlin, Springer-Verlag, p. 21-41. 
Bartholomé, P., Katekesha, F., and Lòpez-Ruiz, J., 1971, Cobalt zoning in microscopic pyrite from Kamoto, Republic of the Congo (Kinshasa): Mineralium Deposita, v. 6, no. 3, p. 167-176.

Baskin, Y., 1956, A study of authigenic feldspars: Journal of Geology, v. 64, p. 132-155.

Bassett, W.A., 1958, Copper vermiculites from northern Rhodesia: American Mineralogist, v. 43, p. 1112-1133.

Bassett, W.A., and Brown, G.E., Jr., 1990, Synchrotron radiation-Applications in the earth sciences: Annual Review of Earth and Planetary Sciences, v. 18, p. 387-447.

Bateman, A.M., 1930, The ores of the northern Rhodesia copper belt: Economic Geology, v. 25, p. 365-418.

Bechtel, A., Elliott, W.C., and Oszczepalski , S., 1996, Indirect age determination of Kupferschiefer-type mineralization in the Polish Basin by K/Ar dating of illite; preliminary results: Economic Geology, v. 91, p. 1310-1319.

Bechtel, A., Elliott, W.C., Wampler, J.M., and Oszczepalski, S., 1999, Clay mineralogy, crystallinity, and K-Ar ages of illites within the Polish Zechstein Basin-Implications for the age of Kupferschiefer mineralization: Economic Geology, v. 94, p. 261-272.

Bechtel, A., Gratzer, R., Püttmann, W., and Oszczepalski, S., 2002, Geochemical characteristics across the oxic/anoxic interface (Rote Fäule front) within the Kupferschiefer of the Lubin-Sieroszowice mining district (SW Poland): Chemical Geology, v. 185, p. 9-31.

Bechtel, A., Yuzhuang, S., Püttmann, W., Hoernes, S., and Hoefs, J., 2001, Isotopic evidence for multi-stage base metal enrichment in the Kupferschiefer from the Sangerhausen Basin, Germany: Chemical Geology, v. 176, p. 31-49.

Beck, R., 1905, The nature of ore deposits: New York, Engineering and Mining Journal, v. 1 and 2, 685 p.

Becker, A., Klöck, W., Friese, K., Schreck, P., Treutler, H.-C., Spettel, B., and Duff, M.C., 2001, Lake Süßer See as a natural sink for heavy metals from copper mining: Journal of Geochemical Exploration, v. 74, no. 1, p. 205-217.

Beitler, B., Chan, M.A., and Parry, W.T., 2003, Bleaching of Jurassic Navajo Sandstone on Colorado Plateau Laramide highs -Evidence of exhumed hydrocarbon supergiants?: Geology, v. 31. p. 1041-1044.

Bekker, A., Holland, H.D., Wang, P.-L., Rumble, D., III, Stein, H.J., Hannah, J.L., Coetzee, L.L., and Beukes, N.J., 2004, Dating the rise of atmospheric oxygen: Nature, v. 427, p. 117-120.
Belenitskaya, G.A., Golubchina, M.N., Gurevich, M.S., and Mishnina, T.A., 1981, Sulfur isotopic composition and origin of hydrogen sulfide in the natural gases of the AmuDar'ya Basin: Lithology and Mineral Resources, v. 16, no. 2, p. 183-201.

Benham, D.G., Greig, D.D., and Vink, B.W., 1976, Copper occurrences of the Mombezhi Dome area, northwestern Zambia: Economic Geology, v. 71, p. 433-442.

Berza, T., Constantinescu, E., and Serban-Nicolae, V., 1998, Upper Cretaceous magmatic series and associated mineralization in the Carpathian-Balkan orogen: Resource Geology, v. 48 , p. 291-306.

Bethke, C.M., 1986, Hydrologic constraints on the genesis of the Upper Mississippi Valley mineral district from Illinois Basin brines: Economic Geology, v. 81, p. 233-249.

Beyschlag, F., Vogt, J.H.L., and Krusch, P., 1916, The deposits of the useful minerals and rocks: London, Macmillan, v. 1, $1,262 \mathrm{p}$.

Bird, K.J., 1986, A comparison of the play analysis technique as applied in hydrocarbon resource assessments of the National Petroleum Reserve in Alaska and the Arctic National Wildlife Refuge, in Rice, D.D., ed., Oil and gas assessment-Methods and applications: American Association of Petroleum Geologists Studies in Geology 21, p. 133-142.

Blanche, J.B., and Whitaker, J.H.McD., 1978, Diagenesis of part of the Brent Sand Formation (Middle Jurassic) of the northern North Sea Basin: Journal of the Geological Society of London, v. 135, p. 73-82.

Blundell, D.J., Karnkowski, P.H., Alderton, D.H.M., Oszczepalski, S., and Kucha, H., 2003, Copper mineralization of the Polish Kupferschiefer-A proposed basement faultfracture system of fluid flow: Economic Geology, v. 98, no. 7, p. 1487-1495.

Bogdanov, Yu.V., Kochin, G.G., Kutyrev, E.I., Travin, L.V., and Feoktistov, V.P., 1966, Geology, formation conditions and distribution of cupriferous sandstones in northeastern Olekma-Vitim mountain province: International Geology Review, v. 8, no. 11, p. 1305-1315.

Boleneus, D.E., Appelgate, L.M., Stewart, J.H., and Zientek, M.L., 2006, Strata-bound copper-silver deposits of the Mesoproterozoic Revett Formation, Montana and Idaho: U.S. Geological Survey Scientific Investigations Report 2005-5231, 55 p.

Boles, J.R., 1978, Active ankerite cementation in the subsurface Eocene of southwest Texas: Contributions to Mineralogy and Petrology, v. 68, p. 13-22. 
Boles, J.R., 1982, Active albitization of plagioclase, Gulf Coast Tertiary: American Journal of Science, v. 282, p. $165-180$.

Boles, J.R., and Franks, S.G., 1979, Clay diagenesis in Wilcox sandstones of southwest Texas-Implications of smectite diagenesis on sandstone cementation: Journal of Sedimentary Petrology, v. 49, p. 55-70.

Borg, G., 1991, The significance of Rotliegend volcanics for the metal provinces of the Kupferschiefer Basin: Zentralblatt für Geologie und Paläontologie, Heft 4, p. 929-943.

Borg, G., and Maiden, K.J., 1989, The Middle Proterozoic Kalahari Copperbelt of Namibia and Botswana, in Boyle, R.W., Brown, A.C., Jefferson, C.W., Jowett, E.C., and Kirkham, R.V., eds., Sediment-hosted stratiform copper deposits: Geological Association of Canada, Special Paper 36, p. 525-540.

Bornhorst, T.J., Kalliokoski, J.O., and Paces, J., 1986, The Keweenaw native-copper district, in Brown, A.C., and Kirkham, R.V., eds., Field Trip 1-Guidebook. Proterozoic sediment-hosted stratiform copper deposits of Upper Michigan and Belt Supergroup of Idaho and Montana: Ottawa, Ontario, Canada, Geological Association of Canada, Ottawa 86 Annual Meeting, p. 21-36.

Bornhorst, T.J., Paces, J.B., Grant, N.K., Obradovich, J.D., and Huber, N.K., 1988, Age of native copper mineralization, Keweenaw Peninsula, Michigan: Economic Geology, v. 83 , p. 619-625.

Braddock, W.A., and Bowles, C.G., 1963, Calcitization of dolomite by calcium sulfate solutions in the Minnelusa formation, Black Hills, South Dakota and Wyoming, in U.S. Geological Survey, Geological Survey research 1963, Short papers in geology, hydrology, Articles 60-121: U.S. Geological Survey Professional Paper 475-C, p. C96-C99.

Branam, T.D., and Ripley, E.M., 1990, Genesis of sedimenthosted copper mineralization in south-central KansasSulfur/carbon and sulfur isotope systematics: Economic Geology, v. 85, p. 601-621.

Brandt, R.T., Burton, C.C.., Maree, S.C., and Woakes, M.E., 1961, Mufulira, in Mendelsohn, F., ed., The geology of the Northern Rhodesian copperbelt: London, MacDonald, p. 411-461.

Brannon, J.C., Podosek, F.A., and McLimans, R.K., 1992, Alleghenian age of the Upper Mississippi Valley zinc-lead deposit determined by Rb-Sr dating of sphalerite: Nature, v. 356, p. 509-511.
Brauns, C.M., Pätzold, T., and Haack, U., 2003, A Re-Os study bearing on the age of the Kupferschiefer mineralization at Sangerhausen (Germany) [abs.]: Abstracts, XV International Congress of Carboniferous and Permian Stratigraphy, Utrecht, p. 66.

Breit, G.N., and Meunier, J.D., 1990, Fluid inclusion, $\delta^{18} \mathrm{O}$, and ${ }^{87} \mathrm{Sr} /{ }^{86} \mathrm{Sr}$ evidence for the origin of fault-controlled copper mineralization, Lisbon Valley, Utah, and Slick Rock district, Colorado: Economic Geology, v. 85, p. 884-891.

Brems, D., Muchez, Ph., Sikazwe, O., and Mukumba, W., 2009, Metallogenesis of the Nkana copper-cobalt South Orebody, Zambia: Journal of African Earth Sciences, v. 55, p. 185-196.

Brett, P.R., 1962, The Cu-Fe-S system-Heating experiments on natural bornites: Carnegie Institute of Washington Yearbook 61, p. 159-160.

Brett, Robin, and Yund, R.A., 1964, Sulfur-rich bornites: American Mineralogist, v. 49, p. 1084-1098.

Brodtkorb, M.K.de, and Brodtkorb, A., 1984, Strata-bound deposits of Argentina, in Wauschkuhn, A., Kluth, C., and Zimmerman, R.A., eds., Syngenesis and epigenesis in the formation of mineral deposits: Berlin, Springer-Verlag, p. 92-101.

Brooks, W.E., 2010, Silver [Advance Release], in U.S. Geological Survey, 2007 Minerals Yearbook: 13 p., accessed November 11, 2009, at http://minerals.usgs.gov/minerals/ pubs/commodity/silver/myb1-2007-silve.pdf.

Broughton, D.W., Hitzman, M.W., and Stephens, A.J., 2002, Exploration history and geology of the Kansanshi $\mathrm{Cu}(-\mathrm{Au})$ deposit, Zambia: Society of Economic Geologists Special Publication 9, p. 141-153.

Brown, A.C., 1971, Zoning in the White Pine copper deposit, Ontonagon County, Michigan: Economic Geology, v. 66, p. 543-573.

Brown, A.C., 1989, Sediment-hosted stratiform copper deposits-Deposit-type name and related terminology, in Boyle, R.W., Brown, A.C., Jefferson, C.W., Jowett, E.C., and Kirkham, R.V., Sediment-hosted stratiform copper deposits: Geological Association of Canada, Special Paper 36, p. 39-51.

Brown, A.C., 2005, Refinements for footwall red-bed diagenesis in the sediment-hosted stratiform copper deposits model: Economic Geology, v. 100, p. 765-771.

Brown, A.C., 2006, Genesis of native copper lodes in the Keweenaw district, northern Michigan-A hybrid evolved meteoric and metamorphogenic model: Economic Geology, v. 101, p. 1437-1444. 
Brown, A.C., 2009, A process-based approach to estimating the copper derived from red beds in the sediment-hosted stratiform copper deposit model: Economic Geology, v. 104, p. $857-868$.

Brown, A.C., and Bartholomé, P., 1972, Inhomogeneities in cobaltiferous pyrite from Chibuluma $\mathrm{Cu}-\mathrm{Co}$ deposits, Zambia: Mineralium Deposita, v. 7, p. 100-105.

Brown, A.C., and Ledesma, J., 2005, Suitable rift environment for sediment-hosted stratiform copper mineralization in the continental-to-marine transition at the north end of the Gulf of California, Mexico, in Yajimovich, O.G., ed., VII International Meeting, Geology of the Baja California Peninsula, Ensenada, B.C., Mexico, April 3-6, 2005: oral and poster presentation.

Brown, B.E., and Bailey, S.W., 1962, Chlorite polytypismI. Regular and semi-random one-layer structures: American Mineralogist, v. 47, p. 819-850.

Brown, M.C., and Oliver, N.H.S., 2002, Veining and fluid flow in the area surrounding Mount Whaleback microplaty hematite ore deposit - Constraints on fluid dynamics before, during, and after orogenesis: Publication Series-Australasian Institute of Mining and Metallurgy, v. 7, p. 77-79.

Brown, R., Slater, D., and Sperinck, M., 2008, Technical report on the updated resource estimates at the Matala and Dunrobin deposits, Luiri Hill Project: Report prepared by RSG Global Consulting for Luiri Gold Resource Development and Exploration Company, 139 p., available at http://www.sedar.com.

Brummer, J.J., 1955, The geology of Roan Antelope orebody: Transactions of the Institution of Mining and Metallurgy, v. 64 , p. 257-318.

Buerger, N.W., 1942, X-ray evidence of the mineral digenite $\mathrm{Cu}_{9} \mathrm{~S}_{5}$ : American Mineralogist, v. 27, p. 712-716.

Burnie, S.W., Schwarcz, H.P, and Crocket, J.H., 1972, A sulfur isotope study of the White Pine mine, Michigan: Economic Geology, v. 67, p. 895-914.

Cailteux, J., 1994, Lithostratigraphy of the Neoproterozoic Shaba-type (Zaire) Roan Supergroup and metallogenesis of associated stratiform mineralization: Journal of African Earth Sciences, v. 19, p. 279-301.

Cailteux, J.L.H., Kampunzu, A.B., Lerouge, C., Kaputo, A.K., and Milesi, J.P., 2005a, Genesis of sediment-hosted stratiform copper-cobalt deposits, central African Copperbelt: Journal of African Earth Sciences, v. 42, p. 134-158.
Cailteux, J.L.H., Kampunzu, A.B.H., and Batumike, M.J., 2005b, Lithostratigraphic position and petrographic characteristics of R.A.T. ("Roches Argilo-Talqueuses") Subgroup, Neoproterozoic Katangan Belt (Congo): Journal of African Earth Sciences, v. 42, p. 82-94.

Canet, Carles, Prol-Ledesma, R.M., Dando, P.R., VázquezFigueroa, Viridiana, Shumilin, Evgueni, Birosta, Elisabet, Sánchez, Alberto, Robinson, C.J., Camprubí, Antoni, and Tauler, Esperança, 2010, Discovery of massive seafloor gas seepage along the Wagner Fault, northern Gulf of California: Sedimentary Geology, v. 228, p. 292-303.

Cathles, L.M., III, Oszczepalski, Slawomir, and Jowett, E.C., 1993, Mass balance evaluation of the late diagenetic hypothesis for Kupferschiefer $\mathrm{Cu}$ mineralization in the Lubin Basin of southwestern Poland: Economic Geology, v. 88 , p. $948-956$.

Cazes, D.K., Domenico, J.A., Hopkins, D.M., and Leach, D.L., 1981, Geochemical analysis of stream sediments and heavy-mineral concentrates collected near a stratabound $\mathrm{Cu}-\mathrm{Ag}$ occurrence in the Cabinet Mountains wilderness, Montana: U.S. Geological Survey Open-File Report 81-665, 29 p.

Cesàro, G., 1912, Sur un nouveau mineral du Katanga: Annales de la Société Géologique de Belgique, Liège, Belgium, v. 39, p. B241-B242 (In French).

Chandler, F.W., 1988, Diagenesis of sabkha-related, sulphate nodules in the Early Proterozoic Gordon Lake Formation, Ontario, Canada: Carbonates and Evaporites, v. 3, p. 75-94.

Chartrand, F.M., Brown, A.C., and Kirkham, R.V., 1989, Diagenesis, sulphides, and metal zoning in the Redstone copper deposit, Northwest Territories, in Boyle, R.W., Brown, A.C., Jefferson, C.W., Jowett, E.C., and Kirkham, R.V., Sediment-hosted stratiform copper deposits: Geological Association of Canada, Special Paper 36, p. 189-206.

Chayes, F., 1952, Notes on the staining of potash feldspar with sodium cobaltinitrite in thin sections: American Mineralogist, v. 37, p. 337-340.

Chenoweth, W.L., 1993, The geology and production history of the uranium deposits in the White Canyon mining district, San Juan County, Utah: Utah Geological Survey Miscellaneous Publication 93-3, 26 p.

Chernykh, E.V., 2004, Kargaly_-The largest and most ancient metallurgical complex on the border of Europe and Asia, in Linduff, K.M., ed., Metallurgy in ancient eastern Eurasia from the Urals to the Yellow River: Lewiston, N.Y., The Edwin Mellen Press, p. 223-237. 
Chernykh, E.V., Kuz'minykh, S.V., and Orlovskata, L.B., 2004, Ancient metallurgy in Northeast Asia-From the Urals to the Saiano-Altai, in Linduff, K.M., ed., Metallurgy in ancient eastern Eurasia from the Urals to the Yellow River: Lewiston, N.Y., The Edwin Mellen Press, p. 15-50.

Chowns, T.M., and Elkins, J.E., 1974, The origin of quartz geodes and cauliflower cherts through the silicification of anhydrite nodules: Journal of Sedimentary Research, v. 44, p. 885-903.

Chu, X., Zhang, T., Zhang, Q., and Lyons, T.W., 2007, Sulfur and carbon isotope records from 1700 to 800 Ma carbonates of the Jixian section, northern China-Implications for secular isotope variations in Proterozoic seawater and relationships to global supercontinental events: Geochimica et Cosmochimica Acta, v. 71, no. 19, p. 4668-4692.

Claypool, G.E., Holser, W.T., Kaplan, I.R., Sakai, H., and Zak, I., 1980, The age curves of sulfur and oxygen isotopes in marine sulfate and their mutual interpretation: Chemical Geology, v. 28, p. 199-260.

Conly, A.G., Beaudoin, Georges, and Scott, S.D., 2006, Isotopic constraints on fluid evolution and precipitation mechanisms for the Boleo $\mathrm{Cu}-\mathrm{Co}-\mathrm{Zn}$ district, Mexico: Mineralium Deposita, v. 41, p. 127-151.

Connor, J.J., Harrison, J.E., and Domenico, J.A., 1981, Distribution of copper in the Blacktail Mountain strata-bound deposit (Belt Supergroup), western Montana [abs.]: Geological Society of America Abstracts with Programs, v. 7, p. 429-430.

Coronation Minerals, Inc., 2006, Coppermine River (Coronation) mining property in Canada, Nunavut/Property Mine: accessed October 8, 2009, at http://www.infomine.com/index/ properties/COPPERMINE_RIVER_(CORONATION).html.

Corsetti, F.A., Stewart, J.H., and Hagadorn, J.W., 2007, Neoproterozoic diamictite-cap carbonate succession and $\delta^{13} \mathrm{C}$ chemostratigraphy from eastern Sonora, Mexico: Chemical Geology, v. 237, p. 129-142.

Cox, D.P., 1986, Descriptive model of sediment-hosted $\mathrm{Cu}$, in Cox, D.P., and Singer, D.A., eds., Mineral deposit models: U.S. Geological Survey Bulletin 1693, p. 205.

Cox, D.P., Carrasco, R., André-Ramos, O., Hinojosa-Velasco, A., and Long, K.R., 1992, Copper deposits in sedimentary rocks, in U.S. Geological Survey and Servicio Geologico de Bolivia, Geology and mineral resources of the Altiplano and Cordillera Occidental, Bolivia: U.S. Geological Survey Bulletin 1975, p. 95-108.
Cox, D.P., Lindsey, D.A., Singer, D.A., Moring, B.C., and Diggles, M.F., 2003, Sediment-hosted copper deposits of the world-Deposit models and database: U.S. Geological Survey Open-File Report 03-107, 53 p.

Craig, L.C., 1982, Uranium potential of the Burro Canyon Formation in western Colorado: U.S. Geological Survey Open-File Report 82-222, 27 p.

Cressman, E.R., 1985, The Prichard Formation of the lower part of the Belt Supergroup (Middle Proterozoic), near Plains, Sanders County, Montana: U.S. Geological Survey Bulletin 1553, 64 p.

Curtis, C.D., Hughes, C.R., Whiteman, J.A., and Whittle, C.K., 1985, Compositional variation within some sedimentary chlorites and some comments on their origin: Mineralogical Magazine, v. 49, p. 375-386.

Dahl, A.R., and Hagmaier, J.L., 1976, Genesis and characteristics of the southern Powder River Basin uranium deposits, Wyoming: Wyoming Geological Association 28th Field Conference Guidebook, p. 243-252.

Dapples, E.D., 1971, Physical classification of carbonate cement in quartzose sandstones: Journal of Sedimentary Petrology, v. 41, p. 196-204.

Darnley, A.G., 1960, Petrology of some Rhodesian Copperbelt orebodies and associated rocks: Transactions of the Institution of Mining and Metallurgy, v. 69, p. 137-173.

Davey, F.J., 1985, The Antarctic margin and its possible hydrocarbon potential: Tectonophysics, v. 114, p. 443-470.

Davidson, C.F., 1965, A possible mode of origin of stratabound copper ores: Economic Geology, v. 60, p. 942-954.

Davis, D.W., and Paces, J.B., 1990, Time resolution of geologic events on the Keweenaw Peninsula and implications for development of the Midcontinent rift system: Earth and Planetary Science Letters, v. 97, p. 54-64.

Davis, J.F., 1969, Uranium deposits of the Powder River Basin: Rocky Mountain Geology, v. 8, no. 2, p. 131-141.

Davis, M., Bertinshaw, R., Guibal, D., Daley, A., and Hanbury, R., 2008, Lumwana Project, Northwestern Province, Republic of Zambia: Report prepared by Ausenco Services, Pty., Ltd. For Equinox Minerals, Ltd., 103 p. NI-43-101 Technical Report to Equinox Minerals, Ltd., 103 p., accessed March 31, 2009, at http://www.sedar.com.

Day, J.M.D., 2008, The 1.27 Ga Mackenzie large igneous province and Muskox layered intrusion: 11 p., accessed October 9, 2009, at http://www.largeigneousprovinces. org/08sep.html. 
Dechow, E., and Jensen, M.L., 1965, Sulfur isotopes of some Central African sulfide deposits: Economic Geology, v. 60, p. 894-941.

Decrée, S., Deloule, É., Ruffet, G., Dewaele, S., Mees, F., Marignac, C., Yans, J., and De Putter, T., 2010, Geodynamic and climate controls in the formation of Mio-Pliocene world-class oxidized cobalt and manganese ores in the Katanga province, DR Congo: Mineralium Deposita, v. 45, p. $621-629$.

Demesmaeker, G., François, A., and Oosterbosch, R., 1963, La tectonique des gisements cuprifère stratiformes du Katanga, in Lombard, J., and Nicolini, P., eds., Gisements stratiformes de cuivre en Afrique (Stratiform copper deposits in Africa): Paris, Association des Services Géologique Africains (Association of African Geological Surveys), p. 47-115 (In French).

Dewaele, S., Muchez, P., Vets, J., Fernandez-Alonzo, M., and Tack, L., 2006, Multiphase origin of the $\mathrm{Cu}-\mathrm{Co}$ ore deposits in the western part of the Lufilian fold-and-thrust belt, Katanga (Democratic Republic of Congo): Journal of African Earth Sciences, v. 46, p. 455-469.

Dimanche, F., and Bartholomé, P., 1976, The alteration of ilmenite in sediments: Minerals Science and Engineering, v. 8 , p. 187-201.

Dingess, P.R., 1976, Geology and mining operations at the Creta copper deposit of Eagle-Picher Industries, Inc., in Johnson, K.S., and Croy, R.L., eds., Stratiform copper deposits of the Midcontinent Region, a symposium: Oklahoma Geological Survey Circular 77, p. 15-24.

Discovery Metals, Ltd., 2011, Mining Indaba, Capetown, 28 p., accessed January 11, 2012, at http://www.discoverymetals. com.au/IRM/Company/ShowPage.aspx/PDFs/145786473384/ MiningIndabaPresentationFebruary2011.

Dixon, G.H., 1967, Northeastern New Mexico and TexasOklahoma Panhandles, in McKee, E.D., Oriel, S.S., and others, Paleotectonic investigations of the Permian System in the United States: U.S. Geological Survey Professional Paper 515, p. 61-80.

Djurle, S., 1958, An X-ray study on the system Cu-S: Acta Chemica Scandinavica, v. 12, p. 1415-1426.

Domarev, V.S., and Bogdanov, Yu. V., 1959, On mineralization zoning in the copper sandstones of the Udokan deposit: Akad. Nauk. SSSR, Geologiya Rudnikh Mestorozhdenii, no. 1, p. $25-34$.

Durieux, C.G., and Brown, A.C., 2007, Geological context, mineralization, and timing of the Juramento sedimenthosted stratiform copper-silver deposit, Salta district, northwestern Argentina: Mineralium Deposita, v. 42, p. 879-899.
E\&MJ, 1979a, Zambia: Engineering and Mining Journal, v. 180 , no. 11, p. $146-159$.

E\&MJ, 1979b, Troy project okayed by Asarco, but may face court action: Engineering and Mining Journal, v. 180, no. 1, p. 37.

E\&MJ, 1982, Asarco's Troy producing copper and silver at a profit, Engineering and Mining Journal, v. 183, no. 12, p. 37.

E\&MJ, 1986a, Poland's copper metallurgical center at Glogow; Engineering and Mining Journal, v. 187, no. 4, p. $38-41$.

E\&MJ, 1986b, Polish copper: Engineering and Mining Journal, v. 187 , no. 2, p. 26-30.

E\&MJ, 1989, Noranda and Montana Reserves develop Montana silver: Engineering and Mining Journal, v. 190, no. 3, p. 7.

Eglinton, Geoffrey, Scott, P.M., Belsky, Ted, Burlingame, A.L., and Calvin, Melvin, 1964, Hydrocarbons of biological origin from a one-billion-year-old sediment: Science, v. 145 , p. 263-264.

Einuadi, M.T., 1979, Description of skarns associated with porphyry copper plutons, southwestern North America, in Titley, S.P., ed., Advances in geology of the porphyry copper deposits, southwestern North America: Tucson, Ariz., The University of Arizona Press, p. 139-183.

El Desouky, H.A., Muchez, P., and Cailteux, J., 2009, Two $\mathrm{Cu}-\mathrm{Co}$ sulfide phases and contrasting fluid systems in the Katanga Copperbelt, Democratic Republic of Congo: Ore Geology Reviews, v. 36, p. 315-332.

El Desouky, H.A., Muchez, Philippe, Dewaele, Stijn, Boutwood, Amanda, and Tyler, Roger, 2008a, Postorogenic origin of the stratiform $\mathrm{Cu}$ mineralization at Lufukwe, Lufilian foreland, Democratic Republic of Congo: Economic Geology, v. 103, p. 555-582.

El Desouky, H.A., Muchez, P., and Tyler, R., 2008b, The sandstone-hosted stratiform copper mineralization at Mwitapile and its relation to the mineralization at Lufukwe, Lufilian foreland, Democratic Republic of Congo: Ore Geology Reviews, v. 34, p. 561-579.

Ellis, M.W., 1961, Aerial photography; Abnormal vegetation patterns, in Mendelsohn, F., ed., The geology of the northern Rhodesian Copperbelt: London, Macdonald and Company, p. 175-178.

Elston, W.E., 1967, Summary of the mineral resources of Bernalillo, Sandoval, and Sante Fe counties, New Mexico: New Mexico Bureau of Mines and Mineral Resources Bulletin $81,81 \mathrm{p}$. 
Enders, M.S., Knickerbocker, C., Titley, S.R., and Southam, G., 2006, The role of bacteria in the supergene environment of the Morenci porphyry copper deposit, Greenlee County, Arizona: Economic Geology, v. 101, p. 59-70.

Ensign, C.O., Jr., White, W.S., Wright, J.C., Patrick, J.L., Leone, R.J., Hathaway, D.J., Trammell, J.W., Fritts, J.J., and Wright, T.L., 1968, Copper deposits in the Nonesuch Shale, White Pine, Michigan, in Ridge, J.D., ed., Ore deposits of the United States, 1933-1967, the Graton-Sales Volume: New York, American Institute of Mining, Metallurgical, and Petroleum Engineers, p. 460-488.

Entwistle, L.P., and Gouin, L.O., 1955, The chalcocite-ore deposits at Corocoro, Bolivia: Economic Geology, v. 50, p. $555-570$.

Esin, U., 1999, Copper objects from the pre-pottery Neolithic site of Aşikli, in Hauptmann, A., Pernicka, E., Rehren, T., and Yalçin, Ü., eds., The beginnings of metallurgy, Proceedings of the international conference: Bochum, FDR, Deutsches Bergbau-Museum, p. 23-30.

Eugster, H.P., 1985, Oil shales, evaporites and ore deposits: Geochimica et Cosmochimica Acta, v. 49, no. 3, p. 619-635.

Eugster, H.P., 1989, Geochemical environments of sedimenthosted $\mathrm{Cu}-\mathrm{Pb}-\mathrm{Zn}$ deposits, in Boyle, R.W., Brown, A.C., Jefferson, C.W., Jowett, E.C., and Kirkham, R.V., eds., Sediment-hosted stratiform copper deposits: Geological Association of Canada, Special Paper 36, p. 111-126.

Evamy, B.D., 1967, Dedolomitization and the development of rhombohedral pores in limestones: Journal of Sedimentary Research, v. 37, p. 1204-1215.

Evans, D.G., and Nunn, J.A., 1989, Free thermohaline convection in sediments surrounding a salt column: Journal of Geophysical Research, v. 94, no. B9, p. 12,413-12,422.

Evans, K.V., Aleinikoff, J.N., Obradovich, J.D., and Fanning, C.M., 2000, SHRIMP U-Pb geochronology of volcanic rocks, Belt Supergroup, western Montana-Evidence for rapid deposition of sedimentary strata: Canadian Journal of Earth Science: v. 37, p. 1287-1300.

Evett, D., 1967, Artifacts and architecture of the Iblis I period-Areas D, F, and G, in Caldwell, J.R., ed., Investigations at Tal-i-Iblis, Preliminary report no. 9: Springfield, Ill., Illinois State Museum Society, p. 202-225.

Fath, A.E., 1915, Copper deposits in the "red beds" of southwestern Oklahoma: Economic Geology, v. 10, p. 140-150.
Ferreyra, R.E., and Lardone, L.E., 1990, Stratabound uranium deposits in the Argentinian Andes, in Fonboté, L., Amstutz, G.C., Cardozo, M., Cedillo, E., and Frutos, J., eds., Stratabound ore deposits in the Andes: Berlin, Springer-Verlag, p. 671-680.

Flint, S.S., 1989, Sediment-hosted strata-bound copper deposits of the Central Andes, in Boyle, R.W., Brown, A.C., Jefferson, C.W., Jowett, E.C., and Kirkham, R.V., Sedimenthosted stratiform copper deposits: Geological Association of Canada, Special Paper 36, p. 371-398.

Folk, R.L., 1974, The natural history of calcium carbonateEffect of magnesium content and salinity: Journal of Sedimentary Petrology, v. 44, p. 40-53.

Folk, R.L., and Pittman, J.S., 1971, Length-slow chalcedonyA new testament for vanished evaporites: Journal of Sedimentary Petrology, v. 41, p. 1045-1058.

Foster, M.D., 1962, Interpretation of the composition and a classification of the chlorites: U.S. Geological Survey Professional Paper 414-A, p. A1-A33.

Fournier, R.O., and Truesdell, A.H., 1973, An empirical NaK-Ca geothermometer for natural waters: Geochimica et Cosmochimica Acta, v. 37, p. 1255-1275.

Francois, Armand, 1992, Synthèse géologique sur l'Arc Cuprifère du Shaba (Rép. Du Zaire) [Geological synthesis for the cupriferous Shaba arc (Republic of Zaire)]: Société Belge de Geologie, Centenaire 1987 [Geology Society of Belgium, 1987 Centennial], p. 15-65 (In French).

Frank, T.D., Lyons, T.W., and Lohmann, K.C., 1997, Isotopic evidence for the paleoenvironmental evolution of the Mesoproterozoic Helena Formation, Belt Supergroup, Montana, USA: Geochimica et Cosmochimica Acta, v. 61, p. 5023-5041.

Freiesleben, J.C., 1807-1817, Geognostischer beytrag zur kenntniss des Kupferschiefer-gebirges mit besonderer hinsicht auf einen theil der grafschacht Mannsfeld und Thüuringens: Freiberg, Graz and Gerlach, pts. I-VI (In German).

Freund, Raphael, 1965, A model of the structural development of Israel and adjacent areas since Upper Cretaceous time: Geological Magazine, v. 102, no. 3, p. 188-204.

Füchtbauer, H., 1972, Diagenesis of arenaceous deposits, in Crawford, F.D., ed., Arenaceous deposits: Sedimentation and diagenesis: Edmonton, Alberta, Canada, Alberta Society of Petroleum Geologists, p. 203-286.

Gablina, I.F., 1981, New data on formation conditions of the Dzhezkazkan copper deposit: International Geology Review, v. 23, no. 11, p. 1303-1311. 
Gablina, I.F., 1997, Formation conditions of large cupriferous sandstone and shale deposits: Geology of Ore Deposits, v. 39, p. 320-333.

Gablina, I.F., and Tsepin, A.I., 1975, Isomorphous impurities in calcite as indicators of the genesis of sandstone of the Dzhezkazgan suite: Doklady Akademii Nauk SSSR, v. 221, p. 714-717.

Gabriel, A., and Cox, E.P., 1929, A staining method for quantitative determination of certain rock minerals: American Mineralogist, v. 14, p. 290-292.

Garlick, W.G., 1961a, Chambishi, in Mendelsohn, F., ed., The geology of the Northern Rhodesian copperbelt: London, MacDonald, p. 281-297.

Garlick, W.G., 1961b, Ore genesis - The syngenetic theory, in Mendelsohn, F., ed., The geology of the Northern Rhodesian copperbelt: London, MacDonald, v. II, p. 146-165.

Garlick, W.G., 1972, Sedimentary environment of Zambian copper deposition: Geologie en Mijnbouw, v. 51, p. 277-298.

Gauthier, G., and Deliens, M., 1999, Cobalt minerals of the Katanga Crescent, Congo: The Mineralogical Record, v. 30, no. 4 , p. $255-273$.

Gautier, D.L., 1979, Preliminary report of authigenic, euhedral tourmaline crystals in a productive gas reservoir of the Tiger Ridge field, north-central Montana: Journal of Sedimentary Petrology, v. 49, p. 911-916.

Geeslin, J.H., and Chafetz, H.S., 1982, Ordovician Aleman ribbon cherts - An example of silicification prior to carbonate lithification: Journal of Sedimentary Petrology, v. 52, p. 1283-1292.

Giddings, J.A., and Wallace, M.W., 2009, Sedimentology and C-isotope geochemistry of the 'Sturtian' cap carbonate, South Australia: Sedimentary Geology, v. 216, p. 1-14.

Giggenbach, W.F., 1997, The origin and evolution of fluids in magmatic-hydrothermal systems, in Barnes, H.L., ed., Geochemistry of hydrothermal ore deposits ( $3 \mathrm{~d}$ ed.): New York, John Wiley and Sons, p.737-796.

Gilbert, G., 1931, Copper on the Coppermine River, N.W.T.: Economic Geology, v. 26, p. 96-108.

Giusíano, Adolfo, Franchíni, M.B., Impiccini, Agnes, and Pons, J., 2008, Mineralización de $\mathrm{Cu}$ en sedimentitas Mesozóicas del Grup Neuquén y habitat de los hidrocarburos en las Dorsal de Huincul Neuquén (abs): Salta, 17o Congreso Geológico Argentino, Actas 2 [17th Argentina Geological Congress, Proceedings 2, Summary in full for the Neuquén Basin symposium, p. 769-770.
Golden, Jonathan, Levy, T.E., and Hauptmann, Andreas, 2001, Recent discoveries concerning Chalcolithic metallurgy at Shiqmim, Israel: Journal of Archaeological Science, v. 28, no. 9, p. 951-963.

Goldhaber, M.B., Reynolds, R.L., Campbell, J.A., Wanty, R.B., Grauch, R.I., and Northrop, H.R., 1990, Genesis of the tabular-type vanadium-uranium deposits of the Henry Basin Utah, Part II. Mechanisms of ore and gangue mineral formation at the interface between brine and meteoric water: Economic Geology, v. 85, p. 236-250.

Gongalsky, B.I., Safonov, Yu.G., Krivolutskaya, N.A., Prokof'ev, V.Yu., and Yushin, A.A., 2007, A new type of gold-platinum-copper mineralization in northern Transbaikalia: Doklady Earth Sciences, v. 415, no. 5, p. 671-674.

Grace, J., and Putnis, A., 1976, Thermal decomposition and cation mobility in bornite: Economic Geology, v. 71, p. 1058-1059.

Gray, G.G., Pottorf, R.J., Summa, L.L., May, S.R., and Holl, J.E., 1996, Fluid flow and the Cashin fault [abs.]: Geological Society of America Abstracts with Programs, v. 23, p. A254.

Groen, H. A., 1961, Luansobe, in Mendelsohn, F., ed., The geology of the northern Rhodesian copperbelt: London, Macdonald, p. 406-419.

Grguric, B.S., Harrison, R.J., and Putnis, P., 2000, A revised phase diagram for the bornite-digenite join from in situ neutron diffraction and DSC experiments: Mineralogical Magazine, v. 64, p. 213-231.

Grzebisz, W., Cieśla, L, and Diatta, J.B., 2001, Spatial distribution of copper in the arable soils and in non-consumable crops (flax, oil-seed rape) cultivated near a copper smelter: Polish Journal of Environmental Studies, v. 10, no. 4, p. 269-272.

Grzebisz, W., Kocialkowski, W.Z., and Chudzinski, B., 1997, Copper geochemistry and availability in cultivated soils contaminated by a copper smelter: Journal of Geochemical Exploration, v. 58, p. 301-307.

Gustafson, L.B., and Williams, N., 1981, Sediment-hosted stratiform deposits of copper, lead, and zinc, in Skinner, B.J., ed., Economic Geology Seventy-Fifth Anniversary Volume, p. 139-178.

Gvirtzman, H., Garven, G., and Gvirtzman, G., 1997, Thermal anomalies associated with forced and free groundwater convection in the Dead Sea rift valley: Geological Society of America Bulletin, v. 109, p. 1167-1176. 
Haggerty, S.E., 1976, Opaque mineral oxides in terrestrial igneous rocks, in Rumble, D., III, ed., Oxide minerals: Mineralogical Society of America Short Course Notes, v. 3, p. Hg101-Hg175.

Hagni, R.D., 1988, Mineralogy, origin, and potential for discovery of Creta, Oklahoma, copper shale-type deposits in Oklahoma, Texas, and Kansas, in Kisvarsanyi, G., and Grant, S.K., eds., North American Conference on Tectonic Controls of Ore Deposits and the Vertical and Horizontal Extent of Ore Systems Proceedings: Rolla, Mo., University of Missouri, Rolla, p. 455-467.

Hagni, R.D., and Gann, D.E., 1976, Microscopy of copper ore at the Creta mine, southwestern Oklahoma, in Johnson, K.S., and Croy, R.L., eds., Stratiform copper deposits of the Midcontinent Region, a symposium: Oklahoma Geological Survey Circular 77, p. 40-50.

Hagni, R.D., and Gann, D.E., 1985, Ore microscopy and genesis of the copper shale deposit at Creta, Oklahoma, in Hausen, D.M., and Kopp, O.C., eds, Mineralogy-Applications to the mineral industry: New York, American Institute of Mining, Metallurgical, and Petroleum Engineers, p. 209-239.

Hall, S.M., and Veizer, J., 1996, Geochemistry of Precambrian carbonates: VII. Belt Supergroup, Montana and Idaho, USA: Geochimica et Cosmochimica Acta, v. 60, p. 667-677.

Halverson, G.P., Hoffman, P.F., Schrag, D.P., Maloof, A.C., and Rice, A.H.N., 2005, Toward a Neoproterozoic composite carbon-isotope record: Geological Society of America Bulletin, v. 117, p. 1181-1207.

Ham, W.E., and Merritt, C.A., 1944, Barite in Oklahoma: Oklahoma Geological Survey Circular 23, 2 p.

Hamilton, S.K., 1967, Copper mineralization in the upper part of the Copper Harbor Conglomerate at White Pine, Michigan: Economic Geology, v. 62, p. 885-904.

Hammer, J., Junge, F., Rösler, H.J., Niese, S., Gleisberg, B., and Stiehl, G., 1990, Element and isotope geochemical investigations of the Kupferschiefer in the vicinity of "Rote Fäule," indicating copper mineralization (Sangerhausen basin, G.D.R.): Chemical Geology, v. 85, p. 345-360.

Hanor, J.S., 1987, Kilometre-scale thermohaline overturn of pore waters in the Louisiana Gulf Coast: Nature, v. 327, p. 501-503.

Hardie, L.A., 1968, The origin of the Recent non-marine evaporite deposit of Saline Valley, Inyo County, California: Geochimica et Cosmochimica Acta, v. 32, p. 1279-1301.

Hardie, L.A., and Eugster, H.P., 1970, The evolution of closedbasin brines: Mineralogical Society of America Special Paper 3, p. 273-290.
Harrison, J.E., 1972, Precambrian Belt Basin of northwestern United States - Its geometry, sedimentation, and copper occurrences: Geological Society of America Bulletin, v. 83, p. 1215-1240.

Harrison, J.E., 1974, Copper mineralization in miogeosynclinal clastics of the Belt Supergroup, northwestern United States, in Bartholomé, P., ed., Gisements stratiformes et provinces cuprifères: Société Géologique de Belgique, Liège, Belgium, p. 353-366.

Harrison, J.E., Domenico, J.A., and Leach, D.L., 1986a, Resource appraisal map for stratabound copper-silver deposits in the Wallace $1^{\circ} \times 2^{\circ}$ Quadrangle, Montana and Idaho: U.S. Geological Survey Map I-1509F, scale: $1: 250,000$.

Harrison, J.E., and Grimes, D.J., 1970, Mineralogy and geochemistry of some Belt rocks, Montana and Idaho: U.S. Geological Survey Bulletin 1312-O, p. O1-O49.

Harrison, J.E., Leach, D.L., Kleinkopf, M.D., Cressman, E.R., Long, C.L., and Domenico, J.A., 1986b, Summary map of resource potential for metallic minerals in the Wallace $1^{\circ} \times 2^{\circ}$ Quadrangle, Montana and Idaho: U.S. Geological Survey Map I-1509J, scale: 1:250,000.

Harrison, J.E., and Reynolds, M.W., 1979, Preliminary geology of the Blacktail Mountain drilling site, Flathead County, Montana: U.S. Geological Survey Open-File Report 79-938, $30 \mathrm{p}$.

Harshman, E.N., 1972, Geology and uranium deposits, Shirley Basin area, Wyoming: U.S. Geological Survey Professional Paper 745, 82 p.

Hauptmann, A., 1989, The earliest periods of copper metallurgy in Feinan, Jordan: Bochum, FDR, Deutschen Bergbau-Museum, Der Anschnitt, Beiheft 7, p. 119-136.

Hauptmann, A., 2000, Zur frühen metallurgie des kupfers in Fenan/Jordanien: Bochum, FDR, Deutschen BergbauMuseum, Der Anschnitt, Beiheft 11.

Hauptmann, A., 2007, The archaeometallurgy of copper, evidence from Faynan, Jordan: Berlin, Springer-Verlag, 399 p.

Hayes, T.S., 1982, Climate dependent geochemical mechanisms of copper, uranium, and vanadium transport and deposition in sandstone ores: Stanford, Calif., Stanford University, M.S. Thesis, 148 p.

Hayes, T.S., 1983, Geologic studies on the genesis of the Spar Lake strata-bound copper-silver deposit, Lincoln County, Montana: Stanford, Calif., Stanford University, Ph.D. dissertation, $340 \mathrm{p}$. 
Hayes, T.S., 1984, Zonation and paragenesis of the Spar Lake strata-bound copper-silver deposit in the Belt Supergroup, Montana [abs.]: Geological Society of America Abstracts with Programs, v. 16, p. 534.

Hayes, T.S., 1990, A preliminary study of thermometry and metal sources of the Spar Lake strata-bound copper-silver deposit, Belt Supergroup, Montana: U.S. Geological Survey Open-File Report 90-484, 30 p.

Hayes, T.S., 1991, A model for genesis of red-bed-evaporite-associated strata-bound copper deposits and potential in the Springfield $1^{\circ} \times 2^{\circ}$ quadrangle and surrounding areas, in Martin, J.A., and Pratt, W.P., eds., Geology and mineralresource assessment of the Springfield $1^{\circ} \times 2^{\circ}$ quadrangle, Missouri, as appraised in September 1985: U.S. Geological Survey Bulletin 1942, p. 95-101.

Hayes, T.S., and Einaudi, M.T., 1986, Genesis of the Spar Lake strata-bound copper-silver deposit, Montana-Part I. Controls inherited from sedimentation and pre-ore diagenesis: Economic Geology, v. 81, p. 1899-1931.

Hayes, T.S., Landis, G.P., Whelan, J.F., Rye, R.O., and Moscati, R.J., 2012, The Spar Lake strata-bound Cu-Ag deposit formed across a mixing zone between trapped natural gas and metals-bearing brine: Economic Geology, v. 107, p. 1223-1249 p.

Hayes, T.S., Rye, R.O., Whelan, J.F., and Landis, G.P., 1989, Geology and sulphur-isotope geothermometry of the Spar Lake strata-bound $\mathrm{Cu}-\mathrm{Ag}$ deposit in the Belt Supergroup, Montana, in Boyle, R.W., Brown, A.C., Jefferson, C.W., Jowett, E.C., and Kirkham, R.V., Sediment-hosted stratiform copper deposits: Geological Association of Canada, Special Paper 36, p. 319-338.

Heijlen, Wouter, Banks, D.A., Muchez, Philippe, Stensgard, B.M., and Yardley, B.W.D., 2008, The nature of mineralizing fluids of the Kipushi $\mathrm{Zn}-\mathrm{Cu}$ deposit, Katanga, Democratic Republic of Congo-Quantitative fluid inclusion analysis using laser ablation ICP-MS and bulk crush-leach methods: Economic Geology, v. 103, p. 1459-1482.

Heinrich, C.A., Pettke, T., Halter, W.E., Aigner-Torres, M., Audédat, A., Günther, D., Hattendorf, B., Bleiner, D., Guillong, M., and Horn, I., 2003, Quantitative multi-element analysis of minerals, fluid and melt inclusions by laserablation inductively-coupled-plasma mass-spectrometry: Geochimica et Cosmochimica Acta, v. 67, p. 3473-3496.

Heinrich, C.A., Ryan, C.G., Mernagh, T.P., and Eadington, P.J., 1992, Segregation of ore metals between magmatic brine and vapor - A fluid inclusion study using PIXE microanalysis: Economic Geology, v. 87, p. 1566-1583.
Helios Rybicka, E., and Jędrzejczyk, B., 1995, Preliminary studies on mobilisation of copper and lead from contaminated soils and readsorption on competing sorbents: Applied Clay Science, v. 10, p. 259-268.

Helios Rybicka, E., Wilson, M.J., and McHardy, W.J., 1994, Chemical and mineralogical forms and mobilization of copper and lead in soils from a Cu-smelting area in Poland: Journal of Environmental Science and Health, Part A, v. 29, issue 3, p. 531-546.

Henchiri, M., and Slim-S'himi, N., 2006, Silicification of sulphate evaporites and their carbonate replacements in Eocene marine sediments, Tunisia-Two diagenetic trends: Sedimentology, v. 53, p. 1135-1159.

Hendry, J.P., Wilkinson, Mark, Fallick, A.E., and Haszeldine, R.S., 2000, Ankerite cementation in deeply buried Jurassic sandstone reservoirs in the central North Sea: Journal of Sedimentary Research, v. 70, p. 227-239.

Hieshima, G.B., and Mauk, J.L., 1990, Maturation of organic matter during mineralization at White Pine, North American Midcontinent Rift [abs.]: Geological Society of America Abstracts with Programs, v. 22, p. A13.

Hitzman, M.W., 1983, Geology of the Cosmos Hills and its relationship to the Ruby Creek copper-cobalt deposit: Stanford, Calif., Stanford University, Ph.D. dissertation, 266 p.

Hitzman, M.W., 2000, Source basins for sediment-hosted stratiform $\mathrm{Cu}$ deposits - Implications for the structure of the Zambian Copperbelt: Journal of African Earth Sciences, v. 30 , p. $855-863$.

Hitzman, M.W., 2002, Iron oxide-Cu-Au deposits-What, where, when, and why, in Porter, T.M., ed., Hydrothermal iron oxide copper-gold and related deposits - A global perspective, v. 1: Adelaide, PGC Publishing, p. 9-25.

Hitzman, M., Kirkham, R., Broughton, D., Thorson, J., and Selley, D., 2005, The sediment-hosted stratiform copper ore system, in Hedenquist, J.W., Thompson, J.F.H., Goldfarb, R.J., and Richards, J.P., eds., Economic Geology OneHundredth Anniversary Volume: Littleton, Colo., Society of Economic Geologists, p. 609-642.

Hitzman, M.W., Selley, David, and Bull, Stuart, 2010, Formation of sedimentary rock-hosted stratiform copper deposits through earth history: Economic Geology, v. 105, p. 627-639.

Ho, E.S., and Mauk, J.L., 1996, Relationship between organic matter and copper mineralization in the Proterozoic Nonesuch Formation, northern Michigan: Ore Geology Reviews, v. 11, p. $71-88$. 
Hoeve, J., and Quirt, D., 1989, A common diagenetichydrothermal origin for unconformity-type uranium and stratiform copper deposits?, in Boyle, R.W., Brown, A.C., Jefferson, C.W., Jowett, E.C., and Kirkham, R.V., Sedimenthosted stratiform copper deposits: Geological Association of Canada, Special Paper 36, p. 151-172.

Hoffman, B.C., and Miller, H., M.-L., 2009, Production and consumption of copper-base metals in the Indus civilization: Journal of World Prehistory, v. 22, p. 237-264.

Hoffman, P., Dewey, J.F., and Burke, K., 1974, Aulacogens and their genetic relation to geosynclines with a Proterozoic example from Great Slave Lake, Canada, in Dott, R.H., Jr., and Shaver, R.H., eds., Modern and ancient geosynclinal sedimentation: Society of Economic Paleontologists and Mineralogists Special Publication 19, p. 38-55.

Hoy, L.D., and Ohmoto, H., 1989, Constraints for the genesis of redbed-associated stratiform $\mathrm{Cu}$ deposits from sulphur and carbon mass-balance relations, in Boyle, R.W., Brown, A.C., Jefferson, C.W., Jowett, E.C., and Kirkham, R.V., Sediment-hosted stratiform copper deposits: Geological Association of Canada, Special Paper 36, p. 135-149.

Huyck, H.L.O., and Chorey, R.W., 1991, Stratigraphic and petrographic comparison of the Creta and Kupferschiefer copper shale deposits: Mineralium Deposita, v. 26, p. 132-142.

Illing, L.V., Wells, A.J., and Taylor, J.C.M., 1965, Penecontemporary dolomite in the Persian Gulf, in Dolomitization and limestone diagenesis: Society of Economic Paleontologists and Mineralogists Special Publication 13, p. 38-111.

Imreh, Lazlo, and Nicolini, Pierre, 1962, Les minéralisations cuprifères du "continental intercalaire" d'Agadez (République du Niger) (The cupriferous mineralizations of the continental Lower Cretaceous of Agadez, Republic of Niger): Bulletin du Bureau de Recherches Géologique et Minières (Bulletin of the French Bureau of Geological and Mining Research), v. 3, p. 151-208. (In French)

Ingram, R.L., 1954, Terminology for the thickness of stratification and parting units in sedimentary rocks: Geological Society of America Bulletin, v. 65, p. 937-938.

Ioganson, A.K., 1988, The geologic structure of the Kurpahdzhin ore field and the conditions of formation for the copper mineralization, Stratiform Mineralization in Yakutia: Yakutsk, Russia, U.S.S.R. Academy of Sciences, Siberian Branch, Institute of Geology, p. 87-98 (In Russian).
Isachsen, Y.W., and Evensen, C.G., 1955, Geology of uranium deposits of the Shinarump and Chinle Formations on the Colorado Plateau, in Page, L.R., Stocking, H.E., and Smith, H.B., comps., Contributions to the geology of uranium and thorium by the United States Geological Survey and Atomic Energy Commission for the United Nations International Conference on Peaceful Uses of Atomic Energy, Geneva, Switzerland, 1955: U.S. Geological Survey Professional Paper 300, p. 263-280.

Jackson, M.P.A., Warin, O.N., Woad, G.M., and Hudec, M.R., 2003, Neoproterozoic allochthonous salt tectonics during the Lufilian orogeny in the Katangan Copperbelt, central Africa: Geological Society of America Bulletin, v. 115, p. 314-330.

Jahn, S., Matheis, G., and Schreck, P., 1997, Schwermetallmobilisierung in typischen Haldenkomponenten am Standort Helbra, Mansfelder Kupferschieferrevier, in Schreck, P., and Glaesser, W., eds., Reststoffe der Kupferschieferverhuttung, v. 23, UFZ-Bericht, p. 17-23 (In German).

Jahn, S., and Witzke, T., 1999, Secondary mineral of zinc and copper in heaps of Kupferschiefer ores at Helbra, Sachsen-Anhalt, Germany- First occurrence of cuprian gordaite: Chemie der Erde, v. 59, p. 223-232.

Japan International Cooperation Agency and Metal Mining Agency of Japan, 1997, Report on mineral exploration in the Zhaman-Aibat and Samarsky area, Republic of Kazakhstan, Part III: Unpublished report: 277 p., accessed March 30, 2010, at http://lvzopac.jica.go.jp/external/ library?func=function.opacsch.mmindex\&view=view. opacsch.toshoshozodsp\&lang=eng\&shoshisbt=1\&shoshino $=0000092476 \&$ volno $=0$.

Jefferson, C.W., 1978, Stratigraphy and sedimentology, Upper Proterozoic Redstone Copper Belt, Mackenzie Mountains, Northwest Territories - a preliminary report, in Mineral industry report for 1975, Northwest Territories, Indian and Northern Affairs, Economic Geology Series, No. 1978-5, p. $157-169$.

Joffe, A.H., and Dessel, J.P., 1995, Redefining chronology and terminology for the Chalcolithic of the Southern Levant: Current Anthropology, v. 36, no. 3, p. 507-518.

Johnson, A.M., Carlson, D.H., Bagley, S.T., and Johnson, D.L., 1988, Investigations related to in situ bioleaching of Michigan chalcocite ores: Mining Engineering, v. 40, no. 12, p. 1119-1122.

Johnson, C.A., Emsbo, P., Poole, F.G., and Rye, R.O., 2009, Sulfur and oxygen isotopes in sediment-hosted stratiform barite deposits: Geochimica et Cosmochimica Acta, v. 73, p. 133-147. 
Johnson, K.S., 1976a, Introduction to the symposium, in Johnson, K.S., and Croy, R.L., eds., Stratiform copper deposits of the Midcontinent Region, a symposium: Oklahoma Geological Survey Circular 77, p. 1-2.

Johnson, K.S., 1976b, Permian copper shales of southwestern Oklahoma, in Johnson, K.S., and Croy, R.L., eds., Stratiform copper deposits of the Midcontinent Region, a symposium: Oklahoma Geological Survey Circular 77, p. 3-14.

Jolly, W.T., 1974, Behavior of Cu, Zn, and Ni during prehnitepumpellyite rank metamorphism of the Keweenawan basalts, Northern Michigan: Economic Geology, v. 69, p. 1118-1125.

Jonas, E.C., and McBride, E.F., 1977, Diagenesis of sandstone and shale-Application to exploration for hydrocarbons: Continuing Education Program Publication Number 1: Department of Geological Sciences, University of Texas at Austin, 165 p.

Jordaan, J., 1961, Nkana, in Mendelsohn, F., ed., The geology of the Northern Rhodesian Copperbelt: London, Macdonald and Co., p. 297-328.

Jowett, E.C., 1986a, Genesis of Kupferschiefer Cu-Ag deposits by convective flow of Rotliegendes brines during Triassic rifting: Economic Geology, v. 81, p. 1823-1837.

Jowett, E.C., 1986b, Section D. Kupferschiefer ore genesis model, in Jowett, E.D., ed., Kupfershiefer and other sediment-hosted deposits in central Europe: Ottawa, Canada, Geological Association of Canada-Mineralogical Association of Canada-Canadian Geophysical Union Joint Annual Meeting Field Trip Guidebook 12, p. 42-52.

Jowett, E.C., 1987, Formation of sulfide-calcite veinlets in the Kupferschiefer $\mathrm{Cu}-\mathrm{Ag}$ deposits in Poland by natural hydrofracturing during basin subsidence: Journal of Geology, v. 95 , p. 513-526.

Jowett, E.C., 1991, The evolution of ideas about the genesis of stratiform copper-silver deposits, in Hutchinson, R.W., and Grauch, R.I., eds., Historical perspectives of genetic concepts and case histories of famous discoveries: Economic Geology Monograph 8, p. 117-132.

Jowett, E.C., Pearce, G.W., and Rydzewski, Andrzej, 1987, A Mid Triassic paleomagnetic age of the Kupferschiefer mineralization in Poland, based on a revised apparent polar wander path for Europe and Russia: Journal of Geophysical Research, v. 92, no. B1, p. 581-598.
Jung, W., and Knitzschke, G., 1976, Kupferschiefer in the German Democratic Republic (GDR) with special reference to the Kupferschiefer deposit in the southeastern Harz foreland, in Wolf, K.H., ed., Handbook of stratabound and stratiform ore deposits, II. Regional studies and specific deposits, Volume 6- $\mathrm{Cu}, \mathrm{Zn}, \mathrm{Pb}$, and $\mathrm{Ag}$ deposits: New York, Elsevier, p. 353-406.

Kabala, C., and Singh, B.R., 2001, Fractionation and mobility of copper, lead, and zinc in soil profiles in the vicinity of a copper smelter: Journal of Environmental Quality, v. 30, p. 485-492.

Kabata-Pendias, A., and Pendias, H., 1992, Trace elements in soils and plants: Boca Raton, Fla., CRC Press, Inc., 315 p.

Kamona, A.F., and Günzel, A., 2007, Stratigraphy and base metal mineralization in the Otavi Mountain Land, northern Namibia-A review and regional interpretation: Gondwana Research, v. 11. p. 396-413.

Kampunzu, A.B., and Cailteux, J., 1999, Tectonic evolution of the Lufilian Arc (Central Africa Copper Belt) during the Neoproterozoic Pan-African orogenesis: Gondwana Research, v. 2, p. 401-421.

Kampunzu, A.B., Cailteux, J.L.H., Kamona, A.F., Intiomale, M.M., and Melcher, F., 2009, Sediment-hosted Zn-Pb-Cu deposits in the Central African Copperbelt: Ore Geology Reviews, v. 35, p. 263-297.

Karczewska, A., 1996, Metal species distribution in top- and sub-soil in an area affected by copper smelter emissions: Applied Geochemistry, v. 11, p. 35-42.

Kastner, M., and Siever, R., 1979, Low temperature feldspars in sedimentary rocks: American Journal of Science, v. 279, p. $3435-479$.

Keith, M.L., 1939, Selective staining to facilitate Rosiwal analysis: American Mineralogist, v. 24, p. 561-565.

Kenny, R., 1992, Origin of disconformity dedolomite in the Martin Formation (Late Devonian, northern Arizona): Sedimentary Geology, v. 78, p. 137-146.

KGHM Polska Midź, S.A., 2009, Resource base, 4 p., accessed August 24, 2012, at http://www.kghm.pl/index.dhtml?module $=$ article\&id $=78 \&$ lang $=$ en.

Kidwell, A.L., and Bower, R.R., 1976, Mineralogy and microtextures of sulfides in the Flowerpot Shale of Oklahoma and Texas, in Johnson, K.S., and Croy, R.L., eds., Stratiform copper deposits of the Midcontinent Region, a symposium: Oklahoma Geological Survey Circular 77, p. 51-60. 
Kinsman, D.J.J., 1969, Modes of formation, sedimentary associations, and diagnostic features of shallow-water and supratidal evaporites: American Association of Petroleum Geologists' Bulletin, v. 53, p. 830-840.

Kirkham, R.V., 1984a, Sedimentary copper, in Eckstrand, O.R., ed., Canadian mineral deposit types-A geological synopsis: Canadian Geological Survey Economic Geology Report 36, p. 27.

Kirkham, R.V., 1984b, Volcanic redbed copper, in Eckstrand, O.R., ed., Canadian mineral deposit types-A geological synopsis: Canadian Geological Survey Economic Geology Report 36, p. 37.

Kirkham, R.V., 1989, Distributions, settings, and genesis of sediment-hosted stratiform copper deposits, in Boyle, R.W., Brown, A.C., Jefferson, C.W., Jowett, E.C., and Kirkham, R.V., Sediment-hosted stratiform copper deposits: Geological Association of Canada, Special Paper 36, p. 3-38.

Kirkham, R.V., 2001, Sediment-hosted stratiform copper (SSC), other strata-bound base metal deposits and the importance of basinal brines and/or evaporites, halotectonics and halokinesis, in Piestrzyński, A., et al., eds., Mineral deposits at the beginning of the 21st century, Proceedings of the Joint Sixth Biennial SGA-SEG Meeting, Kraków, Poland, 26-29 August 2001: Lisse, Belgium, A.A. Balkema Publishers, p. 15-18.

Kirkham, R.V., Carriére, J.J., Laramée, R.M., and Garson, D.F., 1994, Global distribution of sediment-hosted stratiform copper deposits and occurrences: Geological Survey of Canada Open-File Report 2915b, 156 p.

Kiwara Resources, PLC, 2009, New release: accessed October 13, 2009, at: http://www.londonstockexchange.com/ exchange/prices-and-news/news/market-news/market-newsdetail.html?announcementId=10174607.

Kleinkopf, M.D., Harrison, J.E., and Zartman, R.E., 1972, Aeromagnetic and geologic map of part of northwestern Montana and northern Idaho: U.S. Geological Survey Geophysical Investigations Map GP-830, scale 1:250,000.

Klemm, L.M., Pettke, Thomas, and Heinrich, C.A., 2007, Hydrothermal evolution of the El Teniente deposit, ChilePorphyry $\mathrm{Cu}-\mathrm{Mo}$ ore deposition from low-salinity magmatic fluids: Economic Geology, v. 102, p. 1021-1045.

Klemm, L.M., Pettke, T., and Heinrich, C.A., 2008, Fluid and source magma evolution of the Questa porphyry Mo deposits, New Mexico, USA: Mineralium Deposita, v. 43, p. 533-552.

Knitzschke, G., and Kahmann, H.J., 1990, Der Bergbau auf Kupferschiefer im Sangerhauser Revier: Gluckauf, v. 126, p. 528-548 (In German).
Kosyak, Ye. A., 1969, Phase transformations in bornite during electron probe analysis: Doklady of the Academy of Sciences of the USSR Earth Sciences Sections, v. 186, p. 145-147.

Krahulec, K., 2006, Lisbon Valley copper project—Utah's newest copper mine: Utah Geological Survey Notes, v. 38, no. 1, p. 1-2.

Kramer, S.N., 1981, History begins at Sumer-Thirty-nine firsts in recorded history: Philadelphia, Pa., The University of Pennsylvania Press, 416 p.

Krouse, H.R., 1977, Sulfur isotope studies and their role in petroleum exploration: Journal of Geochemical Exploration, v. 7, p. 189-211.

Kucha, Henryk, and Cichowska, Renata, 2001, Precious metals in copper smelting products: Physicochemical Problems of Mineral Processing, v. 35, p. 91-101.

Kucha, H., and Przybyłowicz, W., 1999, Noble metals in organic matter and clay-organic matrices, Kupferschiefer, Poland: Economic Geology, v. 94, p. 1137-1162.

Kulick, J., Leifeld, D., and Theuerjahr, A.-K., 1986, Section B-German Kupferschiefer excursion, in Jowett, E.C., ed., Kupferschiefer and other sediment-hosted deposits in central Europe: Geological Association of Canada, Mineralogical Association of Canada, Canadian Geophysical Union Joint Annual Meeting, Ottawa, Ontario, 1986 Field Trip Guidebook 12, p. 11-34 (translation by E.C. Jowett).

Kurosawa, M., Shimano, S., Ishii, S., Shima, K., and Kato, T., 2003, Quantitative trace element analysis of single fluid inclusions by proton-induced X-ray emission (PIXE) Application to fluid inclusions in hydrothermal quartz: Geochimica et Cosmochimica Acta, v. 22, p. 4337-4352.

Kvasnytsya, V.M., Zagnitko, V.M., and Kvasnytsya, 2001, Native copper occurrences of the West Ukraine, in Piestrzyński and others, eds., Mineral deposits at the beginning of the 21st century, Proceedings of the Joint Sixth Biennial SGS-SEG Meeting, Kraków, Poland, 26-29 August 2001: Lisse, Belgium, A.A. Balkema Publishers, p. 595-597.

Land, L.S., and Milliken, K.L., 1981, Feldspar diagenesis in the Frio Formation, Brazoria County, Texas Gulf Coast: Geology, v. 9, p. 314-318.

Lang, A.H., Goodwin, A.M., Mulligan, R., Whitmore, D.R.E., Gross, G.A., Boyle, R.W., Johnston, W.G., Chamberlain, J.A., and Rose, E.R., 1976, Economic minerals of the Canadian Shield, in Douglas, R.J.W., eds., Geology and economic minerals of Canada: Geological Survey of Canada Economic Geology Report No. 1, p. 152-226. 
Lange, I.A., Moore, J.N., and Krouse, H.R., 1987, Diagenesis and copper mineralization in carbonates in the Spokane Formation, Belt Supergroup, at Wolf Creek, Montana: Economic Geology, v. 82, p. 1334-1347.

LaPoint, D.J., 1974, Possible source areas for sandstone copper deposits in northern New Mexico: New Mexico Geological Society Guidebook, 25th Field Conference, Ghost Ranch, p. 305-308.

LaPoint, D.J., 1976, A comparison of selected sandstone copper deposits in New Mexico, in Johnson, K.S., and Croy, R.L., eds., Stratiform copper deposits of the Midcontinent region, a symposium: Oklahoma Geological Survey Circular 77, p. 80-96.

Lavier, L.L., Steckler, M.S., and Brigaud, F., 2001, Climatic and tectonic control on the Cenozoic evolution of the West African margin: Marine Geology, v. 178, p. 63-80.

Lebedev, L.M., and Nikitina, I.B., 1968, Chemical properties and ore content of hydrothermal solutions at Cheleken: Doklady of the Academy of Sciences of the USSR Earth Sciences Sections , v. 183, p. 180-182.

Lee, J.E., and Glenister, D.A., 1976, Stratiform sulfide mineralization at Oamites copper mine, South West Africa: Economic Geology, v. 71, p. 369-383.

Lee, J.H., and Kim, S.H., 1970, Mineralization and ore deposits of native copper in Seachondong basalt flows in Yongyang Basin, Korea: Journal of the Geological Society of Korea, v. 6, p. 230-245.

Lee-Potter, J.B., 1961, Baluba, in Mendelsohn, F., ed., The geology of the northern Rhodesian copperbelt: London, Macdonald, p. 343-351.

Lefebure, D.V., and Church, B.N., 1996, Volcanic redbed $\mathrm{Cu}$, in Lefebure, D.V., and Höy, T., eds., Selected British Columbia mineral deposit profiles, Volume 1 - Metallic deposits: British Columbia Ministry of Employment and Investment Open File 1996-13, p. 5-7.

Lehman, J.C., 1756, Versuch einer geschichte von flötzgegürgen: Berlin, F.A. Lange, p. 163-175 (In German).

Levandowski, D.W., Kaley, M.E., Silverman, S.R., and Smalley, R.G., 1973, Cementation in Lyons Sandstone and its role in oil accumulation, Denver Basin, Colorado: American Association of Petroleum Geologists Bulletin, v. 57, p. 2127-2244.

Levy, T.E., Adams, R.B., Najjar, M., Hauptmann, A., Anderson, J.D., Brandl, B., Robinson, M.A., and Higham, T., 2004, Reassessing the chronology of Biblical EdomNew excavation and ${ }^{14} \mathrm{C}$ dates from Khirbat en-Nahas (Jordan): Antiquity, v. 78, p. 863-876.
Lind, L.E., 1961, Conditions of ilmenite alteration: Economic Geology, v. 56, p. 994-995.

Lindgren, Waldemar, Graton, L.C., and Gordon, C.H., 1910, The ore deposits of New Mexico: U.S. Geological Survey Professional Paper 68, $361 \mathrm{p}$.

Lindsey, D.A., Woodruff, L.G., Cannon, W.F., Cox, D.P., and Heran, W.D., 1995, Sediment-hosted $\mathrm{Cu}$ deposits, in du Bray, E.A., ed., Preliminary compilation of descriptive geoenvironmental mineral deposit models: U.S. Geological Survey Open-File Report 95-831, p. 214-224.

Linduff, K.M., and Mei, J., 2009, Metallurgy in ancient eastern Asia - Retrospect and prospects: Journal of World Prehistory, v. 22, p. 265-281.

Livnat, A., 1983, Metamorphism and copper mineralization of the Portage Lake Lava Series, northern Michigan: Ann Arbor, Mich., University of Michigan, Ph.D. dissertation, $270 \mathrm{p}$.

Ljunggren, P., and Meyer, H.C., 1964, The copper mineralization in the Corocoro Basin, Bolivia: Economic Geology, v. 59 , p. $110-125$.

Lobo-Guerrero, A., 2004, Granitoid-related iron-oxide-coppergold mineralization, Greater Lufilian Arc, Zambia and Namibia [abs.], in Muhling, J., Goldfarb, R.J., Vielreicher, N., Bierlein, F.P., Stumpfl, E.F., Groves, D.I., and Kenworthy, S., eds., SEG 2004; Predictive mineral discovery under cover; SEG conference and exhibition; extended abstracts: Perth, Publication - Geology Department and Extension Service, University of Western Australia, v. 33, p. 277-0280.

Lockwood, R.P., 1972, Geochemistry and petrology of some Oklahoma redbed copper occurrences: Norman, Okla., University of Oklahoma, Ph.D. dissertation, 125 p.

Lopatin, N.V., 1971, Temperature and geologic time as factors in coalification (in Russian): Akad. Nauk SSSR Izv. Ser. Geol., no. 3, p. 95-106.

Luebking, G.A., Longman, M.W., and Carlisle, W.J., 2001, Unconformity-related chert/dolomite production in the Pennsylvanian Amsden Formation, Wolf Springs fields, Bull Mountains basin of central Montana: American Association of Petroleum Geologists Bulletin, v. 85, p. 131-148.

Lur'ye, A.M., and Gablina, I.F., 1972, The copper source in production of Mansfeld-type deposits in the West Ural Foreland: Geochemistry International, v. 9, p. 56-67.

Lur'ye, A.M., and Gablina, I.F., 1976, Zoning of sulfides in the copper deposits localized in red beds: Geochemistry International, v. 13, no. 1, p. 72-77. 
Lur'ye, A.M., and Gablina, I.F., 1978, Basic scheme of formation of supergene copper deposits: Doklady Akademii Nauk S.S.S.R., v. 241, p. 126-129.

Lustwerk, R.L., and Rose, A.W., 1983, Source and segregation of transition metals during diagenetic formation of the Redstone stratiform copper deposit, Mackenzie Mts., N.W.T., Canada [abs.]: Geological Society of America Abstracts with Programs, v. 15, p. 632.

Lustwerk, R.L., and Wasserman, M.D., 1989, Water escape structures in the Coates Lake Group, Northwest Territories, Canada, and their relationship to mineralization at the Redstone stratiform copper deposit, in Boyle, R.W., Brown, A.C., Jefferson, C.W., Jowett, E.C., and Kirkham, R.V., Sediment-hosted stratiform copper deposits: Geological Association of Canada, Special Paper 36, p. 207-224.

Lyle, J.R., 1977, Petrography and carbonate diagenesis of the Bonneterre Formation in the Viburnum Trend area, Southeast Missouri: Economic Geology, v. 72, p. 420-434.

Macaulay, C.I., Haszeldine, R.S., and Fallick, A.E., 1993, Distribution, chemistry, isotopic composition, and origin of diagenetic carbonates: Magnus Sandstone, North Sea: Journal of Sedimentary Petrology, v. 63, p. 33-43.

MacDonald, D.D., Ingersoll, C.G., and Berger, T.A., 2000, Development and evaluation of consensus-based sediment quality guidelines for freshwater ecosystems: Archives of Environmental Contamination and Toxicology, v. 39, p. 20-31.

MacIntyre, T.J., 2006, Fault-controlled hydrocarbon-related bleaching and sediment-hosted copper mineralization of the Jurassic Wingate Sandstone at the Cashin mine, Montrose County, Colorado: Golden, Colo., Colorado School of Mines, M.S. Thesis, 335 p.

MacKevett, Jr., E.M., Cox, D.P., Potter, II, R.W., and Silberman, J.L., 1997, Kennecott-type deposits in the Wrangell Mountains, Alaska: High-grade copper ores near a basaltlimestone contact, in Goldfarb, R.J., and Miller, L.D., eds., Mineral deposits of Alaska: Economic Geology Monograph 9, p. 66-89.

MacLachlan, M.E., 1967, Oklahoma, in McKee, E.D., Oriel, S.S., and others, Paleotectonic investigations of the Permian System in the United States: U.S. Geological Survey Professional Paper 515, p. 81-92.

Maddin, R., Stech, T., and Muhly, D., 1991, Çayönü TepesiThe earliest archaeological metal artifacts, in Mohen, J-P., ed., Découvetre de metal (Amis du Musée des Antiquités Nationales, Millénaires 2): Paris, Picard, p. 375-386.

Magoon, L.B., ed., 1988, Petroleum systems of the United States: U.S. Geological Survey Bulletin 1870, 68 p.
Maiden, K.J., 1989, Structural taps for stratabound copper deposits in the Mount Gunson area, South Australia, in Boyle, R.W., Brown, A.C., Jefferson, C.W., Jowett, E.C., and Kirkham, R.V., eds., Sediment-hosted stratiform copper deposits: Geological Association of Canada, Special Paper 36, p. 543-554.

Maksaev, V., and Zentilli, M., 2002, Chilean strata-bound $\mathrm{Cu}-(\mathrm{Ag})$ deposits - An overview, in Porter, T.M., ed., Hydrothermal iron oxide copper-gold and related depositsA global perspective, v. 2: Adelaide, PGC Publishing, p. 185-205.

Malaisse, F., Gregoire, J., Brooks, R.R., Morrison, R.S., and Reeves, R.D., 1978, Aeolanthus biformifolius De Wild. - a hyperaccumulator of copper from Zaire: Science, v. 199, no. 4331, p. 887-888.

Malan, R.C., 1968, The uranium mining industry and geology of the Monument Valley and White Canyon districts, Arizona and Utah, in Ridge, J.D., ed., Ore deposits of the United States, 1933-1967, the Graton-Sales Volume: New York, American Institute of Mining, Metallurgical, and Petroleum Engineers, p. 790-804.

Maree, S.C., 1961, Soil, in Mendelsohn, F., ed., The geology of the Northern Rhodesian copperbelt: London, MacDonald, v. II, p. 63-80.

Marowsky, G., 1969, Schwefel-, kohlenstoff-, und sauerstoffisotopenuntersuchungen am Kupferschiefer als beitrag zur genetischen Deutung (Sulfur, carbon, and oxygen isotope investigations at the Kupferschiefer as a contribution to genetic interpretation): Contributions to Mineralogy and Petrology, v. 22, p. 290-334.

Matheis, G., Jahn, S., Marquardt, R., and Schreck, P., 1999, Mobilization of heavy metals in mining and smelting heaps, Kupferschiefer district, Mansfeld, Germany: Chronique de la Recherche Miniérem v, 67, no. 534, p. 3-12.

Mattesich, R., 2002, The oldest writings, and inventory tags of Egypt: The Accounting Historians Journal, June, 2002 issue, 9 p.

Mauk, J.L., Brown, A.C., Seasor, R.W., and Eldridge, C.S., 1992a, Geology and stable isotope and organic geochemistry of the White Pine sediment-hosted stratiform copper deposit, in Bornhorst, T.J., ed., Keweenawan copper deposits of western upper Michigan: Society of Economic Geologists' Guidebook Series, v. 13, p. 63-98.

Mauk, J.L., Kelly, W.C., van der Pluijm, B.A., and Seasor, R.W., 1992b, Relations between deformation and sedimenthosted copper mineralization-Evidence from the White Pine part of the Midcontinent Rift system: Geology, v. 20, p. $427-430$. 
Mauk, J.L., Seasor, R.W., Andrews, R.A., Nelson, W.S., and Robinson, R., 1992c, An underground guide to the geology of the White Pine mine, in Bornhorst, T.J., ed., Keweenawan copper deposits of western Upper Michigan: Society of Economic Geologists' Guidebook Series, v. 13. p. 145-162.

Maxwell, D.T., and Hower, J., 1967, High-grade diagenesis and low-grade metamorphism of illite in the Precambrian Belt Series: American Mineralogist, v. 52, p. 843-857.

McCarthy, J.H., and Reimer, G.M., 1986, Advances in soil gas exploration for natural resources: Journal of Geophysical Research, v. 91, p. 12,327-12,338.

McGowan, R.R., Roberts, S., and Boyce, A.J., 2006, Origin of the Nchanga copper-cobalt deposits of the Zambian Copperbelt: Mineralium Deposita, v. 40, p. 617-638.

McGowan, R.R., Roberts, S., Foster, R.P., Boyce, A.J., and Coller, D., 2003, Origin of the copper-cobalt deposits of the Zambian Copperbelt-An epigenetic view from Nchanga: Geology, v. 31, p. 497-500.

McKinnon, D., and Smit, N.J., 1961, Nchanga, in Mendelsohn, F., ed., The geology of the Northern Rhodesian Copperbelt: London, Macdonald and Co., p. 234-275.

Mendelsohn, F., ed., 1961a, The geology of the Northern Rhodesian Copperbelt: London, Macdonald and Co., 523 p.

Mendelsohn, F., 1961b, Metamorphism, in Mendelsohn, F., ed., The geology of the Northern Rhodesian Copperbelt: London, Macdonald and Co., p. 106-116.

Menning, M., Alekseev, A.S., Chuvashov, B.I., Davydov, V.I., Devuyst, F.X., Forke, H.C., Grunt, T.A., Hance, L., Heckel, P.H., Izokh, N.G., Jin, Y.G., Jones, P.J., Kotlyar, G.V., Kozur, H.W., Nemyrovska, T.I., Schneider, J.W., Wang, X.D., Weddige, K., Weyer, D., and Work, D.M., 2006, Global time scale and regional stratigraphic reference scales of Central and West Europe, East Europe, Tethys, South China, and North America as used in the DevonianCarboniferous-Permian Correlation Chart 2003(DCP 2003): Palaeogeography, Palaeoclimatology, and Palaeoecology, v. 240), p. 318-372.

Meyer, C., and Hemley, J.J., 1967, Wall rock alteration, in Barnes, H.L., ed., Geochemistry of Hydrothermal Ore Deposits: New York, Holt, Rinehart and Winston, p. 166-235.

Michalik, M., 1997, Chlorine containing illites, copper chlorides and other chlorine bearing minerals in the ForeSudetic copper deposit (Poland) (extended abstract), in Papunen, H., ed., Mineral Deposits: Research and Exploration / Where do they meet?: Proceedings of the Fourth Biennial SGA Meeting, Turku, Finland, 11-13 August 1997: Rotterdam, The Netherlands, A.A. Balkema, p. 543-546.
Michalik, M., 2001, Diagenesis of the Weissliegend sandstones in the southwest margin of the Polish Rotliegend Basin: Krakow, Poland, Polska Akademia Nauk, Prace Mineralogiczne 91, 176 p.

Michalik, M., and Sawłowicz, Z., 2001, Multi-stage and long-term origin of the Kupferschiefer copper deposits in Poland [extended abs.], in Piestrzyński, et al., eds., Mineral deposits at the beginning of the 21 st century, Proceedings of the Joint Sixth Biennial SGA-SEG Meeting/Kraków/ Poland 26-29 August 2001: Lisse, Belgium, A.A. Balkema, p. $235-238$.

Miesch, A.T., 1963, Distribution of elements in Colorado Plateau uranium deposits - A preliminary report: U.S. Geological Survey Bulletin 1147-E, p. E1-E57.

Miller, D.S., and Kulp, J.L., 1963, Isotopic evidence on the origin of Colorado Plateau uranium ores: Geological Society of America Bulletin, v. 74, p. 609-630.

Miller, L.J., 1955, Uranium ore controls of the Happy Jack deposit, White Canyon, San Juan County, Utah: Economic Geology, v. 50, p. 156-169.

Milliken, K.L., 1979, The silicified evaporite syndrome - two aspects of silicification history of former evaporite nodules from southern Kentucky and northern Tennessee: Journal of Sedimentary Petrology, v. 49, p. 245-256.

Milner, S., 1976, Carbonate petrology and syndepositional facies of the lower San Andres Formation (Middle Permian), Lincoln County, New Mexico: Journal of Sedimentary Petrology, v. 46, p. 463-482.

Mining Record, 1995, Summo successful at Lisbon Valley copper project: The Mining Record, v. 106, no. 5, p. 1.

Moine, B., Guilloux, L., and Audeoud, D., 1986, Major element geochemistry of the host rocks in some sedimenthosted copper deposits, in Friedrich, G.H. and others, eds., Geology and metallogeny of copper deposits: Berlin, Springer-Verlag, p. 443-460.

Morency, M., Weiss, H., Freyer, K., Bourne, J., Fontaine, D., Mineau, R., Möder, M., Morgenstren, P., Popp, P., Predea, M., Treutler, H-C., and Wennrich, R., 1998, Oxidation treatment of a sulphide-bearing scrubber dust from the Mansfeld Region, Germany; Organic and inorganic phase changes and multi-element partition coefficients between liquid and solid phases: Science for the Total Environment, v. 223, p. 87-97.

Morimoto, N., and Kato, K., 1970, Phase relations of the $\mathrm{Cu}-\mathrm{S}$ system at low temperatures - Stability of anilite: American Mineralogist, v. 55, p. 106-117. 
Morimoto, N., Kato, K., and Shmazaki, Y., 1969, Anilite, $\mathrm{Cu}_{7} \mathrm{~S}_{4}$, a new mineral: American Mineralogist, v. 54, p. $1256-1268$.

Morrison, S.J., and Parry, W.T., 1986, Formation of carbonatesulfate veins associated with copper ore deposits from saline basin brines, Lisbon Valley, Utah-Fluid inclusion and isotopic evidence: Economic Geology, v. 81, p. 1853-1866.

Mosier, D.L., Singer, D.A., and Cox, D.P., 1986, Grade and tonnage model of sediment-hosted $\mathrm{Cu}$, in Cox, D.P., and Singer, D.A., eds., Mineral deposit models: U.S. Geological Survey Bulletin 1693, p. 206-208.

Moura, A., 2008, Metallogenesis at the Neves Corvo VHMS deposit, Portugal; a contribution from the study of fluid inclusions: Ore Geology Reviews, v. 34, p. 354-368.

Muchez, Ph., Vanderhaeghen, P., El Desouky, H., Schneider, J., Boyce, A., Dewaele, S., and Cailteux, J., 2008, Anhydrite pseudomorphs and the origin of stratiform $\mathrm{Cu}-\mathrm{Co}$ ores in the Katangan Copperbelt (Democratic Republic of Congo): Mineralium Deposita, v. 43, p. 575-589.

Mudge, M.R., 1967, Central Midcontinent region, in McKee, E.D., Oriel, S.S., and others, Paleotectonic investigations of the Permian System in the United States: U.S. Geological Survey Professional Paper 515, p. 93-123.

Muszer, A., 2004, Mineralogical characteristics of metallurgical dust in the vicinity of Glogow: Physicochemical Problems of Mineral Processing, v. 38, p. 329-340.

Mwase, M., Viktor, T., and Norrgren, L., 1998, Effects on tropical fish of soil sediments from Kafue River, Zambia: Bulletin of Environmental Contamination and Toxicology, v. 61, p. $96-101$.

Nadoll, P., Mauk, J.L., Hayes, T.S., Koenig, A.E., and Box, S.E., 2012, Geochemistry of magnetite from hydrothermal ore deposits and host rocks of the Mesoproterozoic Belt Supergroup, United States: Economic Geology, v. 107, p. 1275-1292.

Nawrocki, J., 2000, Clay mineralogy, crystallinity, and $\mathrm{K}$-Ar ages of illites within the Polish Zechstein basinImplications for the age of Kupferschiefer mineralization a discussion: Economic Geology, v. 95, p. 241-242.

Nimry, Y.F., 1973, Copper and manganese prospects of Wadi Araba: Amman, Jordan, Hashemite Kingdom of Jordan, Natural Resources Authority, Mining Division, 107 p.

Nishioka, G.K., 1983, Origin of late veins in the White Pine copper deposit, northern Michigan: Ann Arbor, Mich., University of Michigan, M.S. Thesis, 35 p.
Norrgren, L., Pettersson, U., Orn, S., and Bergqvist, P.-A., 2000, Environmental monitoring of the Kafue River, located in the Copperbelt, Zambia: Archives of Environmental Contamination and Toxicology, v. 38, p. 334-341.

Northrup, H.R., Goldhaber, M.B., Landis, G.P., and Unruh, J.W., 1990a, Genesis of the Tabular-type vanadium-uranium deposits of the Henry Basin, Utah, Part I. Geochemical and mineralogical evidence for the source of the ore-forming fluids: Economic Geology, v.; 85, p. 215-236.

Northrup, H.R., Goldhaber, M.B., Whitney, G., Landis, G.P., and Rye, R.O., 1990b, Genesis of the tabular-type vanadiumuranium deposits of the Henry Basin, Utah, Part III. Evidence from the mineralogy and geochemistry of clay minerals: Economic Geology, v. 85, p. 250-269.

Norton, D., and Knight, J., 1977, Transport phenomena in hydrothermal systems - Cooling plutons: American Journal of Science, v. 277, p. 937-981.

Notebaart, C.W., and Vink, B.W., 1972, Ore minerals of the Zambian Copperbelt: Geologie en Mijnbouw, v. 51, p. 337-345.

Nowak, G.J., Speczik, S., and Oszczepalski, S., 2001, Petrographic composition of organic matter in the Kupferschiefer horizon of Poland, in Piestrzyński, A., et al., eds., Mineral deposits at the beginning of the 21 st century, Proceedings of the joint sixth biennial SGA-SEG meeting, Kraków, Poland, 26-29 August 2001: Lisse, Belgium, A.A. Balkema Publishers, p. 67-70.

Nuccio, V.F., and Condon, S.M., 1996, Burial and thermal history of the Paradox Basin, Utah and Colorado, and petroleum potential of the Middle Pennsylvanian Paradox Formation: U.S. Geological Survey Bulletin 2000-O, p. O1-O41.

Ohr, M., 1993, Geochronology of diagenesis and low-grade metamorphism in pelites: Ann Arbor, Mich., University of Michigan, Ph.D. dissertation, 147 p.

Oosterbosch, R., 1951, Copper mineralization in the Fungurume region, Katanga: Economic Geology, v. 46, p. 121-148.

Oszczepalski, S., 1989, Kuperschiefer in southwestern Poland-Sedimentary environments, metal zoning, and ore controls, in Boyle, R.W., Brown, A.C., Jefferson, C.W., Jowett, E.C., and Kirkham, R.V., Sediment-hosted stratiform copper deposits: Geological Association of Canada, Special Paper 36, p. 571-600.

Oszczepalski, S., 1999, Origin of the Kupferschiefer polymetallic mineralization in Poland: Mineralium Deposita, v. 34, p. 599-613. 
Oszczepalski, S., Nowak, G.J., Bechtel, A., and Zák, K., 2002, Evidence of oxidation of the Kupferschiefer in the LubinSieroszowice deposit, Poland-Implications for $\mathrm{Cu}-\mathrm{Ag}$ and Au-Pt-Pd mineralization: Polish Geological Institute Geological Quarterly, v. 46, p. 1-23.

Oszczepalski, S., and Rydzewski, A., 1997, Metallogenic atlas of the Zechstein copper-bearing series in Poland: Warsaw, Państwowy Instytut Geologiczny (Polish Geological Institute), $32 \mathrm{p}$ pamphlet and 16 oversized plates.

Oszczepalski, Sławomir, and Speczik, Stanisław, 2011, Rudy miedzi i srebra [copper and silver ore], in Wołkowicza, Stanisława, Smakowskiego, Tadeusza, and Speczika, Stanisława, eds., Bilans perspektywicznych zasobów kopalin Polski wg stanu na 31 XII 2009 r. [Balance of Polish prospective minerals resources as of 31 December 2009]: Warsaw, Ministry of Environment, Polish Geological Institute, p. 76-93, accessed September 5, 2011, at http://www.pgi. gov.pl/pl/component/docman/doc_download/218-bilanszasobow-perspektywicznych-2010.

Pašava, J., Vymazalová, A., Mao, J., Du, A., Qu, W., and Korzekwa, W., 2007a, Re-Os study of noble metal-rich black shales from the Polish Kupferschiefer [extended abs.], in Andrew, C.J., ed., Digging deeper. Proceedings of the 9th Biennial SGA Meeting, Dublin, Ireland: Irish Association for Economic Geology, p. 221-224.

Pašava, J., Vymazalová, A., Qu, W., and Korzekwa, W., 2007b, Re-Os study of the Polish Kupferschiefer: implications for source and timing of metal enrichment [abs.]: Geochimica Cosmochimica Acta, v. 71, Issue 15, Supplement 1, p. A763.

Paschke, A., Freyer, K., Treutler, H.-C., Wennrich, R., Popp, P., Möder, M., Weiss, H., and Schüürmann, G., 2001, Assessment of Theisenschlamm leaching behavior, in Daus, B., and Weiss, H., eds., Fine-grained residues from copper smelting and their environmental impacts, v. 22, UFZBericht, p. 71-81.

Pätzold, T., Brauns, C.M., and Haack, U., 2002, A Re-Os study bearing on the age of Kupferschiefer mineralization at Mansfeld (Germany) [abs.]: Abstract to the symposium "Highly siderophile elements in terrestrial and meteoritic samples: implications for planetary differentiation and igneous processes," Nancy, France, August 26-28, 2002.

Payne, W.D., 1971, The role of sulphides and other heavy minerals in copper-anomalous stream sediments: Stanford, Calif., Stanford University, Ph.D. Dissertation, 119 p.

Person, Mark, and Garven, Grant, 1994, A sensitivity study of the driving forces on fluid flow during continental-rift basin evolution: Geological Society of America Bulletin, v. 106, p. $461-475$.
Peryt, T.M., 1989, Basal Zechstein in southwestern PolandSedimentation, diagenesis, and gas accumulations, in Boyle, R.W., Brown, A.C., Jefferson, C.W., Jowett, E.C., and Kirkham, R.V., Sediment-hosted stratiform copper deposits: Geological Association of Canada, Special Paper 36, p. 601-625.

Peters, S.G., Ludington, S.D., Orris, G.J., Sutphin, D.M., Bliss, J.D., Rytuba, J.J., and the U.S. Geological SurveyAfghanistan Ministry of Mines Joint Mineral Resource Assessment Team, 2007, Preliminary non-fuel mineral resource assessment of Afghanistan: U.S. Geological Survey Open-File Report 2007-1214, 810 p.

Pettersson, U.T., and Ingri, J., 2001, The geochemistry of Co and $\mathrm{Cu}$ in the Kafue River as it drains the Copperbelt mining area, Zambia: Chemical Geology, v. 177, p. 399-414.

Pettersson, U.T., Ingri, J., and Andersson, P.S., 2000, Hydrogeochemical processes in the Kafue River upstream from the Copperbelt mining area, Zambia: Aquatic Geochemistry, v. 6, p. $385-411$.

Phillips, J.S., 1960, Sandstone-type copper deposits of the western United States: Cambridge, Mass., Harvard University, Ph.D. dissertation, 320 p.

Pieczonka, J., Piestrzyński, A., and Sawłowicz, 2001, Coppersilver deposits in the Lubin-Głogow district (Poland), in Sawłowicz, Z., ed., Geological excursion guide, Mineral deposits at the beginning of the 21 st century, the Joint 6th Biennial SGS-SEG Meeting, August 26-29, 2001, Krakow, Poland: Krakow, Wydawnictwo Naukowe „Akapit”, p. 5-50.

Piestrzyński, A., and Pieczonka, J., 1997, Gold and PGE on an oxide-reducing interface in Lower Zechstein sediments of the Fore-Sudetic Monocline, SW Poland, in Papunen, H., ed., Mineral deposits: research and exploration - where do they meet?: Rotterdam, Balkema, p. 99-102.

Piestrzyński, A., Pieczonka, J., and Gluszek, A., 2002, Redbed-type gold mineralization, Kupferschiefer, south-west Poland: Mineralium Deposita, v. 37, p. 512-528.

Pilc, L., Rosada, J., and Siepak, J., 1999, The influence of dust emission from the "Glogow" copper foundry on heavy metal concentrations in agrocoenoses: Polish Journal of Environmental Studies, v. 8, no. 2, 107-110.

Pirmolin, J., 1970, Inclusions fluids dans la dolomite du gisement stratiforme de Kamoto (Katanga Occidental): Annales de la Société Géologique de Belgique, T. 93, p. 397-406 (In French). 
Plazas, C., and Falchetti, A.M., 1986, Patrones culturales en la Orfebrería Prehispaánica de Colombia, in Plazas, C., ed., Metalurgia de América Precolombina: Bogota, Banco de la República, p. 201-246 (In Spanish).

Plumlee, G.S., Goldhaber, M.B., and Rowan, E.L., 1995, The potential role of magmatic gases in the genesis of Illinois-Kentucky fluorspar deposits-Implications from chemical reaction path modeling: Economic Geology, v. 90, p. 999-1011.

Plumlee, G.S., Leach, D.L., Hofstra, A.H., Landis, G.P., Rowan, E.L., and Viets, J.G., 1994, Chemical reaction path modeling of ore deposition in Mississippi Valley-type $\mathrm{Pb}-\mathrm{Zn}$ deposits of the Ozark Region, U.S. Midcontinent: Economic Geology, v. 89, p. 1361-1383.

Posnjak, E., and Merwin, H.E., 1919, The hydrated ferric oxides: American Journal of Science, v. 47, p. 311-348.

Pratt, L.M., Summons, R.E., and Hieshima, G.B., 1991, Sterane and triterpane biomarkers in the Precambrian Nonesuch Formation, North American Midcontinent Rift: Geochimica Cosmochimica Acta, v. 55, p. 911-916.

Price, J.B., Hitzman, M.W., Nelson, E.P., and Humphrey, J., 2004, Copper mineralization at Kennecott, Alaska-A fluid mixing event controlled by high-angle structures [abs.]: Geological Society of America Abstracts with Programs, v. 36, p. 516.

Proctor, P.D., 1953, Geology of the Silver Reef (Harrisburg) mining district, Washington County, Utah: Utah Geological and Mineralogical Survey Bulletin 44, 169 p.

Pryor, W.A., 1971, Petrology of the Weissliegendes sandstone in the Harz and Werra-Fulda areas, Germany: Geologische Rundschau, Bd. 60 , p. 524-552.

Püttmann, W., Hagermann, H.W., Merz, C., and Speczik, S., 1987, Influence of organic material on mineralization processes in the Permian Kupferschiefer Formation, Poland: Organic Geochemistry, v. 13, p. 257-363.

Püttmann, W., Merz, C., and Speczik, S., 1989, The secondary oxidation of organic material and its influence on Kupferschiefer mineralization of Southwest Poland: Applied Geochemistry, v. 4, p. 151-161.

Rabb'a, I., and Nawasreh, M., 2006, Copper-Natural Resources Authority, Hashemite Kingdom of Jordan: 21 p., accessed March 12, 2010, at http://www.nra.gov.jo/images/ stories/pdf_files/Copper.pdf.

Radivojević, M., Rehren, T., Pernicka, E., Šljivar, D., Brauns, M., and Borić, D., 2010, On the origins of extractive metallurgy - New evidence from Europe: Journal of Archaeological Science, v. 37, p. 2775-2787.
Raffensperger, J.P., and Garven, G., 1995a, The formation of unconformity-type uranium ore deposits; 1 . Coupled groundwater flow and heat transport modeling: American Journal of Science, v. 295, p. 581-636.

Raffensperger, J.P., and Garven, G., 1995b, The formation of unconformity uranium ore deposits; 2 . Coupled hydrochemical modeling: American Journal of Science, v. 295, p. 639-696.

Rainaud, C., Master, S., Armstrong, R.A., Phillips, D., and Robb, L.J., 2005, Monazite U-Pb dating and ${ }^{40} \mathrm{Ar}-{ }^{39} \mathrm{Ar}$ thermochronology of metamorphic events in the Central African Copperbelt during the Pan-African Lufilian Orogeny: Journal of African Earth Sciences, v. 42, p. 183-199.

Reilly, C., 1967, Accumulation of copper by some Zambian plants: Nature, v. 215, no. 5101, p. 667-668.

Reilly, C., and Stone, J., 1971, Copper tolerance in Becium homblei; Nature, v. 230, no. 5293, p. 403.

Renfro, A.R., 1974, Genesis of evaporate associated stratiform metalliferous deposits-A sabkha process: Economic Geology, v. 69 , p. 33-45.

Rentzsch, J., 1974, The "Kupferschiefer" in comparison with the deposits of the Zambian Copperbelt, in Bartholomé, P., ed., Gisements stratiformes et provinces cuprifères: Société Géologique de Belgique, Liège, Belgium, p. 403-426.

Rentzsch, J., and Knitzschke, G., 1968, Die Erzmineralparagenesen des Kupferschiefers und ihre regionale Verbreitung: Freiberg. Forschungsh, C/231, p. 189-211 (In German).

Reynolds, R.L., and Goldhaber, M.B., 1978, Origin of a South Texas roll-type uranium deposit: 1. Alteration of iron-titanium oxide minerals: Economic Geology, v. 73, p. 1677-1689.

Richard, L.M., 1915, Copper deposits in the "red beds" of Texas: Economic Geology, v. 10, p. 634-650.

Richards, J.P., Cumming, G.L., Krstic, D., Wagner, P.A., and Spooner, E.T.C., 1988a, $\mathrm{Pb}$ isotope constraints on the age of sulfide ore deposition and $\mathrm{U}-\mathrm{Pb}$ age of late uraninite veining at the Musoshi stratiform copper deposit, Central African Copper Belt, Zaire: Economic Geology, v. 83, p. 724-743.

Richards, J.P., Krogh, T.E., and Spooner, E.T.C., 1988b, Fluid inclusion characteristics and $\mathrm{U}-\mathrm{Pb}$ rutile age of late hydrothermal alteration and veining at the Musoshi stratiform copper deposit, Central African Copper Belt, Zaire: Economic Geology, v. 83, p. 118-139.

Ridge, J.D., 1976, Shinkolobwe (Kasolo), in Annotated bibliographies of mineral deposits in Africa, Asia (exclusive of the USSR) and Australasia: New York, Pergamon Press, p. $184-189$. 
Ridgley, Jennie 1990, Genetic lithofacies in the Dakota Sandstone, a major oil- and gas-producing formation, northern San Jan Basin, Colorado and New Mexico [abs.], in Carter, L.M.H., ed., USGS Research on Energy Resources-1990, Program and Abstracts, Sixth V.E. McKelvey Forum on Mineral and Energy Resources: U.S. Geological Survey Circular 1060, p. 67-68.

Riley, J.F., 1968, The cobaltiferous pyrite series: American Mineralogist, v. 53, p. 293-295.

Robertson, J.M., 1975, Geology and mineralogy of some copper sulfide deposits near Mount Bohemia, Keweenaw County, Michigan: Economic Geology, v. 70, p. 1202-1224.

Roedder, E., 1984, Fluid inclusions: Reviews in Mineralogy, v. 12,644 p.

Rose, A.W., 1976, The effect of cuprous chloride complexes in the origin of red bed copper and related deposits: Economic Geology, v. 71, p. 1036-1048.

Roseboom, E.H., Jr., 1962, Djurleite, $\mathrm{Cu}_{1.96}$ S, a new mineral: American Mineralogist, v. 47, p. 1181-1184.

Roseboom, E.H., Jr., 1966, An investigation of the system $\mathrm{Cu}-\mathrm{S}$ and some natural copper sulfides between $25^{\circ}$ and $700{ }^{\circ} \mathrm{C}$ : Economic Geology, v. 61, p. 641-672.

Rosenblum, S., 1956, Improved techniques for staining potash feldspars: American Mineralogist, v. 41, p. 662-664.

Roszyka, E., and Szerszen, L., 1988, Accumulation of heavy metals in arable layer of soils in the protection zones of copper smelters: Rocz. Glebozn. v. 39, p. 135-156.

Rothenberg, B., and Merkel, J., 1995, Late Neolithic copper smelting in the Arabah: Institute for Archaeometallurgical Studies Newsletter 19, p. 1-7.

Rowlands, N.J., 1974, The geology of some Adelaidean stratiform copper occurrences, in Bartholomé, P., ed., Gisements stratiformes et provinces cuprifères: Société Géologique de Belgique, Liège, Belgium, p. 419-427.

Ruelle, J.C.L., 1982, Depositional environments and genesis of stratiform copper deposits of the Redstone Copper Belt, Mackenzie Mountains, N.W.T., in Hutchinson, R.W., Spence, C.D., and Franklin, J.M., Precambrian sulphide deposits, HS. Robinson Memorial Volume: Geological Association of Canada, Special Paper 25, p. 701-737.

Rye, R.O., Whelan, J.F., Harrison, J.F., and Hayes, T.S., 1984, The origin of copper-silver mineralization in the Ravalli Group as indicated by preliminary stable isotope studies (abs.), in Hobbs, S.W., ed., The Belt: Montana Bureau of Mines and Geology Special Publication 90, p. 104-107.
Sanders, R.N., 1983, Mineral potential of the Al Mehdadah prospect (19/41D): Saudi Arabian Deputy Ministry for Mineral Resources Open-File Report DGMR-OF-03-27, 32 p.

Santos, R.V., de Alvarenga, C.J.S., Dardenne, M.A., Sial, A.N., and Ferreira, C., 2000, Carbon and oxygen isotope profiles across Meso-Neoproterozoic limestones from central Brazil: Bambui and Paranoá Groups: Precambrian Research, v. 104, p. 107-122.

Satpaeva, S.A., 1958, Genetic features of deposits of the type copper sandstone in connection with mineralogic composition of their ore: Proceedings of the Academy of Sciences, Institute of Geological Science, Kazakhstan SSR, Alma Ata, $243 \mathrm{p}$.

Sawlowicz, Z., 1989, On the origin of copper mineralization in the Kupferschiefer-A sulfur isotope study: Terra Nova, v. 1, p. 339-343.

Sawlowicz, Z., 1990, Primary copper sulphides from the Kupferschiefer, Poland: Mineralium Deposita, v. 25, p. 262-271.

Schmidt, F.P., 1987, Alteration zones around Kupferschiefertype base metal mineralization in West Germany: Mineralium Deposita, v. 22, p. 172-177.

Schneiderhöhn, H., 1923, Chalkographische untersuchung des Mansfeler Kupferschiefer: Neues Jahrb. Mineralogies Geologie Beil, v. 47, p. 1-38 (In German).

Schneiderhöhn, H., 1932, The geology of the copper belt, Northern Rhodesia: Mining Magazine, v. 46, p. 241-245.

Schoep, A., and Billiet, V., 1935, Contribution à l'étude du réseau de la julienite $\left[\mathrm{Na}_{2} \mathrm{Co}(\mathrm{CSN})_{4} 8 \mathrm{H}_{2} \mathrm{O}\right]$ : Zeitschrift fur Kristallographie, v. 91, p. 229-234 (In French).

Schreck, P., and Glaesser, W., 1998, Pollution of the environment by heavy metals from copper shale mining in Central Germany-Dispersion, transport and immobilization, in Peterson, K., ed., Prospective terrestrial environment and groundwater pollution research: European Science Foundation Conference, Göteborg, Sweden, 64-71.

Schreck, P., Schubert, M., Freyer, K., Treutler, H.-C., and Weiss, H., 2005, Multi-metal contaminated stream sediments in the Mansfeld mining district-Metal provenance and source detection: Geochemistry; Exploration, Environment, and Analysis, v. 5, p. 51-57.

Schubert, M., Morgenstern, P., and Wennrich, R., 2001, On the weathering behavior of Theisenschlamm, in Daus, B., and Weiss, H., eds., Fine-grained residues from copper smelting and their environmental impacts, v. 22, UFZ-Bericht, p. $37-45$. 
Schubert, M., Morgenstren, P., Wennrich, R.,, Freyer, K., and Weiss, H., 2003, The weathering behavior of heavy metals in ore processing residues (Mansfeld Region, Germany): Mine Water and the Environment, v. 22, p. 2-6.

Schwellnus, J. 1961, Bancroft, in Mendelsohn, F., ed., The geology of the Northern Rhodesian Copperbelt: London, Macdonald and Co., p. 214-234.

Scotese, C.R., and McKerrow, W.S., 1990, Revised world maps and introduction, in McKerrow, W.S., and Scotese, C.R., eds., Paleozoic palaeogeography and biogeography: Geological Society of London Memoir 12, p. 1-21.

Sears, J.W., and Price, R.A., 2003, Tightening the Siberian connection to western Laurentia: Geological Society of America Bulletin, v. 115, p. 943-953.

Selley, D., Broughton, D., Scott, R., Hitzman, M., Bull, S., Large, R., McGoldrick, P., Croaker, M., and Pollington, N., 2005, A new look at the geology of the Zambian Copperbelt, in Hedenquist, J.W., Thompson, J.F.H., Goldfarb, R.J., and Richards, J.P., eds., Economic Geology 100th Anniversary Volume, p. 965-1000.

Seyfullin, S.S., Kalinin, S.K., Strutinskiyi, A.V., and Fayn, E. Ye., 1974, Rhenium in stratified copper deposits and showings in west-central Kazakhstan: Geochemistry International, v. 11, no. 2, p. 414-418.

Shearman, D.J., and Fuller, J.G., 1969, Anhydrite diagenesis, calcitization, and organic laminites, Winnipegosis Formation, Middle Devonian, Saskatchewan: Bulletin of Canadian Petroleum Geology, v. 17, p. 496-525.

Shinn, E.A., 1983, Tidal flat, in Scholle, P.A., Bebout, D.G., and Moore, C.H., eds., Carbonate depositional environments: American Association of Petroleum Geologists' Memoir 33, p. 171-210.

Shockey, P.N., Renfro, A.R., and Peterson, R.J., 1974, Coppersilver solution fronts at Paoli, Oklahoma: Economic Geology, v. 69, p. 266-268.

Shoemaker, E.M., Miesch, A.T., Newman, W.L., and Riley, L.B., 1959, Part 3. Elemental composition of the sandstonetype deposits, in Garrels, R.M., and Larsen, E.S., III, comps., Geochemistry and mineralogy of the Colorado Plateau uranium ores: U.S. Geological Survey Professional Paper 320, p. 25-54.

Siedlecka, A., 1976, Silicified Precambrian evaporite nodules from northern Norway-A preliminary report: Sedimentary Geology, v. 16, p. 161-175.
Sillitoe, R.H., and Clark, A.H., 1969, Copper and copper-iron sulfides as the initial products of supergene oxidation, Copiapó mining district, northern Chile: American Mineralogist, v. 54 , p. $1684-1710$.

Singer, D.A., Berger, V.I., and Moring, B.C., 2008, Porphyry copper deposits of the world-Database and grade and tonnage models, 2008: U.S. Geological Survey Open-File Report 2008-1155, 43 p.

Singewald, J.T., Jr., and Berry, E.W., 1922, The geology of the Corocoro copper district of Bolivia: The Johns Hopkins University Studies in Geology, no. 1, 117 p.

Skirrow, R.G., Bastrakov, E., Davidson, G., Raymond, O.L., and Heithersay, P., 2002, The geological framework, distribution and controls of $\mathrm{Fe}$-oxide $\mathrm{Cu}$-Au mineralisation in the Gawler Craton, South Australia: Part II: Alteration and mineralization, in Porter, T.M., ed., Hydrothermal iron oxide copper-gold and related deposits: A global perspective, v. 2, Adelaide, PGC Publishing, p. 33-47.

Słowakiewicz, M., Kiersnowski, H., and Wagner, R., 2009, Correlation of the Upper Permian marine and terrestrial sedimentary sequences in Polish, German, and USA Western Interior Basins with reference to global time markers: Palaeoworld, v. 18, p. 193-211.

Smith, A.G., Hurley, A.M., and Briden, J.C., 1981, Phanerozoic paleocontinental world maps: London, Cambridge University Press, $102 \mathrm{p}$.

Smith, C.S., 1969, Analysis of the copper bead from Ali Kosh, in Hole, F., Flannery, K.V., and Neely, J.A., eds., Prehistory and human ecology of the Deh Luran Plain-An early village sequence from Khuzistan, Iran: Ann Arbor, Mich., University of Michigan, p. 427-428.

Smith, G.E., 1976, Sabkha and tidal-flat facies control of stratiform copper deposits in North Texas, in Johnson, K.S., and Croy, R.L., eds., Stratiform copper deposits of the Midcontinent region, a symposium: Oklahoma Geological Survey Circular 77, p. 25-39.

Soulé, J.H., 1956, Reconnaissance of the "red bed" copper deposits in southeastern Colorado and New Mexico: U.S. Bureau of Mines Information Circular 7740, 74 p.

Sracek, O., Milhaljevič, M., Kříbek, B., Majer, V., and Veselovský, F., 2010, Geochemistry and mineralogy of $\mathrm{Cu}$ and Co in mine tailings at the Copperbelt, Zambia: Journal of African Sciences, v. 57, p. 14-30.

Stephens, A.J., 2003, The Lonshi copper mine, Katanga Province, Democratic Republic of the Congo: NI 43-101 Technical Report, First Quantum Minerals, Ltd., 30 p., accessed May 29, 2009, at http://www.sedar.com. 
Steven, N., and Armstrong, R., 2003, A metamorphosed Proterozoic carbonaceous shale-hosted $\mathrm{Co}-\mathrm{Ni}-\mathrm{Cu}$ deposit at Kalumbila, Kabompo Dome-The Copperbelt Ore Shale in northwestern Zambia: Economic Geology, v. 98, p. 893-909.

Stoffell, B., Appold, M.S., Wilkinson, J.J., McClean, N.A., and Jeffries, T.E., 2008, Geochemistry and evolution of Mississippi Valley-type mineralizing brines from the Tri-State and Northern Arkansas districts determined by LA-ICP-MS microanalysis of fluid inclusions: Economic Geology, v. 103, p. 1411-1436.

Stoiber, R.E., and Davidson, E.S., 1959, Amygdule mineral zoning in the Portage Lake Lava Series, Michigan copper district: Economic Geology, v. 54, p. 1250-1277.

Strauch, G., Schreck, P., Nardin, G., and Gehre, M., 2001, Origin and distribution of sulfate in surface waters of the Mansfeld mining district (Central Germany) - A sulphur isotope study: Isotopes in Environmental and Health Studies, v. 37, p. 101-112.

Sun, Y., and Püttmann, W., 1997, Metal accumulation during and after deposition of the Kupferschiefer from the Sangerhausen Basin, Germany: Applied Geochemistry, v. 12, p. 577-592.

Sutton, S.J., and Maynard, J.B. 2005, A fluid mixing model for copper mineralization at Konkola North, Zambian Copperbelt: Journal of African Earth Sciences, v. 42, p. 95-118.

Sweeney, M.A., and Binda, P.L., 1989, The role of diagenesis in the formation of the Konkola $\mathrm{Cu}-\mathrm{Co}$ orebody of the Zambian Copperbelt, in Boyle, R.W., Brown, A.C., Jefferson, C.W., Jowett, E.C., and Kirkham, R.V., Sedimenthosted stratiform copper deposits: Geological Association of Canada, Special Paper 36, p. 499-518.

Swenson, J.B., Person, M., Raffensperger, J.P., Cannon, W.F., Woodruff, L.G., and Berndt, M.E., 2004, A hydrogeologic model of stratiform copper mineralization in the Midcontinent Rift System, Northern Michigan, USA: Geofluids, v. 4, p. 1-22.

Syakalima, M.S., Choongo, K.C., Chilonda, P., Ahmadu, B., Mwase, M., Onuma, M., Sugimoto, C., Tsubota, T., Fukushi, H., Yoshida, M., Itagaki, T., Yasuda, J., and Nakazato, Y., 2001, Bioaccumulation of lead in wildlife dependent on the contaminated environment of the Kafue Flats: Bulletin of Environmental Contamination and Toxicology, v. 67 , p. 438-445.

Syusyura, B., and Tyugay, O., 2008, Cupriferous sandstones of Kazakhstan: International Geological Congress Abstracts, v. 33 , no. 1342858 .
Talbott, L.W., 1974, Nacimiento pit, a Triassic strata-bound copper deposit, in Silver Anniversary Guidebook; Ghost ranch, Central-Northern New Mexico: New Mexico Geological Society Guidebook, v. 25, p. 163-183.

Tarr, W.A., 1910, Copper in the "red beds" of Oklahoma: Economic Geology, v. 5, p. 221-226.

Tarr, W.A., 1933, The origin of the sand barites of the Lower Permian of Oklahoma: American Mineralogist, v. 18, p. $260-272$.

Taylor, B.E., Turner, R.J.W., Leitch, C.H.B., Watanabe, D.H., and Lydon, J.W., 2000, Isotopic stratigraphy of carbonate in wall rocks and bedded ores, Sullivan $\mathrm{Pb}-\mathrm{Zn}$-Ag mine, British Columbia; Chapter 36, in Lydon, J.W., Höy, T., Slack, J.R., and Knapp, M.E., eds., The geological environment of the Sullivan deposit, British Columbia: Geological Association of Canada, Mineral Deposits Division, Special Publication No. 1, p. 673-695.

Temple, A.K., 1966, Alteration of ilmenite: Economic Geology, v. 61, p. 695-714.

Thaden, R.E., Trites, A.F., Jr., and Finnell, T.L., 1964, Geology and ore deposits of the White Canyon area, San Juan and Garfield Counties, Utah: U.S. Geological Survey Bulletin $1125,166 \mathrm{p}$.

Thiede, D.S., and Cameron, E.N., 1978, Concentration of heavy metals in the Elk Point evaporative sequence, Saskatchewan: Economic Geology, v. 73, p. 404-415.

Thode, H.G., and Monster, J., 1965, Sulfur isotope geochemistry of petroleum, evaporites, and ancient seas: American Association of Petroleum Geologists Memoir 4, p. 367-377.

Thode, H.G., and Monster, J., 1970, Sulfur isotope abundances and genetic relations of oil accumulations in the Middle East Basin: American Association of Petroleum Geologists Bulletin, v. 54, p. 627-637.

Thomas, C.A., Hagni, R.D., and Berendsen, P., 1991, Ore microscopy of the Paoli silver-copper deposit, Oklahoma: Ore Geology Reviews, v. 6, p. 229-244.

Thornton, C.P., 2009, The emergence of complex metallurgy on the Iranian Plateau-Escaping the Levantine paradigm: Journal of World Prehistory, v. 21, p. 301-327.

Thorson, J.P., ed., 2005, Lisbon Valley sediment-hosted copper deposits and Paradox Basin fluids field trip: Society of Economic Geologists' Guidebook Series, v. 37, 50 p.

Thorson, J.P., and MacIntyre, T.J., 2005, Geology of the Cashin mine sandstone-hosted disseminated copper deposit, Montrose County, Colorado: Society of Economic Geologists, Guidebook Series, v. 37, p. 43-50. 
Titley, S.R., 2007, Surface characteristics and expression of disseminated sulfide ores and related capping interpretations, in Titley, S.R., and Stegen, R.J., eds., Leached capping and enrichment of porphyry copper deposits of Arizona and New Mexico-A field trip guidebook, September 22-24, 2007 : Tucson, Ariz., Society of Economic Geologists, p. 1-46.

Titley, S.R., and Marozas, D.C., 1995, Processes and products of supergene copper enrichment, in Pierce, F.W., and Bolm, J.G., eds., Porphyry copper deposits of the American Cordillera: Arizona Geological Society Digest 20, p. 156-168.

Torrealday, H.I., Hitzman, M.W., Stein, H.J., Markley, R.J., Armstrong, R.A., and Broughton, D., 2000, Re-Os and $\mathrm{U}-\mathrm{Pb}$ dating of the vein-hosted mineralization at the Kansanshi copper deposit, northern Zambia: Economic Geology, v. 95, p. 1165-1170.

Touwaide, M.E., 1930, Origin of the Boléo copper deposit, Lower California, Mexico: Economic Geology, v. 25, p. 112-144.

Trites, A.F., Jr., and Chew, R.T., III, 1955, Geology of the Happy Jack mine, White Canyon area, San Juan County, Utah: U.S. Geological Survey Bulletin 1009-H, p. 235-248.

Tschanz, C.M., Laub, D.C., and Fuller, G.W., 1958, Copper and uranium deposits of the Coyote district, Mora County, New Mexico: U.S. Geological Survey Bulletin 1030-L, p. 343-398.

Turner, P., 1980, Continental red beds: New York, Elsevier, $562 \mathrm{p}$.

Tye, R.S., and Hickey, J.J., 2001, Permeability characterization of distributary mouth bar sandstones in Prudhoe Bay field, Alaska-How horizontal cores reduce risk in developing deltaic reservoirs: American Association of Petroleum Geologists Bulletin, v. 85, p. 459-475.

Ulmer-Scholle, D.S., Scholle, P.A., and Brady, P.V., 1993, Silicification of evaporites in Permian (Guadalupian) back-reef carbonates of the Delaware Basin, West Texas and New Mexico: Journal of Sedimentary Petrology, v. 63, p. $955-965$.

Ulmishek, G., 1986, Stratigraphic aspects of petroleum resource assessment, in Rice, D.D., ed., Oil and gas assessment-Methods and applications: American Association of Petroleum Geologists Studies in Geology \#21, p. 59-68.

U.S. Environmental Protection Agency, 1994, Extraction and beneficiation of ores and minerals - Copper: EPA-530-R-94-031.

U.S. Environmental Protection Agency, 2006, National recommended water quality criteria: accessed November 16, 2009 at http://www.epa.gov/waterscience/criteria/nrwqc-2006.pdf.
U.S. Forest Service, Montana Department of State Lands, Montana Department of Health and Environmental Sciences, and Montana Department of Natural Resources, 1992, Noranda Minerals Corp.-Montana Reserves Company Joint Venture, Montanore project: Final Environmental Impact Statement, v. 1, 625 p.

U.S. Forest Service, Kootenai National Forest, Montana Department of Environmental Quality, 2009, The Montanore Project Draft Environmental Impact Statement: 1383 p. accessed April 8, 2010 at http://deq.mt.gov/eis/ Montanore/DraftEIS/MontanoreProjectDraftEISopt75.pdf.

Van Der Heever, D., Arengi, J., and van Rensburg, J., 2009, Technical report, Ghanzi copper-silver project, Ghanzi district, Botswana: Report prepared by GeoLogix Mineral Resource Consultants (Pty.) Ltd., for Hana Mining Ltd., 86 p., available at http://www.sedar.com.

van Eden, J.G., 1974, Depositional and diagenetic environment related to sulfide mineralization, Mufulira, Zambia: Economic Geology, v. 69, p. 59-79.

Vanko, D., Bonnin-Mosbah, M., Philipott, P., Roedder, E., and Sutton, S.R., 2001, Fluid inclusions in quartz from oceanic hydrothermal specimens and Bingham Canyon, Utah, porphyry-Cu deposit; a study with PIXE and SXRF: Chemical Geology, v. 173, p. 227-238.

Viets, J.G., Hofstra, A.H., and Emsbo, P., 1996, Solute compositions of fluid inclusions in sphalerite from North American and European Mississippi Valley-type ore deposits-Ore fluids derived from evaporated seawater: Society of Economic Geologists Special Publication No. 4, p. 465-482.

Volodin, R.N., Chechetkin, V.S., Bogdanov, Yu.V., Narkelyun, L.F., and Trubachev, A.I., 1994, The Udokan cupriferous sandstones deposit (Eastern Siberia): Geology of Ore Deposits, v. 36, no. 1, p. 1-25.

von der Heyden, C.J., and New, M.G., 2003, Natural wetland for mine effluent remediation? The case of the Copperbelt, in Bernard, T., Mosepele, K., and Ramberg, L., eds., Environmental Monitoring of Tropical and Subtropical wetlands. Harry Oppenheimer Okavango Research Center of the University of Botswana and H.T. Odum Center for Wetlands of the University of Florida, Maun, Botswana, p. 444-457.

von der Heyden, C.J., and New, M.G., 2004a, Groundwater pollution on the Zambian Copperbelt-Deciphering the source and the risk: Science of the Total Environment, v. 327 , p. $17-30$.

von der Heyden, C.J., and New, M.G., 2004b, Sediment chemistry - A history of mine contaminant remediation and an assessment of processes and pollution potential: Journal of Geochemical Exploration, v. 82, p. 35-57. 
von der Heyden, C.J., and New, M.G., 2005, Differentiating dilution and retention processes in mine effluence remediation within a natural wetland on the Zambian Coppperbelt: Applied Geochemistry, v. 20, p. 1241-1257.

Walker, T.R., 1989, Application of diagenetic alterations in redbeds to the origin of copper in stratiform copper deposits, in Boyle, R.W., Brown, A.C., Jefferson, C.W., Jowett, E.C., and Kirkham, R.V., Sediment-hosted stratiform copper deposits: Geological Association of Canada, Special Paper 36, p. 85-96.

Walker, T.R., Ribbe, P.H., and Honea, R.M., 1967, Geochemistry of hornblende alteration in Pliocene red beds Baja California, Mexico: Geological Society of America Bulletin, v. 78 , p. $1055-1060$.

Wallier, S., Rey, R., Kouzmanov, K., Pettke, T., Heinrich, C.A., Leary, S., O'Connor, G., Tămaş, C., Vennemann, T., and Ullrich, T., 2006, Magmatic fluids in the breccia-hosted epithermal Au-Ag deposit of Roşia Montană, Romania: Economic Geology v. 101, p. 923-954.

Waples, D.W., 1980, Time and temperature in petroleum formation-Application of Lopatin's method to petroleum exploration: American Association of Petroleum Geologists Bulletin, v. 64, p. 916-926.

Warren, J.K., 2000, Evaporites, brines and base metalsLow-temperature ore emplacement controlled by evaporite diagenesis: Australian Journal of Earth Sciences, v. 47, p. 179-208.

Waterman, G.C., and Hamilton, R.L., 1975, The Sar Cheshmeh porphyry copper deposit: Economic Geology, v. 70, p. 568-576.

Wedepohl, K.H., 1964, Untersuchungen am Kupferschiefer in Nordwestdeutschland; Ein Beitrag zur Deutung der Genese bituminöser sedimente: Geochimica et Cosmochimica Acta, v. 28, p. 305-364 (In German).

Wedepohl, K.H., Delevaux, M.H., and Doe, B.R., 1978, The potential source of lead in the Permian Kupferschiefer bed of Europe and some selected Paleozoic mineral deposits in the Federal Republic of Germany: Contributions to Mineralogy and Petrology, v. 65, p. 273-281.

Weeks, A.D., Coleman, R.G., and Thompson, M.E., 1959, Part 5. Summary of the ore mineralogy, in Garrels, R.M., and Larsen, 3d., E.S., comps., Geochemistry and mineralogy of the Colorado Plateau uranium ores: U.S. Geological Survey Professional Paper 320, p. 65-79.
Weisgerber, G., 2006, The mineral wealth of ancient Arabia and its use I-Copper mining and smelting at Feinan and Timna - Comparison and evaluation of techniques, production, and strategies: Arabian Archaeology and Epigraphy, v. 17 , p. $1-30$.

Weiss, H., Morency, M., Freyer, K., Bourne, J., Fontaine, D., Ghaleb, B.1, Mineau, R., Möder, M., Morgenstern, P., Popp, P., Preda, M., Treutler, H-C., and Wennrich, R., 1997, Physical and chemical characterization of a complexly contaminated scrubber dust - a by-product of copper smelting in Sachen-Anhalt, Germany: Science of the Total Environment, v. 203, p. 65-78.

Wells, J.D., Domenico, J.A., Frisken, J.G., and Hopkins, R.T., 1981, Geochemical survey of the Cabinet Mountains wilderness, Lincoln and Sanders Counties, Montana, in U.S. Geological Survey and U.S. Bureau of Mines, mineral resources of the Cabinet Mountains wilderness, Lincoln and Sanders Counties, Montana: U.S. Geological Survey Bulletin 1501, p. 25-51.

Wennrich, R., Morgenstern, P., Moder, M., Popp, P., Paschke, A., and Vrana, B., 2001, Chemical characterization of Theisenschlamm, in Daus, B., and Weiss, H., eds., Finegrained residues from copper smelting and their environmental impacts: UFZ-Bericht, v. 22, p. 17-24.

White, D.E., 1965, Saline waters of sedimentary rocks, in Young, A., and Galley, J.E., eds., Fluids in subsurface environments-A symposium: American Association of Petroleum Geologists' Memoir 4, p. 342-366.

White, W.S., 1968, The native copper deposits of northern Michigan, in Ridge, J.D., ed., Ore deposits of the United States, 1933-1967, the Graton-Sales Volume: New York, American Institute of Mining, Metallurgical, and Petroleum Engineers, p. 303-325.

White, W.S., 1971, A paleohydrologic model for mineralization of the White Pine copper deposit, northern Michigan: Economic Geology, v. 66, p. 1-13.

White, W.S., and Wright, J.C., 1966, Sulfide-mineral zoning in the basal Nonesuch Shale, northern Michigan: Economic Geology, v. 61, p. 1171-1190.

Williams, T., Schultz-Stoker, J., and Duvall, E., 2002, Tailings stabilisation at White Pine: Mining Environmental Management, v. 10 , no. 3, p. 6-12.

Wilson, I.F., in collaboration with Rocha, V.S., 1955, Geology and mineral deposits of the Boleo copper district, Baja California, Mexico: U.S. Geological Survey Professional Paper 273, $134 \mathrm{p}$.

Wilson, J.T., 1966, Did the Atlantic close and then re-open?: Nature, v. 211, p. 676-681. 
Wilson, M.D., and Pittman, E.D., 1977, Authigenic clays in sandstones - Recognition and influence on reservoir properties and paleoenvironmental analysis: Journal of Sedimentary Petrology, v. 47, p 3-31.

Wilson, N.S.F., and Zentilli, M., 1999, The role of organic matter in the genesis of the El Soldado volcanic hosted manto-type $\mathrm{Cu}$ deposit, Chile: Economic Geology, v. 94, p. 1115-1136.

Wilson, N.S.F., Zentilli, M., and Spiro, B., 2003, A sulfur, carbon, oxygen, and strontium isotope study of the volcanichosted El Soldado manto-type copper deposit, Chile-The essential role of bacteria and petroleum: Economic Geology, v. 98 , p. 163-174.

Wilton, D.H.C., and Sinclair, A.J., 1988, Ore petrology and genesis of a strata-bound disseminated copper deposit at Sustut, British Columbia: Economic Geology, v. 81, p. $30-45$.

Winfield, O., 1961, Chibuluma, in Mendelsohn, F., ed., The geology of the Northern Rhodesian Copperbelt: London, Macdonald and Co., p. 328-342.

Witzke, T., and Pöllmann, H., 1996, Mineralneubildungen in den Schlacken der Kupferschieferverhüttung des Mansfelder Reviers, Sachsen-Anhalt: Hallesches Jahrbuch für Geowissenschaften, v. B18, p. 109-118 (In German).

Woodward, L.A., Kaufman, W.H., Schumacher, O.L., and Talbott, L.W., 1974, Strata-bound copper deposits in Triassic sandstone of Sierra Nacimiento, New Mexico: Economic Geology, v. 69, p. 108-120.
World Health Organization (WHO), 2006, Guidelines for drinking-water quality ( $3 \mathrm{~d}$ ed.): Geneva, Switzerland, World Health Organization Press, accessed November 16, 2009 at http://www.who.int/water_sanitation_health/dwq/gdwq3rev/ en/index.html.

Yalçin, Ü., 2000, Anfänge der metallverwendung in Anatolien, in Yalçin, Ü., ed, Anatolian Metal I: Bochum, FDR, Deutsches, Bergbau-Museum, p. 75-82 (In German).

Yeo, W.Ja., Wyche, J., Holmes, M., Norton, E., Hunter, D., Ross, T., Britton, S., and Bosworth, G., 2007, El Boleo project feasibility study, summary report, Baja California South, Mexico: Report prepared by Baja Mining Corporation for Minera Y Metalurgica del Boleo, S.A. de C.V., 211 p., accessed April 9, 2009, at http://www.sedar.com.

Yigit, O., 2009, Mineral deposits of Turkey in relation to Tethyan metallogeny-Implications for future mineral exploration: Economic Geology, v. 104, p. 19-51.

Young, H.R., 1979, Evidence of former evaporites in the Cambro-Ordovician Durness Group, Northwest Scotland: Sedimentary Geology, v. 22, p. 287-303.

Yund, R.A., and Kullerud, Gunnar, 1966, Thermal stability of assemblages in the $\mathrm{Cu}-\mathrm{Fe}-\mathrm{S}$ system: Journal of Petrology, v. 7, part 3, p. 454-488.

Zhang, Q., Zhu, X., and Zhang, Z., 2006, Lead isotopic composition and lead source of the Tonchanghe basalt-type native copper-chalcocite deposit in Niglang, western Yunnan, China: Chinese Journal of Geochemistry, v. 25, p. 112-121.

Zielinski, R.A., Bloch, S., and Walker, T.R., 1983, The mobility and distribution of heavy metals during the formation of first cycle red beds: Economic Geology, v. 78, p. 1574-1589. 


\section{Appendix 1. Summary of Representative Sediment-Hosted Stratabound Copper Deposits}

A. Name: Lubin-Sieroszowice-Polkowice-Rudna(-Glogow

Giboki-Przemyslowy-Bytom Odrzanski-RetkowGaworzyse-Radnawice Zachody), Poland

Deposit subtype: Reduced-facies

Location: $51^{\circ} 24^{\prime} \mathrm{N} 16^{\circ} 08^{\prime} \mathrm{E}$

Grade/tonnage: Oszczepalski and Speczik, 2011: 3612.499 Mt, 1.99 percent $\mathrm{Cu}, 57.5 \mathrm{~g} / \mathrm{t} \mathrm{Ag}$

Associated deposits: Cut by sparse Rücken veins

Regional geologic setting: Southern flank of the Zechstein Basin

Regional tectonic setting: Extensional tectonic regime in homoclinally northeastward dipping sedimentary rock on the northeast flank of the Fore-Sudetic block, a northwesttrending horst with its highest parts composed of Variscan (Carboniferous and Early Permian) metamorphic rocks subcropping below Tertiary and Quaternary cover. Age of the Fore-Sudetic block is Tertiary, pre-Pliocene in age but may mark the position of a pre-Middle Permian basement high from pre-Kupferschiefer, Lower Rotliegendes time. However, the Fore-Sudetic block was not a topographic high in evidence at all at the time of Kupferschiefer deposition - Kupferschiefer lithofacies boundaries cross it trending east-west without perturbation.

\section{Significant structural control (Y/N): N}

Primary host rocks and their ages: In ascending order: Late Permian (Guadalupian) Weissliegendes light gray to white sandstones (well-sorted, well-rounded, fine to coarse), Kupferschiefer dark gray to black shale and mudstone, and Zechstein I (Werra) Carbonates (predominantly gray lime wackestones) beds.

Associated red beds: Subjacent Upper Rotliegendes Formation, 100-450 m thick beneath ore; as much as $650 \mathrm{~m}$ thick in Fore-Sudetic basin to the northeast though locally pinching out over basement highs: conglomerates less than sandstones greater than lacustrine mudstones; in areas tens of kilometers to the north and southwest, Lower Rotliegendes includes subaerial rhyolite greater than andesite greater than basalt.

Associated evaporites: In mining area, Zechstein I anhydrite 100-200 m thick overlies Werra carbonates; Zechstein II, III, and IV evaporites overlie that in cycles, totaling 50-100 m, including minor halite; in the Polish basin $200 \mathrm{~km}$ to the northeast, these evaporites total more than $5 \mathrm{~km}$ and are affected by halokinesis. Hundreds of kilometers to the northwest or north in northern Germany and Poland, Upper Rotliegendes beds downsectionward from barren Kupferschiefer are up to $1 \mathrm{~km}$ thick and also contain halite.
Age of mineralization: Uncertain. Depositional age of the Kupferschiefer bed is 258 to $260.4 \mathrm{Ma}$. Paleomagnetism of Rote Fäule alteration gives 255 to $245 \mathrm{Ma}$ (latest Permian and earliest Triassic; late Zechstein to early Bunter time, a time of renewed continental rifting) (Jowett and others, 1987, as modified by Nawrocki, 2000). K-Ar on authigenic illite in Kf shale yields 216 to $190 \mathrm{Ma}$ (Late Triassic to Early Jurassic; later Keuper to Poidonia Shale time - coincides with the Central Atlantic Magmatic Province flood basalts, Brazil, Morocco, Newark basin; mantle plume)(Bechtel and others, 1999). K-Ar on authigenic illite in mineralized Weissliegendes sandstone gives 188-159 Ma (Early Jurassic through Middle Jurassic) (Michalik, 1997). U-Pb on thucolite (black, shiny, urnao-organic compound in Kf shale gives 175-180 Ma (early Middle Jurassic) (Kucha and Przybyłowicz, 1999). Re-Os gives $240 \pm 3.8 \mathrm{Ma}$ from whole-rock samples of Cu-rich mineralization from Lubin mine (Early Triassic, age of the Bunter Sandstone that was deposited in renewed continental rifting events) (Pašava and others, 2007b). Pašava and others (2007a) reported an "altered" age of $279 \pm 14 \mathrm{Ma}$ from the Au-Pt-Pd rich zone within Rote Fäule rocks of the Polkowice mine (probably comparable with the "J lead" of Mississippi Valley-type deposits. Probably indicates an epigenetic addition of platinoid metals with old radiogenic ${ }^{187} \mathrm{Re}$, coming from rocks older than the Kupferschiefer itself).

Hypogene ore characteristics and mineral/metal zoning: Mineral-zone boundaries cross gently downsectionward from southwest to northeast, crossing through the entire host sequence. From inboard (west-southwest) to outboard (east-northeast), the zones are (1) Rote Fäule (hematite); (2) Rote Fäule with native gold, native platinum, native palladium, and minor covellite; (3) chalcocite; (4) bornite; (5) chalcopyrite; (6) galena; (7) sphalerite; and (8) pyrite. Coincidence of chalcocite and bornite zones with the host sequence (above) defines an orebody that is $2-10 \mathrm{~m}$ thick more than $15 \mathrm{~km}$ northeast-southwest $\times 28 \mathrm{~km}$ northwestsoutheast (and continuing northward beyond at depths greater than $1,300 \mathrm{~m}$ ). Thus, overall, a thin, nearly continuous sheet geometry. Ag in solid solution in chalcocite, digenite, and bornite with minor native silver and stromeyerite. At the scale of the whole deposit, grades are highest in chalcocite zone (all lithologies) and in Kupferschiefer shale bed (mean value of approximately 8.5 percent $\mathrm{Cu}$ ), but that bed is typically just $30-50 \mathrm{~cm}$ thick. About half of all sulfides are in Weissliegendes sandstones averaging about 1.5 percent $\mathrm{Cu}$. Werra carbonate ore has mean values of about 1.3 percent $\mathrm{Cu}$. 
Hypogene gangue characteristics and alteration: Gangue zonation, other than hematite, is poorly documented. However, alteration to hematitic Rote Fäule is accompanied by dolomitization of the Kupferschiefer bed, which is silicic (as contrasted with argillitic) and calcareous in chalcocite zone, calcareous and marly in outboard zones in Poland. However, Rentzsch (1974, p. 411) shows, instead, dolomitic rocks in $\mathrm{Pb}, \mathrm{Zn}$, and pyrite zones and calcite alteration accompanying Rote Fäule alteration (opposite what the first author sampled in Poland), assumedly from Spremburg-Graustein deposit. Elemental analyses show $\mathrm{K}$ metasomatism in chalcocite zone, mineral residence unknown.

Geochemical characteristics: In Kupferscheifer shale, the following are anomalous and probably enriched in ore processes: As (182 ppm, in trace tennantite, enargite), Co (69 ppm, in linnaeite, pyrite), $\mathrm{Hg}$ (3-61 ppm, in native metal alloys and chalcocite), $\mathrm{Ni}$ (90-125 ppm, in bravoite, millerite), Sb (15 ppm, in tennantite), and U (39-62 ppm, in organic fraction). Anomalous in Kupferschiefer shale but probably attributable to its euxinic depositional environment: Mo (158 ppm, in castaingite and organic fraction), Se (24 ppm, in clausthalite and organic fraction), and V (182 ppm, in organic fraction). As above, chalcocite zone appears to be K-metasomatized.

Petrology: Michalik (2001) is the best. Many others are narrowly focused on sulfides. None have addressed Rotliegendes footwall red-bed petrology, particularly not to look for metals pathways signatures. Good organic petrology (Nowak and others, 2001) documents that liptinite group macerals (most typically, alginate, but also sporinite and liptodetrinite) in the unmineralized Kupferschiefer are altered to more and more solid bitumen and amorphous unstructured organic matter across the mineralized zone and into the Rote Fäule. Vitrinite reflectance typically increases from around 0.72 percent to around 1.13 percent in the same direction, suggesting $130^{\circ} \mathrm{C}$ as the maximum temperature reached in the Rote Fäule, thus probably $150^{\circ} \mathrm{C}$ and greater for most $\mathrm{Cu}$ transport.

Style(s) of mineralization: (1) Disseminated within Weissliegendes, Kupferschiefer, and Werra carbonate, (2) lenses flattened within bedding during compaction, within Kupferschiefer, (3) replacements of pyrite framboids and stepwise in the sequence, pyrite, chalcopyrite, bornite, chalcocite, hematite, (4) bedding plane and high-angle veinlets of $\mathrm{Cu}$ sulfides \pm calcite, (5) special textures (for example, rhythmic layers of dense dissemination in Weissleigendes), mineralized pillars, (6) sparse Rücken veins of Co-Ni arsenides, crosscutting disseminated ore, in faults

Post-ore deformation: Sparse extensional fracturing and veins

Other notable features: Lubin-Sieroszowice is the largest single SSC deposit known in the world. It has been frequently studied. It is, nonetheless, an excellent choice among deposits for new work because it is totally unmetamorphosed. Work has focused on the deposit itself. Still needed are (1) fluid-inclusion microthermometry work, best done in Weissliegendes sandstone ore authigenic phases (overgrowth quartz and coarse carbonate cements, or in sulfides using IR illumination) (this should allow recognition of appropriate inclusions to study in source and pathway rocks for metals-transporting solutions),

(2) fluid-inclusion compositions via PIXE or LA-ICPMS if possible, by thermal decrepitation of an authigenic fraction followed by leach and ion chromatography if micro methods are not possible, to define the mixing that probably went on within Weissliegendes ore and to extrapolate compositions to a metals-transporting solution composition, (3) mineralogy, geochemistry, and mapping in the Rotliegendes footwall rocks and possibly basement rocks to the Rotliegendes to stratigraphic depths as great as possible with the purpose to determine alteration pathways to the deposit, then to determine transport conditions by fluid-inclusion microthermometry and fluid compositions via PIXE, LA-ICPMS, or decrepitate-andleach within the pathway rocks to define origin of the mineralizing brines. (4) reliable isotope age dating of the mineralizing event(s). K-Ar or Ar-Ar on illite has provided results that lack certainty; it is unclear that the illites date the mineralizing event(s). They may be dating other events in the basin. Re-Os on consistently treated sulfides may succeed — avoid pyrite-containing rock. Try Rb-Sr on sphalerite. Look for xenotime overgrowths on detrital zircon or authigenic monazite in Weissliegendes ore, for $\mathrm{U}-\mathrm{Pb}$ or $\mathrm{Pb}-\mathrm{Pb}$ by SHRIMP. Upgrade and separate the heavy mineral content $\mathrm{w} /$ Wilfley table.

Important references: Jowett and others (1987), Oszczepalski (1989), Michalik (2001), Nowak and others (2001), Bechtel and others (2002), Piestrzyński and others (2002), Oszczepalski and others (2002).

B. Name: Kolwezi Klippe, Democratic Republic of Congo, including Dikuluwe, Mashamba West, Mashamba East, Kamoto Principal, Mupine, Musonoi, KOV, T17, Kananga, and Mutoshi (Ruwe) mines

Deposit subtype: Reduced-facies

Location: 1043'S 2524'E (@ Kamoto Principal shaft)

Grade/tonnage: $1200 \mathrm{Mt}, 4.5$ percent $\mathrm{Cu}, 0.40$ percent $\mathrm{Co}$

Associated deposits: Relatively nearby and in same host sequence, Shinkolobwe U deposit, Kipushi Zn-Cu-Pb-Ge carbonate-hosted vein-and-replacement deposit

Regional geologic setting: Within the Lufilian Arc in Neoproterozoic Katangan (meta)sedimentary rocks

Regional tectonic setting: Within fold-and-thrust belt; folded and thrust assumedly in the Lufilian orogeny (790-540 Ma with folding and thrusting principally 
790-750 Ma according to Kampunzu and Cailteux (1999); others would date the major deformation after the Marinoan glacial diamictite at $635 \mathrm{Ma}$ ). The area has also seen considerable halokinetic deformation (salt domes and walls and related structures) of uncertain age, but postmain-stage ore.

Significant structural control (Y/N): Orebody boundaries are structural boundaries and outcrop. The most common boundary type is the contact of mineralized beds within an ecaille (French: flake, scale) against polymictic breccias interpreted to be replaced evaporites.

Primary host rocks and their ages: Neoproterozoic Katangan, (post-877 $\pm 11 \mathrm{Ma}$ ) Supergroup, Lower Roan Group (Roan 2, R-2), Kamoto Dolomite (R-2.1): in ascending order, the "lower orebody" 6-11 m thick stratigraphically; consisting of locally the topmost beds of Gray RAT (R-2.1.1) — gray chloritic siltstone - then the D.Strat. (stratified dolomite, R-2.1.2.1) - gray, very thinly laminated dolostone - then the RSF (R-2.1.2.2) — gray to black carbonaceous dolosiltite, locally cherty; overlain by 13-25 m of RSC beds (R-2.1.3) - partially silicified stromatolitic dolostone, typically mineralized but not ore grade; overlain by the "upper orebody" in the lower part of Dolomitic Shales Fm. (R-2.2), 8.5-15 m of the SDB (dolomitic shales, basal) beds - gray, silty dolostonethen BOMZ (black ore mineral zone) - thinly laminated black argillitic dolostone. Stratigraphically overlying beds are a continuation of dolomitic shales, carbonaceous dolomitic shales, stromatolitic dolostones, and thin units of massive dolostone, all generally sparsely pyritic.

Associated red beds: Subjacent Red RAT (R-1) of the lower Roan Supergroup, base of the sequence not locally known (cut out on tectonic contacts). Red RAT is dolomitic sandstone containing hematite pigment and (or) crystalline hematite overlain by chloritic dolomitic siltstone also with hematite pigment and (or) crystalline hematite. Typically only 5 to $15 \mathrm{~m}$ thicknesses exposed below the Kamoto Dolomite before reaching a tectonic contact.

Associated evaporites: Trace anhydrite and abundant pseudomorphs of anhydrite in Red RAT, Gray RAT, Kamoto Dolomite, and additional formations upsectionward. Three zones, stratigraphically, are everywhere unconformable and marked by breccias. These are below RAT (between RAT and basal conglomerates that are known only adjacent to basement exposures), between RAT (R-1) and Kamoto (R-2), and between Dipeta Group (R-3) and Mwashya (R-4). From Mwashya upward, stratigraphy continues conformable for several kilometers thickness. The breccias are inferred to mark zones of dissolved evaporites. The effect is that ecaille (French: scales, flakes, slices) of many different sizes of coherent, though folded, upper RAT through Dipeta stratigraphy float within breccia, some places seeming to be merely parted from the adjacent ecaille, other places almost randomly oriented. Ecailles with mineralized R-2 may be continuous for several kilometers but in large continuous ecaille, eventually grade laterally to merely pyritic R-2.

Age of mineralization: Two stages. First and predominant is disseminated and replaces anhydrite and is clearly pre-folding. Re-Os age of $816 \pm 62$ Ma from Konkola, Zambia, is reasonable but imprecise. Second stage is veinlet controlled and overprinted on first and likely postdates the peak of Lufilian orogeny. Similar veins have been dated to $514 \pm 2 \mathrm{Ma}$ at Musoshi and to $525.7 \pm 3.4 \mathrm{Ma}$ at Nkana-Mindola, Zambia.

Hypogene ore characteristics and mineral/metal zoning: Upper orebody is consistently zoned chalcocite to bornite to chalcopyrite to pyrite stratigraphically upwards at the top. In rare ecaille at Kambove West, the same lateral zonation was observed from orebody center to margin. Carrollite is the major primary Co mineral and is found from chalcocite-bearing rock into chalcopyrite zone. Corich pyrite present from there outward in zonation.

Hypogene gangue characteristics and alteration: Gangue zonation, other than hematite and pyrite, is not documented. Quartz and dolomite, together with sulfides, replace early diagenetic anhydrite.

Geochemical characteristics: Elemental geochemistry not well documented but demonstrably different than Ore Shale ores in Zambia (Moine and others, 1986).

RAT Group rocks in Democratic Republic of Congo are extremely magnesian and almost alkali-free, whereas Ore Shale ores in Zambia are intensely K-metasomatized with $\mathrm{K}$-feldspar. $\mathrm{Mg}$ richness is probably not just because of evaporitic depositional environment. An important metasomatic addition of $\mathrm{Mg}$ is probable.

S-isotope study shows an early, broad distribution of $\delta_{34} \mathrm{Ss}$ of $\mathrm{Cu}$ sulfides that replaced earliest diagenetic pyrite retaining the pyrite's isotope signature, followed by a later, extremely strong addition of relatively heavy $\delta^{34} \mathrm{~S}$ sulfide with values about +3 to $+9 \%$ (Hoy and Ohmoto, 1989). By comparison with sulfur isotope values at the Spar Lake sandstone $\mathrm{Cu}$ deposit, this is probably thermochemically reduced $\mathrm{S}$ that is a direct reflection of $\mathrm{S}$ earlier stored in organic matter, then freed by cracking the organics (interpretation of Hayes).

Fluid-inclusion microthermometry shows two mineralization stages: (1) early cementation disseminated and anhydrite replacement with temperatures $105-220^{\circ} \mathrm{C}$ and salinities of 8.4-20.9 eq. wt. \% $\mathrm{NaCl}$ (Dewaele and others, 2006; El Desouky and others, 2009). Broad ranges of $T_{h}$ and salinity indicate mixing of extant formation waters of low $\mathrm{T}$ and salinity with hot metals-transporting brines, and (2) post-orogenic mineralization (veinlet-controlled) took place from hotter $\left(200-415^{\circ} \mathrm{C}\right)$ even more saline $(35-55$ eq. wt. $\% \mathrm{NaCl}$ ) brines that almost certainly signal dissolution of evaporites. 
Petrology: Important ore-stage replacement of early diagenetic anhydrite by quartz, dolomite, and $\mathrm{Cu}$ sulfides. Chlorite needs study and promises to be involved in ore processes.

Style(s) of mineralization: $\mathrm{Cu}$ sulfides localized along all slightly coarser laminae, in precompaction nodules, with quartz and coarse dolomite in pseudomorphic replacements of tabular crystals $1 \times 5 \mathrm{~mm}$ (formerly anhydrite). Second-stage veinlets are typically not through-going, are quartz-dolomite-Cu sulfides.

Post-ore deformation: Extreme folding and thrusting of already formed orebodies. Poorly defined but also extreme effects of halokinetic structural deformation. Low-grade metamorphism.

Other notable features: Supergene environment separates $\mathrm{Cu}$ (mobile and probably forming chalcocite enrichment at depth) from Co (residual and forming "cobalt caps.") World's largest known resource of Co.

Important references: Demesmaeker and others (1963); Bartholomé (1974); Bartholomé and others (1976); Hoy and Ohmoto (1989); Cailteux and others (2005a); Dewaele and others (2006); El Desouky and others (2009)

C. Name: Creta, Okla., United States

Deposit subtype: Reduced-facies

Location: $34^{\circ} 39^{\prime} \mathrm{N} 99^{\circ} 21^{\prime} \mathrm{W}$

Grade/tonnage: $5.4 \mathrm{Mt}, 1.9$ percent $\mathrm{Cu}, 5.5 \mathrm{~g} / \mathrm{t} \mathrm{Ag}$

Associated deposits: Industrial gypsum

Regional geologic setting: Approximately central to the greater U.S. Permian Basin extending from near Big Bend National Park, Tex., north-northeastward to south-central Nebraska; the basin probably opened to the south-southwest.

Regional tectonic setting: On the south-southwest-dipping north flank of the Hollis Basin in southwestern Oklahoma. The basin sits on the south flank of the Oklahoma Aulacogen that had thick deposits in the early Paleozoic Era and again in the Pennsylvanian. Permian thickness trends appear, instead, to cross the west-northeast trending aulacogen (Mudge, 1967). Creta is underlain by more than $1,000 \mathrm{~m}$ of Permian rock, mostly red beds. Relatively flatlying Permian sediments at surface overlie Early Paleozoic rocks that are considerably folded and offset by major prePermian faults.

\section{Significant structural control (Y/N): N}

Primary Host Rocks and their ages: uniquely, the Prewitt Copper Shale bed of the Flowerpot Shale, El Reno Group of Late Leonardian-Early Guadalupian Age, overlain by the Haystack Gypsum bed, underlain by Flowerpot red mudstone and siltstone. The Prewitt Copper Shale bed has a drill-demonstrated lateral extent between pinchouts in every direction, except northeastward toward its pre-mining outcrop belt, of about $75 \mathrm{~km}^{2}$. Examining isopach trends, perhaps $25 \%$ of its original extent was eroded.

Associated red beds: Subjacent section more than 1,000 $\mathrm{m}$ thick of Permian dolostone, red siltstone and mudstone, and gypsum-anhydrite; red beds predominate (Dixon, 1967; MacLachlan, 1967). Next underlying Pennsylvanian rocks are mostly gray shales of a deeply subsiding basin, lesser coal measures to the east.

Associated evaporites: Gypsum and anhydrite are common within the local Permian section and halite appears tens of kilometers to the west particularly in the stratigraphically overlying and partly equivalent Blaine Fm. The greatest thicknesses of salt lie in slightly older and age-equivalent rocks on the opposite, northern side of the Wichita uplift, in the Anadarko Basin and northward into central Kansas (Wellington and Ninnescah Fm., respectively).

\section{Age of mineralization: Not known}

Hypogene ore characteristics and mineral/metal zoning: Zonation is broadly typical. Most abundant ore mineral is anilite (Hagni and Gann, 1985). Digenite, djurleite, pyrite also significant. Argentiferous chalcocite, geerite, yarrowite, chalcopyrite, bornite, covellite, stromeyerite, also present; carrollite, galena and native bismuth in traces (Hagni, 1988). Cu sulfides replace pyrite and replace Triletes spores (Hagni and Gann, 1976). Minor bornite, chalcopyrite, and galena generally overlie chalcocite zones. In this and other $\mathrm{Cu}$-shale beds in southwestern Oklahoma and the northeastern Texas Panhandle (includes Mangum, Okla., and Medicine Mounds, Tex.--Johnson, 1976b; Smith, 1976), the favorable gray, host shale has the geometry of a "puddle," an ovoid perhaps $11 \mathrm{~km} \times 7 \mathrm{~km}$ and less than $100 \mathrm{~cm}$ thick at its maximum. Only that rock probably had early diagenetic pyrite (or pyrrhotite; Hagni, 1988) within rocks that are otherwise red. Carbonized plant debris in sandstones in the same and underlying Permian section are also mineralized (red-bed-type deposits) but lack continuity needed for ore. Occurrence of monoclinic, pseudo-orthorhombic chalcocite crystals in ore (Hagni and Gann, 1976) constrains temperature at ore stage to $103.5^{\circ} \mathrm{C}$ or less.

Hypogene gangue characteristics and alteration: Trace barite with chalcocite (Kidwell and Bower, 1976). Gangue minerals generally poorly described but include (semiquantitatively by XRD) illite approximately 48 percent, quartz approximately 19 percent, chlorite approximately 16 percent, gypsum approximately 16 percent. Adjacent and nearby red shales have more quartz, less gypsum, and similar amounts of illite and chlorite (Lockwood, 1972).

Geochemical characteristics: $\mathrm{CuO}$ has the following correlation coefficients with other elements and parameters: With quartz XRD abundance -0.30 , gypsum +0.15 , illite -0.12 , chlorite $+0.11, \mathrm{Ag}-0.49, \mathrm{~Pb}+0.36, \mathrm{~V}-0.20$, 
$\mathrm{Co}-0.07, \mathrm{Ni}+0.64, \mathrm{Fe}_{2} \mathrm{O}_{3}-0.31, \mathrm{~K}_{2} \mathrm{O}-0.13, \mathrm{CaO}+0.47$, Organic Matter $-0.11, \mathrm{ZnO}-0.13, \mathrm{U}-0.65$, and $\mathrm{MoO}_{3}$ -0.31 (Lockwood, 1972). The major elements above indicate that the mineralization occurs in gypsiferous gray shale, rather than in non-gypsiferous red shale. $\delta^{34} \mathrm{~S}$ of sulfides range from -1 to -34 ; gypsum +4 to +6 , indicating bacteriogenically fractionated seawater sulfur in early diagenetic pyrite was replaced - $\mathrm{Cu}$ sulfides replaced pyrite with little change to the S-isotope ratios.

Petrology: As above; Hagni and Gann (1976), Kidwell and Bower (1976), Dingess (1976).

Style(s) of mineralization: (1) Bedform disseminations preferentially within silty and sandy lamina in the shale, (2) replaced Triletes spores, (3) replaced pyrite octahedra, (4) dense dissemination within former burrows (are they burrows, or are they pillars?), (5) bedding plane and lesser high-angle veinlets, (6) free monoclinic (pseudo-orthorhombic) microcrystals of chalcocite, and (7) slickensided chalcocite on surfaces of compaction features.

Post-ore deformation: Sparse extensional fracturing and veins

Other notable features: Unreplaced spores are flattened by compaction by at least $2.5 \times$; anilite-replaced spores are not at all flattened by compaction. Replaced spores did not undergo pre-ore pyrite replacement. Thus, $\mathrm{Cu}$-sulfide mineralization preceded compaction almost entirely (Huyck and Chorey, 1991).

Important references: Hagni and Gann (1976); Johnson (1976a, b); Kidwell and Bower (1976); Lockwood (1972); Hagni (1988); Huyck and Chorey (1991).

D. Name: Udokan, Transbaikalian Russia

Deposit subtype: Sandstone $\mathrm{Cu}$

Location: 56³4'37" N 118 30'47" (@ the junction of Naminga R. and a major tributary within the vertical projection of the deposit)

Grade/tonnage: $1528 \mathrm{Mt}, 1.45$ percent $\mathrm{Cu}, 12.6 \mathrm{~g} / \mathrm{t} \mathrm{Ag}$ (V. Chechetkin, oral commun., 2010)

Associated deposits: Sediment-hosted U (details unavailable). Deposits of Fe, Ti, V, Cu, and PGE associated with the Chenei layered mafic-ultramafic complex are nearby; appear to be younger than Udokan, include basal zones of pentlandite-chalcopyrite ores in Udokan Supergroup wallrocks.

Regional geologic setting: Miogeosynclinal sequence within synclinal "troughs" within Archean craton

Regional tectonic setting: Southern margin of the Archean Aldan Shield in "troughs" filled with metasediments of low metamorphic grade - middle greenschist

Significant structural control (Y/N): N
Primary host rocks and their ages: Upper Sakukan Formation of the Kemen Series, Paleoproterozoic Udokan Supergroup. Paleoproterozoic-age sedimentation based on a metatuff dated 2,180 $\pm 50 \mathrm{Ma}(\mathrm{U}-\mathrm{Pb}$, zircon) in the conformably underlying and similarly metamorphosed Chinei Group. The favored lithologic package (U. Sakukan) is of fine- to coarse-grained, well-sorted quartzite with calcareous cements and with mud intraclasts varying locally up to $30 \mathrm{v}$. \% of the rock. Overlying (Naminga Formation) rocks are argillitic and considered transgressive over the deltaic environments of the Sakukan.

Associated red beds: Lower Sakukan Formation is 1,000-1,700 m of "magnetite carrier sandstone"and below that the Talakan Formation is 1,100-1,400 m also with much "magnetite carrier sandstone." The origin of this magnetite, called detrital in the literature, is suspected to be burial metamorphic after hematite of former red beds similar to Belt Supergroup, United States (Nadoll and others, 2012).

Associated evaporites: None known locally. Carbonate-rich units downsection by more than $3 \mathrm{~km}$ have hopper casts. Overlying argillitic rocks have abundant desiccation cracks but no mention of evaporites or pseudomorphs.

\section{Age of mineralization: Unknown}

Hypogene ore characteristics and mineral/metal zoning: Strongly zoned pyrite to chalcopyrite to bornite to chalcocite (to hematite?). The mineralogical zoning defines several anastomosing lens- to layer-form bodies of ore within the Upper Sakukan, with lengths up to $6.1 \mathrm{~km}$, widths of typically $0.8 \mathrm{~km}$ but up to $3 \mathrm{~km}$, and thickness 20 to $130 \mathrm{~m}$ (commonly 70 to $100 \mathrm{~m}$ ). Complex inter-tonguing relations of sulfide mineral zones. Coarser lithology commonly bears chalcocite whereas finer lithology carries chalcopyrite and (or) pyrite. $\mathrm{Ag}$ is mostly in solid solution in chalcocite (10-3,000 ppm Ag) and bornite (10-300 ppm). Au should be recoverable at $0.5 \mathrm{~g} / \mathrm{t}$ in concentrate.

Hypogene gangue characteristics and alteration: Includes ("idiomorphic, regenerated") magnetite, probably calcite, trace barite, but not described to accompany specific sulfide zones. Albitization in cross-stratal zones described throughout the Udokan Supergroup and interpreted to be localized along faults (Abramov, 2008). Albitization described to accompany sediment-hosted $\mathrm{U}$ deposits nearby, also in the Udokan Supergroup (V. Chechetkin, oral commun., 2010), but no particular association of albite with mineralization described.

Geochemical characteristics: Anomalous in ore are Co (10-100 ppm), Ni (10-100 ppm), Ag (trace to $100 \mathrm{ppm}$ ), $\mathrm{Pb}(10-100 \mathrm{ppm})$, Mo (less than 10 to rarely $100 \mathrm{ppm}$ ), $\mathrm{V}(10-1,000 \mathrm{ppm}), \mathrm{Ba}$ (trace to 1 percent) (probably mostly in barite), and Mn (0.1 to 1 percent) (probably sited in calcite). A suite of elements probably sited in former ilmeno-magnetite, ilmeno-hematite, and heavy 
minerals is also found including Ti (everywhere greater than 1,000 ppm), Zr, and Cr (Bakun and others, 1966, table 2). Organic carbon co-varies with $\mathrm{Cu}$ in mineralized rocks; Corg greater than 0.3 percent corresponds to $\mathrm{Cu}$ grades greater than 1 percent (Volodin and others, 1994, p. 10). No data on stable isotopes or fluid inclusions.

Petrology: Not described in literature available in English though hosts are feldspathic (10-15 percent total feldspars; plagioclase $10-30$ percent, K-feldspar 5 percent) to sericitic quartzites (5-15 percent muscovite).

Style(s) of mineralization: (1) $\mu$-scale sulfides enclosed within magnetite, calcite, and epidote, (2) sandstone cements, and (3) replacements of framework grains to form patchy disseminations, lenses, and laminae of sulfides varying up to massive replacements.

Post-ore deformation: Broadly folded into an open syncline with its south limb locally overturned to the north, cut and offset by high-angle faults, also cut by thick gabbro-diabase dikes, and by later, thin quartz porphyry and lamprophyre dikes.

Other notable features: Udokan is the largest known sandstone $\mathrm{Cu}$ deposit in the world.

Important references: Bakun and others (1966); Bogdanov and others (1966); Volodin and others (1994); Abramov (2008)

E. Name: Spar Lake, Mont., United States (also known as the Troy mine)

Deposit subtype: Sandstone $\mathrm{Cu}$

Location: 48 $13^{\prime} 49^{\prime \prime} \mathrm{N}, 115^{\circ} 54^{\prime} 19^{\prime \prime} \mathrm{W}$

Grade/tonnage: $80.6 \mathrm{Mt}, 0.63$ percent $\mathrm{Cu}, 46 \mathrm{~g} / \mathrm{t} \mathrm{Ag}$

Associated deposits: None, though others within the basin include sedex (for example, Sullivan, Sheep Creek) and mesothermal Ag veins (Coeur d'Alene). Laramide overprint of the Belt Basin includes porphyry $\mathrm{Cu}$, porphyry Mo, and polymetallic veins.

Regional geologic setting: Host rocks are deltaic topset beds; within a belt where former red-bed host rocks are bleached or partly bleached in contrast to outside the belt where all are still red beds; the belt may have been a structural high as indicated by lesser deposition of Missoula Group sediments in the "post-Ravalli dome" (Harrison, 1972).

Regional tectonic setting: Within probable aulacogen; probable association with growth faults that may have been used as conduits of metals-transporting brines (fault offsets may have alternatively or also contributed to preore natural gas trapping).

Significant structural control (Y/N): Y, the East Fault, a down-to-the-east normal fault. Deposit occurs as two connected lobes elongate parallel to and on opposite sides of the East Fault within Revett Formation, upper member, host sandstones. Zonal geometry suggests that metals-transporting groundwater came upward across stratigraphy, then spread laterally within sandstones that had already been offset, boundaries of lobes at places where confining beds were faulted into contact with sandstones.

Primary host rocks and their ages: Mesoproterozoic Belt Supergroup (greater than 1470-less than $1400 \mathrm{Ma}$ deposition); Ravalli Group; Revett Formation (lithostratigraphic metasandstone-rich package); upper member; lower, middle, and upper quartzite beds; and lower member; C quartzite beds; depositional environments of host quartzites included beach-and-offshore bar and subtidal channels and bars.

Associated red beds: Burke Formation (1-2 km thick, lavender-gray, hematite- and magnetite-bearing siltite greater than argillite greater than quartzite) and laterally equivalent Revett, also lavender-gray. Burke is $500 \mathrm{~m}$ downsection from host beds, separated from it by beds that are trace-mineralized or ore-mineralized.

Associated evaporites: Nearest known are Missoula Group (greater than $4 \mathrm{~km}$ upsection); none known at or below the host level stratigraphically, though more examination is due certain breccias within Prichard Formation greater than $3 \mathrm{~km}$ downsection (Cressman, 1985, p. 44-51).

Age of mineralization: $1409 \pm 8 \mathrm{Ma}$ in rocks that were deposited between 1470 and 1454 Ma.

Hypogene ore characteristics and mineral/metal zoning: Nested tongues expand laterally within sandstone layers, contract within intervening silty argillitic layers. Pyrite to galena to chalcopyrite to bornite ( + magnetite) to digenitechalcocite ( + hematite).

Hypogene gangue characteristics and alteration: Ferroan calcite with pyrite, galena, chalcopyrite. Manganiferous calcite with bornite-digenite. Ankerite, Fe-rich chlorite, hematite with digenite-chalcocite. Barite together with chalcocite, digenite, bornite, and rarely, chalcopyrite or galena. Intense potassium metasomatism as potassium feldspar overgrowth on detrital Kspar grains within galena-chalcopyrite zone, increasing into bornite-digenitechalcocite. Silicification as quartz overgrowth on detrital quartz. Late, cementing and replacing albite increases in the direction of chalcocite-hematite.

Geochemical characteristics: Elementally, the outstanding characteristics are $\mathrm{K}$ metasomatism accompanying ore deposition and $\mathrm{Ca}$ metasomatism in the distal-fringe zones. Additional elements transported with $\mathrm{Cu}$ and deposited within the zoned array are $\mathrm{Ag}, \mathrm{Pb}, \mathrm{Sb}, \mathrm{As}, \mathrm{Ba}$, $\mathrm{Na}, \mathrm{S}$.

Fluid inclusions $\mathrm{T}_{h}$ and salinity indicate mixing of a greater than $175^{\circ} \mathrm{C}$ metals-transporting brine with a cooler, less-saline formation water. Fluid-inclusion 
volatile compositions indicate mixing a $200{ }^{\circ} \mathrm{C}$ metalstransporting brine with reservoired sour gas in the host sandstones. There are systematic arrangements of other hydrocarbon volatiles, of $\mathrm{H}_{2}$, probably of $\mathrm{H}_{2} \mathrm{~S}$. No indication of magmatic volatiles or of any mantle contributions.

$\mathrm{C}$ isotopes of carbonates are light in fringing zone of $\mathrm{Mn}$ and Fe-rich calcites (see below). $\mathrm{O}$ isotopes of carbonates indicate either an elevated $\mathrm{T}$ brine or freshwater (the latter unlikely).

$\mathrm{S}$ isotopes show a spread from +2 to +29 but no negative values. S-isotopic equilibrium was approached between galena, chalcopyrite, and $\mathrm{H}_{2} \mathrm{~S}$ at ore-stage and with declining temperatures, $130{ }^{\circ} \mathrm{C}$ to less than $100^{\circ} \mathrm{C}$, outward from ore across the galena fringe. History of $S$ is (1) bacterial sulfate reduction of seawater sulfate that started with $\delta^{34} \mathrm{~S}$ of about +20 , (2) sequestering and storage of the then-reduced $\mathrm{S}$ in organic matter of downsection Prichard Formation, (3) maturation and migration of hydrocarbons carrying the S, (4) thermochemical sulfate reduction from formation waters and addition to the migrating hydrocarbons, (5) entrapment of sour gas with continued thermochemical sulfate reduction from formation waters, (6) ore-stage reaction of metals in hot brine with rapid deposition across a mixing zone utilizing the $\mathrm{H}_{2} \mathrm{~S}$ of the sour gas, and accompanied at the distal fringes of the mixing zone by ore stage coupled redox between $\mathrm{SO}_{4}$ of the metals-transporting solution and the $\mathrm{C}$ in $\mathrm{CH}_{4}$ of the sour gas, depositing sulfides with heavy $\delta^{34} \mathrm{~S}$ and manganiferous calcite with light $\delta^{13} \mathrm{C}$. The sulfide thus formed was thermochemically reduced. Direct deposition of barite from metals-transporting solution $\mathrm{SO}_{4}$, not in thermal equilibrium with the metalstransporting brine.

Petrology: Ore minerals and ore-stage gangue are dominantly cements and replacements. Earliest stage of diagenesis probably forms red beds (ferric oxide grain coatings). At the stage of petroleum migration, red beds were bleached and porosity increased from loss of ferric-oxide grain coatings. Emplacement of sour gas in reservoir rocks was accompanied/followed by deposition of pyrite, possibly some Fe-rich calcite, possibly some apatite, possibly some tourmaline overgrowth. Invasion of the gas reservoir was accompanied by pyrite replaced by galena-chalcopyrite, replaced by bornite, replaced by digenite-chalcocite; all accompanied by K-feldspar overgrowth, quartz overgrowth, manganiferous calcite cementation, chlorite cementation, barite cementation, late (in the ore-stage) hematite cementation and albite cementation and replacement.

Style(s) of mineralization: Ore minerals and ore-stage gangue are predominantly cements and replacements of earlier cements and clasts. Many bedform disseminations and clots of the ore minerals and zonally distributed gangue minerals. Notable mineralized large seepage pillars with local-scale evidence of rising metals-transporting solutions. Minor (less than 5 percent) ore sulfides in later, post-metamorphic veinlets in brittle fractures with demonstrable contribution of ore components to veinlets from local wallrocks (nowhere the opposite - veinlets contributing ore components to the local wallrocks).

Post-ore deformation: Pure burial metamorphism to the biotite isograd of greenschist facies with estimated conditions of $425^{\circ} \mathrm{C}$ and perhaps 1.5 kilobars. Except within local clots of anomalous composition, sulfides melted into solid solutions within the confines of each former pore, but enclosing carbonates and silicates did not melt or react. Within former hematite-sulfide clots, magnetite, ankerite formed by de-oxidation of hematite. In retrograde metamorphism, sulfide solid solutions exsolved to incoherent bornite-digenite, coherent bornite-digenitechalcopyrite, and others. Folding and thrusting in the Mesozoic was not probably at metamorphic conditions and was accompanied by reverse faulting. Relaxation of Laramide compressional stresses accompanied by brittle fracturing, veinlet formation, and (renewed, at places) normal faulting.

Other notable features: Silver predominantly in solid solution in chalcocite, digenite, and bornite with $0.1 \mathrm{wt} . \% \mathrm{Ag}$ typically found in each sulfide. Native silver, stromeyerite, and argentite or acanthite rare to trace. Every aspect of genesis of Spar Lake, except post-ore metamorphism and tectonism, is matched by Zhilandy-type deposits in the Dzhezkazgan district, Kazakhstan (B. Syusyura, oral commun., 2009).

Important references: Hayes and Einaudi (1986); Hayes and others (1989); Hayes (1990); Boleneus and others (2006); Hayes and others (2012)

F. Name: Juramento, Argentina

Deposit subtype: Sandstone $\mathrm{Cu}$

Location: $25^{\circ} 13^{\prime} \mathrm{S}, 65^{\circ} 09^{\prime} \mathrm{W}$

Grade/tonnage: $44.7 \mathrm{Mt}, 0.80$ percent $\mathrm{Cu}, 21.8 \mathrm{~g} / \mathrm{t} \mathrm{Ag}$

Associated deposits: None known.

Regional geologic setting: Within belt of folded Mesozoic sediments in the foreland between the Andean continental arc and the Rio de la Plata craton

Regional tectonic setting: Within intracontinental rift of Jurassic-Cretaceous age associated with the breakup of South America from Pangean Africa

\section{Significant structural control (Y/N): N}

Primary host rocks and their ages: Late Cretaceous (Maastrichtian) Lecho and Yacoraite Formations in ascending order; white to cream calcareous sandstone and oolitic, stromatolitic limestone with lesser calcareous siltstone, respectively 
Associated red beds: Late Cretaceous (Campanian) Pirgua Supergroup red coarse clastics with minor bimodal basalt-rhyolite; total thicknesses up to $3,000 \mathrm{~m}$ in the adjacent basin

Associated evaporites: Only evaporites nearby are those of the early Tertiary Tunal Olmedo Formation, hundreds of meters upsectionward from host rocks. Host limestones contained blades of early diagenetic gypsum in trace amounts, now replaced by $\mathrm{Cu}$ sulfides.

Age of mineralization: Unknown. Gravity-driven groundwater circulations were available in Early to Late Miocene and Plio-Pleistocene

\section{Hypogene ore characteristics and mineral/metal zoning:}

Strongly zoned pyrite to sphalerite to galena to minor tetrahedrite to chalcopyrite to bornite to chalcocite (to hematite) both downsectionward across bedding and from north to south in steeply west-dipping sedimentary host rocks.

Hypogene gangue characteristics and alteration: No gangue minerals interpreted to date from ore-stage (illogical). Early meniscus and isopachous calcite cements and framboidal and other pyrite followed by coarse dolomite, apparently followed by ore sulfides in the sequence galena, sphalerite, tetrahedrite, chalcopyrite, bornite, and chalcocite. Those apparently followed by quartz and K-feldspar. Followed by stylolytization. Followed by dead oil staining in relict pores and dead oil in veinlets.

Geochemical characteristics: Insufficient data but sufficient indication to state that As in tetrahedrite-tennantite is anomalous in a fringe zone. $\mathrm{Zn}$ and $\mathrm{Pb}$ anomalous in a more distant fringe.

$\mathrm{S}$ isotopes ( $\mathrm{n}=12$ samples) of sulfides range from $\delta^{34} \mathrm{~S}$ of -42.9 to -8.0 . Pyrite mean is -37.8 . Base metal sulfide mean is -17.0. By comparison with Spar Lake sandstone $\mathrm{Cu}$ deposit (fig. 47) this probably should be taken to indicate that (1) pyrite formed by bacteriogenic $\mathrm{S}$ reduction, and (2) $\delta^{34} \mathrm{~S}$ of $\mathrm{Cu}$ sulfides indicate addition of relatively heavy sulfide at ore stage, probably by thermochemical sulfate reduction of metals-transporting brine sulfate.

Ag is reported by Alexander Mining (2005) and Durieux and Brown (2007) to be only in tetrahedrite-tennantite but that is inconsistent with results from core samples reported by Alexander Mining (2005, p. 45-46). In the data there, $\mathrm{Cu}$ and $\mathrm{Ag}$ grades co-vary strongly. Tetrahedrite-tennantite is found only as a fringe on Cu-mineralized rock, so high $\mathrm{Ag}$ in tennantite would occur in samples from the fringes of mineralized zones with $\mathrm{Cu}$ grades of a few tenths of a percent (roughly 1 v. \% disseminated chalcopyrite). Instead, $\mathrm{Ag}$ occurs throughout $\mathrm{Cu}$-rich zones and clearly is highest in rock with highest $\mathrm{Cu}$ grades (probably consisting of chalcocite and bornite rather than chalcopyrite). Ag is probably in solid solution in chalcocite, digenite, and bornite.
Petrology: Host carbonate grainstones have an apparent sequence: (1) meniscus and isopachous calcite cements + framboidal fine-crystalline pyrite, (2) coarse dolomite + coarse crystalline pyrite, (3) 2nd calcite cement (not described further), (4) base-metal sulfide mineralization with sequence sphalerite, galena, tetrahedrite, chalcopyrite, bornite, and finally chalcocite, (5) quartz and K-feldspar cements and replacements, (6) major compaction, carbonate neomorphism, and stylolytization, (7) hydrocarbons (now dead oil) coating relict pores followed by 3rd calcite cement (not further described), and "late" fracturing with filling by dead oil, and (8) uplift and supergene alterations. As described, this sequence is too rigorous, as above. Instead of rigorously "first this, then that," numerous textures could alternatively have been interpreted "synchronously and later than." (for example, Authigenic quartz and K-feldspar that cement ooid grainstones and partially replace ooids probably accompanied $\mathrm{Cu}$-sulfide deposition, and it may have been happening while compaction with stylolytization was ongoing.)

Style(s) of mineralization: $\mathrm{Cu}$ sulfides are predominantly cements and replacements in carbonate grainstones in the Lecho sandstones and Yacoraite grainstones and siltstones. Replacement of gypsum by $\mathrm{Cu}$ sulfides.

Post-ore deformation: Mild. Open folding rarely with vertical or overturned dips. Relatively intense post-ore fracturing. Essentially no metamorphism.

Other notable features: SSC deposits occur, as well, within Middle- and Late-Cretaceous sandstones in the Neuquén Basin in west-central Argentina, several hundred kilometers south of Juramento. All occurrences there are classic sandstone $\mathrm{Cu}$ deposits mineralizing rock that was first red, then bleached and associated with petroleum, and finally, $\mathrm{Cu}$ mineralized (J. Thorson, private consultant, written commun., 2009; Giusíano and others, 2008).

Important references: Durieux and Brown (2007); Alexander Mining (2005).

G. Name: Corocoro, Bolivia

Deposit subtype: Red-bed $\mathrm{Cu}$

Location: $17^{\circ} 10^{\prime} 09^{\prime \prime} \mathrm{S}, 68^{\circ} 27^{\prime} 04^{\prime \prime} \mathrm{W}$

Grade/tonnage: 7.8 Mt, 7.1 percent $\mathrm{Cu}, 106 \mathrm{~g} / \mathrm{t} \mathrm{Ag}$ (These grades, reflect hand-sorting of ore. Average grades closer to those mentioned under Other Notable Features, below.)

Associated deposits: Salt diapirs

Regional geologic setting: Bolivian altiplano between eastern and western Andean Cordillera. Intermontane basin in hyperarid climate.

Regional tectonic setting: Strong halokinesis produced salt diapirs and probably the related anticlines and synclines, as well as high-angle reverse faults.

Significant structural control (Y/N): Y. Steep dipping dragfolded flanks of salt domes and halokinetic faults 
Primary host rocks and their ages: In ascending order, Corocoro Group, Huayllamarca Formation (locally called Ramos Formation) red mudstone and lesser red sandstone and gypsum with local bleaching, and Totora Formation (locally called Vetas Formation) gray sublitharenites with lesser red mudstone.

Associated red beds: Within the locally $10 \mathrm{~km}$-thick Corocoro Group. The group is dominated by red beds with no less than 2,700 m of red beds downsection.

Associated evaporites: Lower Tertiary or Upper Cretaceous Jalluma or Chuquichambi Formation salt; expressed as gypsiferous shale breccias at surface. Halite penetrated in drilling at $386 \mathrm{~m}$.

Age of mineralization: Not known.

Hypogene ore characteristics and mineral/metal zoning: Native copper dominates in sandstone-hosted ores in bleached Ramos. Chalcocite replaces carbonized plant fragments and forms cements in Vetas gray sandstones. Multiple "manto" levels and also bedding plane and faultfilling veins of native copper. Minor bornite, covellite, chalcopyrite, galena, sphalerite, stromeyerite, and tennantite are also locally present.

\section{Hypogene gangue characteristics and alteration: No} gangue minerals described as ore stage. Overgrowth quartz, authigenic K-feldspar, celestite, and barite likely date from ore stage. Those minerals cement sandstones and are replaced along with earlier cements (hematite dust rims, clays, gypsum, and albite) by chalcocite or native copper. Gangue also includes anhydrite, aragonite, and chalcedony. Pre-ore bleaching in Ramos speculatively caused by a "mobile reductant" (dissolved humic acids and their precipitates) (Flint, 1989, p. 394-395).

Geochemical characteristics: Little-described. Chalcocite or native copper is accompanied by trace domeykite (isometric $\mathrm{Cu}_{3} \mathrm{As}$ ). Ore is said to have $15 \mathrm{~g} / \mathrm{t} \mathrm{Ag}$ per 1 percent $\mathrm{Cu}$.

No fluid-inclusion studies, but dissolved evaporites in the metals-transporting brines are likely with the occurrence of mantos in beds dipping steeply off flanks of salt domes and adjacent to related reverse faults.

Petrology: Earliest diagenesis of sandstone hosts (probably the Ramos) is hematite and clay dust rims and gypsum. Next is albite. These were followed apparently by quartz overgrowth, then K-feldspar, and celestite and barite. These were followed by generation of secondary porosity by destruction of hematite dust rims and dissolution of plagioclase in detritus. Followed by $\mathrm{Cu}$ sulfides and native $\mathrm{Cu}$ and slightly later native Ag. Followed by covellite, secondary $\mathrm{Cu}$ minerals, gypsum, and quartz. Minor supergene enrichment as native $\mathrm{Cu}$, chalcocite, and covellite. (Like Juramento, this paragenetic sequence gives interpretations only as "first this, then that." Some could have been interpreted "synchronous with or later than." The likelihood is that quartz overgrowth, authigenic K-feldspar, and barite are all ore stage.)

Style(s) of mineralization: Sandstone cements predominate. Bedding plane veins important at places. In Vetas, replacement of carbonized plant debris important. Observation that basal zones of each sandstone are favored might be interpreted that these are the coarsest, most permeable parts of each fluvial fining-upward sequence.

Post-ore deformation: Little or none.

Other notable features: Grades reflect hand sorting of ores. Corocoro is the longest-mined, best known of more than 20 deposits and districts on a north-northwest trend of salt diapirs with related SSC deposits that extends $200 \mathrm{~km}$. Others on the trend from north-northwest to south-southeast are Porvenir mine, Llallagua mine, Maria Elena-Victoria mine, Pisaqueri mine, American Unidas mine, Transvaal mine, (Corocoro district -8 mines), Veta Verde mine, El Hogar mine, Noe group, San Augustin mine, San Francisco prospect, San Miguel mine, Chacarilla district (Porfia, Congreso, Amigo, Borda, Esperanza Eurea, San Fermin, and Tiviña mines and prospects), and Chuquichambi district (Llanquera-San Miguel and Santa María prospects). Corocoro district production 1963-1976 was $1,457,000 \mathrm{t}$ of 2.55 percent $\mathrm{Cu}$. Reserves in 1992 were $1,186,000 \mathrm{t}$ of 2.78 percent $\mathrm{Cu}$.

Important references: Singewald and Berry (1922); Ljunggren and Meyer (1964); Entwistle and Gouin (1955); Flint (1989); Cox and others (1992).

H. Name: Nacimiento, N. Mex., United States

Deposit subtype: Red-bed $\mathrm{Cu}$

Location: $35^{\circ} 59^{\prime} 41^{\prime \prime} \mathrm{N}, 106^{\circ} 53^{\prime} 54^{\prime \prime} \mathrm{W}$

Grade/tonnage: $10.0 \mathrm{Mt}, 0.67$ percent $\mathrm{Cu}, 2.4 \mathrm{~g} / \mathrm{t} \mathrm{Ag}$

Associated deposits: None

Regional tectonic and geologic setting: Flank between the Nacimiento Precambrian-cored uplift and the San Juan Basin.

Significant structural control (Y/N): Probably N

Primary host rocks and their ages: Middle to Late Triassic Chinle Formation, basal Agua Zarca Sandstone Member (correlative with Shinarump Conglomerate of the following example deposit).

Associated red beds: Underlying Early to Middle Permian Abo and Yeso Formations (red-brown mudstone and lenticular red-brown and greenish gray arkosic sandstone; and reddish-orange-buff very fine-grained quartzose sandstone, respectively), totaling $265 \mathrm{~m}$ thick locally (much more to the east, north, and northwest); overlying Salitral Shale and Upper Shale Members of the Chinle totaling $245 \mathrm{~m}$ thick (with intervening Poleo Sandstone Member of gray sandstone with carbonaceous plant debris). 
Associated evaporites: Thick Permian sections to the east in the Permian Basin, particularly in southeastern New Mexico, and Pennsylvanian sections to the northwest in the Paradox Basin, southwestern Colorado and southeastern Utah. None locally.

Age of mineralization: Not known, but likely pre-Tertiary. Cellular structure of wood was not collapsed before the wood was mineralized (petrified), but the first mineralization of the wood was not necessarily the $\mathrm{Cu}$ sulfides found replacing it now.

Hypogene ore characteristics and mineral/metal zoning: Principally chalcocite replacing carbonized plant debris up to the size of logs. Individual logs have pyrite replaced by bornite replaced by chalcocite replaced by covellite. Native silver described from near the modern water table (probably supergene).

Hypogene gangue characteristics and alteration: None described. Host sandstones are 90-95 percent quartz, 2-5 percent feldspar, 1-5 percent chert, 1-2 percent magnetite, 1 percent muscovite, traces of zircon, tourmaline, chlorite, and biotite. Authigenic quartz overgrowth described but host rocks are friable and have clayey matrix (clay minerals not identified).

Geochemical characteristics: Not described.

Petrology: Carbonized logs have wood cell walls replaced by or edged by bornite and cells filled by pyrite that was later replaced by chalcocite. Relict wood found as films of carbonaceous materials in boundary lines between the former cells. Quartz overgrowth appears to precede chalcocite cements (but could be interpreted as synchronous, as above).

Style(s) of mineralization: Dominating replacements of carbonized wood (deposit could be described as a replaced log-jam in sandstone). Lesser sandstone cements. Supergene malachite and chrysocolla cements form halos around sulfidized logs and other sulfides in porous sandstones.

Post-ore deformation: Host rocks have been folded and post-ore offset by faults.

Other notable features:

Important references: Lindgren and others (1910); Soulé (1956); Elston (1967); Woodward and others (1974)

I. Name: Happy Jack, Utah, United States

Deposit subtype: Red-bed U-Cu

Location: $37^{\circ} 45^{\prime} 06^{\prime \prime} \mathrm{N}, 110^{\circ} 17^{\prime} 37^{\prime \prime} \mathrm{W}$

Grade/tonnage: $0.573 \mathrm{Mt}, \sim 0.74 \% \mathrm{Cu}, 0.25 \% \mathrm{U}_{3} \mathrm{O}_{8}$, $\sim 0.047 \% \mathrm{~V}_{2} \mathrm{O}_{5}$ : tonnage and $\mathrm{U}$ grade from Chenoweth (1993, p. 21), $\mathrm{Cu}$ and $\mathrm{V}_{2} \mathrm{O}_{5}$ grades from splits of 5 uranium ore shipments to the Monticello, Utah, refining plant (Shoemaker and others, 1959, p. 27).
Associated deposits: 24 other small U-Cu deposits in Shinarump channels cut into the underlying Moenkopi Formation in the White Canyon district.

Regional geologic setting: Gently folded package of siliciclastic sedimentary rocks on the southwest flank of the Paradox Basin of Pennsylvanian-Permian age.

Regional tectonic setting: Colorado Plateau; a long-term stable region with only gentle folding, lying between the region of steeply folded, Precambrian-cored Rocky Mountain uplifts and the Sevier fold-and-thrust belt.

\section{Significant structural control (Y/N): N}

Primary host rocks and their ages: Upper Triassic Chinle Formation, basal Shinarump Conglomerate Member, very fine to very coarse grained and locally conglomeratic quartzose (approximately 5 percent K-feldspar) sandstone with lesser siltstone and minor mudstone and with conspicuous concentrations of carbonized plant debris. Occurs in channel complexes with bases eroded into the underlying dusky red Moenkopi siltstone/sandstone. The Happy Jack Channel is $230 \mathrm{~m}$ wide and cut $3 \mathrm{~m}$ down into the Moenkopi, trending westward into the subsurface (from a cliff). The channel is a limit on the tonnage of the deposit that sits entirely within it.

Associated red beds: Underlying, predominantly redbed sandstone section including, in ascending order, Pennsylvanian-Permian Rico Formation, Permian Cutler Formation, and Lower Triassic Moenkopi Formation, totaling about $540 \mathrm{~m}$ thick; Chinle is predominantly red beds about $155 \mathrm{~m}$ thick interrupted by two gray sandstone units, at the base (Shinarump) and in the middle (Mossback Member).

Associated evaporites: Beneath the Rico: Paradox Formation evaporites of the Pennsylvanian Hermosa Group; consisting of 29 cycles of, in ascending order; black calcareous shale; bioturbated, silty, sucrosic dolomite; laminated anhydrite; halite with or without potash; nodular anhydrite; black calcareous shale. The Paradox evaporites, as much as about 3,000 m thick along the basin axis just southwest of the Uncompahgre uplift in southwestern Colorado, thin to the southwest, pinching out by facies change to shelf carbonate-clastic cycles about $40-50 \mathrm{~km}$ to the northeast of Happy Jack, so no known evaporites vertically downsection from ore. A second basin with Pennsylvanian evaporites lies more than $150 \mathrm{~km}$ to the south, the Holbrook Basin, Ariz.

Age of mineralization: Not known but definitely older than $23 \pm 3 \mathrm{Ma}$ (Miller and Kulp, 1963). Probably, it is of similar age to U deposits in the Shinarump in Lisbon Valley, Utah, which are $197 \pm 15 \mathrm{Ma}$ in host rocks that were deposited by about $210 \mathrm{Ma}$. Deposits are epigenic, though.

Hypogene ore characteristics and mineral/metal zoning: $\mathrm{U}-\mathrm{Cu}$ ores include ore layers in siltstone or at contacts with sandstone, replacements of carbonaceous trash zones, 
and replacements of larger carbonized wood fragments. Most of uraninite and $\mathrm{Cu}$ sulfides replace carbonized plant debris; less is cementing in the sandstone. Uraninite is commonly microscopically associated with chalcopyrite. Chalcocite is predominantly supergene, veining and replacing bornite and chalcopyrite tens of meters laterally from outcrop with only minor grade enrichment. Largescale zonation has not been recognized. Minor galena and sphalerite also replace carbonized wood. Paragenesis: pyrite is replaced by galena, then chalcopyrite, then bornite, then uraninite, then sphalerite (Chalcocite considered entirely supergene).

Hypogene gangue characteristics and alteration: Quartz overgrowth is abundant. Local poikilotopic calcite may or may not be ore-stage and hypogene. Minor barite cements and crystals growing into pores in carbonized wood.

Geochemical characteristics: The weighted average of four ore shipments totaling 210 short tons contained the following concentrations of elements by semiquantitative, 15-class, X-ray spectrography, in parts per million: $\mathrm{Al}-15,000 ; \mathrm{Fe}-30,000 ; \mathrm{Mn}-70 ; \mathrm{Ca}-1,500 ; \mathrm{Mg}-700$; $\mathrm{Ti}-1,500 ; \mathrm{Na}-300 ; \mathrm{Ba}-150 ; \mathrm{Sr}-70 ; \mathrm{Zr}-150$; $\mathrm{Cr}-30 ; \mathrm{Sc}-15$; B - 15; Y - 30; V-540 (by Quantitative Spectrography); $\mathrm{Ni}-30 ; \mathrm{Co}-700 ; \mathrm{Cu}-7,000 ; \mathrm{Pb}-150$; U-7,700 (by Fluorimetric); $\mathrm{Mo}-70 ; \mathrm{Ag}-3$; $\mathrm{Be}-1.5$; Zn-1,500 (A. Miesch, U.S. Geological Survey, retired, written commun., 1981). Ilsemannite and erythrite are secondary minerals found locally, signaling anomalous $\mathrm{Mo}$ and Co, respectively. Black Mn oxides with greater than 10 wt. \% Co are found locally (given the Mn and Co concentrations above, these are probably heterogenite).

Petrology: Uraninite preferentially replaces the carbonized wood cell walls whereas $\mathrm{Cu}$ sulfides, bornite, and especially chalcopyrite fill the cell lumens. (Note the contrast with the $\mathrm{Cu}$-dominated system at Nacimiento where the cell walls were bornite-replaced, and the cell lumens were filled in the sequence pyrite, then chalcocite.) Pyrite and chalcopyrite form pore-lining and pore-filling sequences in sandstone pores at places. Sulfides replace detrital quartz and K-feldspar, and locally also, overgrowth quartz.

Style(s) of mineralization: Predominant replaced carbonized wood. Lesser cements in sandstones. Replacements of both detrital feldspar and quartz and overgrowth quartz.

Post-ore deformation: Rocks have been gently folded to dip about 2 to $3^{\circ}$ to the southwest on the west flank of the Monument Valley Upwarp

Other notable features: Other sandstone-hosted $U$ deposits in the Chinle on the Colorado Plateau have dramatically different concentrations of $\mathrm{Cu}$ and $\mathrm{V}$ (Hayes, 1982).

Important references: Trites and Chew (1955), Isachsen and Evensen (1955), Miller (1955), Thaden and others (1964), Chenoweth (1993).
Publishing support provided by:

Denver Publishing Service Center, Denver, Colorado

For more information concerning this publication, contact:

Center Director, USGS Central Mineral and Environmental Resources

Science Center

Box 25046, Mail Stop 973

Denver, CO 80225

(303) 236-1562

Or visit the Central Mineral and Environmental Resources Science Center

Web site at:

http://minerals.cr.usgs.gov/

This publication is available online at:

http://dx.doi.org/10.3133/sir20105070M 



\section{通}

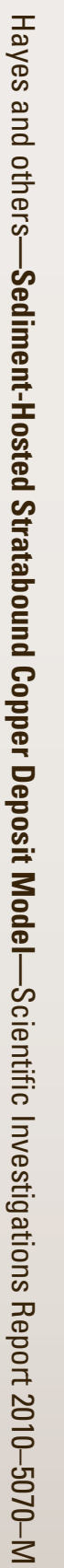

